\title{
Oferta de audiolibros digitales en español: propuesta de análisis de aplicaciones de audiolectura
}

Tesis doctoral presentada por Paula María Fernández Rodríguez Dirigida por

Dra. Fernanda Garzón Farinós

Dra. Dóra Klempáné Faix Dr. Tomás Saorín Pérez

Dra. Fernanda Peset Mancebo

Programa de Doctorado en: Industrias de la Comunicación y Culturales

Septiembre - 2021

UNIVERSITAT

POLITẼCNICA

DE VALĖNCIA 


\section{Agradecimientos}

En primer lugar, quiero agradecer a mis directores de tesis, Fernanda Peset Mancebo, Dora Faix, Tomás Saorín Pérez y Fernanda Garzón Farinós por la motivación y los sabios consejos que hicieron que todo fuese más fácil. A Fernanda Peset le doy las gracias por la confianza que depositó en mí, incluso en el momento previo a la materialización de la idea de la tesis.

A mis padres, por todo, pero especialmente por la compañía durante el año 2020. A mi hermana, por su apoyo diario e interés por los audiolibros y a mi hermano, por sus paseos y su paz.

A mis amigos, cada vez más dispersos geográficamente, pero siempre presentes, de Argentina, España, Suecia, Ecuador y Hungría. A Pablo, por tener siempre la palabra precisa.

Recuerdo también con generosidad a personas a las que no conocía y que me ayudaron de diversas maneras, como Valeria Marcon y profesionales de la Biblioteca Nacional de España, que me facilitaron información valiosa para este trabajo.

Por último, a mis compañeros del Instituto Cervantes, en particular a los del Departamento de Bibliotecas y Documentación, de Madrid y a los de Budapest.

A todos, gracias. 


\section{Resumen}

La importante transformación digital a la que asistimos en nuestra sociedad ha tenido su impacto también en el ámbito cultural. Nos encontramos actualmente en una fase postdigital en la cual interactuamos diariamente con productos y servicios emergentes.

Tras observar los cambios más significativos en torno al mundo del libro y las bibliotecas, destacamos como uno de los más notorios el de los audiolibros digitales, además de tratarse de un tema muy poco investigado, especialmente en España.

En la tesis profundizamos en los factores que determinaron el crecimiento del formato, en particular en el ámbito comercial, y esbozamos las posibles razones de su estancamiento desde entornos documentales. Para ello, y para tener una visión amplia de la situación actual, analizamos la oferta de los audiolibros en el mercado y sus modelos de distribución.

Valiéndonos de esta experiencia, propusimos una metodología para evaluar aplicaciones de audiolectura. Dicha metodología, tiene como objetivo ofrecer el punto de vista del área de las ciencias de la información y la documentación en un proyecto sonoro de esta índole. Desde esa perspectiva determinamos los aspectos de calidad indispensables en cualquier aplicación de audiolectura. La metodología servirá como base para futuras investigaciones, propias y ajenas, tanto en el ámbito documental como en el comercial.

\section{Palabras clave}

Audiolibros digitales; Literatura y tecnología; Lectura digital; Circuito del audiolibro; Aplicaciones de lectura; Audiolibros 


\section{Abstract}

The important digital transformation that we are witnessing in our society has also had an impact in the cultural sphere. We are currently in a post-digital phase in which we interact daily with emerging products and services.

After observing the most significant changes around the world of books and libraries, we stand out as one of the most notorious that of digital audiobooks, in addition to being a very little researched topic, especially in Spain.

In the thesis we delve into the factors that determined the growth of the format, especially in the commercial sphere, and we outline the possible reasons for its stagnation of digital audiobooks in documentary environments. To do this, and to have a broad vision of the current situation, we analyze the supply of audiobooks on the market and their distribution models.

Using this experience, we proposed a methodology to evaluate audio reading applications. This methodology aims to offer the point of view of the area of information sciences and documentation in a audio project of this nature. From this perspective, we determine the essential quality aspects in any audio-reading application. This methodology will serve as a basis for future research, both in the documentary and commercial fields.

\section{Keyword}

Digital audiobooks; Literature and technology; Digital reading; The audiobook circuit; Reading applications; Audiobooks 


\section{Resum}

La important transformació digital a la qual assistim en la nostra societat ha tingut el seu impacte també en l'àmbit cultural. Ens trobem actualment en una fase postdigital en la qual interactuem diàriament amb productes i serveis emergents.

Després d'observar els canvis més significatius entorn del món del llibre i les biblioteques, Destaquem com un dels més notoris el dels audiollibres digitals, a més de tractar-se d'un tema molt poc investigat, especialment a Espanya.

En la tesi aprofundim en els factors que van determinar el creixement del format, en particular en l'àmbit comercial, i esbossem les possibles raons del seu estancament des d'entorns documentals. Per a això, i per a tindre una visió àmplia de la situació actual, analitzem l'oferta dels audiollibres en el mercat i els seus models de distribució.

Valent-nos d'aquesta experiència, vam proposar una metodologia per a avaluar aplicacions d'àudiolectura. Aquesta metodologia, té com a objectiu oferir el punt de vista de l'àrea de les ciències de la informació i la documentació en un projecte sonor d'aquesta índole. Des d'aqueixa perspectiva determinem els aspectes de qualitat indispensables en qualsevol aplicació d' audiolectura. La metodologia servirà com a base per a futures investigacions, pròpies i alienes, tant en l'àmbit documental com en el comercial.

\section{Paraules clau}

Audiolibros digitals; Literatura i tecnologia; Lectura digital; Circuit de l'audiolibro; Aplicacions de lectura; Audiolibros 


\section{Tabla de contenidos}

1 Introducción

1.1 Presentación del trabajo e hipótesis de partida........................................................... 12

1.2 Definición del objeto de estudio ........................................................................ 14

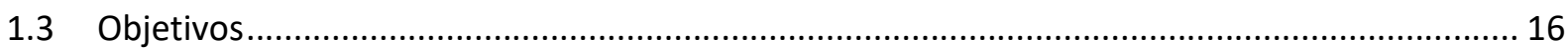

2 Metodología de la investigación...................................................................... 17

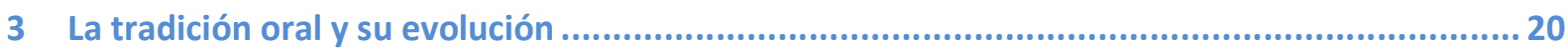

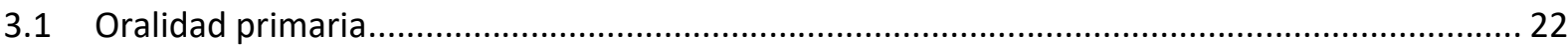

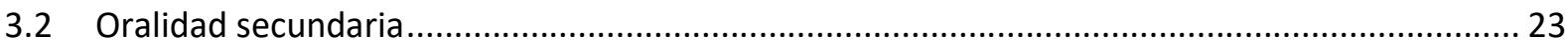

3.3 Orígenes de la escritura: el paso de la literatura oral a la escrita .........................................25

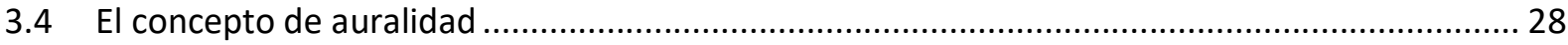

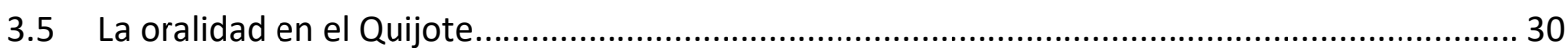

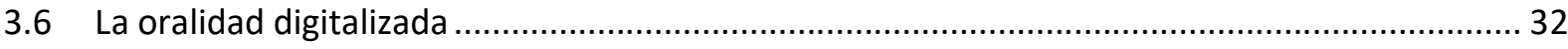

4 Nuevos contenidos y nuevas formas de lectura .................................................. 37

4.1 Nuevas materialidades del libro y surgimiento de términos relacionados con libros digitales.. 37

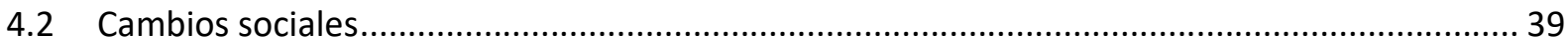

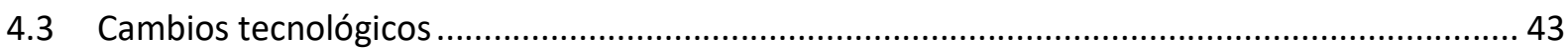

4.4 Diferencias entre la lectura de imagen (o impresa) y la audiolectura ...............................45

4.4.1 La lectura, la literacidad y su relación con la oralidad ....................................................45

4.4.2 Definición de términos relacionados con la escucha de audiolibros ............................... 46

4.4.3 Diferencias entre la lectura textual y la audiolectura................................................48

5 El Audiolibro............................................................................................... 53

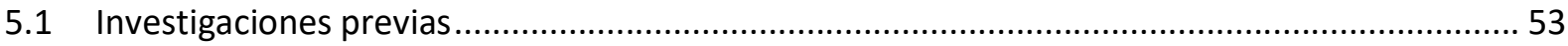

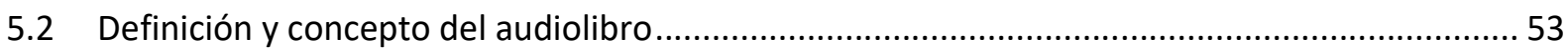

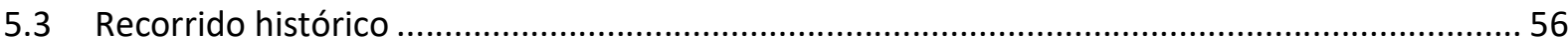

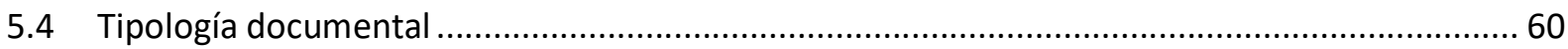




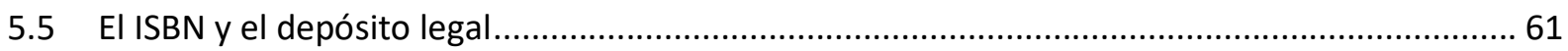

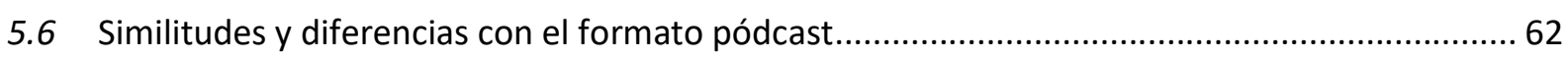

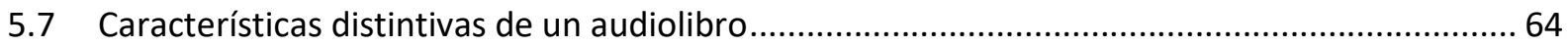

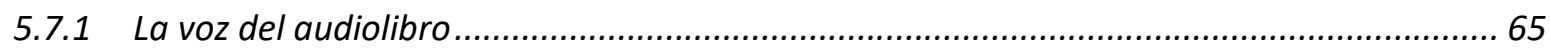

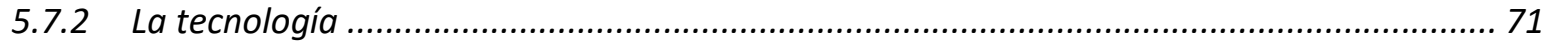

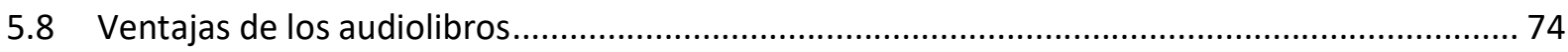

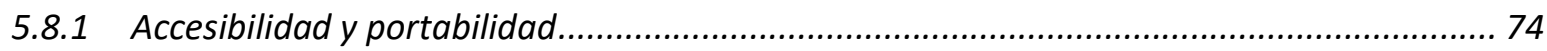

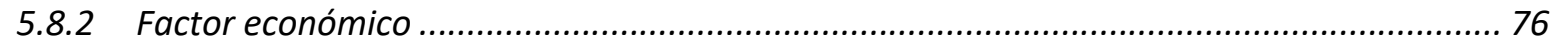

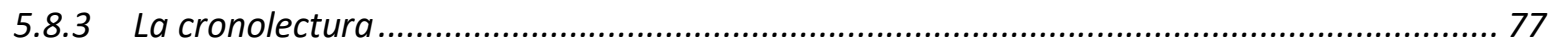

5.8.4 Almacenamiento y ventaja medioambiental ................................................................. 81

5.8.5 Mayor conexión con el libro y compañía parasocial ........................................................... 81

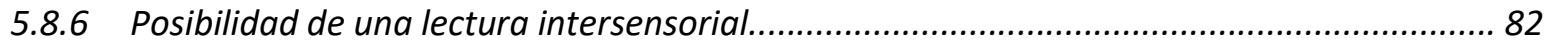

5.8.7 Facilidades para personas con necesidades especiales................................................... 83

5.8.8 Integración del formato con hábitos de vida saludables..................................................... 86

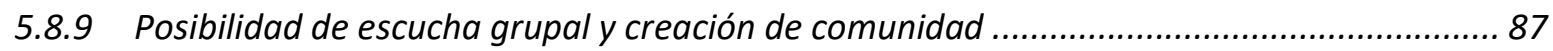

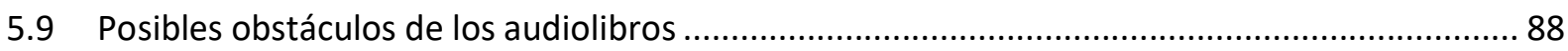

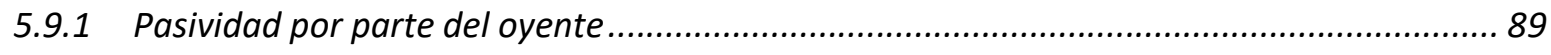

5.9.2 Problemas relativos al nivel de concentración ................................................................ 90

5.9.3 Posible distorsión de las narraciones originales .............................................................. 90

5.9.4 Problemas relacionados con el ritmo de lectura ............................................................ 91

5.9.5 Asociación de la audiolectura con una actividad infantil .................................................. 91

5.9.6 Posible interferencia negativa del narrador ................................................................. 92

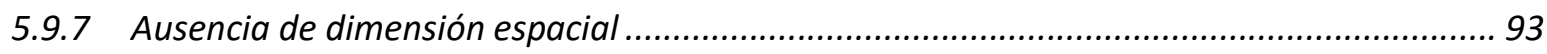

5.9.8 Posible interferencia del campo visual durante la experiencia auditiva ............................. 94

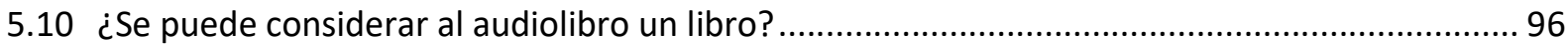

5.11 La comunicación literaria a través del audiolibro................................................................ 97

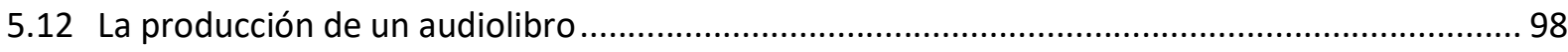

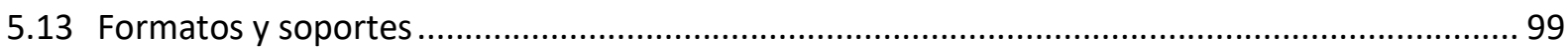

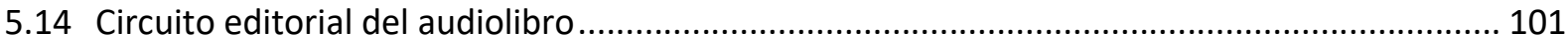

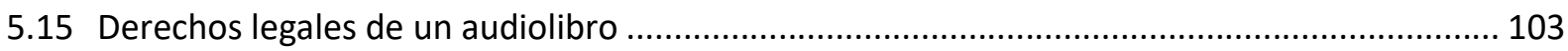


5.15.1 Acuerdo o contrato para la cesión de derechos de autor.............................................. 104

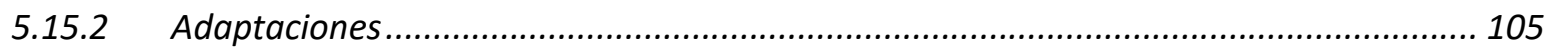

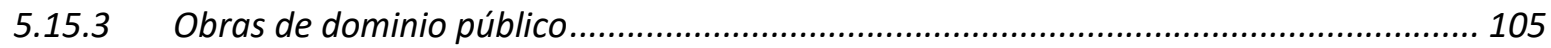

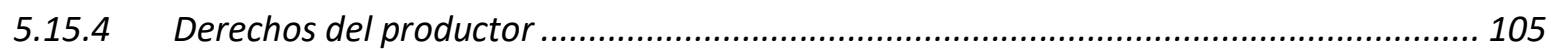

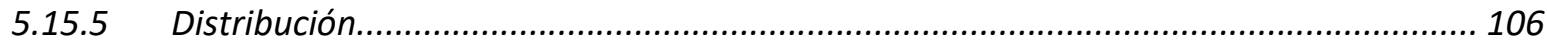

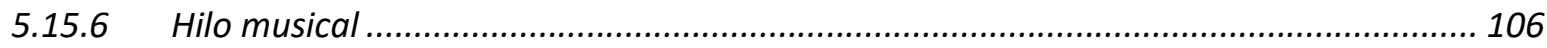

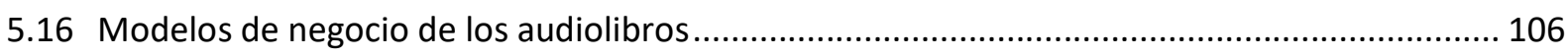

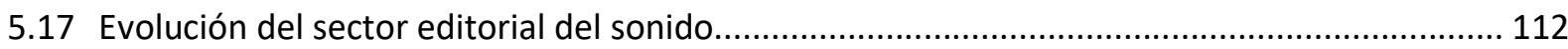

6 Los audiolibros en los centros de documentación ................................................ 122

6.1 El acceso a los audiolibros como un derecho ......................................................................... 124

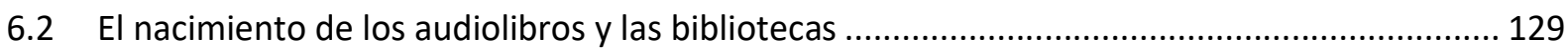

6.3 Desarrollo de colecciones para ciegos en España ................................................................ 131

6.4 Las colecciones en audio de la Biblioteca Nacional Española ................................................ 132

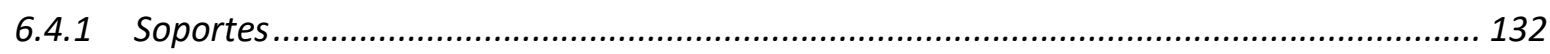

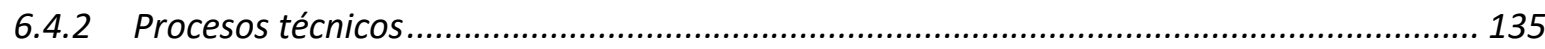

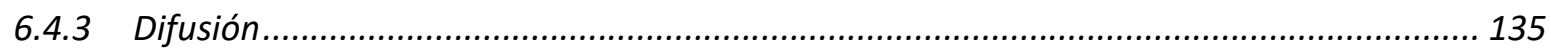

7 Relevamiento de plataformas y aplicaciones que distribuyen audiolibros ....................... 139

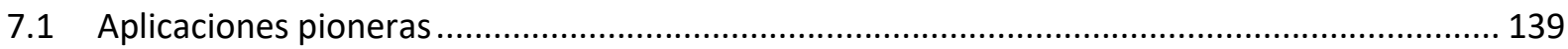

7.2 Plataformas y aplicaciones que contienen audiolibros en español ........................................ 139

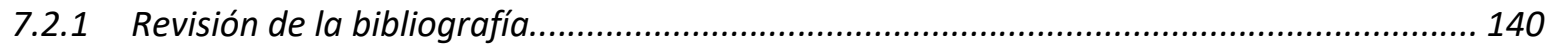

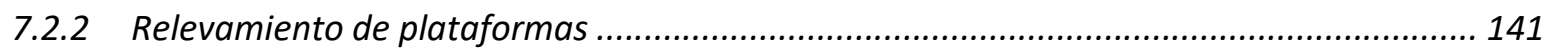

7.2.3 Recogida de información en todas las plataformas ...................................................... 145

7.2.4 Resultados y análisis del relevamiento del Quijote en diversas plataformas en español .. 161

8 Diseño de una metodología para evaluar aplicaciones de audiolectura ........................... 174

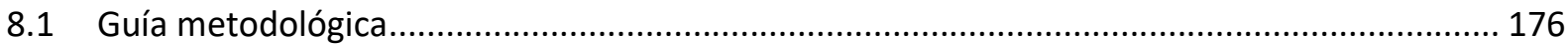

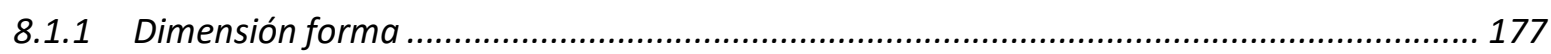

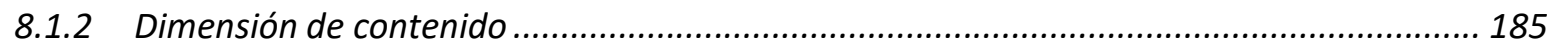

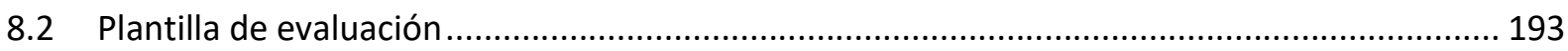

8.2.1 Simulación gráfica de indicadores a incluir en una aplicación de audiolectura .................. 202

9 Conclusiones 


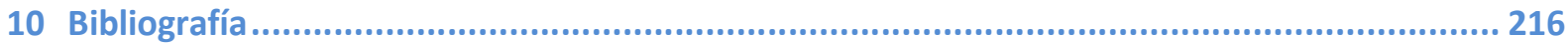

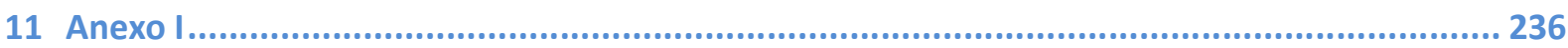

11.1 Búsqueda bibliográfica del Quijote, por plataforma........................................................ 237 


\section{Índice de tablas}

Tabla 1. Esquema de la comunicación literaria 97

Tabla 2. Contenidos digitales en e-Biblio

Tabla 3. Plataformas de audiolibros digitales con colecciones en español

Tabla 4. Listado de audiolibros digitales del Quijote

Tabla 5. Oferta de títulos del Quijote en formato audiolibro digital

Tabla 6. Precios de audiolibros (por compra individual)

Tabla 7. Precios de audiolibros (por suscripción mensual)

Tabla 8. Plantilla de evaluación original

Tabla 9. Plantilla de evaluación para aplicaciones de audiolectura 
Tabla de ilustraciones

Ilustración 1. Metodología para la realización del trabajo de campo___ 18

Ilustración 2. Fases para el diseño de una metodología___ 19

Ilustración 3. Franjas de horario de escucha de audiolibros __ 42

Ilustración 4. Estudio del abandono de la audiolectura___ 70

Ilustración 5. Elementos del texto oralizado___ 98

Ilustración 6. Flujograma de producción de un audiolibro___ 99

Ilustración 7. Soporte de los audiolibros___ 101

Ilustración 8. Modelo genérico del circuito de distribución en Internet de audiolibros digitales ___ 102

Ilustración 9. Promoción realizada por Audible, año $2018 \_110$

Ilustración 10. Publicidad realizada por Storytel a través de Instagram. __ 111

Ilustración 11. Frecuencia de escucha de audiolibros, año $2018 \_113$

Ilustración 12. Frecuencia de escucha de audiolibros, año $2019 \_113$

Ilustración 13. Audiolectores por franja etarea, sexo y nivel educativo __ 114

Ilustración 14. Estadísticas de la edición electrónica de libros, año 2018. __ 116

Ilustración 15. Editoriales optan por publicar audiolibros __ 117

Ilustración 16. Análisis de ventas de audiolibros en mercados en español __ 120

Ilustración 17. Set de audiolibros enviados por la Library of Congress ___ 130

Ilustración 18. Colecciones de la Biblioteca Nacional___ 136

Ilustración 19. Captura de pantalla del Archivo de Palabra__ 137

Ilustración 20. Grabaciones de voces de la BNE___ 137

Ilustración 21. Repetición de un mismo audiolibro en todas las plataformas evaluadas__ 171

Ilustración 22. Audiolibros del Quijote ordenados por plataforma __ 172

Ilustración 23. Propuesta de AA. Pantalla inicial __ 203

Ilustración 24. Propuesta de AA. Menú personal __ 203

Ilustración 25. Propuesta de AA. Criterios de búsqueda___ 204

Ilustración 26. Propuesta de AA. Resultados de búsqueda__ 204

Ilustración 27. Propuesta de AA. Acceso al menú desde la pantalla de resultados___ 205

Ilustración 28. Propuesta de AA. Visualización del audiolibro seleccionado___ 206

Ilustración 29. Propuesta de AA. Pantalla de reproducción de un audiolibro ___ 207

Ilustración 30. Opciones de filtrado de búsquedas en la plataforma BEEK___ 263

Ilustración 31. Página principal en línea de Literatura Sonora___ 303

Ilustración 32. Capítulos del Quijote___ 304

Ilustración 33. Opciones de búsqueda de la plataforma Literatura Sonora___ 304

Ilustración 34. Opción de búsqueda por duración del texto en Literatura sonora___ 305

Ilustración 35. Opción de búsqueda por personaje en Literatura Sonora ___ 305

Ilustración 36. Resultado de la búsqueda por personaje en Literatura Sonora___ 306 


\section{INTRODUCCIÓN}

\subsection{PRESENTACIÓN DEL TRABAJO E HIPÓTESIS DE PARTIDA}

La transformación digital a la que asistimos en nuestra sociedad actual está presente en múltiples ámbitos de nuestra vida cotidiana. En el sector editorial, que es el que nos atañe, se han producido cambios significativos en las últimas dos décadas.

La masiva popularización de los dispositivos móviles y los medios digitales ha tenido como consecuencia que sectores como el editorial o el de las bibliotecas se replanteen su rol, a fin de acompañar de forma más eficiente el desarrollo de esta creciente cultura digital.

Pocas son las referencias analógicas con las que nos encontramos a diario. Hemos superado ya la fase digital, que sirvió de cimiento para la denominada postdigital. Esta condición actual está caracterizada, según Lamas Ubieto, por una presencia cotidiana de lo digital y una computerización sin precedentes, también por su ubicuidad, así como por la conectividad permanente. Es una fase totalmente atravesada por lo digital, más orientada a las prácticas culturales, los medios y las nuevas formas de relacionarse con lo analógico y lo digital (Lamas Ubieto, 2020:1).

Si nos detenemos en al ámbito cultural, observaremos que está profundamente signado por esta nueva era digital. Existen infinidad de estudios académicos que analizan diversas aristas de procesos y técnicas que se han visto influidos por los cambios tecnológicos, especialmente consolidados en museos y bibliotecas.

Durante las últimas décadas, la relación entre el mundo editorial y las bibliotecas, así como entre dicho mundo y las tecnologías, han generado sinergias muy interesantes que benefician a los principales interesados, los usuarios.

Sin embargo, existen algunos fenómenos que, por su reciente irrupción, han sido poco estudiados hasta el momento, y que merecen ser profundamente evaluados, ya que pueden cambiar el modo en que nos relacionamos con la literatura. Uno de estos fenómenos es el auge del audiolibro digital.

La transformación del medio sonoro y su progresiva incursión en el escenario digital, con el consecuente crecimiento de uso de teléfonos móviles, se ha evidenciado tanto en el entorno del libro como en el de la radio. En este último se expresa en su modalidad pódcast.

La presente investigación nos permitirá, en primer lugar, vislumbrar las tendencias que van surgiendo en torno a este nuevo formato, desde el punto de vista de las ciencias de la documentación.

En segundo lugar, nos permitirá ofrecer una clara imagen de la situación actual de los audiolibros, de los agentes implicados en este mercado, y de las formas de distribución de los mismos. Desentrañar todas las funcionalidades del nuevo formato inserto en el nuevo ecosistema digital móvil y mutante es nuestra tarea como profesionales de la cultura, y a ello apunta el presente estudio.

Una vez realizado el retrato de los audiolibros, tanto de sus orígenes como de su situación actual, dedicaremos la última parte de la tesis a diseñar una metodología de evaluación de aplicaciones de audiolectura que pueda ser de utilidad tanto para profesionales del ámbito de la biblioteconomía y la documentación como para el sector editorial. El esquema de análisis propuesto ha unificado otras 
propuestas anteriores, y modificado los ítems que creímos necesarios para realizar un modelo a medida de los documentos digitales sonoros.

El mundo editorial está cambiando, y actualmente existen una gran cantidad de iniciativas incipientes tanto a nivel internacional como nacional que están orientadas a los formatos sonoros. Los profesionales de la información debemos ser proactivos en el conocimiento y la utilización de este nuevo formato aural. La hipótesis que vertebra nuestra investigación es la falta de información relacionada con el formato audiolibros desde el ámbito de la documentación y la necesidad su conocimiento a través de una metodología de evaluación. A lo largo del trabajo de investigación iremos resolviendo algunas preguntas relevantes que nos acercarán a la confirmación de la hipótesis. Enunciaremos las más importantes tras presentar los objetivos del estudio. 


\subsection{DEFINICIÓN DEL OBJETO DE ESTUDIO}

Partiendo de la hipótesis planteada en el punto anterior, establecemos como objeto de estudio al audiolibro digital, debido a la importancia que este formato ha cobrado en la última década.

Profundizaremos en la potencialidad que tiene actualmente en España entre el público adulto. Nos centraremos en las nuevas posibilidades que ofrece a través de las tecnologías. Por ello, nos limitaremos al análisis en profundidad de audiolibros digitales en MP3, MP4 y en formato streaming, dejando de lado los audiolibros en otros soportes (casetes o CD Roms). Restringiremos el término audiolibros a los textos que son narrados palabra por palabra por una o más personas, dejando de lado formatos como el radioteatro, o los textos abreviados.

Se excluyen asimismo los audios relacionados con la educación. Nos centraremos en obras de ficción en español, ya que es el género más popular y está presente en un mayor número de bases de datos, lo cual nos permitirá realizar un estudio más abarcador.

Durante la investigación profundizaremos en distintos ejes de interés tangencial con el objetivo de poder definir un marco teórico adecuado. Además, a partir de nuestra experiencia en el ámbito de la biblioteconomía, presentaremos y analizaremos ejemplos de modos de almacenamiento y difusión de audiolibros digitales, de manera que podamos formular parámetros básicos que deberían estar presentes en una metodología para evaluar aplicaciones de audiolectura.

Para poder progresar con nuestra investigación, utilizaremos un método basado en la deducción a partir de hipótesis, que resolveremos mediante el análisis de varios ejes fundamentales:

- Los distintos tipos de oralidad a través de la historia

- Las nuevas formas de lectura que fueron surgiendo a raíz de la evolución de la oralidad y la escritura

- La diferenciación de los audiolibros de otros tipos de formato

- Las características más importantes de los audiolibros, sus ventajas y desventajas.

- La identificación de las editoriales que producen audiolibros y de las plataformas de distribución de los mismos

- La búsqueda y comparación de un título en todas las plataformas relevadas

- Identificación de puntos fuertes y débiles en la utilización de las plataformas

- El diseño de una metodología que contenga los parámetros adecuados de calidad para una aplicación de audiolectura

Para avanzar con la investigación resultará fundamental la consulta de material teórico. Pero, dado que son escasas las investigaciones sobre el tema, procederemos al relevamiento y testeo de una importante cantidad de plataformas para obtener información de las fuentes de audiolibros digitales en español.

Para llegar a definir las características de este nuevo formato, y de sus usuarios reales y potenciales, resultará fundamental tanto el relevamiento de investigaciones previas al respecto, como la consulta a una importante cantidad de aplicaciones, bibliotecas virtuales y plataformas que contienen el formato audio. 
Habiendo profundizado en las posibilidades de los audiolibros, su oferta en el mercado y la consulta de las aplicaciones más importantes presentes en este, concluiremos la investigación con el planteamiento de una metodología para medir la calidad de las aplicaciones de audiolectura. Esta propuesta contribuye a planificar la aplicación ideal para la escucha de libros de ficción, algo que habría sido imposible sin haberse realizado la investigación previa sobre distribuidores, oferta de libros y nuevas características del uso de los audiolibros. 


\subsection{OBJETIVOS}

1) Conceptualizar el objeto de estudio, el audiolibro, y sus usuarios, entendidos en el contexto de los cambios culturales de la sociedad y de las nuevas formas de lectura.

2) Diferenciar el audiolibro de otros formatos digitales, pódcasts o libros electrónicos, destacando las consecuencias de su evolución.

3) Sistematizar una amplia selección de aplicaciones móviles y plataformas de distribución especializadas en audiolibros.

4) Identificar cuáles son las características deseables en una aplicación de audiolectura, tanto para la búsqueda como para la escucha de audiolibros.

5) Proponer una metodología que sirva para medir su calidad y para diseñar una aplicación orientada a los usuarios

Las preguntas de investigación que nos planteamos son las siguientes:

1. ¿Cuál es el origen del audiolibro y qué vínculo tiene este formato con las ciencias de la información y documentación?

2. ¿Cuál es el panorama actual del mercado editorial del audiolibro en España?

3. ¿Cuáles son los canales o vías de distribución a través de los cuales se comercializan los audiolibros y qué características tienen?

4. ¿Resulta válido el diseño de una metodología para evaluar aplicaciones de audiolectura?

5. ¿Qué características fundamentales debería ofrecer una aplicación de audiolectura? 
La investigación se desarrolla en ocho capítulos que podemos agrupar en cuatro bloques principales en cuanto a su metodología (excluyendo los capítulos 1 y 2 que corresponden a la presentación del estudio y el número 9 , que contiene las conclusiones).

Dedicaremos este apartado a definir de forma escueta los materiales y métodos utilizados, que serán descritos en profundidad en cada uno de los capítulos.

- En primer lugar, en los capítulos tres y cuatro, contextualizaremos el objeto de estudio a través de un análisis de conceptos relacionados con la oralidad y la escritura, observando su evolución, junto a la exposición de los cambios sociales y tecnológicos suscitados en los últimos años. Para ello se ha realizado una revisión bibliográfica en distintas bases de datos especializadas.

- En los siguientes dos capítulos, 5 y 6, comenzaremos por definir términos relacionados con los audiolibros digitales y también con la lectura, y profundizaremos en las diferencias conceptuales entre leer y escuchar cuando nos referimos a formatos sonoros. Analizaremos su recorrido histórico y su tipología documental, además de ahondar en cuáles son las ventajas y las desventajas asociadas con nuestro objeto de estudio.

Posteriormente, nos detendremos en el centro documental más importante de España, la Biblioteca Nacional, para ofrecer información acerca de sus colecciones sonoras.

Para este fin nos valdremos de una exhaustiva revisión bibliográfica y, dado que en algunos temas específicos la información publicada es muy escasa, hemos recurrido también a consultas personales con especialistas en la materia.

- A continuación, en el capítulo 7, nos acercaremos a nuestra hipótesis valiéndonos de ejemplos de aplicaciones de audiolectura del mercado, para poder obtener una radiografía de la oferta existente en la actualidad. Para este fin, combinamos la revisión bibliográfica con un estudio de campo. Al trabajar directamente sobre las aplicaciones, la investigadora ha podido extraer las conclusiones que serán aplicadas en la última fase del trabajo de investigación, como podrá verse en el capítulo 8.

El trabajo de campo es una investigación llevada a cabo por la investigadora durante el año 2020-2021, que consistió en la búsqueda de un título bibliográfico en todas las plataformas de audiolibros en español existentes en el mercado y disponibles a través de internet, además de una sistematización de la información y la extracción de conclusiones.

Se constataron diferencias sustanciales entre aplicaciones de audiolectura digital, que van desde diferencias formales, relacionadas con la presentación de la información, hasta diferencias de contenido, además de la cantidad de audiolibros que ofrecen.

Dichas desigualdades reafirman la necesidad de contar con una metodología adecuada para evaluar este tipo de aplicaciones de audiolectura. 
Resumimos a continuación los pasos llevados a cabo en este capítulo:

\section{Selección de título}

Búsqueda y selección de aplicaciones

Búsqueda del título en las aplicaciones elegidas

\section{Volcado de informacion a fichas}

\section{Extracción de conclusiones}

Ilustración 1. Metodología para la realización del trabajo de campo

- En el capítulo 8 nos planteamos una búsqueda tanto a nivel nacional como internacional de una metodología para evaluar aplicaciones de audiolectura que contemplara todos los aspectos que pueden ser útiles a los profesionales de la información y documentación.

Tras una revisión bibliográfica y normativa muy exhaustiva y amplia no encontramos metodologías específicas para la evaluación de aplicaciones de audiolectura, por lo cual fue necesario adaptar metodologías más generales.

De estos documentos se seleccionó uno y se adaptó a nuestro objeto de estudio, modificando, eliminando y aceptando algunas de sus variables y subvariables.

Para una mayor comprensión del capítulo 8 , ofrecemos a continuación un esquema que sintetiza los pasos llevados a cabo: 


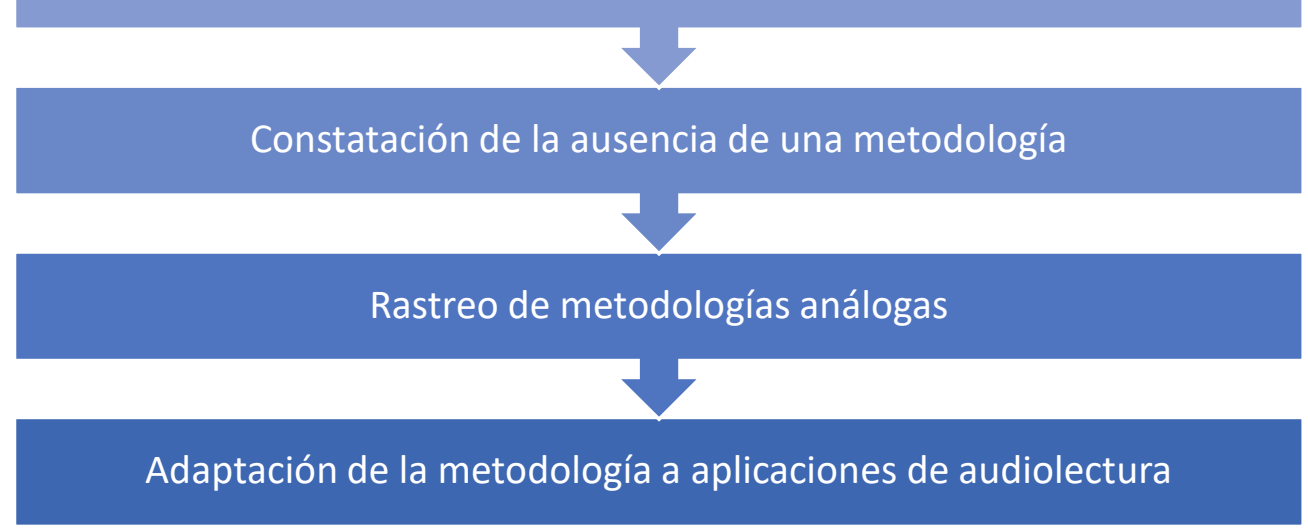

Ilustración 2. Fases para el diseño de una metodología

Por todo lo dicho en este apartado, proponemos una investigación estructurada en base a la contextualización y la confirmación de hipótesis, de forma que se pueda comprobar nuestro planteamiento inicial respecto a la relación entre profesionales de la información y documentación y audiolibros digitales. El objetivo es validar nuestra propuesta y obtener una metodología útil para cualquier centro documental o plataforma que ofrezca aplicaciones de esta índole. Para este fin, hemos llevado a cabo una investigación cualitativa de carácter mixto, ya que incluimos una fase documental y otra de campo. 
En los últimos anuarios dedicados a cultura digital, correspondientes a los años 2018 y 2019, y publicados por Acción Cultual Española (AC/E), se anuncia "el regreso de la oralidad», por la tendencia actual ascendente en la escucha de contenidos sonoros, como los pódcasts y los audiolibros.

El aumento de los recitales poéticos, novelistas grabando sus libros en audio, dramaturgos realizando contenido para radios, e intelectuales transmitiendo sus mensajes a través de pódcasts, son muestras de cómo la narrativa tradicionalmente escrita está siendo transmitida a través de medios aurales (Cannon y Rubery, 2020:352-353).

¿A qué momento histórico nos tenemos que remontar para buscar los comienzos del audiolibro?, ¿por qué se habla de «el regreso de la oralidad»? Para analizar las razones de la actual situación debemos primero tener en claro que existen estrechas relaciones entre los siguientes tres conceptos: escritura, lectura y oralidad.

A fin de dilucidar cómo leemos en la actualidad, estudiaremos el concepto de oralidad a través de la historia trazando una línea de tiempo hasta nuestros días, para observar cómo han ido sucediendo los cambios en relación con la lectura en voz alta y la escritura, así como las transformaciones tecnológicas que se produjeron tras la aparición de la imprenta y las posteriores innovaciones de las tecnologías de la comunicación y la información.

En este capítulo buscamos dotar al audiolibro de historicidad, para lo cual fue necesario preguntarnos cuáles son las herencias legadas de aquella temprana oralidad de la que hablamos al comienzo del apartado. Más adelante realizaremos un abordaje del audiolibro y su comprensión desde el punto de vista conceptual acercándonos a la sociedad actual y a los modos en los que nos relacionamos con este nuevo formato digital.

Observaremos que este camino nos conduce a una oralidad hasta cierto punto literaria, codificada, mediatizada y presente en diversos ámbitos culturales. Observaremos que la oralidad ya no es segregada por escritores ni por lectores.

¿A qué denominamos «oralidad»? Lo que denominamos oralidad son los aspectos verbales de la comunicación humana. El lenguaje basado en el habla/discurso (speech), que ocurre en la esfera acústica, es el canal central entre los seres humanos (Soffer, 2016:1).

Existen, sin embargo, otras formas de comunicación, que muchas veces pasamos por alto, como los gestos o lenguajes de signos.

La oralidad nos ofrece, a lo largo de su milenaria historia, una herramienta de análisis para explorar diferentes aspectos de la cultura textual y tecnológica. En principio, la oralidad contrasta con el alfabetismo por el gran impacto que la tecnología de la escritura ha tenido en la mente humana (ídem). Este paralelismo entre oralidad y escritura se verá detalladamente en este capítulo, en el que se recogerán y analizarán diversas teorías y definiciones propuestas por especialistas en el área de la comunicación. 
Para Walter Ong (2016:38-46) la expresión oral estuvo presente en todas las épocas y coexiste con la escritura; sin embargo, la escritura no puede existir sin oralidad. Según Ong:

Todos los textos escritos tienen que estar relacionados de alguna manera, directa o indirectamente, con el mundo del sonido, el ambiente natural del lenguaje, para transmitir sus significados. "Leer» un texto quiere decir convertirlo en sonidos, en voz alta o en la imaginación, sílaba por sílaba en la lectura lenta o a grandes rasgos en la rápida, acostumbrada en las culturas altamente tecnológicas. La escritura nunca puede prescindir de la oralidad. (ibídem, 44)

Según especialistas en la oralidad, como el citado Walter Ong y Paul Zumthor, se deduce que hasta el Renacimiento la lectura fue comunicada oralmente. Solo con este movimiento se dieron las condiciones para que comenzase a realizarse en silencio y, por lo tanto, el sentido mancomunado de lectura mermara.

Este fue un proceso de varios siglos que convirtió en lectores de textos impresos a quienes antes eran oyentes. La práctica silenciosa se enraizó en la sociedad y se fortaleció con la aparición de la imprenta. En su famoso tratado Introducción a la poesía oral Paul Zumthor enunciaba que «en nuestras sociedades se ha extinguido la pasión por la palabra viva» (1991:26). El lingüista afirmaba que todo producto derivado de las artes del lenguaje se identifica con la escritura y que eso dificultaba el reconocimiento de la validez de lo que no está escrito y que a la sensibilidad estética de la época le repelía la aparente inmediatez de la voz. Incluso imaginaba una ciencia de la voz (que no llegó a concretarse) que pudiera funcionar como base teórica de diversos estudios, abarcando física, fisiología, lingüística, antropología e historia.

Zumthor enuncia que resulta difícil desde la perspectiva de nuestros días comprender la importancia que tiene la oralidad, como indica en el siguiente fragmento:

Pese a haber sido durante largo tiempo ignorada por historiadores casi exclusivamente atentos a los documentos escritos, hoy nadie discute la importancia del papel que la voz desempeña en la conservación de las sociedades humanas. En cada grupo social eso que llamamos sus tradiciones orales constituyen una red de intercambios vocales vinculados con comportamientos más o menos estrictamente cifrados cuya finalidad esencial consiste en mantener la continuidad de una percepción de la vida y de una experiencia colectiva sin las cuales el individuo quedaría abandonado a su soledad, si no a su desesperación. La cosa nos parece evidente cuando se trata de civilizaciones arcaicas, o de determinadas culturas marginales del mundo contemporáneo. En cambio, mucho más difícil nos resulta conocer que efectivamente nuestra cultura occidental de este final del siglo XX, con su racionalidad y su tecnología, está también impregnada de tradiciones orales y que malamente podría subsistir sin ellas. (Zumthor, 1985:4)

Las reminiscencias de la oralidad son escasas y quedan solo algunos objetos testimoniales en forma de libros. En palabras de Irene Vallejo, Dra. en Filóloga Clásica, esta es una gran paradoja, ya que provenimos de un mundo perdido al que solo podemos asomarnos cuando desapareció. En sus palabras: «nuestra imagen de la oralidad procede de los libros».

Herida y aun así fascinante, la gran riqueza el imaginario auroral de nuestra cultura ha sobrevivido sin desvanecerse del todo en los confines del tiempo. Escuchamos sus ecos distantes en la transcripción de mitologías, fábulas, sagas, canciones folclóricas y cuentos tradicionales. Transformada, refundida y reinterpretada, la encontramos en la llíada y la Odisea, en las tragedias griegas, en la Torá -[y en $]^{1}$ el Antiguo Testamento-, en el Ramayana, en las Edda, en Las mil y una noches. Y precisamente esos relatos exiliados -refugiados literarios en el país extranjero en los textos escritos- son la espina dorsal de nuestra cultura. (Vallejo, 2019:35)

${ }^{1}$ [y en] Así figura en original. 
Oran Soffer (2016:1) afirma que se le atribuye mucha importancia al mundo escrito en nuestro mundo alfabetizado, si bien gran parte de la historia del lenguaje no fue escrito, sino solo hablado. Incluso después del desarrollo de la escritura coexistieron en una dislogia cultural con lenguas vernáculas orales (ejemplos que cita de estas coexistencias son los textos latinos «altos» con textos «bajos» regionales en la edad Media; hebreo escrito con lenguajes judíos como el Ídish, o el árabe escrito y hablado).

Como veremos más adelante, la cultura oral fue desafiada por las tecnologías de la comunicación, principalmente a través del desarrollo de la escritura y luego por la invención de la imprenta.

Para el gran lingüista del siglo XX, Ferdinand de Saussure, la escritura es la transcripción de un lenguaje oral a un código de signos visibles. Estableció su teoría semiótica en la que distingue langue (lenguaje) de parole (palabra). Esta división situaba por un lado un sistema abstracto, compuesto por signos que designan conceptos, el lenguaje; y por el otro, su artificio, la palabra, un significante, una combinación de sonidos fonéticos que representan esa idea. El lenguaje o sistema abstracto se desprende de una facultad humana, y la escritura, el artificio que surge para representar al lenguaje oral.

Havelock dedica un capítulo de su libro La musa aprende a escribir (1996), titulado «El descubrimiento moderno de la oralidad» en el que presenta la investigación del tema desde diferentes ángulos, haciéndose una serie de preguntas en torno a la voz: ¿qué significaba para las sociedades del pasado y sus culturas prescindir de los medios de comunicación orales a favor de varias clases de medios escritos?, ¿cuál es la relación precisa entre la palabra hablada de hoy (o de ayer) y el texto escrito?, ¿qué le sucede a la estructura de una lengua hablada cuando se convierte en artefacto escrito, si es que algo sucede? Y, por último, si es la comunicación oral el instrumento de una mentalidad oral. Para dar respuesta a todas estas preguntas el escritor recurre a una vasta bibliografía y fija en el año 1963 un momento clave en la investigación de la oralidad en la historia de la cultura humana y la escritura.

Como punto de partida Havelock analiza el libro de Walter Ong, Orality and Literacy (1982) y revisando su bibliografía, encuentra que cinco libros, provenientes de tres países diferentes, Francia, Gran Bretaña y Estados Unidos, en un lapso de 12 meses (entre 1962 y 1963) habían editado obras referentes al tema: El pensamiento salvaje (Lévi-Strauss), The Consequences of Literacy, La Galaxia Gutenberg (McLuhan), Animal Species and Evolution y Prefacio a Platón, del mismo autor que los cita, Havelock.

Por el análisis de los libros antes mencionados y la finalidad de aportar su propio corpus teórico, la obra de W. J. Ong, es la que de manera más clara y didáctica delinea los grandes modelos referenciales: el de las sociedades que no conocían la escritura y las sociedades o modelos que surgen tras la alfabetización. Cada una de estas sociedades posee unas habilidades cognitivas diferentes que él segmenta en dos grandes tipologías: oralidad primaria y oralidad secundaria.

La influencia que tuvo la oralidad en cada etapa fue muy distinta y merece la pena que realicemos un recorrido cronológico por estos modelos de oralidad, comenzando por la oralidad primaria.

\subsection{ORALIDAD PRIMARIA}

Actualmente en la mayoría de las sociedades conviven tanto la expresión escrita como la oral, si bien existieron culturas $-y$ siguen existiendo- que carecen de escritura. 
A estas culturas ágrafas Walter Ong las denominaba culturas de "oralidad primaria». Son aquellas que se desarrollaron plenamente en comunidades arcaicas ya desaparecidas, y en las llamadas culturas primitivas que aún subsisten y están en vías de desaparición. Según Haarman (2001:19), de todas las lenguas vivas del mundo, que fija en 5.103 , solo un $13 \%$ aproximadamente se escriben. Pero hay que tener en cuenta que este porcentaje es bajo solo en apariencia, ya que a las cien lenguas con mayor número de hablantes les corresponden por sí solas más del $90 \%$ de la población mundial, y las lenguas escritas suponen, en conjunto, un $60 \%$ mundial.

En estas culturas ágrafas el esfuerzo se centra en preservar el conocimiento, no en extenderlo. La cultura oral y la tradición son transmitidas cara a cara (Goody y Watt, 1963:344). Esta comunicación, en la que los oyentes se congregaban en un lugar físico, reforzaba los lazos solidarios comunitarios y aseguraba la transmisión y conservación de la lengua. Lamentablemente, desaparecen unas 25 lenguas cada año, y existen actualmente unas 473 clasificadas como en peligro de desaparecer, según la organización estadounidense Ethnologue.

Oran Soffer (2016:2), indica que las sociedades pertenecientes a este grupo carecen de capacidad analítica compleja, que se atribuye por lo general a habilidades requeridas para el uso del alfabeto fonético. Por esta razón, las sociedades orales utilizaron categorías más simples y abarcadoras. El pasado se encarnaba en la noción del presente, al no poseer documentos literarios ni históricos. No existía escritura que desligara esa situación concreta de su efímero momento histórico.

Walter Ong define la oralidad primaria en contraposición con la oralidad secundaria del siguiente modo:

\begin{abstract}
Llamo "oralidad primaria» a la oralidad de una cultura que carece de todo conocimiento de la escritura o de la impresión. Es «primaria» por el contraste con la «oralidad secundaria» de la actual cultura de la alta tecnología, en la cual se mantiene una nueva oralidad mediante el teléfono, la radio, la televisión y otros aparatos electrónicos que para su existencia y funcionamiento dependen de la escritura y la impresión. Hoy en día la cultura oral primaria casi no existe en sentido estricto puesto que toda cultura conoce la escritura y tiene alguna experiencia de sus efectos. No obstante, en grados variables muchas culturas y subculturas, aun en un ambiente altamente tecnológico, conservan gran parte del molde mental de la oralidad primaria. (Ong, 2016:49)
\end{abstract}

\title{
3.2 ORALIDAD SECUNDARIA
}

Ong (2016) sugiere una especie de ósmosis entre la oralidad primaria y secundaria, y la denomina oralidad residual. Esta se caracteriza por estar en contacto con la cultura gráfica, realidad que puede influir sobre el pensamiento lingüístico y que va transformando a la sociedad para el siguiente tipo de oralidad. La cultura del manuscrito en un principio, en culturas como la griega y la romana, fueron afianzando las habilidades retóricas.

Tal como afirma Ong, los textos estuvieron siempre relacionados, de una forma u otra, con el mundo del sonido; sin embargo, el grado de influencia varía si se tienen en cuenta los diferentes contextos históricos.

El aspecto oral del manuscrito significó que «la escritura, la lectura y la oratoria permaneciesen inseparables hasta bastante después de la imprenta» (McLuhan, 1993:56). Muestra de ello es que los manuscritos eran leídos en voz alta, incluso cuando esta lectura era privada. 
Tras varios siglos de convivencia, se comenzó a producir un giro del lenguaje oral al escrito que inauguró la llamada «oralidad secundaria». Este pasaje se produjo gracias, en gran medida, a la irrupción de la imprenta, como podemos observar en las propias palabras de Walter Ong:

El avance decisivo en la historia de la imprenta fue la invención de la impresión tipográfica alfabética en la Europa del siglo XV. La escritura alfabética había dividido la palabra en los equivalentes espaciales de las unidades fonéticas (en principio, aunque las letras nunca funcionaron como indicadores enteramente fonéticos). Sin embargo, las letras utilizadas en la escritura no existen antes del texto en el cual aparecen. Con la impresión tipográfica alfabética, las cosas cambian. Las palabras se componen de unidades (tipos) que existen como tales antes que las palabras que le darán forma. La impresión sugiere, mucho más de lo que jamás lo hizo la escritura, que las palabras son cosas [...]. Pese a las conjeturas de muchos estructuralistas semióticos, fue la impresión, no la escritura, la que de hecho reificó la palabra y, con ella, la actividad intelectual.

Más que la visión, el oído había dominado de manera significativa el mundo intelectual de la Antigüedad, incluso mucho después de que la escritura fuera profundamente interiorizada. (ibídem, 223-224)

Este predominio todavía podía percibirse en las primeras portadas de libros. En ellas se dividían con frecuencia las palabras con guiones, hecho que choca con nuestro concepto del diseño textual actual. Según Ong, en el siglo XVI la organización de las portadas tenía menos en cuenta el aspecto de la palabra, priorizando su sonido.

Mientras ahora experimentamos la lectura como una actividad visual que suscita sonido en nosotros, la primera etapa de la impresión aún la consideraba fundamentalmente como un proceso auditivo al cual la vista sólo ponía en marcha. Si uno como lector sentía que estaba escuchando palabras ¿qué diferencia había si el texto visible emprendía su propio camino visualmente estético? Se recordará que los manuscritos anteriores a la impresión por lo común juntaban las palabras o dejaban un espacio mínimo entre ellas. (ibídem, 228-229)

Aunque la imprenta inauguró una nueva etapa, hasta mucho tiempo después de la invención de la misma el proceso auditivo siguió dominando el texto impreso, pero finalmente la imprenta acabó por superarlo. "A medida que la tipografía de Gutenberg ha ido llenando el mundo, la voz humana ha ido extinguiéndose. Las gentes comenzaron a leer silente y pasivamente, como consumidores» enunció McLuhan (1993:147).

Las ventas de los libros aumentaron, así como mejoraron las destrezas lectoras, propiciando el fin de la hegemonía de las culturas orales y se pasó de la lectura en común (en voz alta) a un acto individual.

Otro hecho a resaltar es que la lectura en voz alta en ambientes familiares y pequeños grupos era usual a principios del siglo XX «hasta que la cultura electrónica reunió a tales grupos alrededor de los aparatos de radio y televisión, en lugar de, como se hacía antes, en torno a un miembro del grupo» (Ong, 2016:288). Por esta razón, según Soffer la oralidad secundaria recobra el sentido comunal que existía con el acto de escuchar la palabra hablada de forma grupal (2016:4). 


\subsection{ORÍGENES DE LA ESCRITURA: EL PASO DE LA LITERATURA ORAL A LA ESCRITA}

Hemos realizado la distinción entre oralidad primaria y secundaria, según la hipótesis de Ong, que separó a las llamadas culturas orales de las culturas letradas. Actualmente para entender el universo de la oralidad debemos recurrir al orden escritural, y uno de los documentos más destacados para ello es la épica homérica (Berg, 1999:16).

Según Havelock (1996:41), la historia de la literatura europea comienza con los poemas de Homero y Hesíodo. En su vertiente escrita, es posible que Homero haya aparecido parcialmente a principios del siglo VII aC. Se infiere este dato a partir de la invención del alfabeto griego, aunque este no adquirió su forma definitiva hasta mediados del siglo VI aC.

Havelock resalta que, sin la literacidad moderna, es decir la griega, no tendríamos ciencia, filosofía, ley impresa, o literatura, tampoco automóviles ni aviones. Según el investigador Havelock «estaba ocurriendo una lenta revolución cuando Platón escribió, y el secreto de ese éxito radica en la tecnología superior del alfabeto griego $»^{2}$ (1991:24).

El proceso de transcripción producido en Grecia fue tema de estudio de Havelock, quien tomó al sistema de escritura griego y lo comparó con las llamadas literaturas sumerias, babilonias y asirias, y con versiones de la literatura sapiencial egipcia. Observemos a continuación un extracto de su libro:

Saltaba a la vista el agudo contraste entre la enorme riqueza de la oralidad griega, tal y como se conserva en las transcripciones, y la cautela de sus competidores. El lujo de detalles y la hondura del sentimiento psicológico contrastaban con la economía del vocabulario y la cautelosa inhibición de las emociones que parecían características específicas de toda la literatura hebrea y de Oriente Próximo. Se me ocurrió que la verdadera oralidad de aquellos pueblos no griegos no había llegado hasta nosotros, que en efecto se había perdido irremediablemente porque los sistemas de escritura que empleaban eran demasiado imperfectos para registrarla adecuadamente. (1996:28)

Irene Vallejo, en su reciente libro El universo en un junco, también nos habla de la literatura occidental y enuncia que el germen de nuestra literatura comienza con una palabra en griego: menin, que significa «cólera»; haciendo referencia al hexámetro inicial de la llíada. Sin embargo, Irene recalca que el mundo de Homero no tiene comparación al nuestro ya que se sitúa en un contexto previo a la expansión de la escritura. En esa etapa los poemas se recitaban en público, se recreaban escenas de la vida nómada en donde, en torno del fuego, los ancestros se reunían para contar hazañas de sus héroes. Era un momento en el cual la poesía estaba socializada, y el contenido de cada poema podía cambiar de orador en orador, por lo que los límites de la autoría no estaban bien delineados. Cada cual podía agregar algún nuevo matiz a la obra, o incluir un nuevo personaje, razón por la cual cada evento era único e irrepetible. La literatura era un arte efímero y los bardos, encargados de estas performances podían acortar o alargar su actuación dependiendo de su auditorio. "Durante los largos siglos de oralidad el romancero griego fue cambiando y expandiéndose, estrato a estrato, generación tras generación, sin que los textos alcanzasen nunca una versión cerrada o definitiva» (2019:93).

\footnotetext{
${ }^{2}$ Traducción de la investigadora: «A slow revolution was ocurring when Plato wrote, and the secret of that success lay in the superior technology of the Greek alphabet»
} 
Irene Vallejo (ibídem, 94) hace alusión a cientos de poemas que se han perdido para siempre, y destaca entre ellos un canto antiquísimo, anterior a la llíada y la Odisea, protagonizado por el guerrero Memnón, nacido en Etiopía. Por lo cual, y como lo indica Vallejo, si las conjeturas sobre su antigüedad son ciertas, significaría que el cantar más antiguo narraba las hazañas de un héroe negro. Lamentablemente, y como es el caso de este canto, muchos poemas no fueron ni escritos ni transcritos y no llegaron a plasmarse en pergamino, ni en papiros.

El alfabeto instaura un nuevo orden. Este cambio, según Vallejo (ibídem, 97), transformaría la memoria, el lenguaje, la manera de organizar el pensamiento y la relación con el saber y con el pasado.

Según Gubern (2010:18), esta sustitución de lo acústico (el habla) por lo visual (la escritura) supuso una revolución cognitiva de enormes consecuencias. Son muchos los autores que examinaron los aspectos sociales e históricos relacionados con este cambio. Uno de los portavoces más renombrados es Goody (1996), quien propone una relación directa entre los modos de comunicación con los cambios ocurridos en las distintas etapas del desarrollo humano, comenzando por la escritura en Babilonia, el alfabeto en Grecia y la tipografía en Europa occidental.

Para Goody los cambios sucedieron gracias a las posibilidades ofrecidas por las «tecnologías del intelecto", ya que la comunicación verbal apoyada en la visión abre nuevas posibilidades cognitivas (López y Jung, 1998:100).

Volviendo a Gubern (2010:18), la sustitución de lo acústico por lo visual vendría dada por la escritura y serviría para «fijar y estabilizar la textualidad oral».

Como añade Irene Vallejo en su ya mencionado libro El Infinito en un junco, retomando las virtudes de la escritura:

Hasta aquel momento, el canto era un organismo vivo que crecía y cambiaba, pero la escritura lo iba a petrificar. Optar por una versión del relato significaba sacrificar todas las demás, y, al mismo tiempo, salvarlo de la destrucción y el olvido. Gracias a este acto audaz, casi temerario, han llegado hasta nosotros dos obras memorables que han conformado nuestra visión del mundo. Los 15.000 versos de la llíada y los 12.000 versos de la Odisea que ahora leemos como si fueran dos novelas son un territorio fronterizo entre oralidad y el nuevo mundo. (2019:97)

En la Antigüedad se insistía en la expresión oral del texto, y la lectura en silencio tenía como finalidad la comprensión de los mismos. El antiguo arte de leer en voz alta sobrevivió en la liturgia (Cavallo y Chartier, 2001:158). En el siglo VII San Isidoro estableció los requisitos que debían cumplir quienes ocupasen el cargo de Lector en la iglesia, que estos autores recogen en su obra Historia de la lectura en el mundo occidental:

\footnotetext{
Quien vaya a ser ascendido a este rango deberá estar versado en la doctrina y los libros, y conocerá a fondo los significados y las palabras, a fin de que en el análisis de las sententiae sepa dónde se encuentran los límites gramaticales: dónde prosigue la lectura, dónde concluye la oración. De este modo dominará la técnica de la expresión oral (vim pronuntíatiorus) sin obstáculos, a fin de que todos comprendan con la mente y con el sentimiento (sensus), distinguiendo entre los tipos de expresión, y expresando los sentimientos (affectus) de la sententia: ora a la manera del que expone, ora a la manera del que sufre, ora a la manera del que increpa, ora a la manera del que exhorta, ora adaptándose a los tipos de expresión adecuada. (ídem)
}

De esta forma, la lectura en voz alta permitía que los principiantes pudiesen ser asesorados en la lectura, perfeccionando de este modo la pronunciación y el uso del latín. 
Siguiendo con el ambiente monástico, Cavallo y Chartier indican que la lectura en voz alta se practicaba asimismo durante la lectio monástica para que el lector ejercitase la memoria auditiva y muscular de las palabras, como base para la meditatio. El término específico era: meditari literas o meditari psalmos (ibídem, 160).

El abandono de la oralidad en la antigua Grecia y el pasaje de la lectura en voz alta a la silenciosa fue una larga etapa que se comenzó a dar en los monasterios cristianos del siglo VI d.C., probablemente por varios motivos: respetar el silencio común, la concentración y la posibilidad de reflexión y meditación, entre otros.

En su libro Una historia de la lectura, Alberto Manguel narra múltiples momentos históricos en donde la lectura en voz alta fue protagonista. Por ejemplo, en las lecturas oralizadas en los monasterios. Este hecho parece enfrentarse al mencionado requisito de San Isidoro, quien había establecido las pautas para la lectura en voz alta en la iglesia, pero Cavallo y Chartier aclaran que San Isidoro también consideró la preparación para el oficio de lector como una etapa inicial de la educación eclesiástica.

Hacia 547, San Benito de Nursia renunció a su fortuna y a sus títulos y a la edad de 14 años fundó un monasterio en Monte Cassino. Preparó para sus monjes unas reglas en las que la autoridad de un código legal reemplazaba la voluntad suprema del superior del monasterio. Benito decretó que la lectura fuese una parte esencial de la vida monástica. Alberto Manguel transcribe el artículo 38 de esta regla en la que se establecía que:

\begin{abstract}
En la mesa de los hermanos no debe faltar la lectura. Pero no debe leer allí el que de buenas a primeras toma el libro, sino que el lector de toda la semana ha de comenzar su oficio el domingo. Después de la misa y comunión, el que entra en función pida a todos que oren por él, para que Dios aparte de él el espíritu de vanidad. Y digan todos tres veces en el oratorio este verso que comenzará el lector: "Señor, ábreme los labios, y mi boca anunciará tus alabanzas». Reciba luego la bendición y comience su oficio de lector. Guárdese sumo silencio, de modo que no se oiga en la mesa ni el susurro ni la voz de nadie, sino sólo la del lector. Sírvanse los hermanos unos a otros, de modo que los que comen y beben, tengan lo necesario y no les haga falta pedir nada. (Manguel, 2014:128)
\end{abstract}

Según Manguel, el silencio en la mesa y la ausencia de respuesta por parte de los oyentes no solo aseguraban la concentración de los discípulos de San Benito, sino que impedían los comentarios personales acerca de los libros sagrados.

Posteriormente, a partir del siglo XII se siguió la regla de San Benito en monasterios cistercienses en donde se privilegiaba la lectura mancomunada. La lectura colectiva se convirtió en una práctica común y conveniente en el mundo monacal de la Edad Media. Pérez-Rioja (1986:29) indica que a partir del desarrollo monástico se estableció una cultura literaria internacional que más allá de su calado religioso significó una continuación de la vida cultural de la Antigüedad clásica.

Esta actitud hacia la lectura en silencio está relacionada con un cambio de actitud hacia la naturaleza de la palabra escrita que duró muchos siglos. La palabra escrita va ganando peso como transmisora de tradiciones de antiguas generaciones a nuevas, cambio que se va haciendo más profundo y asentado con el correr de los años. Según Cavallo y Chartier «ya no se veía como un simple registro de la palabra hablada» (2001:161).

Durante la época medieval preimpresa, en la que los manuscritos ayudaban en la propagación del conocimiento, la lectura se realizaba en voz alta, incluso cuando se leía en privado. Por esta razón, los libros de estos tiempos fueron escritos bajo el precepto de que serían oralizados. 
La estructura del texto en los siglos XI y XII poseía cierta soltura, y carecía de la estructura literaria de "un principio, medio y fin" (Morrison, 1990:154); los procesos de preimpresión se regían más por la retórica que por su linealidad literaria y/o gramatical.

Este hábito de la lectura en voz alta, sumado a la flexibilidad del texto, propiciaba que los oyentes participaran agregando anotaciones personales, variando de esta forma el desarrollo de las narraciones. La figura del lector era clave en la época de la preimpresión, como enlace entre el libro y los lectores. Era una sincronización que se realizaba simultáneamente a la lectura.

Los escribas continuaron teniendo un rol en la literatura escrita, aunque ya avanzada la irrupción de la imprenta. Su figura se extinguió con el tiempo, y sin embargo Cannon y Rubery encontraron un paralelismo con los escribas en el modo en el que, mucho tiempo después, autores como John Milton, Jame Joyce, Fiodor Dostoyeskyi, Marcel Proust y Sthendhal plasmaban sus textos en papel, ya que estos autores dictaban sus trabajos a sus secretarios. El texto dictado es una producción que no es ni oral ni escrita, pero que contiene algo de ambas (Cannon y Rubery, 2020: 350).

Para ejemplificar, los autores recuerdan que Henry James en el año 1897 deja de escribir sus novelas a mano, por el llamado writer's cramp o "calambre del escritor», y comienza a dictarlas a su secretariado. Los amanuenses o copistas fueron los primeros en notar, -luego se harían eco los críticos literarios-, que hubo un cambio de estilo en la escritura, tornándose un estilo más libre y desenvuelto. $Y$ no fue simplemente que la escritura de James se volvió más parecida al discurso oral, sino que su discurso se volvió también más parecido a la escritura, ya que cuando dictaba sus trabajos deletreaba palabras y verbalizaba la puntuación (ibídem, 352).

Desde luego, las posibilidades que abren actualmente los softwares de reconocimiento de voz vuelven a ofrecer a los escritores la posibilidad de que sus trabajos no deban ser tipeados ni escritos a mano. También aumentan las nuevas formas de producir ficciones sonoras, ya que, si bien pueden partir de un texto impreso, la finalidad de algunas ficciones es que sean publicadas en formato audiolibro. El caso más reciente es el del escritor Vicente Molina Foix, quien está editando una audionovela seriada titulada Las hermanas gourmet.

\subsection{EL CONCEPTO DE AURALIDAD}

“Pienso que el hombre debe amar la confusión. De otra forma no hubiera pronunciado «oral»y «aural» igualmente" ${ }^{3}$ (Richards citado por Cannon y Rubery, 2020:353). Tanto en inglés como en español se prestan a confusión las dos palabras, oral y aural, pues suenan de forma similar, y en ocasiones también se puede confundir su significado.

En su reciente artículo, Cannon y Rubery intentan explicar la compleja relación entre la escritura, la lectura y el sonido, intentando desprenderse de la dualidad oralidad-escritura y resaltando el concepto de auralidad, que es el menos representado en la bibliografía que hemos revisado y que merece la pena que sea conceptualizado.

\footnotetext{
${ }^{3}$ Traducción de la investigadora: "I think man must love confusion, otherwise he wouldnt pronounce "oral" and "aural" alike".
} 
Si nos remontamos a la historia de los libros, «han tenido más audiencia que lectores. Han sido más escuchados que vistos» (Robert Darnton citado por Cannon y Rubery, 2020:350).

Rubery nos remite al poema inglés más antiguo, el Himno de Caedmon (Cædmon's Hymn), compuesto y recitado por un pastor iliterato. En una clase que dictó Jorge Luis Borges de literatura inglesa en la Universidad Nacional de Buenos Aires, resumió la historia de este poema del siguiente modo:

En la Historia Ecclesiastica Gentis Anglorum, "de las gentes de Inglaterra", de Beda, se habla del primer poeta cristiano de Inglaterra, del cual se han conservado apenas unas líneas. ${ }^{4}$ Se llamaba Caedmon y la historia de ese primer poeta cristiano es bastante curiosa y la recordaremos más adelante cuando hablemos de Coleridge y de Stevenson. La historia es ésta: Caedmon era un hombre entrado en años, era pastor de hacienda de un monasterio, era un hombre viejo y tímido. Y era costumbre entonces que después de las comidas el arpa fuera pasando de mano en mano, cada uno de los comensales tenía que tocar el arpa y cantar. Y Caedmon se sabía igualmente incapaz de la música y el canto. Una noche, una noche entre tantas noches, Caedmon, que estaba cenando con sus compañeros en la sala del monasterio, vio el arpa, el arpa temida que iba acercándose a él. $Y$ entonces, para no decir lo que había dicho tantas veces, lo que todos sabrían que él diría, se levantó con un pretexto cualquiera y se fue. Sería el invierno, porque él se fue al establo y se tendió a dormir junto a los animales del establo, que no serían muchos, desde luego. Inglaterra era -estamos en el siglo VII- un país pobre, de ciénagas, de inviernos aún más crudos que los de ahora, y el pobre Caedmon se quedó dormido y en sueños vio un personaje, sin duda un ángel, y ese personaje -los psicólogos pueden explicar esto fácilmente, y los que no somos psicólogos, también- le dio un arpa y le dijo: "Canta". El pobre Caedmon dijo en sueños, como tantas veces en la vigilia: "No sé cantar", y el otro dijo: "Canta el origen de las cosas creadas". Y entonces Caedmon, asombrado, compuso un poema. Luego se despertó y recordó el poema que había compuesto. El poema se ha conservado y no es demasiado bueno. Se trata de los primeros versículos del Génesis, que él habría oído, más o menos amplificados y con palabras alteradas. (Borges, 2000)

Cannon y Rubery indican que había una diferente y relacionada auralidad en el alfabeto en el cual fue fijado ese texto, y resaltan las circunstancias orales de su composición y su estilo, ligadas a la improvisación.

Otro ejemplo de auralidad al que hacen referencia es tomado del Evangelio de Juan, cuando Jesús es interrumpido por un grupo de escribas y fariseos que le traen a una mujer que había sido sorprendida en adulterio. Le piden que la juzgue, mientras Jesús se agacha y se pone a escribir en el suelo con el dedo. Cannon y Rubery enuncian que Jesús está escribiendo por una razón, si Jesús parodia a los escribas para menospreciar lo que ellos hacen, él también establece una equivalencia.

By interposing an act of writing between all that he so memorably said, in other words, Jesus is also insisting that literacy is not an alternative to orality but its twin. I may speak or I may write, he is saying, and both are (as John had already put it) the Word. $(2020,351)$

Según los autores, tanto el himno de Caedmon como el Evangelio de Juan fueron casi con certeza compuestos de memoria y transmitidos oralmente, al menos en sus etapas iniciales, por lo cual, cuando Jesús se agacha para escribir las palabras en el suelo no solo se está burlando de los escribas, sino que también está prefigurando la decisión posterior de preservar y diseminar las enseñanzas de Juan como un texto (ídem).

\footnotetext{
${ }^{4}$ Borges refiere y comenta el pasaje del libro IV de la Historia Ecclesiastica que narra la historia de Caedmon en Literaturas germánicas medievales, OCC pág. 881.
} 


\subsection{LA ORALIDAD EN EL QUIJOTE}

Sin dudas, la obra cumbre de la literatura española es Don Quijote de la Mancha. Como señala Francisco Rico en la introducción a la obra de Cervantes, el impresor Juan de la Cuesta comenzó la impresión a finales del año 1604. También detalla que el conjunto del Ingenioso hidalgo era un volumen de seiscientas sesenta y cuatro páginas, en ochenta y tres pliegos en cuarto (en general conjugados en cuadernos de dos pliegos) del que se realizó una tirada estimativa de mil quinientos a mil setecientos cincuenta ejemplares.

Rico hace notar que no se trató de ninguna obra maestra de la tipografía, ya que desde el papel del Monasterio del Paular hasta la letra del texto: a grandes rasgos redonda de estilo romano y cuerpo catorce, se mantenía en la media de la imprenta de la época, que "solo cabe calificar de bajo» (Rico, 1998:83). Tras los ochenta pliegos en cuestión, Francisco Murcia de la Llana firmó el «Testimonio de las erratas» el 1 de diciembre, y se añadió a los dos cuadernos que los tipógrafos tenían preparados. Se había dejado en blanco el folio $2 \mathrm{R}$ del pliego de la portada, para poder imprimir la tasa, que tenía que expedirse en la Corte, en Valladolid. La tasa, que era la indicación de precio al público, debió ser improvisada y estampada en el taller de Luis Sánchez.

La continuación de la obra, que vio la luz en 1615 se publicaría por el mismo editor y en los mismos talleres bajo el título Segunda parte del ingenioso caballero don Quijote de la Mancha.

Paz Gago (1996:1169) nos indica que hasta el siglo XII la oralidad fue el régimen predominante y casi exclusivo en España y que hasta ese siglo los manuscritos eran escasos. Ya a partir del siglo XV, con la invención de la imprenta y los caracteres múltiples se produce una proliferación de los textos y cita precisamente al Quijote, como la primera novela moderna que manifiesta la literatura impresa y el relato de ficción; sin embargo, la oralidad que predominaba en los siglos precedentes le otorga a la novela una clara huella que podemos observar en los personajes que narran, leen en voz alta o escuchan buena parte de las narraciones contenidas en la obra.

El Quijote se encuentra precisamente, en los primeros años de la décimo-séptima centuria, en ese umbral entre oralidad y escritura, entre medievalidad y modernidad, acogiendo en sus páginas esa coexistencia de la voz y la letra, el griterío del recitador multiforme y el silencio del libro. (ibídem, 1170)

La obra, como metáfora de los cambios que suceden en la sociedad, está atravesada por la oralidad y la escritura. Por un lado, la oralidad sustentada en siglos de tradiciones que han sucedido a través de la voz y por el otro lado, una incipiente cultura escrita asentándose en la reciente invención de la imprenta.

La oralidad en el Quijote ha sido extensamente estudiada, ya que presenta muchas referencias relacionadas con las huellas de dicha tradición, como las técnicas juglarescas, las lecturas en público de sus personajes, la inclusión de dichos populares y refranes, entre otros recursos literarios. Es ineludible que Cervantes incluye en su novela referentes sociolingüísticos de su tiempo, y por esta razón puede servir al presente estudio, por su carácter liminar.

Según Martín Morán (1997:338) «El Quijote es un libro fronterizo entre oralidad y literatura, publicado cuando aún la escritura no había suplido por completo a la oralidad como principal medio de difusión cultural». 
El lugar simbólico que tienen don Quijote y Sancho en la obra, representan dos universos imbricados de manera compleja, en donde el primer personaje representa una esfera más textual, relacionada con los libros impresos y el segundo personaje, más cercana a una semblanza relacionada con la cultura oral.

Si nos remontamos a un diccionario del 1600, el primer diccionario monolingüe español, el Tesoro de la lengua castellana o española, de Sebastián de Covarrubias, y buscamos la definición del término «leer» obtendríamos la siguiente respuesta: «pronunciar con palabras lo que por letra está escrito». Paz Gago $(1996,1173)$ nos ilustra, con este ejemplo, la sinonimia y falta de delimitación existente en los siglos XVI y XVII entre los términos leer, oír, escuchar e incluso ver y mirar.

En el artículo «Literatura oral y ficción cervantina», el hispanista francés Maxime Chevalier, en referencia a los indicios orales de su obra, enuncia que «Cervantes mucho más debe a las sugerencias de la literatura oral que a las fuentes librescas que con tanto empeño y tan moderado éxito hemos buscado» (citado en Botello, 2010:131).

El trabajo de Chevalier ha sido continuado por Michel Moner, quien afirma que el discurso cervantino también ha estado profundamente marcado por las estrategias narrativas y las técnicas de dinamización de los narradores, entre los que nombra: las inflexiones de la voz, el flujo del habla y las técnicas de puesta en escena, entre otras (Moner, 1989:309).

Moner encuentra una oralidad de carácter residual en el Quijote, en varios niveles del texto. Estos indicios de oralidad residual son de carácter auditivo, visual y estructural.

La lectura en el Quijote se plantea como el origen de su locura, ya que esta refuerza su identidad y lo distancia del pensamiento colectivo de la comunidad. Y, de hecho, como resalta Martín Morán, (1997: 341) los primeros síntomas de enajenación, cuando aún no se había convertido en caballero andante, se presentan tras algunas sesiones de lectura solitaria, según atestigua el personaje de la sobrina y podemos corroborarlo en el siguiente fragmento de la obra:

Sepa, señor maese Nicolás (que este era el nombre del barbero) que muchas veces le aconteció a mi señor tío estarse leyendo en estos desalmados libros de desventuras dos días con sus noches, al cabo de los cuales arrojaba el libro de las manos, y ponía mano a la espada, y andaba a cuchilladas con las paredes, y cuando estaba muy cansado decía que había muerto a cuatro gigantes como cuatro torres, y el sudor que sudaba del cansancio decía que era sangre de las feridas que había recibido en la batalla. $(D Q, I, 5,67)$

En este escenario surge la obra más importante de la literatura española: El Quijote, que además de ser una novela excepcional y fundacional, retrata las pinceladas de oralidad que aún retenía la sociedad, además de permitirnos vislumbrar la incipiente cultura impresa y prácticas lectoras del siglo XVI.

Alonso Quijano, don Quijote, lee compulsivamente libros de caballerías, situación que le era posible por la época en la que se encuadra la novela, en la era tipográfica. Don Quijote, como enuncia Michel Foucault, en su famoso libro Las palabras y las cosas tiene que cumplir la promesa de los libros: «rehacer la epopeya, pero en sentido inverso: ésta relataba (pretendía relatar) hazañas reales, prometidas a la memoria; Don Quijote, en cambio, debe colmar de realidad los signos sin contenido de relato» (Foucault, 2005:54).

La obra maestra cervantina contiene una fuente inagotable de paremias populares de la lengua española, razón por la cual la obra es conocida como «el refranero popular». Consciente de haberlo escrito 
en una época de cambio, tanto en el modo de escribir como de hablar y pensar, Cervantes hizo de su obra un repertorio de otras obras y autores.

Antonio Viñao (2004:44) realiza la apreciación de que, aunque no fuese el propósito de Cervantes, en su obra se pone de manifiesto que, a juzgar por los modos de expresión oral de Sancho y de otros personajes rústicos, estos eran ya considerados «analfabetos sin ingenio ni entendimiento» frente a otros que ya eran lectores asiduos de novelas de caballerías y habían accedido a la educación formal.

Este momento bisagra en el que surge el Quijote, se hace evidente por las varias ocasiones en que se hace referencia a la forma en la que se leía. Uno de los capítulos que recoge este testimonio es el 32, en el que uno de los personajes, el ventero, enuncia lo siguiente:

-... Porque cuando es tiempo de la siega, se recogen aquí, las fiestas, muchos segadores, y siempre hay algunos que saben leer, el cual coge uno destos libros en las manos, y rodeámonos del más de treinta, y estámosle escuchando con tanto gusto, que nos quita mil canas... (DQ,32:321)

Cervantes está tan en sintonía con su tiempo que en el Quijote de 1615 un buen número de personajes ya habían leído la novela de 1605, integrando la realidad en la ficción y mostrando de ese modo la relevancia del soporte impreso. Además, hacen una alusión a la imprenta, lo cual supone un guiño al nuevo paradigma de la época y una profunda reflexión sobre el cambio que estaba ocurriendo en la sociedad. Estos fragmentos son recogidos del artículo de Paz Gago (1996:1178):

Un personaje letrado, el bachiller Sansón Carrasco, se refiere a la historia de don Quijote que anda ya impresa en libros (DQ II, 2: 57); un representante de la nobleza culta, la duquesa, también habla del caballero de quien anda impresa una historia (DQ II, 30: 270) y el pastor fingido hace referencia a una historia que de sus hazañas anda impresa y yo he leído. (DQ II, 58: 478)

A la luz de lo anteriormente expuesto podemos afirmar que la cultura escrita y la cultura oral están entrelazadas en el Quijote de tal forma que retratan perfectamente el paso de una sociedad oralizada a una en donde predomina la escritura y un lector preparado para una lectura más compleja y ajena a los tópicos imperantes hasta el siglo XVI, como lo era la lectura de novelas de caballerías.

Asimismo, y como destaca Mario Vargas Llosa, el Quijote también presenta trascendentales innovaciones en otro aspecto de la forma novelesca: el tiempo narrativo. Cervantes expande y multiplica el tiempo de la ficción en una especie de juego de cajas chinas

En donde nos enteramos de que existe otra realidad, otros tiempos, ajenos al novelesco, al de la ficción, en los que el Quijote y Sancho Panza existen como personajes de un libro, en lectores que están, algunos dentro, y otros fuera de la historia, como es el caso de nosotros, los lectores de la actualidad. (Vargas Llosa, 2004:25)

\subsection{LA ORALIDAD DIGITALIZADA}

Según Lev Manovich, autor de varios libros sobre teoría de los medios, los últimos cambios tecnológicos han sido los más significativos. Los mismos han producido un giro que impulsó a la cultura hacia nuevas formas de producción, distribución y comunicación. En la actualidad todas estas fases se encuentran mediatizadas por el uso de ordenadores. En sus palabras: 
Los medios y el ordenador, el daguerrotipo de Daguerre y la maquina analítica de Babbage, el cinematógrafo de los Lumiere y el tabulador de Hollerith se funden en uno. Todos los medios actuales se traducen a datos numéricos a los que se accede por ordenador. Y con esto tenemos como resultado los gráficos, las imágenes en movimiento, sonidos, formas, espacios y textos se vuelven computables; es decir, conjuntos simples de datos informáticos. (Manovich, 2005:71)

Esta mutación técnico-comunicativa se evidencia en el sector editorial, y especialmente en los últimos años, en el sector de los audiolibros.

Para Ema Rodero, profesora de comunicación de la Universidad Pompeu Fabra de Barcelona, la vuelta a la oralidad sucedió simultáneamente a la aparición de la radio, medio que hizo posible la comunicación de masas. La profesora resalta también el protagonismo que cobra la oralidad en la era digital y se focaliza en uno de los principales cambios que la nueva oralidad está propiciando en comparación a los ocurridos con los medios más convencionales como la radio o la televisión. Estos cambios apuntan a una mayor autonomía por parte de los usuarios, quienes pasan de ser meros receptores a ser usuarios más activos, con más capacidad para decidir de qué forma van a consumir los contenidos, dónde y cuándo (Rodero, 2018: 82-83).

Emma Rodero lo resume de la siguiente manera: «la oralidad digital se caracteriza por cuatro factores: la mediatización tecnológica, la transmisión masiva a distancia, la capacidad de almacenamiento y la reproducción cuando el sujeto decida y las posibilidades de interacción» (ibídem, 83).

Peter Logan (2010) también postula una teoría sobre la digitalidad oral. En su libro Understanding new media: extending Marshall Mcluhan retoma el estudio de Walter Ong que hemos citado. Enuncia la teoría de las dos oralidades, la primaria y la secundaria y alega que, en función en la naturaleza conversacional de la comunicación basada en textos de internet (text-based Internet communication), se desprende un tercer tipo de oralidad, que él denomina terciaria u oralidad digital. Puntualiza que esta se compone de emails, posts de blogs, listservs, mensajes de texto, que paradójicamente están mediatizados por textos escritos transmitidos por internet.

También Oren Soffer (2010), en su artículo Silent Orality, analiza en profundidad la llamada oralidad digital. En primer lugar, nos acerca a un tipo de oralidad vinculada con la comunicación mediada por ordenadores (computer-mediated communication) y los SMS (short message service), coincidiendo con los estudios citados con anterioridad. En estas teorías podemos observar que existe una ósmosis entre las esferas textuales y orales en chats o mensajes de texto que están produciendo algunos cambios a nivel de la comunicación social. Soffer concluye que a pesar de que las dos oralidades, la secundaria (de la radio y la televisión) y la mediada por ordenadores, evolucionaron en atmósferas tipográficas y dependen de textos escritos, las características de ambas difieren radicalmente.

De la oralidad secundaria, en otro trabajo Soffer dice que (2010:400) "el hecho de que sea frecuentemente invisible es prueba de su eficiencia - testigo de la adaptación del proceso de adaptación que los textos escritos pasaron a través del sonido de forma "natural» al oído" ${ }^{5}$; mientras que la oralidad digital se manifiesta silenciosa y fundamentalmente a través de comunicaciones interpersonales digitales, que son menos presentes en la esfera pública. Agrega Soffer que no solo esta última oralidad

\footnotetext{
${ }^{5}$ Texto original: The fact it is often invisible is proof of its efficiency-testament to the adaptation process that written texts pass through to sound "natural" to the ear.
} 
tiene que ver con características meramente tecnológicas, sino que subyacen en ella los cambios lingüísticos dados por algunos cambios que se evidencian en relación con la comunicación escrita-hablada.

Klaus Jensen, basa sus cimientos en las teorías de Walter Ong (1982) y postula su propia hipótesis bajo el lema de los «medios de tres grados» (media of three degrees), en donde el lenguaje (discurso) y la escritura pertenecen al primer grado, y están ligados al cuerpo y a extensiones en forma de instrumentos; los medios de segundo grado comprenden lo que él engloba como tecnologías: libros impresos, periódicos, radio y televisión; y el tercer grado abarca las meta-tecnologías, como las computadores digitales y teléfonos móviles (Jensen, 2011). Puntualiza en otro artículo las características principales de este último grupo:

A characteristic feature of media of the third degree is their (potential) multimodality, partially reenacting or simulating the qualities of interaction in the flesh. In certain respects, humans are media; in certain respects, digital media can substitute the social roles of humans. (Jensen, 2006:20) ${ }^{6}$

Junto a su esquema nombra algunos ejemplos en donde la oralidad confluye con lo textual, como pueden ser discursos descargables, discursos políticos, himnos, etc. y enuncia que «The human voice is putting body as well as mind in vibration in the media of the third degree ${ }^{7}$ (Jensen, 2006:12).

Have y Stougaard Pedersen, (2016:136), al igual que los anteriores autores, parten de las dos oralidades propuestas por Ong, y a partir de ahí expanden su teoría hacia una tercera oralidad. No obstante, se detienen en el concepto de oralidad, y encuentran más apropiado utilizar el término verbality (verbalidad). La explicación que aportan es que la propia etimología de la palabra oralidad está relacionada tanto con la boca como con la escucha y los oídos, por lo cual encuentran engañoso utilizar el término cuando se puede hablar de situaciones en las cuales se encuentran separadas la comunicación oralauditiva, como por ejemplo emails, que nunca han sido convertidos al sonido.

A las especialistas les parece útil, de todas formas, el marco que brinda la llamada "tercera oralidad», sugerida por Finnemann y Jensen, ya que sirve para situar al audiolibro y entender cómo y por qué este ha experimentado su renacimiento digital y se convirtió en un medio de masas, en una cultura en donde las ventajas y el potencial del sonido digital y la voz todavía están por descubrirse.

Para profundizar un poco más acerca de la relación de la tercera oralidad con los audiolibros, recordemos que fue clave la popularización de los teléfonos móviles, y cabe la pena señalar que Soffer (2010:394) realiza el siguiente apunte: "The influence of the oral nature of the medium itself -the mobile phone-on SMS cannot be ignored ${ }^{8}$. Si bien en este artículo Soffer se refiere a los medios tecnológicos y cómo se han generalizado los chats y redes sociales promoviendo el intercambio de mensajes instantáneos y personales, también puede ser tenido en cuenta en la utilización de los móviles para la escucha de audiolibros.

Las nuevas formas de comunicación de las que habla Soffer en su artículo y en las que se desdibujan los límites entre la oralidad y la escritura, no las adjudica solo a un resultado de las tecnologías o al uso de los medios, sino que las sitúa en un contexto más amplio. $Y$ para esto cita a Zygmunt Bauman, y su

\footnotetext{
${ }^{6}$ «Un rasgo característico de los medios de comunicación de tercer grado es su (potencial) multimodalidad, que recrea o simula parcialmente las cualidades de interacción en persona. De cierta forma, los humanos son medios de comunicación; en ciertos aspectos, los medios digitales pueden sustituir los roles sociales de los humanos» (trad. a.)

${ }^{7}$ "La voz humana está poniendo cuerpo al mismo tiempo que mente en vibraciones en el medio de tercer grado» (trad. a.)

8 "La influencia de la naturaleza oral del propio medio -el teléfono móvil- en los SMS no puede ser ignorada» (trad. a.)
} 
concepto de «modernidad líquida», en el cual habla de cambios en la sociedad moderna en el que la comunicación fluye de una forma líquida, individualizada y privatizada, además de que no se puede mantener por mucho tiempo de la misma forma (ibídem, 395).

También realiza esa analogía el catedrático Vázquez Medel (2014:126), vinculando la nueva oralidad a los tiempos líquidos de los que nos habla Bauman, afirmando que, al haber sido siempre líquida, dinámica y fungible, la oralidad tiene los rasgos de ser la mejor forma de comunicación posible en estos tiempos cambiantes, y agrega que sería deseable que convivan la oralidad con las nuevas formas de escritura que podrían, todavía, estar por nacer.

Es interesante el surgimiento del estilo híbrido escrito-hablado de la oralidad digital, que es parte de nuestra realidad posmoderna. El uso de mensajes de texto y sistemas de reconocimiento de voz son cada vez más populares, y se evidencia un cambio sustancial en la forma de relacionarnos con la voz; según Have y Stougaard Pedersen (2016:137) parece que tiende a tener efectos sostenidos en el tiempo.

En este nuevo escenario casi todo está regido por la ley de la economía lingüística en la cual prevalecen dos características principales de la técnica: la velocidad y la iconicidad. Los medios sociales impulsan una revolución sutil en la manera en que nos comunicamos con un amplio público pasando a ser más informales y abiertos combinando palabras y emoticones. Esta forma de comunicación llega a otras áreas de la vida y la cultura (Vilches, 2014:28-29).

La informalidad de la que habla Vilches se pone en evidencia en las comunicaciones de texto en, por ejemplo, la supresión de tildes y signos de puntuación, lo cual es parte de los cambios que se van instaurando para simplificar y acelerar el intercambio de los contenidos por chat. Como indica Sanmartín Sáez, (2007) es muy común simplificar también la ortografía, utilizando abreviaturas (p. ej. $Q, q e, t b$ ) y suprimiendo sílabas (p.ej. na' por «nada»; pa' por "para»). Es un fenómeno vinculado a las redes sociales y que se va extendiendo favorecido por los medios electrónicos.

Soffer indica que parte de los errores -ortográficos, gramaticales o sintácticos- no son deliberados, sino que ocurren a raíz de la rapidez del intercambio y de las características técnicas de los dispositivos, como el teclado miniaturizado incluido en la pantalla y la importancia en la rapidez de la respuesta, aunque esta no sea sincrónica (2016:3).

En otro de sus estudios, el especialista Oran Soffer analiza la aplicación Snapchat y la relaciona con su teoría de la oralidad (en la que los límites entre lo escrito y lo hablado no están fijos). El investigador sostiene que en la naturaleza efímera de esta aplicación subyace un paradigma oral. Para comprender su hipótesis es necesario saber que este programa aplica a las imágenes la misma metáfora que la de las palabras pronunciadas, que desaparecen una vez dichas. De esta manera el programa rescata una de las características de la oralidad primaria:

Imagine a Polaroid photo that, instead of becoming sharper, ades away after $10 \mathrm{~s}$ as if it were an uttered oral sentence.

This example clearly demonstrates the cultural gap between the idea of ephemeral oral culture and visual culture. ${ }^{9}$ (Soffer, 2016b:2)

\footnotetext{
${ }^{9}$ «Imagine una foto Polaroid que, en lugar de volverse más nítida, se desvanece después de 10 segundos, como si fuera una frase pronunciada. Este ejemplo demuestra claramente la brecha cultural entre la idea de la cultura oral efímera y la cultura visual» (trad. a.)
} 
Y concluye el artículo de la siguiente manera:

The hybridity of these two distinct cultures in the attempt to treat text as conversation may be seen as part of the tolerant liquid environment of late modernity, along with the unique affordances of digital technology. ${ }^{10}$ (ibídem, 4)

En sintonía con esta idea, Antonio Rodríguez de las Heras, nos habla de una crisis y pérdida de confianza en lo visual. Es, para él «el desmoronamiento de otra certeza en este mundo digital».

Estamos ante algo más que la desaparición de unas palabras escritas raspando el pergamino (palimpsesto) y escribiendo otras encima; mucho más que el maquillaje para ocultar los defectos o resaltar los rasgos; más, mucho más que la sustitución de un personaje por su doble e igualmente que el engaño consentido de los sentidos con cartón piedra o imagen sintética... Es una crisis de lo visual como garantía de certeza y de la pantalla como ventana. Y esta pérdida solo se podrá compensar asegurando en este mundo digital nuevas y sólidas formas de autoridad y de confianza. Como lo ha requerido siempre la oralidad. Y es que la oralidad digital que está emergiendo es más que palabra hablada. (Rodríguez de las Heras, 2020, párr. 6)

Esta crisis puede ser uno de los motivos por los cuales estamos recurriendo nuevamente a la oralidad tras pasar por un mundo donde la pantalla fue omnipresente. Partiendo de estas ideas, el catedrático se pregunta:

¿Esta debilidad inesperada, esta desilusión, será una causa más que añadir a la recuperación y reinterpretación de la oralidad? Una oralidad digital que significa que hasta aquello que entra por los ojos se comporta como la palabra hablada, aunque en vez de estar sostenido en el aire y sus ondas lo sostiene un éter de ceros y unos.

(Rodríguez de las Heras, 2020, párr. 7)

Tras este recorrido social y los cambios que se fueron produciendo con el desarrollo de las nuevas tecnologías, resulta de especial interés para nuestra investigación el capítulo de Have y Stougaard Pedersen, (2016:136-138), en el que relacionan a la tercera oralidad con un cambio de valores hacia la audiolectura y la comunicación.

En dicho texto mencionan algunas condiciones que hicieron propicio el aumento de la escucha de audiolibros. Algunas de ellas las ampliaremos en el capítulo 5.8 (ventajas de los audiolibros). Entre las condiciones propicias para las autoras está el ahorro de tiempo, ya que la escucha de un audiolibro permite realizar a los lectores otras actividades; producen un enganche mental; pueden ocupar tiempo que sería tiempo perdido (mientras se realiza ejercicio o en traslados en coche); y son convenientes y poco costosos.

En el texto de Have y Stougaard Pedersen sugieren que los audiolibros no deben ser comparados con los libros impresos sino con un fenómeno popular que es parte de una cultura digital y audio móvil dentro de un medioambiente mixto que ofrece intimidad y sociabilidad al mismo tiempo. Los cambios no tienen solo que ver con la utilización de una pantalla en vez de un libro impreso, sino que tiene que ver con cambios más radicales «una transformación semiótica de la vista al audio, (con una voz narradora como un importante transformador) ${ }^{11} »$ (ibídem, 138).

\footnotetext{
10 «La hibridación de estas dos culturas distintas en el intento de tratar el texto como una conversación puede verse como parte del entorno líquido imperante de la modernidad tardía, junto con las posibilidades únicas de la tecnología digital» (trad. a.)

11 Texto original: A semiotic transformation from visual to audio (with the narrating voice as an important transformer).
} 
En este capítulo se revisan conceptos esenciales para nuestra investigación: las nuevas materialidades del libro, la irrupción del soporte digital en nuestra sociedad y cómo influyen estas nuevas tecnologías. En relación con las nuevas formas de lectura realizaremos una introducción a la lectura de audiolibros, - este tema se tratará en profundidad en el siguiente capítulo-. Cerraremos con las diferencias conceptuales entre la lectura textual versus la audiolectura.

\subsection{NUEVAS MATERIALIDADES DEL LIBRO Y SURGIMIENTO DE TÉRMINOS RELACIONADOS CON LI- BROS DIGITALES}

El investigador dedicado al futuro del libro y la lectura, Lorenzo Soccavo, nos advierte que la revolución de la lectura que estamos viviendo es más importante y tendrá mayores consecuencias que la revolución de la imprenta en el siglo XVI (Soccavo, 2013:9).

Soccavo realiza una analogía con los primeros incunables impresos entre 1550 y 1501 y llama a nuestra era «la era de los incunables electrónicos», fijando como inicio de la misma el 4 de julio de 1971, fecha de la primera retranscripción de un texto en soporte informático, el EText\#1. Esta transcripción se trataba de la Declaración de Independencia de los Estados Unidos de América, digitalizada por el norteamericano Michael Hart, y que poco después haría despegar el primer proyecto de biblioteca digital internacional, el Proyecto Gutenberg. Una puntualización interesante que realiza Soccavo es que no solo se está produciendo una mutación en la técnica de reproducción, como sucedió con los incunables originales, sino una metamorfosis más amplia, que alcanza tanto al soporte como al contenido (ídem).

En palabras de Carlos Scolari, la "web no es «un medio más» como la televisión o la radio: es un gran nicho dentro del ecosistema de medios que, desde su aparición, no paró de generar nuevas formas disruptivas de comunicación" y agrega que a esta gran revolución se suman los dispositivos móviles acelerando y aumentando las hibridaciones intermediáticas (Scolari, 2017:175).

En este contexto, la unanimidad en cuanto a las definiciones en torno a al libro se vuelven cada vez más difíciles. Algunos contenidos, especialmente los que vinculan texto con nuevas tecnologías, como, por ejemplo, el libro transmedia, crossmedia, el libro aplicación, etc. no se encuentran reflejados aun en el diccionario de la RAE, si bien ya forman parte de la bibliodiversidad que podemos encontrar en la web.

La decisión de la Academia ante el vertiginoso crecimiento digital fue la de ampliar los horizontes de la palabra «libro» hacia una definición donde pudieran caber algunos de los contenidos antes mencionados; y lo hace definiendo al libro de la siguiente manera: "Obra científica, literaria o de cualquier otra índole con extensión suficiente para formar volumen, que puede aparecer impresa o en otro soporte».

De esta forma se cambia el concepto del «libro unitario» hacia una nueva materialidad ajena a lo físico, vinculado tradicionalmente al papel. Y, según Roger Chartier es a la par que una revolución de la modalidad técnica de la reproducción de lo escrito, «una revolución de la percepción de las entidades 
textuales y una revolución de las estructuras y formas más fundamentales de los soportes de la cultura escrita» (2012:13).

A los efectos del artículo número dos, publicado en el BOE del año 2007, la Ley 10/2007, de la lectura del libro y de las bibliotecas, se entienden incluidos en la definición de libro «los libros electrónicos y los libros que se publiquen o se difundan por Internet o en otro soporte que pueda aparecer en el futuro, los materiales complementarios de carácter impreso, visual, audiovisual o sonoro que sean editados conjuntamente con el libro y que participen del carácter unitario del mismo, así como cualquier otra manifestación editorial».

Pese a la intención de abarcar los contenidos digitales en dicha ley, no puede pasarse por alto que se realiza una distinción entre "los libros electrónicos» y «los libros que se publiquen o se difundan por internet», situándolos en dos categorías distintas. Tras consultar documentos interpretativos de esta ley entienden que se trataría de una sola categoría: la del libro electrónico o digital en tanto que contrapuesto al libro analógico o convencional (Alonso Suárez, 2019:257). Con las expresiones «libro electrónico» o «libro digital», se hace referencia tanto a las obras puestas a disposición del lector a través de un equipo o soporte de lectura de cualquier tipo, como así también a aquellas puestas a disposición del lector mediante transmisión en línea, que pueden permitir la visualización en streaming o descarga (downloading) para su almacenamiento (ídem).

Otra confusión proviene de que se hace referencia al «libro electrónico», tanto si se habla del soporte físico como si habla del contenido. Se utiliza indistintamente para designar a las obras en formato digital y al soporte o equipos electrónicos que sirven para la reproducción o lectura de los contenidos (ibídem, 258).

Existen definiciones más generales y simplificadoras, alejadas de la etiquetación posmoderna, y son las que se mantienen vigentes por más tiempo, como la definición del escritor e historiador Román Gubern, quien enuncia que el libro es: «cualquier texto disponible, en el soporte que sea» (Cita textual tomada de: Vázquez, 2010, párr. 9).

Siguiendo esta misma línea, uno de los referentes en el ámbito de los audiolibros, Javier Celaya, máximo responsable de Storytel en España, postula que:

Debemos considerar libro todo aquello que nos cuente historias, que es lo que nos interesa como humanos, da igual el soporte; por eso ha triunfado Netflix, que, para mí, es el editor del siglo 21 . Se trata de hacer libros digitales inmersivos, con texto, vídeo, imágenes, canciones, etc. (El futuro del libro digital, disparado, 2019, párr. 3)

Para Jorge Carrión nos encontramos en el momento en el que delineamos la terminología que tiene que ver con lo analógico y lo digital en torno al libro, pero al mismo tiempo ello nos debe llevar a repensar en la forma en la que nos relacionamos con los mismos, ya que el formato del pódcast y del audiolibro tienen relación para él con la omnipresencia de las voces digitales en nuestras vidas cotidianas (Carrión, 2020b).

Vivimos en una auténtica explosión creativa de los formatos de audio que ha empezado a establecer un nuevo canon del arte y del entretenimiento, el de obras de ficción y documentales que crean sofisticados paisajes sonoros para introducirse -a través de nuestros tímpanos- directamente en la imaginación. Pero las narrativas artísticas y las corporativas se confunden. Y las razones profundas de la expansión del universo pódcast son tan complejas que por momentos también parecen ficción. (Carrión, 2020b, párr. 3) 
El escritor fija en el año 2011 el año en el que se empezó a producir la actual revolución del audio, ya que el 14 de octubre se presentó a Siri como parte de los servicios del iPhone 4S, y a su vez Spotify desembarcó en Estados Unidos y Amazon comenzó a trabajar en el llamado «Proyecto D» con el objetivo de construir Echo y Alexia, cuya primera versión llegó al mercado en 2014 (Carrión, 2020:143). Otros hitos relacionados con la ficción fueron las primeras temporadas de Serial (pódcast) y Homecoming.

Esta compleja metamorfosis está afectando todo el circuito del libro, tanto a las empresas relacionadas con la edición como a los diferentes agentes que la componen. Por esta razón indagaremos más sobre el tema en el apartado 5.14, el circuito del libro.

\subsection{CAMBIOS SOCIALES}

En nuestra aproximación conceptual al audiolibro no solo hay que evaluar los cambios que tienen que ver con su producción y consumo sino todos los cambios sociales ligados al aumento de su uso, para comenzar a comprender cuáles pueden ser las tendencias de su desarrollo.

En el apartado "La oralidad digitalizada» presentamos algunas transformaciones dadas por la tecnología móvil que alteran las relaciones entre los grupos, crean estilos híbridos escritos-hablados en el que predomina una economía lingüística más informal y etérea que va desdibujando la confianza en lo visual.

Actualmente, el lector está enmarcado en lo que se puede definir como «cultura móvil», idea que se ajusta al concepto de «tiempos líquidos», como lo denominó el sociólogo Zygmunt Bauman (Bauman, 2007). El sociólogo señalaba que:

\footnotetext{
En el mundo de la modernidad líquida, la solidez de los vínculos humanos se interpretan actualmente como una amenaza, y que en el plano cultural también las cosas más preciadas envejecen rápido. Hoy se espera que ni siquiera los hábitos que supuestamente habrían de durar un poco más permanezcan inalterables. Un anuncio reciente de oferta de teléfonos móviles atrae a los curtidos usuarios de teléfonos con esta exhortación: "Usted ya no puede presentarse en público con ese móvil que tiene ahora...vea los nuevos modelos». [...] La capacidad de durar mucho tiempo y servir indefinidamente a su propietario ya no juega a favor de un producto. Se espera que las cosas, como los vínculos, sirvan sólo durante un «lapso determinado» y luego se hagan pedazos [...].El consumismo de hoy no se define por la acumulación de cosas, sino por el breve goce de esas cosas. (Bauman, 2008:28-29)
}

Actualmente, según Bauman, se vive más para olvidar que para aprender, y va en contra de la esencia de lo que se conocía como aprendizaje y educación a lo largo de la historia. Actualmente, la memoria en muchos casos puede ser engañosa (ibídem, 37). Los marcos cognitivos sólidos y aquellos valores estables de antaño son reemplazados por otros móviles. El cambio actual no tiene precedentes; según el investigador, nunca vivimos en un mundo tan sobresaturado de información.

Esta sociedad que retrató y acuñó Bauman con la analogía del agua es también una sociedad signada por lo que se viene denominando VUCA, siglas en inglés creadas por el ejército americano tras la Guerra fría y más generalizadas en la pasada década de los años 90 que están compuestas por las palabras Volatilidad, Incertidumbre/ Uncertainty, Complejidad y Ambigüedad. 
Los anteriores conceptos relacionados con el cambio, nacidos en el ámbito militar, derivaron hacia áreas relacionadas con las ciencias empresariales que se valen de ellos para analizar e intentar diagnosticar posibles escenarios en diversos ámbitos. EI VUCA está en el ADN de nuestro entorno y como Gordon Fletcher y Marie Griffiths postulan en un artículo dedicado a la transformación digital producida durante el confinamiento por la pandemia producto del COVID-19 «el VUCA es todavía impredecible» (Fletcher, Griffiths, 2020).

Si bien no podemos predecir todas las variables con las que nos encontraremos en el futuro, sí podemos realizar un diagnóstico lo más ajustado posible, e intentar vislumbrar cuál es la tendencia en los cambios relacionados con la lectura. Have y Stougaard Pedersen (2016:14) nos hablan de las variaciones que tienen que ver con la lectura en nuestra práctica diaria y en la interacción con nuestro entorno. Estos cambios no solo reemplazan la interacción con una pantalla en vez del papel, sino con un cambio de lectura con los ojos a otro que se realiza auditivamente, en una transformación semiótica de lo visual al audio, con la voz como un importante agente de este giro conceptual.

Jorge Carrión, en su ensayo Lo viral resalta el éxito de descargas que obtuvo un pódcast, en un contexto que él denomina como «la omnipresencia de las voces digitales», y que explica del siguiente modo:

Con más de seis millones de descargas desde su estreno en 2016, El gran apagón muy probablemente sea el pódcast de ficción en español más escuchado de la historia. Y ya han sobrepasado el millón de descargas las dos temporadas emitidas de Guerra 3, que estrenaron dos años después los mismos creadores, el guionista José A. Pérez Ledo y la directora Ana Alonso. Mientras que la primera historia fabula las consecuencias de una intensa tormenta solar, que deja sin electricidad al planeta entero, la segunda reconstruye los movimientos mediáticos, políticos y militares que conducen a la Tercera Guerra Mundial.

Tal vez porque ambos excelentes relatos coinciden en ser globales y conspiranoicos, de pronto he sido consciente de que no es casual que la explosión del formato pódcast y del audiolibro -en cuyo contexto se inserta el fenómeno de las ficciones sonoras- haya coincidido con la paulatina omnipresencia de voces digitales en nuestras vidas cotidianas. No hacen más que multiplicarse los chatbots, los mensajes sonoros, las interfaces de búsqueda, los asistentes personales, los dispositivos conversacionales, los auriculares inalámbricos y los sistemas de reconocimiento por la voz. Las grandes empresas tecnológicas tramaron una gran ficción sonora hace más de una década, que se ha ido convirtiendo en una realidad unánime. (Carrión, 2020: 141-142)

Ormaechea y Fernández Delkader (2019:16) plantean que nuestra jornada se está audificando y no solo por el aumento del consumo en formato audio sino porque lo sonoro también está irrumpiendo en la forma de interactuar con las tecnologías. Según citan los autores escribimos a mano 31 palabras por minuto, 70 palabras si es a máquina, pero podemos emitir 200 palabras por minuto cuando hablamos. La explosión de la inteligencia artificial y el Procesamiento del Lenguaje Natural (PNL) añaden condiciones que explican el auge de los nuevos dispositivos electrónicos relacionados con la voz, como los altavoces inteligentes y las nuevas interfaces parlantes.

En este trabajo destacan que, si bien el consumo social del audio es difícil de cuantificar, la mensajería tiene un gran potencial como herramienta de descubrimiento y consumo de audio. La mensajería, según la AIMC ${ }^{12}$, es utilizada por el $96,9 \%$ de los españoles y las actividades más frecuentes son: envío de vídeos, fotos y audios. Este estudio también vaticina nuevos formatos de contenido que contribuirán más a la audificación de la que hablan Ormaechea y Fernández Delkader.

\footnotetext{
${ }^{12}$ Asociación para la Investigación de Medios de Comunicación
} 
Schulz (2004:89) puntualiza que la música, la radio y los audiolibros convergen en una tecnología de entrega individualizada y computarizada como la de los iPods, y se amalgaman con las actividades diarias de la vida privada y social.

Casi en la introducción de su famoso libro Sounds moves, Michael Bull nos advierte que por primera vez en la historia la mayoría de los ciudadanos de culturas occidentales posee la tecnología para crear su «propio mundo auditivo privado $»^{13}$, se muevan por donde se muevan. Más adelante nombra algunos elementos que hacen posible esta universalización:

IPod culture represents a world in which we all possess mobile phones, iPods or automobiles -it is a culture which universalises the privatisation of public space, and it is a largely auditory privatization. (Bull, 2007:4)

Emergen nuevos lugares y espacios comunes: trayectos de casa al trabajo (commuting) se convierten en un lugar común para la escucha. No podemos pasar por alto que viajar solo en el coche es el modo preferido de viaje en Europa y América. En España, más del 47 \% de los oyentes escucha al volante. De la soledad en los desplazamientos en coche habla Robert Putnam en su prestigioso libro Bowling alone, en el que realiza un riguroso estudio sobre los cambios acontecidos en la sociedad americana en los 25 años anteriores al año 2000. Los desplazamientos en coche son solo una metáfora de todos los cambios que se fueron desarrollando en las diversas sociedades en las que los ciudadanos tienden a realizar cada vez más actividades de forma aislada (Putnam, 2001).

Si bien existe esta experiencia de privatización, aislamiento o soledad en espacios públicos, en las ciudades este recogimiento crea una disconformidad, un miedo al silencio, que se resuelve con el uso de medios de sonido móviles (mobile sound media). Las tecnologías cumplen una doble función al mismo tiempo: aíslan y conectan (Bull, 2007:9).

La experiencia urbana es sometida a una ghettoisation, de la cual el uso de los iPod es su más reciente manifestación, y que transforma la naturaleza polirrítmica en sonidos interiorizados monorrítmicos de los usuarios. Las tecnologías permiten cerrarse o aislarse de aquella naturaleza urbana llena de estímulos (ibídem, 28).

Los usuarios de iPod viven en diferentes mundos, dentro de matrices y capas de sonido mediatizados. Según Bull, los usuarios están satisfechos con estos procesos de «filtrado», dejando pasar solo aquello que quieren escuchar y permaneciendo en su propia burbuja sonora que comienza al salir de sus casas y finaliza al llegar a destino.

El denominado "filtrado» se convierte en algo completamente natural para los usuarios de las tecnologías móviles, a medida que va permeando la experiencia cotidiana. Bull lo explica del siguiente modo:

Esta es una mecánica esencial para los usuarios del iPod que subjetivizan el espacio- lo consumen, como si fuera un artículo de compra. La experiencia tecnológica es experiencia fetiche-la experiencia se convierte en real o hiperreal precisamente gracias a la tecnología-y a través de la apropiación tecnológica. El impulso utópico de transformar el mundo sólo ocurre en el imaginario -en su instrumentalización tecnológica- el mundo permanece intacto. Los usuarios prefieren vivir en este espacio tecnológico en el que la experiencia está bajo control manejada y plasmada estéticamente- mientras que la naturaleza contingente del espacio urbano y del «otro» es rechazada. (2010:61)

\footnotetext{
${ }^{13}$ Own private mobile auditory word (trad. a.)
} 
Bajo esta lógica Bull argumenta que todo espacio es en potencia un no-lugar, en la medida en que se le puede asignar una realidad diferente y privada. El significado que cada persona le imprime a los espacios de las ciudades deriva, según el autor, de su playlist (Bull, 2007:37).

Siguiendo esta tendencia a la que hace referencia el citado investigador, gracias a la ubicuidad de los audiolibros, podemos inferir que los mismos van abriéndose un lugar a nuevos espacios, no restringiéndose solo a los transportes, como en un comienzo, e imbricándose cada vez más con los sonidos urbanos.

Aquí hay que tener en cuenta que los libros electrónicos comparten con los audiolibros las cualidades de ubicuidad y accesibilidad, pero los audios logran crear, en palabras de Michael Bull, «una burbuja» en torno a las personas, modificando incluso la forma de relacionarse con el medio: "La ciudad es percibida a través de los productos de la industria cultural en forma de música, libros auditivos o el iPod» (Bull, 2010:61).

En relación con la escucha de audios en España, la Asociación para la Investigación de Medios de Comunicación de España (AIMC) realizó un estudio que registró que el mayor consumo se da en las siguientes franjas horarias: entre las 07:00 y 13:00 por la mañana y por la tarde, entre las 18:00 y las 20:00 h y un último pico al llegar la medianoche.

En línea con los resultados de esta investigación y evaluando los citados horarios, podemos mencionar una de las conclusiones a las que arriban las autoras Have y Stougaard Pedersen (2016:14): el aumento de los trayectos de casa al trabajo y del ejercicio físico en las sociedades occidentales modernas afectó el desarrollo y aumento del consumo de audiolibros.

La empresa sueca Storytel realizó también su propio estudio sobre la escucha de audiolibros a nivel global, y los resultados arrojados fueron los siguientes:

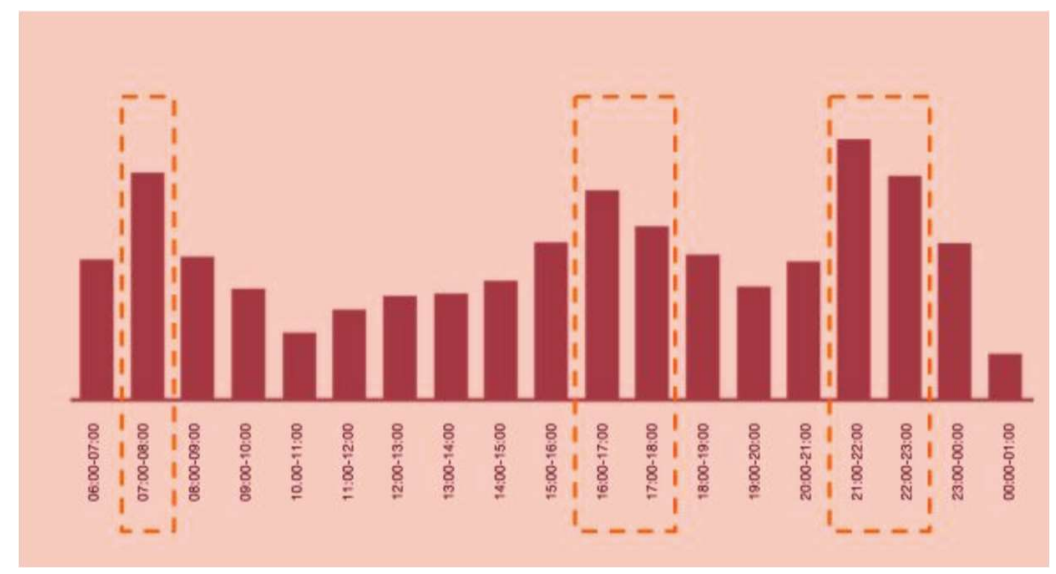

Ilustración 3. Franjas de horario de escucha de audiolibros Fuente: Bookwire. "All about audio" 2020

En el gráfico se puede observar un desplazamiento de los horarios del segundo y tercer pico del día si comparamos este estudio global frente al español, lo que indica que en España la segunda y tercera franja de horario se producen más tarde, lo que puede estar relacionado con los usos y costumbres del país. 


\subsection{CAMBIOS TECNOLÓGICOS}

El escritor Jorge Carrión (2020c, párr. 1) enuncia en un reciente artículo que «hoy, cada libro es, al menos, tres: papel, píxel y audio». La influencia que puede tener una obra depende de la capacidad para entusiasmar a lectores rápidamente y de su potencial de adaptarse a otros canales y lenguajes. El éxito puede medirse tanto por lo viral de su aparición como por las sucesivas adaptaciones que presente.

Según Carrión, el nuevo canon libresco rompe con los antiguos códigos de bestsellers. Los libros que se consagran son libros sólidos y ambiciosos, de estética realista y éxito inesperado. Primero se editan las versiones en ebook y audiolibro y, tras ellas, las películas, series, obras de teatro o cómics perpetúan la obra, y, como indica:

\section{[...] les aseguran una influencia sociocultural que, en estos tiempos de competencia feroz por la atención y el} tiempo, difícilmente puede conseguir la literatura sin otros lenguajes como aliados». (Carrión(c): 2020, párr. 6)

Las editoriales están en este momento publicando más audiolibros que nunca. Muchas de ellas están dejando de tercerizar ese servicio y se convierten en productoras de audio también, como veremos más adelante.

Antonio Rodríguez de las Heras (2019) presenta un interesante artículo en el que reflexiona acerca de la palabra hablada y de los cambios que se suscitaron para llegar al actual panorama digital relacionado con los audios.

Según este profesor, en primer lugar, el mundo ilimitado de la información tuvo su gran salto, del papel a los bytes. De esta forma y a través de la hipertextualidad, el lector no encontraría la información empaquetada, sino que podía, a través de enlaces invisibles, saltar de un texto a otro. Un segundo cambio se debió a la reducción del tamaño de la pantalla; el mundo que antes conformaban el ratón y la pantalla da paso a una nueva configuración con las tecnologías y la información. Este avance supone para Rodríguez de las Heras una importante aceleración del proceso de miniaturización.

Los dos cambios tecnológicos que menciona Rodríguez de las Heras lo llevan a reflexionar acerca del perfil del lector y de la relación de este con los dispositivos móviles. Según su artículo, el móvil es un aparato ligero y pequeño pero que demanda toda nuestra atención, no solo a través de nuestra mirada, sino también con el sostén de nuestras manos. En sus palabras «son unos gramos de peso, pero las manos le pertenecen, así que las demás cosas y acciones del entorno se vuelven ajenas. Hoy las disfunciones que provocan esta atracción son bien perceptibles y generalizadas» (Rodríguez de las Heras, 2019:39).

Más adelante agrega que «la estructura hipertextual de la información digital y la habituación rápida y universal (...) nos ha preparado además para una relación dialógica con la información» (ibídem, 40). El hecho de depender de una pantalla tanto para cuestiones sociales como informativas nos hizo muy dependientes de ella, según Rodríguez Las Heras, «difuminando la sensación de presencia del lugar donde estamos» (Rodríguez Las Heras, 2018, párr. 8). 
Ante esta situación, el catedrático se pregunta si podría haber un retroceso o una vuelta atrás del proceso que ha seguido la tecnología hasta el momento y que ha desembocado en esta relación simbiótica de las personas con la tecnología móvil. Concluye que el cambio podría estar dado por una sustitución del píxel por la voz, como enuncia a continuación:

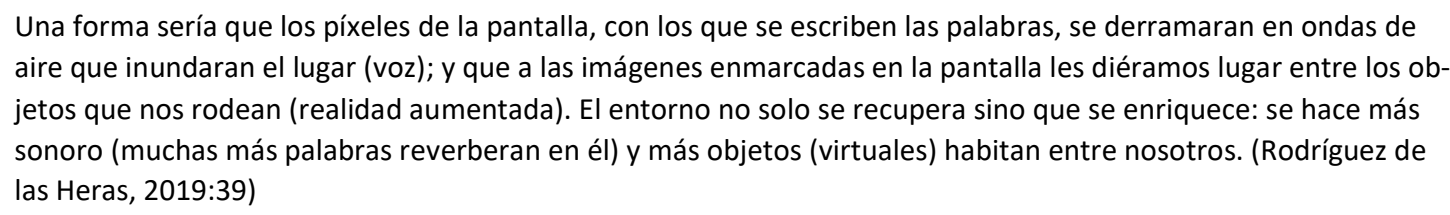
aire que inundaran el lugar (voz); y que a las imágenes enmarcadas en la pantalla les diéramos lugar entre los objetos que nos rodean (realidad aumentada). El entorno no solo se recupera sino que se enriquece: se hace más sonoro (muchas más palabras reverberan en él) y más objetos (virtuales) habitan entre nosotros. (Rodríguez de las Heras, 2019:39)

Un aspecto por destacar es que, si bien vislumbra un prolífico futuro en relación con el audio, en la actualidad la educación está inclinada todavía hacia la cultura escrita, inmersa en la redundancia de la comunicación audiovisual y la omnipresencia de la pantalla, razón por la cual no se ha producido hasta el momento en este ámbito un avance hacia la oralidad.

Son hasta el momento casos muy aislados aquellos en los que los contenidos audio están presentes en las aulas. En Estados Unidos la Audio Publishers Association en su página web comparte programaciones para que los educadores puedan incluir audiolibros en sus clases, y también realiza lo propio para padres que quieran formar a sus hijos a través de dicho formato.

Volviendo a los avances tecnológicos, además de los ya citados relacionados con la hipertextualidad y la miniaturización de los móviles, el siguiente salto fue la creación de un ecosistema de aplicaciones específicas destinadas para estos dispositivos móviles (las llamadas aplicaciones o apps) distribuidas a través de diferentes tiendas en línea, como Google Play o Apple Store, configurando un nuevo modelo de distribución y uso de contenidos digitales.

Cada aplicación descargada cuenta con un seguimiento de actualizaciones que hacen que el usuario reciba periódicamente notificaciones y mejoras de los sistemas elegidos. Además, puede entenderse como un sistema de fidelización, ya que cada cierto tiempo recibimos el aviso de una nueva versión de la aplicación elegida, lo cual nos da cuenta de que hay alguien que está detrás de nuestro programa trabajando para que el sistema no se torne obsoleto y no lo sustituyamos por otra aplicación. Las apps especializadas en audiolibros se han multiplicado en los últimos tres años, y existe una gran variedad, desde las que se ofrecen de forma gratuita, pasando por modelos de suscripción o de venta unitaria. (Profundizaremos en los modelos de distribución en el apartado 5.16).

Se vislumbra otro importante avance tecnológico, según Ana Ormaechea, directora de Producto Digital de PRISA Radio, con la popularización en España en unos cinco años de los smart speakers.

En junio de 2018 llegó a España el Google Home, un altavoz inteligente, y unos meses después Amazon comercializaba sus altavoces Echo en España. En diciembre de 2019 dos millones de internautas españoles ya comenzaron a utilizan estos altavoces.

Según Ana Ormaechea y Pablo Delkader, ya no solo escuchamos audio, sino que también interactuamos con él, en una especie de audio conversacional (Ormaechea y Delkader, 2019:16).

Jorge Carrión menciona en su libro Lo viral un ensayo de Kai-Fu Lee, un programador, inversor y divulgador chino-americano que diseñó el primer sistema de reconocimiento independiente de voz. En este ensayo, titulado Superpotencias de la inteligencia artificial, Lee afirma que la llamada Inteligencia Ar- 
tificial nos está invadiendo en cuatro olas sucesivas. Las primeras son la IA de internet y la IA empresarial; la tercera IA tiene que ver con la digitalización del mundo físico, y el aprendizaje para reconocer nuestros rostros, «se trata de la transformación radical de las interacciones entre humanos y máquinas, borrando los límites entre lo digital y lo físico»; la cuarta está por llegar y supondrá la automatización de trabajos y procesos. Este es el contexto favorable a la explosión creativa relacionada con el audio al que se refiere Jorge Carrión, porque según él, detrás del auge o declive de un determinado lenguaje o canal existen intereses empresariales.

La nueva realidad tecnológica nos conmina a ser consumidores, espectadores o lectores cada vez más conscientes y críticos. No es un delirio pensar que, como el tacto de los teclados y de las pantallas sigue siendo frío, los tecnólogos han encontrado en el sentido del oído una estrategia para inyectar calidez en nuestras relaciones con nuestra maquinaria cotidiana. Y que las series para escuchar de Spotify o Storytel, o los documentales sonoros de la BBC, son una consecuencia directa de ese plan maestro. (Carrión, 2020:144)

\subsection{DIFERENCIAS ENTRE LA LECTURA DE IMAGEN (O IMPRESA) Y LA AUDIOLECTURA}

Es frecuente escuchar el cuestionamiento de si es lo mismo escuchar un libro que leerlo. $Y$ de este interrogante se desprende, inexorablemente, la duda tácita de si el audiolibro posee el mismo nivel de importancia o relevancia que el libro impreso.

Según Cordón-García (2018:176) «muchas de las respuestas a estos interrogantes están impregnadas de un prejuicio culturalista que afecta no solo a los audiolibros sino a cualquier contenido digital». Según el catedrático, la legitimación lectora estaría relacionada con el soporte impreso como medio consagrado para el ingreso a la cultura, mientras que otros formatos son subestimados, penalizados por prejuicios o valoraciones infundadas.

Creemos que para ofrecer una respuesta a este respecto debemos prestar atención a los siguientes conceptos:

\subsubsection{La lectura, la literacidad y su relación con la oralidad}

La visión moderna y científica de leer es la que va más allá de la oralización de grafía y pone el acento, no solo en la capacidad de decodificar el mensaje, sino de comprenderlo. Para este fin, es necesario desarrollar previamente varias destrezas mentales o procesos cognitivos (Cassany, 2006:21).

El término preciso para referirse a las prácticas de comprensión de escritos es literacidad y abarca todo lo relacionado con el uso del alfabeto - desde la correspondencia entre sonido y letra hasta las capacidades de decodificación- (ibídem, 38).

Cassany (ibídem, 38-40) desglosa el abanico de elementos que abarca la literacidad:

1. El código escrito: que estaría compuesto por las reglas lingüísticas que gobiernan la escritura (ortografía, sintaxis, morfología y párrafos) sumadas las convenciones físicas y formales como el diseño, puntuación y maquetación. 
2. Los géneros discursivos: básicamente se refiere a las convenciones de cada tipo de discurso, según este sea una carta, un informe, o un soneto, por ejemplo, teniendo en cuenta cuál es la función que desempeña el mismo para la comunidad en relación con el contenido y la forma.

3. Los roles de autor y lector: Cassany se refiere a qué función desempeñan los locutores teniendo en cuenta varios niveles: el tratamiento, referencias, grado de subjetividad, etc.

4. Las formas de pensamiento: ya que el contenido de cada discurso parte de unos métodos y unos sistemas conceptuales particulares.

5. La identidad y el estatus como individuo, colectivo y comunidad: en este punto incluye rasgos y atributos que los individuos - y en otras escalas: colectivo y comunidad - consiguen a través de un determinado discurso, ya sea el beneficiario el emisor o el receptor del mismo. Los ejemplos que Cassany incluye son: estatus, poder, valores, reconocimiento, etc.

6. Los valores y representaciones culturales: en este último punto incluye los rasgos y atributos de cualquier elemento de la realidad (religión, deporte, ecología, política, etc.) que han sido transmitidos a través del discurso escrito, ya que muchos de ellos se han construido o se fundamentan en la escritura.

Según estos elementos, la literacidad, es ese complejo conjunto de aptitudes, habilidades y características que exceden nuestra capacidad lectora, y a la que suman otra serie de características que conforman nuestra identidad. No podría existir una literacidad sin una comunidad en la cual existe un emisor y un receptor, ya que la sinergia entre ambos configura el germen para el desarrollo de diferentes actividades, formas de pensamiento y creencias.

Cassany (ibídem, 40) remarca que la literacidad no incluye solo lo escrito, ya que actualmente se puede acceder a «muchos discursos a través de la oralidad, que se han planificado previamente con la escritura», e incluye a la radio, a la televisión, y a charlas e intervenciones orales, que según sus palabras tienen un envoltorio acústico, pero fueron planteadas en formato impreso.

\subsubsection{Definición de términos relacionados con la escucha de audiolibros}

Consideramos que elucidar la terminología referente a la escucha de audiolibros es indispensable para comprender nuestro objeto de estudio y dotar a nuestra investigación de la rigurosidad académica necesaria.

No existe consenso en la bibliografía estudiada en cuanto a la palabra para referirnos a la figura del lector de audiolibros. Si acudimos al diccionario de la Real Academia Española no encontraremos los términos «audiolectura» ni «audiolector». Sin embargo, desde el año 2017 sí ha sido incorporada al diccionario el término: «audiolibro».

Volviendo a la figura del lector, encontramos una referencia que nos da respuesta al término que podríamos utilizar para referirnos al receptor de una obra en formato aural. Esta referencia fue localizada en Twitter, lo cual da cuenta de la incertidumbre que tienen los usuarios de audiolibros; $y$, por otra parte, de la actualidad que reviste el tema. En la cuenta de twitter de Fundéu BBVA —Fundación 
patrocinada por la Agencia Efe y el BBVA, y asesorada por la RAE - un usuario realizó la siguiente consulta en el año 2018: «¿Cómo se llama la persona que escucha audiolibros?».

La Fundación se pronunció al respecto y contestó que se denominan «lectores de audiolibros» y agrega en dicha respuesta que también puede utilizarse el término «audiolectores».

A fin de incluir todos los términos relacionados con la escucha de un libro, y clarificar de esta forma las denominaciones que podemos encontrar en nuestra bibliografía, debemos primero profundizar en las diferencias terminológicas con las que nos hemos encontrado, por ejemplo, entre: "oír un audiolibro» $y$ «escuchar un audiolibro».

Comenzaremos con la distinción de los dos verbos que en el idioma español están relacionados con la audición: oír y escuchar. Según recoge el Diccionario de la Real Academia oír significa «percibir con el oído los sonidos» mientras escuchar "aplicar el oído para oír», prestar atención a lo que se oye.

En el Diccionario Panhispánico de las dudas, sugieren que, puesto que oír tiene un significado más general que escuchar, casi siempre puede usarse en lugar de este y que menos justificable sería el empleo de escuchar en lugar de oír para referirse a la acción de percibir un sonido a través del oído sin que exista intencionalidad previa por parte del sujeto; pero es utilizado desde la época clásica, incluso por autores de prestigio, especialmente de América Latina.

Se desprenden de las anteriores dudas terminológicas las opciones relacionadas con el receptor del audiolibro: "oyente» y «escuchante», adjetivos que han sido muy debatidos recientemente, producto del propio auge del formato audio.

La Real Academia Española indica que tanto «oyente» como «oidor» (que tiene además otros sentidos) se ajustan al sentido de "que oye», son por lo tanto válidas y figuran en el diccionario académico. Como derivados de «escuchar», el Diccionario de la Lengua Española registra como sinónimos «escuchador» y "escuchante». Cabe mencionar que esta última es una palabra que estuvo en dicho diccionario desde el año 1732 hasta 1984 y desapareció en las siguientes ediciones, para reaparecer en la edición del tricentenario en el año 2014.

Cervantes emplea la palabra, en el tomo II, capítulo 33 del Quijote:

Y cómo que no mienten — dijo a esta sazón doña Rodríguez la dueña, que era una de las escuchantes-: que un romance hay que dice que metieron al rey Rodrigo vivo en una tumba llena de sapos, culebras y lagartos, y que allí a dos días dijo el rey desde dentro de la tumba, con voz doliente y baja: Ya me comen, ya me comen, por do más pecado había. (DQ, II, XXXIII)

Otros grandes referentes de la literatura española como Tirso de Molina y Góngora también la emplean en sus obras.

María José Fernández Vallés -más conocida como Pepa Fernández- exdirectora del programa radial No es un día cualquiera se dirigía a sus oyentes con el apelativo de "escuchantes», ya que consideraba que quienes sintonizaban el programa radial lo hacían con voluntad y de forma activa. En el blog de RTVE (Radiotelevisión Española) se puede encontrar un artículo con la fundamentación de la elección del término por parte de la periodista, sustentada en la diferencia entre los verbos oír y escuchar (Fernández Vallés, 2010). Cabe mencionar que en el lapso de tiempo en el que el programa salió al aire, la palabra ya había sido eliminada del diccionario RAE, por lo que hubo muchos cuestionamientos de seguidores del programa radial que creían que su uso no era adecuado. Hubo quienes acudieron a la 
Real Academia Española a través de sus redes sociales a formular sus dudas. Se pueden ver más de una decena de consultas sobre el mismo tema si consultamos la plataforma en línea de la RAE. Las dudas fueron disipadas cuando la propia Academia, en el año 2014, empleó el término en cuestión indicando que quien era en ese momento su director, José Manuel Blecua, se dirigiría a los «escuchantes» de No es un día cualquiera, a través de sus redes sociales, en la Biblioteca Nacional Española.

Conforme a lo anteriormente expuesto, si bien Fundéu indicó que los términos «lectores de audiolibros" y "audiolectores" serían los más correctos para referirse a una persona que escucha audiolibros, no debemos descartar ni considerar erróneos los términos «oyentes de audiolibros» ni «escuchantes de audiolibros».

En inglés también existe la misma distinción entre escuchar y oír (listening y hearing). Tattersall Wallin y Nolin (2020), investigadores suecos en el área de la información y documentación, toman el modelo de Michel Chion (1993) para aplicarlo a la escucha de los audiolibros y sugieren que la escucha de un audiolibro se puede considerar una escucha semántica, ya que implica dotar de sentido al lenguaje hablado.

El modelo citado, de Michael Chion (1993:28-33), presenta tres tipos de escucha: la «casual», la «reducida» y la "semántica». La escucha casual consiste en servirse del sonido para informarse de su posible causa. Chion propone un ejemplo: el sonido que puede aportar un recipiente cerrado que cae y golpea el suelo nos puede brindar información acerca de si el mismo está vacío o lleno. Dicho sonido casual puede a su vez ser visible o invisible, es decir, puede que el sonido constituya nuestra principal fuente de información. El sonido "reducido» se focaliza en las características del propio sonido sin interpretación de la causa o el significado; y, por último, el tipo de escucha "semántico» es el que se refiere a un código o a un lenguaje para interpretar un mensaje: puede ser el lenguaje hablado, pero también se extiende a otros códigos, como puede ser el morse.

Tattersall Wallin y Nolin sugieren que «la lectura por escucha es una forma específica de escucha semántica separada de otras formas de escucha semántica, como aquellas involucradas en conversaciones o consumo de música vocal» (trad. a.) $)^{14}$ (ídem).

\subsubsection{Diferencias entre la lectura textual y la audiolectura}

Los comienzos del lenguaje oral en los seres humanos se remontan tal vez a 2 millones de años atrás y fueron acompañados por cambios cerebrales que facilitaron su manejo. Este no es el caso del lenguaje escrito, ya que el primer alfabeto surge hace unos 4.000 años -el primer alfabeto formal conocido surgió en Egipto en el año 2000 a. C-.

La impronta cultural más destacada de cada sociedad, su idioma, pasa por un proceso similar que va de la oralidad a la escritura; $y$, a nivel individual, el proceso de aprendizaje de la primera lengua adquirida por un niño comienza por la oralidad hasta llegar a la lectoescritura.

La neurolingüística moderna, la que estudia las relaciones entre cerebro y lenguaje, comienza en el año 1865. En este año dos científicos franceses, Michel Dax y Paul Broca (citados en Manguel, 2014:48-

\footnotetext{
${ }^{14}$ «Reading by listening is a specific form of semantic listening separate from other forms of semantic listening such as those involved in conversations or consumption of vocal music» (original).
} 
50), realizaron sendos estudios que arrojaron que, como resultado de un proceso genético, el ser humano viene al mundo con un hemisferio cerebral izquierdo que se termina convirtiendo en la parte dominante del cerebro a la hora de codificar y decodificar el lenguaje. Existe un número mucho menor de personas, en su mayor parte diestras o ambidiestras, que desarrollan esa función en el hemisferio cerebral derecho. Según Manguel, ninguno de los dos hemisferios actuará como codificador o decodificador hasta que la persona se exponga a la práctica del lenguaje.

Nuestra habilidad para la lectura es previa al momento histórico en el que alguien comenzó a escribir. Y según el profesor Andrés Roch Lecours, la exposición exclusiva al lenguaje oral quizá no baste para que uno de los dos hemisferios desarrolle las funciones del lenguaje. Es necesario para esto, aprender a leer (Citado en Manguel, 2014:50). Leer reclama dos fases: «ver» primero la palabra y «considerarla» luego, según la información previamente recibida. Según las propias palabras de Lecours:

\begin{abstract}
Es como si la información que los ojos reciben de la página viajara por el cerebro a través de una suerte de conglomerados de neuronas especializadas, localizados en secciones concretas del cerebro, efectuando funciones específicas. Todavía no sabemos exactamente en qué consiste exactamente cada una de esas funciones, pero en determinados casos de lesiones cerebrales uno o varios conglomerados se desconectan, por así decirlo, de la cadena, y el paciente es incapaz de leer determinadas palabras, o cierto tipo de lenguaje, o deja de poder leer en voz alta, o reemplaza un conjunto de palabras por otro. Las posibilidades de desconexión parecen ser infinitas. (Lecours, citado en Manguel: 2014, p. 50)
\end{abstract}

Matthew Rubery (2016:14) también resalta la complejidad del proceso de lectura, que no incluye una sola actividad neurológica, sino que se conforma de una serie de múltiples procesos cerebrales. La comprensión lectora depende de la ejecución e integración de muchos procesos cognitivos.

Leer es, para Alberto Manguel, «un proceso de reconstrucción laberíntico, desconcertante y común a todos los lectores y al mismo tiempo, personal» (2014:52), y prosigue haciendo notar que seguimos hoy en día leyendo sin disponer de una definición satisfactoria de qué es lo que estamos haciendo.

Matthew Rubery realiza una distinción entre leer con los ojos (en donde trabaja la corteza visual del cerebro) y leer con los oídos (proceso en el cual trabaja la corteza auditiva). Estudios de imagen del cerebro han identificado un área del cerebro dedicada al proceso de las palabras. Desde un punto de vista neurocientífico, leer implica decodificar símbolos gráficos en lenguaje utilizando una pequeña región del cerebro asociada a la visión. De hecho, menciona que personas que han sufrido un accidente en esta área particular, pierden la habilidad de leer. Leer no involucra solamente la vista, es un proceso complejo en el que están imbricadas la visión y la audición. La lectura adulta involucra un balance entre el sonido de las palabras y la traducción silenciosa a su significado (2016:14-15).

Para Have y Stougaard Pedersen lo fundamental es que la audiolectura es una forma de leer, al no considerar la lectura como un proceso exclusivamente visual. Las investigadoras agregan que no se lee la radio, se escucha; pero leemos audiolibros, porque estos han sido impresos antes de nuestra experiencia decodificadora (2016:149). Afirman que la lectura de audiolibros no es menos profunda que la lectura visual, y enuncian que, en ocasiones, y dependiendo de las circunstancias y la capacidad de atención, puede incluso ser más profunda (ibídem, 150). Para estas investigadoras, la tecnología es el elemento que ha dado nueva forma al acto de leer, tornándolo multimodal y multisensorial.

Respecto a lo visual y lo hablado en la formación de los lectores, son especialmente interesantes los estudios en niños. Ellos, para volverse lectores deben aprender el mapping (mapeo) entre el lenguaje hablado y las palabras escritas. Para el inglés y la mayoría de los lenguajes, este mapeo está basado en 
el sonido, incluso los estudios resaltan que los niños sordos están en desventaja para desarrollar habilidades de lectura - les lleva unos cuatro años más que a los niños sin esta dificultad auditiva- (Goldin-Meadow; Mayberry; 2001).

En el caso de los ciegos, es interesante destacar que algunos experimentos han llegado a la conclusión de que es posible leer sin utilizar la vista, ya que la visión no es la única que conduce al área responsable por el procesamiento de textos. Estudios de imagen revelan que, en ciegos congénitos adultos, la lectura en braille utiliza la misma área de la corteza visual que la de lectores que no tienen impedimento visual, por lo cual la lectura táctil es equivalente a la lectura visual, ya que ambas actividades conllevan la traslación de códigos abstractos para el lenguaje (Reich, et al., 2011:363-368).

Incluso la lectura en silencio no es del todo realizada en silencio, ya que en el proceso de lectura está presente la llamada "voz interior», y según Rubery (2016:16) hablamos con nosotros mismos cuando leemos, utilizando nuestras voces, en un proceso denominado "subvocalización» en el cual pequeños movimientos en la laringe, lengua, labios y otros músculos involucrados en el discurso acompañan la actividad mental.

Estos descubrimientos fueron realizados gracias a registros electromiográficos, en los que se constata que músculos asociados con la articulación del lenguaje (como la laringe) se ponen en marcha incluso si se lee silenciosamente (Allen, 2020:211); en palabras de Rubery: «In a sense, we're reading aloud to ourselves even when reading silently ${ }^{15}(2016: 16)$.

En los últimos años se han realizado distintos estudios científicos que tienen como objetivo comprender cómo leemos y comparar las dos modalidades: la lectura convencional con la audiolectura.

En un artículo del año 2019, llevado a cabo por investigadores británicos (Taylor, Davis y Rastle, 2019) se ha rastreado cuál es la ruta neuronal que siguen los símbolos escritos a medida que van ganando significado y sonido.

Como sabemos, cada palabra lleva asociados un sonido y un significado. Se sabe que el proceso de transformación de símbolos en sonidos y significados tiene lugar en la corteza occipitotemporal ventral (VOT), pero no se contaba con los detalles que revelaran en qué áreas de la corteza (VOT) ocurría cada fase y cómo era el proceso de estos símbolos que comenzaban con la visualización de las letras hasta la transformación en sonidos con significado.

El experimento descubrió que la región posterior de la corteza occipitotemporal ventral es la encargada de procesar la información visual. En esa zona tiene lugar la decodificación del código alfabético, pero allí las palabras aún no poseen sonido. Esto sucede en la siguiente secuencia de pasos, para llegar a lo que entendemos por lectura y que se produce en la zona anterior. Dotadas de sonido y significado, los armazones de cada letra se llenan y cobran vida, o, dicho de otra forma: las oímos en nuestro cerebro.

Otro estudio realizado en el año 2016 en el Pew Research Center, por Rogowsky et al. y motivado por el creciente interés por los audiolibros, comparó las diferencias entre la escucha de audiolibros, la lectura de libros y una experiencia dual. Para esto separó en tres grupos de estudio a 91 participantes. El primer grupo escuchó secciones de Unbroken, un libro de no ficción sobre la Segunda Guerra

\footnotetext{
15 «En algún sentido estamos leyendo en voz alta cuando leemos en silencio» (trad. a.)
} 
Mundial, de la autora Laura Hillenbrand, mientras un segundo grupo leía las mismas partes en un ereader. Un tercer grupo realizaba tanto la lectura como la escucha del mismo texto.

Tras esta consigna, todos los participantes debían someterse a un quiz diseñado para medir cómo habían recibido (cuánto recordaban) el material. El resultado reveló que no se encontraron diferencias significativas entre los tres grupos.

Un nuevo descubrimiento fue realizado por un grupo de neurocientíficos de la Universidad de California, Berkeley, en septiembre de 2019. Los mencionados expertos crearon mapas interactivos que predicen qué parte del cerebro activa diferentes categorías de palabras. Una de las investigaciones, muy relevante para la comprensión lectora relacionada con los audiolibros, centró su foco en qué le pasa al cerebro cuando lee historias tanto escritas como oídas.

Este estudio arrojó evidencias de que diferentes personas comparten similares topografías semánticas (o significado de palabras), abriendo otra puerta hacia los pensamientos y las narrativas.

At a time when more people are absorbing information via audiobooks, podcasts and even audio texts, our study shows that, whether they're listening to or reading the same materials, they are processing semantic information similarly," dijo Fatma Deniza, una investigadora postdoctoral de neurociencias en Gallant Laboratorio en UC Berkeley. (University of California-Berkeley, 2019)

Para la realización del estudio liderado por Deniz, los participantes escucharon historias de The Moth Radio Hour, un pódcast muy popular en Estados Unidos, y luego leyeron esas mismas historias en papel.

Utilizando aparatos de RMI (resonancia magnética por imagen), los investigadores escanearon el cerebro en ambas situaciones, leyendo y escuchando, y estas fueron comparadas, encontrando que los mapas que creaban ambos sets de datos eran virtualmente idénticos.

La importancia de este reciente estudio que compara al audio con la imagen demostró que el cerebro activa las mismas regiones con la misma intensidad sin importar el método de entrada, sea la vista o el oído. Más allá de las diferencias que existen entre la escucha y la lectura, la comprensión general y el procesamiento de los detalles semánticos resultaron ser los mismos en ambos casos (English, 2020:424).

Estos estudios son especialmente interesantes para disléxicos, ya que se podrá sugerir la inclusión de más material en soporte audiolibros en las clases o para personas que tienen problemas relacionados con la imposibilidad de distinguir sonidos o fonemas que conforman palabras. En el trabajo mencionan que se podría replicar el estudio con estos grupos de personas y extenderlo a que hablen un idioma diferente al inglés.

Conforme este resultado, leer un audiolibro es leer, si nos referimos de nivel de comprensión y almacenamiento de información, dado que ambas actividades activan las mismas zonas cerebrales (vóxeles) de significados. Los resultados del estudio conducido por Fatma Deniz, autora principal del estudio, dan la razón a hipótesis postuladas previamente, como las del neurocientífico David Eagleman.

Pablo Eguía, miembro de la Sociedad Española de Neurología, también considera que tanto si hablamos de lenguaje oral como de lenguaje escrito, el cerebro descodifica las palabras e interpreta su significado, e indica que cuando se analizan las áreas del lenguaje se observa que tanto a nivel frontal, 
temporal y parietal existen redes neuronales que participan en el lenguaje y son las mismas (citado en Mendoza, 2020, párr. 9-10). 


\subsection{INVESTIGACIONES PREVIAS}

Lo que Have y Stougaard Pedersen denominaron en un artículo del año 2019 como la «revolución de los audiolibros» o el "auge de audiolibros» refiriéndose a las ventas que reportan los audiolibros digitales y al aumento de estos préstamos en bibliotecas de muchos países, se enfrenta al mismo tiempo al oxímoron «revolución silenciosa» que vemos en los medios de comunicación, tanto en el ámbito general como en círculos académicos.

Es cierto que poco se sabe sobre esta nueva vertiente editorial. Como señalan las citadas investigadoras Have y Stougaard Pedersen, en uno de los estudios más exhaustivos sobre el tema (2016), las investigaciones realizadas sobre los audiolibros son escasas pese a que el tema representa un fenómeno muy actual. El de Have y Stougaard Pedersen fue el primer trabajo que se fijó como objetivo desafiar la noción histórica de la escucha de audiolibros como una experiencia compensatoria y de segunda clase, y, en cambio, examinó el uso de los audiolibros como una experiencia auditiva contemporánea de primer orden.

En el mencionado libro, las investigadoras danesas realizan un relevamiento de los trabajos más importantes en el área de los contenidos sonoros, entre los que encontramos el de Wittnen (2002), Bednar (2010), Koepnick (2013) y Colbjornsen (2015). Se hace una mención especial al trabajo editado por Matthew Rubery (2011), en el cual el investigador inglés realiza un estudio muy detallado sobre este nuevo formato y también sobre los prejuicios más frecuentes con los que se enfrenta el audiolibro (véase apartado 5.9). De hecho, Have y Stougaard Pedersen, en el año 2013 (p.126) mencionan que el de Rubery es el único libro académico que tiene como objeto de estudio el audiolibro.

Tres años después de este artículo, las mismas investigadoras publicarían Digital audiobooks: new media, users, and experiences, una obra que podemos considerar como la más importante a nivel internacional sobre la temática. Matthew Rubery, también en 2016, publicaría su segunda gran obra The untold story of the talking book. Este último título de Rubery, trata en su gran mayoría de aspectos históricos y curiosidades del audiolibro, y representa un pilar en la investigación acerca del uso de este formato por parte de discapacitados visuales.

\subsection{DEFINICIÓN Y CONCEPTO DEL AUDIOLIBRO}

Es necesario establecer una conceptualización de los audiolibros, ya que como veremos a continuación, es un formato que no solo ha sufrido una aceleración en los últimos años, sino que a juzgar por el creciente interés en el tema se prevé una proliferación de estudios científicos al respecto.

La definición del audiolibro no es una tarea fácil por varios motivos, especialmente por el hecho de que se trata de un formato que ha variado con el paso de los años y ha conservado la misma denominación, tanto en inglés como en español. 
Mediante la indagación lexicográfica, lo primero que se constata es que la palabra audiolibro figura en el Diccionario de la Real Academia Española recién desde el año 2017, con la siguiente definición: «Grabación sonora del texto de un libro».

Gómez Díaz et al., (2016:83) enuncian que: "Los audiolibros digitales son locuciones narradas o leídas automáticamente por programas informáticos, de libros ya existentes o creados expresamente para ser difundidos en este formato audible. Pueden ser escuchados en el ordenador, tabletas, teléfonos inteligentes, IPod, reproductores de MP3, etcétera».

Have y Stougaard Pedersen (2016:3) indican en su obra que el término audiobook (audiolibro) fue introducido en relación con los audio casetes, como resultado de la movilidad que ofrecían los walkman y los reproductores de los coches.

Matthew Rubery (2016:4) puntualiza que actualmente se utilizan los términos talking book y audiobook indistintamente para describir cualquier narrativa grabada en un registro, que puede ser casete, compac disc, MP3 u otro formato. Quizás talking book es un poco más extensivo, ya que el escritor titula su libro The untold story of the talking book, justificando su elección en que este nombre cubre todas las grabaciones de libros.

En un comienzo y por más de 50 años fueron llamados phonografic books; agencias de gobierno y de caridad hablaban de talking books cuando se referían a los discos de vinilo y de goma laca en los años 30 para las personas ciegas; $y$, la discográfica Caedmon label se refería a spoken word records en los años 50.

En los años setenta dos editores de audio protestaron porque el nombre de sus propias firmas: Books on Tape, Inc. y Recorded Books eran utilizadas para denominar al formato audio. La prensa siguió utilizando alternativas como: audio cassettes, spoken cassettes o recorded readings. Según Rubery no hubo consenso hasta los primeros años de los 90, cuando los editores decidieron eliminar la confusión de los diferentes términos utilizados en la industria. En el año 1994 la Audio Publishers Association confirmó el término audio book como una palabra estandarizada (ibídem, 2).

Have y Stougaard Pedersen analizan el término en inglés audiobook teniendo en cuenta su composición. Como podemos observar y así como el término en español «audiolibro», se compone de book, que determina el medio, y audio que determina el modo sensorial en el que el medio es percibido.

Para las autoras puede haber especulaciones en cuanto a cuál sería el medio: si book o radio; el contenido: literature o voice o el modo sensorial: sound, audio u oral. Teniendo en cuenta estas variables ellas proponen otras alternativas, como oral literature, o books in audio ya que se acentuaría la parte auditiva. También incluyen audio narratives que abrirían los límites del formato a medios mucho más amplios y otros géneros. Dentro de las audionarrativas, podrían caber grabaciones de storytelling, radio drama, radio pódcasts, etc. (2016:153-154). Sin embargo, las autoras consideran que introducir un nuevo término podría resultar confuso, a pesar de que podría ser más apropiado. Muestra de su opción conservadora es el título de libro que editaron en el año 2016: Digital Audiobooks, new media, users and experiences.

En cuanto al paso del formato analógico al formato digital, conviene antes hacer notar que tanto en inglés como en español hubo una diferenciación terminológica que tuvo que ver con el paso del libro tradicional impreso textual al libro electrónico o digital. El libro impreso no sufrió ningún cambio, siguió 
denominándose tanto en español como en inglés libro o book, mientras que cuando nos referimos a un libro en formato digital, se le agrega el prefijo «e» en inglés: e-book. En español se suele utilizar la palabra en inglés, y si se utiliza en español, solemos llamarlo «libro electrónico».

Sin embargo, no hubo una denominación especial para los audiolibros que pasaron de un soporte analógico, como es el caso del casete, a un soporte digital o electrónico, como son los CD o los audiolibros en MP3 que podemos encontrar en línea o almacenados en un dispositivo móvil. Tanto en español como en inglés se utiliza la misma denominación: audio book o audiobook en inglés, y audiolibro en español.

En la bibliografía podemos encontrar la denominación «audiolibros digitales», o digital audiobooks haciendo alusión a los libros exclusivamente digitales, pero hay que tener en cuenta que coloquialmente se utiliza simplemente la palabra "audiolibros» o audiobooks, lo cual puede despertar en el oyente un simbolismo ligado a los antiguos soportes analógicos. Es un detalle a tener en cuenta en posteriores estudios, ya que puede manifestarse ambigua la utilización de esta última forma. En bibliotecas, incluso, podría disuadir a los usuarios del préstamo de audiolibros, ya que lo asocian directamente con soportes analógicos. Existen muchos usuarios que nunca utilizaron una plataforma o una aplicación con audiolibros digitales.

En internet también puede resultar confusa la búsqueda de bibliografía específica de audiolibros digitales, ya que no existen descriptores diferenciados para ambos tipos de soporte; por ello, un resultado puede arrojar ruido en nuestra recuperación de información.

García Rodríguez y Gómez Díaz (2019:2) en su trabajo ¿Leer con los oídos?: audiolibros y literatura infantil y juvenil conciben el audiolibro como una grabación de un libro leído en voz alta, por una sola persona o dramatizado con varias voces, al que se suma la incorporación de música y efectos sonoros. Los autores llaman la atención sobre la importancia de no confundir los audiolibros con los textos a voz (TTs), puesto que el TTs es un software que lee en voz alta un texto digital y que generalmente está destinado a personas con dificultades lectoras.

Have y Stougaard Pedersen, (2016:4) definen a los audiolibros como "una grabación de sonido de un libro realizada por un narrador profesional (a menudo un actor) o el autor ${ }^{16}$.

Las autoras resaltan que en sus estudios no incluyen como audiolibros a los audios que no han sido previamente textos impresos, pero son conscientes de que los formatos de audio nativos pueden anunciar el futuro del desarrollo del audiolibro, como lo demuestran las iniciativas Storytel Originals y Audible Originals.

En relación con las posibilidades del formato, las mismas autoras (2013:124) indican que, como los libros impresos, el audiolibro es también un medio one-to-many (uno a varios), que distribuye contenido estandarizado a una audiencia anónima; y al mismo tiempo, sin embargo, es un nuevo medio altamente individualizado y móvil, adaptado a necesidades y usos individuales con posibilidades interactivas todavía latentes.

\footnotetext{
${ }^{16}$ «A sound recording of a book that is performed by a professional narrator (often an actor) or the author» (trad. a.).
} 


\title{
5.3 RECORRIDO HISTÓRICO
}

El origen de los audiolibros puede relacionarse a Thomas A. Edison, quien inventó el fonógrafo en el año 1877. En su artículo The phonograph and its future (1878) ya imaginaba su aplicación en diversos ámbitos: en libros, en educación, en libros fonográficos, también en música, juguetes, relojes, publicidades, entre otros usos varios. A continuación, citamos el párrafo que Edison dedica a la posible aplicación del fonógrafo en el mundo editorial:

\begin{abstract}
Books - Books may be read by the charitably-inclined professional readers, by such readers especially employed for that purpose, and the record of such book used in the asylums of the blind, hospitals, and the sick-chamber, or even with great profit and amusement by the lady or gentlemen whose eyes and hands may be otherwise employed; or, again, because of the greater enjoyment to be had from a book when ready by an elocutionist than when read by the average reader. The ordinary record-sheet, repeating this book from fifty to a hundred times as it will, would command a price that would pay the original reader well for the slightly increased difficulty in reading it aloud in the phonograph. (Edison, 1878)
\end{abstract}

Por un lado, el fonógrafo posibilita variaciones espaciales, ya que permite que las señales sean emitidas a sitios distantes y, por otro lado, permite que el momento de la emisión y de la recepción puedan ser diferentes. En un comienzo, estaban compuestos por una hoja de estaño que se ajustaba a un cilindro metálico. Más adelante se hicieron de cera y luego de materiales plásticos. En los cilindros el sonido está grabado en forma vertical (hill-and-dale). Su duración oscila entre dos y cuatro minutos, dependiendo de la velocidad de reproducción y de los surcos por pulgada, y por esta razón las primeras grabaciones fueron versos.

Matthew Rubery (2011:3-4) afirma que las primeras palabras pronunciadas en los cilindros del fonógrafo fueron el recital Edison de Mary Had a Little Lamb ${ }^{17}$ en noviembre de 1877, la primera instancia de un verso grabado con la finalidad de ser posteriormente reproducido. La demostración del fonógrafo en la Royal Institution en Gran Bretaña el año siguiente, comenzó con los versos que incluían: Hey Diddle Diddle, the Cat and the Fiddle y una línea de la poesía de Tennyson.

Otro hallazgo importante se produjo en 2008, y fue documentado en el periódico The New York Times. En el artículo se informa que muchos años antes del fonógrafo de Edison, ya en 1860, había sido grabada una pequeña estrofa de una canción popular francesa, Au clair de la lune, fijada en una hoja de papel y descubierta a principios de marzo de 2008 en un archivo de París por un grupo de historiadores estadounidenses especializados en música. Esta grabación fue realizada en un fonoautógrafo - una tecnología ideada para el registro de sonidos sin pretensión de ser reproducidos en el futuro-.

Volviendo a los fonógrafos, la prensa en Estados Unidos comenzó a especular sobre el impacto que esta tecnología tendría sobre el libro. El New York Times utilizó una analogía para explicar la invención. La preservación del discurso (speech) en tinfoil (papel de aluminio), era comparable al del vino en una botella; en relación con el sonido, el fonógrafo lo embotella (bottles it up) para el futuro. La audiencia podría comprar oraciones embotelladas vendidas por cincuenta centavos la pieza. Estas botellas se encontrarían en un almacén (ibídem, 32).

\footnotetext{
${ }^{17}$ Mary Had a Little Lamb (María tenía un corderito) es una canción infantil perteneciente a la música estadounidense.
} 
Unos años después, en el año 1885 bajo el título The book of the Future: or whispering machines. $A$ speculation publicado en 1885 en el periódico australiano The Mercury, Thomas Edison ya vislumbra algunas características distintivas de los actuales audiolibros, como la portabilidad y las nuevas posibilidades que aportaban los fonógrafos a la lectura:

\begin{abstract}
By a development of the phonograph or by the construction of a musical alphabet, based on sounds, and not on arbitrary spoiling, the book of the future is to be printed on a metal cylinder, and placed in a small automation which can be wound up at pleasure, and which will read from the place at which it is set right on to the end, unless it is stopped. This automaton, with the book enclosed, may be placed for convenience in the hat or bonnet and be connected with the oars by wires, Thus when we take our walks abroad or travel by land or water we can be accompanied by the book of our choice, which will be read in a whisper audible to ourselves alone. No need of straining our eyes in omnibuses or railway carriages and inducing shortsightedness or myopia, or wearing out our eyes before their time.
\end{abstract}

En el siguiente fragmento se imagina una biblioteca llena de cilindros de papel de aluminio, que en la realidad fueron rápidamente reemplazados por una tecnología superior:

Still, even supposing that for correspondence for newspapers and placards paper were retained, what a revolution there would be in the paper trade if books were no longer printed on that material! What a curious appearance a great library full of metal cylinders would present! There is one gleam of hope for South Australia in this distant promise. A new use for copper has been long a desideratum.

Y finaliza el artículo del siguiente modo:

The book of the future may after all spring out of some other application of some yet undiscovered force of nature. While people are groping after a sixth sense and a fourth dimension no one can speak with certainty as to what may or may not be.

En las posibles aplicaciones, ya se advierte una gran ventaja respecto a lo que Thomas Edison imaginó al describir el fonógrafo: la portabilidad.

Ranera Sánchez y Crespo Arca (2010:53) afirman que en el año 1897 ya existían en España establecimientos dedicados a la fonografía y a la venta de cilindros. Entre los pioneros, Hugens, con su Laboratorio Fonográfico A. Hugens (situado en la calle Barquillo, 34, en Madrid) o la óptica Viuda de Aramburo, cuyos primeros anuncios de venta de fonógrafos y cilindros impresionados son del mismo año. Álvaro Ureña también inauguró su centro de electricidad en la calle Barquillo número 13 y Arco de Santa María, 47 en el mes de julio, si bien no existe constancia de que los fabricara el siguiente año.

En la Biblioteca Nacional de España tienen una colección de cilindros españoles entre los que predominan las grabaciones musicales, especialmente las de voz y piano. Teniendo en cuenta la cantidad de grabaciones por géneros, los más representados son la ópera y la zarzuela.

En cuanto a las grabaciones de palabra hablada predominan los chistes, llamados genéricamente «cuentos» y la figura que más aparece es el maestro Domínguez. También hay ejemplos de oratoria de fin de siglo, del escritor Antonio Jiménez Guerra, espectáculo de éxito, consistente en una sucesión de monólogos en los que el intérprete (lo que actualmente denominamos narrador) adoptaba distintas personalidades: anarquista, cura, forense, etc. (ibídem, 58).

Se ha realizado una consulta a los bibliotecarios del Departamento de Música y Audiovisuales de la Biblioteca Nacional de España, quienes nos indicaron que los audiolibros más antiguos, denominados por ellos "archivo de palabra», están plasmados en cilindros de cera o de fonógrafo, datan del año 1897 y son recitados por el maestro Domínguez. Podríamos considerarlos los primeros audiolibros 
españoles. A continuación, ofrecemos los datos catalográficos, así como el hipervínculo a través del cual se puede escuchar las dos grabaciones:

Título 1: Giralda [Grabación sonora] ; y Hotel

Publicación: Madrid (Príncipe, 12) : Viuda de Aramburo, [entre 1897 y 1900]

Descripción física: 1 cilindro ( 2 min, 34 seg.) ; 5,5 x 10,5 cm

Nota general: Duración tomada de la copia digital proporcionada por

el anterior propietario

Nota general: Nivel parcial de catalogación

Intérprete: Maestro Domínguez

Fuente de adquisiciones: Comprado a Mariano Gómez Montejano; Madrid; 2008

Nota tít. y men. res: Título tomado de la etiqueta del envase

Nota tít. y men. res: Precede al título: cuentos

Nota tít. y men. res: Título al comienzo de la grabación: Cuentos del maestro Domínguez

N. área desc. fis.: Cera marrón

Encabez. materia: Humorismo

Autor personal: Domínguez, Maestro

Otro título: Hotel

Otro título: Cuentos del maestro Domínguez

Enlace: Biblioteca Digital Hispánica

http://bdh.bne.es/bnesearch/detalle/bdh0000046275

\section{Título 2 : Rey perdido [Grabación sonora] ; y Escribanos}

Publicación: Madrid (Príncipe, 12) : Viuda de Aramburo, [entre 1897 y 1900$]$

Descripción física: 1 cilindro (2 min, $35 \mathrm{seg}$.) ; 5,5 x 10,5 cm

Nota general: Duración tomada de la copia digital proporcionada por el anterior propietario

Nota general: Nivel parcial de catalogación

Intérprete: Maestro Domínguez

Fuente de adquisiciones: Comprado a Mariano Gómez Montejano; Madrid; 2008

Nota tít. y men. res: Título tomado de la etiqueta del envase

Nota tít. y men. res: Precede al título: cuentos

Nota tít. y men. res: Título al comienzo de la grabación: Cuentos del maestro Domínguez

N. área desc. fis.: Cera marrón

Encabez. materia: Humorismo

Autor personal: Domínguez, Maestro

Otro título: Escribanos

Otro título: Cuentos del maestro Domínguez

Enlace: Biblioteca Digital Hispánica

http://bdh.bne.es/bnesearch/detalle/bdh0000046274

Varios fueron los organismos que vieron en el invento otra posibilidad que siempre había sido deseada: la de reproducir asincrónicamente una voz grabada. Ya en el año 1906, en Estados Unidos, la American Library Association comenzó a considerar utilizar los fonógrafos para grabar las lecturas en voz alta a 
los ciegos, como está reflejado en los Papers y proceedings of the twenty eight general meeting (ALA, 1906 citado por Rubery, 2016:64).

Continuando en el terreno de las bibliotecas, surgió un proyecto bajo el nombre "Libros parlantes» alrededor de 1920 en Reino Unido, en el Instituto Nacional Real para las Personas Ciegas, destinado en un principio a los soldados y veteranos de guerra. Pero, el primer proyecto real fue titulado del mismo modo: Talking Books (libros parlantes), en Estados Unidos en 1932, momento en el que la Fundación Estadounidense para los Ciegos consiguió financiación para acercar la literatura a las personas no videntes.

El formato, que comenzó a despegar en Estados Unidos, también se concretó en Reino Unido con la entrega a personas con discapacidad visual de grabaciones de El asesinato de Roger Ackroyd, de Agatha Christie, y Tifón, de Joseph Conrad, en discos Lp de 25 minutos por cara.

Queda claro que las bibliotecas comenzaron rápidamente a asistir a las personas con discapacidades visuales, y como mencionamos anteriormente, un público al que se pretendía asistir con prioridad era al de los veteranos de guerra que habían sufrido alguna lesión ocular y que por alguna razón no habían comenzado a estudiar braille o no leían con ese sistema, como detalla Rubery en el ya citado The untold story of the talking book (Rubery, 2016:185). Para Rubery, la iniciativa tuvo tanto éxito que se asociaba indefectiblemente a los audiolibros con los discapacitados visuales.

A los editores les resultó difícil deshacer este vínculo entre ceguera y palabra hablada. Y como Rubery apunta, para que la palabra hablada tuviese éxito, no era suficiente presentarse como una opción similar a la lectura, sino que debía sobrepasar la experiencia en términos de entretenimiento (ibídem, 186). En 1952 la editorial privada Caedmon ${ }^{18}$ encontró la llave para entrar en la literatura sonora: la voz cautivadora del poeta contemporáneo Dylan Thomas con quienes grabaron su primer elepé de poemas. Thomas grabó In the White Giant's Thigh y otros cuatro poemas. El disco vendió más de 400.000 copias para el año 1960 y se convirtió en una de las 20 grabaciones más famosas en Estados Unidos (ídem). El escritor grabaría más de 20 discos y se convertiría en la voz más representativa de la firma.

La empresa ya se había forjado el éxito en la industria de los audiolibros y más específicamente en los especializados en literatura, ya que grabó a muchos de los escritores más influyentes del siglo XX: W.H. Auden, Albert Camus, Colette, E.E. Cummings, T.S. Eliot, William Faulkner, Robert Frost, Langston Hughes, James Joyce, Thomas Mann, Marianne Moore, Sylvia Plath, Katherine Anne Porter, Ezra Pound, Anne Sexton, Gertrude Stein, Wallace Stevens, May Swenson, Eudora Welty, Tennesse WiIliams, William Carlos Williams, y W.B. Yeats (ibídem, 188).

La firma priorizaba su integridad artística por sobre el interés comercial grabando a los autores en su idioma original. Este es el caso de Diego Rivera, Pablo Neruda y Juan Ramón Jiménez, en español (Rubery, 2016:210). Aunque no a todos les seducía la idea por igual. El Premio Nobel de Literatura español, Juan Ramón Jiménez, contestó a la invitación de la firma Caedmon con el siguiente texto: «La poesía no está hecha para ser leída en voz alta» ${ }^{19}$. Finalmente accedió a hacerlo durante una visita a la Universidad de Maryland (ibídem, 198).

\footnotetext{
${ }^{18}$ Actualmente el nombre de la empresa es HarperCollins.

19 Poetry is not made to read aloud (trad. a.)
} 
Otros idiomas grabados fueron el alemán, al que le dio vida Lotte Lehmann, recitando el libreto de Rosenkavalier y Katina Paxinou realizando una performance de Oedipus Rex, en griego. La firma, incluso inmortalizó en la voz del propio J.R.R. Tolkien, el idioma inventado por él: el Elvish.

"Caedmon respondía a la pregunta que muchos lectores tenían en mente: cómo sonaban los autores» (ibídem, 209). Hay que tener en cuenta que no todos los autores tienen habilidades para la lectura en voz alta, por lo cual se buscaban voces de actores profesionales para realizar dicha tarea. Luego veremos que hoy en día sigue siendo un recurso muy utilizado. Varias empresas eligen celebridades para que la voz resulte familiar y pueda captar más público.

La poesía, por su brevedad y ritmo es uno de los géneros más interesantes para ser representados por sus propios autores.

Otra empresa que hizo historia en el mundo del audio fue Books on Tape, una compañía fundada en 1975 por Duvall Hecht, dedicada exclusivamente a comercializar audiolibros. Su idea fundadora se basaba en que los americanos necesitaban leer más libros, pero carecían de tiempo. Como la tecnología de los casetes ya era accesible en el mercado, los usuarios podrían disfrutar de los audiolibros en los trayectos que realizaban en automóviles.

Parte del trabajo lo había comenzado la empresa Caedmon, al intentar presentar contenidos de alta literatura para ser escuchados. Ciertamente había un nicho de mercado entre los trabajadores que realizaban estos trayectos y querían reconectarse con la lectura. Además, la empresa ofrecía un servicio de préstamos similar al de las bibliotecas. Los casetes se prestaban por 3 días (la duración media de los mismos era de 8 a 12 horas). La empresa también vendía obras a bibliotecas y a particulares, pero en un $85 \%$ los audiolibros se prestaban (ibídem, 221). Sus suscriptores eran personas con una educación por encima de la media, y con una edad que rondaba los 40 años.

El siguiente hito en la historia de los audios fue el walkman, introducido por Sony en los años 80 . Este invento le dio mucha más autonomía a los usuarios, quienes podían moverse a la par de escuchar literatura. La explosión fue tal que ya para el año 1985 la mitad de los norteamericanos poseía uno de estos reproductores (ibídem, 229).

La cantidad de empresas que se dedicaron a la grabación creció exponencialmente, y así también lo hicieron los géneros y temáticas de sus colecciones. Books on tape continuaba siendo la empresa líder teniendo en cuenta la riqueza de su catálogo, que cerca de los años 90 contaba con más de 20.000 títulos.

Ya, por último, y antes del streaming, en el año 2002 los audiolibros comenzaron a estar disponibles a través de archivos MP3, en internet. Eso posibilitó, según Rubery, (2011:8) que la grabación de obras como Guerra y Paz, de Leon Tolstói, requiriesen un solo archivo para ser escuchados en un iPod, en vez de 119 discos de long play, 45 cintas de casets o 50 CD.

\subsection{TIPOLOGÍA DOCUMENTAL}

Según Rodríguez-Reséndiz (2016:174) durante muchos años se consideró a los documentos sonoros, también denominados fonorregistros, documentos especiales teniendo en cuenta por el otro lado el 
predominio del documento textual; los documentos sonoros fueron definidos a partir del universo librario, considerados y catalogados como documentos no librarios.

Para Jean Weihs (citado por Rodríguez-Reséndiz, p.174) los documentos sonoros comenzaron a hacerse visibles en la década de los 50, con particular incidencia en las bibliotecas universitarias de Estados Unidos y Canadá. La aparición de estos nuevos documentos fomentó la creación en su momento de catálogos especiales en las bibliotecas.

Ya en el año 1967, Jay E. Dayli evidenció y postuló en un artículo que los fonorregistros requerían otros procesos técnicos, almacenamiento y catalogación, y por esta razón desarrolló una crítica a las Reglas de Catalogación Angloamericanas.

Para Dayli, la responsabilidad de los bibliotecarios tenía que ver con almacenar ${ }^{20}$ recursos de información independientemente de su forma. Pero, prosigue su reflexión con que:

\footnotetext{
Unfortunately for the exercise of this expanded responsibility, non-book materials are not controlled nearly so well for selection purposes as are books; they should not be treated (as they so frequently are) as a kind of subbook for cataloging purposes; nor can they be stored and preserved as easily as printed materials in the traditional library building. Thus, non-book materials, especially those in non-print form, have come to represent a special concern in most libraries and must be given extra consideration. (Dayli, 1967:283)
}

Este trabajo presentado a fines de los años 60, sentó las bases para comenzar a situar a las grabaciones sonoras al nivel de los libros, teniendo en cuenta que, por sus particularidades y su novedad, requerían un tratamiento especial.

Rousseau y Couture (1994:217) sitúan a la década que va de 1960 a 1970 como el período en que los archivistas se interesaron verdaderamente por los documentos no textuales de sus archivos y la disciplina archivística comienza a desarrollar las normas y prácticas ampliando el espectro de soportes tratados.

El desarrollo de la archivología y el creciente interés por los documentos sonoros coincidió temporalmente con la creación de la Asociación Internacional de Archivos Sonoros y Audiovisuales (IASA) en Ámsterdam en 1969. El nacimiento de esta asociación tuvo como objetivo contar con un foro para promover la cooperación entre archivistas y bibliotecarios quienes trabajaban con documentos sonoros (Rodríguez Reséndiz, 2004:175).

Tras este importante hito, y según reseña Rodríguez Reséndiz (ídem), comienza un proceso progresivo de integración de las tecnologías de la información y comunicación llamada revolución del conocimiento, en el cual se sitúa a la información como base de la economía informacional. En este contexto la archivística experimenta un importante desarrollo.

\subsection{EL ISBN Y EL DEPÓSITO LEGAL}

En el Boletín Oficial Español del 12 de enero de 2009 se publicó el Real Decreto 2063/2008, del 12 de diciembre, por el que se desarrolla la Ley 10/2007, de 22 de junio, de la Lectura, del Libro y de las

\footnotetext{
${ }^{20} \mathrm{El}$ autor utiliza la palabra collecting.
} 
Bibliotecas en lo relativo al ISBN. En ella se indica que los audiolibros ya se encuentren en soporte físico (casete, CD, DVD, etc.) o por Internet, deben utilizar código ISBN.

También realizamos la consulta a la Biblioteca Nacional Española acerca del depósito legal, quienes nos confirmaron que los audiolibros están sujetos a esta obligación (com. pers., 11 enero 2021).

\subsection{SIMILITUDES Y DIFERENCIAS CON EL FORMATO PÓDCAST}

Para conocer en profundidad el formato pódcast debemos remitirnos a las radios, dado que fueron el germen desde donde éste nuevo formato nació y se fue consolidando.

Las radios también tuvieron su salto de lo analógico a lo digital; y uno de los formatos que ofrecieron tras esta transformación fueron los pódcasts, adecuándose a los nuevos modos de consumo de información de los usuarios. Actualmente, en muchos casos han formado alianzas estratégicas y se han unido a plataformas que ofrecen servicios de descargas, para que cualquier contenido pueda ser escuchado sin importar el momento del día ni el lugar.

La radio digital puede significar diferentes cosas. Adelaida Bolea de Anta y Pablo Ferrando García, aclaran en un artículo que cuando se habla de radio digital puede hacerse referencia al proceso por el cual una señal analógica pasa a ser una señal digital; pero hablando en un sentido más amplio mencionan que puede referirse a las estaciones de radio que tienen presencia en la web, así como a través de redes sociales, streaming de audio o a través de IP o la posibilidad de descarga de contenidos pódcast y también la presencia en otros dispositivos conectados como videoconsolas (IP) (Bolea de Anta; Fernando García, 2013:19).

La palabra podcast fue inventada por el periodista del diario The Guardian Ben Hammersley, y es la contracción de iPod (el lector portátil de Apple que permitió a los usuarios descargar ficheros de audio) y de broadcast (difusión, en inglés) (McHugh, 2020:7).

Frecuentemente, estos archivos son programas convencionales de radio, subidos de forma gratuita a plataformas como iVoox o iTunes. Aunque ya con anterioridad se realizaba esta puesta en común de contenidos para que los oyentes pudiesen disfrutar de la programación más allá del horario fijo de la emisión fue en el año 2004, con el nacimiento del RSS (Really Simple Sindication), que se utilizó por primera vez con el neologismo pódcast.

Este vuelco tecnológico comenzó en los años noventa, y actualmente afecta todo el flujo de trabajo, desde la producción, entrega y recepción. La radio tradicional en el ámbito de Internet devino en ciberradio, modificando los modelos radiofónicos tradicionales, «consiguiendo una nueva fórmula de programación fragmentada o de contenidos aislados, que sustituye a la oferta de programas de emisión única y continuada, y audición masiva». (González Conde, 2010:53). Los elementos comunes de internet se acoplan a la radio tradicional, y la transforman en productos signados por elementos como la fragmentación, interactividad e individualización (ídem).

La diferencia principal entre un podcasting y la radio en internet es que el podcasting es asincrónico. Solo depende de la conexión para el proceso de aviso, si se utiliza RSS, y luego si se desea para proceso de descarga del archivo o bien para la escucha en streaming. 
Hablando de aspectos técnicos, el pódcast combina tres tecnologías ya existentes: una forma eficiente de comprimir la información sonora (audio digital, MP3, MP4); una red de conexiones punto a punto (Internet) y un sistema de suscripción automatizada para la descarga de contenidos (Pedrero Esteban y Contreras-Pulido, 2019:360).

Fue en la segunda década del siglo XXI que la penetración de los teléfonos inteligentes movilizó el consumo de contenidos antes ligados a medios tradicionales, especialmente en música (Spotify) y video (YouTube) (ibídem, 361).

Lourdes Moreno Cazalla menciona tres elementos clave para el desarrollo del podcasting: el cambio en los procesos de recepción, el paradigma espaciotemporal y la personalización. Además, menciona que tras superar una primera etapa en la cual se reciclaban contenidos ya emitidos, llegó la segunda fase, que fue la de creación de archivos originales para su consumo en Internet (Moreno Cazalla, 2017:337).

Comenzó entonces el surgimiento de plataformas en línea y de pódcasts generados para ser difundidos a través de ellas. Parra Valcarce y Onieva Mallero (2020:13) nos hablan de una tipología sumamente variada que va desde las que permiten el alojamiento gratuito de contenidos, hasta las que ofrecen un sistema de pago; también existen las centradas en suscripciones y las que combinan esta modalidad con la descarga libre de programas. En cuanto a la especialización, los autores indican que existen de índole generalistas y las centradas en algún tema específico; las que operan a una escala local por la idiosincrasia de sus contenidos (a pesar de la globalización de los contenidos de internet) y las que surgieron con planteamientos globales y de carácter internacional.

Esta fragmentación lanza al mercado un abanico de aplicaciones y plataformas como Apple Pódcasts (i-Tunes), CastBox, iVoox, Live 365, Player FM, Pódcast Go, Pódcast Alley, Pocket Casts, Podfeed, Podomatic SoundCloud, Spotify, Spreaker o Tunelln, entre otras muchas. Esta proliferación de plataformas muestra la disrupción del mercado convencional identificado con el de las empresas radiofónicas (ídem).

En España una de las primeras experiencias profesionales de las que se tiene constancia es Comunicando, un espacio sonoro grabado y lanzado el 18 de octubre de 2004 por José Antonio Gelado. Con grabaciones de aproximadamente 46 minutos en donde se hablaba de internet, de reproducciones portátiles, videojuegos, etc. (Orrantia Herrán, 2019:13). En 2005, Jaime Cristóbal lanzaba Popcasting, con una periodicidad semanal y con contenidos relacionados con los contenidos musicales (ibídem, 109), en 2007 Soundcloud y en 2008 surgía iVoox. Otras que se unieron alrededor de la fecha fueron Spreaker, iTunes, Tuneln, Stitcher, Spotify o Google.

Orrantia Herrán nos habla de una segunda etapa del desarrollo de este formato en España a través de tres experiencias puntuales: 1) El extrarradio, una emisora online que comenzó en noviembre de 2012 con una parrilla de 12 programas de diversa temática 2) la experiencia de Carne Cruda, de Javier Gallego y su programa en el periódico digital eldiario.es y 3) la experiencia de La Cafetera de Fernando Berlín, un programa que surge en el año 2014 en RadioCable.com (ibídem, 110-111).

Estas innovaciones van creando el terreno para que, en el año 2016, de la plataforma de PRISA se cree la primera red de podcasts en español (ibídem, 112) y bajo el eslogan «lo mejor está por escuchar» en sus primeros dos años produjo 55 shows agrupados en cuatro bloques: periodismo, entretenimiento, esenciales y ficción. Dentro de la temática de ficción se engloba El Gran Apagón, que sumó 4,5 millones 
de descargas de sus tres temporadas en junio de 2018; y Bienvenido a la vida peligrosa, con casi tres millones de descargas de los más de 24 millones de audios que Podium Podcast había suministrado en junio de 2018 (Espinosa de los Monteros, citada en Pedrero Esteban y Contreras-Pulido, 2019:363).

En el VII Congreso del Libro Electrónico llevado a cabo en el 2019 en Barbastro, se desarrolló una mesa redonda titulada: Pódcasts y audiolibros: ¿compiten por la misma audiencia o son contenidos complementarios? En la citada charla participaron Juan Ignacio Solera, socio fundador de Ivoox y Francisco Izuzquina, de YesWeCast, especializado en radio en línea y podcasting. $Y$ ante la pregunta de si estos dos formatos, el audiolibro y los pódcasts compiten, el primer disertante consideró que «el perfil del oyente de pódcast es más abierto», mientras Francisco Izuzquina aseguró que «los pódcasts y los audiolibros compiten entre sí en la medida en la que lo hacen con otros soportes como la televisión o el cine. Eso sí, tienen puntos de convergencia y pueden complementarse, pues se pueden crear nuevos contenidos en formato pódcast que complementen a los audiolibros».

Respecto a la tipología de oyentes, Solera opinó que las plataformas de audiolibros están vinculadas a un perfil socioeconómico más alto cuya media de edad es ligeramente mayor al del oyente de pódcasts.

Los especialistas en medios sonoros coincidieron en los cambios en el modo de distribución de contenidos, remarcando que "se ha pasado de un entorno de broadcast a un modelo a la carta, a la capacidad de personalizar playlists, registrar las rutinas de la audiencia para ofrecer una selección de audios basada en sus gustos, etc." Este modelo a la carta, fragmentado, distribuido como hemos visto en diferentes plataformas y organizados según diversas temáticas ha contribuido a que los oyentes se acostumbraran a una escucha asincrónica y en movilidad de los contenidos sonoros, propiciando un mayor uso de formatos como los audiolibros.

\subsection{CARACTERÍSTICAS DISTINTIVAS DE UN AUDIOLIBRO}

Según Matthew Rubery (2016:3) la identidad de un audiolibro estuvo siempre definida en relación con lo impreso. El argumento principal de uno de los libros más relevantes dedicados a los audiolibros, el ya mencionado The untold story of the talking book, es que los mismos se desarrollaron, por un lado, como un modo de reproducir el libro impreso y, por el otro, de superar sus limitaciones.

La affordance ${ }^{21}$ más destacable del audiolibro es que la comunicación tiene lugar a través del sonido. El mismo es autónomamente controlado por el narrador, situación que Have y Stougaard Pedersen denominan como un tipo de audiotización (audiotization) del libro escrito, transformando el texto y el acto de leer en una experiencia totalmente diferente (Have y Stougaard Pedersen, 2013:131).

A nuestro juicio son dos las características principales del audiolibro: una es la voz y la segunda son características de índole tecnológicas.

\footnotetext{
21 Affordanes: «user posibilities afforded by technology»: Posibilidades dadas por las tecnologías (trad. a.) (Have y Stougaard Pedersen, 2016:8).
} 
En el primer apartado, referido a la voz del audiolibro, hablaremos también del papel del narrador, además de metodologías existentes para la evaluación de audiolibros, a través de su narración. En segundo lugar, nos referiremos a las características de índole tecnológicas.

\subsubsection{La voz del audiolibro}

«Ni siquiera estamos seguros de cómo llamar a esa voz» enuncia el mencionado investigador Mattew Rubery (2016:7), y agrega que los términos reader (lector) y narrator (narrador) generan una innecesaria confusión cuando se utilizan para describir a la voz de un audiolibro.

El término reader se referiría a quien cuenta una historia en voz alta, leyendo ${ }^{22}$ una página en silencio, o incluso escuchando la historia; y en el caso de narrator puede significar un personaje de ficción o una persona real (ídem).

Cavender y Stuchell (2006:155) lo ejemplifican muy bien. La novelista inglesa Charlotte Brontë escribió un pasaje de su libro Jane Eyre, en el que dice lo siguiente: «Reader, though I look comfortably accommodated, I am not very tranquil in my mind». Brontë alude a un lector, que en la versión impresa del libro está claramente identificado, pero no así en la versión audiolibro, que puede causar dudas. ¿Quién es el lector?, ¿el que sostiene físicamente el libro o los audiolectores?, ¿̇o ambos? Cambiar la palabra de lector a escuchante, afirman Cavender y Stuchell estaría cambiando la intención de la propia autora. En estos casos puntuales los directores de edición pueden tomar alguna decisión y realizar mínimas alteraciones cuando lo consideren oportuno.

En español sucede algo similar con las palabras «lector» y «narrador». Un ejemplo similar, pero a nivel nacional podemos encontrarlo en el Quijote, que comienza su prólogo dirigiéndose al público como: «Desocupado lector».

El propio diccionario de la RAE presenta sus dos acepciones de "lector»: que lee o tiene el hábito de leer y que lee en voz alta para otras personas, mientras que a "narrador» le cabe la siguiente definición: «que narra».

Rubery nombra otros términos que pueden estar relacionados con la voz narradora, como son: speaker y performer. El primero puede representar figuras dentro y fuera de la narrativa, y performer apunta más una industria del entretenimiento que muchos editores evitan. En español speaker podría ser traducido por orador y performer no tiene una traducción precisa, la más cercana podría ser intérprete.

En las definiciones de la palabra audiolibro hemos visto que algunos autores realizan una discriminación entre las grabaciones realizadas automáticamente, por un lado, y por otro, aquellas que llevan a cabo los narradores. En el presente estudio, hemos optado por limitarnos a los audios narrados por personas, ya sean actores o narradores profesionales, ya que creemos que es la característica distintiva de los audiolibros, y la que está produciendo que este formato cuente cada vez más con más adeptos. Profundizaremos este punto bajo el epígrafe «Ventajas de los audiolibros».

\footnotetext{
${ }^{22}$ En el original: scanning. Consideramos que se refería a pasar la vista por la hoja.
} 
La voz de un audiolibro, que pasa de ser una voz metafórica a ser una voz literal, se encuentra entre el lector y el texto, conformando un nuevo actor, como lo indican Have y Stougaard Pedersen en el siguiente fragmento:

The voice becomes a mediating actor or a natural center in the relationship between reader and text, a kind of oral software that mediates language, but which also in itself produces material and rhetorical meaning. (Have, Stougaard Pedersen, 2016:79)

Podríamos inferir que la voz del audiolibro enlaza la retórica del propio texto escrito y la voz que lo narra, y a su vez agrega su significado a través de su propio estilo.

Esta voz despojada de cualquier tipo de expresión visual contiene, sin embargo, un lazo muy importante con el escuchante: el contacto auditivo. En palabras de Matthew Rubery:

The portable player does not present an actual person before you; there is no body movement, no facial expression, and no eye contact. The difference here lies in what might be called ear contact, the unbroken link between voice and ear. (Rubery, 2008:72)

La voz puede parecernos íntima y anónima al mismo tiempo (Have y Stougaard Pedersen, 2016:79), ello depende la interpretación del narrador.

Para algunos autores los audiolibros ofrecen un número de beneficios estéticos en comparación con la lectura silenciosa, ya que la presencia de la voz humana es capaz de hacer que cada palabra pueda contener una carga afectiva. En este sentido el peso está puesto sobre los narradores; estos profesionales pueden abrir nuevos caminos interpretativos a través de la prosodia y la modulación de la voz (Kuzmičová, 2016:218).

Juliana Rueda (2019), maestra de música e ingeniera en sonido enunció que en este mundo tecnologizado la voz genera emoción. Así también lo considera Rodríguez de las Heras (2019) agregando que esa emoción está enraizada desde los primeros pasos de la hominización, como recurso para la supervivencia y que mientras que con los ojos vemos la mitad del mundo que tenemos delante, la otra permanece invisible; no así sucede con el oído que percibe un mundo esférico. Ampliaremos las ventajas de la escucha relacionadas con la voz bajo los epígrafes: 5.8.5 Conexión con el libro y compañía parasocial y 5.8.6 Posibilidad de lectura intersensorial.

Adentrándonos en un plano más tecnológico, un estudio neurocientífico llevado a cabo por la Universitat Pompeu Fabra (UPF) ha revelado que la escucha de audiolibros con sonido 3D produce efectos emocionales y reacciones fisiológicas más intensas que la lectura tradicional impresa. Esta es una de las conclusiones a las que arribó un estudio de la UPF en el que se ha medido la respuesta de la conducta de 60 personas que escucharon distintas historias contadas con diversas voces, tipos de narración y recursos sonoros (Rodero, 2020).

El sonido en 3D -también conocido como biaural-, ofrece al oyente una experiencia más real. Según la directora e investigadora del Media Psychology Lab de la UPF, Emma Rodero, este estudio es innovador ya que es el primero que mide la reacción fisiológica del cuerpo ante distintos tipos de escucha.

El principal descubrimiento, según Rodero, ha sido que una historia biaural posee muchos estímulos y permite captar y mantener la atención del oyente, dado que se ha añadido a la voz una tercera dimensión que hace que el receptor se sienta dentro de la historia. En el estudio evaluaron el nivel de 
activación emocional y el tipo de emoción que los participantes estaban sintiendo al escuchar un relato, obteniendo resultados acerca de lo que los oyentes habían "sentido, pensado y recordado" de la historia que se les entregó en formato sonoro.

Los resultados revelaron que los oyentes prestan más atención a las voces graves y humanas además de preferir voces interpretadas por distintos personajes y que incluyan música y efectos sonoros. Esta reciente investigación podría resultarle útil a los editores de audiolibros a la hora de realizar la selección de voces para los personajes.

5.7.1.1 El narrador

"¿Qué elementos equivalentes a la estructura de un texto impreso, determinan en el audiolibro su memoria ecoica?», se pregunta en un artículo García-Cordón (2018:178). Y la respuesta la encuentra en la necesaria existencia de un narrador y detrás de él la planificación de la grabación, la técnica y un determinado estilo, según el género, la edad y el formato en el que se plantea el proyecto. El papel del narrador, recalca Cordón-García, es clave en el éxito de estos productos (ídem).

En relación con los audiolibros, Juliana Rueda realza también la función del actor, que pone la voz del autor y conecta a este con su oyente. Pero este actor tiene que ser capaz de extraer las emociones que quiere expresar el autor "palabra por palabra». Asimismo, afirma que para que la experiencia de escuchar esa voz sea placentera:

Necesitamos crear técnicamente un entorno que funcione, que facilite el encuentro. Cuando escuchamos la narración, tenemos una persona dentro de los oídos; es una experiencia tremendamente íntima. La tecnología crea ese ambiente de intimidad y emoción; nos acerca. La palabra es vital para conectar con el otro. Es lo que nos define como especie. (Rueda, 2019:31)

El papel del narrador es crucial teniendo en cuenta que la voz se encuentra en el centro de la experiencia de audiolectura. El estilo debería estar en sintonía con aspectos semánticos del texto e interpretar su significado para darle el justo valor que el escritor le ha aportado en papel.

Eva Güell, directora de marketing y negocio digital de la editorial Anagrama, participó en la mesa redonda Lecciones aprendidas y retos a la hora de producir audiolibros dentro del Congreso del Libro Electrónico (2019) en donde surgió la pregunta de hasta dónde el narrador debía realizar una lectura llamada plana - sin demasiados altibajos en la prosodia ni muestras de emoción-o bien podía tener más libertad en la interpretación. Eva respondió que es mejor equivocarse por defecto e ir hacia una interpretación más sutil, ya que si un texto original no es plano es difícil que su lectura resulte del mismo modo.

También indicó que el narrador no puede interponerse entre el texto y el escuchante, que tiene que ser un vehículo y permitir al que escucha activar su imaginación y construir el imaginario que se está transmitiendo a través del texto. Además, concluyó que de esta forma se tendrá menos riesgo de equivocación por una sobre interpretación, que pueda sobrecargar al escuchante, y como consecuencia pueda disuadirlo de continuar con la audiolectura.

Irene Fortes, productora de audio y responsable de marketing en Penguin Random House, comentó en la misma mesa redonda Lecciones aprendidas y retos a la hora de producir audiolibros, que tratan 
a cada audiolibro como si fuera un proyecto por sí mismo y que por esta razón piensan muy bien qué voces van a narrar el texto. Irene utilizó de ejemplo el libro Voces de Chernóbil, de Svetlana Aleksiévich. Este es un libro coral en el que participan 98 personajes en total, por lo cual han necesitado 28 voces distintas que realicen estos 98 registros diferentes.

En un tema tan incipiente en España es muy importante consultar con especialistas de probada trayectoria en la edición de audiolibros, como es el caso de Celeste Lawson, directora del NLS Recording Studio, perteneciente a la National Library Services for the Blind. Ante la pregunta de cuáles son las características que distinguen a un buen narrador de audiolibros, Celeste enumera los siguientes atributos: calidad, fuerza y resistencia ${ }^{23}$. Y como otros componentes necesarios incluye: la claridad y el control. La directora del estudio de grabación indica que el poseer una voz fabulosa -cualidad que podríamos creer imprescindible - no es una cualidad prioritaria para ella. Por encima de ello Celeste prioriza el poseer una voz interesante, ya que de otro modo el sonido puede resultar agradable, pero agotador para el oyente (Lawson, 2015).

Agrega otra interesante reflexión acerca del requisito más importante para un narrador: la de contar con un buen oído, ya que:

[...] eso es lo que ayuda al narrador a reproducir los ritmos de acentos e idiomas extranjeros, discernir las sutilezas de la lengua materna y mantener el diálogo natural y creíble. Escuchar las voces en la vida (de amigos, extraños, personas en la televisión) se suman a la caja de herramientas del narrador. Escuchar a otros narradores y elegir qué emular y qué evitar es invaluable. (Lawson, 2015)

Sumada a estas consideraciones Celeste Lawson afirma que un narrador debe llevar a la cabina de grabación su propia experiencia de vida, sus opiniones, ira, sarcasmo, pasión y especialmente el humor, ya que «El narrador debe aportar tanta vitalidad e interés en el tema como el autor» y agrega más adelante: «un buen libro requiere un buen narrador y un mal libro requiere un gran narrador» (Lawson, 2015).

Nicolás Soames, es uno de los más importantes editores de audiolibros y fundador de Naxos Audiobooks, y también fue entrevistado acerca de su empresa. Cuestionado sobre el hecho de que algunas personas encuentran que los audiolibros son muy lentos, Soames respondió:

Sean Barrett, one of the great readers of his time with a remarkable range from Cormac McCarthy to Samuel Beckett and Dickens, has quite a fast reading speed, but you never notice. But generally we find that the book sets its own pace (if the actor has been well chosen). (Soames, 2010)

Esta reflexión coincide con lo antes mencionado por Lawson, ya que, si el narrador es experimentado, no notaremos ciertas particularidades como una lectura más lenta o más rápida.

Cecilia Vallorani compara la labor del narrador con la del traductor, en el sentido de que del mismo modo que un traductor opta por una u otra expresión, el narrador hará lo propio con una u otra entonación (Vallorani, 2011:115).

Andersen (2015:11) estima que las diferentes versiones leídas de un texto pueden ser entendidas como performances, en el sentido musical de la palabra, como lecturas de una partitura, en la que el

\footnotetext{
${ }^{23}$ En el original: quality, strength, and stamina. Stamina también podría ser traducido por «aguante».
} 
performer/intérprete agrega capas de significación al original, de acuerdo con su modo de lectura o interpretación.

En la revista especializada en biblioteconomía Reference and User Services Quarterly, Kaite Mediatore enumera algunos de los elementos a tener en cuenta a la hora de realizar el servicio de referencia en la biblioteca enfocándose en los audiolibros. Según la columnista, el elemento más significativo de los audiolibros, su naturaleza audible, debe ser tenida en cuenta en el momento de recomendar o asesorar acerca de la elección de un título determinado. Preguntas como: ¿el narrador distingue distintos personajes?, ¿la historia se desarrolla bien en formato grabado?, ¿mejora la grabación con los «extras», como la música, efectos de sonido o entrevistas al autor? deben poder ser respondidas (Mediatore, 2003:319).

Del mismo modo que Lawson y Soames, Kaite agrega que el modo en el que un narrador enfoca el ritmo de la historia puede determinar cuán interesado estará el lector-oyente, y para ilustrar cita el trabajo realizado por Barbara Rosenblant leyendo El diario de Bridget Jones (en inglés), de Helen Fielding. Mediatore destaca el trabajo de la autora/intérprete, quien rápidamente atrapa al lector leyendo de forma acelerada las frases cortas del diario de Bridget. En sus palabras:

The quick, breathy voice Rosenblant employs makes this briskly paced story simulate a highly entertaining onesided conversation between narrator and listener. ${ }^{24}$ (ídem)

En línea con lo anterior, para Cordón-García son varios los elementos de orden técnico que se conjugan y que pueden proporcionar resultados totalmente diferentes según las editoriales y plataformas que Ilevan a cabo cada proyecto. Un narrador puede ser individual o múltiple, masculino o femenino, con una cadencia más o menos matizada y a una velocidad determinada, y tal y como ocurre con un texto impreso, la imbricación de todos estos elementos con una acertada edición es lo que puede resultar en el abandono o la culminación de la audiolectura (Cordón-García, 2018:178).

Como el mundo de los contenidos sonoros digitales recién comienza a despegar, todavía no se han realizado muchos estudios de lectores, lo cual resultaría de gran interés tanto para los editores como para los propios narradores. Una experiencia interesante es la comunicada el presente año 2020, por Helena Gustasen.

Helena, de la empresa Storytel, relató en una reciente intervención en el marco de un congreso que versaba sobre el audio digital, que su empresa realizó un estudio en el cual se analizaba en qué momento preciso los usuarios de audiolibros abandonaron una lectura (sin detallar cuál era el título, el autor o el narrador).

En este caso se trató de un libro sueco, ya que la empresa es de esa nacionalidad. Como podemos observar en la siguiente imagen, la gran mayoría de los usuarios abandonaron la audiolectura en el minuto catorce. La conclusión de Helena es que o bien en este momento el escuchante no disfruta de esta voz, o bien se distrajeron, se confundieron y decidieron abandonarla. Esta información para ella es muy útil ya que los editores podrían plantearse realizar una segunda edición del libro con otra voz y ver si sigue ocurriendo este abandono de la lectura en este primer cuadrante de la misma.

\footnotetext{
${ }^{24}$ «La voz rápida y entrecortada que emplea Rosenblant hace que esta historia simule una conversación unilateral altamente entretenida entre narrador y oyente» (trad. a.)
} 


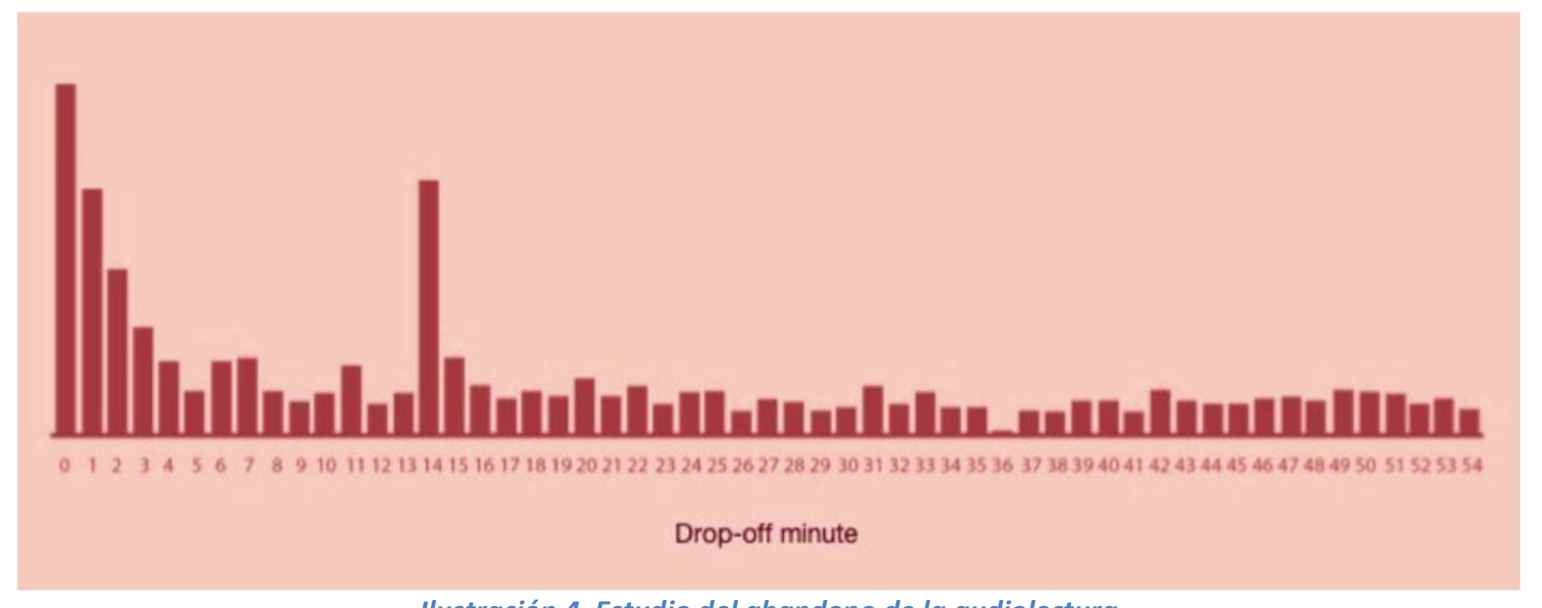

Ilustración 4. Estudio del abandono de la audiolectura

Fuente: Gustafsson, 2020

\subsubsection{Metodología para el análisis de voz de un audiolibro}

Have y Stougaard Pedersen (2016:86-94) han creado un modelo para analizar la voz de un audiolibro, tomando ideas de Performing Rites, de Simón Frith; un estudio basado en las voces en el canto y en ideas de Don Ihde relacionados con el concepto de la voz dramatúrgica.

Esta metodología está centrada en el proceso tecnológico de la voz, su carácter estético y sensorial, así como su situación contextual y sociológica.

El modelo de análisis contiene en total cinco puntos. En el texto original de Have y Stougaard Pedersen se analizan tres audiolibros, Dreams from My Father (2004); Sunset Park (2004) y Visit from the Goon Squad (2010). Incluiremos, a continuación de cada punto del modelo solo los fragmentos del texto Sunset Park de Paul Auster:

1. Este primer punto uno analiza el modo en el que la voz es grabada y procesada.

The sound quality of the recordings seem relatively dry, but the sound of the voice contains acoustic shadows in the sense that you gear some co-sounds belonging to the voice not to the language. You hear the performing narrator breathe, and you notice single audible cuts in the recording, sometimes with a slight change in the volume. (Have y Pederson, 2016:89)

2. La materialidad de la voz: en este punto los autores proponen medir cómo es la calidad de la voz, el ritmo y su dicción

The material voice of this autor is also deep and relatively sonorous. It has a husky touch, an aspect that indicates a relatively touth lifestyle; this is clearly not the voice of a young man, but of a man who has experienced many things. The rhythm of Auster's reading is relatively slow and steady, somewhat meditative; the voice seems to savor the words while rading. This is most evident in passages with enumeration. (ídem) 
3. La situación retórica: este punto investiga cómo un narrador de modo oral entrega una historia a un escuchante, desplegando una doble e intensificada intencionalidad a través del acto retórico.

The rethorical act of performing narrator toward the reader is less pronounced; instead it appears slightly laconic. Auster's style of reading brings the audible, poetic aspect of his literary language to the forefront. This partly happens because Auster does not dramatize the text, and hereby the text seems more closely related to the written experience; it is as if the performing narrator tries to be as loyal as posible to the text in this transition from writing to sound, avoiding a too-explicit interpretation. However, the voice of the author who performs the text nevertheless adds depth to the rethorical situation. (ídem)

4. La enunciación del texto: este punto tiene que ver con la posición del narrador en relación con el texto. En modelo original sugieren en este punto discutir al autor que lee el texto como un posible autor desplazado.

This example seems especially interesting as regards the double enunciation. Auster is especially famous for inserting the author «Paul Auster» into his early novels, and this (partly time-bound, 1980s-like) play on the position of enunciation also seems to haunt Auster when he reads Sunset Park, introducing the doubled, yet displaced, author inside the text. He is both a character that interprets the text and an author who embodies his own work, or at least this is continuously negotiated throughout the audiobook. (ídem)

5. La etnicidad, edad, nacionalidad y género de la voz performática. En este punto se evalúa la contextualización general de la situación de escucha.

With regard to the contextualization it is worth pointing to Auster's position as one of the central figures of postmodern American fiction and to his marriage to another prominent contemporary author, Siri Hustvedt. Both are part of an intellectual elite, which naturally affects the reader's expectations to the literary style and the literary network of which Auster is part [...]. (ibídem, 89-90)

\subsubsection{La tecnología}

Juliana Rueda asegura que una buena escucha de audiolibros se vuelve adictiva, y la tecnología es la clave para conseguirla. Gracias a las nuevas tecnologías, la voz ha dado un salto en calidad, además de contar con modos más modernos de almacenamiento y conservación que garantizan que la voz perdure por mucho más tiempo que con los antiguos soportes analógicos (2019:31).

Para conseguir este salto en calidad se han mejorado las técnicas de producción de audiolibros, así como las de entrega y almacenamiento de información.

Pero fue la llegada de los dispositivos móviles inteligentes la que provocó un punto de inflexión fundamental en este ámbito. Por esta razón nos detendremos para definir cuáles son sus características fundamentales y cuáles son compatibles con la escucha de audiolibros.

\subsubsection{Tecnologías para la recepción de audiolibros digitales}

Las tecnologías más utilizadas para la escucha de audiolibros digitales son los dispositivos móviles, con 
capacidad de procesamiento y conexión permanente a la red y con memoria suficiente para realizar varias funciones al mismo tiempo.

La característica principal es la movilidad (o portabilidad, ya que son las personas las que transportan los teléfonos o dispositivos móviles), y un factor clave en el desarrollo y diseño de este tipo de dispositivos es el de la accesibilidad, que permite el uso de las aparatos y aplicaciones a usuarios con necesidades especiales.

La gama de dispositivos móviles es muy amplia y está en continua evolución. Sin embargo, podemos realizar un breve análisis de los dispositivos más frecuentemente utilizados para la escucha de audiolibros digitales, comenzando por el teléfono móvil.

- El teléfono móvil pasó de ser una herramienta exclusiva de la comunicación para convertirse en un personal trusted device o dispositivo personal de confianza (ISEA, 2009). La posibilidad de integrar en un mismo dispositivo de tan reducido tamaño las funciones de navegación de Internet, descarga de apps y reproducción multimedia, convirtieron al teléfono móvil en el preferido para la escucha de audiolibros.

Gracias a la posibilidad de descargas de actualizaciones, aplicaciones como Storytel están permanentemente ofreciendo ventajas a sus usuarios.

En el caso de la escucha de los audiolibros, las tecnologías representan un medio que nos permite llevar a cabo nuestro propósito, para lo cual sería imprescindible que nuestros dispositivos móviles contaran con:

a) Capacidad de memoria y almacenamiento de datos.

b) Procesamiento rápido.

c) Soporte simultáneo de diferentes interfaces radioeléctricas como wifi, Bluetooth, GPRS, UMTS, etc.

d) Dispositivo ligero y cómodo de sujetar y transportar.

e) Óptima independencia de la batería.

f) Óptima calidad de sonido

g) Posibilidad de conexión de auriculares (de ser posible con entradas independientes para la carga del aparato y el auricular ${ }^{25}$ ).

- Los teléfonos inteligentes o smartphones son dispositivos más sofisticados que un teléfono móvil simple, ya que presentan ciertas características similares a las de un ordenador personal. Estos dispositivos aúnan las funcionalidades del teléfono móvil convencional en lo relacionado con el envío de mensajería, pero permiten al mismo tiempo la posibilidad de instalar programas o aplicaciones para incrementar el procesamiento de datos y la conectividad. El tamaño de los dispositivos oscila entre 2 pulgadas a más de 4 pulgadas. Las resoluciones más típicas varían entre $320 \times 240$ y $1280 \times 800$.

Entre las posibilidades de este tipo de dispositivos multitarea están:

${ }^{25}$ En el caso de iPhone X, XS, XR, iPhone 8, 8 Plus, iPhone 7, 7 Plus no es posible la carga del dispositivo y la conexión del auricular al mismo tiempo. 
a) Acceso a internet a través de wifi o redes $3 G$ y $4 G$

b) Función multimedia (cámara y reproductor de videos o audio)

c) Agenda y funciones administrativas básicas

d) GPS

e) Grabadora de voz

f) Capacidad de editar documentos como PDF u Office

- Tableta y e-readers: según Gómez Díaz, et al. (2016:59), el dispositivo por excelencia para la lectura fue el e-reader, especialmente a partir del año 1998, cuando se les añadió la tinta electrónica.

La mayoría de kindles modernos pueden reproducir audios. Audible lista en su página todos los modelos de kindles que tienen la funcionalidad para reproducir audiolibros (14) y los que no (3). ${ }^{26}$ Sin embargo, y como hacen notar Gómez Díaz, (ídem) los lectores de tinta electrónica quedan en desventaja frente a los dispositivos multitarea, como las tablets, que han incorporado progresivamente funciones correspondientes a la lectura como a la telefonía y en ocasiones procesamiento de textos, también.

Las tabletas utilizan los mismos sistemas operativos que emplean los smartphones, permitiendo acceder a las plataformas de compra y descarga de aplicaciones desde las tiendas integradas, según su sistema operativo.

Una tableta es un tipo de ordenador portátil, de mayor tamaño que los móviles, integrado en una pantalla táctil con la que se interactúa con los dedos o una pluma stylus. Por lo general carecen de teclados integrados, aunque pueden conectarse a uno de forma inalámbrica o mediante un cable USB.

- Reproductores portátiles de MP3 y MP4. Un simple reproductor de música puede servir para reproducir un audiolibro, ya que es un dispositivo específico para almacenar y escuchar audio en diferentes formatos.

Entre las posibilidades que ofrecen estos dispositivos encontramos la posibilidad de descargar aplicaciones específicas, como puede ser el caso de las relacionadas con la audiolectura.

- Videoconsolas portátiles: si bien están asociadas al público joven y adolescente, debemos hacer referencia a este dispositivo ya que también permite tanto la escucha de audiolibros en formato MP3 y MP4, como la escucha en streaming.

- Ordenadores portátiles o laptops: según Elena Otto, (2017:163) no existe consenso sobre si deben o no ser considerados dispositivos móviles o no. Alguna de las características que poseen este tipo de ordenadores no parecen compatibles con las que tenemos para la audiolectura. Si bien los ordenadores pueden almacenar y reproducir audiolibros, sus propias características están reñidas con algunas de las ventajas principales que ofrecen otro tipo de dispositivos móviles, como un peso y un tamaño mucho menores.

\footnotetext{
${ }^{26}$ El listado completo puede accederse a través de esta página web, consultada el 10 de julio de 2020. https://audible.custhelp.com/app/answers/detail/a_id/4679/ /does-audible-work-on-all-the-kiS/Dle-devices/
} 


\subsection{VENTAJAS DE LOS AUDIOLIBROS}

Las ventajas que ofrecen los audiolibros son numerosas, y conforme las tecnologías avanzan y se populariza su uso se van descubriendo nuevas cualidades, tanto si hablamos del uso personal, para estudio, o incluso desde un punto de vista terapéutico.

Comenzaremos por la accesibilidad y la portabilidad que ofrece este nuevo formato, con la consecuente posibilidad de su acceso desde cualquier lugar, con la única condición de poseer un dispositivo.

\subsubsection{Accesibilidad y portabilidad}

Podemos situar como una de las principales ventajas de los audiolibros a la accesibilidad, ya que cuando no existe la posibilidad de lectura por limitaciones físicas, las nuevas tecnologías de la voz han aportado la audiolectura, principalmente a personas con discapacidad visual, necesidades especiales o dislexia, entre otros impedimentos.

Si bien los audiolibros parecen ser una puerta abierta a la literatura para aquellas personas con discapacidad y entendemos que suponen una ventaja cualitativa, la rapidez con la que proliferan las aplicaciones de audiolectura ha producido que, en ocasiones, las mismas no cuenten con todos los principios necesarios para ofrecer garantías de accesibilidad a algunos grupos de lectores, como las personas que presentan deficiencias visuales.

La tecnología digital también democratizó el acceso de los contenidos en audio a todos los lectores, ya que no se necesitan mediadores en el proceso de acceso y escucha de los libros, siendo los proveedores los que directamente suben contenidos que pueden ser disfrutados a través de páginas webs o aplicaciones de audiolectura; pero, en muchas ocasiones, la premura de las empresas por comercializar sus productos puede ir en detrimento de la calidad de sus productos.

Por esta razón, destacamos el trabajo realizado por la NNELS de Canadá (la National Network of Equitable Library Service), organismo que aboga por un acceso equitativo a la lectura para todos los ciudadanos canadienses y que realizó un estudio, difundido a través de su propia página web en octubre de 2020, sobre la accesibilidad que ofrecen diversas aplicaciones de audiolectura en múltiples plataformas, incluyendo dispositivos IOS, Android, Windows y Mac.

El estudio puso de manifiesto algunas carencias que presentan una serie de aplicaciones de lectura en cuanto a la accesibilidad y, tras estas conclusiones, el organismo contactó a cada uno de estos proveedores ofreciéndoles un informe de estos resultados. El feedback entre el organismo y cada proveedor beneficiará a los usuarios finales, que probablemente puedan disfrutar de una accesibilidad sin ningún tipo de barrera, gracias a haber sido auditadas por la NNELS. 
Las trabas más importantes identificadas por el organismo ${ }^{27}$ que realizó la evaluación y que vale la pena tener en cuenta incluyeron:

- Botones o enlaces sin etiquetas: no todos los botones en las aplicaciones móviles y en los sitios web están etiquetados con su respectivo texto. Esto presenta una barrera para los usuarios de lectores de pantalla, que no pueden determinar la función de un botón o un enlace antes de hacer clic en ellos.

- Interfaces desorganizadas y/o abarrotadas: algunas secciones de las aplicaciones móviles o sitios web aparecen abarrotadas y no poseen encabezados que separen las secciones claramente. Cuando las pantallas contienen demasiada información, no es fácil para alguien que no puede explorarlas visualmente orientarse y encontrar lo que está buscando.

- Problemas con obstáculos/gestos: hubo algunas dificultades para alcanzar elementos y activar controles a través del teclado o con gestos de deslizamiento comunes.

- Abrir en la «vista de imágenes»: algunas publicaciones (por ejemplo, artículos de revistas o libros electrónicos) se abren en la vista de imágenes de forma predeterminada. Cuando no hay texto en la pantalla, los usuarios que dependen de los lectores de pantalla no pueden acceder al contenido.

Sumada a la accesibilidad, existen otras ventajas específicas para personas con necesidades especiales que revisaremos en el apartado 5.8.7.

La accesibilidad también favorece a las bibliotecas. Por un lado, pueden dar acceso a sus colecciones a sitios remotos - siempre y cuando cuenten con las licencias suficientes- ; y, por el otro lado, organizar eventos en línea, como clubes de lectura o festivales orales, con la ventaja de que pueden acceder desde cualquier lugar del mundo.

Otra virtud que está ligada a la accesibilidad es la portabilidad (o movilidad) (APA, 2018; Have y Stougaard Pedersen, 2016).

Irene Vallejo (2019:35) indica que, aunque pueda resultar paradójico, la oralidad debe enormes triunfos a los avances tecnológicos, ya que desde tiempos remotos el poder de la voz humana solo podía alcanzar a las personas físicamente presentes. Además de la radio, Irene suma al teléfono como uno de los fulminadores de las limitaciones que existían en esta propagación de la voz. Y como un último avance, los teléfonos móviles, los satélites y la cobertura que hacen que nuestra voz ya no tenga límites geográficos.

No hay que remontarse muchos años atrás para situar el comienzo de esta portabilidad; el 27 de junio de 2007 Steve Jobs lanzó al mercado el primer iPhone.

Tras esta innovación, las tecnologías móviles despegaron llegando a ser las más extendidas de la historia de la tecnología, incluso en países en vías de desarrollo (Unesco, 2013).

\footnotetext{
${ }^{27}$ Se encuentran en el siguiente enlace, bajo el subtítulo: what we found https://www.accessiblepublishing.ca/reading-app-reports/ (Consultada el 10/01/2021).
} 
En muchos lugares del mundo, a pesar de la escasez de libros, existe una tendencia creciente del uso de teléfonos móviles. Hoy en día las Naciones Unidas calculan que las redes móviles dan cobertura a más del 90 por ciento de la población (Unesco, 2019).

La Fundación Telefónica, en su informe anual Sociedad Digital en España 2019, que analiza los indicadores y tendencias de la evolución digital en España, reveló que nueve de cada diez españoles cuentan con acceso a internet, y tres de cada cuatro hogares cuentan con cobertura de fibra óptica. De hecho, España se sitúa en primer lugar en cuanto a cobertura y cantidad de clientes de esta última tecnología.

Otra conclusión a la que arriba dicho informe es que el acceso a internet móvil de alta velocidad es el servicio que más crece a nivel global: ya hay casi 5.300 millones de habitantes que disponen de este servicio en todo el mundo. No en vano, en los últimos cinco años, el número de usuarios de banda ancha móvil ha crecido con una tasa media anual del $22 \%$, frente al 9,2\% de la banda ancha fija o el $4,1 \%$ de la telefonía móvil.

Como mencionamos, según Have y Stougaard Pedersen (2013:54), la movilidad (o portabilidad) es una de las más importantes affordances de los audiolibros, y la relacionan con otra importante affordance, el micro-archivo - hoy en día la mayoría son archivos MP3 o MP4-, que actualmente han revolucionado el sector del libro y han incluido la flexibilidad y la movilidad como signos de identidad del audiolibro.

Los dispositivos móviles, como consecuencia de su diseño, como regla general no ofrecen tanta capacidad de almacenamiento y tráfico de datos como pueden hacerlo los ordenadores convencionales o portátiles. La memoria que ofrecen estos dispositivos no supera, por regla general, los $128 \mathrm{~GB}$, y de esta capacidad una parte es utilizada por el propio sistema operativo.

En muchas ocasiones la memoria del dispositivo colapsa con el uso simultáneo de varias aplicaciones, por lo cual, en muchos casos es recomendable la escucha de audiolibros en modo streaming o suplir esta carencia con el almacenamiento en «la nube». Con este término hacemos alusión a diferentes servicios para el almacenamiento de datos, lo que además nos ofrece la posibilidad de acceder al mismo en cualquier momento y desde cualquier dispositivo.

El acceso alternado desde dispositivos es muy útil, ya sea porque tenemos varias terminales o porque compartimos con otras personas la suscripción a una misma cuenta.

\subsubsection{Factor económico}

Si se comparan con el coste que supone la adquisición de libros impresos a nivel individual o a nivel institucional, además de los costes que acarrea el transporte, almacenamiento y gestión de colecciones, los audiolibros suponen una considerable reducción presupuestaria desde varios puntos de vista.

Por empezar, existen diversas modalidades para escuchar audiolibros digitales. Desde aplicaciones gratuitas - muchas veces gestionadas por voluntarios - pasando por modelos de compra individual de audiolibros, hasta modelos de suscripción. Asimismo, existe la posibilidad de utilizar un servicio de membresía de una biblioteca que disponga de una colección de contenido sonoro en español. 
Si nos detenemos en las modalidades de suscripción (tanto de títulos individuales como de colecciones), normalmente estos servicios en línea son más económicos que los libros tradicionales, además de ser fácilmente descargables y de que su compra puede realizarse de forma automática (Gómez Díaz, et al., 2016:24). Las suscripciones en general son mensuales y no superan los 15 euros, y las mismas dan acceso a una innumerable cantidad de títulos. (Puntualizaremos los diferentes modelos de suscripción en el apartado 5.16).

En este punto hay que destacar que además de la posibilidad que ofrecen varias editoriales a sus servicios de suscripción, existen otros beneficios que aportan los audios digitales a través de plataformas o aplicaciones de internet. Hedda Hanner y Alice O'Connor (2019:18) utilizan el término trialability (en español podría ser testeabilidad), adaptado del concepto de Roger (2003), y lo definen como «el grado en el cual un producto puede ser experimentado». Este concepto está relacionado con la posibilidad de que un usuario pueda utilizar sin restricciones todas las posibilidades que ofrece un servicio al cual se ha suscrito. En el caso de una suscripción de lectura podría ser pasar ilimitadamente de un libro a otro, a diferencia de una compra individual, en la que si este producto no lo satisfizo no tendría posibilidad de seguir disfrutando de otros ejemplares.

Al hilo del anterior concepto, Hanner y O'Connor (2019:18) mencionan the taxi meter effect (efecto taxímetro). Existen consumidores que disfrutan más el uso o consumo de un producto o servicio cuando este es ofrecido a través de un servicio plano a diferencia de otro que ofrezca la tarifa de pago por uso (Lambrecht y Skiera, 2006:221). Este efecto se refiere a los consumidores que pagan por un servicio fijo y su nombre deriva del malestar de ver el taxímetro corriendo en un trayecto en taxi; este fenómeno es extensivo a una variedad de servicios incluyendo aquellos digitales y es favorable en el caso de algunos modelos propuestos por empresas de suscripción de audiolibros ya que estas ofrecen ventajosas ofertas, en muchos casos dando acceso ilimitado a sus catálogos.

El progresivo abaratamiento de los dispositivos móviles es uno de los motivos por los que los audiolibros se están volviendo cada vez más utilizados, con aplicaciones más accesibles e intuitivas. Para aquellas personas que no dispongan de un dispositivo móvil, las bibliotecas también son una buena alternativa para solicitar un préstamo de tabletas electrónicas. Este servicio es cada vez más frecuente y utilizado, por lo cual esta situación no debería suponer un impedimento para comenzar una nueva audiolectura.

\subsubsection{La cronolectura}

El concepto de tiempo, según Raquel Gómez Díaz, et al. (2016:19), comienza a ser una variable inseparable de la lectura. Los autores utilizan el término "cronolectura» para abarcar este concepto que está en el vértice de la lectura y del tiempo, y del que el sector del audiolibro está siendo uno de los mejores representantes.

En el ámbito del audiolibro, el tiempo opera como variable desde dos puntos de vista: uno es el de la posibilidad de la multitarea, y otro es el que ofrecen algunas plataformas con contenidos "a la carta» destinados a aquellas personas que poseen cortos períodos de tiempo, y pueden realizar una lectura de forma fragmentada (ídem). 
A estas dos variables que mencionan Gómez Díaz et al. podemos sumarle una tercera, que radica en la posibilidad de la «escucha acelerada» o speed listening. Este método es equivalente a los de lectura rápida sobre textos impresos y existen muchas aplicaciones que ofrecen dicha posibilidad, especialmente a través de sus apps.

\subsubsection{Lectura fragmentada}

Aunque la lectura esté asociada a momentos de ocio y recreación, especialmente cuando se trata de leer ficción, existen algunas iniciativas que intentan dar respuesta a un lector que no posee tanto tiempo para dedicar a la lectura. Una de ellas es Blinklist, empresa fundada en el año 2012 en Alemania, que ofrece un servicio de suscripción de resúmenes de libros. Otro ejemplo, dedicado a literatura académica es el propuesto por Koober, que ofrece la posibilidad de resúmenes tanto textuales como en audio.

\subsubsection{Escucha acelerada}

Aunque los métodos de lectura y escucha rápida se hicieron más populares en un principio para el aprendizaje, la práctica del speed listening también se asocia al ocio (Vázquez Karelia, 2015). Respetar el ritmo original del audiolibro o no queda en manos del oyente, ya que las aplicaciones de audiolectura ofrecen la posibilidad de acelerar o retrasar en varios puntos la velocidad del audio.

5.8.3.3 Multitarea

Muchos autores coinciden en que el mayor beneficio que invita al uso de los audiolibros está dado por la propia naturaleza de estos, y la ausencia de dependencia de estos del sistema motor y ocular (VaraoSousa, et al., 2018:6). Esta característica que permite a una persona realizar otras tareas al mismo tiempo que la escucha de un audiolibro, es según la American Publisher Association (2018), la razón principal adjudicada a su uso.

Una de las vertientes con mayor proyección del consumo del audiolibro es, según Gómez Díaz, et al. (2016:29), el transporte particular. También lo afirman Have y Stougaard Pedersen (2012:90), quienes sugieren que en el commuting space el audiolibro aparece como una alternativa que rompe la monotonía propia de los viajes en coche.

Por esta razón, muchas firmas del sector automotriz están integrando en sus prestaciones aplicaciones para la escucha de audiolibros, como anunció Volskwagen para todos los países latinoamericanos, en abril de 2020, con su nuevo sistema multimedia VW Play.

Dado el aumento de conductores que escuchan audiolibros, un equipo de investigadores de la Universidad de Guelph (Canadá, 2018), realizaron un estudio de simulación de conducción en silencio comparado con un grupo que escuchaba audiolibros a fin de medir la distracción de los oyentes al volante (Nowosielski, et al., 2018:202-209). 
Dicha simulación comprendía cambios en la densidad del tráfico, en el escenario que los rodeaba y en la dificultad de la ruta. Los participantes se podían encontrar, incluso, con algunos riesgos en el camino. Los investigadores utilizaron el tiempo de respuesta frente a estos peligros o amenazas como una medida de su desempeño en la conducción. Los resultados mostraron que la escucha de audiolibros influyó en cómo los conductores reaccionaron, pero esta respuesta estuvo relacionada con el contexto de conducción. En la respuesta a la conducción simple, poco estimulante, los conductores reaccionaron más rápido- podían mantenerse alertas y concentrados- cuando escuchaban un audio, mientras que si la conducción era más compleja la respuesta se veía afectada.

Si bien el escuchar un audiolibro en un viaje solitario suele ser bastante común, también existe la opción de compartir esta experiencia con la familia o con otras personas.

El compartir un espacio, según Michael Bull (2007:61) es un fenómeno multifacético y muchas veces reproduce o refleja las divisiones de espacio existentes en un hogar, donde existen espacios separados o individuales para cada miembro de la familia. A pesar de que el libro de Bull, Sound moves, está más orientado a la música, el mismo mecanismo opera con los audiolibros, ya que el uso individual no es incompatible con el placer colectivo de los ocupantes de un vehículo.

En la tercera novela de la escritora mexicana Valeria Luiselli, del año 2019, encontramos una mezcla de ficción y documental en la cual una pareja emprende un viaje en coche junto a sus dos hijos desde Nueva York hasta Texas para documentar, entre otras cosas, la desaparición de menores migrantes. La escritora cita en varias oportunidades la utilización de los audiolibros, como podemos ver en algunos de los fragmentos del libro:

Las historias de los niños perdidos perturban más y más a nuestros hijos. Mi marido y yo decidimos dejar de escuchar las noticias en la radio, al menos mientras estén despiertos. En lugar de eso, decidimos escuchar música. O, mejor aún, audiolibros.

Al despertarse en el bosque en medio del frío y la oscuridad nocturnos..., dice una voz de hombre por las bocinas del coche, «había alargado la mano para tocar al niño que dormía a su lado». Le doy stop tan pronto como hace una pausa al final de la frase. Mi marido y yo coincidimos en que Cormac McCarthy, aunque nos guste, y a pesar de que La carretera nos gusta especialmente, puede ser demasiado duro para los niños. Además, coincidimos en que el lector de esta versión en audiolibro es un actor actuando -se esmera demasiado, sus inflexiones son artificiales-, y no una persona leyendo. Así que le doy stop. Luego desplazo la lista hacia abajo y le doy play a otro audiolibro.

Vine a Comala porque me dijeron que acá vivía mi padre, un tal Pedro Páramo», la voz fluye como con prisa, atropellando la sintaxis característica de Rulfo y añadiendo un énfasis telenovelesco en algunas líneas. Desplazo nuevamente la lista y le doy play otra vez.

Soy un hombre invisible». Es una primera frase seca y perfecta. Pero no, tampoco El hombre invisible de Ralph Ellison es lo que queremos escuchar. Lo que queremos es superponer, al territorio que recorremos en coche, una voz y una narrativa que se amolden de alguna forma al paisaje, y no algo que nos distraiga del todo de la realidad mientras nos movemos a través de esta húmeda amalgama de hiedras y bosques. Siguiente. Play.

En la ciudad había dos mudos, y siempre estaban juntos». Me gustaría escuchar este libro, pero no obtengo la aprobación de los dos traidores que viajan en el asiento trasero. Mi esposo tampoco quiere oírlo, dice que el único logro de Carson McCullers es el título y solamente el título de esa novela: El corazón es un cazador solitario. Se equivoca, y se lo digo, lanzándole mi desacuerdo con un poco de veneno al preguntarle si no cree que esa primera frase es, justamente, sobre nosotros dos, y si no deberíamos escuchar el resto de la historia, como quien visita al oráculo. Ignora mi comentario; no se ríe ni sonríe. Siguiente libro. 
Conocí a Dean poco después de que mi mujer y yo nos separásemos. Pausa. Éste lo comentamos con mayor detenimiento. Mi esposo opina que En el camino, de Jack Kerouac, es la elección perfecta. Incluso si los niños no entienden su significado, dice, todos podemos disfrutar del ritmo del libro mientras vamos en coche. Recuerdo que leí a Kerouac a mis veintipocos años, cuando tuve un novio librero. Me regaló todos sus libros, uno por uno. Los leí como si tuviera que terminarme un plato infinito de sopa tibia. Cada vez que estaba a punto de terminar, me llenaba el plato de nuevo. Algunos años después releí algunos libros de Kerouac, empecé a agarrarles el modo y llegó a gustarme su prosa, esa forma desgarbada de anudar las frases, el modo en que acelera en ciertas partes de la historia como si no estuviera imaginando o recordando sino poniéndose al corriente, y su forma de cerrar los párrafos como quien hace trampa en un examen. Pero no quiero concederle esta victoria a mi esposo, así que digo:

Preferiría escuchar una estación de radio evangélica antes que En el camino. [...]

Y mientras aceleramos nuevamente, deslizo la lista en la pantalla de mi teléfono y le doy play al siguiente audiolibro.

El niño rubio se dejó caer por la roca y se abrió paso hacia la laguna». Tras escuchar esa primera frase, los cuatro coincidimos: éste es el bueno, éste es el que vamos a escuchar: El señor de las moscas leído en voz del propio William Golding. Sabemos que no se trata de un cuento de hadas, ni de una visión edulcorada de la infancia, pero al menos es ficción. Una ficción que no nos alejará de la realidad ni a nuestros hijos ni a nosotros, sino que incluso puede ayudarnos a hacerla parcialmente comprensible para ellos. Y si no hacerla comprensible, al menos puede ayudarnos a formular preguntas que nos permitan contemplarla con mayor claridad.

Escuchamos la lectura durante algunas horas, y probablemente tomamos algunas salidas equivocadas y nos perdemos un poco, así que escuchamos la lectura un rato más, hasta que no podemos seguir escuchando, ni manejando, ni estar un minuto más sentados. (Luiselli, 2019:98-100)

Más adelante:

Compramos el mapa que nos recomienda -detallado y gigante-, aunque lo cierto es que no necesitamos otro mapa. Mi esposo compra un libro sobre la historia de los caballos, el niño escoge una edición ilustrada de $E /$ señor de las moscas de Golding, para acompañar el audiolibro que hemos estado escuchando, y la niña un libro titulado El libro sin dibujos. (ibídem, 110-111)

\section{Y, por último:}

De regreso en el coche, los niños exigen que pongamos un audiolibro. El niño quiere seguir escuchando El señor de las moscas.

Al despertarse en el bosque en medio del frío y la oscuridad nocturnos..., dice la voz masculina cada vez que conecto mi teléfono al sistema de sonido del coche. Supongo que es porque La carretera de McCarthy es el primero en la lista de reproducción, pero no logro descifrar por qué comienza a sonar en automático, como un juguete diabólico. Los niños se quejan desde el asiento trasero. Le pongo stop y les pido que tengan paciencia mientras busco El señor de las moscas.

La niña dice que no quiere seguir oyendo esa historia, que no la entiende, y que además, cuando sí la entiende le da miedo. El niño le dice que se calle, que sea más madura y aprenda a escuchar historias. Le dice, también, que El señor de las moscas es un clásico, y que tiene que entender los clásicos si quiere llegar a entender cualquier otra cosa. Yo tengo el impulso de preguntarle al niño de dónde sacó eso, pero no lo hago, por el momento. A veces me pregunto si los niños, en efecto, entienden algo de El señor de las moscas, o incluso si deberían entenderla. Tal vez los exponemos demasiado -a demasiado mundo-. Y tal vez esperamos demasiado, esperamos que entiendan cosas que quizá no están listos para entender. (ibídem, 115)

Para concluir, es frecuente que quienes realizan actividades en conjunto en sus casas también lo hagan en estos trayectos compartiendo música o lecturas y quienes estén acostumbrados a su espacio sonoro individual no tengan que negociar el contenido de lo que se va a escuchar ya que disponen de su propio 
dispositivo.

\subsubsection{Almacenamiento y ventaja medioambiental}

En estos momentos de una mayor conciencia medioambiental y a la vista de los graves problemas que acarrea la deforestación, el mundo editorial no está exento de buscar alternativas sostenibles para la impresión de sus ejemplares, que cuenten con las garantías de calidad y que no encarezcan el precio final al consumidor.

Esa garantía, en el mundo impreso, la han encontrado en un sello de calidad que certifica Europa y es el FSC (Forest Stewardship Council). Es un certificado que hoy en día pocas editoriales han conseguido, pero que indica el camino hacia un ecosistema más sostenible y un mapa de ruta a seguir. Entre las editoriales que han adherido a este certificado se encuentra Penguin Random House, que publicó su primera novela impresa bajo su rúbrica en el año 2014, con El Bosque de los Pigmeos, de Isabel Allende.

Además del proceso de producción de los libros está el de almacenamiento. Las bibliotecas, tanto personales como privadas, se encuentran muchas veces al límite de sus capacidades y deben realizar expurgos para poder actualizar sus colecciones. En algunas áreas el material se vuelve obsoleto con más rapidez que en otras, como es el caso de las ciencias biomédicas o informática, por ejemplo. En literatura sucede en muchos casos lo contrario, ya que las primeras ediciones, los libros raros y las primeras ediciones son muy valorados, pero en muchas ocasiones el papel no resiste el paso del tiempo y puede llegar a deteriorarse.

Como consecuencia de la falta de espacio, el Grupo Planeta anunció a fines de 2019 que ya no podía almacenar algunas de sus colecciones, desterrando la posibilidad de custodiar por más tiempo los excedentes de las ventas de varios autores de Obras completas de Círculo de Lectores. Para ello llevaría a cabo una «operación de destrucción parcial» de los ejemplares que guardaba en sus almacenes (EI País, 30/09/2019).

No solo en comparación con los libros impresos los audiolibros suponen una solución menos exigente con el medio ambiente, sino con sus mismos predecesores analógicos. Recordemos una vez más que antes de los audios digitales, la grabación de obras como Guerra y Paz, de Leon Tolstói, requería 119 discos de long play, 45 cintas de casetes o 50 CD (Rubery, 2011:8).

\subsubsection{Mayor conexión con el libro y compañía parasocial}

En muchas ocasiones, la conexión que puede generar la voz humana puede ser superior a la que nos produce la lectura de un libro impreso, y por esta razón podríamos continuar con una determinada historia gracias a esta interpretación (Gómez Díaz, et al.,2016:24).

Isabel Coixet, relata en un artículo de opinión de la revista $X L$ Semanal, la conexión que un audiolibro determinado le produce:

Me pongo los cascos y escucho Un pedigree, de Patrick Modiano, leído por Jean Louis Trintignant. Tengo pocos audiolibros, pero en este la memoria del texto de Modiano se mezcla con la voz cargada de tristeza y evocación 
de Trintignant. No hay banda sonora mejor para este trayecto en un autocar vacío bajo la lluvia al que nadie sube y del que nadie baja. (Coixet, 2020)

Existen estudios que hablan de este efecto de intimidad que produce una voz en los oídos, y que nos brinda una sensación de compañía. A esta sensación o sentimiento que aparece en la bibliografía sin un nombre preciso Horton y Wohl la denominaron: compañía parasocial (Horton and Wohl, 1997, citado en Have y Stougaard Pedersen, 2013:54).

El concepto de parasocial fue acuñado originalmente por Horton y Wohl en 1956, para describir la ilusión de interacción recíproca que muchos individuos que formaban parte de audiencias experimentaban hacia las figuras mediáticas, especialmente de la televisión (Caro Castaño, 2015:24). Actualmente dicho concepto se puede extender a otros formatos y medios de comunicación.

Este efecto positivo no debe ser subestimado ya que, en neurobiología, como indica la ensayista y novelista Siri Hustvedt, la memoria se consolida por las emociones, por lo cual lo que ella denomina «fuerza abrazadora» -y se refiere a ese vínculo entre libro y lector- puede extenderse a la relación narrador oyente, y como la autora indica, puede hacer que una persona recuerde incluso dónde estaba cuando leía un libro en particular (Hustvedt, 2020, youtube).

\subsubsection{Posibilidad de una lectura intersensorial}

La experiencia de la lectura de audiolibros permite que mientras utilizamos nuestro sentido de la audición, el sentido de la vista y nuestro cuerpo estén libres. "Esta negociación espaciotemporal hace que la experiencia del audiolibro sea extremadamente compleja» (Have y Stougaard Pedersen, 2016:34). Según las autoras, el proceso cognitivo de la escucha de un audiolibro y su consecuente adquisición de contenidos, como el de la historia y su trama, es idéntico al de la lectura de un libro impreso; sin embargo, para los escritores «el imaginado espacio ficticio es constantemente desafiado por inputs sensoriales, por el espacio físico real por el cual el ojo y el cuerpo de uno se mueven» (ídem).

Estos estímulos pueden ser visuales, táctiles, pero también enriquecidos por inputs audibles (provenientes de la propia ciudad, cuando estamos en movimiento) (ibídem, 11).

El exterior configura un papel muy importante, tanto que Michael Bull (2007:40) lo denomina la «estética de la calle»; ya que, si bien la actividad de escuchar un audiolibro a través de auriculares se encuadra en lo que podemos denominar una actividad privada, la misma puede ser voluntariamente transportada al exterior en busca de nuevos espacios cognitivos.

Bull ilustra esta lectura intersensorial con el ejemplo de una persona que disfruta la experiencia de escuchar una ficción estando en un lugar público, como una cafetería. «En ese caso el impulso estético transforma el espacio mundano del café en el escenario de la novela que se está escuchando, con sus clientes como personajes desconocidos» (ídem). Este testimonio que recoge Bull en su libro también es extrapolable a la experiencia de la escucha de música a través de un iPod, en donde el exterior puede resultar un input para nuestro estado emocional cuando escuchamos, por ejemplo, una pieza musical.

Por este cariz dinámico y multisensorial Have y Stougaard Pedersen proponen que la escucha de un audiolibro debe ser descrita y analizada como una experiencia multisensorial y la encuadran en un 
evento poliestético (2016:12). De esta apreciación lo interesante es que el lector debe tener la habilidad de crear una «atención estética».

Wendy listens to The Waves by Virginia Woolf read by Frances Jeater while working in her new flower bed under the copper beech in the corner of the garden. The audiobook includes short musical interludes played by a solo violin or by violin/piano. While planting rhododendrons she listens to the descriptions of the landscapes in Woolf's novel. Touching the soil and the sturdy leaves of the bushes and the hard work of digging endow her listening experience with a certain type of tactility. It is as if the description of landscapes coincide with the tactile dimension of the gardening-negotiating the experience of interior and exterior. Wendy's experience of the movements of her hands handling the organic material and the audible dimension of the voice in her ears seems to create an intersensorial moment. Through the following autumn and winter she often casts a glance at the new bed, which continues to remind her of the melancholy mood of the novel as well as the audible character of Woolf's language. It seems that the poetic quality of Woolf's language when read aloud is underlined. The rhythmic structure of Woolf's narration in some ways tends to step forward when one is listening, and the sense of the voice of the performing narrator Reading this in itself very audible language, is creating a specific haptic listening situation. (ídem)

Comparando la experiencia de la escucha de un audiolibro frente a la visualización de una pantalla con una obra fílmica, la University College of London realizó un estudio para determinar si la primera actividad podía ser más emocionante que la segunda (Richardson, et al., 2018).

En el mencionado estudio se concluye que escuchar audiolibros resulta más emocionante que mirar películas o televisión. El estudio fue realizado en colaboración con Audible, el mayor proveedor mundial de entretenimiento sonoro. Los investigadores de la UCL proyectaron escenas de historias conocidas sobre delitos, ciencia ficción, fantasía, acción y géneros clásicos a 103 participantes de entre 18 y 67 años para evaluar el impacto fisiológico de los medios de narración auditiva en comparación con medios visuales. El análisis de esos datos, así como la respuesta biológica de los participantes, revelaron que escuchar audiolibros provocó una reacción fisiológica y emocional más intensa comparado con la visualización de las escenas en pantalla.

\subsubsection{Facilidades para personas con necesidades especiales}

Cuando se piensa en potenciales audiolectores, en primer lugar, podríamos situar a las personas con discapacidad visual, pero existe un espectro mayor de posibles usuarios, como menciona Judith Elkin a continuación:

El rango de las discapacidades de las personas que utilizan audiolibros es amplio e incluye discapacidades motoras, visuales, intelectuales y emocionales. Muchos de nosotros probablemente tenemos discapacidades que ni siquiera son reconocidas como tales ${ }^{28}$. (Elkin, 2003:143)

Resumiremos a continuación cuáles son los grupos más destacados que encuentran beneficios en la utilización de los audiolibros.

\footnotetext{
${ }^{28}$ The range in disabilities is wide and includes motor, visual, aural, intelectual and emotional. Many of us probably have disabilities which are not even acknowledged as such (trad. a).
} 
Como la propia página de la ONCE (Organización Nacional de Ciegos Españoles) menciona, «la visión representa un papel central en la autonomía y desenvolvimiento de cualquier persona y, especialmente, durante el desarrollo infantil». Por esta razón, las diferentes patologías relacionadas con la vista pueden reducir o anular por completo la entrada de información a través de los ojos. De hecho, la ONCE cifra en un $80 \%$ la cantidad de información necesaria que diariamente captamos a través de la vista.

Según la citada organización, cuando se habla de ceguera o deficiencia visual se está haciendo referencia a condiciones caracterizadas por una limitación total o muy seria de la función visual en uno o varios de esos parámetros medidos. "Es decir, se trata de personas que, o bien no ven absolutamente nada, o bien, en el mejor de los casos, incluso llevando gafas o utilizando otras ayudas ópticas, ven mucho menos de lo normal y realizando un gran esfuerzo de enfoque» (ONCE, 2020).

Una de las dificultades con las que se enfrenta este grupo tiene que ver con la accesibilidad a soportes tradicionales de lectura, como libros y revistas, entre otros documentos. Por esta razón se han introducido diferentes sistemas y tecnologías tendientes a un acceso más abarcador de toda la comunidad que presenta alguna deficiencia visual.

El sistema braille, creado a mediados del siglo XIX a partir del sentido del tacto, ofreció un grado de autonomía en la lectoescritura a aquellas personas privadas de vista. Actualmente, las nuevas tecnologías sumadas a los sistemas de audiolectura digitales abren un acceso sin precedentes para aquellas personas que no pueden leer en formato impreso.

Los teléfonos inteligentes y las tabletas incorporan funciones de accesibilidad muy útiles para la población con discapacidad visual. De hecho, se realizó un estudio en la Network of Quebec based Vision Rehabilitation Centers, con un total de 466 participantes, que arrojó el dato de que el 87,4\% de los mismos consideran que los dispositivos actuales están reemplazando a los tradicionales, especialmente en actividades tales como: identificación de objetos, navegación, solicitud de ayuda visual, lectura de libros electrónicos y audiolibros (Martiniello, et al., 2019:1).

Hay que mencionar también que paralelamente a estos avances tecnológicos, se realizaron importantes acuerdos a nivel internacional que favorecieron aún más la accesibilidad a documentos en formato audio. Profundizaremos en el desarrollo de colecciones para ciegos en España (véase apartado 6.3).

En educación, la inclusión de recursos sonoros es una acción formativa muy utilizada, ya que puede servir para completar, documentar o ilustrar algún tema específico. La reproducción de una conferencia, un pódcast o una entrevista son algunas de las posibilidades más utilizadas en las aulas; sin embargo, también hay que pensar en aquellos estudiantes que por orden físico no pueden leer en formato impreso.

Cada vez la sociedad se vuelve más consciente de la necesidad de democratizar el acceso a los recursos, por lo cual la incorporación de contenidos didácticos sonoros deja de ser un proyecto para ir convirtiéndose en una realidad en algunas universidades españolas.

Aunque el profesor puede valerse de recursos en soporte audio que encuentra a través de distintas bases de datos, plataformas o aplicaciones, también existe la posibilidad de que sea el propio profesor o alumno el que se convierta en un creador de contenido. 
Para este fin existen diversas aplicaciones en internet que posibilitan la conversión de textos a audio. Las ventajas nombradas en la Guía para crear contenidos digitales accesibles (Hilera-González, CampoMontalvo, 2015:174) del año 2015 son las siguientes:

a) Permite a cualquier estudiante acceder a los contenidos a través del sentido de la audición, en cualquier momento y en cualquier lugar.

b) Proporciona una alternativa accesible a los contenidos textuales para personas con discapacidad visual.

c) Se puede utilizar la versión textual del audiolibro por parte de las personas con discapacidad auditiva.

5.8.7.2 Dislexia

La dislexia es un trastorno del aprendizaje, que entra dentro de la tipología de las llamadas Dificultades Específicas de Aprendizaje (DEA) y supone una dificultad para leer, a raíz de problemas para identificar sonidos del habla; por esta razón, las capacidades de comunicación se ven alteradas.

No existen estudios oficiales que recopilen una estadística fidedigna de la incidencia de la dislexia en España. Sin embargo, en el Anuario AC/E de Cultura Digital del año 2018 se cifra que este trastorno afecta aproximadamente a entre un 5 y un $10 \%$ de la población de niños y adultos. Solo en el entorno escolar la cifra se eleva a unos 700000 alumnos (Cencerrado, et al., 2018:128).

El dato de la incidencia en la infancia y adolescencia es importante ya que dadas las dificultades en el aprendizaje se estima que el 40 \% del fracaso escolar en España está provocado por la dislexia (ibídem, 134).

Entre las tecnologías que son de interés para niños disléxicos se encuentran los audiolibros, ya que los que sufren este trastorno pueden leer y escribir, pero no puede hacerlo de forma automática, se cansan y cometen errores (Vallorani, 2011:60).

La Asociación Andaluza para la Dislexia recomienda que los libros de lectura deben ser adecuados al nivel lector del alumno e insta, de ser posible, a buscar lecturas que se puedan encontrar en audiolibros, ya que según explican «si el material no se ajusta a su nivel, solo lograremos aumentar más su fobia a la lectura y su sentimiento de frustración» (ASANDIS, 2010:55).

Nos llama la atención la escasez de estudios realizados respecto a la audiolectura y los disléxicos. Existen numerosos estudios encontrados sobre este trastorno en la base de datos PUBMED con relación a la lectura en general, pero no relacionado con audiolibros. Las recomendaciones en el resto de artículos son muy vagas y no están sustentadas en una base científica. Sin embargo, el tema excede nuestro objetivo de estudio por lo cual sugerimos una investigación más profunda sobre esta relación.

\subsubsection{Otros trastornos o discapacidades}

Para conocer las novedades y obtener un amplio panorama en cuanto a la utilización de audiolibros por parte de personas con diferentes trastornos o patologías, hemos realizado una búsqueda en la 
base de datos biomédica que contiene más de 19 millones de referencias, llamada PubMed, y hemos analizado los resultados de los últimos 10 años en búsquedas relacionadas con el término "audiolibros». Cabe mencionar que no existe el descriptor audiobook en su tesauro de encabezamientos de materia MESH, por lo cual realizamos la búsqueda en todos los campos.

Descartamos muchos artículos que tratan de títulos relacionados con mindfulness, ya que, si bien son considerados audiolibros, su contenido no está relacionado con ficción y se encuadra más con la temática de la autoayuda o la meditación.

Un ejemplo interesante del uso de los audiolibros fue publicado en una revista holandesa de psiquiatría, en la cual fue presentado un artículo relacionado con la escucha de audiolibros de ficción en pacientes psiquiátricos. La revista estima que son una valiosa alternativa cuando por orden físico o mental no pueden realizar una lectura tradicional (Herpers, et al., 2016:480).

Dos artículos orientaron sus estudios sobre el uso de audiolibros y música para la recuperación de pacientes que han sufrido accidentes cerebrovasculares, sugiriendo ensayos a mayor escala, pero dando prioridad en este caso a la música sobre la utilización de los audiolibros (Baylan, et al., 2018; Baylan, et al., 2020).

\subsubsection{Estrés o necesidad de relajación}

Este es un tipo de trastorno que podríamos englobar dentro de los que Elkin denomina trastornos emocionales (2003:143) y que muchas veces es pasado por alto.

Have y Stougaard Pedersen, (2016:133) mencionan una tendencia en Dinamarca que consiste en la escucha de CD con sonidos naturales cuyo objetivo es el de la relajación, o la llamada por ellas musicure. Este tipo de terapia es narrada por psicólogos que tratan de aliviar algunos síntomas relacionados al estrés o la depresión. En España también existe un mercado creciente de obras de autorrelajación o relajación autoinducida, y uno de los formatos preferidos de estos libros es el audio.

Según las autoras, y en contraste con la affordance de movilidad, que ya hemos mencionado en otro apartado, existe un grupo de audiolectores que utilizan los audiolibros como un medio para relajarse o dormirse. Have y Stougaard Pedersen hablan en su libro de esta posibilidad como una ventaja:

If the aim is to fall asleep, audiobook reading is more convenient tan eye reading; the intimate, narrating voice calms you down, the lights may be off, and you can lie flat on the bed while listening. So, the audiobook has some advantages compared to the paper or e-book when it comes to relaxed reading you can close your eyes and you do not have to move a muscle. (ídem)

\subsubsection{Integración del formato con hábitos de vida saludables}

Según Gómez Díaz, et al. (2016:24) los audiolibros son perfectos para integrarlos dentro de los hábitos de vida saludables, como puede ser pasear o hacer ejercicios. 
La idea de hacer deporte al aire libre se contrapone con la idea de leer un libro impreso o de ver audiovisuales. En general quienes miran series lo hacen en casa, desde la comodidad de un sofá. Es necesario estar quieto para conectarse a Netflix, una de las plataformas más famosas distribuidoras de contenido audiovisual. En el año 2017 el CEO y cofundador de esta empresa, Reed Hasting, publicó un tweet evocando, según su entender, a su competidor real. Cualquiera podría pensar que el mayor competidor de Netflix es HBO o Amazon, pero el mensaje de Reed Hasting rezaba lo siguiente: «Estamos compitiendo con el sueño».

Luego amplió su enunciación asegurando que compiten, en general, por tiempo de pantalla, es decir, no solo contra un proveedor, sino con cualquier actividad que una persona pueda hacer, como hacer deporte, o dormir, por ejemplo.

Los audiolibros, por lo contrario, están muy presentes entre aquellos que realizan deporte, y las editoriales dedicadas al audio no pierden la oportunidad de promocionarse entre estos grupos de deportistas. Un ejemplo es el de la empresa francesa Audiolib, que ofreció gratuitamente audiolibros a los corredores de la semi-maratón de París (Cordón-García, 2018:180).

En este caso, los oyentes además de realizar una multitarea (correr y escuchar un libro), estarían realizando una actividad compatible con la vida saludable.

\subsubsection{Posibilidad de escucha grupal y creación de comunidad}

Cuando hablamos de lectura en soporte papel estamos refiriéndonos a una lectura silenciosa y solitaria, mientras que la escucha de un audiolibro es sonora, pero puede ser solitaria o grupal.

Es interesante el artículo de Francisca Goldsmith (2017:32), en el cual introduce una idea sobre los audiolibros muy abarcadora y conectada con el entorno. Para la autora, el acceso a voces reales conduce a una mayor conciencia cultural, mayores aspiraciones y al desarrollo de personas que puedan conectar con otros en una discusión. Para Goldsmith, vivimos en una alfabetización transmedia en donde las noticias, información de seguridad y salud, exposición a opiniones e ideas requieren oyentes hábiles, y los audiolibros pueden ofrecer una plataforma para el desarrollo crítico personal, e incluso un anclaje en la comunidad.

Las tecnologías móviles, al facilitar y agilizar enormemente los procesos de comunicación tanto de forma sincrónica como asincrónica, permiten la creación de grupos de interés o comunidades. Una de las posibilidades es la de crear redes de comunicación o grupos de lectura dependientes de bibliotecas o creados por instituciones públicas y privadas. 


\subsection{POSIBLES OBSTÁCULOS DE LOS AUDIOLIBROS}

Aunque el audiolibro está mostrando su potencial en nuestra sociedad actual gracias a múltiples factores, y superando con creces los posibles obstáculos, es cierto que todavía existen algunos problemas, retos o desafíos que tendrá que ir venciendo para que se integre aún más en el camino evolutivo de la cultura digital.

En primer lugar, habría que realizar una pequeña introducción sobre los prejuicios que la lectura digital enfrenta actualmente, para luego puntualizar los prejuicios específicos asociados a los audiolibros.

En una reciente intervención de José Antonio Cordón-García (2020) ofrecida en una conferencia que tuvo lugar en el Instituto Cervantes de Madrid, en torno a «Narrativas digitales: aliados en la promoción de la lectura», el académico propuso tres grandes categorías para agrupar los posibles problemas o prejuicios con los que se enfrenta la lectura digital en general, que tienen que ver fundamentalmente con: problemas cognitivos; problemas de carácter fisiológicos; o relacionados con la cultura y la economía, que resumimos a continuación:

1. Problemas cognitivos: en este grupo incluyó a los problemas de comprensión, de concentración, de memorización y de dispersión, entre otros apelativos.

2. Problemas de carácter fisiológicos: algunos de ellos pueden ser los relacionados con el insomnio, con la pérdida visual y auditiva, entre otros - esta última relacionada con el uso de los audiolibros.

3. Problemas culturales y económicos: se comenzó a hablar de los peligros de la desaparición del libro impreso desde el año 2006 (se asocia a ese año por la aparición en el mercado de los ereaders); la idea de la posible desaparición de las librerías; dudas en torno a la función de las bibliotecas en un entorno digital y problemas de piratería, entre otros.

Cordón-García, insistió en que un 99 \% de las noticias que aparecen en los medios sobre las lecturas en este formato tienen una carga negativa, y en el artículo «Combates por el libro: inconclusa dialéctica del modelo digital», explica que este hecho puede deberse a una resistencia a los saltos tecnológicos que han existido siempre en la historia de la humanidad. "La separación con el contacto directo con el objeto libro, o incluso con el papel, se ha percibido como una pérdida cognitiva y social» (CordónGarcía, 2018b:478).

Sin duda, los audiolibros poseen sus propios obstáculos fruto de los prejuicios o percepciones negativas, en su gran mayoría, por la comparación de la audiolectura con la lectura en papel.

Es importante conocer cuáles son estos puntos de fricción que ha encontrado este formato en las últimas décadas, para poder obtener conclusiones acerca de cuáles son meros prejuicios exentos de reflexión y análisis crítico y cuáles son problemáticas más profundas o debilidades intrínsecas de esta nueva tecnología. 
Resulta de especial interés para nuestra investigación el libro de Matthew Rubery Audiobooks, literature and sound studies (2011), en el que resume estas críticas en 8 puntos que detallaremos a continuación. Rubery llama la atención acerca de este reduccionismo de estar «a favor» o "en contra» de la lectura de audiolibros y alienta a realizar estudios más profundos que justifiquen dichas preferencias.

Tras este resumen de los ocho puntos realizaremos una categorización similar a la de José Antonio Cordón-García, agregando a las tres mencionadas por él, una categoría más vinculada al universo sonoro:

\subsubsection{Pasividad por parte del oyente}

En primer lugar, Rubery sitúa al prejuicio de que escuchar es una actividad pasiva:

En el esquema de Cordón-García podríamos encuadrarlo en dos categorías: como un problema cognitivo y un problema cultural.

La primera de las críticas es la supuesta pasividad del lector de audiolibros que hace que muchos se planteen si audioleer puede equipararse a leer un texto impreso.

Mientras que leer un texto impreso exige formas activas de comportamiento que incluyen desciframiento, interpretación y juicio, escuchar puede llevar al lector a un estado pasivo de absorción del contenido. Las críticas asocian esta calma a la falta de espíritu crítico.

Matthew cree que el vocabulario relacionado con la audiolectura -nombra: seducción, sumisión y transfixión $n^{29}$ - refuerza la percepción del audiolibro como un «opiáceo sonoro». Algunos ejemplos los podemos encontrar en páginas de internet, las cuales animan a la audiolectura con frases como: «Déjate leer» o «Deja que te cuente».

Se suma a esto que los oyentes suelen tomar una actitud defensiva ante una interpelación respecto a la escucha, y en cierto modo Rubery afirma que se disculpan por escuchar, y no por leer en impreso. Esta situación se puede deber a que en un comienzo los audiolibros que existían en el mercado carecían de calidad y eran versiones abreviadas del libro original. Los progresos sobre el mundo del audio no cesan y cada vez existen más posibilidades de acceder a audiolibros narrados palabra por palabra en la voz de profesionales y con una mejor calidad auditiva. Sin embargo, no todos los usuarios son conscientes de estas posibilidades, y fruto del desconocimiento rechazan la idea antes de llevar a cabo una experiencia sonora.

Una buena opción que están desarrollando algunas aplicaciones que se dedican a audiolibros es proponer unos minutos de prueba del audio elegido, para que cualquier interesado pueda, de antemano, decidir si le interesa.

Matthew cita a Birkerts, que introduce el término "oyente cautivo" que es aquel que entrega el control sobre los elementos clave de la experiencia lectora, incluidos el ritmo, el timbre y la inflexión. Para Birkets la narración de audiolibros es una forma de "tiranía vocal" en su negación de la voz interior del

\footnotetext{
${ }^{29}$ Traducido de: transfixtion
} 
lector invocada por la página impresa. La llamada «intrusión del narrador externo» sugiere a los escépticos que la historia ya ha sido interpretada de antemano. Sin embargo, para Rubery tales afirmaciones carecen de fundamentos críticos literarios (Rubery, 2011:10-11)

\subsubsection{Problemas relativos al nivel de concentración}

Prejuicio: Que los audiolibros no requieren el mismo nivel de concentración que los libros impresos.

En el esquema de Cordón-García se podría asociar este prejuicio a la categoría de problema cognitivo.

Rubery, alude que las mismas características promovidas por los vendedores de audiolibros como puntos a favor de su comercialización, dados por su portabilidad y suplementabilidad, por ejemplo, son las mismas que utilizan los críticos para desmerecer el formato asociándolos a una versión diluida del libro impreso.

Para el autor, el nivel de concentración no debería asociarse a un formato u a otro ya que los audiolibros se pueden escuchar en un estado de distracción al igual que los textos impresos. El nivel de concentración dependería de que el propio oyente garantizase un entorno acústico adecuado.

Matthew Rubery (ídem) cita al famoso sociólogo Michael Bull quien nos habla de que un oyente puede discernir múltiples capas de significado incrustadas en la palabra hablada a través del aislamiento que le produce el uso de auriculares, y que de otro modo pasarían desapercibidas en el mundo del texto. $Y$ concluye que los actos de leer y escuchar pueden no ser equivalentes, pero es engañoso situar a uno sobre el otro en términos de concentración.

Relacionado con la concentración, también merece la pena puntualizar un hecho que se evidencia en el uso de los audiolibros, sumado al citado por Rubery. Si bien es cierto que cada persona debe gestionar su ambiente adecuado para la lectura, en el caso de los audiolibros la escucha se realiza la mayoría de las veces desde un dispositivo móvil. Estos dispositivos tienen instaladas otras aplicaciones, muchas de ellas son redes sociales programadas para que nos avise si ingresa alguna notificación.

Algunas aplicaciones como Storytel, por ejemplo, anulan la posibilidad de recibir dichas actualizaciones, pero si escuchamos un audiolibro en Youtube, estas siguen descargándose. Una opción interesante para escuchar audiolibros sin distracciones podría ser evitar la escucha en streaming, y descargar el libro para poder escucharlo offline.

\subsubsection{Posible distorsión de las narraciones originales}

Los audiolibros distorsionan las narraciones originales con las adaptaciones (abridgment) También podríamos asociar este prejuicio a un problema cognitivo.

Con frecuencia, los editores abrevian los audiolibros comerciales para reducir los costos de producción y atraer a los lectores a acceder a obras extensas y clásicas que pueden resultar más complejas de leer enteras. 
Sin embargo, el resumen no es una característica distintiva del formato de audiolibro, sino más bien una opción disponible para cualquier formato de texto, ya sea impreso o en voz alta. El contenido es exactamente el mismo en textos hablados e impresos, lo que está en cuestión es el modo de recepción.

Cuando la narración es realizada por un profesional, este se ciñe al texto y evita cualquier distracción que pueda disuadir a un lector de su audición (véase el apartado 5.7.1.1) Existen otros casos, por ejemplo, el audiolibro La ridícula idea de no volver a verte, escrito y narrado por Rosa Montero, que presenta mínimas diferencias comparado con su versión impresa. Muchas de estas diferencias son licencias que se toma la narradora, para enriquecer aún más la narración.

\subsubsection{Problemas relacionados con el ritmo de lectura}

El cuarto prejuicio es que el ritmo del audiolibro elimina el control del lector

Este problema o prejuicio incluido por Rubery podría asociarse a la categoría problema cognitivo. Esta crítica está relacionada con el ritmo del narrador e imposibilidad del usuario de audiolibros de detener el transcurso de la narración como lo realizaría con un libro impreso.

En este sentido Rubery indica que este implacable avance puede hacer que alguna de las palabras que en formato impreso pueden saltarse en la escucha no se perderían en el audio ya que no existe un correlato en audio de lo que es «lectura rápida» en impreso.

Quizás no tuvo en cuenta Rubery, o no existía cuando editó su libro en 2011, la alternativa a la lectura rápida de los textos impresos y es la que mencionamos dentro del apartado "Ventajas de los audiolibros: la cronolectura", y tiene que ver con la posibilidad que ofrecen las actuales plataformas y aplicaciones actuales de acelerar o ralentizar la grabación, llamada en inglés speed listening.

Sumando una ventaja donde otros ven una falta, el autor indica que la narrativa hablada recupera el ritmo y la cadencia de la prosa del modo que se hacía en los antiguos tiempos de tradición oral.

\subsubsection{Asociación de la audiolectura con una actividad infantil}

Al quinto problema podríamos asociarlo a la categoría problema cultural.

A muchas personas les cuesta imaginar que los audiolibros puedan ser utilizados por adultos mayores. Normalmente asocian este formato con la práctica de lectura de niños o adolescentes, ya que a muchas personas les leían de pequeños y es la única referencia que asocian a este tipo de lectura. Además, en los comienzos de la industria editorial, muchas empresas realizaban versiones de audiolibros abreviadas, incluso las que se comercializaban en casetes.

Actualmente estas ideas son frutos del desconocimiento y la falta de experiencia con el formato, ya que los catálogos editoriales en audio son cada vez más variados y abarcan más géneros. 
Rubery subraya que los propios términos «libros parlantes» y «audiolibros» encapsulan la paradójica combinación entre oralidad e imprenta. La tesis fundamental de este prejuicio se sustenta en el interrogante de si se relaciona a los audiolibros con la llamada cultura oral o no. Para esto cita a Walter Ong y a la llamada oralidad secundaria, que hemos ya desarrollado en el capítulo 3.2 y que nos habla de unas tecnologías de la comunicación modernas que representan una simulación de las condiciones de una sociedad oral, pero que están impregnadas por la palabra escrita.

Rubery afirma que sería una simplificación y una falta de documentación creer que por el mero hecho de escuchar un audiolibro estaríamos volviendo a los inicios de la oralidad, así como es un error asociar este tipo de lectura a un determinado grupo etareo.

Una posible explicación de este prejuicio es la que incluyen Jennifer Cavender y Lisa Tuchell (2006:152), en su artículo Reviving the oral tradition, en la que afirman que una de las causas fundamentales de debate dentro de los audiolibros son las diferencias entre las versiones de estos, las versiones íntegras o abreviadas (unabridged y abridged).

En esta tesis hemos desarrollado los cambios sociales y tecnológicos que propiciaron el despegue de los audiolibros, que tienen más que ver con la oralidad digitalizada que con la llamada oralidad secundaria.

\subsubsection{Posible interferencia negativa del narrador}

El narrador del audiolibro interfiere con la recepción del texto por parte del lector.

En el esquema de Cordón-García también lo encuadramos como un problema cognitivo.

Los audiolibros, como mencionamos anteriormente, se distinguen de otros formatos literarios por la presencia de una voz literal en lugar de metafórica. Según el artículo casi todos los lectores informan que comprenden textos idénticos de manera diferente en formatos hablados frente a la lectura silenciosa, ya que varios elementos difieren según el modo de recepción.

Rubery presenta las cuatro categorías existentes de narradores:

El narrador puede ser el autor del libro, como es el caso de audiolibros narrados por Stephen King, Toni Morrison o Barack Obama; puede ser un actor de voz profesional, por ejemplo: Scott Brick, Jim Dale, Barbara Rosenblat; pueden ser celebridades, como Johnny Cash, Jeremy Irons u Oprah Winfrey; o bien, simplemente un aficionado.

Otra posibilidad es la de un elenco de actores, algo muy utilizado en libros corales. La prominencia de los actores famosos que narran audiolibros ha tendido a reforzar las sospechas sobre la naturaleza comercial del formato. En octubre de 2020 Audible anunció su llegada a España con un catálogo dotado de voces como la de Leonor Watling que leyó íntegra la saga de Harry Potter, José Coronado hizo lo propio con El gran Gatsby y Juan Echanove prestó su voz a El corazón de las tinieblas. 
Coincidimos con Rubery en que el narrador de audiolibros puede mejorar o interferir en la experiencia de lectura en diversos grados y no hay duda de que la voz del hablante tiene una profunda influencia sobre la recepción de texto, como hemos analizado en el apartado: 5.7.1, la voz del audiolibro.

Esta narración puede afectar al texto si el oyente no encuentra una neutralidad en la voz que narra, entrometiéndose entre escritor y oyente.

Rubery señala que existe otra dimensión, la potencialmente ideológica de categorías como clase, etnia, género, raza y nacionalidad que también deben tenerse en cuenta a la hora de la selección de un narrador ya que podrían generar suspicacias por parte del oyente.

\subsubsection{Ausencia de dimensión espacial}

En el esquema de Cordón-García también lo encuadramos como un problema cultural/cognitivo

Según Rubery, la disposición espacial se ha convertido en una dimensión cada vez más importante para la composición literaria desde la experimentación vanguardista y modernista de principios del siglo XX, aunque los efectos visuales han sido esenciales en diversos grados, para todas las formas de literatura impresa.

Los elementos paratextuales de todo tipo (incluidas las cubiertas de libros, títulos de capítulos, epígrafes, ilustraciones, cuadros, mapas, notas al pie, bibliografías, etc.) plantean serios desafíos para las grabaciones sonoras.

Incluso un simple cambio de tipografía del original impreso a la cursiva puede ser difícil de transmitir a través de un tono de voz. Las narraciones experimentales que involucran múltiples voces o monólogos interiores compuestos por un discurso fragmentario pueden ser mucho más desorientadores para el oído que para el ojo - porque estaban escritas para ser leídas en soporte papel-. Rubery se pregunta acerca de la versión audio y de cómo una voz podría hacerle justicia, por ejemplo, al verso libre de Stéphane Mallarmé, con los espacios en blanco de la página, Un coup de dés jamais n'abolira le hasard. En español tenemos muchos ejemplos que plantearían un problema a la hora de la audificación, como por ejemplo la poesía rupturista de Nicanor Parra, o algunas obras de teatro que revisten gran dificultad debido a la cantidad de personajes que contienen.

No hay duda de que, en estos últimos años, los narradores han ido ganando destrezas a la hora de narrar los textos. Un buen ejemplo es la versión audio de El coloquio de los perros, de Miguel de Cervantes, narrado por Pablo López, Noloofer Khan, Daniel Millet, Rubén del Castillo, José Vera y Alba Tardón.

Los protagonistas de esta obra clásica son dos perros, Cipión y Berganza, que tras haber adquirido el don del habla se cuentan su vida uno al otro. Quienes dramatizaron esta obra le aportaron sus habilidades relacionadas con el arte dramático, con lo cual no solo aportaron la narración del libro, sino que le proporcionaron a este un valor agregado, suplantando el desafío de la complejidad de la trama con una solución creativa y artística. 
Como menciona Rubery, el desafío de reemplazar el texto por una representación auditiva genera, en algunos casos, sus propias innovaciones formales.

El escritor estadounidense David Foster Wallace, que narró su propio libro Hablemos de langostas (Consider the lobster), en las notas al pie de página manipulaba su voz para que fuera fácilmente distinguible del resto del texto. Como el propio escritor explicaba:

I sometimes use footnotes in these essays, which presents kind of a nasty problem for an audiobook: where do the footnotes go? There is no bottom of the page in an audiobook, obviously. (Wallace en New York Times, January 20, 2006, 33)

La distribución del texto en formatos impresos es analizada por Cordón-García, quien alude que en el libro impreso no existe distancia respecto al texto y el medio, mientras que:

los dispositivos de lectura introducen diferentes grados de distanciamiento, en función de la mayor o menor facilidad de apropiación, en función de la calidad de sus prestaciones y en función de la permeabilidad e interoperabilidad de sus aplicaciones que, finalmente, determinan diferentes grados de legibilidad. (Cordón-García, 2019:12)

Numerosas investigaciones, especialmente las orientadas a libros electrónicos textuales inciden, según Cordón-García (ídem), en la precaria situación de los textos digitales para desencadenar procesos asociativos que faciliten la lectura digital y la asimilación y memorización de su contenido, en comparación con la lectura tradicional.

Uno de los problemas que resalta Cordón-García es la falta de señales físicas o asociaciones que un lector utiliza normalmente para recordar la información, ya que el mismo contexto del libro aporta puntos de referencia que pueden servir para esta asimilación y memorización de contenido.

El catedrático focaliza su artículo en la lectura en pantalla, pero de algún modo lo relacionamos con los audiolibros, ya que también en ellos se inhabilitan ciertas referencias clásicas de la lectura. Algunos ejemplos de ello serían la imposibilidad de recordar si se lee algo en la parte superior o inferior de la página, si el texto estaba situado en una página par o impar de un libro, o algo acerca de un gráfico, todas ellas cuestiones que pueden ayudar a consolidar el recuerdo en la mente Cordón-García (ídem).

Por esta razón creemos que está fundamentado el prejuicio de la ausencia de dimensión espacial. En los últimos congresos a los que hemos asistido se habla cada vez más de permitir la navegabilidad dentro de un audiolibro. Pocos son los audiolibros que contienen un índice y permiten la navegabilidad, saltando de un capítulo a otro, pero ayudaría mucho el desarrollo de estas facilidades a un mayor anclaje con el audiotexto, y sin duda, ayudaría a aumentar el grado de legibilidad de los mismos.

\subsubsection{Posible interferencia del campo visual durante la experiencia auditiva}

No encontramos dentro de las categorías que propone Cordón-García una que se acerque a este prejuicio, pero agregamos una categoría llamada: problema fenomenológico, e incluimos esta reclamación dentro de dicha categoría.

Este problema que plantea Rubery está relacionado con su aspecto más distintivo y menos estudiado: su fenomenología. Como se recoge en este trabajo, la propia naturaleza de nuestro objeto de estudio 
está relacionada con el sentido aural, por lo cual existe una disyunción a la hora de la audiolectura con el sentido de la vista.

Rubery se llega a preguntar el grado en el que el campo visual influye en la recepción de un texto literario, tópico acerca del cual no refiere bibliografía consultada y solo menciona que existe muy poco documentado sobre el tema.

Cabe mencionar que el estudio de Rubery que recoge estos supuestos obstáculos relacionados con los audiolibros fue editado en el año 2011. En el año 2016, las especialistas Have y Stougaard Pedersen ya profundizan en este tema y nos hablan del cariz dinámico y multisensorial de la escucha de un audiolibro, como hemos detallado en el apartado 5.8.6 (Posibilidad de una lectura intersensorial).

A fin de resumir las desventajas u obstáculos enumerados por Matthew Rubery con relación a los audiolibros, nos valdremos de las categorías propuestas por José Antonio Cordón-García (2020), agregando la categoría fenomenológica. Hacemos notar que un mismo obstáculo puede encontrarse en dos categorías.

1. Problemas cognitivos: actividad pasiva; difiere el nivel de concentración; fragmentación (abreviación del texto); el ritmo del audiolibro elimina el control del lector; el narrador interfiere en el proceso de emisión-recepción del texto.

2. Problemas de carácter fisiológicos: ninguno

3. Problemas culturales y económicos: los audiolibros carecen de forma; leer es para niños; refiere a una actividad pasiva.

4. Problema fenomenológico: Interferencia del campo visual durante la experiencia auditiva.

Se desprende de este listado que la mayoría de los problemas o prejuicios asociados con los audiolibros se relacionan con problemas cognitivos, pero - como hemos observado- muchos de ellos carecen de fundamentación sólida. 


\subsection{0 ¿SE PUEDE CONSIDERAR AL AUDIOLIBRO UN LIBRO?}

En el plano legal nacional, como vimos en el párrafo "Nuevas materialidades del libro», dentro de la propia Ley del libro 10/2007, artículo 2, se incluyen como tales a los libros electrónicos y publicados a través de internet. También están comprendidos los que poseen otro soporte que pueda aparecer a posteriori, los materiales complementarios impresos, visuales, audiovisuales y sonoros editados conjuntamente con el libro y que participen del carácter unitario del mismo, así como cualquier otra manifestación editorial.

Algunos de los prejuicios acerca de si el audiolibro es o no un libro vienen, según Have y Stougaard Pedersen, en primer lugar, del hecho de que en principio los audiolibros eran un subproducto (by product) del texto impreso, como un servicio para discapacitados (2016:152). La situación está cambiando, ya que actualmente varios formatos son publicados simultáneamente, siendo el lanzamiento de un título, en muchos casos, doble o triple: impreso, libro electrónico y audiolibro digital.

En segundo lugar, según las autoras, los audiolibros son actualmente para todo el mundo, ya que el desarrollo tecnológico ha favorecido que este formato pueda llegar a un grupo más extenso de lectores convirtiéndolo en un medio de comunicación de masas (mass media). (Estos desarrollos tecnológicos han sido ampliamente detallados en el apartado 5.7.2) (ídem). Asimismo, y reforzando la idea de que ya no representa un subproducto, resaltan que actualmente los usuarios de audiolibros acuden directamente a este formato desligándose de alguna manera del impreso y convirtiéndolo en un medio en sí mismo (ídem).

Según Have y Stougaard Pedersen, tecnológica y materialmente el audiolibro no se parece en nada a un libro y comparte, en cambio, plataformas y formatos en común con la música. Pero tampoco allí podemos buscar su germen. Muchas personas lo asocian al storytelling o la tradición oral (que podríamos ubicar en la primera oralidad), pero Have y Stougaard Pedersen argumentan que sin el libro impreso no hubiéramos llegado a los actuales audiolibros: (2016:153).

\footnotetext{
The detour through print determined the structure of the audiobook in certain ways, making it different from oral storytelling, and making an argument for calling it an audiobook. The transposition to audio changes the experience and use fundamentally, but without a printed book there will be no audiobook in our definition - at the present state. (ídem)
}

Para las especialistas, el audiolibro es un medio diferente, que genera una experiencia que debe ser conceptualizada individualmente y más relacionada con las prácticas de escucha digitales móviles como parte de la «cultura del iPod» (2016:154). Lo dicho no está reñido con la importancia que para ellas tiene la audiolectura, ya que en un artículo del año 2013 ponen en la palestra la idea de que es necesario expandir el concepto de lectura, ya que no se lee solo con los ojos. Para esto mencionan el ejemplo de la lectura en braille y apuntan que «no tocas braille, lo lees»; pero, por alguna razón es más natural decir «escucho audiolibros» que «leo audiolibros» (Have y Stougaard Pedersen, 2013:127). 


\subsection{LA COMUNICACIÓN LITERARIA A TRAVÉS DEL AUDIOLIBRO}

Las manifestaciones literarias (cuento, poesía, novela, canción, etc.) presentan los elementos inherentes a cualquier acto de comunicación, que comienza con un emisor, al que le siguen los siguientes elementos: receptor, mensaje, código, canal y contexto, que pueden observarse en la siguiente tabla (Vallorani, 2011:109).

\begin{tabular}{|l|l|}
\hline Situación comunicativa & Comunicación literaria \\
\hline Emisor & Es el autor del texto \\
\hline Receptor & Es el lector del texto \\
\hline Mensaje & Es el propio texto \\
\hline Código & El idioma \\
\hline Canal & $\begin{array}{l}\text { Texto escrito u oralizado (lectura a } \\
\text { viva voz, audiolibro) }\end{array}$ \\
\hline Contexto & $\begin{array}{l}\text { Marco en el cual ha sido escrito. } \\
\text { Situación lingüística, literaria, his- } \\
\text { tórico y cultural. }\end{array}$ \\
\hline
\end{tabular}

Tabla 1. Esquema de la comunicación literaria Fuente: Vallorani, 2011:34

Para que se lleve a cabo un acto de comunicación literaria el emisor dirige un mensaje al receptor, y para esto utiliza un código; este mensaje posee un contexto o referente que remite a la realidad y se transmite a través de un canal, que puede ser un medio oral o escrito.

Es en el «canal» donde se presenta la opción de que el mensaje sea visual u oral (ibídem, 35). Si el mensaje se transmite oralmente, en su propia naturaleza conlleva la interacción personal y presencial. Su presencia se da en un lugar establecido y durante un tiempo determinado. El contexto sí que podría estar ausente durante el acto comunicativo, ya que puede referirse tanto a un hecho presente como distante en el tiempo-espacio (ibídem, 36). Cecilia Vallorani agrega que los principios que rigen la oralidad son la territorialidad y la temporalidad, en donde una situación comunicativa tiene principio y fin y es un hecho irrepetible relacionado con un determinado tiempo y espacio.

Si tenemos en cuenta los elementos involucrados en un audiolibro podemos resumirlos en el siguiente gráfico: 

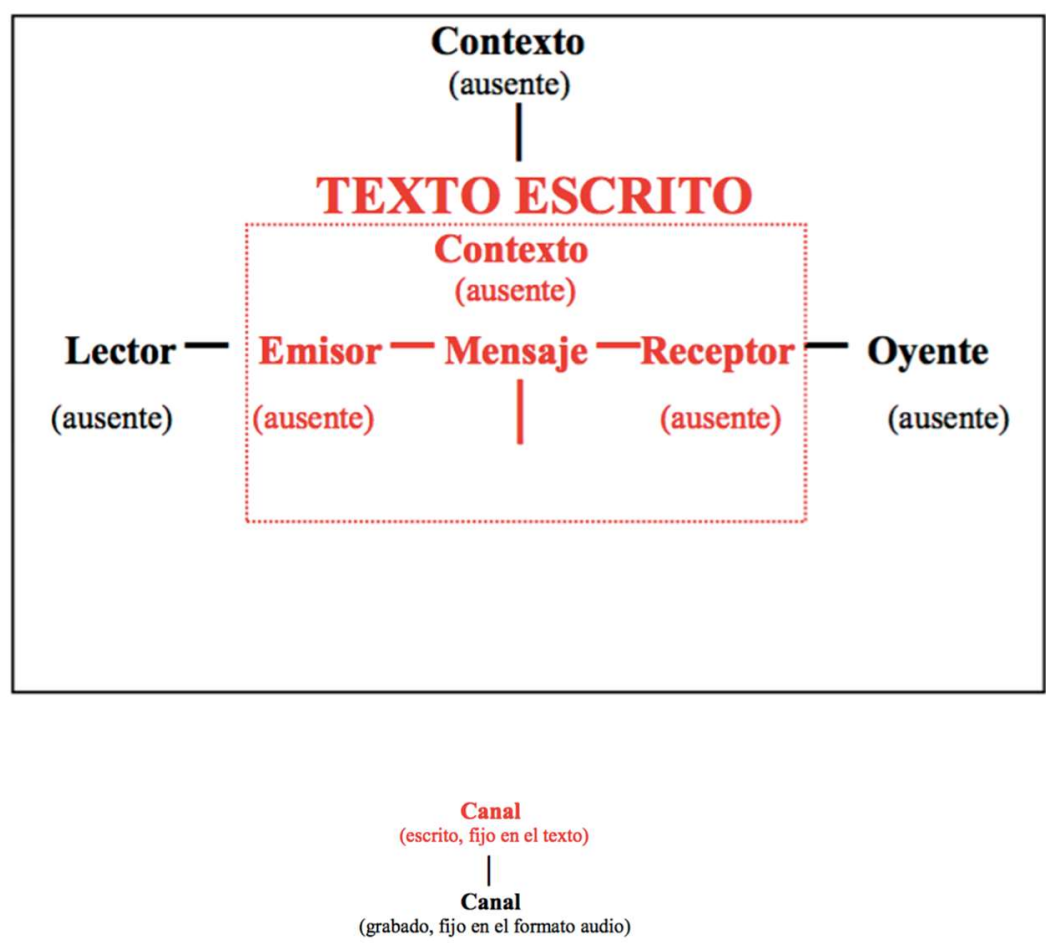

Ilustración 5. Elementos del texto oralizado

Fuente: Vallorani, 2011:37

Los elementos en rojo son compartidos con un esquema tradicional de comunicación impresa, pero a este se le suman 3 elementos: el lector (o narrador), el oyente y un nuevo canal.

Este nuevo canal dependiente de un texto impreso puede fijarse sobre un nuevo material tangible (como un CD), o bien puede ser digital (como un archivo MP3), y al igual que la escritura, puede ser revisado en cualquier momento y lugar, considerando que el medio electrónico que permite la «lectura audio» es transportable al igual que un texto impreso (ibídem, 37).

Por último, hacemos notar que en el contexto digital existen nuevas narrativas genuinamente orales, por lo cual se vería modificado el elemento canal: «escrito» o «fijo en texto», y se podría agregar la posibilidad de streaming.

\subsection{LA PRODUCCIÓN DE UN AUDIOLIBRO}

Marta Magadán y Jesús Rivas García diseñaron un flujograma (que puede observarse en la llustración 6. Flujograma de producción de un audiolibro) que representa la producción del audiolibro, y en el que están presentes todos los agentes involucrados en dicho proceso.

El proceso comienza con una obra impresa o manuscrito, publicada o no con anterioridad, que luego entra en la fase de preproducción, que puede ser realizada por la propia editorial o bien, tercerizada. 
En esta fase se decide si la grabación se ajustará al texto de forma literal o, de lo contrario, habrá que realizar una guionización de la grabación (Magadán y Rivas-García, 2020:7).

También se tienen en cuenta los elementos paratextuales, y otros documentos que suponen un desafío, como pueden ser mapas, textos, ilustraciones, etc. para lograr que el audiolibro pueda ser llevado a cabo armónicamente (ídem).

Tras estas decisiones editoriales, prosigue la producción del libro, que supone la selección de voces y narradores, una prueba que servirá para decidir si se continúa hacia la grabación definitiva. Y, una vez llevada a cabo esta confirmación, en último lugar, los autores sitúan al tratamiento de limpieza y masterización del audio a fin de lograr el audiolibro ya editado por completo.

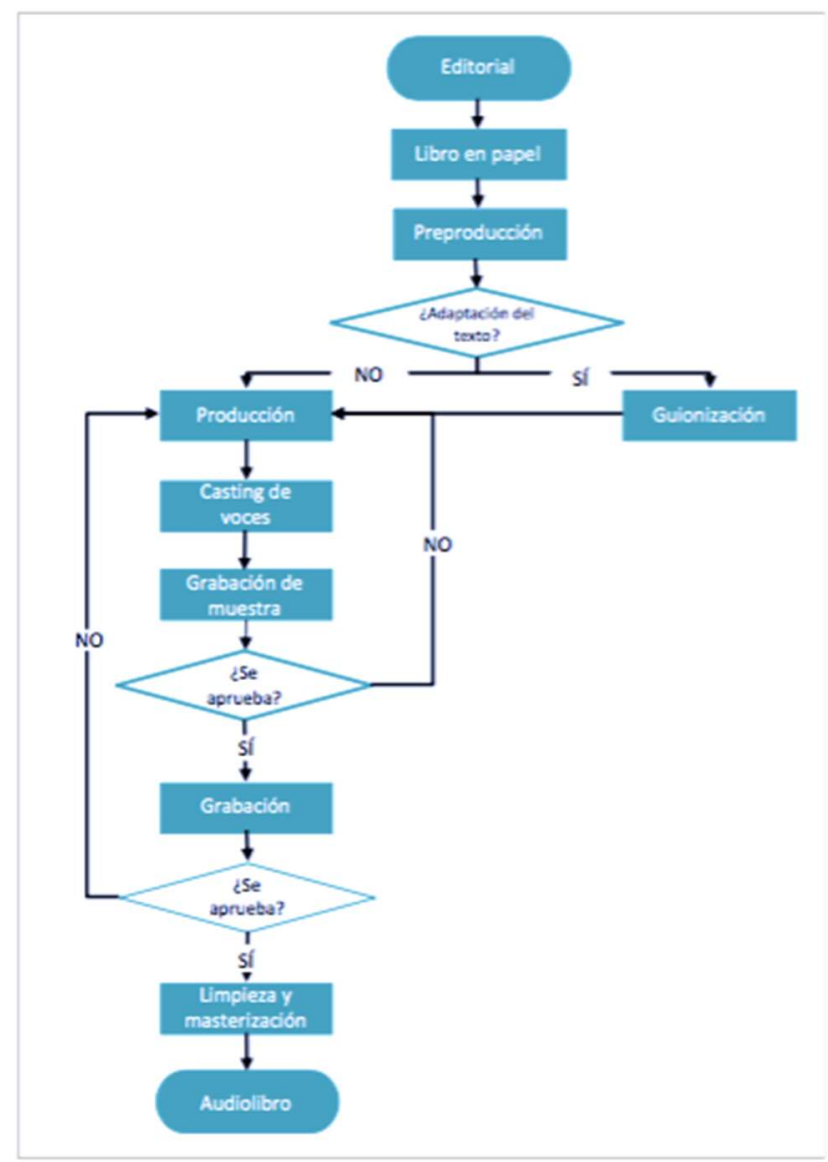

Ilustración 6. Flujograma de producción de un audiolibro Fuente: Magadán y Rivas-García, 2020:7

\subsection{FORMATOS Y SOPORTES}

La Unesco considera que un documento consta de dos componentes: el contenido informativo y el soporte en el que se consigna (Unesco, 2002). Los profesionales de la información estamos muy fami- 
liarizados con los diferentes formatos, que hasta hace unas décadas eran predominantemente impresos. De hecho, en las bibliotecas se utilizaba la denominación «documentos especiales o no librarios» a aquellos que no habían sido editados en soportes tradicionales (Rodríguez Bravo, 2002:111).

Poco a poco el abanico de soportes y formatos se fue ampliando hacia el entorno digital. Dicha migración supone una separación del contexto físico y del contenido, ya que según Edmonson ya no existe una experiencia táctil de manipular o examinar la reproducción a través de su tecnología original. En palabras del autor «la experiencia sensorial y estética desaparece» (Edmondson, 2004:51).

Los soportes, según Blanca Rodríguez Bravo, han perdido relevancia dado que los mensajes que contienen se copian con facilidad en otro soporte, "lo que los convierte en transformables o manipulables y en transportables» (Rodríguez Bravo, 2005:10).

Teniendo en cuenta nuestro objeto de estudio, nos parece de interés destacar la clasificación de los audiolibros realizada por García Rodríguez y Gómez Díaz (2019:7), ya que en ella se tienen en cuenta, además, otros aspectos, como el soporte, el tipo de narración y la gestión del contenido.

Las especialistas diferencian a los audiolibros por soporte en dos categorías, los tangibles e intangibles. Pertenecen al primer grupo los ya tradicionales discos de vinilo, cintas de casete, DVD o CD.

Dentro de la segunda categoría la subdivisión es triple:

- El libro app: estos libros existen fundamentalmente para público infantil, pero existen algunos casos para adultos, como el de narratores.com

- Aplicaciones de audiolibros: según las autoras estas aplicaciones disponen de un software que permite la audición de diferentes títulos, que se pueden adquirir tanto de forma unitaria como a través de suscripción, y como ejemplo citan a aplicaciones tales como Audio cuentos infantiles, Audioclásicos infantiles, Roald Dahl Audiobooks, entre otros.

- Ficheros disponibles en plataformas generalistas, como Audible, Storytel, Audiolibros HW, Audioteka, Fonolibro, Audiolibros.com, etc. 


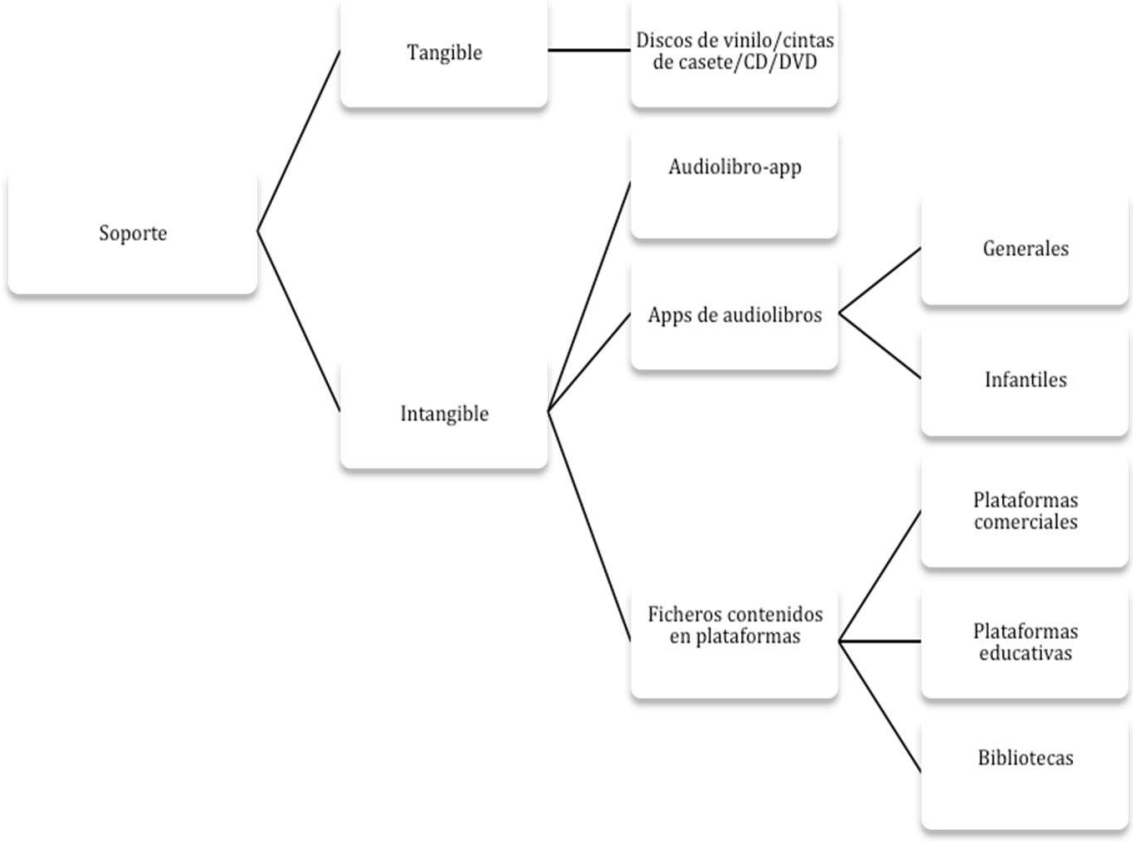

Ilustración 7. Soporte de los audiolibros

Fuente: García-Rodríguez y Gómez Díaz, 2019:7

\subsection{CIRCUITO EDITORIAL DEL AUDIOLIBRO}

El ecosistema tradicional del libro y de la lectura se ha visto transformado por las nuevas tecnologías, que por primera vez en la historia de la edición afectan a toda la cadena o circuito del libro, en todos sus elementos, desde la autoría hasta el usuario, articulando un nuevo sistema que produce desplazamientos significativos entre ambos formatos, impresos y digitales (Cordón-García, 2016:16).

En este nuevo ecosistema coexisten además del formato impreso varias versiones digitales, como reza el ya citado anuncio de Jorge Carrión «hoy, cada libro es, al menos, tres: papel, píxel y audio». Estas versiones aluden a cómo llega el texto al lector, porque si hablamos del proceso editorial existe una sola división: libro digital (que luego se imprime) y audio, si nos referimos a ediciones miméticas.

Teniendo en cuenta el circuito de la editorialización de los audiolibros, según Have y Stougaard Pedersen, estos se desprenden de los mismos circuitos editoriales institucionalizados de la editorialización tradicional, constituidos por los siguientes elementos: autores, editores, librerías y bibliotecas, si bien puede que en algunos puntos el circuito se complejice o adquiera diferente matiz en el mundo digital (Have y Stougaard Pedersen, 2020:18).

Have y Stougaard Pedersen (2020) fueron los primeros en diseñar el circuito editorial completo en el mundo del audio, desde la perspectiva danesa. Hay que tener en cuenta que España no se encuentra al mismo nivel editorial que ese país, y que desde que las empresas dedicadas al contenido sonoro 
aterrizaron en España debieron realizar un trabajo muy cuidadoso de implantación y de promoción de los audiolibros.

El modelo o circuito del audio comienza con el autor que escribe un libro. Este libro es enviado a un editor, que está encargado de la producción del audiolibro, o bien en su propio departamento de edición de audiolibros o enviándolo a un servicio independiente, tercerizado. En España existen más de veinte estudios de grabación entre los que encontramos Miut, Kilohercios, SoNido de Ideas o Voces de Cine.

El dispositivo principal para la escucha de audiolibros son los teléfonos móviles inteligentes, y una de las causas del porqué de su rápida proliferación. El circuito finaliza con los usuarios, escuchantes o lectores.

Entre los autores y los lectores, se sitúan las plataformas social media que, como en cualquier campo cultural, ofrecen el vínculo entre ambos favoreciendo, por ende, la experiencia lectora (ibídem, 9).

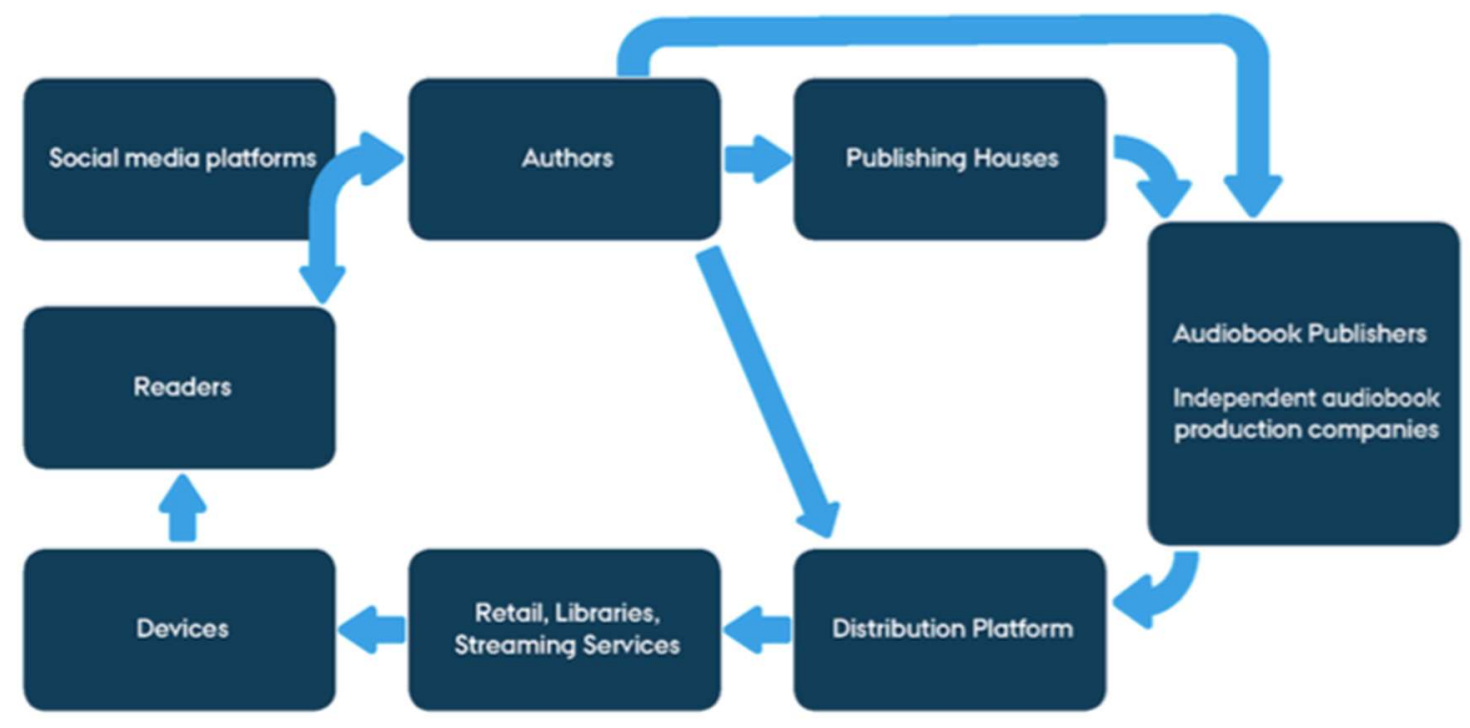

Ilustración 8. Modelo genérico del circuito de distribución en Internet de audiolibros digitales Fuente: Have y Stougaard Pedersen, 2020: 8

En el entorno digital, cuanta más actividad se comparta, mayor reputación virtual se detenta y mayor autoridad se confiere al responsable o remitente de estas intervenciones (Cordón-García, 2016:33). Este fenómeno motiva a las editoriales a promocionar sus obras dentro del ámbito virtual. 


\subsection{DERECHOS LEGALES DE UN AUDIOLIBRO}

En la edición o producción de un audiolibro participan varios agentes, con distinto grado de imbricación en el proyecto. Cada uno de estos participantes debe tener en cuenta aspectos legales tanto a la hora de producir, participar o distribuir un audiolibro.

Como cualquier otra creación artística o literaria debemos, en primer lugar, tener como referencia la Ley de Propiedad Intelectual. Cabe mencionar que, en dicha ley, de aquí en adelante denominada LPI, no encontramos el término audiolibro, sino fonograma. El abogado y experto en audiolibros, José Carlos Sánchez (2020), indica que el concepto de audiolibro se ajusta a la segunda acepción la RAE de fonograma: Registro del sonido en soportes especiales que permiten su reproducción.

La LPI está integrada por una serie de derechos de carácter personal y/o patrimonial que atribuyen al autor y a otros titulares la disposición y explotación de sus obras y prestaciones.

Esta propiedad, según recoge el propio Ministerio de Cultura y Deporte Español, protege «las creaciones originales literarias, artísticas o científicas expresadas en cualquier medio, tales como libros, escritos, composiciones musicales, obras dramáticas, coreografías, obras audiovisuales, esculturas, obras pictóricas, planos, maquetas, mapas, fotografías, programas de ordenador y bases de datos. También protege las interpretaciones artísticas, los fonogramas, las grabaciones audiovisuales y las emisiones de radiodifusión».

"La propiedad intelectual de una obra literaria, artística o científica corresponde al autor por el solo hecho de su creación", como enuncia el propio artículo I de la LPI. Y en el siguiente artículo puntualiza que dicha propiedad intelectual está integrada por derechos de carácter personal y patrimonial, que atribuyen al autor la plena disposición y el derecho exclusivo a la explotación de la obra, sin más limitaciones que las establecidas en la Ley.

Según aclara José Carlos Sánchez (2020), por derechos de carácter personal nos referimos también a los morales, derechos que no pueden transferirse ni comercializarse y por derechos patrimoniales nos referimos a los llamados derechos de autor que sí se pueden ceder, vender o extrapolar.

Los audiolibros requieren su propio acuerdo de cesión de derechos de una obra primigenia para poder llevarse a cabo. Se debe contar con los derechos de la obra que se va a transformar en audiolibro en el caso de que sea el autor el que quiera realizarlo-, o contar con el permiso del autor para llevarlo a cabo. A su vez, esta transformación generaría también derechos de propiedad intelectual.

José Carlos Sánchez explica que, en el caso de un audiolibro, este es el resultante de una obra anterior (un libro impreso), y aunque no difiera en contenido, a efectos legales es una interpretación de la primera, ya que cambia del soporte papel a uno totalmente diferente.

Para ampliar esta idea de transformación es preciso referirnos al artículo 21 de la LPI, titulado «transformación»:

La transformación de una obra comprende su traducción, adaptación y cualquier otra modificación en su forma de la que se derive una obra diferente. 
Y en el punto número dos, dicho artículo regula que los derechos de la segunda obra, la obra transformada, adaptada o modificada corresponden a quien realiza estas modificaciones:

Los derechos de propiedad intelectual de la obra resultado de la transformación corresponderán al autor de esta última, sin perjuicio del derecho del autor de la obra preexistente de autorizar, durante todo el plazo de protección de sus derechos sobre ésta, la explotación de esos resultados en cualquier forma y en especial mediante su reproducción, distribución, comunicación pública o nueva transformación.

En el caso de los audiolibros, es el narrador el que ha recreado la obra original para ofrecerla en un nuevo soporte, por lo cual le corresponden a él estos nuevos derechos de propiedad intelectual.

En el caso de que sea una compañía quien adquiere los derechos de una obra para editar un audiolibro, seguirá siendo el narrador quien posea los derechos de autor ya que fue él quien llevó a cabo la transformación de un soporte a otro, añadiendo además su entonación e impronta personal.

En cuanto a la cesión, transferencia u objeto de concesión de los fonogramas, la citada LPI recoge en el artículo 115 titulado Reproducción, lo siguiente:

Corresponde al productor de fonogramas el derecho exclusivo de autorizar su reproducción, según la definición establecida en el artículo 18.

Este derecho podrá transferirse, cederse o ser objeto de concesión de licencias contractuales.

\subsubsection{Acuerdo o contrato para la cesión de derechos de autor}

José Carlos Sánchez indica que no existe un contrato específico para la cesión de derechos de autor con el fin de su transformación en audiolibro, si bien la ley indica que debe haber una cesión de derechos y que debe realizarse por escrito. Con relación a dicha formalización, la LPI recoge en su artículo 45 que:

Toda cesión deberá formalizarse por escrito. Si, previo requerimiento fehaciente, el cesionario incumpliere esta exigencia, el autor podrá optar por la resolución del contrato.

Deberán estar reflejadas, como mínimo las siguientes cuestiones, que tienen que ver con tiempo y forma de la circulación de los contenidos y que podemos ver a continuación en el listado presente en el artículo 60 de la Ley de PI.

1.ㅇ Si la cesión del autor al editor tiene carácter de exclusiva.

2.ㅇ Su ámbito territorial.

3. El número máximo y mínimo de ejemplares que alcanzará la edición o cada una de las que se convengan.

4.ㅇ La forma de distribución de los ejemplares y los que se reserven al autor, a la crítica y a la promoción de la obra.

5. La remuneración del autor, establecida conforme a lo dispuesto en el artículo 46 de esta Ley.

6. El plazo para la puesta en circulación de los ejemplares de la única o primera edición, que no podrá exceder de dos años contados desde que el autor entregue al editor la obra en condiciones adecuadas para realizar la reproducción de la misma.

7. I plazo en que el autor deberá entregar el original de su obra al editor. 
Para información concreta acerca de temas relacionados con la cesión de derechos al productor de fonogramas, recomendamos recurrir al artículo $110 \mathrm{~b}$ que contiene tres puntos que profundizan en temas referentes al transcurso de los plazos desde que se lleva a cabo el contrato y las especificaciones para la labor posterior respecto al audiolibro.

\title{
5.15.2 Adaptaciones
}

El texto abreviado, o la adaptación de un texto también configuran una transformación, por lo cual se procedería del mismo modo que al realizar un audiolibro que sigue fielmente palabra por palabra el original, ya que como indica el artículo 21 de la LPI ya citado:

\begin{abstract}
La transformación de una obra comprende su traducción, adaptación y cualquier otra modificación en su forma de la que se derive una obra diferente.
\end{abstract}

\subsubsection{Obras de dominio público}

En primer lugar, si nos referimos a audiolibros, como la tecnología digital es más moderna que el plazo mínimo requerido para que sea considerada de dominio público, José Carlos Sánchez (2020) considera que todavía no se ha dado el caso de un audiolibro digital de dominio público. Pero existe otro punto a tratar acerca del dominio público y tiene que ver con qué obras se pueden transformar en audiolibros sin tener que pagar derechos de adaptación.

En España son obras en dominio público aquellas cuyo autor falleció en el año 1927, dado que la Ley de Propiedad Intelectual reconoce a los autores fallecidos antes de 1987, el período de protección de 80 años tras la muerte del autor, previsto en la ley de 1879. Para todos los creadores que hayan fallecido a partir de 1987 la LPI vigente prevé un periodo de protección de 70 años tras la muerte del autor.

Existen otro tipo de obras, las denominadas obras huérfanas, para las que se prevé un plazo de 50 años. La LPI la define del siguiente modo:

Se considerará obra huérfana a la obra cuyos titulares de derechos no están identificados o, de estarlo, no están localizados a pesar de haberse efectuado una previa búsqueda diligente de los mismos.

\subsubsection{Derechos del productor}

En el punto dos del artículo 116 de la LPI habla de los fonogramas con fines comerciales y estipula que:

Los usuarios de un fonograma publicado con fines comerciales, o de una reproducción de dicho fonograma que se utilice para cualquier forma de comunicación pública, tienen obligación de pagar una remuneración equitativa y única a los productores de fonogramas y a los artistas intérpretes o ejecutantes, entre los cuales se efectuará el reparto de aquélla. A falta de acuerdo entre ellos sobre dicho reparto, éste se realizará por partes iguales. Se excluye de dicha obligación de pago la puesta a disposición del público en la forma establecida en el artículo 20.2.i), sin perjuicio de lo establecido en el apartado 3 del artículo 108. 
Ligado a lo anterior, además del derecho a la reproducción existe una ley que regula el derecho a la comunicación pública y está desarrollado en el artículo 20 de la LPI.

En el turno de preguntas de la mesa redonda Pódcast y audiolibros ¿compiten por la misma audiencia? desarrollada en el VII Congreso del Libro Electrónico y llevado a cabo a fines de 2019 en Barbastro, una asistente alertó sobre el hecho que algunos de los libros de su editorial eran leídos y fragmentados en archivos de dos horas - tiempo máximo que permite la aplicación para subir archivos de forma gratuita- y subidos a la plataforma Ivoox. Juan Ignacio Solera, socio fundador de dicha empresa, le contestó que Ivoox es una empresa user generated content, al estilo Youtube o cualquier otra plataforma de autopublicación, y que no cuentan con la capacidad para velar por los más de 15.000 audios que se suben cada día, y que, por el momento, como solución a este recurrente problema, existe la opción de notificar que se infringe la ley de protección intelectual y se procedería a retirar dicho audio.

Solera recalcó que al momento no tienen las tecnologías ni las herramientas para anticipar que ese contenido que se está subiendo cumple con los requisitos establecidos por la ley, y que por esta razón ofrecen dicha posibilidad de notificación. El fundador de Ivoox recalcó la diferencia que existe con Youtube, que sí cuenta con la tecnología de inteligencia artificial que anticipa la subida de este tipo de contenidos.

\subsubsection{Distribución}

Otro derecho recogido es el de la distribución y figura en el artículo 117 en el que indica que:

Corresponde al productor de fonogramas el derecho exclusivo de autorizar la distribución, según la definición establecida en el artículo 19.1 de esta Ley, de los fonogramas y la de sus copias. Este derecho podrá transferirse, cederse o ser objeto de la concesión de licencias contractuales.

Y el artículo 118 nos habla de la legitimación activa, que es utilizada en el caso de que se produzca cualquier tipo de infracción, e indica quién tiene la capacidad de defender los derechos en tal situación:

En los casos de infracción de los derechos reconocidos en los artículos 115 y 117 corresponderá el ejercicio de las acciones procedentes tanto al productor fonográfico como al cesionario de los mismos.

\subsubsection{Hilo musical}

La musicalización y efectos de sonido también generan derechos de autor. La música que se crea para acompañar el producto final de un audiolibro puede que sea originalmente creada para este fin, o bien haya sido adquirida a otro creador.

\subsection{MODELOS DE NEGOCIO DE LOS AUDIOLIBROS}

Conforme las tecnologías avanzan, van surgiendo nuevos formatos para almacenar y distribuir los audiolibros. En este mismo capítulo hemos estudiado el desarrollo de los diferentes soportes del audio, 
y quedó demostrado que lo que representa realmente una novedad es el formato, no su contenido. Para decirlo de otra manera, la novedad es el cómo y no el qué, ya que los audiolibros existen desde hace varias décadas.

Desde los registros fonógrafos para discapacitados visuales en el año 20 hasta los $C D$, pasando por los casetes orientados para viajeros en los años 70 , muchos han sido los cambios que han sucedido en el ámbito editorial. El último gran salto fue hacia lo digital y la posibilidad de almacenar un libro entero en un solo archivo.

Como consecuencia de lo anterior, se abrió un mundo de nuevas oportunidades para la distribución de los audiolibros. No solo ocurrió una remediación del audiolibro a un nuevo formato, sino también una remediación del libro impreso. Se produjeron varios cambios en el orden de la distribución, en la práctica y la lectura, y aparecieron nuevos actores económicos (Tattersall Wallin y Nolin, 2020).

Los cambios citados por los autores mencionados afectan a diversos órdenes e incluyen los siguientes niveles:

a) Artefacto: del papel al soporte intangible.

b) De sentido: de los ojos a los oídos.

c) Movilidad: con contenido disponible en cada teléfono inteligente, con un amplio catálogo de libros.

d) Modelo económico y de distribución: de librerías o bibliotecas a proveedores de contenido centralizados.

Del modelo editorial tradicional pasamos a un modelo cloud-based en donde todo el output puede ser denominado contenido. Estamos tratando con un formato cuyo contenido es intangible, ya que es un contenido digital. Dada esta intangibilidad todo el proceso alrededor de él cambia y se readapta. EI libro, en este nuevo entorno, puede ser consumido como otros contenidos de audio, como pueden ser los pódcasts, la radio y la música (ídem).

En lo referente a la adquisición de este contenido el cambio es radical. Los cambios se enfocan hacia modelos de streaming. Al no haber ningún tipo de materialidad (casete o $C D$ ), la gente tiende a adquirirlos más en relación con un modelo de biblioteca que de librería (ídem). Es un producto que no acumulamos: lo usamos y lo devolvemos como en el tradicional modelo bibliotecario.

Tal y como sucedió con otros hitos tecnológicos, hubo una ola desde el 2017 hasta el 2020 de empresas editoriales que se sumaron a la carrera de ofrecer sus contenidos audio on line, ofreciendo diversos servicios y productos. Muchas empresas crearon su propia app, y diseñaron modelos de suscripción para captar clientes y competir con otras empresas del sector.

Existen diversos modelos ofrecidos para la distribución de audiolibros digitales. A continuación, podemos delinear algunas de las características principales de cada uno de ellos:

1. En primer lugar, la venta por suscripción: los audiolectores pueden acceder a los contenidos a través de plataformas que ofrecen modelos de suscripción. El usuario paga y tiene acceso a todo el catálogo, sin contrato de permanencia. 
Storytel y BookBeat adoptaron más claramente la noción de un libro como un contenido, replicando el modelo de los libros prestados en una biblioteca (Tattersall Wallin y Nolin, 2020). Suecia es uno de los mercados que apostó más fuerte por este formato, el $30 \%$ de la población hace uso de los audiolibros, a través de tres distribuidoras Storytel, Book Beat y Nextory (Dakik, 2019:1).

Dentro de la venta por suscripción existen dos tipos de modelo.

a. La suscripción ilimitada: donde es posible tener acceso a todo el catálogo sin límite en el tiempo de escucha ni en el número de títulos.

b. Suscripción limitada: el cliente tiene acceso a un título una vez al mes. Ej. КОВO. Un libro al mes con suscripción mensual.

2. El segundo modelo es la venta unitaria: este modelo de negocio también se denomina «a la carta». Es parecido a la venta en papel, solo que el cliente lo compra en formato digital o en CD. Un ejemplo lo tenemos en la empresa Sonolibro, Google Play, o Apple. Con este modelo, es posible descargar el archivo y conservarlo para siempre, si el cliente así lo desea.

3. Tenemos en tercer lugar las plataformas de acceso gratuito, con plataformas como Spotify o Ivoox.

4. Por último, podemos nombrar a las licencias de bibliotecas. En España está poco desarrollado este sistema que consiste en la venta de audiolibros a centros de información o documentación.

Según el último informe Bookwire, publicado en 2020, en España el 83\% de la comercialización de audiolibros proviene de plataformas que ofrecen sus audiolibros por suscripción, como Storytel, Audible y Scribd, entre otras. En segundo lugar, con un $14 \%$ de las ventas, figuran plataformas de venta unitaria de audiolibros, y tras ellas encontramos a las ventas de audiolibros a bibliotecas.

El informe también revela un descenso en los ingresos por ventas unitarias de audiolibros en comparación con años anteriores, y fundamenta dicha caída en el elevado precio de venta unitaria del formato audio, que ronda los 20 euros, si estos pertenecen al catálogo de novedades. Por otra parte, también recalcan la competencia que suponen las plataformas de suscripción.

El rápido posicionamiento en el mercado de los modelos de streaming y suscripción ilimitada trae a un primer plano el cuestionamiento acerca de esta forma de venta, frente a los modelos «a la carta» o por venta unitaria. Ambos modelos son respaldados por fundamentos que Linda Lee resume en el llamado Libro blanco - documento publicado previamente a la celebración anual de la Feria del Libro de Frankfurt del año 2020- (Lee, 2020:6).

Quienes argumentan a favor de las ventas de descargas unitarias sostienen que se mantiene el valor del audiolibro y que los autores reciben una compensación más justa. 
Por otra parte, los que se inclinan por el streaming argumentan que los audiolibros compiten por el tiempo que los usuarios dedican a Netflix, a la música y a otros medios y que el llegar con los audiolibros a los usuarios en vez de al revés aporta valor directo tanto a los audiolibros como a los autores.

Los que están a favor del streaming también argumentan que la cantidad de suscritos compensará los ingresos perdidos en comparación con el otro modelo. Por último, aseguran que es un modelo más accesible económicamente para oyentes jóvenes, que además han tenido experiencias previas en el uso de servicios similares centrados en la música.

La industria del libro, especialmente en su vertiente digital, se va adecuando a la oferta y a la demanda día a día. En el mundo del audiolibro se puede ver como se cercenan o fusionan empresas, dejando entrever la flexibilidad del sector y la continua búsqueda de modelos rentables. Fue de público conocimiento la decisión que tomó la editorial Penguin Random House, que retiró a principios de 2020 todo su catálogo de audiolibros a nivel internacional de las plataformas de streaming. Según la marca editorial, el ofertar sus obras en paquetes y por suscripción les resta valor y, como estiman el gran potencial de este formato a futuro, optaron por reformular su modelo de negocio y vender sus libros con un modelo de venta unitaria.

La citada decisión llevada a cabo por Penguin fue fundamentada por el departamento de comunicación de dicha empresa afirmando que había sido tomada a fin de «preservar una diversidad de contenidos en el mercado y el valor real y percibido de la propiedad intelectual de nuestros autores a largo plazo» (Ruiz Mantilla, 2020, parr. 6). Otra decisión adoptada por la empresa fue la de montar sus propios estudios de grabación. La exclusión del catálogo de Penguin afectó a muchas plataformas, como por ejemplo a Storytel, cuyo catálogo contenía un $10 \%$ de títulos de la editorial.

Parte del trabajo de distribución de audiolibros es el de la promoción de los productos. Algunas de las campañas realizadas en el sector invitan a la audiolectura a través de la gran creatividad y modernidad de sus anuncios. Con el eslogan "Listening is the new reading» (Escuchar es el nuevo leer) - utilizando una analogía con la famosa serie Orange is the new Black-, Audible promocionó a nivel internacional su catálogo en línea.

Storytel hizo lo propio con el eslogan «Ahora los libros también se escuchan», con el que se promociona desde las redes sociales y también desde spots publicitarios televisivos. 


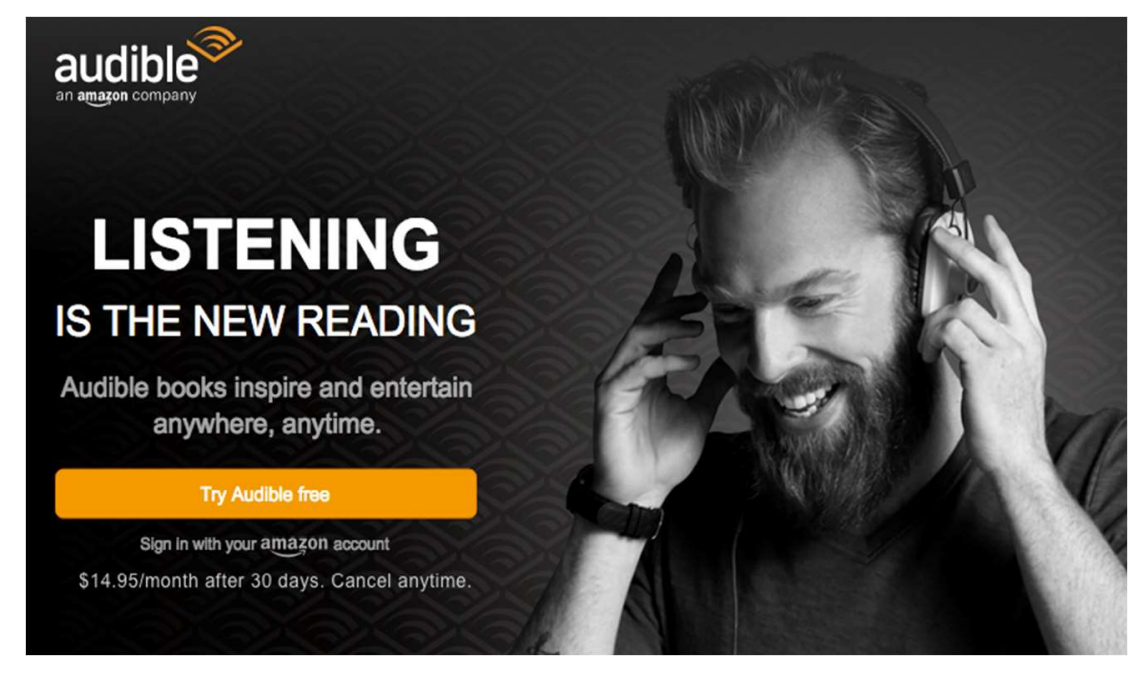

Ilustración 9. Promoción realizada por Audible, año 2018 Fuente: Página web de Audible

Otro modo de llamar la atención del usuario fue el utilizado por Storytel España, que ha diseñado en el 2020 una campaña a través de su cuenta en Instagram. La elección de ese canal de comunicación puede deberse a que los usuarios de Facebook han caído en el 2020 a niveles del año 2015 con un segmento de edad que va de los 40 a los 64 años mayoritariamente, al igual que el descenso de perfiles de Twitter que reporta casi medio millón menos de usuarios que en el 2019.

Instagram, sin embargo, reportó un crecimiento del $6 \%$ respecto al año anterior en 2020 , por lo cual creemos que es un dato que han tenido en cuenta los creativos y profesionales del departamento de ventas para realizar sus campañas publicitarias. Una de las más llamativas consistía en la simulación de una llamada por parte de la propia empresa y que podemos ver a continuación. La publicidad se ejecutaba sola y, anunciaba finalmente una promoción con 14 días gratis del servicio de audiolibros digitales. La secuencia la podemos ver en la siguiente ilustración: 

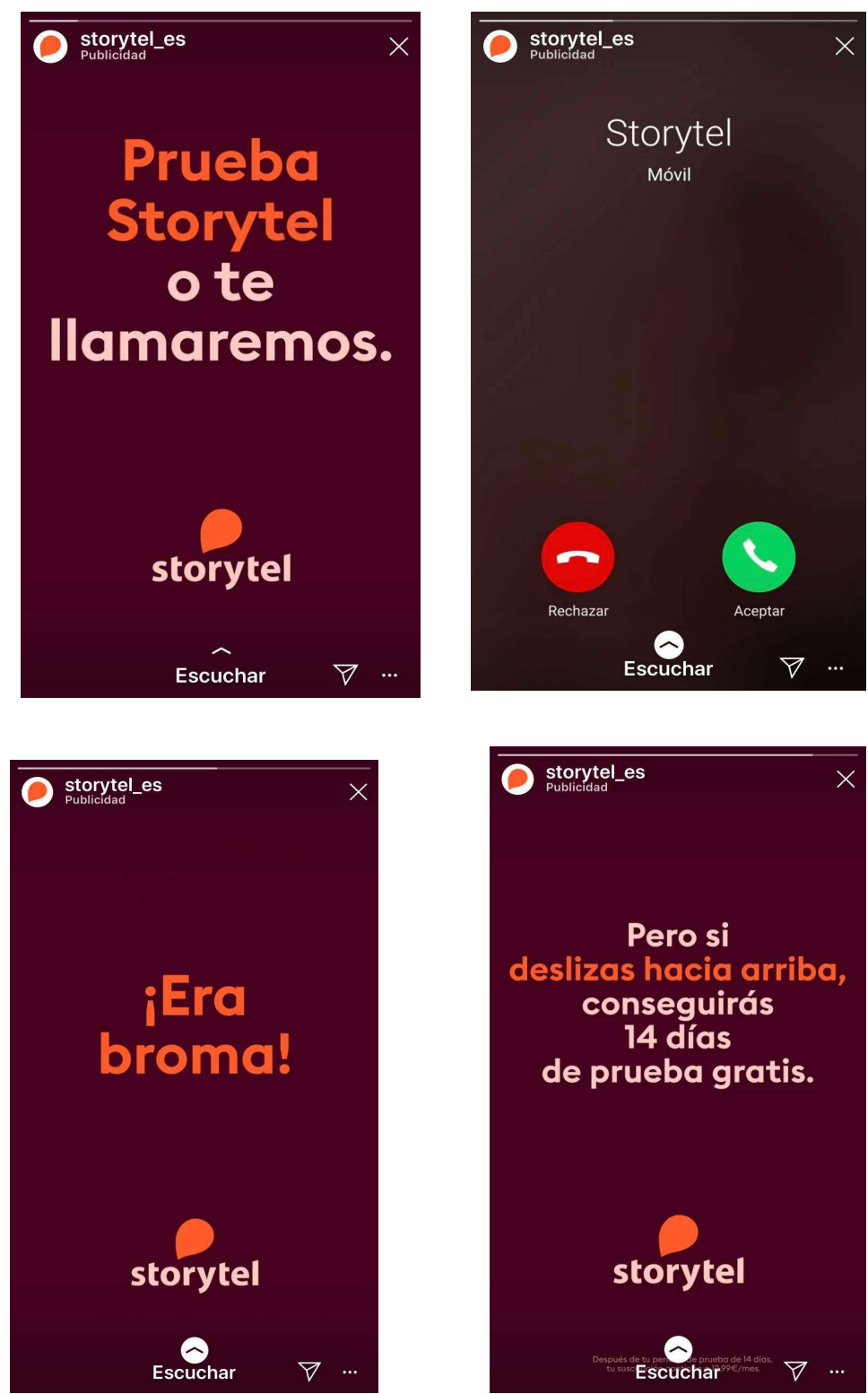

Ilustración 10. Publicidad realizada por Storytel a través de Instagram.

Fuente: Captura de pantallas, Instagram, 2020 


\subsection{EVOLUCIÓN DEL SECTOR EDITORIAL DEL SONIDO}

Según la revisión de la bibliografía, la evolución del sector no fue un fenómeno previsible. En el título Libros o velocidad: reflexiones sobre el oficio editorial se incluye un artículo del año 2000 en el que se enunciaba que el mundo editorial estaba ilusionado por los cambios que se avecinaban con los nuevos formatos electrónicos y las nuevas ediciones que supondrían los avances en el medio y largo plazo. En dicho artículo presagiaban que muchas de estas innovaciones no prosperarían y se quedarían en el plano de curiosidades, y en un apartado firmado por Francisco García titulado La triste historia del audiolibro, analizaban ya más en detalle la situación de los audiolibros alrededor del año 2000, fecha en la cual, según indicaban, la sociedad española estaba acostumbrada a oír la radio, escuchar música e interactuar con dispositivos pequeños desde hacía ya tiempo.

García afirmaba lo siguiente: «podemos tener al alcance de la mano un reproductor de audio, ya sea el popular walkman o el inevitable radio-casete del coche» (Nadal y García, 2005:103). A pesar de ello, García mencionó que entre los fracasos tecnológicos se encontraba el audiolibro. En sus palabras: «Un ejemplo claro de este fracaso tecnológico lo tenemos en la corta y triste historia del libro hablado» (ídem).

Para la fecha de publicación del artículo la edición de audiolibros era anecdótica, ya que los mismos no superaban el centenar teniendo en cuenta los registros del ISBN, mientras la producción anual impresa era de 50.000 títulos anuales en España (ibídem, 104).

El artículo de García del año 2000 sirvió para reflejar una coyuntura de los libros hablados, en virtud de la cual el autor estimó que el negocio no prosperaría. En ese momento no se vislumbraban todavía las innovaciones de la telefonía móvil y las plataformas y aplicaciones que favorecerían la situación en la que nos encontramos casi veinte años después.

En la actualidad, tras evaluar las cifras que arrojan los diferentes estudios y estadísticas, advertimos que en general existe una disparidad en cuanto a los datos estadísticos y, como lo denomina CordónGarcía, «un elevado grado de inconcreción» (2016:17) en relación con saber cuánto se lee y, sobre todo, cómo se lee. Cada país realiza su cuantificación y vuelca sus datos anuales en panorámicas, observatorios y anuarios, que revierten un carácter siempre aproximativo, pues debemos tener en cuenta la irrupción de la autopublicación, que representa, según Cordón-García (ídem) uno de los escenarios que dificulta la normalización de la estadística.

Podríamos agregar a la piratería como otro impedimento para obtener datos fiables del mundo editorial cuando se analizan datos referentes al consumo.

Para los fines de la investigación recurrimos a los documentos que José Antonio Cordón-García (2018) lista como fiables para obtener datos relativos al contexto en el que se mueve el libro electrónico y la lectura digital: Encuesta de hábitos de lectura y compra de libros (Federación de Gremios de Editores); Panorámica de la edición española de libros (Ministerio de Educación, Cultura y Deporte); Comercio interior del libro (Federación de Gremios de Escritores); El comercio exterior del libro (Fedecali); Encuesta de hábitos y prácticas culturales (MECD) e Informes de Dosdoce y BookWire. 
Tal y como recomienda Cordón-García, realizamos una revisión de los documentos relacionados con el ámbito de la edición en España, a fin de obtener una visión panorámica de nuestro objeto de estudio, comenzando por el barómetro confeccionado por el Gremio de Editores de España:

Teniendo en cuenta el último documento publicado de la Federación del Gremio de Editores, el Barómetro de hábitos de lectura y compra de libros, en España, durante el año 2019, el 3\% de la población escuchó audiolibros (en 2018 fue un 2,4\%); y un 1,3\% lo hizo de forma regular (en 2018 era un 1,1\%).

La pregunta acerca de la escucha de audiolibros se introduce por primera en la encuesta en el año 2018, por lo cual solo tenemos como referencia para comparaciones estos dos últimos años, con una tendencia de crecimiento de su uso, como se puede observar en las siguientes ilustraciones:

\section{¿Suele escuchar audiolibros?* ¿Con qué frecuencia?}

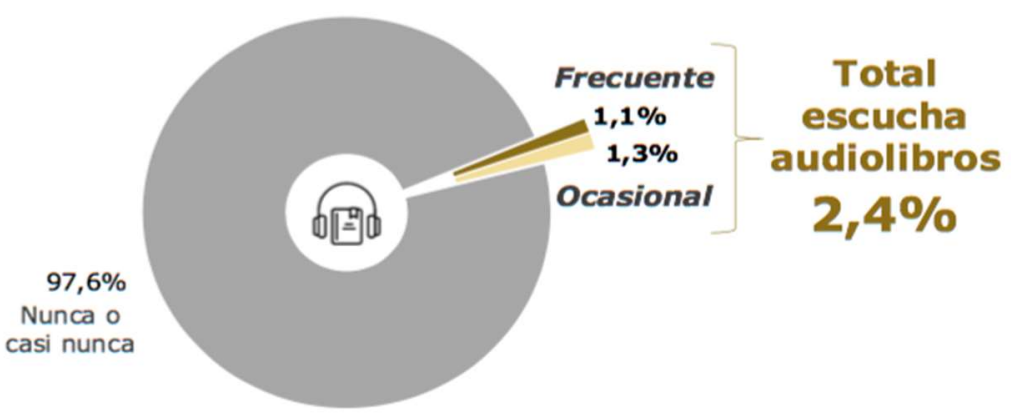

Ilustración 11. Frecuencia de escucha de audiolibros, año 2018 Fuente: FGEE, Barómetro de hábitos de lectura y compra de libros, 2018.

\section{¿Suele escuchar audiolibros?* ¿Con qué frecuencia?}

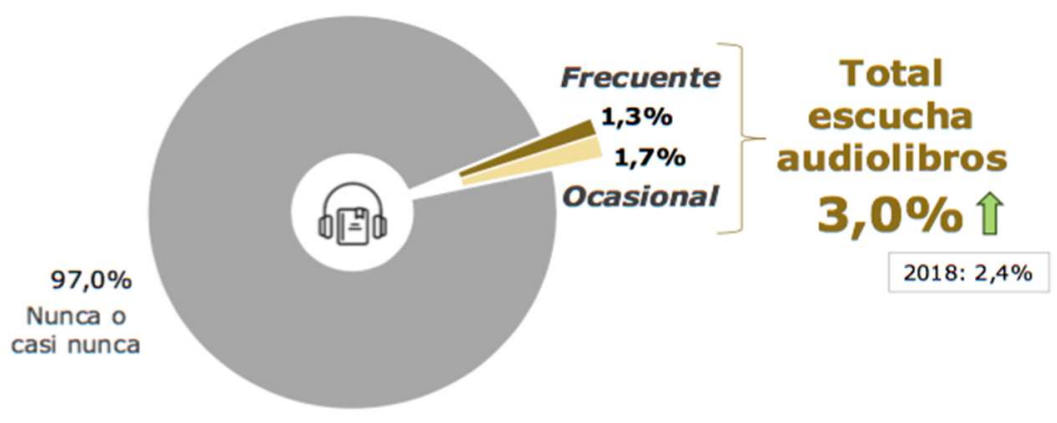

Ilustración 12. Frecuencia de escucha de audiolibros, año 2019

Fuente: FGEE, Barómetro de hábitos de lectura y compra de libros, 2019

En el barómetro se incluyen más detalles que pueden resultar de interés, como la franja etarea, el sexo y el nivel educativo de los usuarios de audiolibros. 


\begin{tabular}{|c|c|}
\hline$\%$ Horizontales & $\begin{array}{l}\text { Escucha } \\
\text { Audiolibros }\end{array}$ \\
\hline TOTAL (4.800) & 3,0 \\
\hline Hombre (2.392) & 3,5 \\
\hline Mujer (2.408) & 2,5 \\
\hline De 14 a 24 años (635) & 3,4 \\
\hline De 25 a 34 años (700) & 4,5 \\
\hline De 35 a 45 años (981) & 4,7 \\
\hline De 45 a 54 años (933) & 3,3 \\
\hline De 55 a 64 años (743) & 1,2 \\
\hline De 65 años y más (809) & 0,7 \\
\hline Hasta primarios (1.015) & 2,6 \\
\hline Secundarios (2.393) & 3,2 \\
\hline Universitarios (1.392) & 3,0 \\
\hline
\end{tabular}

Ilustración 13. Audiolectores por franja etarea, sexo y nivel educativo

Fuente: Barómetro de hábitos de hábitos de lectura y compra de libros en España, 2019

Otro dato relevante que se incluye en dicho estudio es que en el año 2019 la lectura en soporte digital continuó creciendo hasta el 29,1\%.

Ante la consulta realizada por el informe acerca de la materia del último libro leído, el 73,3\% de los lectores indicó que esta se trataba una obra literaria, y la forma más habitual de obtención de los libros digitales fue la descarga gratuita.

Según este barómetro, el 68,5 \% de la población española lee libros; un 62,2 \% por ocio, en su tiempo libre (con tendencia ascendente) y el $27,5 \%$ lee por razones laborales o de estudio.

El segundo documento que consultamos y del cual realizaremos un sucinto análisis es: $\underline{\text { La Panorámica }}$ de la Edición Española de Libros, publicación que recoge y analiza las estadísticas del sector del libro en España. Es una publicación elaborada por la Subdirección General de Promoción del Libro, la Lectura y las Letras Españolas del Ministerio de Cultura y Deporte, a partir de los datos gestionados por la Agencia Española del ISBN (International Standard Book Number). Por ello, esta publicación abarca únicamente los libros que han sido previamente registrados en la Agencia.

Los últimos datos disponibles - consultados en abril de 2020- son los relativos al año 2018. En la página del Ministerio de Cultura y Deporte, indican que, desde el año 2015 la Agencia del ISBN no tiene en cuenta las reimpresiones ni se podrán obtener datos de videolibros ni de audiolibros.

Cabe señalar que esta agencia registró por primera vez en el año 2000 títulos en la modalidad de archivo de Internet. Doce años más tarde, las tecnologías irrumpen con fuerza con la utilización de los nuevos formatos PDF, ePub, Mobi (Kindle), y otros formatos ebooks que han sustituido a los archivos de Internet. Es por esta razón que se puede ver que, desde del año 2005, el número de ISBNs inscritos de archivos digitales no ha parado de crecer, llegándose en el año 2010 a superar las cifras del año anterior en un 155 \% (Magadán Díaz y Rivas García, 2019). 
Para poder observar los datos en perspectiva, el comienzo de la crisis financiera de 2008 impulsó, según Magadán Díaz y Rivas García (2020), a la industria editorial española hacia un movimiento estratégico de mayor edición de libros electrónicos, que condujo hacia un crecimiento sostenido entre 2008 y 2011 que comienza a caer desde 2011 hasta 2013. A partir del año 2013 y hasta el año 2015 se consolidan los números volviendo a repuntar hasta el 2018.

Con la actualización de la séptima edición del manual de usuario del ISBN elaborado por la International ISBN Agency, (Londres 2017), se han renovado los ejemplos de publicaciones y tipos de material que deben o no deben llevar ISBN. Cabe aclarar que el registro es recomendable, pero no obligatorio para publicar y comercializar un libro.

El ámbito de aplicación del ISBN abarca las siguientes publicaciones, según el Real Decreto 2063/2008, del 12 de diciembre, en lo relativo al ISBN.

Entre los ejemplos de publicaciones monográficas a las que sí se les puede asignar un código ISBN, nos encontramos con una relación de ítems en el cual se encuentran los audiolibros:

- Libros y folletos impresos (y sus diferentes formatos de producto).

- Publicaciones en Braille.

- Publicaciones que el editor no va a actualizar regularmente o a continuar indefinidamente.

- Audiolibros (libros leídos) tanto en soporte físico como accesibles en internet para su descarga o retransmisión.

- Publicaciones electrónicas (e-books), sea en un soporte físico (como cintas legibles por máquina, disquetes o CD-ROM), o en internet (para descarga o retransmisión).

- Copias digitalizadas de publicaciones monográficas impresas que están disponibles en la cadena de suministro.

- Etc.

Algunas plataformas, como es el caso de Amazon, asignan a los libros electrónicos, de forma gratuita, el Amazon Standard Identification Number, ASIN, en lugar del ISBN, que los valida para publicar el libro en Amazon y no en otras plataformas (Cordón-García, 2016 citado en Gómez Díaz et al., 2016:19).

Si bien las estadísticas oficiales no reflejan toda la producción a la que no se le asignó un ISBN, tenemos una tendencia a la baja en relación con la publicación de libros en general, en el año 2018 en comparación con el 2017. La producción de libros impresos disminuyó un 1,1\% con un total de 60.835 libros (61.519 en 2017), representando el 74,9\% del total, mientras que la caída más grande la sufrió la edición en otros soportes, que ha disminuido un 28,3\%, con un total de 20.393 ISBN (28.443 en 2017).

Como se puede observar en el siguiente gráfico, la edición electrónica, incluida en la edición en otros soportes, pierde peso un 28,6\% (20.287 en el 2018 respecto a los 28.433 de 2017). 


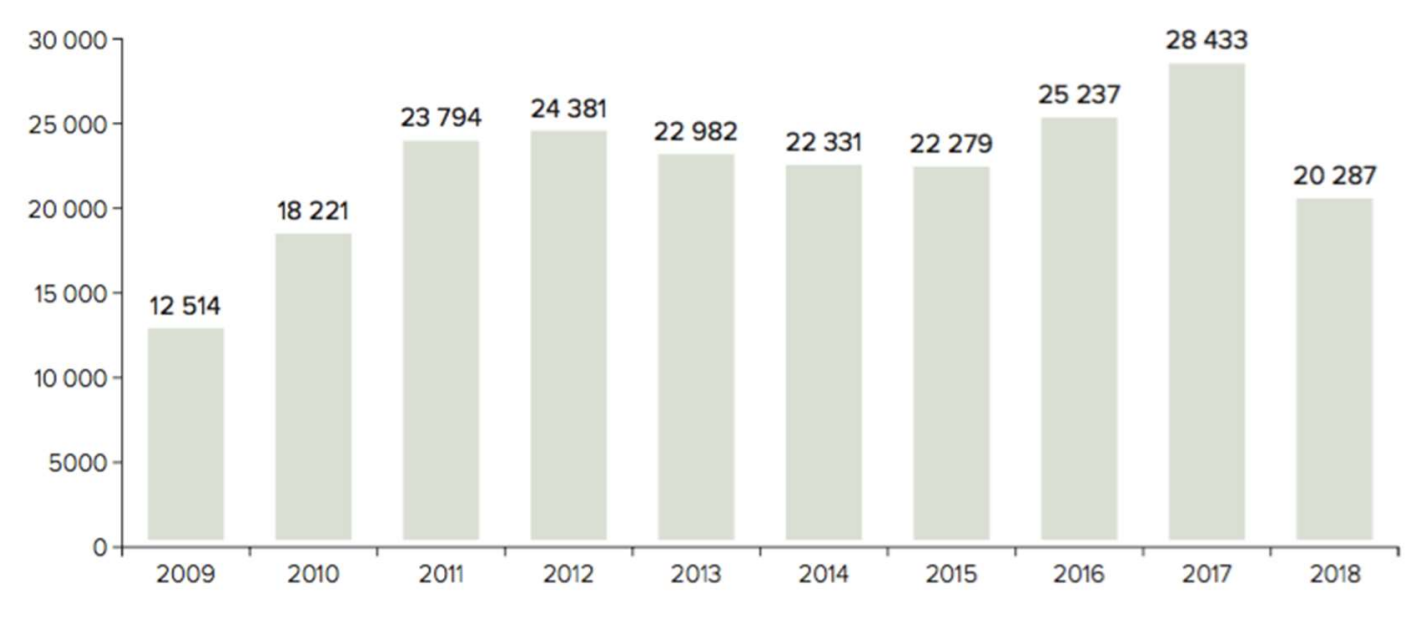

Ilustración 14. Estadísticas de la edición electrónica de libros, año 2018.

Fuente: Panorámica de la edición española de libros, 2018

La mayor parte de los registros electrónicos (un 93,2\%) son libros digitales. Estos muestran un descenso del $31,4 \%$, con un total de 18.900 ISBN (27.546 ISBN en 2017), representando el $23,3 \%$ del total de la producción.

Otro dato que menciona es que la mayor parte de los libros digitales se publican en formato PDF, un $42,5 \%$, seguidos por ePub, con un 33,0\%, Mobi (580 ISBN) y otros - dentro de los cuales podrían situarse los audiolibros- (4.054 ISBN).

Teniendo en cuenta el último documento publicado del Comercio interior de libro, referente también al año 2018, el sector editorial vuelve a experimentar una subida en su facturación. El ascenso representa un $1,9 \%$ respecto a 2017 , basado fundamentalmente en la fortaleza del libro en papel, mientras se estanca el libro digital con una leve caída del $0,1 \%$.

Antonio María Ávila, miembro de la Junta Directiva del Gremio de Editores, haciéndose eco de esta leve caída digital, declaró que «El mercado del libro digital está siguiendo en realidad la misma pauta que en el resto de Europa y también en EEUU», y agrega que «hay cierto cansancio digital» (Asociación de Editores de Madrid, 2019).

José Antonio Cordón-García indica que «la bibliografía científica apunta hacia la emergencia de síntomas por fatiga por uso o abuso de los nuevos medios tecnológicos» y agrega que la "fatiga digital» tiene que ver con la «usabilidad de dispositivos, el cansancio atribuible a la conectividad forzada y con el uso excesivo de pantallas» (Cordón-García, 2018b:473).

En esta línea, Markus Dohle enunció en una entrevista publicada en El periódico de España en el año 2018 que la "fatiga digital», que explica más adelante como "el intento de escapar de las pantallas», es una de las razones que explicaría el aumento de ventas de libros impresos y un descenso de ventas de libros electrónicos a nivel global.

Otros factores que influyen en este estancamiento son: la piratería (13 millones de descargas legales frente a 300 millones de descargas ilegales) y el IVA (en el período estudiado aún no se había aplicado la rebaja del $21 \%$ al $4 \%$ ). 
Teniendo en cuenta los géneros más vendidos, los especializados en ficción crecieron un 20,7\%, mientras la no ficción ha subido un $29,5 \%$ debido, en gran medida a la publicación de obras sobre temas actuales de política o feminismo, por ejemplo.

Según destaca este informe, las exportaciones del sector del libro español continuaron creciendo en 2018 hasta alcanzar los 615,40 millones de euros, un 4,5\% más que el año anterior.

El informe revela que, del total de 724 empresas editoriales, el 51,2\% (371) editaron en 2018 libros en distintos soportes al papel. Este porcentaje aumenta levemente con respecto al año anterior. Otro dato a tener en cuenta es que se redujo ligeramente el porcentaje de empresas que solo producen en papel, con un $48,8 \%$ (353). El número de empresas editoriales que editan en formato electrónico se mantiene estable, con un $88,4 \%$ en el año 2017 y un $88,1 \%$ en 2018 .

El $88,1 \%$ de las empresas que editan en formatos fuera del formato en papel lo hacen en digital. El informe muestra una caída de $2,2 \%$ en los audiolibros y en el resto de los campos mantienen una tendencia plana con pocos cambios. Esta reducción de las ventas podría deberse a que en el ámbito de los audiolibros son más comunes las suscripciones a plataformas que las compras unitarias.

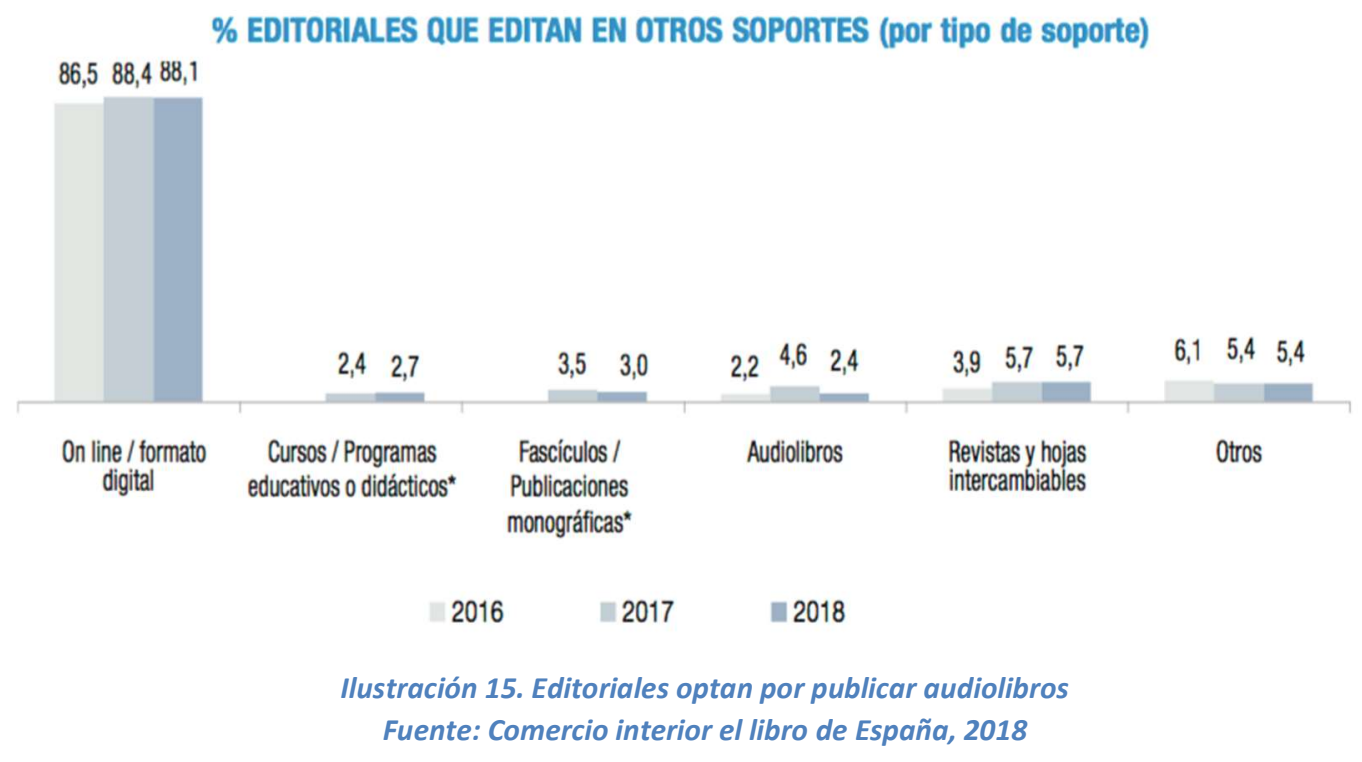

\section{Comercio exterior del libro 2018 (Fedecali)}

En su vigésimo séptimo estudio, refleja la cultura española en los mercados exteriores. Resalta la internacionalización de la economía española. No encontramos una distinción de libros en soporte digital en este estudio, por lo cual tampoco encontramos datos sobre audiolibros digitales.

\section{Encuesta de hábitos y prácticas culturales}

El documento 2018-2019 refleja un resultado oficial con periodicidad cuatrienal incluido en el Plan 
Estadístico Nacional. Es una investigación por muestreo realizada por la División de Estadística y Estudios de la Secretaría General Técnica del Ministerio de Cultura y Deporte dirigida a una muestra de 16 mil personas de 15 años en adelante. En el documento no se detalla el sector de los audiolibros, ni en el apartado audiovisuales ni en el cultural. Algunos de los datos más relevantes con relación a los hábitos lectores son los siguientes:

Los resultados de la encuesta indican que las actividades culturales más frecuentes, en términos anuales, son: escuchar música, leer e ir al cine, con tasas del $87,2 \%$, el $65,8 \%$ y el $57,8 \%$, respectivamente.

El 26,8\% de la población acude anualmente a una biblioteca o accede virtualmente a ella. Las visitas a archivos son realizadas en el mismo período por el 7,1\% del colectivo objeto de estudio.

La encuesta revela preferencias en relación con el formato de libro utilizado: el 61,9\% de la población total analizada lee al menos un libro al año en soporte papel y el 20,2\% leyó en soporte digital.

El desglose de lectura digital se compone del siguiente modo: el 9,9\% de la población estudiada manifiesta leer libros directamente en Internet, el 8,5\% a través de un lector de libros digitales, el 7,3\% lo hace con otros soportes móviles y un 1,2\% a través de plataformas digitales.

Los lectores de libros digitales presentan tasas ligeramente superiores de lectura de novela contemporánea, especialmente de aventura o policíaca y en libros divulgativos que versan sobre ciencias físicas, química, matemáticas o informática.

Aquellos que suelen escuchar radio, muestran preferencia por programas musicales, $75,2 \%$, y noticias, $61,7 \%$, siendo muy inferior la preferencia por las tertulias, 15,4\%, los programas deportivos, 16,6\%, y muy escasa la incidencia de documentales y programas culturales, representados con un $3,1 \%$.

Un 19\% de oyentes de radio declaran que suelen utilizar el móvil para ello, el 7,4\% el ordenador o tablet y un $13,3 \%$ de la población que ha escuchado en el último mes la radio ha utilizado directamente Internet.

Un dato que puede resultar interesante para hacernos una idea de los cambios socioculturales es que más de la mitad de la población investigada, el 52,2\%, dispone en su hogar de suscripciones a plataformas digitales de contenidos culturales. El $38,9 \%$ de películas o series, el $28,8 \%$ de plataformas de canales de televisión, el $26,8 \%$ de contenidos musicales y el $4,1 \%$ de plataformas de videojuegos.

El informe Evaluación del mercado digital (ebooks y audiolibros) en España y América Latina arroja luz sobre el estado actual del formato audiolibro, ya que los datos son muy actuales -corresponden a 2019- y porque analizan muy exhaustivamente tanto el mercado del audiolibro como el de sus usuarios. Este trabajo sirve para completar todas las ausencias con las que nos encontramos en los anteriores reportes realizados a nivel nacional.

Todos estos datos, recogidos en el informe, nos dan cuenta de las ventas de ebooks y audiolibros ocurridas en 2019 por las más de 450 editoriales españolas y latinoamericanas que gestionan la distribución de libros electrónicos y audiolibros a través de la plataforma Bookwire.es.

Estas 450 editoriales mencionadas han experimentado nuevamente $-y$ por sexto año consecutivoun crecimiento en las ventas de sus libros electrónicos y audiolibros. Así como en 2017 las ventas crecieron un 52\% respecto al año 2016, en 2018 alcanzaron un 57\% de aumento y en 2019 el crecimiento alcanzó el 35\% en comparación con su año anterior. 
La venta de licencias de libros electrónicos y audiolibros a las bibliotecas se mantiene en un $3 \%$ del total de las ventas digitales respecto al año anterior. Según los propios datos recogidos del Ministerio de Cultura de España, los préstamos de libros electrónicos en bibliotecas se han duplicado en 2018 de menos de 500.000 a más de un millón de préstamos digitales.

La oferta de audiolibros no superaba los 6000 títulos en 2017; a finales de 2018 se acercaba a los 8000 títulos y en el último año, 2019 alcanzó los 10.000 títulos. La previsión para el 2020 fue de 14000 títulos.

Las ventas de audiolibros digitales generaron en 2019, según el citado informe de Bookwire alrededor de cinco millones de euros, y según indica el mismo documento y para tener como parámetro, en el año 2017 se estimaba un negocio de entre uno y tres millones de euros.

En comparación con los otros modelos de comercialización, las editoriales que distribuyen hoy en día audiolibros indican que las plataformas de suscripción como Storytel, Audible, Scribd, Kobo, entre otras, se han convertido en el principal canal de venta de audiolibros en español.

En segundo lugar, sitúan a los canales de venta unitaria como Google Play o Apple Books, y en tercer lugar a las plataformas de streaming como Spotify, Deezer y similares. El informe concluye que, a diferencia de los mercados anglosajones, la venta de audiolibros a bibliotecas es un canal muy poco desarrollado en los mercados en español, situándose en cuarto lugar.

Según el citado trabajo existen nuevos canales de venta de audiolibros. El informe de Bookwire indica que las plataformas de streaming de música se están convirtiendo en uno de los principales canales de promoción y escuchas de audiolibros. En 2019, las pistas de este formato distribuidos por Bookwire se reprodujeron más de 800 millones de veces, triplicando las reproducciones del año 2018 en las plataformas streaming de música.

El informe recoge los datos de la inversión que están realizando las bibliotecas por dar un mayor espacio al formato audiolibro en sus plataformas de préstamo digital y bibliotecas electrónicas. Según los datos que figuran en el informe, los ingresos que han percibido las editoriales a través del modelo de venta de licencias a bibliotecas de audiolibros han crecido un $1.298 \%$ en valor económico en el año 2019 comparándolo con el año anterior. Si bien las ventas de audiolibros a bibliotecas representan solo el $3,4 \%$ del total de las ventas digitales de las editoriales en 2019 , han crecido un $1,9 \%$ más que las del año 2018. 


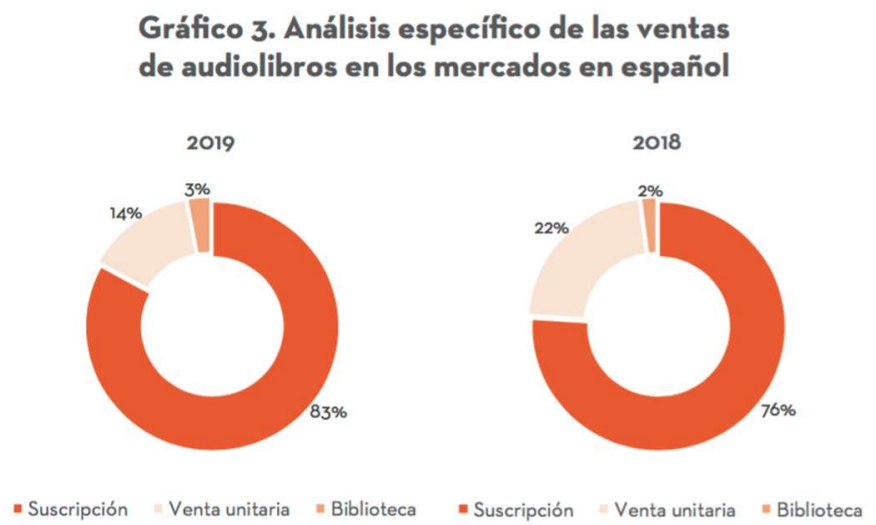

Ilustración 16. Análisis de ventas de audiolibros en mercados en español Fuente: Evolución del mercado digital (ebook y audiolibros) en España y América Latina, 2019

Consultados los informes e-Biblio de los años 2017 al 2019 del Ministerio de Educación, Cultura y Deporte, podemos encontrar que, ciertamente, ha habido una progresión muy marcada en la cantidad de audiolibros que este servicio ofrece a sus usuarios:

\begin{tabular}{llll}
\hline & $\mathbf{2 0 1 7}$ & $\mathbf{2 0 1 8}$ & $\mathbf{2 0 1 9}$ \\
\hline Libros & 12959 & 19517 & 22684 \\
Audiolibros & 200 & 465 & 1122 \\
Revistas & 69 & 88 & 71 \\
Periódicos & 7 & 22 & 40 \\
\hline
\end{tabular}

Tabla 2. Contenidos digitales en e-Biblio Fuente: Informes E-Biblio. Elaboración propia

No observamos un correlato en la evolución del uso de estos documentos sonoros ya que, según las estadísticas, en el año 2017 un 7\% de los préstamos totales de e-Bibio correspondían a audiolibros con tan solo una oferta de 200 audiolibros-, mientras que en 2018 y 2019 caen a 3\% y a 4\% respectivamente cuando la oferta fue ampliamente superior.

Tras el análisis de estos documentos representativos para obtener datos referentes al mundo del libro digital, hemos observado que algunas agencias realizan sus relevamientos y publicaciones más rápidamente que otras, ofreciendo por consiguiente datos poco actualizados.

Pese a esto, hemos tomado siempre los informes de los últimos años para que nos den una idea de las tendencias generales del sector del libro electrónico, así como la importancia que desde los organis- 
mos públicos y privados le otorgan al formato audiolibro. Encontramos que en algunos casos el formato directamente no se incluye, como es el caso del Informe de Comercio exterior del libro 2018, de Fedecali o La Panorámica de la Edición Española de Libros.

Los estudios y encuestas del sector son, en muchos casos contradictorios y requieren un análisis posterior. Este es el caso de la Panorámica de la Edición Española de Libros, que al recoger únicamente los libros a los que han sido asignados un número de ISBN - y al no ser una obligación por parte del editor del mismo- deja fuera un número incalculable de obras. Esta situación deja en una nebulosa fundamentalmente a los registros digitales, y los nuevos formatos que no hayan optado por incluir dicho número ISBN.

Es escasa la información referida expresamente a los audiolibros, pero hemos encontrado datos de interés como en el de la Evaluación del mercado digital (ebooks y audiolibros) en España y América Latina en el que refleja que los audiolibros en español alcanzaron en 2019 los 10.000 títulos, mientras que el Barómetro de hábitos de lectura y compra de libros en España evidenció que hubo un incremento de este formato sonoro durante el 2019 en el que el 3\% de la población escuchó audiolibros (en 2018 fue un 2,4\%), de los cuales un 1,3\% lo hizo de forma regular (en 2018 era un 1,1\%). 
En España es necesario retrotraernos a la década de los sesenta, momento en el cual las bibliotecas comenzaron a ofrecer libros en formato audio, como hemos visto en un apartado anterior: el «Servicio de Libro Hablado», haciendo despegar la producción de libros en sistema sonoro - en ese momento, en formato analógico-.

El impacto y la llegada de internet en los años 90 supuso para los profesionales de la información el desafío de volcarse a las nuevas tecnologías en todas las áreas: adquisiciones, procesos técnicos, referencia, extensión cultural, etc., pero las bibliotecas no tuvieron que replantearse sus principios con la llegada de estas tecnologías. Sus bases quedaron sentadas en el Manifiesto de la IFLA/UNESCO sobre la Biblioteca Pública, del año 1994, donde están presente todos los elementos constitutivos, además de sus usuarios y sus servicios, como podemos observar a continuación:

\footnotetext{
La biblioteca pública es un centro local de información que facilita a sus usuarios todas las clases de conocimiento e información.

Los servicios de la biblioteca pública se prestan sobre la base de igualdad de acceso para todas las personas, sin tener en cuenta su edad, raza, sexo, religión, nacionalidad, idioma o condición social. Deben ofrecerse servicios y materiales especiales para aquellos usuarios que por una u otra razón no pueden hacer uso de los servicios y materiales ordinarios, por ejemplo, minorías lingüísticas, personas con discapacidades o personas en hospitales o en prisión.
}

Todos los grupos de edad han de encontrar material adecuado a sus necesidades. Las colecciones y los servicios han de incluir todo tipo de soportes adecuados, tanto en modernas tecnologías como en materiales tradicionales. Son fundamentales su alta calidad y adecuación a las necesidades y condiciones locales. Los materiales deben reflejar las tendencias actuales y la evolución de la sociedad, así como la memoria del esfuerzo y la imaginación de la humanidad.

Ni los fondos ni los servicios han de estar sujetos a forma alguna de censura ideológica, política o religiosa, ni a presiones comerciales (IFLA, 1994).

Este manifiesto nos habla, por un lado, de que los servicios deben estar orientados a todos los usuarios: todas las personas sin distinción de raza, religión, nacionalidad o condición social, además de las minorías lingüísticas y personas con discapacidades o incapacitados de moverse, como las personas discapacitadas o en prisión; por otro lado, nos habla de colecciones que deben incluir todo tipo de soportes, y con un contenido que refleje las tendencias actuales de la humanidad.

Las bibliotecas, en suma, deben resguardar el material y los documentos asociados al pasado, preservar los del presente y adecuarse continuamente a los cambios que acontecen en la sociedad, mirando hacia el futuro. Por tanto, el modelo tradicional de biblioteca cohabita con un modelo más amplio en donde caben todo tipo de formatos y donde los límites del concepto de lectura están en estrecha relación con el entorno.

Tras este arribo del formato digital las bibliotecas se encontraron en un momento especialmente destacable, en el que tuvieron que planificar y construir su imagen y colección virtual, más allá de los límites de sus colecciones físicas. Desde la irrupción de los formatos digitales los centros documentales se encuentran en la dualidad de mantener las colecciones impresas y dedicarles parte del presupuesto, al mismo tiempo que reasignar fondos a recursos digitales. 
Hasta el momento en el que comienzan a proliferar formatos digitales las bibliotecas competían con otros centros análogos, con librerías y copisterías. Pero se suman a estos agentes, competidores específicos del entorno digital; en otras palabras: aparecen nuevos competidores directos, a través de operadores que ofrecen servicios de lectura en tarifa plana (Alonso-Arévalo y Cordón-García, 2015).

Esta revolución de las comunicaciones con su consecuente revolución digital y aluvión de recursos sitúa a los profesionales de la información en otro escenario, en el que todo el mundo puede acceder a recursos en línea, pero las tareas se complejizan si lo que buscamos es un uso eficiente de los recursos y de acceso a información de calidad.

Evaluar y discernir la calidad de los contenidos entre diferentes distribuidores y editores de libros electrónicos y audiolibros, los títulos, períodos de préstamo, licencias, interfaces, costos y formas de descargas es una tarea que debería formar parte de la rutina de los profesionales de la información y documentación.

Otro aspecto a tener en cuenta son las restricciones económicas que frecuentemente aquejan a las bibliotecas y por consiguiente a sus colecciones. Los sistemas bibliotecarios deben evaluar detenidamente las prestaciones de cada plataforma de audiolibros, así como de libros electrónicos para determinar cuál es la más adecuada para las necesidades de los usuarios a quienes sirve (Acedo y Leverkus, 2014).

En esta década en la cual el audiolibro está viviendo un auge, debemos contar con todas las herramientas tanto para seleccionar audiolibros de calidad, como para llegar a acuerdos beneficiosos con editores de audios, conocer muy bien los canales en los cuales circula este tipo de formato, y realizar tareas de formación de usuarios.

Es de destacar como un logro del mundo de las bibliotecas que el entorno privado busque copiar sus estrategias, como los servicios que ofrecen Storytel u otras plataformas similares. Como puntualiza Martina Dakik, esas compañías están adoptando y adaptando el modelo bibliotecario (Dakik, 2019:1).

Las plataformas provenientes de iniciativas privadas ofrecen los libros para leer y prestar por una cuota mensual, mientras que en la misión de las bibliotecas está el hacerlo gratuitamente, ofreciendo acceso al conocimiento en todas las formas, incluyendo la digital (Svensk biblioteksförening, 2015, citado por Dakik, 2019:1).

Para poder ofrecer un buen servicio de referencia, los bibliotecarios deben conocer en profundidad su colección. Pero además de sus propios recursos también es deseable que dominen cuáles son los distintos formatos bibliográficos que existen en el mercado y los dispositivos con los cuales pueden ser reproducidos - en el caso de que no sean impresos-.

Ya sea que posea o no su propia colección de audiolibros, la biblioteca debe tener conocimiento actualizado de la oferta que existe en el mercado, para poder orientar al usuario sobre los recursos o aplicaciones que vayan surgiendo. Los usuarios pueden sentirse desbordados ante la oferta, que muchas veces comparte contenidos y consiste en propuestas que se distinguen entre sí apenas por una $u$ otra prestación extra. Para poder discernir si una aplicación es mejor que la otra es necesario estar mínimamente familiarizado con su uso o poseer un documento que pueda servirles como guía. 
Los profesionales de la información necesitan, según Jessica Moyer, ofrecer a los lectores información relacionada con los audiolibros y los libros electrónicos, ya que de otra forma los mismos estarían corriendo «el riesgo de perder y alienar a una generación entera de lectores de la biblioteca» (Moyer, 2012:351).

Este asesoramiento debería comenzar en los primeros niveles de la escuela primaria e ir acompañando a los usuarios en los sucesivos niveles, como la secundaria y la universidad y abarcar todo tipo de bibliotecas: especializadas, barriales, públicas, etc.

La pregunta que cualquier bibliotecario de referencia debería realizar, según Moyer, es la siguiente: «¿Prefieres el libro impreso, para escuchar o leer electrónicamente?» (ídem) y de ninguna manera se debería dar prioridad a uno u otro formato. Por supuesto, se puede indicar que determinada biblioteca es limitada en alguno de ellos, pero se podrían dar los datos de otras bibliotecas que sí posean determinado título en uno u otro formato.

Yendo un poco más allá en las preguntas de referencia también se debería recabar información sobre qué dispositivo tiene el usuario, a fin de ofrecer información ajustada a sus posibilidades. De no estar dotados con colecciones acordes a las que el usuario demanda debemos contar con la información para referirlos a determinadas páginas o plataformas que cumplan con los criterios de búsqueda, ahorrándoles tiempo y esfuerzo.

Moyer insiste que debemos aprender todo acerca de los lectores de libros electrónicos y sobre las editoriales; conocer los sitios que venden audiolibros y los editores que los ofrecen desde sus propias plataformas (ídem).

En biblioteconomía como en museología la popularización de los reproductores MP3 propició la aparición de la experiencia BYOD (bring your own device/trae tu propio dispositivo). Basándonos en experiencias relacionadas al mundo bibliotecario, en muchas ocasiones, resulta más fácil enseñarles a los usuarios teniendo delante sus propios dispositivos móviles, ya que, en ocasiones, la falta de destrezas en el manejo de ciertas aplicaciones puede disuadirlos de utilizar los servicios en línea de la biblioteca.

\subsection{EL ACCESO A LOS AUDIOLIBROS COMO UN DERECHO}

Keren Dali y Leah K. Brochu, profesionales del ámbito de la información y la documentación, dejan de lado las preferencias de los usuarios en relación con los formatos de lectura y ofrecen una mirada más amplia que tiene que ver con el acceso al audio como sinónimo de inclusión y equidad por parte de la comunidad a la que sirven las bibliotecas. En su artículo concluyen que «en el contexto de las bibliotecas, el acceso a la información y al entretenimiento a través de la escucha o de la audiolectura debe ser garantizado como un derecho» (Dali y Brochu, 2020:116).

Según estos especialistas, los argumentos que los bibliotecarios pueden utilizar como base para la promoción de la inclusión del formato audiolibros son de diversa índole y pueden variar teniendo en cuenta el contexto socioeconómico en el cual están insertas. En sus palabras, a través de su artículo instan a: 
Construir una línea convincente de promoción en apoyo de la integración de audiolibros en sus prácticas profesionales, colecciones, centros de recursos, programas, planes de estudios y actividades de divulgación. (Dali y Brochu, 2020:116)

Los autores promueven una visión en la que se les atribuya el mismo peso, importancia, respeto y consideración dentro del ámbito bibliotecario a todos los formatos en los que se puede encontrar un libro, de forma de convertir a las bibliotecas en entornos inclusivos, ya que relegar al audio a un segundo plano estaría promoviendo el privilegio de algunos grupos dentro de la comunidad. ¿A qué se refieren con privilegio? Los autores respaldan sus ideas en los trabajos realizados por la científica Peggy Mclntosh.

Para los autores existen una serie de privilegios que pueden beneficiar a un grupo de ciudadanos, sean estos conscientes o no de ello. Estos privilegios pueden ser desde condiciones sociales, pasando por situaciones económicas, hasta niveles educativos. Dali y Brochu organizan estos privilegios en seis categorías, a través de las cuales pueden observarse diversas situaciones en las que la posibilidad de la lectura impresa frente a la audiolectura podría entenderse como un factor de privilegio.

El documento que utilizan como base es la "Lista de verificación de privilegios» ${ }^{30}$ desarrollada por la Boise State University. En ella se enumeran una serie de ítems, organizados por grupos, entre los que se encuentran: privilegio de clase; raza blanca, etnia y privilegio cultural; privilegio de ciudadanía; privilegio cisgénero; privilegio de la sexualidad; privilegio masculino; privilegio de habilidad y privilegio lingüístico. En este cuestionario cada categoría está desglosada en preguntas discretas que ayudan a identificar la presencia o ausencia de cada privilegio.

Basándose en estas preguntas que les sirvieron como referencia y utilizando la definición de privilegio como "un derecho, inmunidad, o beneficio disfrutado solo por una persona más allá de las ventajas de la mayoría $)^{31}$, los autores operacionalizaron los privilegios centrándose en los siguientes seis ítems o categorías:

- El privilegio de la capacidad corporal;

- El privilegio del estilo de vida;

- El privilegio occidental;

- El privilegio de la alfabetización;

- Privilegiar el formato sobre la historia; y

- El privilegio de ciudadanía e idioma.

Para ofrecer más detalles y aclarar cada una de estas categorías ofrecemos una escueta descripción de cada ítem:

\section{El privilegio de la capacidad corporal}

\footnotetext{
${ }^{30} \mathrm{https} / / /$ sites.google.com/a/u.boisestate.edu/social-justice-training/about-us/our-training/privilege-checklist

31 «A right, immunity, or benefit enjoyed only by a person beyond the advantages of most» (Deli y Brochu, 2020:113).
} 
En este caso, los autores relacionan este privilegio con el de poseer buena vista y no tener ningún impedimento para leer impresos, o lo que ellos denominan en su artículo no poseer print disabilities (Dali y Brochu, 2020:113).

En virtud de esta condición, una persona podría elegir cualquiera de los medios que existen en el mercado para el ocio, y como hemos mencionado anteriormente en esta tesis, los audios son muy utilizados por lectores que tienen algún tipo de discapacidad, que puede ir desde algún tipo de problema de aprendizaje hasta discapacidades más serias.

Para los autores, estamos tan acostumbrados a ignorar y excluir a las personas con discapacidad en el diseño y desarrollo de nuestro entorno físico y social que les podemos llegar a negar la única forma de acceder a la lectura:

Rarely do we stop to consider what denying audioreading the status of legitimate and valuable reading does to readers for whom it is a primary means of engaging with the story. (ibídem, 114)

Dali y Brochu nos hablan del término autoeficacia, que según ellos es uno de los conceptos más importantes relacionados a la lectura, e introducen la siguiente cita textual para definirlo: «belief in one's own ability; this belief affects people's choices and actions because individuals tend to engage in tasks when they feel competent and confident, and avoid those in which they do not» (Clark y Rumbold, 2006, citado en Dali y Brochu, 2020:113).

A la luz de la anterior cita entendemos que cuanto más facilitemos el acceso a la lectura a las personas que tienen algún tipo de impedimento a través del audiolibro, más estaremos favoreciendo a que se sientan más seguros y, por consiguiente, estaremos promoviendo un uso más asiduo del formato.

Los autores concluyen que construir un compromiso con el audio "como acto de lectura» no es solo una distinción semántica; sería una forma de que las personas con alguna dificultad para leer formen parte de la definición de lectores y puedan autodefinirse como tales.

\section{El privilegio del estilo de vida}

En segundo lugar, encontramos los beneficios relacionados con un equilibrio entre la vida laboral y el ocio. La lectura implica la dedicación de un tiempo fuera de esa vida de trabajo y ajetreo diario. Y la situación de privilegio estaría relacionada a aquellas personas que poseen más flexibilidad laboral o una situación más acomodada, ya que encontrarán más fácilmente espacio para dedicarle a la lectura.

En este sentido los audiolibros, al permitir la multitarea, podrían llegar a un grupo de personas que por quehaceres laborales no encontrarían un momento oportuno para dedicarle a un libro impreso.

Para Dali y Brochu (2020:114) existe más de un privilegio bajo el paraguas del "estilo de vida". Es el privilegio que se relaciona con "una situación socioeconómica, antecedentes familiares, nivel de ingresos, nivel de educación, ciudadanía y muchos otros tipos de privilegios». 


\section{El privilegio occidental}

En tercer lugar, los autores sitúan al privilegio de los occidentales, o el beneficio del acceso y el disfrute de las comodidades de una «literate, technologically advanced, and comparatively democratic life» (ídem). Los autores citan a Tien, quien indica que la llamada por él «ansiedad por los audiolibros» puede remontarse a comienzo del período de la llustración, cuando Occidente hizo un cambio en el que privilegió la vista sobre los otros sentidos (Tien, 2020).

Para ampliar el espectro de lo que consideramos lectura, los autores citan un artículo editorial del año 2019 de la revista International Jounal of Information, Diversity and Inclusion en el que se habla de diferentes formas de lectura, y como ejemplo destacan una lectura que se realiza en Filipinas, que tiene que ver con la práctica de leer tatuajes.

\section{El privilegio de la alfabetización}

En cuarto lugar, y relacionado con el punto anterior se encuentra el privilegio de la alfabetización y el beneficio y derecho que tenemos los ciudadanos a una garantía educacional pública y a una red auxiliar de educación, formada por bibliotecas públicas y centros comunitarios.

Dali y Brochu (2020:114) señalan que, incluso en las sociedades occidentales, este privilegio no se distribuye equitativamente, ya que, así como sucede en situaciones de discapacidad, la pobreza y la falta de alfabetización pueden ser también un obstáculo para el acceso a la literatura, dejando excluidos a gran parte de adultos que no cuentan con un nivel básico de educación.

Además, en relación con la alfabetización, los audiolibros también pueden servir como herramientas para el aprendizaje, y un medio de automotivación de los lectores para adquirir o mejorar su nivel de educación.

\section{Privilegiar el formato sobre la historia}

Los autores sitúan en quinto lugar y relacionado con el concepto de la alfabetización, así como con el privilegio occidental, el de privilegiar el formato sobre la historia, que deriva de las conexiones que tienen las sociedades occidentales con la llustración, el nivel de educación y los medios impresos (ibídem, 115).

Este es un tema ya tocado con anterioridad, el de la romantización de la palabra impresa sobre la hablada. 


\section{Privilegio de ciudadanía e idioma}

Según los autores, este es un tema menos discutido y tiene que ver con el privilegio de la ciudadanía y el idioma; o, dicho de otro modo, el beneficio y el derecho de acceder a la información en la lengua materna y de poder hacerlo a través de diferentes formatos (impresos, electrónicos o audio).

Otro aspecto que los escritores mencionan es el de vivir en el país de origen, habiendo aprendido la lengua materna de ese mismo país, lo cual supone un acceso más fácil a fuentes y opciones de ocio y entretenimiento, lo cual supone un privilegio comparado con la vida de los migrantes, quienes pueden perder el privilegio de hablar en su idioma materno en la mayoría de las interacciones sociales (ibídem, 115). 


\subsection{EL NACIMIENTO DE LOS AUDIOLIBROS Y LAS BIBLIOTECAS}

Para entender la relación de los audiolibros con sus predecesores, los libros impresos, hay que entender que solo existen porque un grupo de gente no tenía acceso a los libros al comienzo del siglo 20 (Rubery, 2016:60). Los primeros en beneficiarse de esta migración de formato, del impreso al audio, fueron las personas con discapacidad visual.

La invención de Edison, como ya hemos tratado en esta tesis, supuso una oportunidad para brindar a la gente con alguna discapacidad la posibilidad de acceder al contenido de un libro, y fue en Estados Unidos, país donde se realizaron las innovaciones en torno a las tecnologías sonoras, el lugar en el cual las primeras bibliotecas comenzaron a formar sus colecciones para servir a los colectivos menos representados.

Los libros en braille costaban alrededor de veinte veces más que los tradicionales - lo cual era disuasorio para los discapacitados visuales, pero también una barrera para los encargados de las adquisiciones de las bibliotecas-; además, no todos los discapacitados visuales habían aprendido a leer con este sistema de escritura. Para estos últimos, la única otra opción era solicitar a otra persona que les leyera en voz alta (ibídem, 61). Más allá del gran costo que suponía la producción completa de un libro hablado, Edward Peterson, presidente de la American Library Association Committee on Work With the Blind, afirmaba en el American Library Association Bulletin de la época, que este era similar al costo de producción de un libro en braille (Peterson, 1934:244).

Si bien Peterson se ocupaba de estudios relacionados con las colecciones para ciegos, vislumbraba una gran posibilidad en los servicios de extensión para las bibliotecas, ampliando su rango de usuarios más allá de los discapacitados visuales, a otras personas que podían sufrir impedimentos en el desarrollo de sus capacidades lectoras o a quienes hubiesen quedado fuera de una educación formal o informal (ibídem, 245).

La Biblioteca del Congreso de Estados Unidos tuvo un papel protagónico para este fin impulsando el proyecto Books for the Adult Blind Projects y por otro lado la American Foundation for the Blind decidió crear un estudio para resolver los temas técnicos para poder encontrar la mejor tecnología para la creación, mantenimiento y difusión de las grabaciones.

Los libros eran grabados en discos analógicos de fonógrafos de 12 pulgadas de diámetro. Podían almacenar unos 15 minutos de grabación por lado, permitiendo grabar una novela promedio en 20 discos, aproximadamente. La Biblioteca del Congreso se ocupó de enviar por correo postal, en octubre de 1934 , un set con varias obras (algunas patrióticas, religiosas y literarias) a los usuarios con discapacidades visuales (Rubery, 2016:66). 


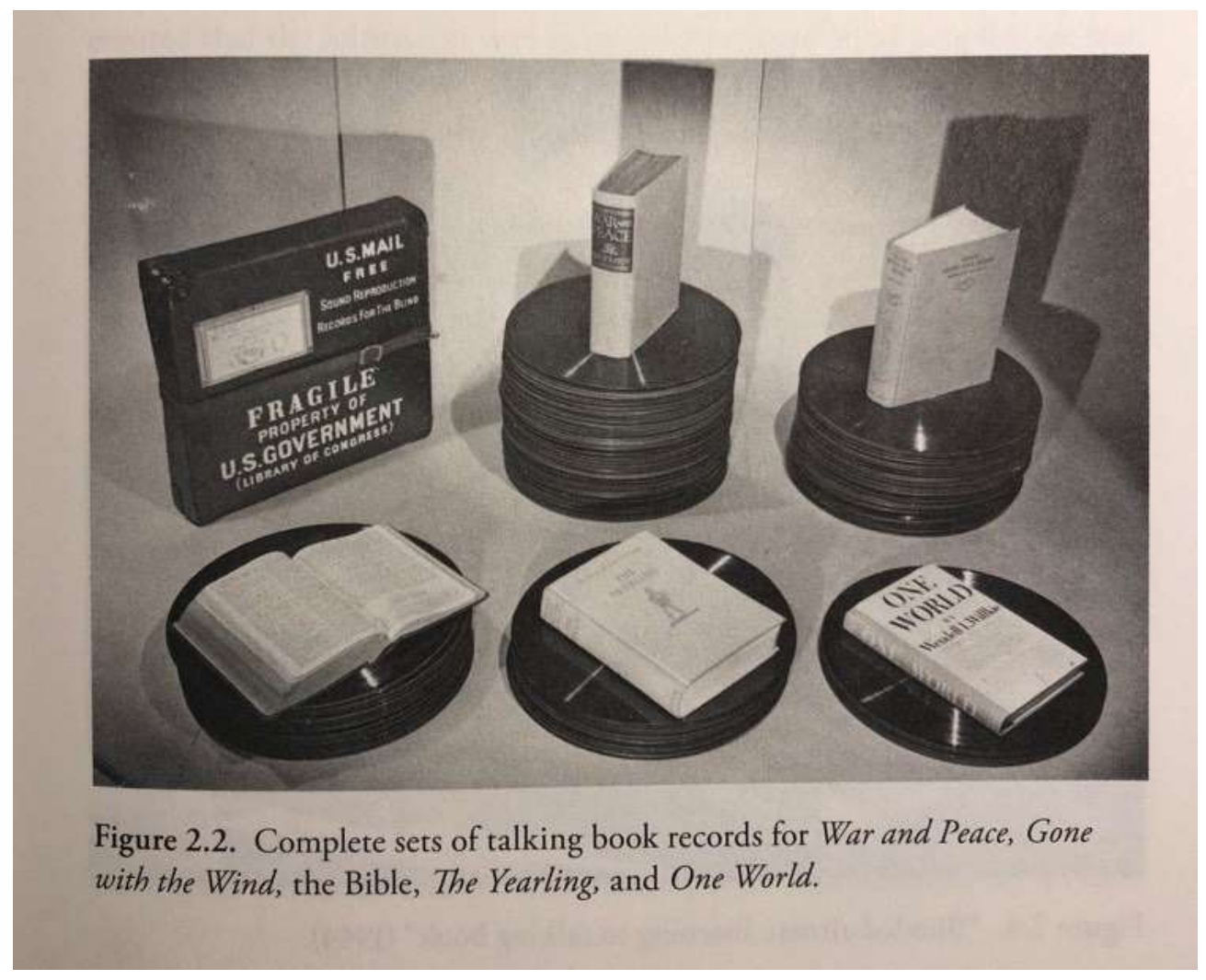

Ilustración 17. Set de audiolibros enviados por la Library of Congress

Fuente: Rubery, 2016

La dualidad braille-grabación sonora no estuvo exenta de polémicas ya en aquella época. Quienes consideraban que era una actividad pasiva, poco demandante y lejana a un desafío intelectual se enfrentaban a aquellos que resaltaban las ventajas y el potencial que presentaba a los usuarios el nuevo formato de lectura.

Otro factor a tener en cuenta es el económico. Mientras el catálogo de libros sonoros iba aumentando, el sector privado vio allí una amenaza a sus ingresos, por lo cual solicitó que solo se realizaran grabaciones de libros cuya publicación fuese anterior al año 1880, ya que, si bien esta colección estaba dirigida a los discapacitados visuales, entendían que también podían ser utilizados por el resto de los usuarios y creaba ciertas suspicacias ya que intuían en ello una amenaza para su negocio (Rubery, 2016:72).

Cómo proteger los intereses de los propietarios de los derechos de copyright fue el objeto de negociaciones que duraron años y que vieron un primer acuerdo en el año 1934. El acuerdo rezaba que, debían abonar 25 dólares por cada título para proteger el copyright, se podían realizar como máximo 300 copias por título; estas debían tener una etiqueta con el texto: "Solamente para el uso de los ciegos»; tampoco podrían ser vendidos a personas videntes, ni ser reproducidos en eventos públicos ni en la radio (AFB; s/f).

Estos acuerdos, originariamente pautados para por un año, fueron renovados con cambios menores hasta el año 1972. 


\subsection{DESARROLLO DE COLECCIONES PARA CIEGOS EN ESPAÑA}

En España, la creación de la Organización Nacional de Ciegos, por decreto del 13 de diciembre de 1938, posibilita la unificación de todas las asociaciones y entidades de diversa naturaleza que se ocupaban de los temas relacionados con la ceguera. Asimismo, se ocupaba de todos los recursos disponibles para la producción de bibliografía para discapacitados visuales.

Se crea la llamada «Imprenta Nacional Braille» en Madrid y, poco más tarde, en 1944, la «Imprenta Braille de Barcelona», que coexistió con la de La Caixa hasta 1985, año en la que cede sus fondos a la ONCE y deja de funcionar. La producción estaba enfocada en un principio en la educación, y poco a poco comenzaron a incluir otros géneros, como la literatura y prensa (Martín García, 2006:66).

En la década del sesenta, y siguiendo los pasos a modelos como el de Estados Unidos, se puso en funcionamiento el denominado "Servicio de Libro Hablado», dando comienzo a la producción de libros sonoros. Paralelamente se crea la «Biblioteca Central Braille», que fusiona tres bibliotecas existentes en Madrid, y se va formando una red nacional de bibliotecas para ciegos.

Con relación a los libros para discapacitados visuales, la tecnología más utilizada son los libros en formato DAISY. DAISY es un formato que nació en la Biblioteca Nacional de Suecia en el año 1988, producto de una investigación sobre alternativas a los casetes audio para ciegos, ya que estos presentaban el problema de una baja usabilidad (Ribera y Moese, 2008:404).

El desafío era crear un libro hablado que fuera más allá de las ya conocidas ventajas del audio digital, y que ofreciera la ventaja de poder moverse dentro de un libro con la misma rapidez y facilidad con que lo hacen las personas videntes (Martín García, 2006:71).

Consultando la propia página de la ONCE, se indica que los libros DAISY son libros en formato MP3, y que la diferencia con un audiolibro en MP3 es que al audio se le agregan otros archivos que permiten su navegación y que definen su estructura.

En Francia y España, Braillenet y la ONCE, respectivamente, lo han adoptado como base para su colección de libros para personas ciegas. La ONCE trabaja con narradores profesionales para ofrecerles una mejor calidad a sus audios (Ribera y Moese, 2008:406). La globalización del uso del formato es otra de las bazas, y ya es utilizado por organizaciones y bibliotecas para ciegos de los cinco continentes. La experiencia en su uso, el abaratamiento de las nuevas tecnologías y las habilidades de los usuarios favorecen el crecimiento tanto del acervo bibliotecario como de su uso.

En octubre de 2019 la ONCE anunció que ponía a disposición de 285 millones de personas ciegas del mundo su biblioteca digital, compuesta por 64.000 obras - de las cuales 27.000 se encuentran en formato DAISY, 27.000 en braille y más de 3.000 son partituras-, la mayor colección de textos en lengua castellana.

A través de una página web, la organización española permitirá a usuarios de todo el mundo acceder a esta información cumpliendo una serie de requisitos marcados por el tratado de Marrakech y por la Organización Mundial de la Propiedad Intelectual (OMPI). 
Para la literatura en español, en palabras de García Montero, director del Instituto Cervantes, lo que pretende este avance es «democratizar la cultura, facilitando su acceso a todas las personas ciegas o con discapacidad visual de cualquier rincón del mundo, y desde el respeto más absoluto a los derechos de autor». El director del Cervantes ha asegurado también que «este tratado multiplicará por 100 las posibilidades de universalización del trabajo del Instituto, basado en la difusión de la lengua castellana, del idioma español y de nuestra cultura» (La Vanguardia, 2019).

\subsection{LAS COLECCIONES EN AUDIO DE LA BIBLIOTECA NACIONAL ESPAÑOLA}

La colección de grabaciones sonoras que conserva la BNE, está compuesta tanto por grabaciones musicales (la mayor parte de la colección), como por grabaciones que registran la palabra hablada, las cuales conforman el «Archivo de la Palabra». Como el resto de las colecciones que conserva la biblioteca, esta colección refleja los diferentes soportes en los cuales la palabra fue grabada y almacenada.

Cronológicamente, encontramos los primeros discos de Aristón, cilindros de cera o rollos de pianola, y, por último, los CD, MP3 y MP4. El mencionado Archivo de la Palabra es el que custodia todo lo relacionado a archivo sonoro, tanto musical como no musical. Este archivo se articula en ramas: a) archivo de la palabra comercial, b) grabaciones sonoras no comerciales y c) la voz en la BNE (López Lorenzo, 2014:52).

\subsubsection{Soportes}

a) Archivo de la palabra comercial

A lo largo del tiempo, tanto los formatos como los sistemas de reproducción de sonido han ido evolucionando y los usuarios finales han ido reemplazando con los más actuales a sus predecesores; sin embargo, la BNE conserva el recorrido completo de los archivos sonoros en una interesante colección documental que sirve como testimonio del recorrido del audio y sus diferentes manifestaciones en España.

Este recorrido comienza con los sistemas tradicionales analógicos (cilindros de cera, discos de pizarra, discos de vinilo, soportes magnéticos, hilo magnético, cintas magnetofónicas, primero en carrete abierto, luego dentro de un casete) hasta llegar a las grabaciones digitales actuales (discos compactos, minidisco, cintas DAT8, MP3, etc.).

\section{- Los cilindros}

El contenido de los cilindros es principalmente humorístico y de enseñanza de idiomas. En el año 2009, la BNE adquirió por compra 25 cilindros sonoros de un curso de español dirigido a hablantes de lengua inglesa, realizado en el año 1905 y editado por Edison. 
Solo se conserva una grabación de contenido literario, el poema iPatria!, recitado por su autor Blanco-Belmonte.

\section{- Discos de pizarra}

La BNE recibió una donación de 24 discos de pizarra, y a esta colección inaugural se le sumará la donación de tres discos de pizarra que en 1958 realizó la "Casa Odeón- La voz de su amo», con las voces de Alfonso XIII y Miguel Primo de Rivera. Estas grabaciones representan una parte muy significativa de la producción nacional española desde 1924 hasta 1957, conservadas gracias a las disposiciones del Depósito Legal de 1938 y Orden Ministerial de 1942, que se refieren a la propiedad intelectual de obras fonográficas. El Decreto de 13 de octubre de 1938 determinó la entrega, por parte del productor, de dos ejemplares de todas las «obras musicales y piezas de gramófono" con destino a la Biblioteca Nacional y al Conservatorio Nacional de Música de Madrid (López Lorenzo, 2014:53).

La colección abarca todos los temas de sonido no musical o hablado que fueron editados por las compañías más importantes de España: la compañía del Gramófono Odeón, Columbia, Philips, además de otros que incluyen voces relevantes de diversas áreas: literarias, científicas, políticas, así como recitales poéticos y humorísticos, cuentos, obras históricas, etc. (ibídem, 54).

\section{- Discos de Vinilo}

Según López Lorenzo (ídem) el ingreso en la BNE de los discos de vinilo tiene su germen con la Ley de Depósito Legal de 1958. Al repertorio de los discos de pizarra: cuentos, enseñanza de idioma y humor, entre otros, aparecen otras grabaciones de cantes y recitales de folclore popular, adaptaciones de obras literarias, discursos de jefes de estado (de Franco o Churchill) o encíclicas de papas.

En este soporte también comienzan a grabarse representaciones teatrales con las voces de actores de la talla de Fernando Fernán Gómez y Agustín González, entre otros.

En relación con las obras de literatura, también se graban obras de prestigiosos escritores como Federico García Lorca, Calderón de la Barca, Cervantes, Shakespeare y muchos otros. A estos textos le ponen voz personas relacionadas al mundo del espectáculo como Nuria Espert, Aurora Bautista, Jaime Blanch, y Luis Varela, entre otros (ibídem, 55).

El Departamento de Música y Audiovisuales de la BNE, ha iniciado una política activa de adquisición de grabaciones con las voces de los autores más importantes de la lengua española, comprendiendo así la importancia documental de estas grabaciones.

Los soportes magnéticos suponen otro salto cualitativo, representado por el carrete de hilo magnético y las cintas del mismo material, representadas por la cinta abierta y la casete (ídem). 


\section{- Los carretes de hilo magnéticos}

La colección está dotada de invaluables documentos políticos: canciones populares de los bandos republicano y nacional, y discursos político militares como el llamamiento a la lucha de Dolores Ibárruri La Pasionaria, así como un sermón del Cardenal Segura en la Catedral de Sevilla en 1950, o el discurso en mayo de 1937 de Lluís Companys, dirigente de la Esquerra Republicana de Catalunya y presidente de la Generalidad de Cataluña desde 1934 y durante la Guerra Civil Española (ídem).

Los nuevos soportes que se suman a las colecciones sonoras y a los discos de vinilo y luego a los CD son las cintas magnéticas, que son las cintas abiertas y los casetes. En ambos soportes se comenzó a grabar en 1973 el Archivo de la palabra institucional, hasta su sustitución por las cintas Dat en 1995. López Lorenzo destaca que en este soporte se encuentran las 16 cintas abiertas que llegaron por donativo de las entrevistas que se le hicieron a Jorge Luis Borges en Argentina, y que además en este momento que ya se encuentran digitalizadas (ibídem, 56). López Lorenzo (ídem) destaca la donación que recibió la Biblioteca Nacional procedente del Servicio de Publicaciones del Ministerio de Educación y Ciencia, que bajo la Serie «Archivo de la Palabra» editó 24 casetes en los años 60 con las voces originales de diversas personalidades de las letras, las ciencias y la política. Como ejemplo de ello destaca el discurso de Cela en su ingreso como académico a la Real Academia Española, el 26 de mayo de 1957.

\section{- Soportes digitales}

En los años 90 se introduce otra innovación tecnológica a través de las cintas DAT (Digital Audio Tape), que es una pequeña casete, pero grabada digitalmente.

Según López Lorenzo (2014:56) este tipo de soporte fue el más usado para la grabación de los actos culturales en la BNE, desde los años 1995 a 2005, y luego fue sustituido por grabaciones en DVD.

b) Grabaciones sonoras no comerciales: trabajos de campo.

A través de las donaciones la BNE ha conseguido interesantes documentos que tienen que ver con el patrimonio oral de la humanidad.

Un ejemplo de este tipo de grabación, difundido a través del gabinete de prensa de la $\mathrm{BNE}^{32}$ es el caso del donativo del archivo del etnomusicólogo argentino Ramón Pelinski, quien en 2012 entregó a la BNE sus estudios de investigación, un total de cien cintas magnetofónicas, realizados en el Ártico Central sobre música y tradiciones del pueblo Inuit. Tras la recepción de esta donación la biblioteca se ocupó de digitalizar esta colección el mismo año.

El 95 \% de la colección está compuesta por canciones rituales y personales. Son composiciones que tienen que ver con cuestiones de la vida cotidiana de hombres y de mujeres desde el punto de vista literario.

\footnotetext{
${ }^{32}$ http://www.bne.es/webdocs/Prensa/Noticias/2013/1004_DonacionRamonPelinski.pdf
} 
Este archivo sonoro y audiovisual tiene una gran importancia puesto que solo existen otros dos trabajos de campo sobre la música y la cultura inuit en el norte de Canadá: uno realizado en el año 1916 y otro en los años 30. El archivo de Ramón Pelinski es muy relevante en el mundo de la etnomusicología, y altamente valorado por todos los profesionales que se trabajan en entornos relacionados con la cultura inmaterial.

c) La voz de la BNE.

Por último, en el año 1973, la BNE comienza a formar una base de datos con su propia memoria oral. El inicio de este archivo es el resultado de la política cultural de D. Hipólito Escolar y D. Manuel Carrión, directores de la BNE en los años 70, que impulsaron la grabación de los actos y su posterior conservación (López Lorenzo, 2014:57).

El abanico de eventos realizados en la BNE y custodiados en soportes sonoros es muy grande, y abarca recitales de poesía, homenajes, y diversos ciclos literarios.

\subsubsection{Procesos técnicos}

Los procesos técnicos llevados a cabo para el material sonoro utilizan, como en el resto de los procesos, normas internacionales.

Como indica López Lorenzo (López Lorenzo, 2014:58) la tarea de procesos técnicos es distinta en el caso de las grabaciones comerciales y no comerciales, ya que, en las primeras, tanto las cubiertas como la propia etiqueta del disco proporcionan información relevante de puntos de acceso del propio material mientras que, en el caso de las segundas, es necesario escuchar toda la grabación para establecerlos.

En cuanto a las signaturas, se organizan en primer lugar en función del soporte de registros sonoros, y en el caso de las no publicadas comercialmente, las grabaciones de campo llevan la signatura de los archivos personales - bajo el nombre del investigador que realizó la donación-, y se relacionan con la base de datos de archivos personales; en cambio, el Archivo de la Palabra de la institución está agrupado bajo una misma signatura para que todas formen parte del mismo conjunto de material.

\subsubsection{Difusión}

La difusión del archivo sonoro se realiza a través de la propia web de la BNE, que da acceso al registro bibliográfico y signatura de la colección a través de la web de la BNE.

Para consultar personalmente los materiales, es necesario dirigirse personalmente a la Sala Barbieri del Departamento de Música y Audiovisuales de la BNE, teniendo en cuenta que solo se reproducen aquellos documentos solicitados para investigación y estudio. La BNE garantiza el cuidado en aplicar las normas de reproducción que protegen los derechos del autor y/o del productor fonográfico. 
En la propia página de la BNE podemos ver las distintas colecciones a las que dan acceso, y situada en segundo lugar de esta tabla encontramos al "Archivo de la palabra», y en la misma ilustración, pero un poco más abajo encontramos la portada de «Grabaciones sonoras». Dentro de esta última categoría se encuentran 60.000 documentos en diversos soportes, ingresados tanto por compra, donativo o Depósito Legal y que incluyen documentos musicales.

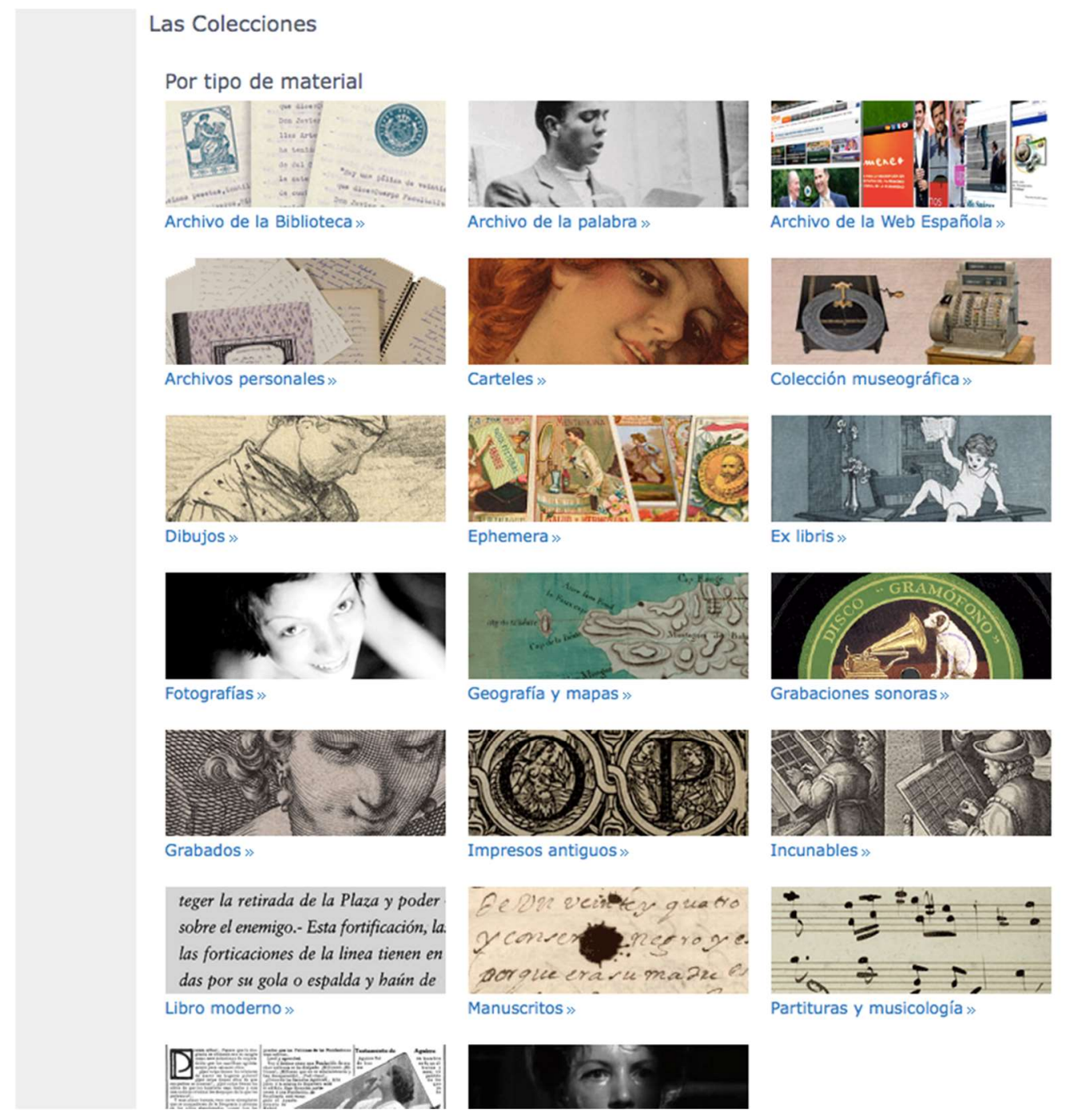

Ilustración 18. Colecciones de la Biblioteca Nacional Fuente: Página web de la Biblioteca Nacional de España

El Archivo de la Palabra se divide en dos subcolecciones: las grabaciones de voces y los actos culturales de la Biblioteca. 


\section{Archivo de la Palabra}

Escuchar

El Archivo de la Palabra contiene los documentos que registran las voces del pasado y del presente de personalidades destacadas (políticos, científicos, artistas y literatos), así como conferencias, recitales, cursos de idiomas, cuentos, etc.

Leer +

\section{Subcolecciones}

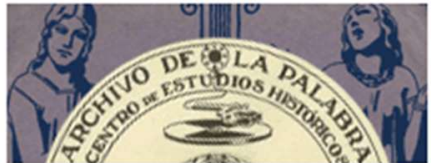

Grabaciones de voces »

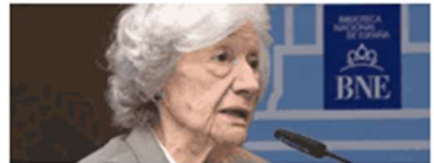

Actos culturales de la Biblioteca»

Ilustración 19. Captura de pantalla del Archivo de Palabra

Fuente: Página web de la Biblioteca Nacional de España

Dentro de la subcolección «Grabaciones de voces» encontramos 430 grabaciones sonoras no musicales, como se muestra en la siguiente imagen.

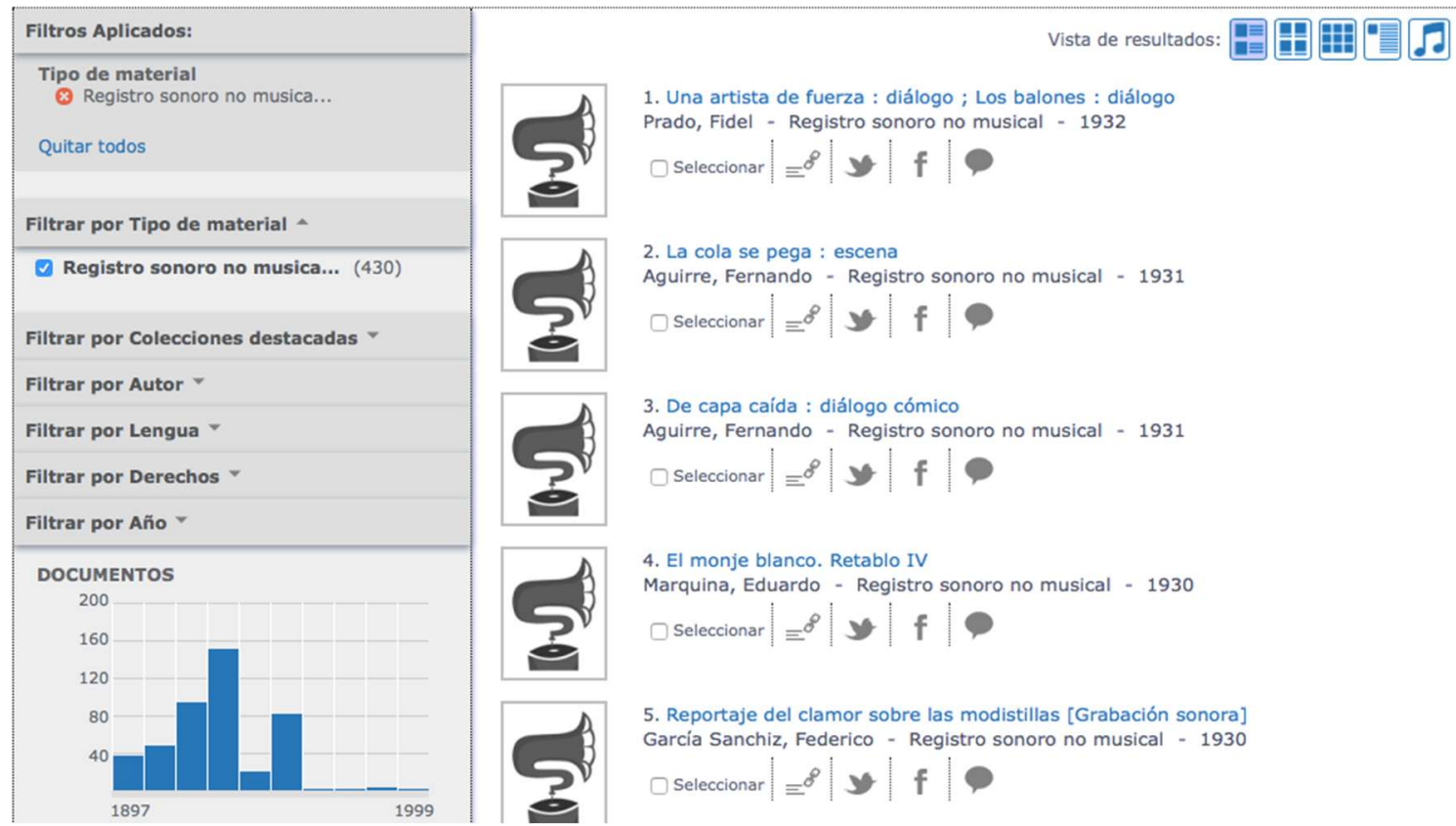

Ilustración 20. Grabaciones de voces de la BNE Fuente: Página web de la BNE

La subcolección «Actos culturales en la BNE» que desde el año 2006 se grababa en DVD, desde el año 201 es subida, en su gran mayoría, al canal de Youtube de la BNE. 
Además de ofrecer a través de su medio de difusión principal, la página web, toda la información y novedades sobre las colecciones, la BNE también hace difusión de sus contenidos a través de sus redes sociales, y aprovecha fechas específicas para difundir sus obras. Un ejemplo de esto es el homenaje que realizaron por el 150 aniversario del nacimiento de Unamuno para dirigir al interesado a un discurso del autor con la propia voz del escritor. 


\subsection{APLICACIONES PIONERAS}

La aceleración de la oferta y demanda de los audiolibros en los últimos años ha ido configurando un abanico de nuevas plataformas y aplicaciones que se suman a aquellos servicios que ya ofrecían libros electrónicos, e incluyeron este formato como parte de sus contenidos en línea.

La variedad de funciones de los teléfonos móviles, sumada a la conectividad y la digitalización de los contenidos propiciaron la llegada de proyectos a España como el de la empresa sueca Storytel, en el año 2017, que ya estaba teniendo éxito en diversos países.

Manrique Sabogal (2019:43) sitúa en el otoño-invierno de 2017-2018 lo que él denomina el «renacer del audiolibro entre los hispanohablantes», gracias a la empresa sueca Storytel. La razón es que la apuesta de esta empresa fue doble: invertir en el proceso de producción y en la postproducción. Allí radicó parte del futuro éxito en el mundo sonoro, el editar audiolibros con una alta calidad de sonido, con un variado catálogo y respetando los derechos de los autores.

El primer objetivo que se fijó la empresa Storytel fue la de realizar un relevamiento de los libros en español libres de derechos de autor. Tras ese relevamiento se puso en contacto con sus autores, agentes literarios o editores para informarse del interés de estos en formar parte de un proyecto audio. Así le pusieron voz, entre otros a: También esto pasará, de Milena Busquets (ibídem, 44).

Storytel, así como otros grandes representantes del audio, le dieron voz a pequeños editores que no contaban con la infraestructura necesaria para saltar al audio, garantizándoles calidad en su producción y una consolidada presencia en el mercado.

Esta rápida implementación produjo un interés por parte de bibliotecas, agentes relacionados con el mundo del libro y usuarios particulares, que fueron iniciando sus propios proyectos. Poco a poco fueron desapareciendo las barreras que había en torno a los audiolibros, una vez que los mitos que subyacían pudieron desterrarse con la propia experiencia en la práctica de la audiolectura.

La primera plataforma en línea de distribución de aplicaciones fue la de AppleStore para iPhone en el año 2008, luego Android casi con un mes de diferencia inauguró la suya. De esta forma se abría un escaparate para miles de aplicaciones de menor o mayor calidad y con una variedad de precios, que irían configurando el actual ecosistema de las aplicaciones dedicadas a formatos sonoros.

Esta frenética producción de aplicaciones configuró en menos de cuatro años una situación totalmente diferente dentro del panorama editorial, por lo cual creemos necesario detenernos a analizar cuáles son las propuestas que podemos encontrar en línea relacionados con la lectura de audiolibros.

\subsection{PLATAFORMAS Y APLICACIONES QUE CONTIENEN AUDIOLIBROS EN ESPAÑOL}

El tercer objetivo de la tesis es el de efectuar un relevamiento de aplicaciones móviles y plataformas especializadas en audiolibros. 
Para obtener un panorama concreto de la situación actual de la oferta de audiolibros digitales, hemos considerado oportuno ejecutar un trabajo de campo a fin de realizar una comparativa en diferentes plataformas y aplicaciones de audiolectura de un título determinado. El resultado de este trabajo de campo nos arrojará una visión panóptica de la situación actual del formato en estudio.

Para ello se llevarán a cabo las siguientes acciones:

a. Revisión de la bibliografía

b. Relevamiento de plataformas de audiolectura

c. Recolección de información de las aplicaciones realizada desde el 20 de febrero de 2020 al 31 de diciembre de 2020 a partir de las siguientes variables:

- Título

- Duración

- Narrador

- Acento de la narración

- Dramatización

- Efectos de sonido

- Contenido

- Lanzamiento

- Editorial

- Enlace

- Tamaño del archivo

- ISBN

- Demo

- Precio

- Imagen

d. Análisis de resultados

\subsubsection{Revisión de la bibliografía}

Según Gómez Díaz et al. (2016:114), el mundo de la edición de los libros electrónicos y las aplicaciones dispone de sus propias fuentes, muchas veces desconocidas, pero que revisten gran interés para el conocimiento, la selección y análisis de este tipo de productos.

En el caso de la búsqueda de información acerca de aplicaciones relacionadas con audiolibros, la fuente principal fue la propia web de cada aplicación; el relevamiento de estas en congresos tanto presenciales como virtuales que versaban sobre el libro electrónico, la consulta de literatura gris y la consulta a especialistas en la materia. En cuanto a fuentes primarias de información, el entorno digital es tan cambiante y son tan escasos los artículos encontrados que rápidamente quedaban obsoletos. 
Producto de este cambiante entorno, algunas iniciativas registradas en el año 2018 por Cordón-García (2018:173), ya no siguen comercializando libros, como es el caso de Seebook, que en su propia página indica que la línea de audiolibros está desactivada.

También hemos consultado a la Federación de Gremios de Editores de España, solicitando un listado de editoriales especializadas en audiolibros; esta entidad ha remitido la consulta a los responsables de la Agencia del ISBN, quienes nos contestaron a través de un email que tampoco poseían dicha información.

La consulta a especialistas fue muy importante para recabar información actualizada, como es el caso del listado de editoriales especializadas en audio enviado por la escritora Valeria Marcon (Marcon, comunicación personal, 07/11/2020).

\subsubsection{Relevamiento de plataformas}

Se realizó un primer abordaje de sitios susceptibles de ser evaluados y encontramos que, dada la cantidad de resultados obtenidos y la heterogeneidad de los mismos, las plataformas y aplicaciones que susceptibles de ser incorporadas en nuestro estudio deberían contar con las siguientes características:

- Poseer una interfaz tanto en la plataforma web como en la aplicación en idioma españo ${ }^{33}$.

- Poseer contenidos respaldados por un sello editorial.

- Ofrecer la posibilidad de realizar la compra o suscripción desde su propia plataforma o aplicación ${ }^{34}$.

- Ofrecer la posibilidad de seleccionar audiolibros individualmente, aunque se trate de una suscripción. ${ }^{35}$

- Tamaño de la base de datos: aunque descartamos iniciativas que contienen muy pocos libros, no podemos fijar un criterio en base al tamaño de la colección, ya que como veremos en el relevamiento de plataformas, la mayoría de las mismas no informan qué cantidad de audiolibros poseen, ni a través de sus portales ni habiendo sido consultadas por email.

A fin de sistematizar la información encontrada, hemos confeccionado una tabla con los siguientes datos:

- Nombre de la plataforma

- Objetivo

- Posibilidad de descarga de la aplicación

- Fecha de inicio de proyecto

- Cantidad de audiolibros en español

\footnotetext{
${ }^{33}$ Por esta razón han quedado fuera de este trabajo sitios como: NookAudiobooks, Libro.Fm o Estories, que si bien tienen en su catálogo colecciones en internet a día de hoy no poseen versiones de sus aplicaciones en español.

${ }^{34}$ Quedan excluidas plataformas como Planeta de Libros o Me gusta leer que, si bien poseen audiolibros redirigen hacia otras plataformas ya incluidas en nuestro relevamiento.

${ }^{35}$ Bookchoice es un ejemplo de plataforma que ofrece actualizaciones mensuales de forma cerrada.
} 
Para la confección de la Tabla 3. Plataformas de audiolibros digitales con colecciones en español, que pueden encontrar a continuación, se han consultado, además de los buscadores más importantes de internet, tanto generales como especializados, tiendas asociadas a los sistemas operativos más importantes, como los sistemas operativos iOS y Android y sus respectivas tiendas Google Play y Apple Store. 
Tabla 3. Plataformas de audiolibros digitales con colecciones en español

\begin{tabular}{|c|c|c|c|c|}
\hline Plataforma & Objetivo & Descargar en & Inicio del proyecto & Audiolibros en español \\
\hline Apple Books & Distribución de contenido & Instalado por defecto en los dispositivos iOS & Estados Unidos, 2010 & $S / D^{36}$ \\
\hline Audible & Distribución y creación de contenidos & Apple Store y Google Play & Estados Unidos, 1995 & $S / D^{37}$ \\
\hline Audio-libros & Producción y distribución de audiolibros & $\begin{array}{l}\text { Descarga de archivo Zip o escucha streaming desde } \\
\text { página }\end{array}$ & $S / D$ & $200^{38}$ \\
\hline Audiolibros & Distribución de contenido & Apple Store y Google Play & $\begin{array}{l}\text { En 2012, Simply Audiobooks lanzó Audiobooks.com, ad- } \\
\text { quirida luego por Rbmedia. }\end{array}$ & $S / D^{39}$ \\
\hline Audiomol & $\begin{array}{l}\text { Producción, distribución y venta de au- } \\
\text { diolibros en español }\end{array}$ & Apple Store y Google Play & España, 2009 & $S / D^{40}$ \\
\hline Audioteka & Distribución de contenidos & Apple Store y Google Play & Polonia, 2008 & $S / D^{41}$ \\
\hline Beek & Distribución de contenidos & Apple Store y Google Play & México, 2019 & $S / D^{42}$ \\
\hline $\begin{array}{l}\text { Booka (web no opera- } \\
\text { tiva) }\end{array}$ & Editorial Booka Audiobooks & $\begin{array}{l}\text { Comercializa a través de Audible.com, Audio- } \\
\text { teka.es, Libromóvil.com, Storytel, Google Play e } \\
\text { Itunes. }\end{array}$ & España, 2014 & $S / D^{43}$ \\
\hline Fonolibro & Creación y distribución de contenidos & Apple Store & Estados Unidos, 2002 & Alrededor de $400^{44}$ \\
\hline Google Play Books & Distribución de contenido & Google Play y Apple Store & Estados Unidos, 2011 & $S / D^{45}$ \\
\hline
\end{tabular}

${ }^{36}$ El servicio de atención al cliente de Apple Books nos contestó a través de un email que no podía brindarnos dicha información ya que los datos cambian «consecuentemente» (consistently). (03/02/2021). ${ }^{37}$ Hemos contactado con el servicio de atención al público de Audible, quienes nos contestaron que no tienen forma de averiguar el dato (email: 6/01/2021).

${ }^{38} \mathrm{El} 6$ noviembre de 2020 nos respondieron la cantidad de audiolibros que poseen en el catálogo en español.

${ }^{39} \mathrm{Hemos}$ contactado con la empresa, pero no hemos obtenido respuesta (email: 04/11/2020).

${ }^{40}$ Consulta enviada sin respuesta (email: 06/01/2021).

${ }^{41}$ Email enviado el 06/01/2021, sin respuesta.

${ }^{42}$ Enviada consulta, sin respuesta.

${ }^{43}$ Enviada la consulta desde el formulario de consultas de su página web en construcción.

${ }^{44}$ Dato aportado por la empresa, el 14/01/2021, por email.

${ }^{45}$ Se envió un email a Google Play Libros, con respuesta el 5 de noviembre de 2020 indicándonos que no podían brindarnos dicha información. 


\begin{tabular}{|c|c|c|c|c|}
\hline Plataforma & Objetivo & Descargar en & Inicio del proyecto & Audiolibros en español \\
\hline Kobo & Distribución de contenido & $\begin{array}{l}\text { Comercializa a través de Audible.com, Audio- } \\
\text { teka.es, Libromóvil.com, Storytel, Google Play e } \\
\text { Itunes. }\end{array}$ & $\begin{array}{l}\text { Fundada en } 2009 \text { en Canadá como Shortcovers, renom- } \\
\text { brada } 10 \text { meses después como Kobo Inc. }\end{array}$ & S/D \\
\hline Leamos & $\begin{array}{l}\text { Distribución, (no se especifica si también } \\
\text { crean audiolibros) }\end{array}$ & Apple Store y Google Play & Argentina, [2017] & $S / D^{46}$ \\
\hline Libro móvil & $\begin{array}{l}\text { No especifican si crean o solo distribuyen } \\
\text { audiolibros }\end{array}$ & Apple Store y Google Play & España, [2020] & $S / D^{47}$ \\
\hline Literatura sonora & Creación y distribución de contenido & Apple Store y Google Play & España, 2018 & 179 \\
\hline Podimo & Creación y distribución de contenidos & Apple Store y Google Play & Dinamarca, 2019 & $2000^{48}$ \\
\hline Scribd & Creación y distribución de contenidos & Apple Store y Google Play & $\begin{array}{l}\text { Estados Unidos, en } 2014 \text { incorpora audiolibros a su ser- } \\
\text { vicio de suscripción. }\end{array}$ & $S / D^{49}$ \\
\hline Sonolibro & Distribución y creación de contenido & Descarga de archivo MP3 desde página web & España, 2009. & Alrededor de $1000^{50}$ \\
\hline Storytel & Distribución y creación de contenidos & Apple Store y Google Play & Suecia (como Bokilur), 2005. & $S / D^{51}$ \\
\hline Ubook & Distribución y creación de contenidos & Apple Store y Google Play & Brasil, 2014 & $S / D^{52}$ \\
\hline
\end{tabular}

Fuente: Elaboración propia, con datos aportados por las empresas dedicadas a los audiolibros digitales

\footnotetext{
${ }^{46}$ Consulta enviada el 06/01/2021 (por email).

${ }^{47}$ Consulta enviada el 29/11/2020 (por email).

${ }^{48}$ Respuesta recibida el $11 / 02 / 2021$

${ }^{49} \mathrm{El}$ día 4 de noviembre de 2020 se envió un email con la consulta de la cifra aproximada de audiolibros, y el 21 de noviembre se recibió la respuesta con el mensaje de que no tenían forma de poder decir-

nos cuántos audiolibros poseen en su biblioteca.

${ }^{50}$ Respuesta enviada por la empresa el 04/02/2021.

${ }^{51} \mathrm{El} 7 / 01 / 2021$ recibimos la respuesta de que no pueden brindarnos la información solicitada ya que es confidencial.

${ }^{52}$ Enviada la pregunta el 06/01/2021, por email, sin respuesta.
} 


\subsubsection{Recogida de información en todas las plataformas}

7.2.3.1 Metodología

Para llevar a cabo nuestro objetivo de realizar una comparación de un título determinado en las diversas plataformas listadas en el punto anterior, y tras contemplar varias opciones, seleccionamos $\mathrm{El}$ ingenioso hidalgo don Quijote de la Mancha, de Miguel de Cervantes, que además de ser la obra cumbre de las letras españolas, podría ofrecernos información valiosa acerca de las diversas adaptaciones y narraciones.

Asimismo, al ser una obra extensa y dividida en dos partes ofrece un desafío extra a la hora de presentarla en audiolibro, y nos interesó saber de qué manera el sector editorial había trabajado con este título.

Como uno de los objetivos es ver cuáles son las versiones en audiolibro narradas palabra por palabra del Quijote, recopilamos todas las versiones en español bajo ese título, para luego analizar cuáles son las diferentes interpretaciones, motivo por el cual nos encontraremos con alguna adaptación para niños que también incluiremos en nuestro trabajo de campo, ya que consideramos de interés ver cuál es la proporción de libros para niños y para adultos que se ofrecen en el universo sonoro.

Una vez localizadas las diferentes plataformas y aplicaciones, proseguimos con nuestro propósito de realizar un relevamiento de audiolibros del Quijote en soporte digital.

Para esto ingresamos a cada una de las distribuidoras de audiolibros listadas en la Tabla 3. Plataformas de audiolibros digitales con colecciones en español teniendo en cuenta las versiones que ofrecían: a través de la propia web o utilizando la aplicación correspondiente (descargada en dispositivos iOS o Android).

Para abordar esta fase del trabajo de campo hemos realizado una serie de pasos que enumeramos a continuación:

1. En primer lugar, fue necesario escoger las palabras clave a introducir en el campo de búsqueda de cada plataforma.

Para realizar una búsqueda similar en cada una de las bases de datos debimos diseñar una sintaxis de búsqueda.

Al principio pensamos buscar tanto en el campo autor como en el campo título; sin embargo, muchas de las aplicaciones no contienen búsqueda avanzada y ofrecen solamente una casilla en la cual ingresar un término o el otro.

Como la obra de Miguel de Cervantes fue muy prolífica, no utilizaremos la búsqueda por autor, ya que la respuesta nos ofrecería muchos resultados. Optamos por buscar por título.

Como afirma Fundéu, aunque en la actualidad el Quijote se concibe como una obra unitaria, podemos encontrar el título por separado, y lo adecuado en este caso, para designar a la obra, según la Fundación, es emplear las formas contractas al y del: «La segunda parte del Quijote» (Fundéu, 20/04/2016). 
Recordemos que el Quijote de 1605 se titula El ingenioso hidalgo don Quijote de la Mancha, y el de 1615 El ingenioso caballero don Quijote de la Mancha.

Dado que el título elegido podía estar dividido en parte 1 y parte 2 , decidimos introducir en el campo título solo la palabra Quijote, sin artículos, para que nos recuperara tanto la obra compilada en un solo tomo, como aquellas que estaban divididas en primera y segunda parte.

No fueron necesarios los operadores booleanos ni posicionales, tampoco truncamientos ni comillas, ya que no utilizamos una frase. En relación con nuestra búsqueda, no existe la posibilidad de que existan variantes ortográficas de la palabra "Quijote», ya que buscamos audiolibros en idioma español.

Si la aplicación permitía buscar también por campo autor (en el caso de que presentara dicha opción dentro de «búsqueda avanzada») y los resultados obtenidos con la palabra Quijote resultaron muchos, introdujimos el primer apellido del escritor: «Cervantes»; $y$, si ofrecía filtros por idioma, restringimos la búsqueda a audiolibros en español.

En algunas ocasiones, la plataforma ofrecía, además de audiolibros digitales, ebooks, revistas u otros formatos. En este caso y si se ofrecía la posibilidad, restringimos la búsqueda a audiolibros, de otra forma habría sido necesario realizar la selección revisando uno por uno.

2. Diseñamos un modelo de ficha para volcar la información que obtuvimos en la observación de cada plataforma.

La información se tomó tal cual aparecía en la página web. Si alguna palabra aparecía en inglés o con errores se transcribía de la misma manera. Si no se encontraba la información se escribía en el campo: S/D (sin datos). El modelo de ficha es el que sigue a continuación:

\begin{tabular}{|l|l|}
\hline \multicolumn{2}{|c|}{ Resultado de la búsqueda del «Quijote» en: [Nombre de la plataforma] } \\
\multicolumn{1}{|l|}{ Ficha . $^{\circ}$ [x] } \\
\hline Título & \\
\hline Duración & \\
\hline Narrador & \\
\hline Acento de la narración & \\
\hline Dramatización & \\
\hline Efectos de sonido & \\
\hline Contenido & \\
\hline Lanzamiento & \\
\hline Editorial & \\
\hline Enlace & \\
\hline Tamaño del archivo & \\
\hline
\end{tabular}




\begin{tabular}{|l|l|}
\hline ISBN & \\
\hline Demo & \\
\hline Precio & \\
\hline Imagen & \\
\hline
\end{tabular}

3. Realizamos la búsqueda por cada una de las plataformas de la Tabla 3. Plataformas de audiolibros digitales con colecciones en español, de forma alfabética. Una primera recogida de información se realizó del 15 de febrero al 15 de abril de 2020. En esta fase se realiza un primer abordaje y se incluyen notas y observaciones de interés para el estudio.

4. Tras las fichas de cada plataforma o aplicación se incluyen unas líneas en las cuales se sintetizan los resultados y se agregan notas de interés.

5. Para completar y clarificar la información relevada se decide realizar dos listados:

a. Uno, sintetizando la totalidad de audiolibros digitales encontrados en todas las plataformas.

b. El segundo, con la oferta de diversas versiones del Quijote, por plataforma.

6. Dada la velocidad con la que se actualizan los datos en el sector audio realizamos una puesta al día de la información de las fichas del punto 2, desde el 1 al 31 de diciembre de 2020, y a fin de poseer un archivo documental que respalde el trabajo de investigación, guardamos cada uno de los archivos en formato PDF bajo el nombre de cada aplicación y que queda como soporte digital en los archivos de la investigadora.

La primera plataforma que aparece en el listado y que utilizamos como ejemplo es Apple Books. Por la gran cantidad de fichas que contienen algunas plataformas decidimos que el resto de las mismas figuren en el Anexo

\section{Apple Books. Información y fichas de audiolibros}

La búsqueda bibliográfica de audiolibros realizada tanto a través de Itunes como de Applicación Libros, diseñada por iOS para dispositivos móviles arrojó 34 resultados.

La plataforma no permite filtrar por idioma, ni en la versión web ni en la aplicación del teléfono, por lo cual algunos de los resultados que nos devolvió la interrogación corresponden a otros idiomas, y debimos seleccionar manualmente cuáles son los audiolibros de interés. 
A continuación, presentamos las fichas de los audiolibros del Quijote en español que ofrece esta primera plataforma estudiada y que en total suman 15 audiolibros:

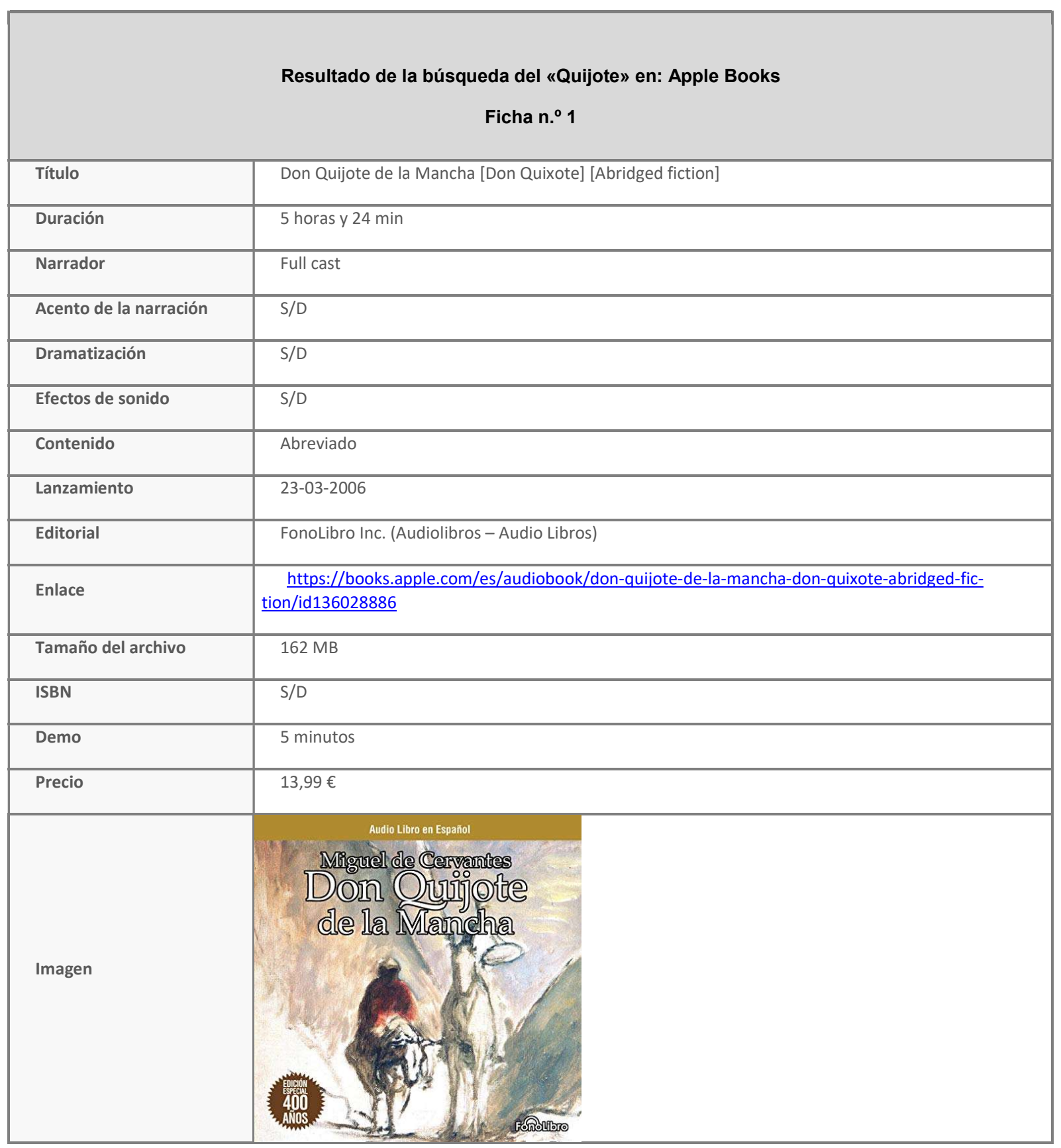




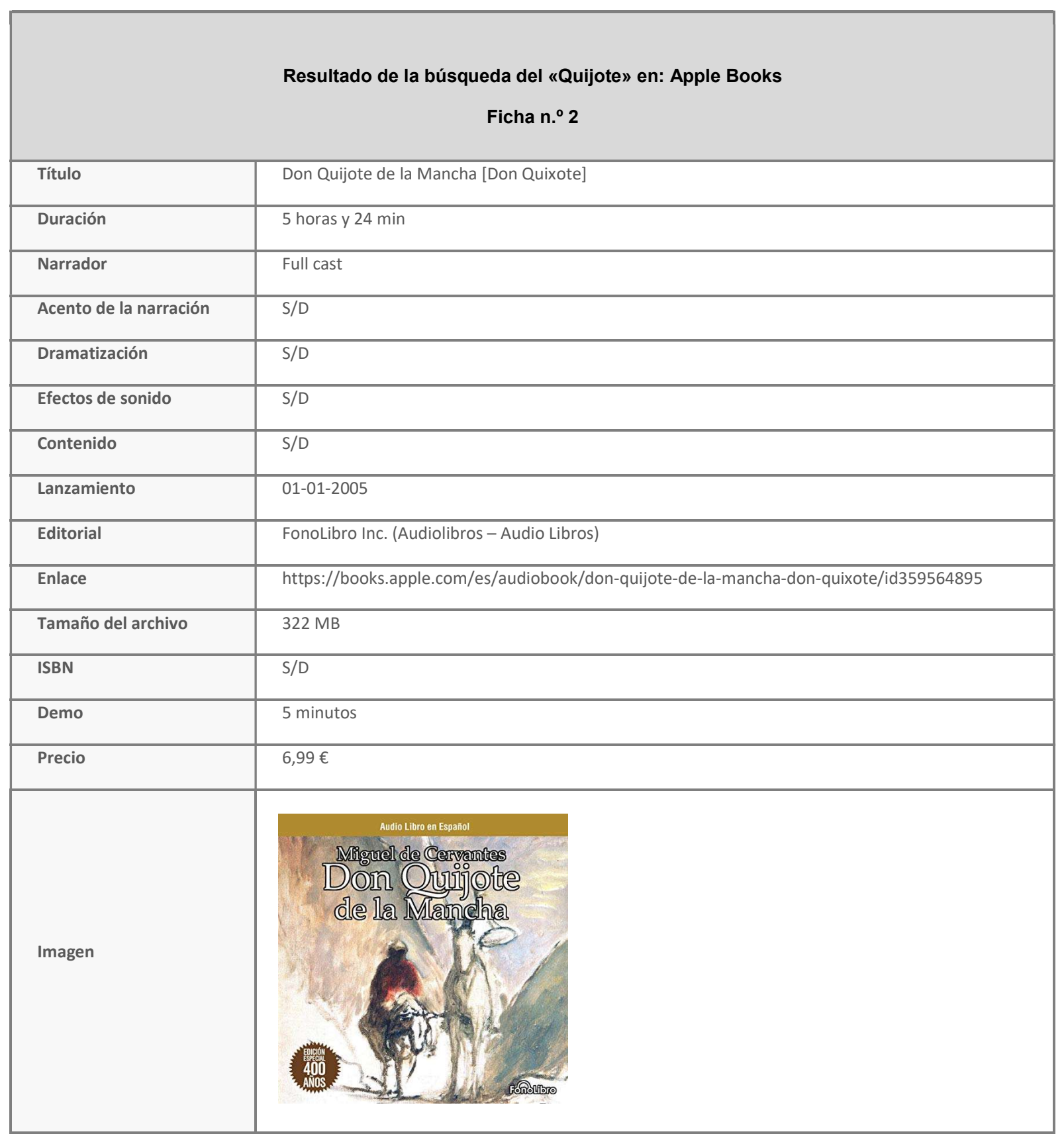

\begin{tabular}{|l|l|}
\hline \multicolumn{2}{|c|}{ Resultado de la búsqueda del «Quijote» en: Apple Books } \\
\multicolumn{2}{|l|}{ Ficha . $^{\circ}$ 3 } \\
\hline Título & Don Quijote de La Mancha (Colección Alfaguara Clásicos) \\
\hline Duración & 3 horas y 42 min \\
\hline Narrador & Raúl Llorens \\
\hline Acento de la narración & S/D \\
\hline
\end{tabular}




\begin{tabular}{|c|c|}
\hline Dramatización & S/D \\
\hline Efectos de sonido & S/D \\
\hline Contenido & Versión abreviada por José Luis Giménez-Frontín \\
\hline Lanzamiento & $22-03-2018$ \\
\hline Editorial & Penguin Random House Audio \\
\hline Enlace & $\begin{array}{l}\text { https://books.apple.com/es/audiobook/don-quijote-de-la-mancha-colección-alfaguara-clási- } \\
\underline{\cos / \text { id1443286154 }}\end{array}$ \\
\hline Tamaño del archivo & $182,6 \mathrm{MB}$ \\
\hline ISBN & $S / D$ \\
\hline Demo & 5 minutos \\
\hline Precio & $8,99 €$ \\
\hline . & MigUEL DE CERVANTES \\
\hline
\end{tabular}

\begin{tabular}{|l|l|}
\hline \multicolumn{2}{|l|}{ Resultado de la búsqueda del «Quijote» en: Apple Books } \\
\multicolumn{1}{|l|}{ Ficha . $^{\circ}$ 4 } \\
\hline Título & El Ingenioso Hidalgo Don Quijote de la Mancha [The Ingenious Don Quijote of la Mancha] \\
\hline Duración & 15 horas y 58 min \\
\hline Narrador & Varios authors \\
\hline Acento de la narración & S/D \\
\hline Dramatización & S/D \\
\hline Efectos de sonido & S/D \\
\hline Contenido & S/D \\
\hline Lanzamiento & $8 / 07 / 2006$ \\
\hline Editorial & Yoyo USA, Inc \\
\hline Enlace & https://books.apple.com/es/audiobook/ingenioso-hidalgo-don-quijote-la-mancha-ingenious- \\
\hline
\end{tabular}




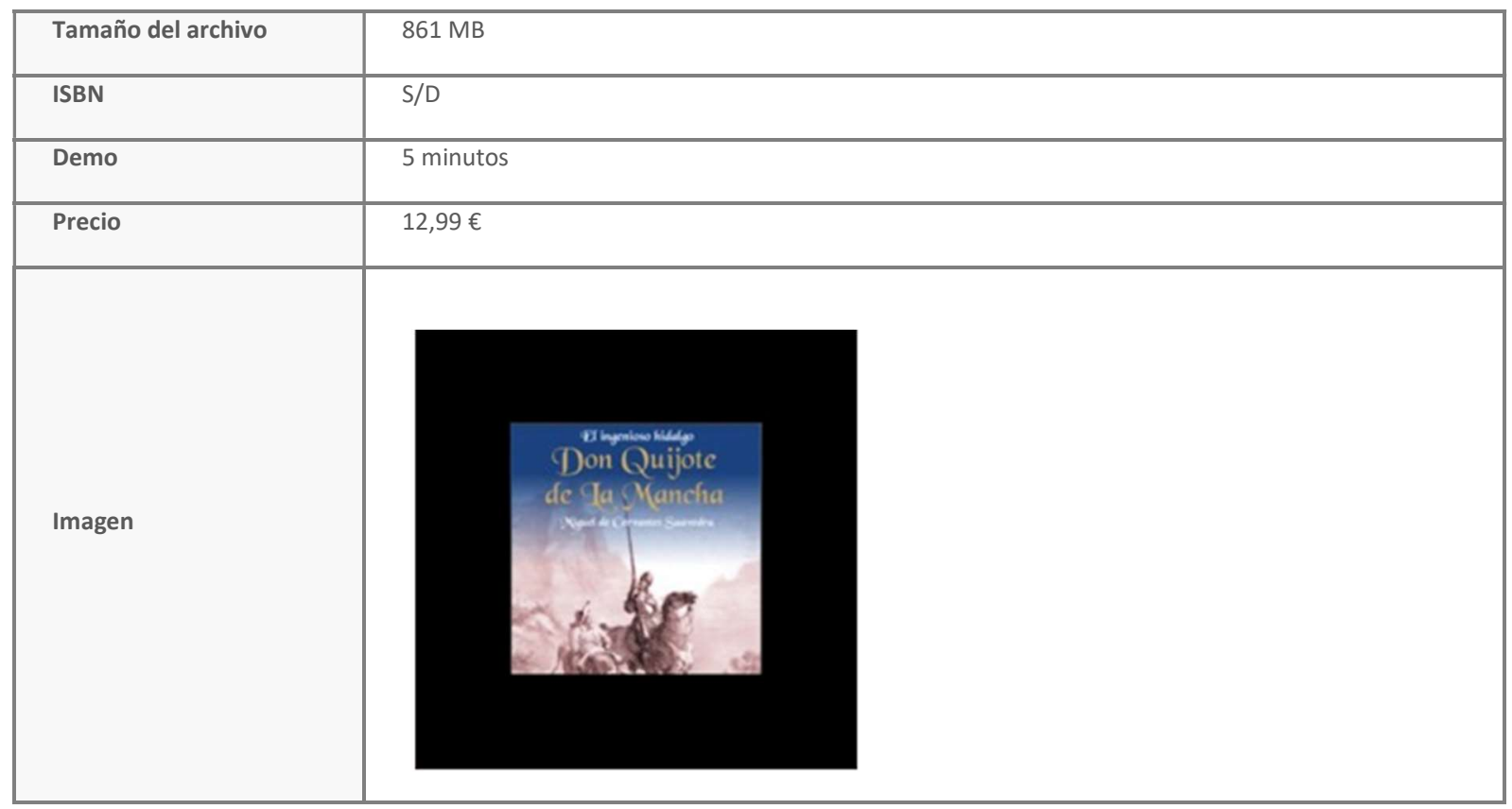

\begin{tabular}{|c|c|}
\hline \multicolumn{2}{|r|}{$\begin{array}{l}\text { Resultado de la búsqueda del «Quijote» en: Apple Books } \\
\qquad \text { Ficha } \text { n. }^{\circ} 5\end{array}$} \\
\hline Título & Don Quijote de la Mancha Tomo I [Don Quixote, Part I] (Unabridged) \\
\hline Duración & 21 horas y $27 \mathrm{~min}$ \\
\hline Narrador & Alejandro Magnone \\
\hline Acento de la narración & S/D \\
\hline Dramatización & S/D \\
\hline Efectos de sonido & S/D \\
\hline Contenido & Unabridged \\
\hline Lanzamiento & $1-01-2005$ \\
\hline Editorial & Emmanuel Michan \\
\hline Enlace & $\begin{array}{l}\text { https://books.apple.com/es/audiobook/don-quijote-de-la-mancha-tomo-i-don-quixote-part-i- } \\
\text { unabridged/id361130675 }\end{array}$ \\
\hline Tamaño del archivo & $952,8 \mathrm{MB}$ \\
\hline ISBN & S/D \\
\hline Demo & 5 minutos \\
\hline Precio & $5,99 €$ \\
\hline Imagen & \\
\hline
\end{tabular}




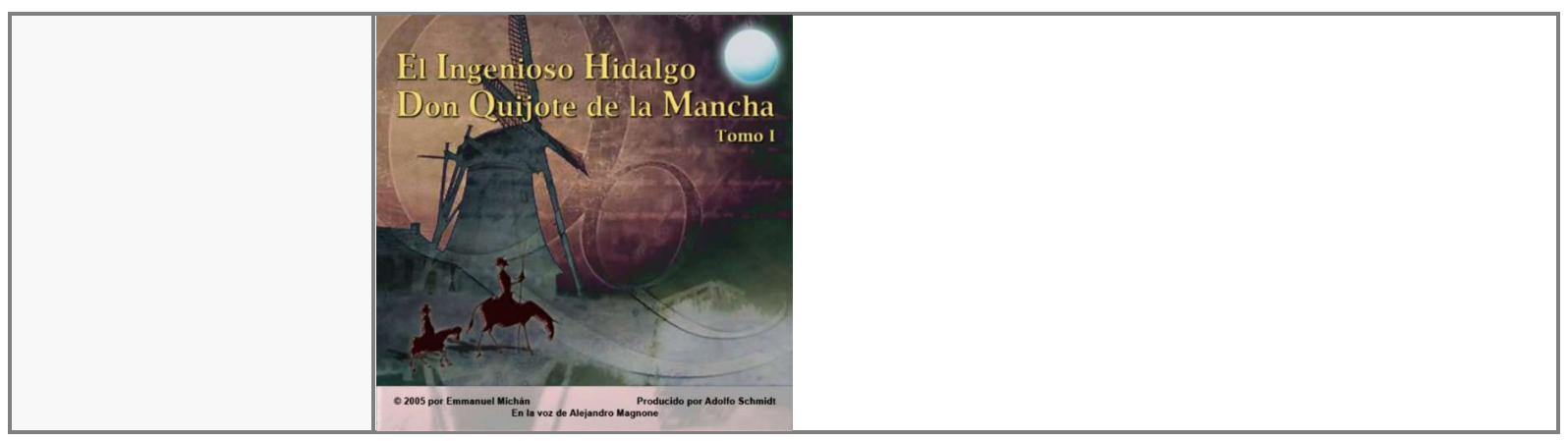

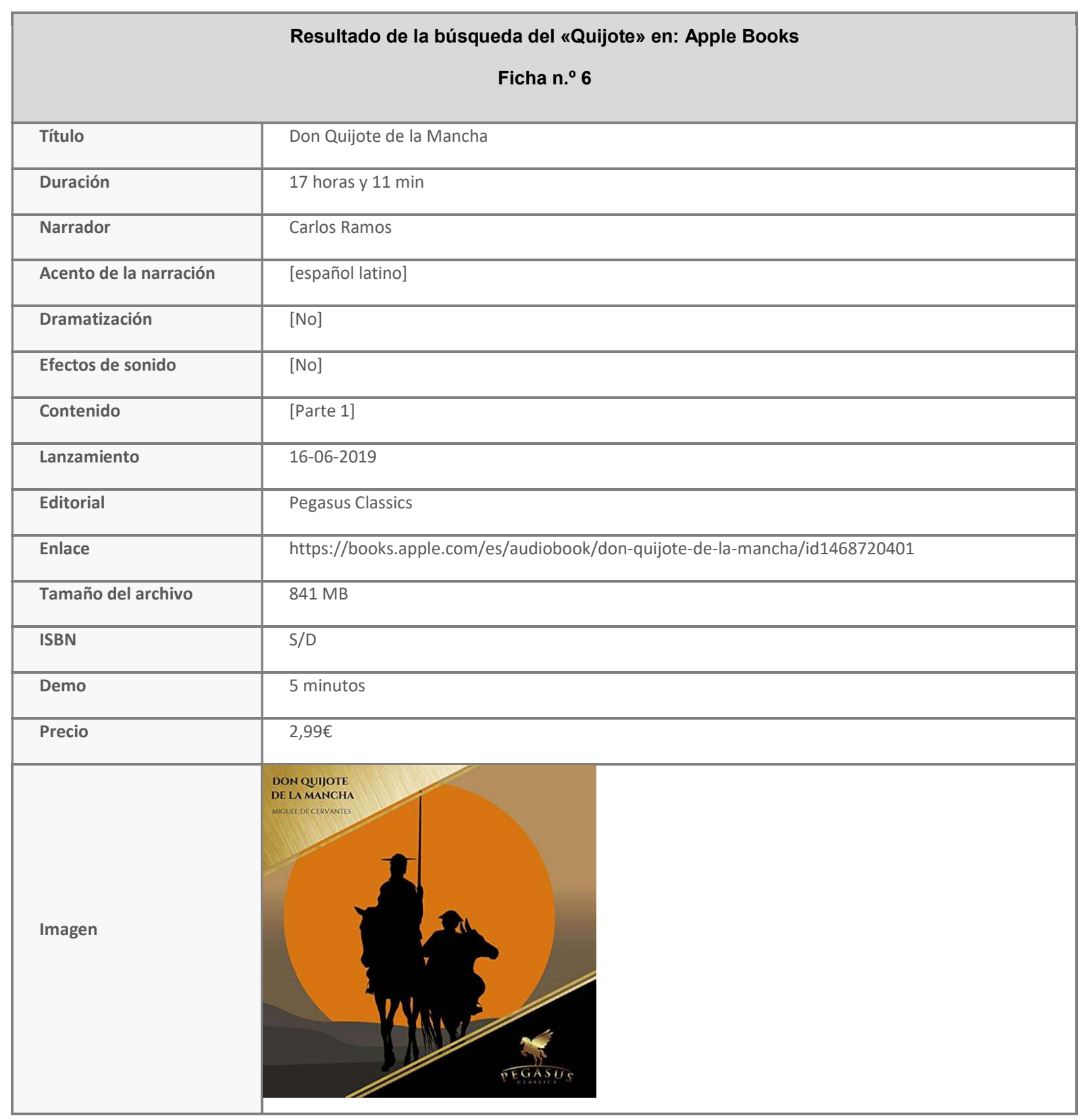




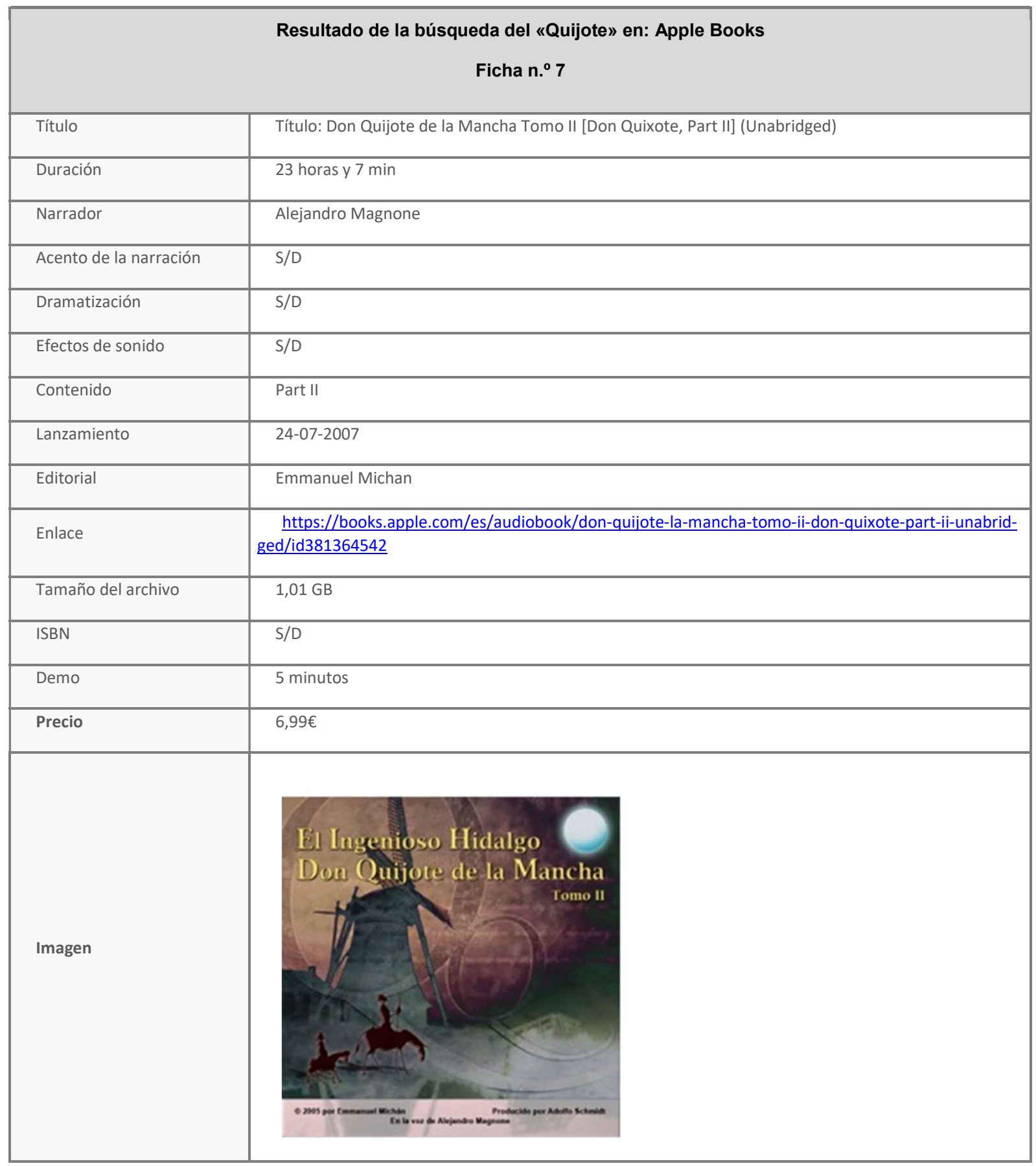

\begin{tabular}{|l|l|}
\hline \multicolumn{2}{|l|}{ Resultado de la búsqueda del «Quijote» en: Apple Books } \\
Ficha $\mathbf{n} .^{\circ} \mathbf{8}$ \\
\hline Título & $\begin{array}{c}\text { El Ingenioso Hidalgo Don Quijote de la Mancha [The Ingenious Don Quijote of la Mancha] [Abridged } \\
\text { fiction] [Abridged Fiction] }\end{array}$ \\
\hline Duración & 15 horas y 58 min \\
\hline Narrador & Various Authors \\
\hline
\end{tabular}




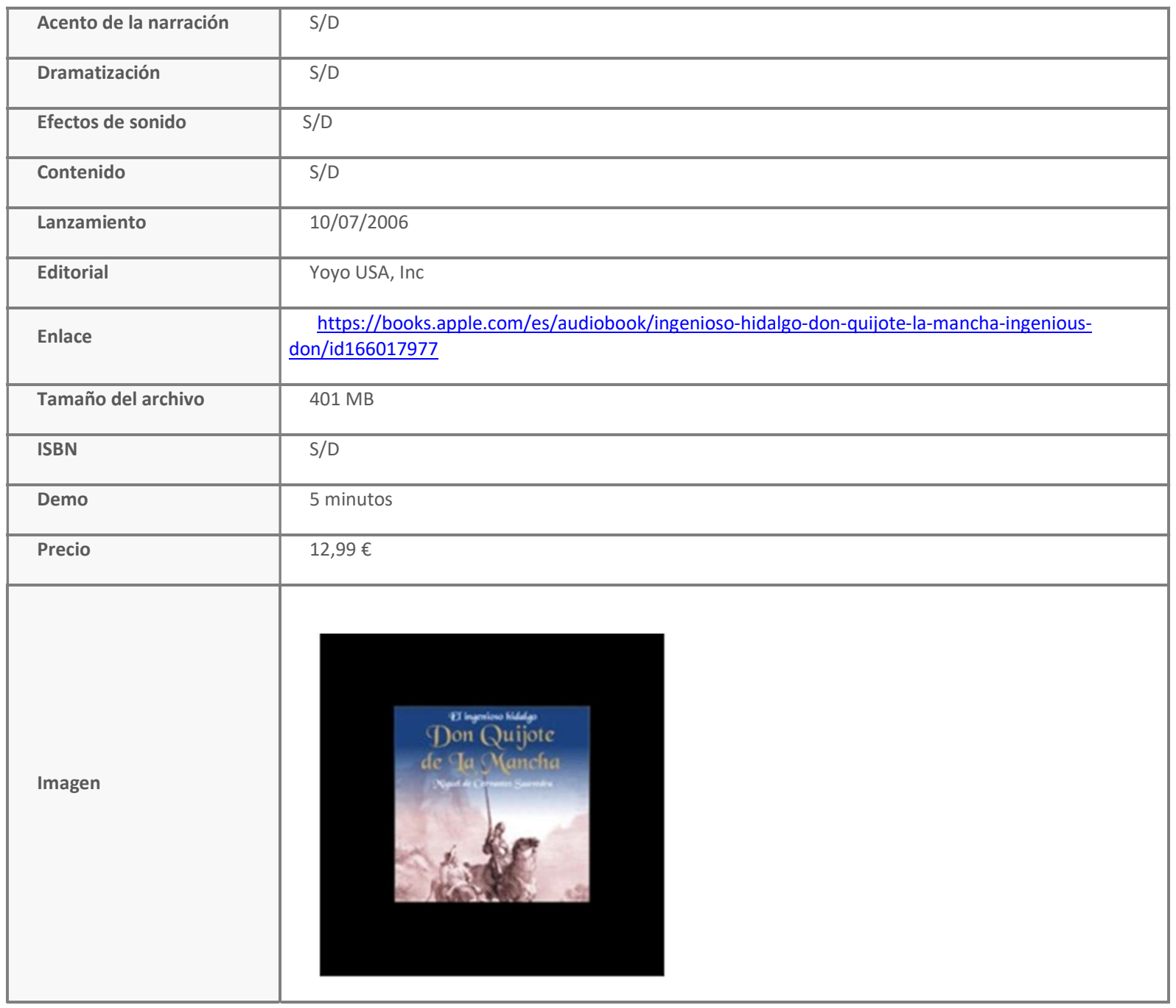

\begin{tabular}{|l|l|}
\hline \multicolumn{2}{|c|}{ Resultado de la búsqueda del «Quijote» en: Apple Books } \\
\multicolumn{2}{|l|}{ Ficha . $^{\circ}$ 9 } \\
\hline Título & Don Quijote de la Mancha (unabridged) \\
\hline Duración & 37 h 53 min \\
\hline Narrador & Eladio Ramos, Jesús Ramos \\
\hline Acento de la narración & S/D \\
\hline Dramatización & S/D \\
\hline Efectos de sonido & S/D \\
\hline Contenido & Unabridged \\
\hline Lanzamiento & $15-06-2017$ \\
\hline Editorial & Audiomol \\
\hline
\end{tabular}




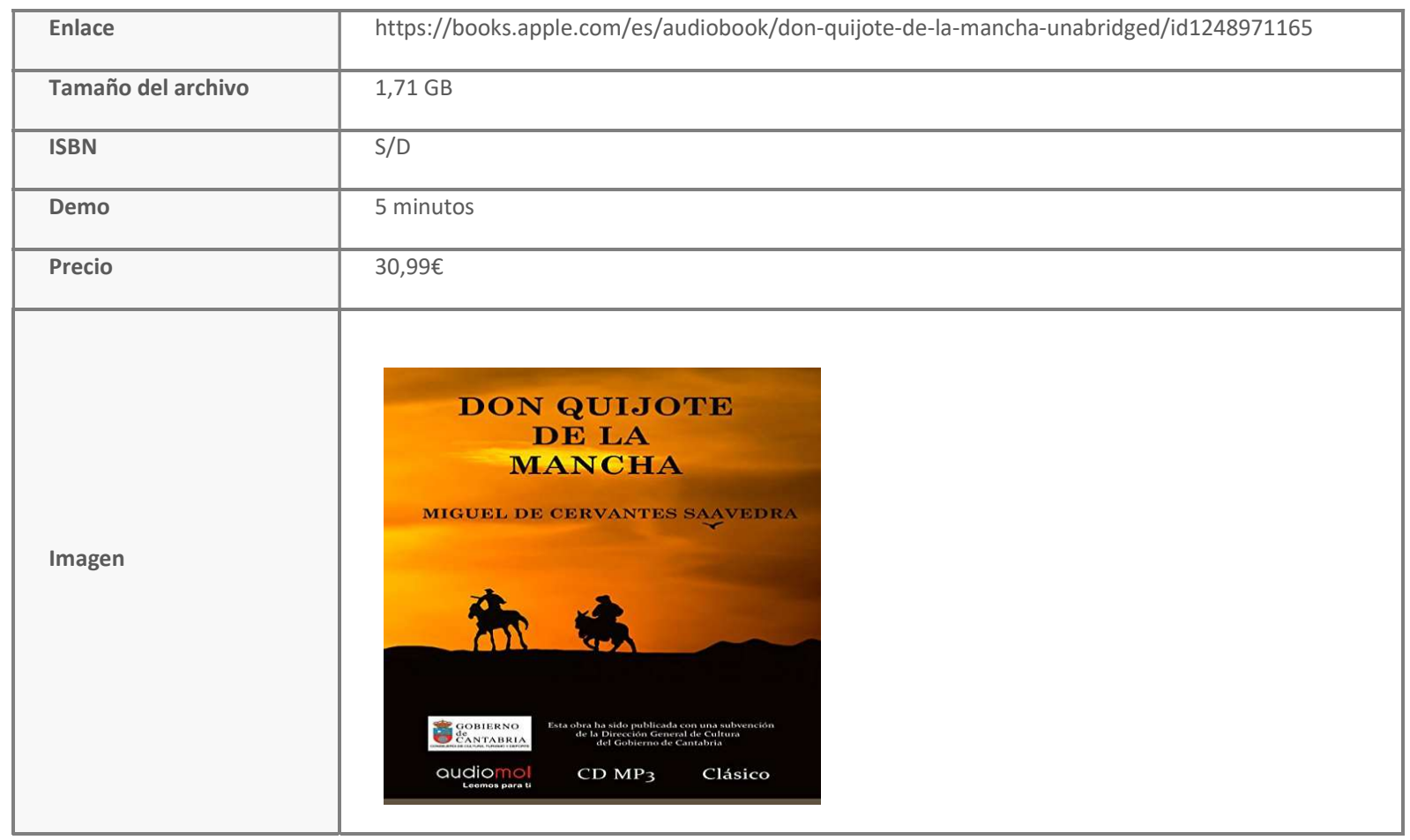

\begin{tabular}{|c|c|}
\hline \multicolumn{2}{|r|}{$\begin{array}{l}\text { Resultado de la búsqueda del «Quijote» en: Apple Books } \\
\qquad \text { Ficha } n .^{\circ} 10\end{array}$} \\
\hline Título & Don Quijote de la Mancha \\
\hline Duración & 40 horas 41 minutos \\
\hline Narrador & Juan Luis Galiardo \\
\hline Acento de la narración & Español Ibérico \\
\hline Dramatización & S/D \\
\hline Efectos de sonido & S/D \\
\hline Contenido & S/D \\
\hline Lanzamiento & 9 de noviembre de 2020 \\
\hline Editorial & Turner \\
\hline Enlace & https://books.apple.com/es/audiobook/don-quijote-de-la-mancha/id1539422226 \\
\hline Tamaño del archivo & $2,4 \mathrm{~GB}$ \\
\hline ISBN & S/D \\
\hline Demo & 5 minutos \\
\hline Precio & $25,99 €$ \\
\hline Imagen & \\
\hline
\end{tabular}




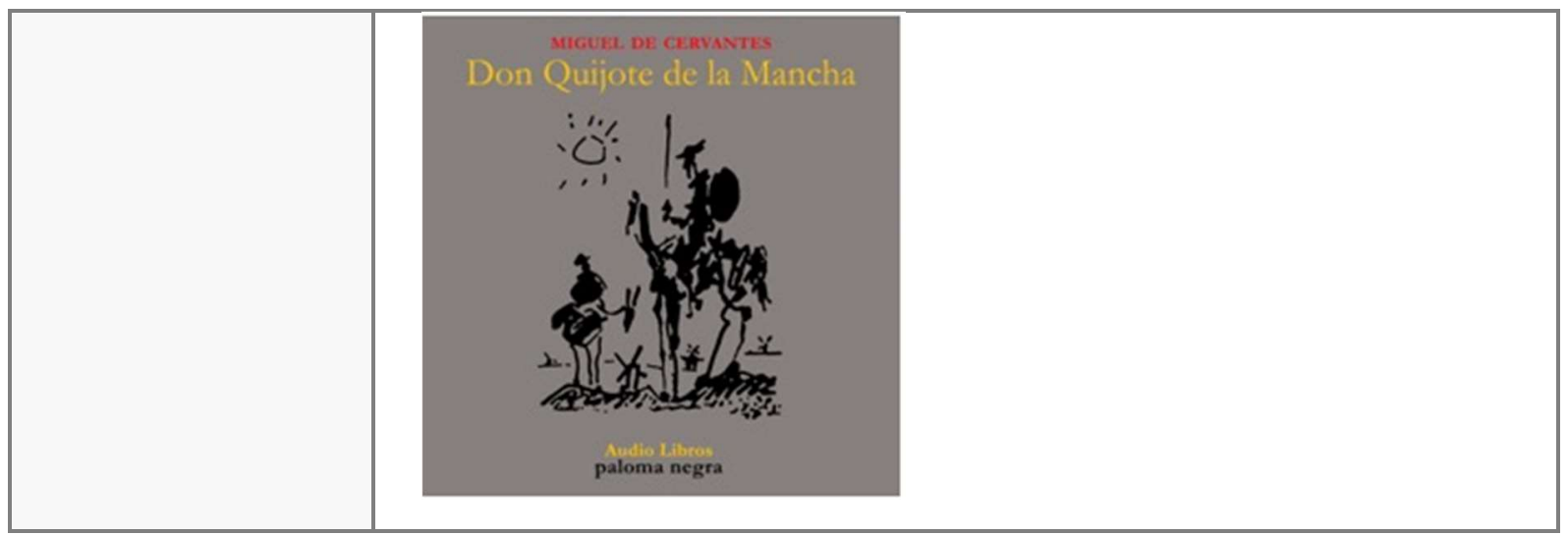

\begin{tabular}{|c|c|}
\hline \multicolumn{2}{|r|}{$\begin{array}{l}\text { Resultado de la búsqueda del «Quijote» en: Apple Books } \\
\qquad \text { Ficha } .^{\circ} 11\end{array}$} \\
\hline Título & $\begin{array}{l}\text { El Quijote Contado a los niños [The Quijote Counted to Children]: Classicos contados a los niños [Clas- } \\
\text { sics counted to children] (Unabridged) }\end{array}$ \\
\hline Duración & $1: 48$ \\
\hline Narrador & Diego del Arco López \\
\hline Acento de la narración & $S / D$ \\
\hline Dramatización & $S / D$ \\
\hline Efectos de sonido & $S / D$ \\
\hline Contenido & Unabridged \\
\hline Lanzamiento & $28-02-2020$ \\
\hline Editorial & Audible Studios \\
\hline Enlace & $\begin{array}{l}\text { https://books.apple.com/es/audiobook/quijote-contado-los-niños-quijote-counted-to-chil- } \\
\text { dren/id1503482389 }\end{array}$ \\
\hline Tamaño del archivo & $107,8 \mathrm{MB}$ \\
\hline ISBN & S/D \\
\hline Demo & 5 minutos \\
\hline Precio & $5,99 €$ \\
\hline Imagen & \\
\hline
\end{tabular}




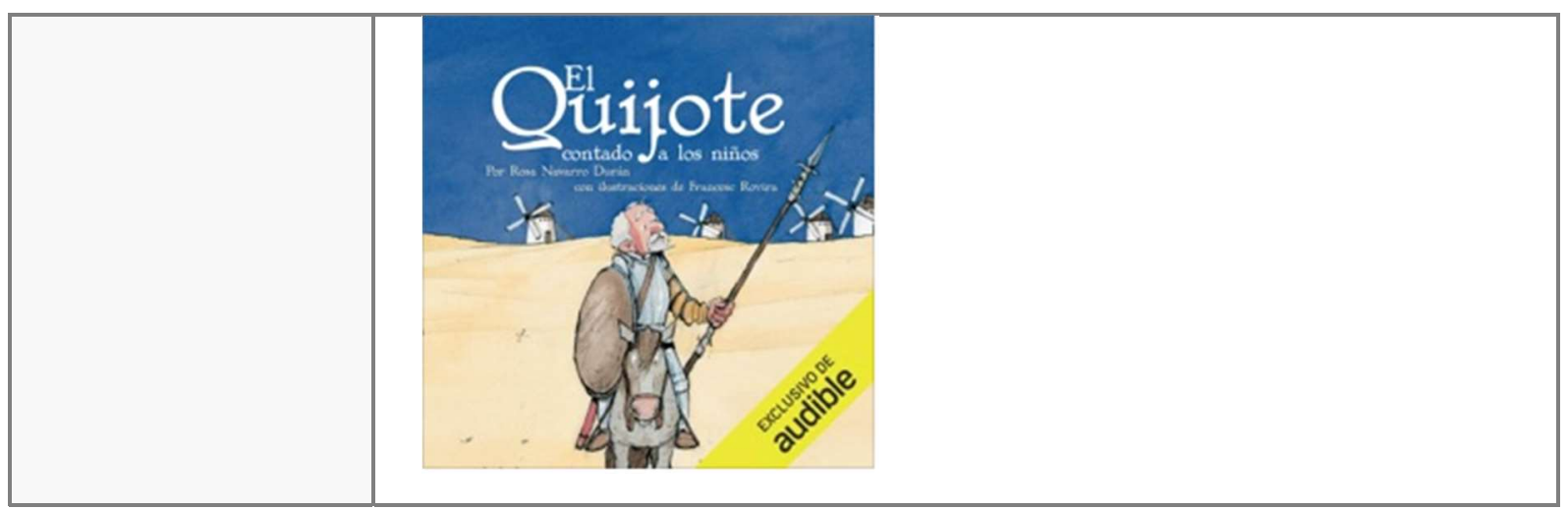

\begin{tabular}{|l|l|}
\hline \multicolumn{2}{|c|}{ Resultado de la búsqueda del «Quijote» en: Apple Books } \\
\multicolumn{1}{|l|}{ Ficha . $^{\circ}$ 12 } \\
\hline Título & Don Quijote de la Mancha \\
\hline Duración & 37 h 52 min \\
\hline Narrador & Jesús Ramos \\
\hline Acento de la narración & S/D \\
\hline Dramatización & S/D \\
\hline Efectos de sonido & S/D \\
\hline Contenido & S/D \\
\hline Lanzamiento & $14-12-2016$ \\
\hline Editorial & Audiomol \\
\hline Enlace & https://books.apple.com/es/audiobook/don-quijote-de-la-mancha/id1456673688 \\
\hline Tamaño del archivo & 1,7 GB \\
\hline ISBN & S/D \\
\hline Demo & 5 minutos \\
\hline Precio & $16,99 €$ \\
\hline
\end{tabular}




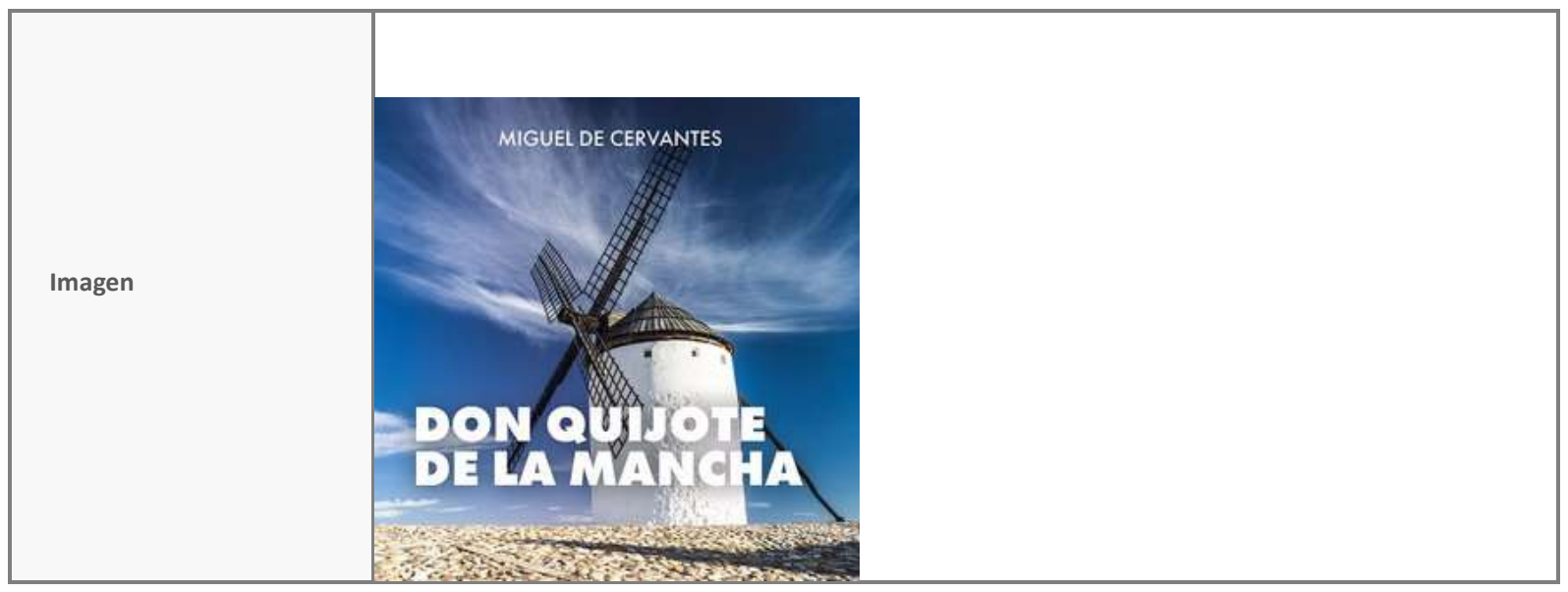

\begin{tabular}{|c|c|}
\hline & $\begin{array}{l}\text { Resultado de la búsqueda del «Quijote» en: Apple Books } \\
\qquad \text { Ficha } n .^{\circ} 13\end{array}$ \\
\hline Título & Don Quijote de la Mancha \\
\hline Duración & 5 horas y $24 \mathrm{~min}$ \\
\hline Narrador & Elenco Fonolibro \\
\hline Acento de la narración & S/D \\
\hline Dramatización & S/D \\
\hline Efectos de sonido & S/D \\
\hline Contenido & S/D \\
\hline Lanzamiento & 01-07-2014 \\
\hline Editorial & FonoLibro Inc. \\
\hline Enlace & https://books.apple.com/es/audiobook/don-quijote-de-la-mancha/id1498274216 \\
\hline Tamaño del archivo & $323,4 \mathrm{MB}$ \\
\hline ISBN & S/D \\
\hline Demo & 5 minutos \\
\hline Precio & $\$ 13,99$ \\
\hline Imagen & \\
\hline
\end{tabular}




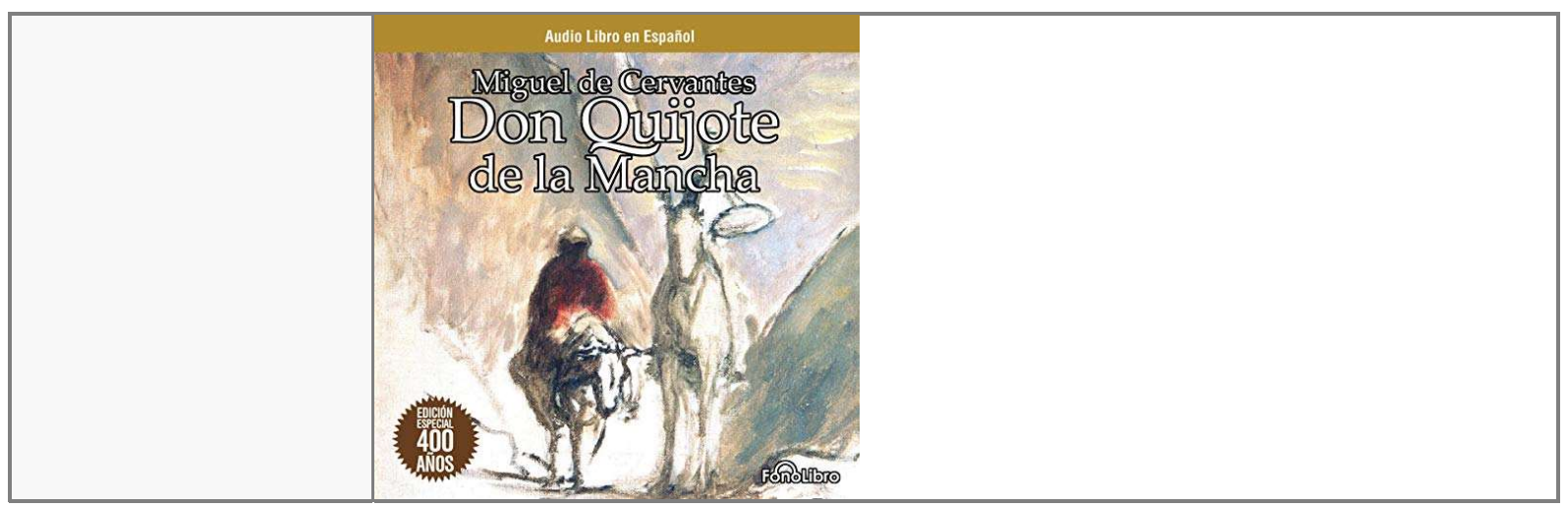

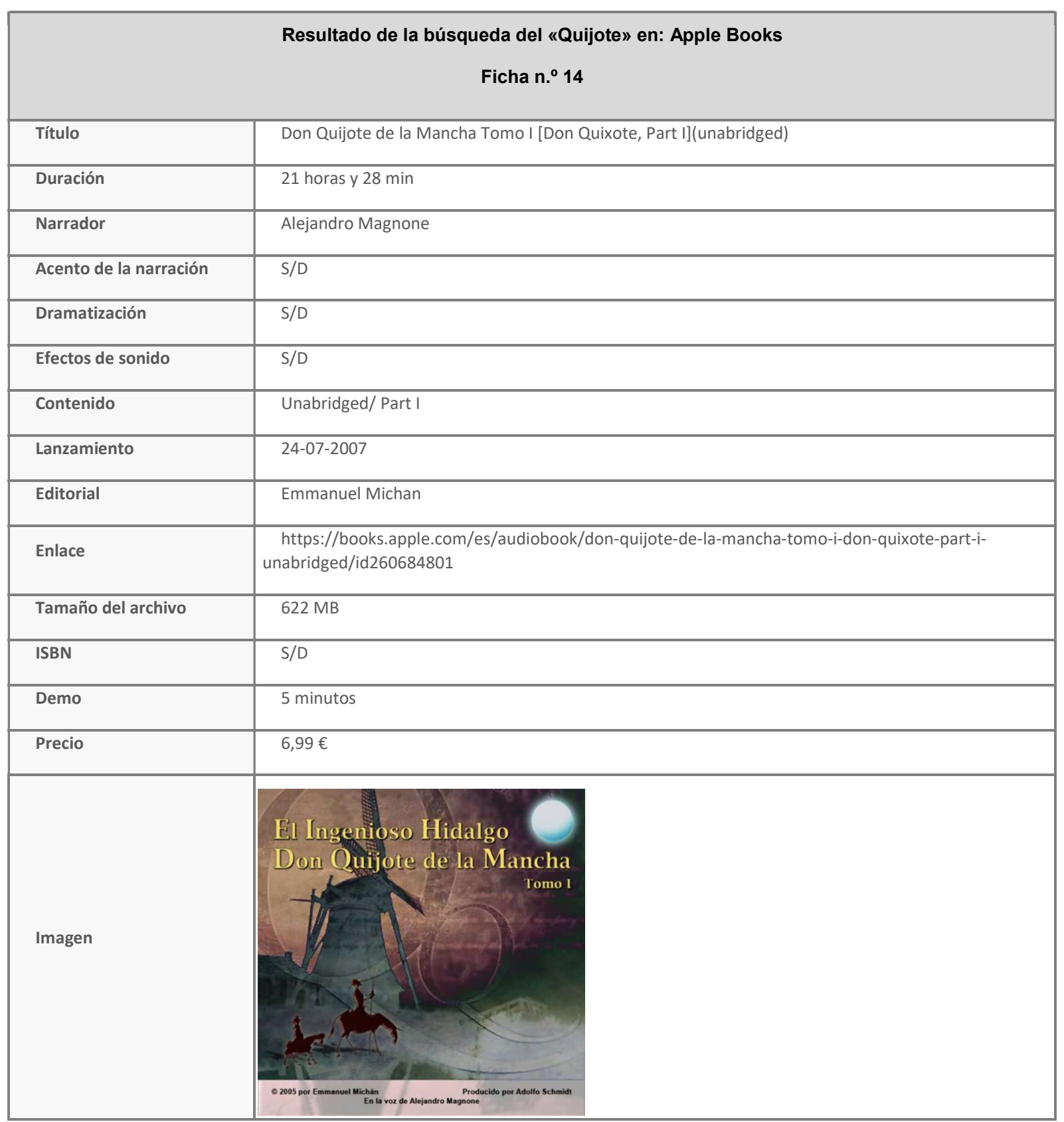




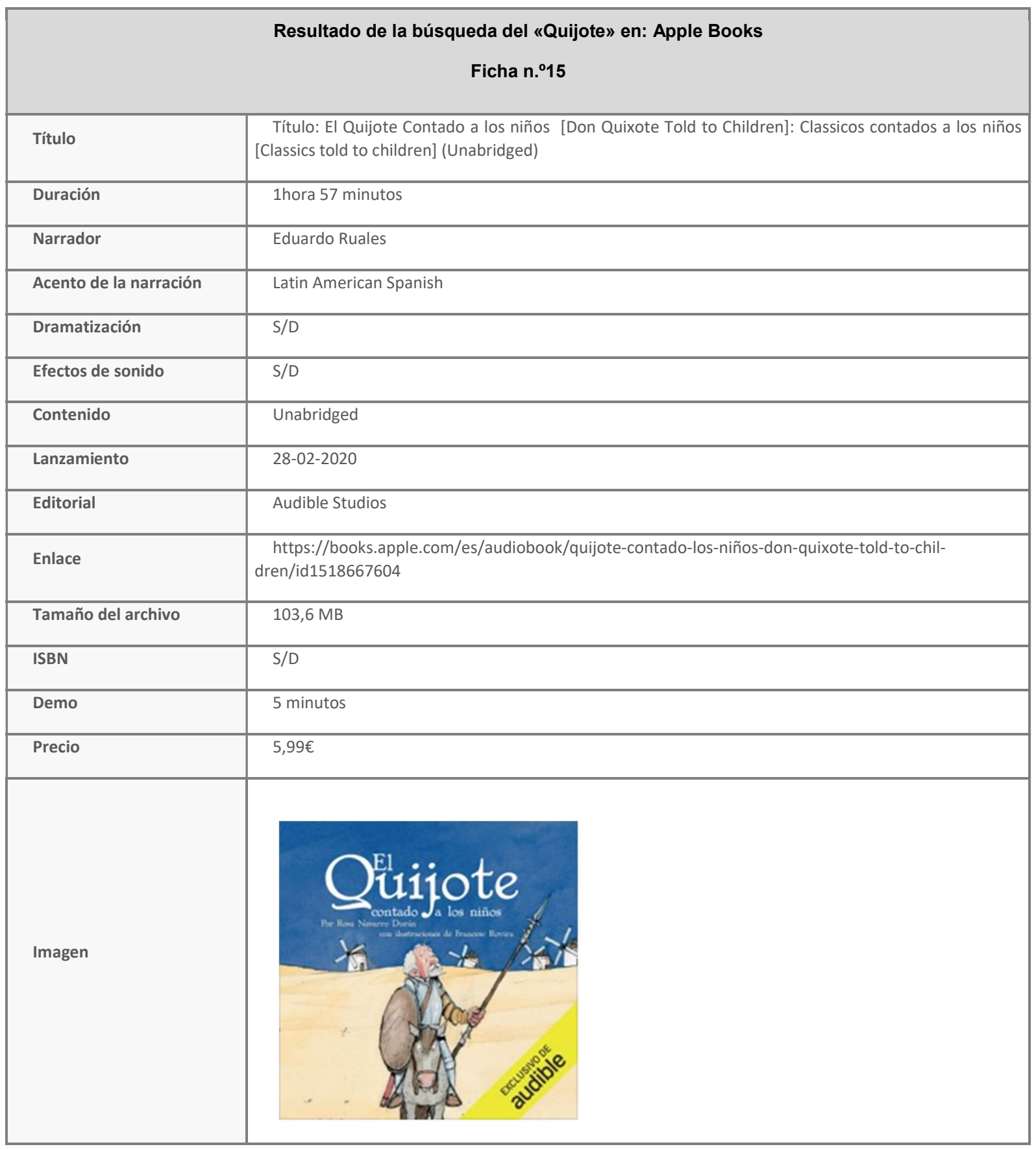

Algunas conclusiones a las que llegamos a raíz de la evaluación de las fichas de Apple Books son las siguientes:

En dos ocasiones se presenta el mismo audiolibro con diferente precio y con variaciones en el peso del archivo.

$\checkmark$ En el primer caso el título es Don Quijote de la Mancha de la editorial Fonolibro, que aparece 3 veces (fichas: 1,2 y 13), con una extensión en tiempo idéntica: 5:24 h, pero en los 
tres casos su precio y tamaño del archivo difiere $(13,99 €$ y $162 \mathrm{MB} ; 6,99 €$ y $322 \mathrm{MB}$ y $13,99 €$ y $323 \mathrm{MB})$.

$\checkmark \quad$ Otro ejemplo es el de la primera parte del Quijote de la editorial Emannuel Michan, que en una ocasión tiene una extensión de 21:27 h, un peso del archivo de 952,8 MB y un costo de 5,99€ (ficha 5) y el otro audiolibro tiene $21: 28$ h, $622 \mathrm{MB}$ y 6,99 € (ficha 14).

En otra ocasión presenta dos audiolibros con la misma información editorial, Yoyo, USA, mismo precio y extensión en tiempo, pero con una diferencia significativa en el peso del archivo, ya que en uno tiene $401 \mathrm{MB}$ y en otro $861 \mathrm{MB}$, como es el caso de los audiolibros de las fichas 4 y 8 , respectivamente.

$\checkmark$ En ninguno de los casos observados en las fichas se presenta información del ISBN del libro y los datos que ofrecen son siempre los mismos: narrador, categoría, proveedor, fecha de publicación, duración, tamaño del archivo, una breve descripción y valoraciones de los usuarios. Además, brinda la posibilidad de una demostración para todos los casos de 5 minutos de extensión. También ofrece el enlace de compra tanto desde la plataforma iTunes como desde la aplicación Libros, para dispositivos móviles.

\subsubsection{Resultados y análisis del relevamiento del Quijote en diversas plataformas en español}

7.2.4.1 Títulos contenidos en las plataformas

Una vez estudiadas todas las plataformas, la primera pregunta intentaremos responder es: ¿cuáles son las ediciones del Quijote en audiolibro presentes en la totalidad de las mismas?

Extraída la información y volcada a las fichas (ver Anexo 1) hemos realizado un archivo de Excel en el cual en cada hoja de trabajo introdujimos el título de un audiolibro del Quijote, a fin de poder obtener, por un lado, el número total de audiolibros encontrados, y por el otro, poder comparar el mismo libro en las diversas plataformas.

La primera impresión que se extrae tras evaluar las fichas en conjunto es la escasa información que las plataformas ofrecen sobre cada obra y la diversidad de versiones que ofrecen.

Exceptuando dos audiolibros, no se indica si la versión incluye el prólogo; podemos ver un caso que cuenta con esta información, en el Quijote que está fraccionado en 9 partes: el título de la primera de ellas es Prólogo-Capítulo 1 y dura unas dos horas. El otro caso es el editado por Literatura Sonora.

Tras agrupar las diferentes fichas por título de la obra, y analizando las 113 fichas hemos realizado un listado de audiolibros Quijote en español, que podemos ver en la Tabla 4. Listado de audiolibros digitales del Quijote Tabla 5. Oferta de títulos del Quijote en formato audiolibro

El listado contiene la siguiente información:

a. Una imagen: a falta de información textual, las imágenes en el audiolibro cobran mucha importancia, por lo cual hemos incluido en una dimensión de $2 \times 2 \mathrm{~cm}$ la portada del audiolibro. 
b. Título del audiolibro: elegimos la forma más utilizada si el audiolibro se repite en varias plataformas.

c. Datos de la edición en papel: Solo en una de las fichas se ofrece información referente a la edición exacta que se está leyendo (es el caso de Literatura Sonora). En el resto nos podemos hacer una idea del tipo de narración por la extensión del audiolibro en minutos al comparar todas las plataformas, pero hay que tener en cuenta que un usuario sin experiencia que busca un audiolibro es probable que no compare varias plataformas y elija un audiolibro sin saber si es una edición abreviada o íntegra, y en muchos casos sin saber si es la obra completa, o si se trata de la primera o segunda parte.

d. Editorial: observando todas las fichas hemos visto que existen casos en los que los datos de título e ISBN son iguales pero la editorial es diferente. En dichos casos incluiremos las dos editoriales con una nota al pie de página.

e. Duración: la inclusión de este dato es fundamental, y afortunadamente se ofrece en el $100 \%$ de los casos.

f. Narrador: entendemos la importancia determinante que tiene un narrador en un audiolibro y por eso incluimos este dato.

g. Tipo de versión: este es un punto débil en la descripción del audiolibro por parte de las plataformas, son muy pocas las que incluyen información referente al tipo de versión.

h. Contenido: ligado al punto anterior

i. ISBN y ASIN: en el caso de no contar con la información se ha intentado encontrar por otros medios. 
Tabla 4. Listado de audiolibros digitales del Quijote

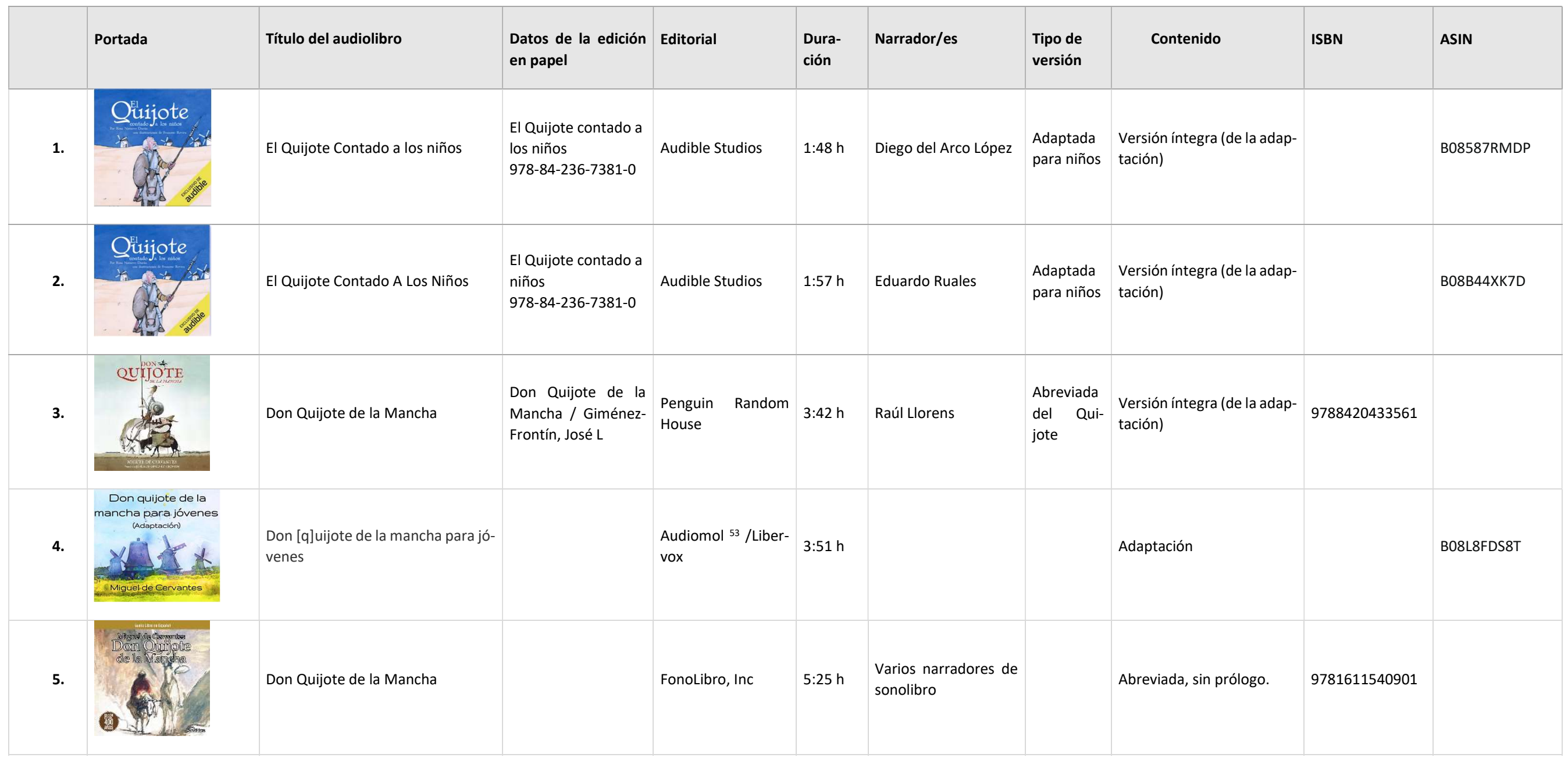

${ }^{53}$ En Audible y Storytel figura como editorial Audiomol, en Google Play: Libervox. 


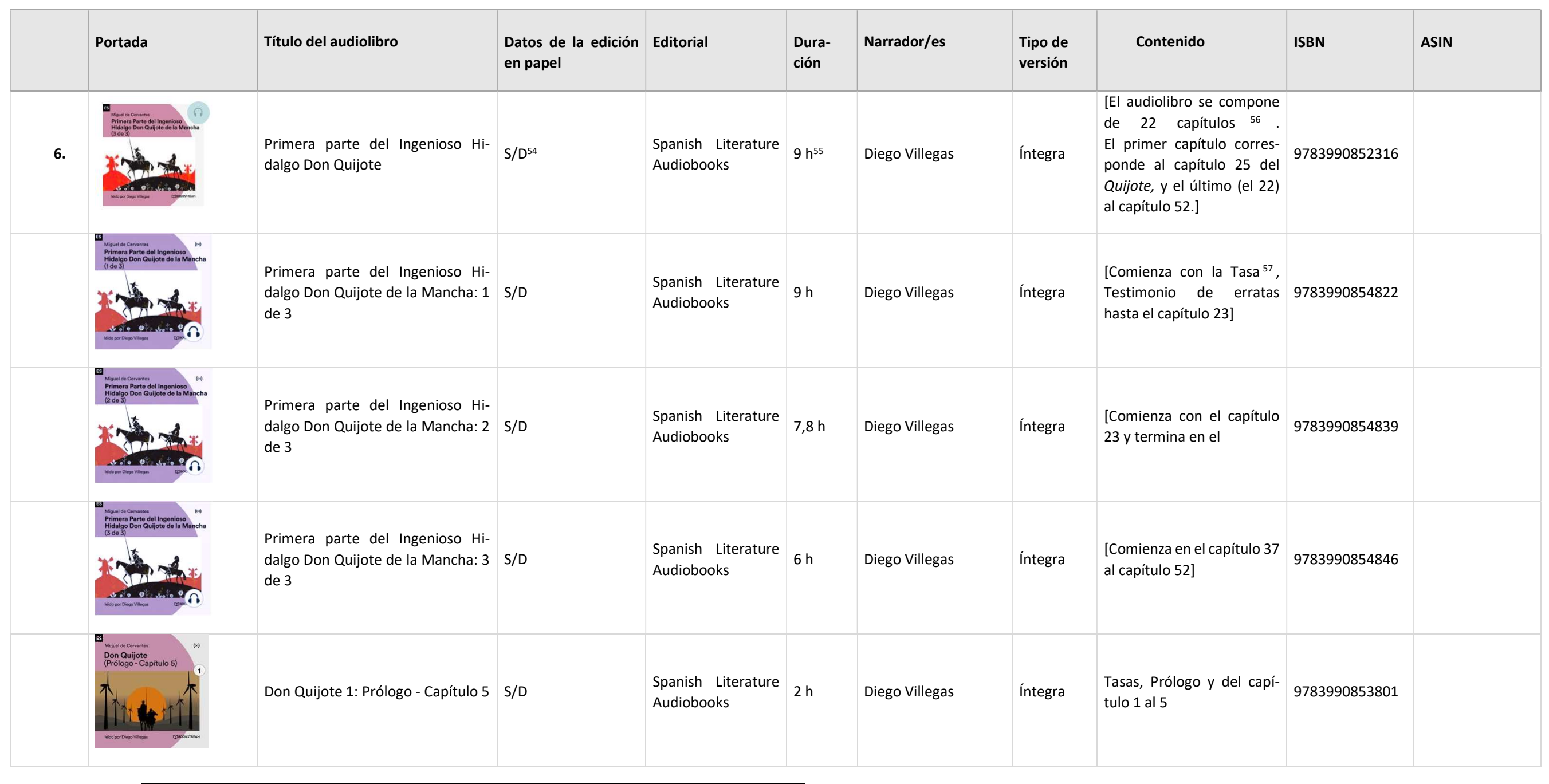

${ }^{54}$ Dado que la numeración del ISBN que aparece en toda la colección corresponde a Austria, hemos contactado con la agencia austríaca del ISBN quien nos indicó la dirección del editor: Bookstream, pero no nos han informado cuál fue la edición utilizada (comunicación personal, 20/11/2020).

55 Tomado de Scribd

${ }^{56}$ Tomado de Scribd

${ }^{57}$ Tomado de Scribd 


\begin{tabular}{|c|c|c|c|c|c|c|c|c|c|c|}
\hline & Portada & Título del audiolibro & $\begin{array}{l}\text { Datos de la edición } \\
\text { en papel }\end{array}$ & Editorial & $\begin{array}{l}\text { Dura- } \\
\text { ción }\end{array}$ & Narrador/es & $\begin{array}{l}\text { Tipo de } \\
\text { versión }\end{array}$ & Contenido & ISBN & ASIN \\
\hline & & $\begin{array}{l}\text { Don Quijote 2: Capítulo } 6 \text { - Capítulo } \\
15\end{array}$ & $S / D$ & $\begin{array}{l}\text { Spanish Literature } \\
\text { Audiobooks }\end{array}$ & $3 \mathrm{~h}$ & Diego Villegas & Íntegra & Del capítulo 6 al 15 & 9783990853818 & \\
\hline & & $\begin{array}{l}\text { Don Quijote 3: Capítulo } 16 \text { - Capí- } \\
\text { tulo } 20\end{array}$ & S/D & $\begin{array}{l}\text { Spanish Literature } \\
\text { Audiobooks }\end{array}$ & $2 \mathrm{~h}$ & Diego Villegas & Íntegra & Del capítulo 16 al 20 & 9783990853825 & \\
\hline & & $\begin{array}{l}\text { Don Quijote 4: Capítulo } 21 \text { - Capí- } \\
\text { tulo } 25\end{array}$ & S/D & $\begin{array}{l}\text { Spanish Literature } \\
\text { Audiobooks }\end{array}$ & $2,9 \mathrm{~h}$ & Diego Villegas & Íntegra & Del capítulo 21 al 25 & 9783990853832 & \\
\hline & & $\begin{array}{l}\text { Don Quijote 5: Capítulo } 26 \text { - Capí- } \\
\text { tulo } 30\end{array}$ & $S / D$ & $\begin{array}{l}\text { Spanish Literature } \\
\text { Audiobooks }\end{array}$ & $3 \mathrm{~h}$ & Diego Villegas & Íntegra & Del capítulo 26 al 30 & 9783990853849 & \\
\hline & & $\begin{array}{l}\text { Don Quijote 6: Capítulo } 31 \text { - Capí- } \\
\text { tulo } 35\end{array}$ & S/D & $\begin{array}{l}\text { Spanish Literature } \\
\text { Audiobooks }\end{array}$ & $2 \mathrm{~h}$ & Diego Villegas & Íntegra & Del capítulo 31 al 35 & 9783990853856 & \\
\hline & & $\begin{array}{l}\text { Don Quijote 8: Capítulo } 41 \text { - Capí- } \\
\text { tulo } 45\end{array}$ & S/D & $\begin{array}{l}\text { Spanish Literature } \\
\text { Audiobooks }\end{array}$ & $2 \mathrm{~h}$ & Diego Villegas & Íntegra & Del capítulo 41 al 45 & 9783990853870 & \\
\hline & & $\begin{array}{l}\text { Don Quijote 9: Capítulo } 46 \text { - Capí- } \\
\text { tulo } 52\end{array}$ & $S / D$ & $\begin{array}{l}\text { Spanish Literature } \\
\text { Audiobooks }\end{array}$ & $2 \mathrm{~h}$ & Diego Villegas & Íntegra & Del capítulo 46 al 52 & 9783990853887 & \\
\hline 7. & 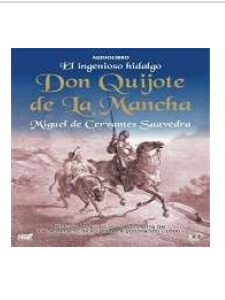 & $\begin{array}{l}\text { El Ingenioso Hidalgo Don Quijote } \\
\text { De La Mancha }\end{array}$ & S/D & Yoyo USA, Inc & $15: 58 \mathrm{~h}$ & $\begin{array}{l}\text { Actores del teatro es- } \\
\text { pañol. Grabado por } \\
\text { Radio Nacional de Es- } \\
\text { paña en } 1960\end{array}$ & Abreviada & $\begin{array}{l}\text { [No es íntegra, la informa- } \\
\text { ción que indica la propia } \\
\text { contraportada es que } \\
\text { "quedan por fuera algunas } \\
\text { digresiones cervantinas ta- } \\
\text { les como los episodios de } \\
\text { las Bodas de Camacho y si- } \\
\text { milares]. }\end{array}$ & 9789588218427 & \\
\hline
\end{tabular}




\begin{tabular}{|c|c|c|c|c|c|c|c|c|c|c|}
\hline & Portada & Título del audiolibro & $\begin{array}{l}\text { Datos de la edición } \\
\text { en papel }\end{array}$ & Editorial & $\begin{array}{l}\text { Dura- } \\
\text { ción }\end{array}$ & Narrador/es & $\begin{array}{l}\text { Tipo de } \\
\text { versión }\end{array}$ & Contenido & ISBN & ASIN \\
\hline 8. & & Don Quijote de la Mancha & $S / D^{58}$ & Pegasus Classics & $17: 11 \mathrm{~h}$ & Carlos Ramos & [íntegra] & $\begin{array}{l}\text { [Del capítulo } 1 \text { al capítulo } \\
52 \text { ] }\end{array}$ & 9782291063971 & \\
\hline 9. & & $\begin{array}{l}\text { Don Quijote de la Mancha Tomo I } \\
\text { [Don Quixote, Part I] }\end{array}$ & $S / D^{59}$ & & $21: 27 \mathrm{~h}$ & Alejandro Magnone & Íntegra & & & BO0OUB3HBS \\
\hline 10. & & $\begin{array}{l}\text { Don Quijote de la Mancha Tomo II } \\
\text { [Don Quixote, Part II] }\end{array}$ & S/D & & $23: 07 \mathrm{~h}$ & Alejandro Magnone & Íntegra & & & BO0OUB3HC2 \\
\hline 11. & & Don Quijote 1 & $\begin{array}{l}\text { El ingenioso hidalgo } \\
\text { don Quijote de la } \\
\text { Mancha, por Miguel } \\
\text { de Cervantes Saave- } \\
\text { dra. Proyecto Guten- } \\
\text { berg. }{ }^{60}\end{array}$ & LibriVox $^{61}$ & $21: 10 \mathrm{~h}$ & $\begin{array}{l}\text { Voluntarios de Libri- } \\
\text { vox }\end{array}$ & Íntegra & $\begin{array}{l}\text { [Tasa, dedicatoria, Prólogo } \\
\text { y capítulos del } 1 \text { al 52] }\end{array}$ & No posee & \\
\hline 12. & 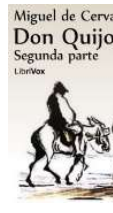 & Don Quijote 2 & $\begin{array}{l}\text { El ingenioso hidalgo } \\
\text { don Quijote de la } \\
\text { Mancha, por Miguel } \\
\text { de Cervantes Saave- } \\
\text { dra. Proyecto Gu- } \\
\text { tenberg. }\end{array}$ & LibriVox & $22: 06 \mathrm{~h}$ & $\begin{array}{l}\text { Voluntarios de Libri- } \\
\text { vox }\end{array}$ & Întegra & $\begin{array}{l}\text { [Tasa, aprobación, privile- } \\
\text { gio, prólogo, dedicatoria y } \\
\text { capítulos del } 1 \text { al } 74]\end{array}$ & No posee & \\
\hline
\end{tabular}

${ }^{58} \mathrm{Hemos}$ enviado la consulta a la editora Pegasus, pero no hemos obtenido respuesta.

${ }^{59} \mathrm{Hemos}$ enviado consultas tanto a Audible, pero no hemos recibido respuesta.

${ }^{60}$ En la propia página de Librivox refieren a la edición empresa del Proyecto Gutenberg: http://www.gutenberg.org/files/2000/2000-h/2000-h.htm

${ }^{61}$ También encontramos las denominaciones: Books Should be Free y Loyal Books. 


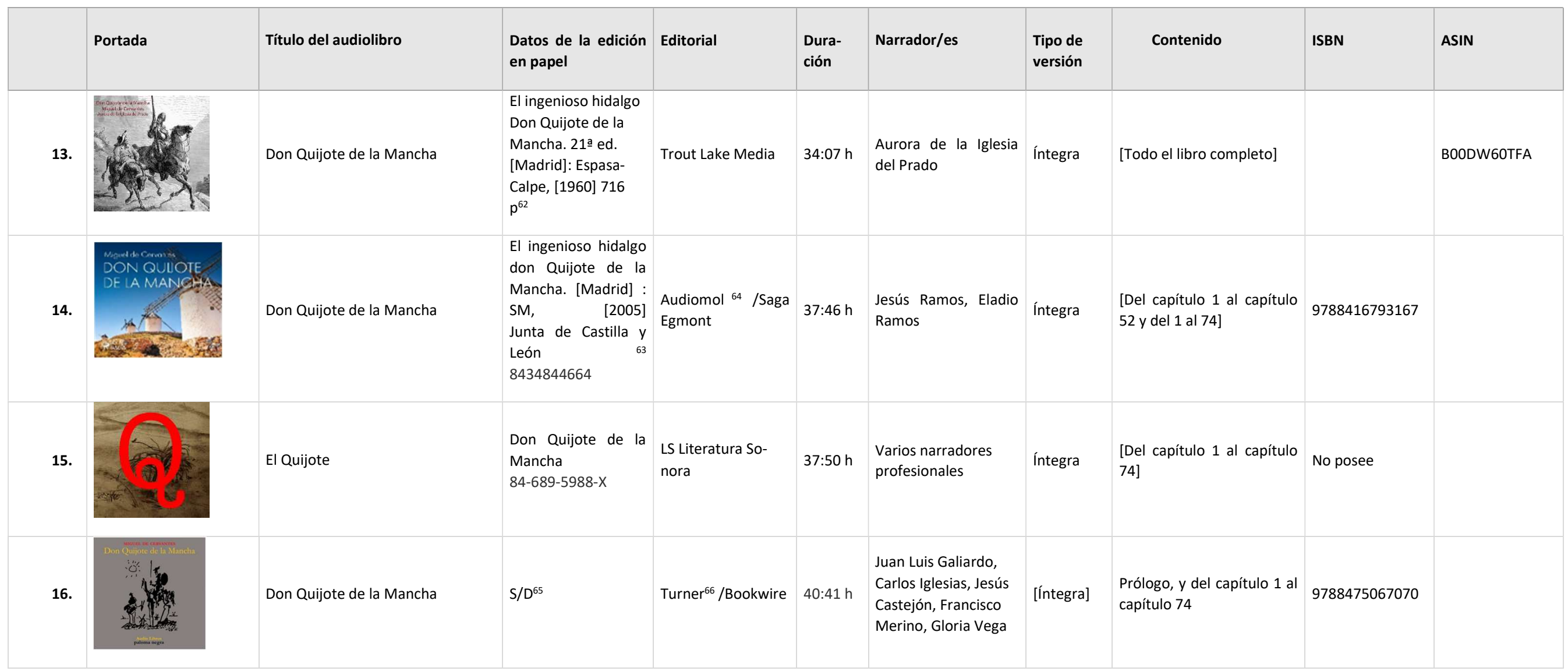

Fuente: Elaboración propia, con datos aportados por las empresas dedicadas a los audiolibros digitales

${ }^{62}$ El dato de la edición impresa fue aportado por Aurora de la Iglesia del Prado, en una comunicación personal con fecha 06/11/2020.

63 Dato aportado por Audiomol el 6/11/2020 (comunicación personal).

${ }^{64}$ Apple, Audible y Audiomol, mientras que Audiolibros, Audioteka, Kobo Scribd, Storytel, Beek, Leamos y Ubook indican en ese campo Saga Egmont (empresa danesa que ha comprado el catálogo de Audio$\mathrm{mol}$ (https://thenewpublishingstandard.com/2020/03/10/denmarks-saga-egmont-becomes-spains-largest-audiobook-publisher-on-audiomol-catalogue-acquisition/)

${ }^{65}$ Enviada la consulta a Turner el 30/12/2020, sin respuesta.

${ }^{66} \mathrm{Apple}$, Kobo y Storytel indican como editorial a Turner, mientras que la plataforma Audiolibros indica: Bookwire 
Como hemos evidenciado en el ejemplo de Apple Books, y se puede constatar en el Anexo 1, una sola plataforma puede contener: un solo título del audiolibro del Quijote, más de un título, ofrecer el mismo título dos o más veces (con diferente tamaño de archivo o precio); o incluso, presentar fraccionado el Quijote en 3 o 9 archivos.

Fueron en total 113 fichas, con diversas ediciones que es necesario organizar para poder sacar conclusiones. Para avanzar en la investigación se cruzan a continuación dos variables, por un lado, los títulos del Quijote presentes en nuestro relevamiento y por el otro lado las plataformas interrogadas. De esta interacción podemos obtener dos datos importantes: a) qué cantidad de veces es ofrecido un mismo título en varias plataformas y b) qué cantidad de títulos ofrece cada plataforma. El siguiente cuadro nos posibilitará obtener estos datos: 
Tabla 5. Oferta de títulos del Quijote en formato audiolibro digital

\begin{tabular}{|c|c|c|c|c|c|c|c|c|c|c|c|c|c|c|c|c|c|c|}
\hline & Título del audiolibro & Editorial & $\frac{0}{\frac{0}{2}}$ & $\frac{\frac{0}{0}}{\frac{0}{\overline{0}}}$ & 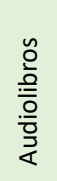 & 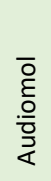 & 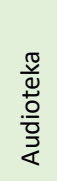 & 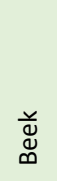 & 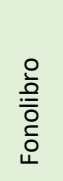 & $\begin{array}{l}\frac{\frac{\pi}{2}}{0} \\
\frac{0}{00} \\
\stackrel{y}{0} \\
0 \\
0\end{array}$ & $\stackrel{\circ}{\circ}$ & 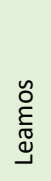 & 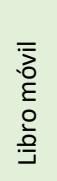 & 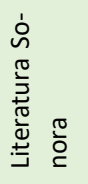 & $\begin{array}{l}\text { D } \\
\text { : } \\
\text { 离 }\end{array}$ & 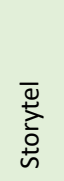 & $\begin{array}{l}\text { 혀 } \\
\text { 임 }\end{array}$ & $\begin{array}{l}\text { Total de } \\
\text { oferta por } \\
\text { audiolibro }\end{array}$ \\
\hline 1. & $\begin{array}{l}\text { El Quijote contado a los ni- } \\
\text { ños (Narrador: Diego del A } \\
\text { López) }\end{array}$ & Audible Studios & $x$ & $x$ & & & & & & & & & & & & & & 2 \\
\hline 2. & $\begin{array}{l}\text { El Quijote Contado a los Ni- } \\
\text { ños (Narrador:Eduardo } \\
\text { Ruales) }\end{array}$ & Audible Studios & $\mathrm{x}$ & $\mathrm{x}$ & & & & & & & & & & & & & & 2 \\
\hline 3. & Don Quijote de la Mancha & $\begin{array}{l}\text { Penguin Random } \\
\text { House }\end{array}$ & $x$ & $x$ & $x$ & & $\mathrm{x}$ & & & $x$ & $x$ & & & & & & & 6 \\
\hline 4. & $\begin{array}{l}\text { Don [q]uijote de la mancha } \\
\text { para jóvenes }\end{array}$ & Audiomol & & $\mathrm{x}$ & & & & & & $x$ & & & & & & $x$ & & 3 \\
\hline 5. & Don Quijote de la Mancha & FonoLibro, Inc & $x x^{67}$ & $\mathrm{x}$ & $\mathrm{x}$ & & $\mathrm{x}$ & & $\mathrm{x}$ & $\mathrm{x}$ & & & $\mathrm{x}$ & & & & & 7 \\
\hline \multirow[t]{3}{*}{6.} & $\begin{array}{l}\text { Primera parte del Inge- } \\
\text { nioso H. Don Quijote }\end{array}$ & $\begin{array}{l}\text { Spanish Literature } \\
\text { Audiobooks }\end{array}$ & & & & & & & & & $x$ & $x$ & & & $\mathrm{x}$ & & $x$ & 4 \\
\hline & $\begin{array}{l}\text { Primera parte del Inge- } \\
\text { nioso H.Don Q. de la Man- } \\
\text { cha (en tres partes) }\end{array}$ & $\begin{array}{l}\text { Spanish Literature } \\
\text { Audiobooks }\end{array}$ & & & & & & & & & $x$ & $x$ & & & $x$ & & $x$ & \\
\hline & Don Quijote (en 9 partes) $)^{69}$ & $\begin{array}{l}\text { Spanish Literature } \\
\text { Audiobooks }\end{array}$ & & & & & & & & & $x$ & $x$ & & & $x$ & & $\mathrm{x}$ & \\
\hline 7. & $\begin{array}{l}\text { El Ingenioso Hidalgo Don } \\
\text { Quijote De La Mancha }\end{array}$ & Yoyo USA, Inc & $\mathrm{xx}$ & $\mathrm{x}$ & & & $\mathrm{x}$ & & & & & & & & & & & 3 \\
\hline
\end{tabular}

${ }^{67}$ Se indican con «X» la cantidad de veces que se repite un audiolibro

${ }^{68}$ Si la primera parte del audiolibro ya está contabilizada, no se vuelve a contabilizar cuando se ofrece la obra divida en tres partes.

${ }^{69}$ Si la plataforma ofrece la primera parte entera, no se contabiliza nuevamente si la ofrece dividida en 9 partes, como es el caso del Quijote número 6. 


\begin{tabular}{|c|c|c|c|c|c|c|c|c|c|c|c|c|c|c|c|c|c|c|}
\hline & Título del audiolibro & Editorial & $\frac{0}{\frac{0}{2}}$ & $\frac{\frac{0}{0}}{\frac{2}{\frac{2}{2}}}$ & 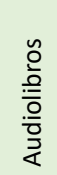 & $\begin{array}{l}\overline{0} \\
\dot{\varepsilon} \\
\text { 읗 } \\
\bar{z}\end{array}$ & 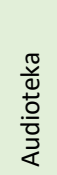 & 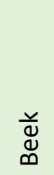 & 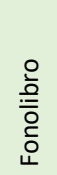 & 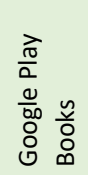 & $\begin{array}{l}\stackrel{\circ}{0} \\
\stackrel{\circ}{0}\end{array}$ & 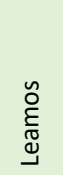 & $\begin{array}{l}\overline{\bar{z}} \\
\stackrel{0}{\varepsilon} \\
0 \\
\stackrel{0}{3}\end{array}$ & 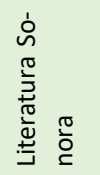 & 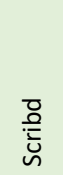 & $\begin{array}{l}\bar{\Phi} \\
\sum_{0}^{ \pm} \\
\dot{D}\end{array}$ & $\begin{array}{l}\stackrel{\circ}{0} \\
\stackrel{\circ}{J}\end{array}$ & $\begin{array}{l}\text { Total de } \\
\text { oferta por } \\
\text { audiolibro }\end{array}$ \\
\hline 8. & Don Quijote de la Mancha & Pegasus Classics & $\mathrm{x}$ & $\mathrm{x}$ & $\mathrm{x}$ & & & $\mathrm{x}$ & & $\mathrm{x}$ & $\mathrm{x}$ & $\mathrm{x}$ & & & & $\mathrm{x}$ & & 8 \\
\hline 9. & $\begin{array}{l}\text { Don Quijote de la Mancha } \\
\text { Tomo I [Don Quixote, Part } \\
\text { I] }\end{array}$ & Emmanuel Michan & $x x$ & $\mathrm{x}$ & & & & & & & & & & & & & & 2 \\
\hline 10. & $\begin{array}{l}\text { Don Quijote de la Mancha } \\
\text { Tomo II [Don Quixote, Part } \\
\text { II] }\end{array}$ & Emmanuel Michan & $\mathrm{x}$ & $\mathrm{x}$ & & & & & & & & & & & & & & 2 \\
\hline 11. & Don Quijote 1 & LibriVox & & & $\mathrm{xx}$ & & & & & & & & & & & & $\mathrm{x}$ & 2 \\
\hline 12. & Don Quijote 2 & LibriVox & & & $\mathrm{x}$ & & & & & & & & & & & & & 1 \\
\hline 13. & Don Quijote de la Mancha & Trout Lake Media & & $\mathrm{x}$ & & & & & & & & & & & & & & 1 \\
\hline 14. & Don Quijote de la Mancha & $\begin{array}{l}\text { Audiomol /Saga Eg- } \\
\text { mont }\end{array}$ & $\mathrm{xx}$ & $\mathrm{x}$ & $\mathrm{x}$ & $\mathrm{x}$ & $\mathrm{x}$ & $x$ & & & $x$ & $\mathrm{x}$ & & & $\mathrm{x}$ & $x$ & $x$ & 11 \\
\hline 15. & El Quijote & LS Literatura Sonora & & & & & & & & & & & & $\mathrm{x}$ & & & & 1 \\
\hline 16. & Don Quijote de la Mancha & Turner /Bookwire & $\mathrm{x}$ & & $\mathrm{x}$ & & & & & & $x$ & & & & & $x$ & & 4 \\
\hline \multicolumn{3}{|c|}{ Total de audiolibros por plataforma ${ }^{70}$} & 10 & 11 & 7 & 1 & 4 & 2 & 1 & 4 & 5 & 3 & 1 & 1 & 2 & 4 & 3 & \\
\hline
\end{tabular}

${ }^{70}$ Se contabilizan una sola vez los títulos que se ofrecen de forma duplicada o triplicada. 
Del cuadro anterior extraemos los totales para dar respuesta a las preguntas:

1) ¿Qué cantidad de veces es ofrecido un mismo título en varias plataformas?

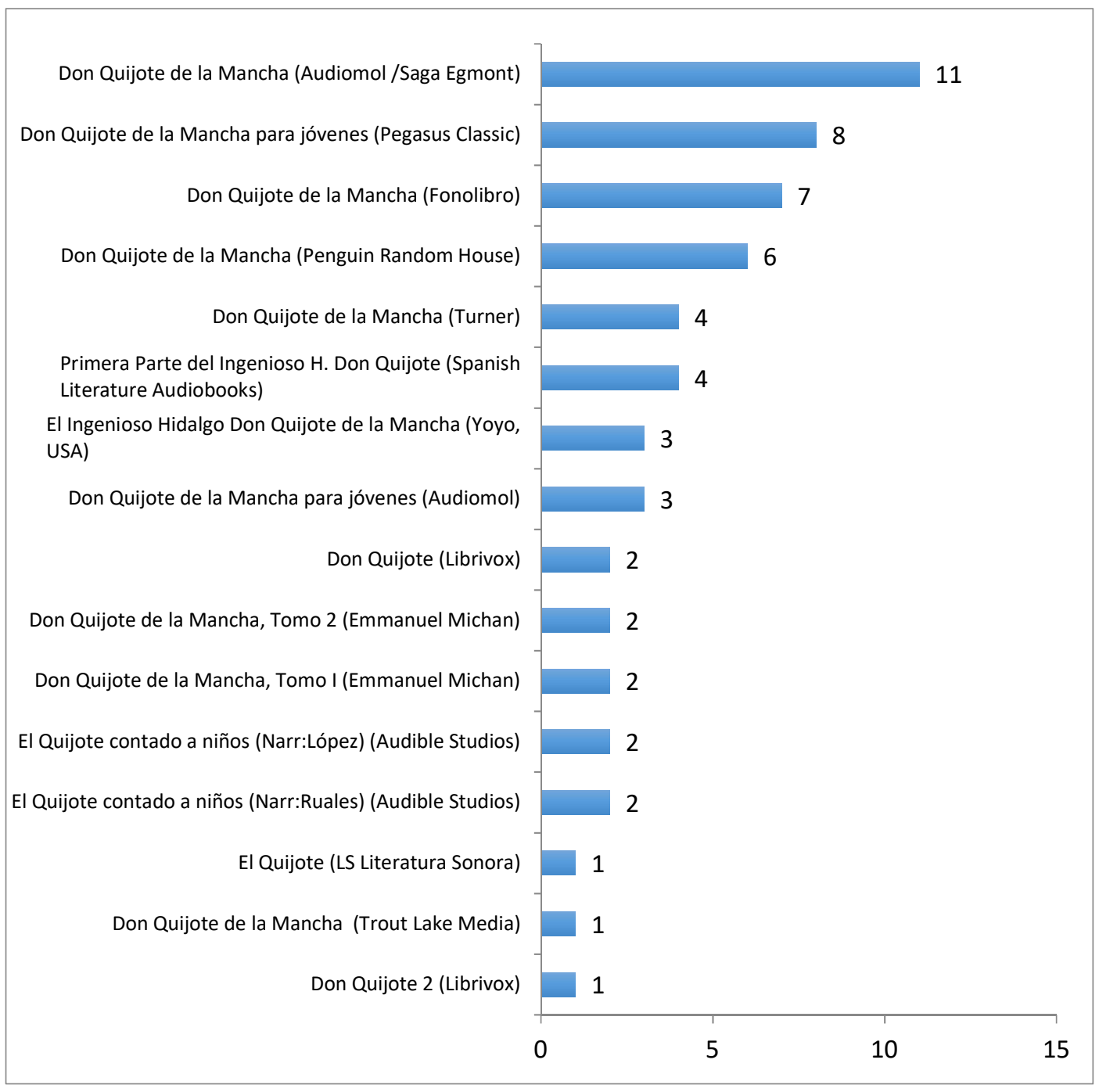

Ilustración 21. Repetición de un mismo audiolibro en todas las plataformas evaluadas

En este cuadro se tienen en cuenta los títulos del Quijote íntegros, sea la obra completa, la primera parte o la segunda, dejando de lado las ediciones de Spanish Literature Edition, fraccionadas en 3 y 9 partes, ya que en este caso coincide que son ofrecidas a través de las mismas 4 plataformas.

El gráfico da cuenta de una característica del mercado del audiolibro y es que para rentabilizar y potenciar los mismos, las empresas los comparten en más de una plataforma, ya que como indica Alejandro Khan (fundador y director de Sonolibro), para competir en el mercado una empresa debería ser capaz de producir entre 500 y 1000 audiolibros anuales y son pocas las que llegan a estos números. 
2) ¿Qué cantidad de Quijotes ofrece cada plataforma?

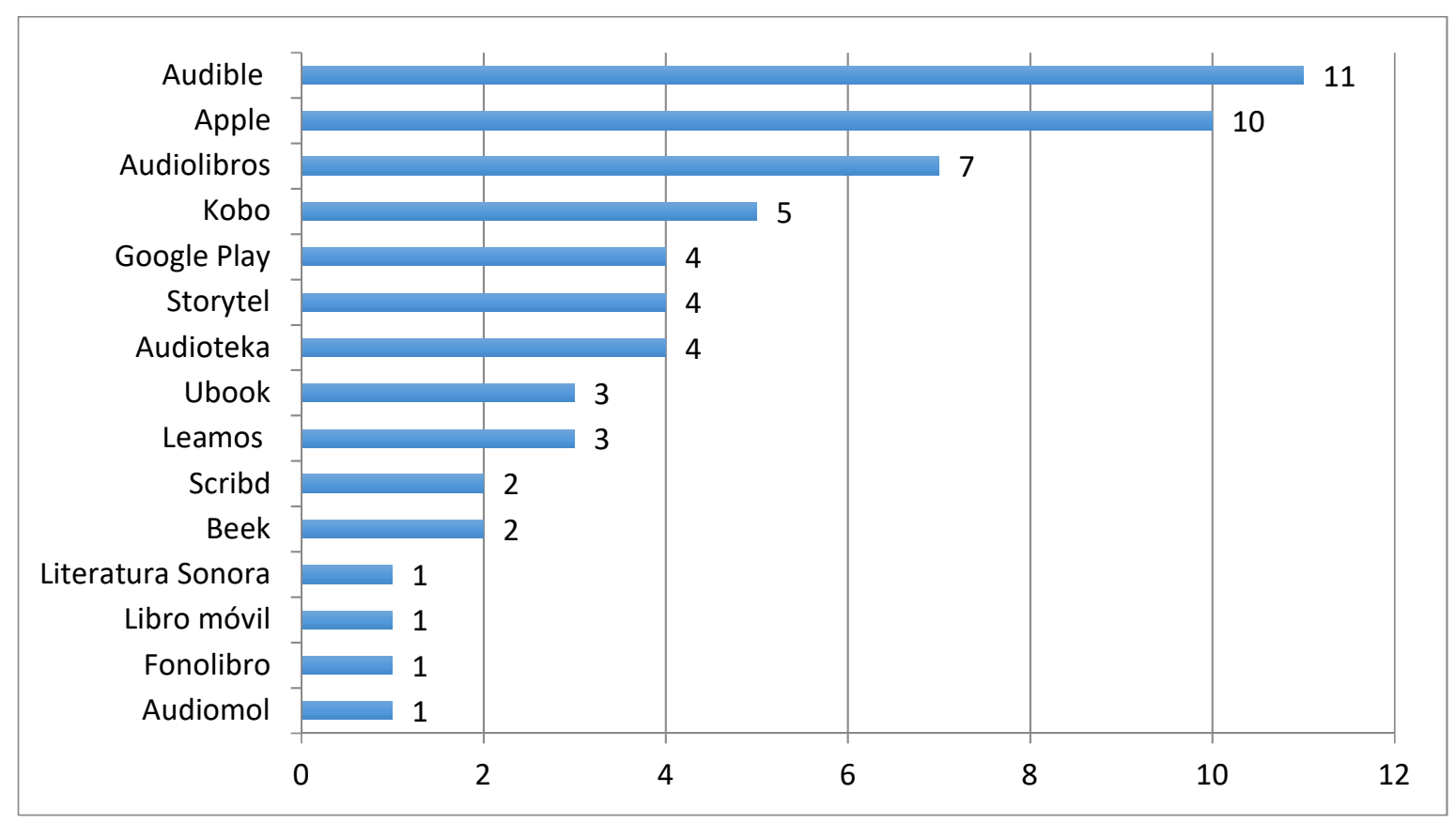

Ilustración 22. Audiolibros del Quijote ordenados por plataforma

Este gráfico contabiliza la cantidad de Quijotes ofrecidos por plataforma. En él podemos observar que Audible es la plataforma que más opciones brinda a los usuarios, con una variedad de 11 títulos diferentes. Este dato no debe sorprendernos si tenemos en cuenta que Audible, como indica Alejandro Khan tiene la mayor base de datos de audiolibros del mundo (Khan, 2020).

\subsubsection{Modo de adquisición de los audiolibros}

En el apartado 5.16 (Modelos de negocio de los audiolibros), detallamos que existen, según la bibliografía estudiada, 4 modelos diferentes: la venta por suscripción, que puede ser ilimitada o limitada; la venta unitaria o a la carta; el acceso gratuito y por último, las licencias de bibliotecas.

Nuestro trabajo de campo se focaliza en los modelos comerciales de audiolibros, y para ilustrar este punto tomaremos el audiolibro Don Quijote de la Mancha editado por Audiomol, que es el audiolibro que se repite en más plataformas (en 11), y detallaremos las opciones que cada plataforma brinda para adquirirlo.

En primer lugar, existen dos formas de adquirir este audiolibro, o bien por compra individual (o modelo a la carta) o bien a través de una suscripción a una plataforma. 


\begin{tabular}{lc}
\hline Compra individual & Precio \\
\hline Audioteka & $8,99 €$ \\
Kobo & $8,99 €$ \\
\hline Audiomol & $10,99 €$ \\
\hline Apple Books & $16,99 €$ \\
\hline Apple Books (2) & $30,99 €$ \\
\hline Audible & $\$ 39,95$ \\
\hline Tabla 6. Precios de audiolibros (por compra individual) \\
& \\
\hline Suscripción mensual & Precio \\
\hline Leamos & $5,95 €$ \\
\hline Scribd & $\$ 8.99$ \\
\hline Ubook & $\$ 14,99$ \\
\hline Storytel & $12,99 €$ \\
\hline Beek & $13,99 €$ \\
\hline Tabla 7. Precios de audiolibros (por suscripción mensual)
\end{tabular}

Es de destacar la notoria disparidad precios en ambos modelos, que van desde los 8,99 $€$ si se adquiere el audiolibro digital a través de la plataforma Audioteka, a \$39,95 si se realiza la misma compra en la plataforma Audible.

En suscripciones mensuales también observamos una disparidad, pero no tan importante como la que presentan las plataformas a través de las compras individuales.

Javier Celaya, en una disertación en la Feria del Libro de Bogotá, en el año 2019, parece reforzar la idea de que el modelo de negocio del audiolibro a diferencia del modelo del libro en papel se distribuye en plataformas de distribución y a través de modelos de suscripción.

En países anglosajones, según Javier, se evidencia la venta unitaria mientras que, en países latinos, incluida España, se ha pasado "del futuro sin pasar por el presente», ya que se ha saltado la venta unitaria yendo directamente al modelo de venta en streaming dentro de un modelo de forma ilimitada, como Scribd, Storytel o Audible (Celaya, 2019).

Si unimos esta disparidad a la falta de información que brindan las empresas (basta recordar que Audible, Google Play, Scribd y Storytel no pudieron informarnos la cantidad de audiolibros que poseen), entendemos la dificultad que puede suponer para un usuario el decidir de qué forma y a través de qué plataforma adquirir un título determinado. 
En la fase anterior de este trabajo de investigación nos familiarizamos con varios conceptos relacionados con los audiolibros digitales. Hemos constatado que este formato, como cualquier otro contenido digital circula tanto por vías informales, así como por vías más tradicionales, como las páginas webs, plataformas, o aplicaciones especializadas.

Nuestro trabajo de investigación partió de un encuadre teórico de los audiolibros, para luego realizar un estudio de campo exploratorio que analizó aspectos relacionados con la industria audio-editorial de España relevando portales, plataformas y aplicaciones de audiolectura.

De acuerdo con nuestro relevamiento y según nuestras predicciones, constatamos que son las aplicaciones las que contienen el acceso al mayor número de audiolibros de calidad. La explicación es que estas aplicaciones pertenecen a empresas privadas que diseñaron un modelo específico de préstamo o escucha de audiolibros digitales, en contraposición a otras iniciativas particulares que no reúnen garantías mínimas de calidad, y que hemos decidido dejar fuera de nuestro trabajo de investigación. Otra razón es el costo de los audiolibros que contienen, que rondan los $€ 4.000$ euros por unidad.

Después de dedicar más de un año a probar e interrogar casi la totalidad de aplicaciones de audiolectura del mercado para realizar el relevamiento de Quijotes en audiolibro este apartado se propone observar cuáles son las funcionalidades más importantes tanto para acceder a su contenido, así como para su audiolectura. Como colofón de nuestro trabajo definiremos cuáles son las características que creemos indispensables y que deberían estar presentes en una aplicación de audiolibros para considerarla de calidad.

Lo primero que haremos será definir qué es una aplicación de lectura:

Las aplicaciones de lectura son programas informáticos que permiten la gestión de contenidos, principalmente textuales, y el acceso a los mismos, así como la interacción con el lector usuario, facilitando en la mayor parte de los casos la adaptación del contenido (cambio de tipo y tamaño de la letra, espaciado, color de fondo...) para que pueda ser leído en un dispositivo móvil de lectura. (Gómez Díaz y Cordón-García, 2015)

García Rodríguez y Gómez Díaz (2015:2) enuncian que «en el mundo digital son necesarios otros criterios que afectan no solo al contenido textual, sino también al audio, la animación, el diseño, al formato, la interactividad, a su visibilidad, valoración, usabilidad, etc.», con parámetros e indicadores propios.

Las autoras reafirman la necesidad de especialización en aplicaciones por parte de los profesionales de la información insistiendo en que el solo hecho de descargarla y probarla no es suficiente para determinar la calidad de una aplicación (ídem), e instan a definir - y agrego: a utilizar- una metodología adecuada, con una serie de criterios, parámetros e indicadores que nos permitan determinar cuáles son los que nos interesan evaluar.

A fin de resumir la sistematización de esta última etapa del trabajo de investigación detallamos las siguientes fases: 


\section{- Fase 1: Búsqueda documental y formulación de la necesidad de una metodología.}

Esta primera etapa fue realizada desde mediados de 2019 hasta la fecha.

Además de las fuentes canónicas que todo doctorando debe consultar y que ya han sido mencionadas a lo largo de la tesis, también se han consultado fuentes específicas relacionadas con la legislación, ya que existen, en muchos casos, vacíos legales que fueron necesarios aclarar antes de confeccionar una metodología modelo.

Asimismo, resultó de mucha utilidad la asistencia a congresos, especialmente al VII Congreso del Libro Electrónico, 2019 celebrado en Barbastro, España, que otorgó la posibilidad de estar en contacto con profesionales relacionados con el ámbito sonoro y de constatar el creciente interés de los investigadores de diversas áreas.

Según Gómez Díaz, et al. (2016:167) «la gran variedad de aplicaciones de lectura hace necesario conocer, evaluar y seleccionar este tipo de productos, así como articular sistemas de recogida de información y valoración». Más adelante, los autores, refiriéndose a la calidad de una app indican que «es necesaria una metodología basada en la definición de criterios, parámetros e indicadores que nos permitan determinar qué es lo que queremos evaluar, cómo se va a evaluar y cómo los vamos a medir».

En relación con nuestra investigación, los resultados obtenidos en el apartado anterior nos ofrecieron información acerca de cuáles son las principales editoriales, los creadores y distribuidoras de audiolibros digitales en la actualidad. También recogimos datos acerca de las fuentes en las que se alojan dichas grabaciones (en qué plataformas o aplicaciones), y cuáles son sus detalles editoriales, como el título completo, narrador, fecha de publicación, etc.

Teniendo este cuadro de situación encontramos que sería útil delinear cuáles son las características de las aplicaciones que contienen estos audiolibros, ya que encontramos que los modelos de plataformas y aplicaciones son muy heterogéneos.

Algunos datos que encontramos de mucha utilidad pueden ser si la aplicación permite la marcación del audio, si se permite adelantar o retroceder el audio o si poseen buscadores por duración del audio, por nombrar solo algunas funcionalidades deseables. Estas características fueron apuntadas en un cuaderno de trabajo a medida que se realizó el relevamiento del capítulo anterior a la espera de constatar si estas funcionalidades estaban sistematizadas en alguna metodología existente.

\section{- Fase 2. Búsqueda y selección de una metodología.}

Tras el análisis de la información derivada de la fase 1 se llega a la conclusión de que no existe a nivel internacional una metodología de evaluación de aplicaciones de audiolectura; sin embargo, existen metodologías que evalúan tanto plataformas web de lectura como aplicaciones de lectura (generales), tanto a nivel nacional como internacional.

Se procedió a elegir una metodología editada y publicada en España para evaluar aplicaciones de lectura que sería adaptada para evaluar específicamente aplicaciones de audiolibros digitales.

La metodología elegida es la que presentan Gómez Díaz, et al. $(2016,168)$ en el libro Leyendo entre pantallas, modelo en el que establecen dos dimensiones para la evaluación de las aplicaciones de lectura: dimensión de forma y de contenido. La fundamentación de esta selección 
está basada en la afinidad de dicho documento con nuestro tema y con la fecha de edición de esta guía. Esta metodología a su vez se basó en la metodología de Lluís Codina $(2000,2007)$.

\section{- Fase 3. Adaptación de la metodología.}

Apoyados en la mencionada guía y teniendo en cuenta que fue diseñada para otros formatos digitales, se han añadido algunos indicadores, se han modificado otros y se han eliminado aquellos que no se ajustan a nuestros intereses, indicando y fundamentando dichas modificaciones en cada caso oportuno.

Esta metodología recogerá de modo explícito los criterios e indicadores que van a servir para evaluar las aplicaciones destinadas a la audiolectura centrándonos en el punto de vista del usuario y valiéndonos de la experiencia de más de dos años de investigación de este tipo de aplicaciones.

Se ha recurrido también a la colaboración de varios profesionales en el ámbito de la documentación, que aportaron sugerencias para la adaptación de la metodología. Asimismo, se han consultado a varios llamados "súper lectores», ya que son personas que han utilizado muchas horas este tipo de aplicaciones y que pueden brindar información genuina y de mucha relevancia.

En cuanto a la forma de medir, se ha eliminado una de las dos columnas de la metodología original, por lo que se anotarán en una sola columna, con un 1 las valoraciones positivas y un 0 las negativas.

\subsection{GUÍA METODOLÓGICA}

La primera conclusión a la que arribamos al comenzar la tarea de analizar aplicaciones de audiolectura fue la escasez de publicaciones referentes al tema. Dada esta situación buscamos documentación de aplicaciones análogas, por lo cual ampliamos el espectro de evaluaciones especializadas en audiolibros a aplicaciones de lectura en general, eligiendo entre las existentes la propuesta de Gómez Díaz, et al. (2016:168).

Como hemos indicado, en base a esta metodología seleccionada se pretende revisar y confeccionar una metodología de evaluación específica para aplicaciones de lectura de audiolibros que pueda servir como un punto de referencia tanto para profesionales de la información como a agentes relacionados con el mundo editorial. Fruto de la aplicación de esta metodología, se obtendrá un resultado que indicará en qué medida una plataforma es recomendable y en qué grado, lo que facilitará la posibilidad de realizar comparaciones entre aplicaciones de audiolectura.

Tras la utilización de este documento, los resultados obtenidos son calificados según el rango que a continuación mostramos:

a. La aplicación es altamente recomendable, cuando están presentes el 80\% de los indicadores imprescindibles y recomendables por la plantilla de evaluación. 
b. Que la aplicación es recomendable: cuando los resultados obtenidos se encuentran entre el $50 \%$ y el $79 \%$ de los indicadores imprescindibles y recomendables;

c. Y que la aplicación es prescindible: cuando los resultados no superan el $49 \%$ de los indicadores imprescindibles y recomendables.

El mercado de las aplicaciones móviles es tan variado, desde distintos puntos de vista, incluido el de la calidad y fiabilidad que debemos ser objetivos a la hora de utilizar y recomendar una aplicación determinada. Puede que alguna cuente con un diseño atractivo y una buena campaña de marketing, pero que no cumpla con los requisitos más básicos de profesionalidad y calidad.

En el desarrollo de la tesis nos hemos familiarizado con una diversa tipología de aplicaciones para realizar el trabajo de campo, y es por esta razón que creemos que contamos con la experiencia suficiente para el diseño de una metodología que quedará abierta a futuras valoraciones. Instamos a que sea un profesional o investigador relacionado con la documentación que prosiga con la investigación, ya que consideramos que la formación en la materia es esencial para tal fin.

Poniendo el foco en la evaluación, en el siguiente apartado detallaremos punto por punto cada una de las dimensiones, indicadores y subindicadores con un breve resumen de cada ítem. Asimismo, detallaremos claramente aquellos indicadores o subindicadores que en la fase de adaptación de la metodología fueron omitidos, modificados o incluidos, con su debida justificación.

Tras este detallado apartado teórico presentaremos la plantilla en blanco para que se pueda observar su diseño final. Comenzaremos a continuación con los parámetros de la evaluación englobados en la primera dimensión:

\subsubsection{Dimensión forma}

Dentro de esta dimensión nos encontramos con parámetros que responderían a preguntas relacionadas con: ¿de qué forma llegamos al contenido?, y que son los siguientes: disponibilidad, adquisición, seguridad, confidencialidad y privacidad, popularidad, reconocimiento y ergonomía.

\section{F.1. Disponibilidad}

La disponibilidad se refiere a con qué facilidad accedemos a la aplicación, y está dada por los siguientes parámetros.

\section{F.1.1. Disponibilidad para diferentes sistemas operativos}

Existen aplicaciones que están diseñadas para un determinado sistema operativo, que puede ser Android, iOS o Windows, o puede que el sistema ofrezca una aplicación multiplataforma. Se valorará positivamente esta última opción. 


\section{F.1.2. Disponibilidad en diferentes sitios}

Actualmente existen miles de productos y servicios a través de internet, y requiere cierto tiempo el encontrar uno que satisfaga nuestras demandas.

Este punto se refiere a de qué manera el desarrollador de la aplicación se muestra y facilita el acceso a su producto. Gómez Díaz et al. (2016:169) utilizan el término: descubribilidad, que significa «la existencia de algo, en nuestro caso la capacidad de que los interesados en una aplicación la encuentren de una forma fácil y sencilla a través de muchos sitios».

También resulta interesante saber dónde publicitar el producto, ya que además de que el mismo aparezca en muchos sitios de internet, actualmente existe más de una vía de llegada, como pueden ser las redes sociales de: Facebook, Twitter o Instagram. Cada una posee su audiencia y su forma de comunicación, que se puede estimar como más o menos formal.

\section{F.1.3 Disponibilidad de la app en varios idiomas}

Este indicador hace referencia solamente al idioma de uso de la aplicación, no al idioma del contenido de la misma - como veremos más adelante, muchas aplicaciones también ofrecen audiolibros en varios idiomas-.

\section{F.1.4 Título identificable}

Según esta metodología, el título es fundamental para la optimización y visibilidad en una tienda de aplicaciones y además es uno de los indicadores principales de la App Store Optimation (ASO $\left.{ }^{71}\right)$.

Se recomienda que el título sea corto, para que ni el buscador ni el usuario demoren en encontrarlo, y que contenga como mínimo, una palabra clave de interés del usuario.

Agregamos que el título debe ser significativo, pero al mismo tiempo no tan general, para evitar ambigüedades y duplicidades con otros productos o servicios. Existe más de una aplicación que contiene la palabra audiolibro, y es difícil diferenciarlas cuando poseen iconos parecidos, por esta razón es de vital importancia la evaluación del siguiente parámetro que tiene que ver con la imagen.

\section{F.1.5 Icono identificable}

El icono de una aplicación es clave y diferenciador de otras aplicaciones. Los iconos despiertan el interés, pero también pueden ser disuasorios a la hora de descargar o no una aplicación.

En la metodología propuesta el icono debe poseer un diseño atractivo, y, de contener texto, este debe ser legible en el dispositivo que estemos utilizando. "Un icono mal diseñado, desagradable visualmente o que no se entiende lo que ofrece, puede ser decisivo a la hora de que el usuario decida descargarlo» (Sáez, 2013 citado en: Gómez Díaz et al. (ídem)).

\footnotetext{
${ }^{71}$ La ASO es «el proceso de optimización de las aplicaciones móviles que permite que aparezcan en los resultados de búsqueda de una tienda, una optimización en la que intervienen factores como el título, la descripción de la app, las valoraciones y los comentarios de los lectores, etcétera» (Gómez Díaz, et al., 2016: 170).
} 
Por último, es recomendable que las aplicaciones utilicen en todas las tiendas, un mismo icono que evoque a la marca.

\section{F.2. Adquisición}

Si realizamos una búsqueda de aplicaciones de audiolibros, la misma nos va a arrojar muchos resultados; tanto iniciativas editoriales como propuestas amateurs. En nuestra fase de relevamiento, solo en raras excepciones la instalación de la aplicación nos solicitaba la realización de un pago. Por lo general, la aplicación puede ser descargada y, una vez ya instalada en nuestros dispositivos, se ofrece información acerca de las formas de pago y de los servicios que prestan.

\section{F.2.1 Modalidad de adquisición de contenidos}

Existen varias modalidades de adquisición, como hemos analizado en el apartado 5.16 correspondiente a modelos de negocio del audiolibro. En la mayoría de los casos, el usuario al descargar una aplicación ya sabe de antemano cuáles son las modalidades de pago del contenido, bien porque llegó a la aplicación a través de una página web, o porque accedió a través de otro tipo de medio, como puede ser por una publicidad o una recomendación.

Si bien no lo detallan en la parte teórica de la metodología, en la misma subdividen a las adquisiciones en dos:

\section{Precio:}

- Gratuita

- Precio unitario de los títulos

Modalidad de adquisición de los contenidos:

- Compras integradas

- Suscripción

- Gratuita con publicidad

- Gratuita sin publicidad

- Versión lite de algunos títulos

- Ofertas (descuentos o lotes)

Para continuar con los modelos encontrados en plataformas de audiolectura, en nuestra metodología las dividiremos en:

1. Venta por suscripción

a. Suscripción ilimitada (cuando es posible acceder a todo el catálogo) 
b. Suscripción limitada (cuando el acceso es restringido a uno o pocos audiolibros)

2. Venta unitaria

3. Gratuita

\section{F.3. Seguridad}

La seguridad es un requisito valorable en todo tipo de aplicaciones y puede observarse a través de varios parámetros.

\section{F.3.1. Bloqueo de compras en la propia aplicación [No incluido en la metodología]}

En la metodología propuesta por Gómez Díaz, et al. incluyen este parámetro por tratarse de aplicaciones relacionadas con público infantil. En nuestra metodología no incluiremos este parámetro.

\section{F.3.2. Bloqueo de acceso a internet en la propia aplicación}

Este caso resulta de gran utilidad cuando el dispositivo electrónico es compartido con menores de edad (Gómez Díaz, et al. 2016:173).

\section{F.3.3. Adaptación de las claves de acceso a la edad}

Las aplicaciones utilizan diversos sistemas de controles de seguridad. El sistema más frecuente es el de la introducción de una clave. Muchos de ellos también solicitan la formulación y resolución de una pregunta de seguridad o realizar una acción en la pantalla. Estos sistemas deben estar acorde a la edad del usuario (ídem).

\section{F.4. Confidencialidad y privacidad}

Este punto es primordial. Las aplicaciones están obligadas a cumplir las leyes de protección de datos y asegurar la confidencialidad y privacidad de la información aportada por sus clientes.

\section{F.4.1. Explicación clara de la política de privacidad}

Para la evaluación de este punto deberemos recurrir a la página del desarrollador del producto cuando no esté claramente ofrecida en la propia aplicación. Qué datos solicitan, cuáles se recogen automáticamente y qué usos le dan a los mismos deberían quedar claramente explicitados.

\section{F.4.2. Anonimato de los menores [No incluido en la metodología]}

Según este modelo, "garantizar el anonimato de los menores es un requisito indispensable en cualquier aplicación, por lo que estas nunca deben solicitar ningún tipo de información personal para activar su funcionamiento y mucho menos sin el consentimiento del adulto» Gómez Díaz et al. (2016: 174). 


\section{F.5. Popularidad [Se incluye un parámetro]}

Este indicador que se expone a continuación no está libre de subjetividad, ya que se tienen en cuenta las propias opiniones de los usuarios y representa uno de los factores que determina la posición de una aplicación según la ASO. En redes sociales, la popularidad podría estar dada por el número de seguidores, o en una página web, las visitas a la misma.

En una aplicación viene dada por: número de descargas y valoraciones y puntuaciones positivas.

\section{F.5.1. Puntuación de los lectores}

Las puntuaciones pueden ofrecer una idea general del éxito de una aplicación determinada. Usualmente, tras la descarga de la App, el usuario ya se encuentra en condición de puntuar desde la propia Apple Store o Google Play, con una puntuación que va de 1 a 5 estrellas. También puede incluir comentarios públicos, que pueden ser útiles tanto a los futuros usuarios como a los propios diseñadores de dicha aplicación, quienes podrán incluir modificaciones o actualizaciones posteriores a su aplicación.

En el caso de las aplicaciones de audiolectura hemos comprobado que los comentarios, en su mayoría, contienen información interesante y coherente; esto puede deberse a que las personas que llegan a una aplicación de este tipo ya han utilizado otras aplicaciones de lectura y saben cuáles pueden ser los fallos o ventajas de una aplicación determinada. Además, suelen ser personas instruidas y con facilidad para la escritura.

Por ejemplo, en la tienda de Apple Store, encontramos bajo la aplicación de Storytel, el siguiente comentario realizado por la usuaria Eslypher, quien además les otorgó una puntuación de 5 estrellas:

Escucho libros todo el tiempo y me encanta, echo en falta en tu biblioteca una opción de estadísticas, que te digan en cuanto tiempo te has escuchado un libro, cuántas horas escuchas al día, cuál es el libro que has escuchado más rápido y más lento, ese tipo de estadísticas que también te hacen ver el valor de la app y te alientan a seguir escuchando. Estaría bien que se guardara dinámicamente la velocidad de escucha para cada libro, no es lo mismo una novela de ficción que un libro filosófico si uno lo tengo a $2 x$ se me guarde la preferencia y del otro a $1,5 x$. Por cierto añadiría más rapidez de $2 x$. Creo que se podría llegar a 2,5x. Se me ocurren muchas mejoras para la experiencia de usuario $[\ldots]^{72}$. Consulta de Apple Store.

Otro usuario les deja una puntuación de dos estrellas, con el siguiente mensaje:

Estaría bien que la suscripción mensual fuese más asequible, el precio actual es muy elevado. Tampoco entiendo por qué cuando sales de la app se para el audio, y estaría bien que no fuese así. Me parece que Storytel todavía está un poco verde aún. Miguecj86, 6 de abril de 2020. Consulta de: Apple Store

La metodología que estamos siguiendo aconseja como una evaluación positiva, aquella que haya recibido una puntuación igual o superior a tres puntos o estrellas sobre un mínimo de 10 valoraciones. Gómez Díaz et al. (2016), realizan una salvedad, y es que se exceptúan las valoraciones cuando la aplicación es de reciente aparición.

\footnotetext{
${ }^{72}$ La consulta fue realizada el 20/06/2020 y el comentario realizado por Eslypher no tiene una fecha exacta. Aparece simplemente la siguiente frase: «hace un año».
} 
Se infiere que las puntuaciones pueden verse afectadas por ciertas situaciones que pueden poner en juego su validez. Por ejemplo, los responsables de Android manifiestan que reciben correos electrónicos ofreciendo sus puntajes positivos a cambio de una compensación económica; y también afirman cómo esta posibilidad puede ser utilizada por la competencia para, a través de los votos negativos, desprestigiar un producto o servicio (Rico Rico, 2017: 299).

Otro punto interesante a tener en cuenta es que las propias plataformas se encargan de evaluar a las apps antes de permitir su acceso a la tienda actuando como un primer filtro. En el caso de Apple, para la evaluación utiliza una serie de criterios que van de los técnicos, estructurales hasta de contenido, para garantizar que funcione bien y que no tenga material ofensivo (ídem).

En cuanto a aplicaciones de lectura, aunque no introduciremos este parámetro, una sugerencia podría ser la de permitir realizar una puntuación de forma oral, ya que, como hemos estudiado en esta tesis existe un grupo de personas que utilizan los audiolibros por algún tipo de deficiencia visual.

\section{F.5.2. Cantidad de descargas}

Incluimos este parámetro que da cuenta de la popularidad de la aplicación. Debemos, sin embargo, tener en cuenta el año de creación de la aplicación y dividir la cantidad de descargas si queremos obtener un dato equiparable entre todas las plataformas.

\section{F.6. Reconocimiento [Se eliminan dos parámetros]}

En este apartado más que la valoración de un usuario se valora el reconocimiento entre profesionales del sector, que puede estar dado por premios y sellos de calidad. Muchas veces esta información está explicitada en la propia página web.

\section{F.6.1. Premios recibidos [Omitido]}

Si bien existen cada vez son más frecuentes los premios otorgados a aplicaciones móviles, no encontramos premios exclusivamente para aplicaciones destinadas a audiolectura, por lo cual no contemplaremos este indicador que sugieren en la presente metodología.

\section{F.6.2. Sellos de calidad obtenidos [Omitido]}

Los sellos de calidad representan una garantía más a la hora de elegir una aplicación u otra. Muchos de ellos son utilizados como reclamo por quienes comercializan la aplicación, pero actualmente existen incipientes sellos de calidad para el sector audio, por lo que dejamos este parámetro para incluir más adelante. 
En Estados Unidos, cada año, la Audio Publishers Association premia a los mejores títulos bajo diferentes categorías. La más importante es la de «audiolibro del año», si bien existen otras 23 categorías más, entre las que podemos encontrar: audio-drama, humor, misterio, no ficción, etc. Estos premios tienen una larga trayectoria, en su propia página web (https://www.audiopub.org/win$\underline{\text { ners/2020-audies) }}$ se puede acceder a las ediciones anteriores. La primera, del año 1996 contaba con 15 categorías.

\section{F.7 Usabilidad [Se elimina uno de los parámetros y se modifica otro] En la metodología final aparecerá como F.6, por haberse omitido el punto anterior.}

La usabilidad es un concepto equiparable al de user friendly en inglés. Con este término se hace hincapié en la facilidad de manejo que ofrece un producto o servicio a través de internet (González Sánchez, et al., 2012:531)

En la metodología citan dos definiciones de la norma ISO. Una es la capacidad de un software de ser comprendido, aprendido, usado y ser atractivo para el usuario, en condiciones específicas de uso (ISO/IEC9126), en la que se hace referencia a aspectos internos y externos del producto y a la dependencia de la usabilidad del propio usuario; y, por otro lado, la «eficacia, eficiencia y satisfacción con la que un producto permite alcanzar objetivos específicos a usuarios específicos en un contexto de uso específico» (ISO/IEC9241). Según González Sánchez, et al. (ídem) esta definición es idónea para evaluar sistemas o softwares de información cuando este está orientado al ámbito profesional, pero presenta limitaciones cuando se trata de productos destinados al entretenimiento, en los cuales «la dimensión satisfacción juega un papel más relevante».

Enriquez y Casas consideran que, con la aparición y el uso masivo de los dispositivos móviles, comenzaron a realizarse mediciones de usabilidad, pero aluden que las métricas actuales no fueron diseñadas para contextos móviles, puesto que normalmente se utilizaban en usuarios que interactuaban con un ordenador y que la usabilidad de las apps está fuertemente influenciada por su contexto (2013:25). En nuestro caso, nosotros mismos, al confeccionar una metodología somos evaluadores, pero también parte o usuarios que experimentamos teniendo en cuenta diferentes factores que conforman el contexto y que pueden ser variables, como el tiempo y el espacio. Por ejemplo, evaluar si una aplicación determinada tiene un «modo noche» o si es apta para utilizarla en trayectos en coche.

Toda la información que se pueda recabar sirve para medir posibles efectos del entorno, y como consecuencia, el desarrollador tendrá información para anticiparse a los requerimientos de los usuarios.

Para simplificar, y aunque resulte un planteamiento obvio desde el punto de vista del usuario, un producto tendrá una buena usabilidad cuando este le resulte fácil de utilizar, teniendo en mente siempre la finalidad del producto:

La usabilidad es un atributo de calidad de un producto que se refiere sencillamente a su facilidad de uso. No se trata de un atributo universal, ya que un producto será usable si lo es para su audiencia específica y para el propósito específico con el que fue diseñada. (Hassan, 2015:9)

Los criterios citados hasta el momento se desglosan en una serie de indicadores que se resumen a continuación:

\section{F.7.1. Velocidad [Se elimina uno de los parámetros y se modifica el nombre del otro]}


Este indicador se refiere al tiempo de apertura de la aplicación. Los tiempos de apertura pueden variar teniendo en cuenta los sistemas operativos utilizados, pero, en general puede que la aplicación incluya este dato. Además, también es aconsejable incluir datos relacionados al proceso de descarga: loading, descargando, etc.

Se elimina la variable Apertura rápida, que tiene más que ver con los libros impresos y no con el formato audiolibro, sin embargo, se deja la subvariable «Mensajes del proceso de descarga durante los tiempos muertos" ya que es deseable que se muestre en qué momento de la descarga nos encontramos. Además, se cambia a "Mensaje del proceso de descarga» ya que no solo hacemos referencia a los tiempos muertos sino a la descarga del audio en cualquier fase del proceso.

\section{F.7.2 Navegación}

Conforme los softwares se actualizan, ofrecen más modernos y variados recursos de navegación, favoreciendo al usuario en el manejo de las aplicaciones.

Entre los elementos recomendados por Gómez Díaz, et al. (2016:176) encontramos: botones operativos, acciones sencillas de realizar, fluidez técnica e indicaciones con un tamaño correcto y ubicados en lugares visibles. Otra forma de mejorar la navegación es indicar la posibilidad de acceder al menú principal desde cualquier página.

Una opción interesante que podrían tener los desarrolladores de aplicaciones de audiolectura, podría ser la de la posibilidad de interactuar con la voz, lo cual permitiría a las personas que no pueden acceder por razones de orden físico, a navegar en la plataforma sin necesidad de ser asistidos por otras personas.

\section{F.8 Ergonomía}

En la tabla final aparecerá como F.7, por haberse omitido el parámetro F.6 (Reconocimiento).

Este concepto abarca varios parámetros que permiten la visualización de la información de una forma clara y sencilla y que veremos en las siguientes variables, todas presentes en la metodología original de Gómez Díaz, et al.

\section{F.8.1 Legibilidad}

La tipografía está ligada a la usabilidad y a la accesibilidad de una aplicación. Para una correcta legibilidad, en primer lugar, es importante tener en cuenta el tamaño de las cajas de texto, el interlineado y el ancho de las columnas.

La mejor forma de asegurar una correcta legibilidad es ponerla a prueba en el teléfono para el cual se diseña (Cuello y Vittone, 2013:139). Para que los diseños se ajusten a la pantalla deben ser testeados en cada uno de los dispositivos, ya que no es lo mismo interactuar con una aplicación de lectura desde un teléfono móvil que desde una tableta. 
Existen algunas recomendaciones básicas con relación al tamaño de letra: para dispositivos Android, se recomienda tamaños de letra entre 12 sp como mínimo y $22 \mathrm{sp}$ como máximo. En cambio, para los dispositivos iOS es recomendable utilizar como mínimo textos de 20px para los textos más reducidos hasta los 32 píxeles a los que se puede llegar en los titulares (ídem).

\section{F.8.2 Claridad}

Este punto tiene que ver con el contraste de la letra y el fondo. Es necesario un equilibrio entre la cantidad de elementos que hay en la pantalla, una tipografía adecuada y su contraste con el fondo.

Por regla general es necesario que la fuente posea un contraste respecto al fondo para que resulte cómoda su lectura, pero que dicho contraste no sea excesivo y que produzca un efecto óptico indeseado.

\section{F.8.3 Uso del color}

La selección adecuada de colores favorece la legibilidad de los elementos de la pantalla.

La utilización de color dentro de las interfaces de una aplicación es un recurso válido para destacar elementos, así como diferenciar categorías o secciones y orientar a un usuario intuitivamente respecto al uso de una aplicación. La utilización de colores globales, bien como fondo o como recurso repetido dentro de los iconos de la interfaz, puede otorgar a la aplicación una armonía que apoyará el concepto de la marca (Sanchis Gandía, 2017:292).

Hay que tener en cuenta el público al cual está orientada la aplicación. Las interfaces fuertes y brillantes suelen ser seleccionadas en aplicaciones infantiles.

\subsubsection{Dimensión de contenido}

Los parámetros que se desprenden de esta dimensión son: autoría, actualización, contenido, accesibilidad, organización de los contenidos, personalización de los contenidos, interacción con los contenidos, calidad del audio e interactividad.

\section{C.1. Autoría}

En este apartado se determina el prestigio o la especialidad de la empresa que desarrolla la aplicación. Para recabar más datos se recomienda acudir a la propia web de este desarrollador. En el caso de las aplicaciones de audiolectura, la autoría no se refiere a los títulos que contiene la app, sino de la propia empresa creadora de la misma.

\section{C.1.1. Mención del editor / desarrollador}


La figura del desarrollador, o la empresa que se encarga del desarrollo tecnológico de una aplicación, es según Gómez Díaz, et al. (2016:179) uno de los nuevos criterios que se introducen con la edición digital, y su importancia en la selección radica en que la calidad técnica de un producto puede contar con el respaldo o el aval de dicha empresa.

\section{C.2.Actualización}

Las aplicaciones no permanecen estáticas desde que salen a la venta. Por esa razón utilizan las actualizaciones para poner al día sus programas. En muchos casos son las propias opiniones de los usuarios las que sirven de base para que se realicen depuraciones o cambios para un mejor uso y aprovechamiento de la aplicación.

\section{C.2.1. Especificación de la fecha de creación}

Es muy útil contar con información acerca de la fecha de creación de una determinada aplicación. Las aplicaciones más antiguas ya habrán pasado por la mayor fase de actualizaciones, mientras que las más recientes todavía no contarán con el feedback de los usuarios.

\section{C.2.2. Especificación de la fecha de la última versión}

La mayoría de las versiones se van actualizando periódicamente, según el sistema operativo y este ítem da cuenta de que la empresa intenta aportar ventajas operativas al sistema, o de subsanar algún error en la programación de la aplicación, por lo cual consideramos que es de mucha utilidad dicho indicador.

\section{C.2.3. Especificación del historial de versiones}

Si queremos realizar un rastreo de cuáles son las actualizaciones realizadas por una determinada aplicación, debemos remitirnos a su historial. Hay casos en donde solo se permite ver la última actualización, mientras que, en otros casos, como en Apple Store el historial estará completo (Gómez Díaz, et al. 2016:180).

\section{C.2.4. Incorporación de nuevos títulos}

Este punto tiene que ver con la frecuencia de actualización de contenido de la aplicación. Para esto, se pueden consultar fuentes externas a la aplicación, como puede ser la propia página web del desarrollador o bien ingresar a la aplicación y consultar la sección de «novedades», si es que dispone de ella.

Una constante actualización de títulos puede darnos la pista de que es una empresa que apuesta por la renovación de su catálogo y la fidelización de sus usuarios. 


\section{C.3. Contenidos}

Esta variable abarca dos indicadores a saber: cantidad y variedad.

\section{C.3.1. Cantidad de contenidos}

Este indicador está dado por el número de títulos que componen la aplicación. Es interesante ver si este número es pequeño o extenso y si el mismo va creciendo o se mantiene estático por mucho tiempo. Nos servirá para realizar comparaciones con otras aplicaciones, y poder tomar decisiones a la hora de subscribirnos a algún servicio de audiolectura.

Desafortunadamente, como hemos evidenciado en nuestro trabajo de campo, en el ámbito de los audiolibros son pocas las empresas que brindan este tipo de información, y deberemos guiarnos por datos generales.

\section{C.3.2. Variedad de temas, géneros y edades.}

Es un parámetro que utilizaremos en nuestra plantilla porque la dotación de diversos contenidos en una aplicación de lectura es muy recomendable. Si bien nuestro objeto de estudio son audiolibros digitales relacionados con la literatura para adultos, es deseable que la aplicación específica para audiolibros ofrezca diversas áreas temáticas, así como opciones para diferentes edades, enriqueciendo de esta forma el catálogo.

\section{C.4.Accesibilidad [se incluye un parámetro y se eliminan otros]}

A través de este parámetro, se comprobarán las herramientas de la app para un mejor acceso o a los contenidos. La accesibilidad, según Sanchiz Gandía (2017:171) es un concepto que surge como una ramificación de la usabilidad y «su objetivo es favorecer la igualdad de condiciones ante la diversidad humana para el acceso a cualquier servicio, producto o tecnología».

La usabilidad no es solo una cuestión de si es o no posible para un usuario la realización de una tarea sino también cuán fácil y rápido puede realizarla (Nielsen, 2001).

Otro aspecto importante a tener en cuenta es que en apps específicas de audiolectura, el contenido es, de por sí, más inaccesible que el textual. Es decir, que para saber si nos interesa o no escuchar un título narrado por determinada persona, debemos reproducir un archivo. De modo que sería deseable contar con la mayor cantidad de metainformación posible de antemano, y para esto es crucial que la app cuente con sistemas de búsqueda preparados para realizar interrogaciones por varios criterios.

\section{C.4.1. Campos de búsqueda en la tienda [inclusión de un parámetro]}

Aquí se enumeran los criterios por los cuales un usuario podría recuperar una obra determinada dentro de una app de audiolectura. Entre ellos encontramos: autor, título, materia, categorías, etc. Estos criterios estarán orientados al perfil de usuarios de cada aplicación. 
Si bien en la descripción de la metodología se indica el título como un criterio para la búsqueda en la tienda de libros, en el cuadro metodológico no incluyen este parámetro los autores Gómez Díaz, et al. Además, la búsqueda por duración del audio también resulta de interés para el formato audio, por lo cual nuestra metodología incorporará los siguientes ítems:
a) Autor
b) Título
c) Tema
d) Duración del audiolibro
e) Edad

\section{C.4.2. Información sobre los títulos [eliminación e inclusión de subindicadores]}

Cuanto más exhaustiva sea la información que se muestra sobre las obras, más datos tendrá el usuario para poder seleccionar la obra de su interés. Según la experiencia recogida en nuestro trabajo de campo es de vital importancia que siempre se muestren los datos de la misma forma dentro de una aplicación, para poder localizar fácilmente la información de interés. Todos los datos deberían aparecer en el primer pantallazo tras haber sido realizada la interrogación.

En la metodología se sugieren tres subindicadores imprescindibles:
a) Autor/llustrador/traductor
b) Precio
c) Resumen

Teniendo en cuenta que la metodología será para contenidos de audio, y el ilustrador hace referencia a bibliografía impresa y/o textual eliminamos al ilustrador de los parámetros a medir y quedaría este ítem del siguiente modo:

\section{a) Autor/traductor}

Incluimos como imprescindible la información dada sobre el "narrador». Ya vimos en el capítulo 5.7.1.1 la importancia que tiene un narrador en la recepción de la audiolectura. De hecho, existen algunas aplicaciones que, dentro de categorías de audiolibros, como pueden ser: audiolibros policiales, infantiles, de amor, incluyen una categoría: "audiolibros narrados por:», dado que existen personas que tras la escucha de un libro priorizan al relator sobre otras cualidades.

Otros elementos importantes a la hora de seleccionar un audiolibro es su duración. El oyente puede desear finalizar una obra en un tiempo determinado o preferir simplemente textos cortos, por lo cual es recomendable que la app ofrezca información acerca de la duración de la obra completa, así en aplicaciones de lectura tradicionales se ofrece información acerca de la cantidad de páginas de una obra.

Es altamente recomendable la presencia de una demo en cada título. Este avance de la lectura es recomendable para audiolibros y está muy relacionado con el ítem «narrador». Una voz puede animar o disuadirnos de elegir una audiolectura. 
Otros datos de interés para los audiolibros, que consideramos deben incluirse y que hemos encontrado en muy pocos casos son los datos del ejemplar que se lee; es decir, el origen editorial del audiolibro. Además, sería deseable que se indique si se trata de una versión íntegra o abreviada.

Por último, sería recomendable incluir la imagen de la portada del audiolibro.

De los tres subindicadores iniciales pasamos a los siguientes nueve:
a) Autor/traductor (imprescindible)
b) Narrador (imprescindible)
c) Precio (imprescindible) * siempre y cuando el precio sea unitario.
d) Resumen (imprescindible)
e) Duración (imprescindible)
f) Disponibilidad de demo (imprescindible)
g) Datos del original impreso o ebook (imprescindible)
h) Tipo de versión (imprescindible)
i) Portada (recomendable)

\section{C.4.3. Lectura sin conexión a Internet}

Según Gómez Díaz, et al. (2016:182) «es conveniente que las apps permitan la lectura sin conexión a Internet, y más en el caso de los menores, para los que hemos podido establecer algún sistema de control parental».

\section{C.5. Organización de contenidos}

Este parámetro mide la forma en la que se organizan y se visualizan los contenidos de cada aplicación.

\section{C.5.1. Tipos de visualización}

Según la metodología de Gómez Díaz et al., existen dos modos de visualización: en forma de expositor y en modo lista.

\section{C.5.2. Posibilidad de cambiar el modo de visualización}

Se valorará la posibilidad de poder elegir un modo u otro: modo expositor y modo lista.

\section{C.5.3. Organización de carpetas}

Según esta metodología, es recomendable que las aplicaciones permitan la opción de personalizar carpetas, a fin de poder encontrar y recuperar más fácilmente las obras. En algunas aplicaciones hemos observado que existe la opción «Mis lecturas», o «Mi biblioteca», carpeta en la cual se van alojando las lecturas que estamos realizando en el momento, o el historial de las lecturas. 


\section{C.5.4. Eliminación de títulos}

Es muy valorable la opción de brindar al usuario la posibilidad de la eliminación de ítems que ya no son de su interés. La facilidad de realizar esta tarea también será evaluada.

\section{C.5.5. Restauración de títulos}

Es imprescindible que exista la posibilidad de restaurar las compras, máxime si hemos comprado o estamos suscritos a una app determinada. Se valorará la facilidad del uso de esta posibilidad.

\section{C.5.6. Restauración sencilla e intuitiva}

Si bien no está incluida en la parte teórica sí existe esta variable en la metodología de Gómez Díaz, et al. (2016:247) y creemos que es importante que esta opción pueda realizarse con facilidad.

\section{C.6. Personalización de los contenidos [eliminación de parámetros e inclusión de nuevos]}

Cada vez son más las opciones que nos brindan las aplicaciones de lectura en relación con la personalización de contenidos. Tareas como comentar, subrayar y copiar son las básicas y las que realizamos corrientemente en cualquier programa informático.

Otras tareas que están más en sintonía con las redes sociales, podrían ser opciones como: compartir nuestras lecturas, tener la librería a golpe de clic o cambiar la tipografía (Gómez Díaz, et al., 2016:183).

\section{C.6.1. Posibilidad del texto [eliminación de dos parámetros de la metodología]}

En la guía indican que se valora la posibilidad de modificar aspectos formales, no de contenido. Estos pueden ser: cambiar el tipo y tamaño de letra, brillo o fondo de pantalla, entre otros.

Para el tipo de formato con el que trabajamos en esta tesis, y como se verá en plantilla de evaluación, se eliminarán de la metodología original los indicadores: «tipo y tamaño de letra» y «lectura a doble página» ya que estos indicadores están relacionados a aplicaciones de lectura textuales y no auditivas. Permanecerá en la plantilla la «Posibilidad de ajuste de brillo y fondo de pantalla» porque resulta útil a la hora de navegar por la aplicación o seleccionar un audiolibro, dado que esta funcionalidad mejora la lectura con contraste.

C.6.2. Posibilidad de personalizar los aspectos formales del audio [eliminación e inclusión de más subindicadores] 
Este indicador mide diversas posibilidades relacionadas con el audio, por lo cual son de crucial interés para nuestro objeto de estudio.

En la metodología original se incluyen los siguientes subindicadores:
a) Locución
b) Cambio de idioma de la narración
c) Grabación personalizada
d) Activación/desactivación de los efectos del audio

Al estar orientada la metodología original a aplicaciones infantiles de lectura, el audio es un complemento que en ocasiones puede sumarse o desactivarse a la experiencia lectora, por lo cual no creemos que ninguno de estos parámetros pueda aplicarse a nuestro objeto de estudio. No hemos observado en nuestro trabajo de campo la posibilidad del cambio de locutor, ni del cambio de idioma de una narración. Tampoco la posibilidad de una grabación personalizada, ni la de desactivar efectos del audio.

Incluiremos como subindicador imprescindible de la personalización del audio la posibilidad de adelantar o retroceder el audio y como recomendables: la posibilidad de modificar la velocidad de reproducción, así como si dispone o no de temporizador (recomendable), si dispone del llamado «modo automóvil» o la opción de desplazarse por capítulos dentro de un libro. En total, este indicador contendría 5 subindicadores, teniendo en cuenta que hemos eliminado los cuatro originales.

\section{Posibilidad de adelantar o retroceder el audio}

2. Posibilidad de modificar la velocidad de reproducción

3. Disponibilidad de temporizador

4. Disponibilidad de modo automóvil

5. Desplazamiento por capítulos del título

\section{C.6.3. Posibilidad de personalizar los aspectos formales del video y de la animación [Omitido]}

La metodología sugiere que cuando todos los ítems de la aplicación incluyan estas posibilidades audiovisuales se podrá evaluar este indicador. Según esta metodología se valoran aquellas en las que los audiovisuales no se activen automáticamente, sino que el lector tenga la posibilidad de realizar dicha acción; sin embargo, dado que nuestro objetivo es el de evaluar solo aplicaciones dedicadas al audio, descartamos este indicador por no ser de relevancia para nuestro estudio.

\section{C.6.4. Búsqueda de contenidos [Omitido]}

En aplicaciones relacionadas con la lectura es indiscutible la importancia de la búsqueda de palabras en un diccionario en la aplicación. En la guía propuesta por Gómez Díaz, et al. subdividen este indicador en tres ítems: búsqueda en diccionarios, búsqueda en internet y búsqueda en Wikipedia.

No consideramos oportuno incluir ninguno de estos tres parámetros para medir la calidad de aplicaciones de audiolectura, sin embargo, sí creemos que resulta de mucha utilidad para nuestro objeto de estudio la posibilidad de realizar anotaciones, ítem evaluado en el siguiente punto. 


\section{C.6.5. Anotaciones [eliminación de alguno de los parámetros de la metodología]}

La metodología original contempla cuatro parámetros:

1. subrayar y destacar

2. incluir/borrar notas

3. incluir, borrar marcadores

4. índice de notas y marcadores.

Eliminamos el primer parámetro: «subrayar y destacar», ya que está más orientado a aplicaciones de lectura textual y no de audiolectura; sin embargo, dejamos los otros tres subindicadores ya que nuestra experiencia en aplicaciones sonoras nos permite asegurar que son de mucha utilidad.

\section{C.7.Interacción con los contenidos}

Las redes sociales nos permiten realizar una lectura más social y conectada. Trasladando esa lectura a una aplicación de audiolibros, ésta debería ofrecer posibilidades de: compartir lecturas, valorarlas, hacer comentarios y conocer la opinión de otros usuarios.

\section{C.7.1. Posibilidad de compartir comentarios o valoraciones}

Existen diversas formas de valorar las aplicaciones. Se determinará de qué manera se ofrece esta posibilidad, si es a través de las redes sociales, desde la propia página de descarga, a través de un correo electrónico, o de otro medio.

\section{C.7.2. Posibilidad de puntuar}

Muchas plataformas incluyen la posibilidad de dar de 1 a 5 estrellas o puntos a fin de valorar una aplicación.

Se tendrá en cuenta desde qué sitios se puede realizar dicha valoración.

\section{C.8. Variedad de audio [se elimina un parámetro y se agrega otro]}

Esta variable mide la calidad de cada tipo de audio, pero si adaptamos la metodología a elementos sonoros debemos eliminar la subvariable «locución» ya que es obligatoria en un audiolibro, y dejar las otras dos opciones que podrían identificar otros aspectos de interés, como se puede observar a continuación:

\section{C.8.1 Tipo de audio}

Se especificará si incluye: 


\section{-Locución [omitido]}

-Varios narradores: Audiolibro con más de una voz. [se incluye]

-Banda sonora: si incluye música de fondo

-Efectos de sonido: si incluye efectos de sonido.

\section{C.9. Interactividad [se elimina el parámetro]}

El parámetro no aparecerá en la metodología, por haberse omitido el único indicador.

El ámbito del libro es especialmente permeable a las posibilidades de la nueva interactividad, en el contexto digital. La web 2.0. configuró una serie de herramientas que luego varios sectores utilizaron en sus propias plataformas.

Algunas de estas posibilidades incluyen al lector como partícipe de la historia, ofreciéndole la posibilidad de que tome decisiones en el proceso de lectura. Si estas posibilidades están bien diseñadas, pueden aportar mucho a la experiencia lectora, pero también pueden causar distracción y abandono de la lectura. Sin embargo, son especialmente utilizadas en literatura infantil y juvenil.

\section{C.9.1 Existencia de interactividad [No incluido en la metodología]}

Si bien la metodología indica que la existencia de interactividad supone un valor añadido, revisadas la totalidad de las aplicaciones de audiolectura no encontramos dicho indicador, por lo cual decidimos eliminarlo de la plantilla.

\subsection{PLANTILLA DE EVALUACIÓN}

La plantilla de evaluación se realizó en tablas utilizando un editor de tipo Word, pero se materializó a través de los recursos del Google Drive, dado que permiten crear formularios en línea y en el caso de aplicar la metodología, realizar el conteo de forma automática.

Soriano Rodríguez (2014:21) recomienda claridad de los conceptos sobre el constructo teórico, medición, confiabilidad y validez para la elaboración de los instrumentos de medición. También afirma que, de acuerdo con la Teoría Clásica de los Test, «la confiabilidad se define como el grado en que un instrumento construido por varios ítems presenta una alta correlación y miden consistentemente una muestra» (ibídem, 31-32).

Todos los anteriores parámetros explicados de forma teórica estarán reflejados en una plantilla que recogerá la información de modo que pueda ser contabilizada numéricamente. Para esta evaluación, se valorará positivamente con un uno (1) o no se valora, indicándolo con un cero (0).

Esta planilla también incluye el detalle de cuándo un ítem es imprescindible y cuándo es recomendable. Una vez volcados los datos, una aplicación determinada podrá ser: 
a. Altamente recomendable: cuando el $80 \%$ de lo sindicadores imprescindibles y recomendables están presentes;

b. Recomendable: cuando presentan entre el 50 y el $79 \%$ de los indicadores antes mencionados.

c. Prescindible: cuando no logran alcanzar el $49 \%$ de los indicadores imprescindibles y recomendables (Gómez Díaz, et al.,2016:187).

Si bien realizamos la explicación de cuáles son los parámetros nuevos, excluidos y modificados, trasladaremos dicha información a la siguiente tabla para que resulte más fácil observar las modificaciones. Para esto resaltaremos los parámetros con los siguientes colores:

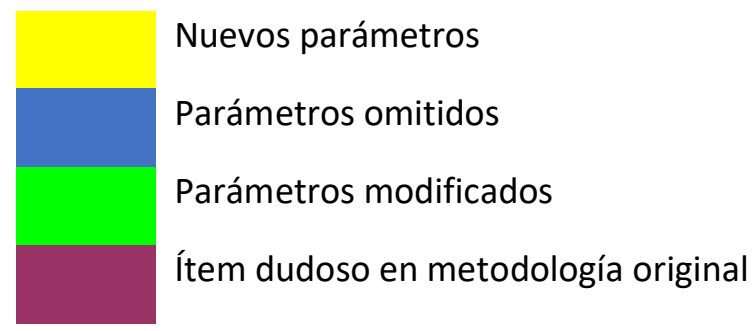

Tabla 8. Plantilla de evaluación original

\begin{tabular}{|l|l|l|l|l|}
\hline \multicolumn{2}{|l|}{ Datos Generales de la Aplicación } & \multicolumn{3}{l|}{} \\
\hline Aplicación: & & & \\
\hline Desarrollador: & & & \\
\hline Fecha de la versión analizada & & & \\
\hline Fecha de Publicación: & & Ingles & Francés & Catalán \\
\hline Tamaño: & Español & Euskera & Otros: \\
\hline Requiere: & Gallego & Infantil (especificar edad) \\
\hline \multirow{2}{*}{ Idiomas } & General & \\
\hline Edad &
\end{tabular}

\section{Dimensión Forma}

\begin{tabular}{|l|l|l|l|l|l|}
\hline Parámetro & \multicolumn{1}{|l|}{ Indicadores } & No = $\mathbf{0}$ & Sí $=\mathbf{1}$ & Observaciones \\
\hline \multirow{3}{*}{ F.1. Disponibilidad } & $\begin{array}{l}\text { Disponibilidad para di- } \\
\text { ferentes sistemas ope- } \\
\text { rativos }\end{array}$ & iOs & & & \\
\cline { 3 - 7 } & Otros & & & \\
\end{tabular}




\begin{tabular}{|c|c|c|c|c|}
\hline & \multicolumn{3}{|c|}{ Disponibilidad en diferentes sitios } & Recomendable \\
\hline & \multicolumn{3}{|c|}{ Disponibilidad de la app en diferentes idiomas } & \\
\hline & \multicolumn{3}{|c|}{ Título Identificable } & Imprescindible \\
\hline & \multicolumn{3}{|c|}{ Ícono Identificable } & Imprescindible \\
\hline \multirow{9}{*}{ F.2. Adquisición } & \multirow{2}{*}{ Precio } & \multicolumn{2}{|l|}{ Gratuita } & \\
\hline & & \multicolumn{2}{|c|}{ Precio unitario de los audiolibros } & \\
\hline & \multirow{7}{*}{$\begin{array}{l}\text { Modalidad d } \\
\text { ción de los cc }\end{array}$} & \multirow{2}{*}{ Venta por suscripción } & llimitada & \\
\hline & & & limitada & \\
\hline & & \multirow{2}{*}{\multicolumn{2}{|c|}{ Venta unitaria }} & \\
\hline & & & & \\
\hline & & \multicolumn{2}{|l|}{ Gratuita } & \\
\hline & & \multicolumn{2}{|c|}{ Versión lite de algunos títulos } & \\
\hline & & \multicolumn{2}{|c|}{ Ofertas (descuentos o lotes) } & \\
\hline \multirow{3}{*}{ F.3. Seguridad } & \multicolumn{3}{|c|}{ Bloqueo de compras en la misma aplicación } & $\begin{array}{l}\text { Imprescindible } \\
\text { para menores }\end{array}$ \\
\hline & \multicolumn{3}{|c|}{ Control de acceso a internet en la propia aplicación } & $\begin{array}{l}\text { Imprescindible } \\
\text { para menores }\end{array}$ \\
\hline & \multicolumn{3}{|c|}{ Adaptación de claves a la edad del usuario } & $\begin{array}{l}\text { Imprescindible } \\
\text { para menores }\end{array}$ \\
\hline \multirow{2}{*}{$\begin{array}{l}\text { F.4. Confidencialidad } \\
\text { y privacidad }\end{array}$} & \multicolumn{3}{|c|}{ Explicación clara de la política de privacidad } & Imprescindible \\
\hline & \multicolumn{3}{|c|}{ Anonimato de los menores } & Imprescindible \\
\hline \multirow[t]{2}{*}{ F.5. Popularidad } & \multicolumn{3}{|c|}{ Puntuación de los lectores } & $\begin{array}{l}\text { Solo valorar posi- } \\
\text { tivamente a par- } \\
\text { tir de } 10 \text { valora- } \\
\text { ciones }\end{array}$ \\
\hline & \multicolumn{3}{|c|}{ Cantidad de descargas de la app } & \\
\hline \multirow{2}{*}{ F.6 Reconocimientos } & \multicolumn{3}{|c|}{ Premios recibidos } & Indicar premios \\
\hline & \multicolumn{3}{|c|}{ Sellos de calidad } & Indicar sellos \\
\hline \multirow{6}{*}{ F.7 Usabilidad } & \multirow[t]{2}{*}{ Velocidad } & \multicolumn{2}{|l|}{ Apertura rápida } & $\begin{array}{l}\text { De } 10 \text { a } 25 \text { se- } \\
\text { gundos, reco- } \\
\text { mendación }\end{array}$ \\
\hline & & \multicolumn{2}{|c|}{$\begin{array}{l}\text { Mensaje del proceso de descarga du- } \\
\text { rante }\end{array}$} & \\
\hline & \multirow{4}{*}{ Navegación } & \multicolumn{2}{|c|}{ Navegación sencilla e intuitiva } & Recomendable \\
\hline & & Funcionamiento correc & & Imprescindible \\
\hline & & $\begin{array}{l}\text { Iconos de los botones } \\
\text { tificables }\end{array}$ & acción iden- & Imprescindible \\
\hline & & Existencias de ayudas & tutoriales & Recomendable \\
\hline
\end{tabular}




\begin{tabular}{|c|c|c|c|}
\hline & & $\begin{array}{l}\text { Acceso al menú desde todas las pági- } \\
\text { nas }\end{array}$ & Recomendable \\
\hline & & $\begin{array}{l}\text { Posibilidad de ocultar y mostrar } \\
\text { menú }\end{array}$ & Recomendable \\
\hline \multirow{4}{*}{ F.8. Ergonomía } & \multirow{2}{*}{ Legibilidad } & Tamaño de letra legible & \\
\hline & & Tipo de letra legible & \\
\hline & \multicolumn{2}{|l|}{ Claridad } & \\
\hline & \multicolumn{2}{|c|}{ Uso adecuado del color } & \\
\hline
\end{tabular}

\section{Dimensión Contenido}

\begin{tabular}{|c|c|c|c|c|c|}
\hline Parámetro & \multicolumn{2}{|l|}{ Indicadores } & No $=0$ & Sí = 1 & Observaciones \\
\hline C.1. Autoría & \multicolumn{2}{|l|}{ Mención del editor/autor } & & & Imprescindible \\
\hline \multirow{4}{*}{ C.2. Actualización } & \multicolumn{2}{|c|}{ Especificación de la fecha de creación } & & & Imprescindible \\
\hline & \multicolumn{2}{|c|}{ Especificación de la fecha de última versión } & & & \\
\hline & \multicolumn{2}{|c|}{ Especificaciones del historial de versiones } & & & \\
\hline & \multicolumn{2}{|c|}{ Incorporación frecuente de nuevos títulos } & & & Recomendable \\
\hline \multirow{2}{*}{ C.3 Contenido } & \multicolumn{2}{|l|}{ Cantidad de contenido } & & & \\
\hline & \multicolumn{2}{|c|}{ Variedad de temas, géneros y edades } & & & $\begin{array}{l}\text { Valorable según } \\
\text { tipo de app }\end{array}$ \\
\hline \multirow{13}{*}{ C.4. Accesibilidad } & \multirow{5}{*}{$\begin{array}{l}\text { Campos de búsqueda } \\
\text { en la tienda }\end{array}$} & Autor & & & *Imprescindible \\
\hline & & Título $^{73}$ & & & *Imprescindible \\
\hline & & Tema & & & *Imprescindible \\
\hline & & Duración & & & *Imprescindible \\
\hline & & Edad & & & $\begin{array}{l}\text { Recomendable en } \\
\text { las infantiles }\end{array}$ \\
\hline & \multirow{8}{*}{$\begin{array}{l}\text { Información sobre los } \\
\text { títulos }\end{array}$} & Autor/traductor & & & Imprescindible \\
\hline & & Narrador & & & Imprescindible \\
\hline & & Precio & & & Imprescindible* \\
\hline & & Resumen & & & Imprescindible \\
\hline & & Duración & & & *Imprescindible \\
\hline & & Disponibilidad de DEMO & & & *Imprescindible \\
\hline & & Datos del original & & & *Imprescindible \\
\hline & & Tipo de versión & & & *Imprescindible \\
\hline
\end{tabular}

\footnotetext{
${ }^{73}$ Presente en la explicación teórica de la metodología, pero no en los formularios de la metodología original (p.188-191) ni en el anexo III
} en donde se ofrece un ejemplo práctico (p.245-252). 


\begin{tabular}{|c|c|c|c|}
\hline & & Portada & Recomendable \\
\hline & \multicolumn{2}{|c|}{ Lectura sin conexión a internet } & Recomendable \\
\hline \multirow{8}{*}{$\begin{array}{l}\text { C.5. Organización de } \\
\text { los contenidos }\end{array}$} & \multirow[t]{2}{*}{ Tipos de visualización } & Estantería & $\begin{array}{l}\text { Recomendables en } \\
\text { las infantiles }\end{array}$ \\
\hline & & Listado & \\
\hline & \multicolumn{2}{|c|}{ Posibilidad de cambiar el modo de visualización } & \\
\hline & \multicolumn{2}{|l|}{ Organización de carpetas } & \\
\hline & \multirow{2}{*}{ Eliminación de títulos } & Posibilidad de eliminar títulos & Imprescindible \\
\hline & & Eliminación directa de la estantería & Recomendable \\
\hline & \multicolumn{2}{|l|}{ Restauración de títulos } & Imprescindible \\
\hline & \multicolumn{2}{|c|}{ Restauración sencilla e intuitiva ${ }^{74}$} & \\
\hline \multirow{15}{*}{$\begin{array}{l}\text { C.6. Personalización de los } \\
\text { contenidos }\end{array}$} & \multirow{12}{*}{$\begin{array}{l}\text { Posibilidad de persona- } \\
\text { lizar los aspectos for- } \\
\text { males del audio }\end{array}$} & Tipo y tamaño de letra & Recomendable \\
\hline & & Ajuste de brillo y fondo de pantalla & Recomendable \\
\hline & & Lectura a doble página & $\begin{array}{l}\text { Solo valorable posi- } \\
\text { tivamente en los li- } \\
\text { bros de imágenes }\end{array}$ \\
\hline & & Locución & \\
\hline & & Cambio de idioma en la narración & Recomendable \\
\hline & & Grabación personalizada & $\begin{array}{l}\text { Recomendable } \\
\text { para menores de } 6 \\
\text { años }\end{array}$ \\
\hline & & $\begin{array}{l}\text { Activación/Desactivación de los efec- } \\
\text { tos del audio }\end{array}$ & Imprescindible \\
\hline & & $\begin{array}{l}\text { Posibilidad de adelantar o retroceder } \\
\text { el audio }\end{array}$ & Imprescindible \\
\hline & & $\begin{array}{l}\text { Posibilidad de modificar la velocidad } \\
\text { de reproducción }\end{array}$ & Recomendable \\
\hline & & Disponibilidad de temporizador & Recomendable \\
\hline & & Disponibilidad de modo automóvil & Recomendable \\
\hline & & $\begin{array}{l}\text { Desplazamiento por capítulos del tí- } \\
\text { tulo }\end{array}$ & Recomendable \\
\hline & \multicolumn{2}{|c|}{$\begin{array}{l}\text { Posibilidad de personalizar los aspectos formales del video y la } \\
\text { animación }\end{array}$} & Recomendable \\
\hline & \multirow{2}{*}{$\begin{array}{l}\text { Búsqueda en los conte- } \\
\text { nidos }\end{array}$} & Búsqueda en diccionarios & \\
\hline & & Búsqueda en internet & \\
\hline
\end{tabular}

${ }^{74}$ Este ítem no está presente en la parte teórica de la metodología (p.183) pero sí se incluye en los formularios de la metodología original (p.188-191) y en el anexo III en donde se ofrece un ejemplo práctico (p.245-252). 


\begin{tabular}{|c|c|c|c|}
\hline & & Búsqueda en Wikipeda & \\
\hline & \multirow{4}{*}{ Anotaciones } & Subrayar y destacar & Recomendable \\
\hline & & Incluir/borrar notas & Recomendable \\
\hline & & Incluir/borrar marcadores & Recomendable \\
\hline & & Índice de notas y marcadores & Recomendable \\
\hline \multirow{2}{*}{$\begin{array}{l}\text { C.7. Interacción con los conte- } \\
\text { nidos }\end{array}$} & \multicolumn{2}{|c|}{ Posibilidad de compartir comentarios y valoraciones } & \\
\hline & \multicolumn{2}{|c|}{ Posibilidad de puntuar } & \\
\hline \multirow{4}{*}{ C.8. Calidad del audio } & \multirow{4}{*}{ Tipo de audio } & Locución & \\
\hline & & Varios narradores & \\
\hline & & Banda sonora & (en algunos títulos) \\
\hline & & Efectos de sonido & (en algunos títulos) \\
\hline C.9. Interactividad & \multicolumn{2}{|c|}{ Existencia de interactividad } & \\
\hline \multicolumn{3}{|l|}{ Valoración global } & \\
\hline
\end{tabular}

Para una mejor visualización de los cambios realizados, ofrecemos a continuación una plantilla sin los campos que consideramos que deberían excluirse y sumando aquellos que creemos necesarios. Posteriormente reflejaremos los datos de forma gráfica simulando que podemos ver los parámetros e indicadores en una aplicación de audiolectura.

Tabla 9. Plantilla de evaluación para aplicaciones de audiolectura

\begin{tabular}{|c|c|c|c|c|}
\hline \multicolumn{5}{|c|}{ DATOS GENERALES DE LA APLICACIÓN } \\
\hline \multicolumn{5}{|c|}{ Aplicación: } \\
\hline \multicolumn{5}{|c|}{ Desarrollador: } \\
\hline \multicolumn{5}{|c|}{ Fecha de la versión analizada: } \\
\hline \multicolumn{5}{|c|}{ Fecha de publicación: } \\
\hline \multicolumn{5}{|l|}{ Tamaño: } \\
\hline \multicolumn{5}{|l|}{ Requiere: } \\
\hline \multirow[t]{2}{*}{ Idiomas } & Español & Ingles & Francés & Catalán \\
\hline & Gallego & Euskera & \multicolumn{2}{|l|}{ Otros: } \\
\hline \multirow[t]{2}{*}{ Edad } & General & \multicolumn{3}{|c|}{ Infantil (especificar edad) } \\
\hline & & & & \\
\hline
\end{tabular}




\section{DIMENSIÓN FORMA}

\begin{tabular}{|c|c|c|c|c|}
\hline Parámetro & \multicolumn{2}{|l|}{ Indicadores } & No $=0 /$ Sí $=1$ & Observaciones \\
\hline \multirow{7}{*}{$\begin{array}{l}\text { F.1. Disponibili- } \\
\text { dad }\end{array}$} & \multirow{3}{*}{$\begin{array}{l}\text { Disponibilidad para dife- } \\
\text { rentes sistemas operati- } \\
\text { vos }\end{array}$} & Android & & \\
\hline & & iOs & & \\
\hline & & Otros & & \\
\hline & \multicolumn{2}{|c|}{ Disponibilidad en diferentes sitios } & & Recomendable \\
\hline & \multicolumn{2}{|c|}{ Disponibilidad de la app en diferentes idiomas } & & \\
\hline & \multicolumn{2}{|l|}{ Título Identificable } & & Imprescindible \\
\hline & \multicolumn{2}{|l|}{ Ícono Identificable } & & Imprescindible \\
\hline \multirow{5}{*}{ F.2. Adquisición } & \multirow{5}{*}{$\begin{array}{l}\text { Modalidad de adquisi- } \\
\text { ción de los contenidos }\end{array}$} & $\begin{array}{l}\text { Venta por suscripción: Suscrip- } \\
\text { ción ilimitada }\end{array}$ & & \\
\hline & & & & \\
\hline & & $\begin{array}{l}\text { Venta por suscripción: Suscrip- } \\
\text { ción limitada }\end{array}$ & & \\
\hline & & Venta unitaria & & \\
\hline & & Gratuita & & \\
\hline \multirow{2}{*}{ F.3. Seguridad } & \multicolumn{2}{|c|}{ Control de acceso a internet en la propia aplicación } & & $\begin{array}{l}\text { Imprescindible para } \\
\text { menores }\end{array}$ \\
\hline & \multicolumn{2}{|c|}{ Adaptación de claves a la edad del usuario } & & $\begin{array}{l}\text { Imprescindible para } \\
\text { menores }\end{array}$ \\
\hline $\begin{array}{l}\text { F.4. Confiden- } \\
\text { cialidad y priva- } \\
\text { cidad }\end{array}$ & \multicolumn{2}{|c|}{ Explicación clara de la política de privacidad } & & Imprescindible \\
\hline \multirow[t]{2}{*}{ F.5. Popularidad } & \multicolumn{2}{|l|}{ Puntuación de los lectores } & & $\begin{array}{l}\text { Solo valorar positiva- } \\
\text { mente a partir de } 10 \\
\text { valoraciones }\end{array}$ \\
\hline & \multicolumn{2}{|c|}{ Cantidad de descargas de la $a p p$} & & \\
\hline \multirow{7}{*}{ F.6 Usabilidad } & Velocidad & $\begin{array}{l}\text { Mensaje del proceso de descarga } \\
\text { durante }\end{array}$ & & \\
\hline & \multirow[t]{6}{*}{ Navegación } & Navegación sencilla e intuitiva & & Recomendable \\
\hline & & Funcionamiento correcto & & Imprescindible \\
\hline & & $\begin{array}{l}\text { Iconos de los botones de acción } \\
\text { identificables }\end{array}$ & & Imprescindible \\
\hline & & Existencias de ayudas o tutoriales & & Recomendable \\
\hline & & $\begin{array}{l}\text { Acceso al menú desde todas las } \\
\text { páginas }\end{array}$ & & Recomendable \\
\hline & & $\begin{array}{l}\text { Posibilidad de ocultar y mostrar } \\
\text { menú }\end{array}$ & & Recomendable \\
\hline
\end{tabular}




\begin{tabular}{|c|c|c|c|c|}
\hline \multirow{4}{*}{ F.7. Ergonomía } & \multirow[t]{2}{*}{ Legibilidad } & \multicolumn{2}{|l|}{ Tamaño de letra legible } & \\
\hline & & \multicolumn{2}{|l|}{ Tipo de letra legible } & \\
\hline & \multicolumn{2}{|l|}{ Claridad } & & \\
\hline & \multicolumn{2}{|l|}{ Uso adecuado del color } & & \\
\hline \multicolumn{5}{|c|}{ DIMENSIÓN CONTENIDO } \\
\hline Parámetro & \multicolumn{2}{|l|}{ Indicadores } & No $=0 /$ Sí= 1 & Observaciones \\
\hline C.1. Autoría & \multicolumn{2}{|l|}{ Mención del editor/autor } & & Imprescindible \\
\hline \multirow{4}{*}{$\begin{array}{l}\text { C.2.Actualiza- } \\
\text { ción }\end{array}$} & \multicolumn{2}{|c|}{ Especificación de la fecha de creación } & & Imprescindible \\
\hline & \multicolumn{2}{|c|}{ Especificación de la fecha de última versión } & & \\
\hline & \multicolumn{2}{|c|}{ Especificaciones del historial de versiones } & & \\
\hline & \multicolumn{2}{|c|}{ Incorporación frecuente de nuevos títulos } & & Recomendable \\
\hline \multirow{2}{*}{ C.3 Contenido } & \multicolumn{2}{|l|}{ Cantidad de contenido } & & \\
\hline & \multicolumn{2}{|c|}{ Variedad de temas, géneros y edades } & & $\begin{array}{l}\text { Valorable según tipo } \\
\text { de app }\end{array}$ \\
\hline \multirow{15}{*}{$\begin{array}{l}\text { C.4. Accesibili- } \\
\text { dad }\end{array}$} & \multirow{5}{*}{$\begin{array}{l}\text { Campos de búsqueda en } \\
\text { la tienda }\end{array}$} & Autor & & Imprescindible \\
\hline & & Título & & Imprescindible \\
\hline & & Tema & & Imprescindible \\
\hline & & Duración & & Imprescindible \\
\hline & & Edad & & $\begin{array}{l}\text { Recomendable en las } \\
\text { infantiles }\end{array}$ \\
\hline & \multirow{9}{*}{$\begin{array}{l}\text { Información sobre los tí- } \\
\text { tulos }\end{array}$} & Autor/traductor & & Imprescindible \\
\hline & & Narrador & & Imprescindible \\
\hline & & Precio & & Imprescindible \\
\hline & & Resumen & & Imprescindible \\
\hline & & Duración & & Imprescindible \\
\hline & & Disponibilidad de DEMO & & Imprescindible \\
\hline & & Datos del original & & Imprescindible \\
\hline & & Tipo de versión & & Imprescindible \\
\hline & & Portada & & Recomendable \\
\hline & \multicolumn{2}{|c|}{ Lectura sin conexión a internet } & & Recomendable \\
\hline \multirow{3}{*}{$\begin{array}{l}\text { C.5.Organiza- } \\
\text { ción de los con- } \\
\text { tenidos }\end{array}$} & \multirow[t]{2}{*}{ Tipos de visualización } & Estantería & & $\begin{array}{l}\text { Recomendables en } \\
\text { las infantiles }\end{array}$ \\
\hline & & Listado & & \\
\hline & \multicolumn{2}{|c|}{ Posibilidad de cambiar el modo de visualización } & & \\
\hline
\end{tabular}




\begin{tabular}{|c|c|c|c|}
\hline & \multicolumn{2}{|l|}{ Organización de carpetas } & \multirow[b]{2}{*}{ Imprescindible } \\
\hline & \multirow[t]{2}{*}{ Eliminación de títulos } & Posibilidad de eliminar títulos & \\
\hline & & $\begin{array}{l}\text { Eliminación directa de la estante- } \\
\text { ría }\end{array}$ & Recomendable \\
\hline & \multicolumn{2}{|l|}{ Restauración de títulos } & Imprescindible \\
\hline & \multicolumn{2}{|c|}{ Restauración sencilla e intuitiva } & \\
\hline \multirow{9}{*}{$\begin{array}{l}\text { C. } 6 \text { Personaliza- } \\
\text { ción de los con- } \\
\text { tenidos }\end{array}$} & $\begin{array}{l}\text { Posibilidad de personali- } \\
\text { zar aspectos formales del } \\
\text { texto }\end{array}$ & $\begin{array}{l}\text { Ajuste de brillo y fondo de panta- } \\
\text { lla }\end{array}$ & Recomendable \\
\hline & \multirow[t]{5}{*}{$\begin{array}{l}\text { Posibilidad de personali- } \\
\text { zar los aspectos formales } \\
\text { del audio }\end{array}$} & $\begin{array}{l}\text { Posibilidad de adelantar o retro- } \\
\text { ceder el audio }\end{array}$ & Imprescindible \\
\hline & & $\begin{array}{l}\text { Posibilidad de modificar la veloci- } \\
\text { dad de reproducción }\end{array}$ & Recomendable \\
\hline & & Disponibilidad de temporizador & Recomendable \\
\hline & & $\begin{array}{l}\text { Disponibilidad de modo automó- } \\
\text { vil }\end{array}$ & Recomendable \\
\hline & & Desplazamiento por capítulos & Recomendable \\
\hline & \multirow[t]{3}{*}{ Anotaciones } & Incluir/borrar notas & Recomendable \\
\hline & & Incluir/borrar marcadores & Recomendable \\
\hline & & Índice de notas y marcadores & Recomendable \\
\hline \multirow{2}{*}{$\begin{array}{l}\text { C.7. Interacción } \\
\text { con los conteni- } \\
\text { dos }\end{array}$} & \multicolumn{2}{|c|}{ Posibilidad de compartir comentarios y valoraciones } & \\
\hline & \multicolumn{2}{|l|}{ Posibilidad de puntuar } & \\
\hline \multirow{3}{*}{$\begin{array}{l}\text { C.8. Calidad del } \\
\text { audio }\end{array}$} & \multirow[t]{3}{*}{ Tipo de audio } & Varios narradores & $\begin{array}{l}\text { En algunos títulos es } \\
\text { recomendable }\end{array}$ \\
\hline & & Banda sonora & (en algunos títulos) \\
\hline & & Efectos de sonido & (en algunos títulos) \\
\hline \multicolumn{3}{|l|}{ Valoración global } & \\
\hline
\end{tabular}




\subsubsection{Simulación gráfica de indicadores a incluir en una aplicación de audiolectura}

Como hemos mencionado en nuestra tesis, es tan reciente la historia de audiolibros digitales en nuestro país, que no hemos encontrado estudios que evalúen las necesidades de los usuarios en torno a este tipo de formato.

Es por esta razón que resulta de interés la presente investigación para tomar en cuenta ciertos indicadores deseables en una aplicación digital de audiolectura, que surgen de la interrogación de este soporte sonoro en más de 3 años de investigación y que proponemos como base para consolidar a futuro y tener en cuenta al acometer cualquier proyecto de esta índole.

La popular expresión content is king refleja la importancia de los contenidos ofrecidos a través de cualquier plataforma; sin embargo, como profesionales de la información, tenemos que garantizar que tanto el almacenamiento como la difusión de cualquier tipo de información se realice de forma eficiente. La planificación estratégica de la gestión de contenidos sonoros debería llevarse a cabo teniendo en cuenta distintos agentes vinculados al proyecto (editoriales, autores, usuarios, profesionales del área de la documentación, etc.). Dado que la presente investigación surge desde el área de la documentación, ofrecemos nuestra visión y proponemos, a modo ilustrativo una serie de imágenes que sintetizan, de algún modo, la plantilla ofrecida anteriormente ${ }^{75}$. Además del diseño gráfico, ofrecemos una propuesta de nombre comercial a nuestra simulación de aplicación: «Sonobuk».

Comenzaremos con la pantalla de inicio de una AA (aplicación de audiolectura). Como podemos observar más adelante, en la Ilustración 23, la aplicación nos ofrece la posibilidad de acceder al perfil personal del usuario.

Si se accede a esta opción (ver Ilustración 24) nos dirigirá a la pantalla «Mi biblioteca» en la cual podremos definir ciertos parámetros, como el idioma de los audiolibros, determinar si queremos audiolibros para mayores o menores de edad, o bien, decidir el modelo de compra de los audiolibros.

También tendremos acceso a carpetas personalizadas y a los audiolibros descargados. Asimismo, y como se puede observar a la izquierda en la parte superior de las pantallas, el menú estará siempre visible.

\footnotetext{
${ }^{75}$ Todas de elaboración propia
} 


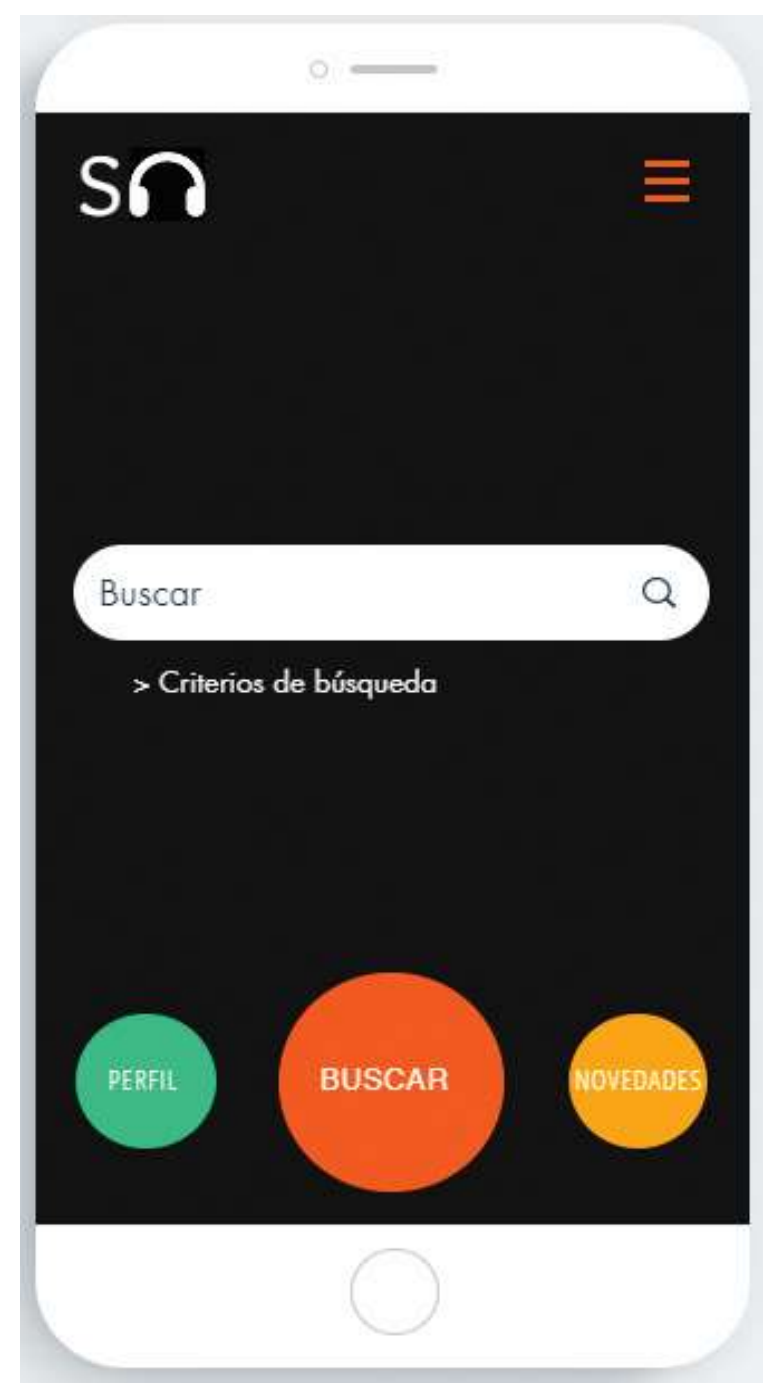

Ilustración 23. Propuesta de AA. Pantalla inicial

\section{Sก}

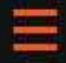

\section{BIBLIOTECA}

$>$ AUDIOLIBROS DESCARGADOS

$>$ CARPETAS PERSONALES

\section{AUDIOLIBROS}

- ESPAÑOL

CATALÁN

EUSKERA

GALLEGO

INGLÉS

EDAD

$D+18$ AÑNS

-18 AÑOS

\section{SUSCRIPCIÓN}

- MENSUAL POR TÍTULO

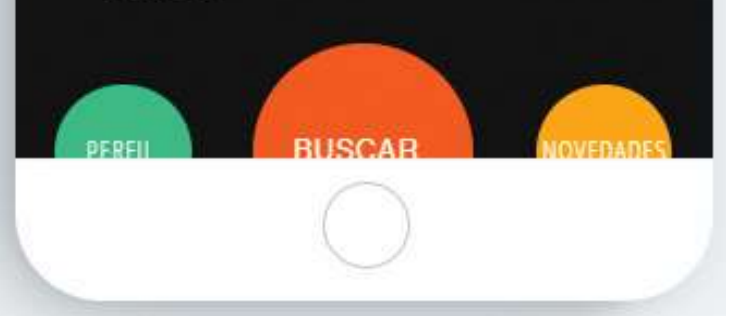

Ilustración 24. Propuesta de AA. Menú personal

Una vez definidos nuestros parámetros en el área de perfil, podemos pasar a las siguientes pantallas, que corresponden a las opciones de búsqueda de audiolibros digitales. 


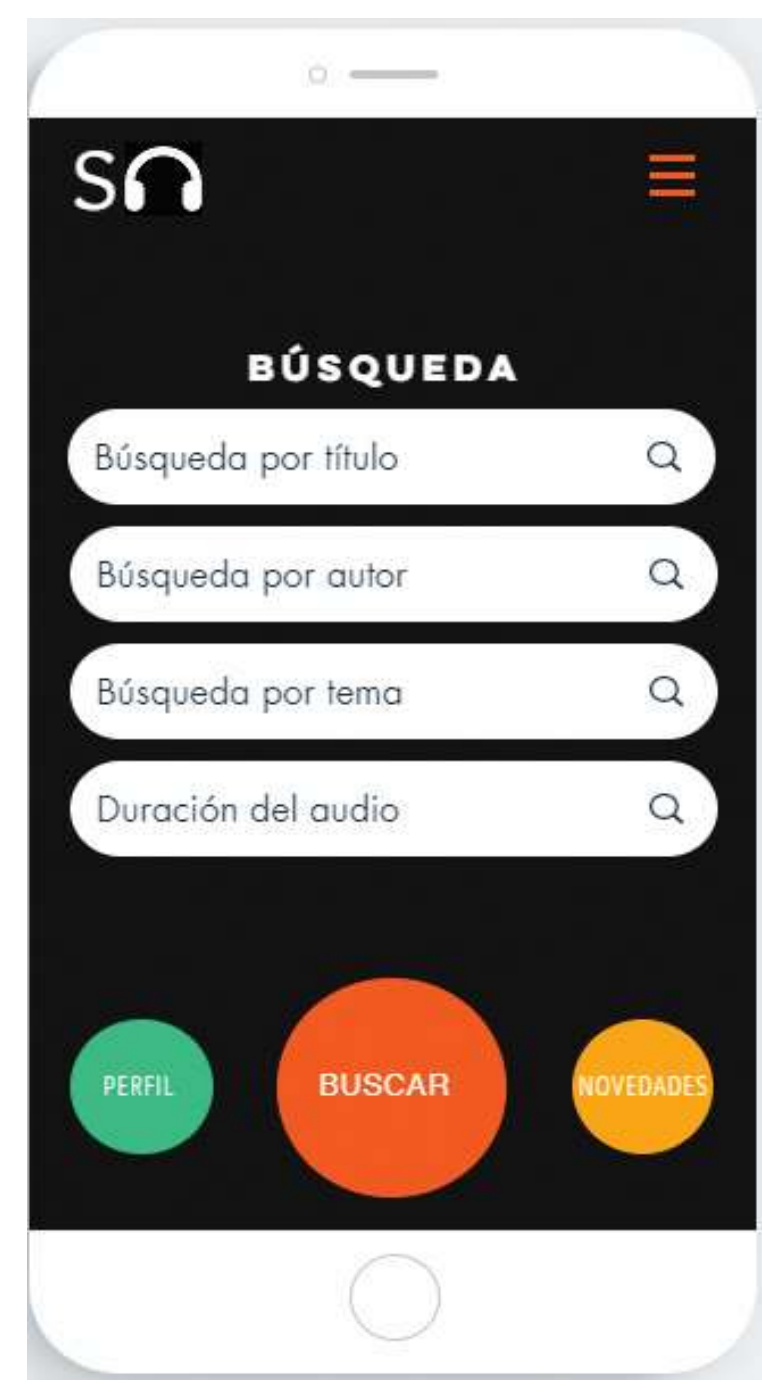

Ilustración 25. Propuesta de AA. Criterios de búsqueda

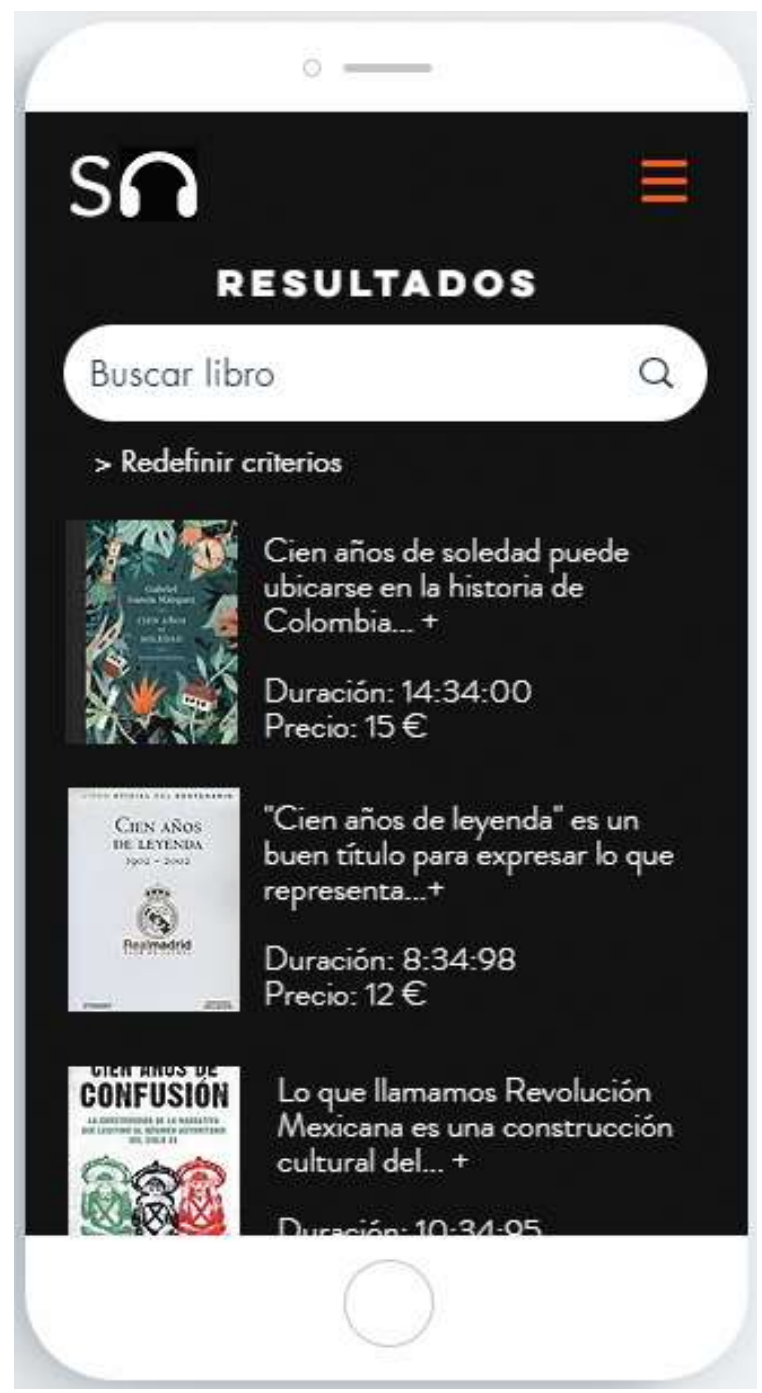

Ilustración 26. Propuesta de AA. Resultados de búsqueda

El acceso a los contenidos es clave en cualquier aplicación que contenga una colección bibliográfica, y es uno de los puntos débiles que hemos detectado en la mayoría de las aplicaciones que existen en el mercado.

Los campos de búsqueda que consideramos imprescindibles (como se puede observar en la ilustración 25) son: autor, título, tema, duración del audio y edad (puede obviarse al definirse en los parámetros de Mi biblioteca).

Los resultados tras la búsqueda se pueden observar en la llustración 26, con un despliegue de títulos con información básica para decidir si un audio nos interesa o no. 


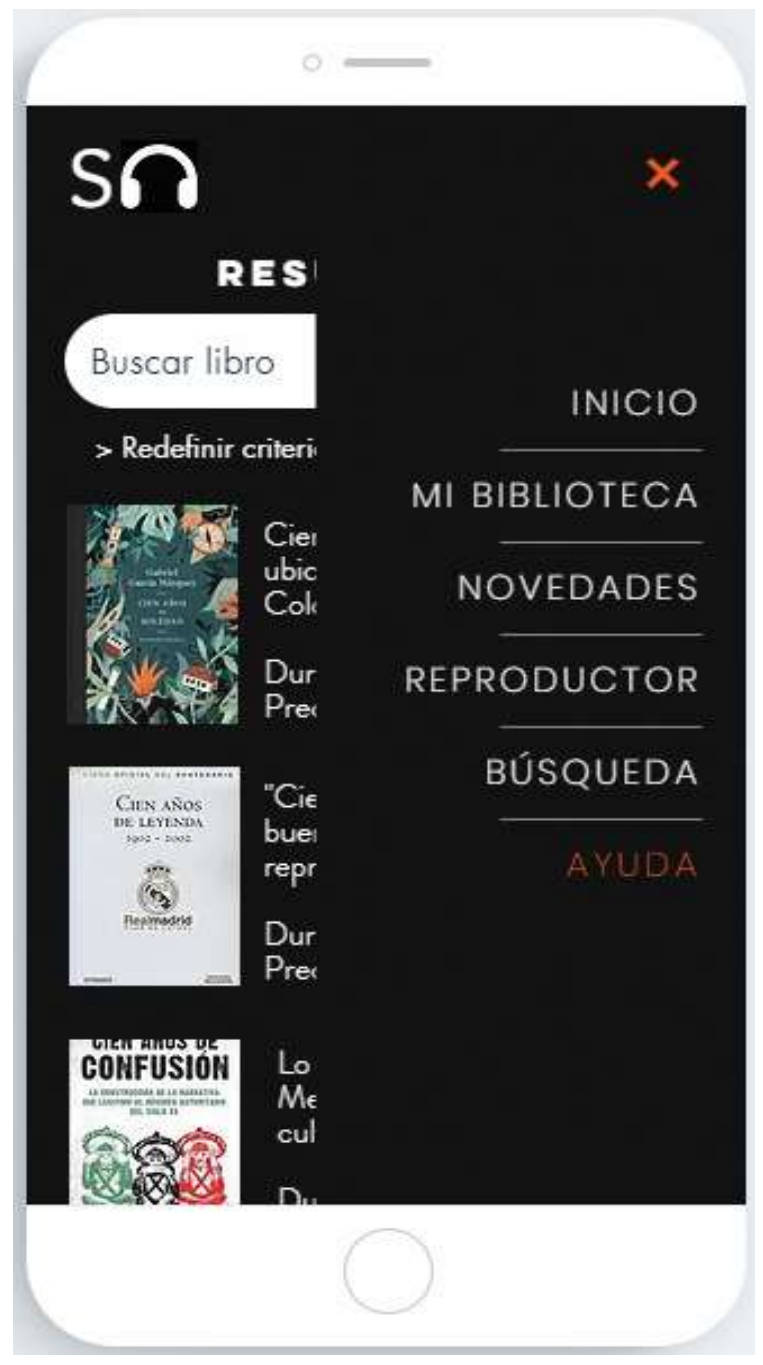

Ilustración 27. Propuesta de AA. Acceso al menú desde la pantalla de resultados

También, y como vemos en la Ilustración 27, la aplicación debe ofrecer la posibilidad de volver al menú para acceder a otras opciones, como: "novedades», «ir al reproductor», o incluso volver a realizar una búsqueda. Asimismo, podemos ingresar a «Mi biblioteca» o dirigirnos a una página para solicitar ayuda. 


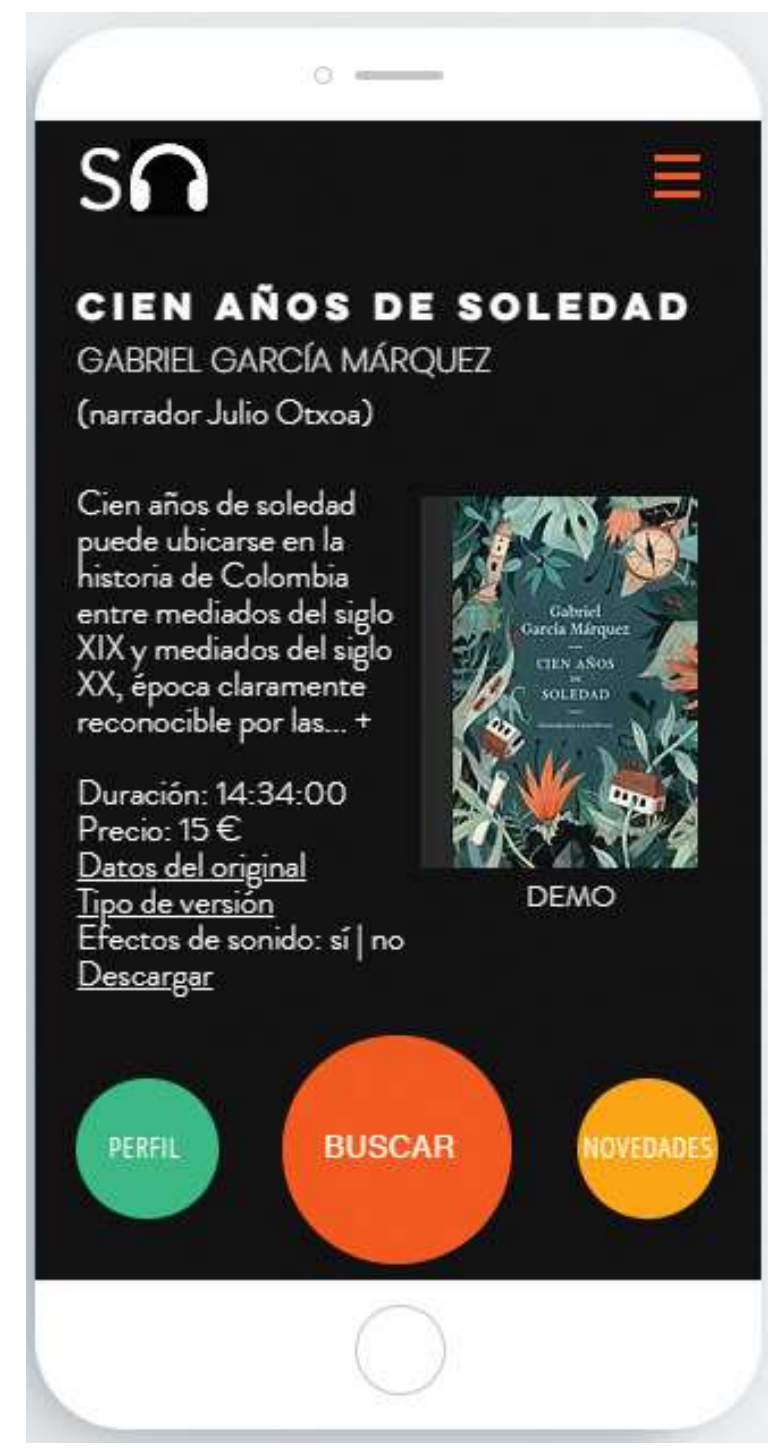

Ilustración 28. Propuesta de AA. Visualización del audiolibro seleccionado

Suponiendo que elegimos el primer ítem listado en la pantalla anterior, correspondiente a un audiolibro de García Márquez, visualizaríamos los detalles del modo en el que aparecen en la llustración 29. Esta pantalla aporta información concisa sobre el título elegido. Consideramos imprescindibles en esta instancia: autor/traductor, narrador, precio, resumen, duración, disponibilidad de DEMO, datos del original y tipo de versión; y como recomendable en este parámetro: la portada. 


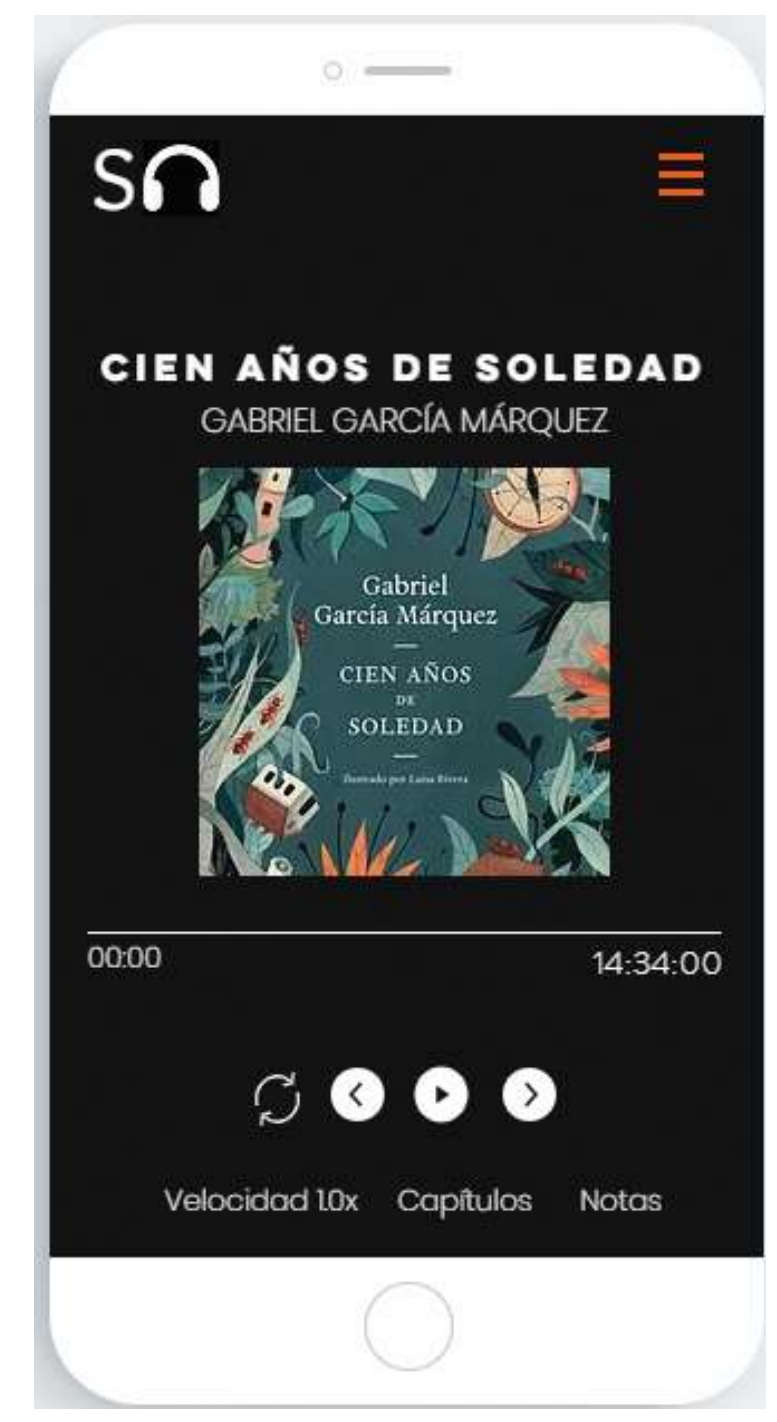

Ilustración 29. Propuesta de AA. Pantalla de reproducción de un audiolibro

Por último, dentro de la dimensión de contenido, destacamos algunos indicadores agrupados en «Posibilidad de personalizar los aspectos formales del audio». Estos tienen que ver con facilidades para la escucha del audiolibro, y son: «posibilidad de adelantar o retroceder el audio» (imprescindible), "posibilidad de modificar la velocidad de reproducción», "disponibilidad de temporizador», "disponibilidad de modo automóvil» y «posibilidad de desplazamiento por capítulos del título» como recomendables (ver Ilustración 29). 
El desarrollo de las nuevas tecnologías hace más necesaria que nunca la aparición de estudios que ayuden a comprender estos profundos cambios sociales. Profesores, bibliotecarios y agentes vinculados a los libros necesitamos entender el impacto del formato audiolibro digital para poder integrarlo en las prácticas educativas y en las bibliotecas.

Estar atentos a estos cambios nos posibilitará adelantarnos a las demandas de los lectores, seleccionar contenidos de calidad, y tomar a los audiolibros no como una amenaza, sino como otra forma de acercarnos a la literatura y al placer por lo sonoro. Por esta razón, hemos realizado un estudio que puso al formato en su contexto histórico, lo cual nos permitió comprender la complejidad de su resurgimiento y su posible proyección.

A continuación, presentamos las principales conclusiones desprendidas de nuestra investigación. Tomamos como punto de partida la hipótesis planteada en la introducción, y las preguntas de investigación ya enunciadas anteriormente y que gracias a la metodología llevada a cabo podemos resolver en este apartado final.

En relación con la pregunta de investigación número 1: ¿cuál es el origen del audiolibro y qué vínculo tiene este formato con las ciencias de la información y documentación? Hemos concluido que:

(C1) El nacimiento de los audiolibros está relacionado estrechamente con las bibliotecas de Estados Unidos y la motivación de los bibliotecarios para brindar a los usuarios que sufrían algún tipo de discapacidad visual una posibilidad para que pudiesen acceder a la literatura y a estudios académicos de interés.

(C2) El impulso inicial realizado por el sector de las ciencias de la información para la difusión de la literatura en formato audio fue continuado por el sector editorial, el cual se preocupó por extender a una mayor cantidad de usuarios colecciones sonoras (no solo a personas con deficiencias visuales). Para este fin, el sector privado, aportó valor añadido a los audios, a través de dos de las características que resaltamos como las principales de un audiolibro: la voz y la tecnología. Las editoriales buscaron voces internacionalmente reconocidas para narrar los libros y se valieron de las nuevas tecnologías para la producción y distribución del formato.

(C3) Si bien las bibliotecas han contado desde su aparición con los contenidos sonoros en sus colecciones, primero en formato analógico y luego digital, la cantidad de préstamos sigue siendo a día de hoy, muy poco significativa.

En cuanto a las colecciones que se ofrecen, en los últimos informes de e-Biblio del Ministerio de Educación, Cultura y Deporte, se puede observar un leve crecimiento de los audiolibros, pero hay que tener en cuenta que la oferta de audiolibros es muy pequeña si la comparamos con la oferta real de audiolibros en español. E-biblio publica en sus estadísticas anuales que, en los años 2017, 2018 y 2019 sus colecciones de audio contenían 200, 465 y 1122 audiolibros, respectivamente. Dichas colecciones distan mucho de aquellas que circulan en los ámbitos comerciales (según el informe Evaluación de 
mercado digital (ebooks y audiolibros en España y América Latina, en 2019 la oferta de audiolibros ascendía a 10.000).

(C4) En el último año se han publicado artículos que hablan del garantizar la escucha de libros como un derecho, como sinónimo de inclusión y equidad. Este planteamiento realizado desde las ciencias de la documentación por profesionales de Estados Unidos, no está restringido solo a personas con impedimentos visuales, sino que amplía el espectro de desigualdades a condiciones sociales, pasando por situaciones económicas, o diferencias en niveles educativos.

La concreción de propuestas como esta, centradas en el usuario, podrían fomentar que las bibliotecas adquieran colecciones sonoras y promuevan su uso.

En respuesta a la pregunta 2, ¿cuál es el panorama actual del mercado editorial del audiolibro en España?, se desprenden las siguientes afirmaciones:

(C5) Tanto los informes estudiados, como la consulta a especialistas, nos indican que en el año 2019 la cantidad de audiolibros en español era de aproximadamente 10.000 unidades, los años anteriores 2018 (8000), 2017 (6000). La tendencia indica que se producen alrededor de unos 2000 nuevos audiolibros por año.

(C6) Nuestro trabajo constata que la globalización del mundo editorial hizo que muchas empresas editen sus libros en idioma español fuera de España. Hemos encontrado en nuestro trabajo de campo casos de audiolibros en español a los que se les asignan números de ISBN de otros países. Esto trae como consecuencia que la Biblioteca Nacional de España no reciba gran parte de los audiolibros digitales en español, en calidad de depósito legal y, por ende, que circulen antes en ámbitos comerciales que en las bibliotecas. Asimismo, se pierde la posibilidad de poseer repertorio que de cuenta de la producción del formato en el país.

(C7) Para continuar construyendo las bases de nuestro discurso, y ofrecer conclusiones contundentes y datos fiables, resultó fundamental situarnos sobre bases sólidas y encontrar una forma de investigar el formato y poder obtener una radiografía de la situación actual fuera del ámbito bibliotecario, que es, como ya hemos afirmado, donde se encuentran la mayor cantidad de plataformas y audiolibros digitales.

La construcción de una metodología robusta de investigación se ha revelado como especialmente necesaria en el campo de los audiolibros. El trabajo de campo consistió en la evaluación e interrogación durante más de un año alrededor de 30 portales y plataformas digitales, a fin de localizar un título específico: Don Quijote de la Mancha.

La compilación de los Quijotes en español nos ha permitido obtener datos actualizados tanto del mercado de audiolibros en español como del mercado de plataformas que los distribuyen. La multiplicidad del título del Quijote en varias plataformas nos aportó información valiosa sobre el sector y las estrategias de venta del formato a través de varias distribuidoras, presentes en portales o en aplicaciones. 
Las conclusiones a las que arribamos en cuanto a nuestra tercera pregunta de investigación, acerca de los canales de distribución:

(C8) Nuestra investigación revela que un mismo título puede ser ofrecido hasta en 11 plataformas diferentes, y esta es una característica distintiva del actual mercado del audiolibro. Especialistas afirman que para competir en el mercado con una colección única y poseer una robusta colección sonora, una empresa debería producir entre 500 y 1000 audiolibros anuales. Los límites son difusos entre muchas plataformas y editoriales, que se fusionan y cercenan de acuerdo con intereses comerciales.

(c9) Las editoriales que comercializan hoy en día audiolibros indican que las plataformas de suscripción como Storytel, Audible, Kobo, entre otras, se han convertido en el principal canal de venta y distribución de audiolibros en español.

Tras este modelo se encuentran otros de venta unitaria, como es el caso de Google Play o iTunes, y en tercer lugar las plataformas de streaming como Spotify o Deezer. Los informes también revelan que, a diferencia de los mercados anglosajones, la venta de audiolibros a bibliotecas en España es un canal muy poco desarrollado en los mercados en español, situándose en cuarto lugar.

(C10) Los informes estudiados indican que los usuarios eligen modelos de streaming para escuchar audiolibros. Los interesados los adquieren más en relación con un modelo de biblioteca; los disfrutan, pero no los acumulan digitalmente. Lo cual nos permite concluir que existe un mercado de usuarios que harían uso de colecciones documentales si la oferta fuera mayor.

(C11) Teniendo en cuenta nuestro trabajo de campo, y observando los datos extraídos de la búsqueda de audiolibros del Quijote en plataformas sonoras, podemos concluir que existe una gran disparidad de precios del mismo título en diversas plataformas.

(C12) Las affordances que ofrece cada plataforma evaluada son muy variadas, y las mismas pueden mejorar significativamente tanto el proceso de búsqueda, como de escucha del audiolibro.

En respuesta a la siguiente pregunta de investigación, número 4: ¿resulta válido el diseño de una metodología para evaluar aplicaciones de audiolectura?, resaltamos que:

(C13) A través de este estudio hemos concluido que existe un largo número de aplicaciones y sitios que ofrecen audiolibros digitales en español, pero dado el incipiente nacimiento del mercado, no todas cuentan con todas las garantías de calidad deseables.

(C14) Tras aplicar varios criterios en nuestro trabajo de campo y restringir las plataformas a estudiar a aquellas que tuvieran un equilibrio entre calidad de contenido y calidad tecnológica, redujimos el número de aproximadamente 30 a un total de 15 . 
Comprobamos que los audiolibros que se comercializan a través de estas plataformas digitales corresponden, salvo escasas excepciones, a libros que ya cuentan con cierto renombre, o bien son publicaciones que se editan simultáneamente con el libro, pero avaladas por un sello editorial. Por otro lado, los narradores son locutores o actores que realizan el trabajo de forma profesional.

Sin embargo, consideramos que se podría mejorar el acceso a los contenidos teniendo en cuenta las particularidades del formato sonoro digital.

(C15) En nuestro trabajo de campo observamos que, al buscar un audiolibro en particular, prácticamente en ningún caso las plataformas detallan qué edición exacta del Quijote es la que el narrador está leyendo; tampoco se indica si se leen los prolegómenos o no; pero lo más llamativo es que siendo consultadas las plataformas a través de sus servicios de atención al cliente, en algunos casos respondieron que era una información confidencial.

(C16) Más allá del gran empujón que el sector editorial le dio al formato audio digital, pensamos que el perfil del documentalista se muestra idóneo para proponer mejoras en la forma de presentar, almacenar y distribuir a los audiolibros. Es, sin duda, en este aspecto en el que se debería incidir en los próximos años si se quiere profesionalizar el sector.

(C17) Todo indica que las tecnologías están ofreciendo un campo fértil para el crecimiento del formato audio, pero no se están realizando estudios desde el ámbito de las ciencias de la información y documentación que a) realicen un estado de situación b) ofrezcan soluciones para mejorar aquellos aspectos más débiles.

(C18) Observado el complejo entramado de elementos que componen las aplicaciones de audiolectura, y, por otro lado, la escasez bibliografía y de materiales, consideramos que resulta válido el diseño de una metodología que pueda resumir las características deseables de una aplicación de audiolectura.

Teniendo en cuenta nuestra última pregunta de investigación, que citamos a continuación: ¿qué características fundamentales debería ofrecer una aplicación de audiolectura?, nuestras conclusiones son:

(C19) El mundo del audiolibro está indefectiblemente enlazado con las tecnologías, y específicamente a las aplicaciones de distribución y escucha digitales, por lo cual nos hemos detenido en este punto, dado que constituyen la forma más extendida de la audiolectura.

Tras el trabajo de campo realizado nos preguntamos cuáles serían las características fundamentales que debería tener una aplicación de audiolectura, además de realizar una extensa búsqueda bibliográfica y consultar a especialistas nacionales e internacionales.

Constatamos que, dado que es muy incipiente el desarrollo de aplicaciones de audiolectura hasta el momento, no existe una metodología que evalúe su calidad. Por lo cual, basándonos en nuestra propia experiencia y en aplicaciones homólogas, diseñamos una propuesta para su estudio, como colofón o último aporte de nuestra investigación. 
En el capítulo 8, valiéndonos de una metodología previa, hemos enumerado una serie de criterios imprescindibles que deberían estar presentes en cualquier aplicación de audiolectura. En primer lugar, hemos evaluado aspectos formales, tales como la disponibilidad, adquisición, seguridad, confidencialidad, popularidad y usabilidad de una aplicación de este tipo. Hemos tomado como referencia la metodología ya citada de Gómez Díaz, et al. y hemos coincidido con muchos de los indicadores relacionados con los aspectos formales, que concuerdan con una aplicación de lectura general.

Sin embargo, en la dimensión de contenido, sí que hemos introducido varios indicadores que consideramos imprescindibles en este tipo de aplicaciones emergentes.

En base a nuestros años de trabajo de campo, hemos evidenciado que el punto débil de las aplicaciones que existen en el mercado se encuentra, fundamentalmente en el parámetro "accesibilidad» y, dentro de éste, en sus indicadores de "campos de búsqueda» y de «información sobre los títulos». Es de rigor, en cualquier base de datos contar con, por un lado, facilidades para recuperar la información, y por el otro, contar con los metadatos suficientes para poder decidir si adquirir o escuchar o no un audiolibro.

Los campos de búsqueda que destacamos como imprescindibles son: autor, título, tema, duración del audio y edad (si no está definida en parámetros del usuario).

Con relación a la información que se aporta sobre cada título destacamos: autor/traductor, narrador, precio, resumen, duración, disponibilidad de DEMO, datos del original y tipo de versión.

En la dimensión de contenido, también hemos agregado varios indicadores, dentro del parámetro "Personalización de los contenidos», y más concretamente en el indicador "Posibilidad de personalizar los aspectos formales del audio». Estos tienen que ver con facilidades para la escucha del audiolibro, y son: posibilidad de adelantar o retroceder el audio, posibilidad de modificar la velocidad de reproducción, disponibilidad de temporizador, disponibilidad de modo automóvil y posibilidad de desplazamiento por capítulos del título.

(C20) Creemos que como resultado de haber investigado en los últimos tres años el formato audiolibro, poseemos los fundamentos necesarios para el diseño de esta herramienta, que puede ser tomada como punto de partida y validada en futuros estudios.

Por tanto, destacamos la confirmación de nuestro estudio al constatar la validez del enfoque del diseño de una metodología como directriz para el conocimiento y evaluación de las aplicaciones de audiolectura, es decir, un conocimiento más profundo tanto de las cualidades de forma como de contenido de este tipo de tecnologías inherentes a nuestro objeto de estudio.

Consideramos el planteamiento de esta metodología como la principal conclusión de nuestra investigación, pues resume todas las variables y subvariables que componen el diseño de una aplicación de audiolibros y a la vez los diversos puntos de acceso cuando se trata de evaluarlo desde el punto de vista del usuario.

Somos conscientes de que la utilización de esta metodología está orientada a profesionales de la información y documentación, que puede ser validada y/o mejorada en el futuro, pero confiamos en que será una referencia de gran utilidad para observar de un modo gráfico qué elementos son recomendables, optativos o imprescindibles a la hora de elegir y/o diseñar una tecnología de este tipo. 
Esperamos que esta investigación sobre los audiolibros resulte de utilidad para todos los interesados en el formato y constituya un punto de partida para futuras investigaciones. 
Por último, además de las conclusiones, ofreceremos a continuación algunas recomendaciones que pueden servir a aquellos que quieran profundizar en este ámbito sonoro.

(R1) Evidenciando que es en el sector privado en donde el formato audiolibro ha dado el gran salto, desde las ciencias de la información y documentación debemos prestar atención a su evolución; aprovechar la inversión realizada por el ámbito privado y observar cuáles son los puntos fuertes y débiles para poder implementarlas en los centros de documentación y asesorar a los usuarios cuando acuden solicitando referencias.

(R2) Teniendo en cuenta las colecciones de audiolibros y la escasa presencia y visibilidad que tienen en el ámbito bibliotecario en este momento, es necesario realizar un esfuerzo adicional de búsqueda por parte de la BNE para poseer un claro estado de la situación y generar un catálogo de los audiolibros editados en español (ya sean editados en España o fuera del país). Recordemos que, según la página del Ministerio de Cultura y Deporte, se indica que desde el año 2015 la Agencia del ISBN no tiene en cuenta las reimpresiones ni se pueden obtener datos de videolibros ni de audiolibros.

(R3) Desde el ámbito bibliotecario, la investigadora ha realizado algunas actividades para la difusión de los audiolibros. La más remarcable fue realizada desde el 17/09/2018 hasta el 10/12/2018 y tuvo lugar en el Instituto Cervantes de Budapest, institución en el que la investigadora trabaja. Dicha actividad consistió en un taller en el que se impartieron contenidos relacionados con los períodos literarios del siglo XX español en audiolibros. Se ofreció bibliografía sonora de, por ejemplo, poesías de Antonio Machado, teatro de Federico García Lorca y otros escritores de la generación del 98. Los alumnos de la cátedra «Literatura española 1» de la universidad húngara ELTE (Eötvös Loránd Tudományegyetem) utilizaron el formato audiolibro en varios de los textos obligatorios del curso.

Esta actividad no se ha incluido en la presente tesis ya que, finalmente, el número de alumnos no fue significativo para un trabajo de campo. Sin embargo, el mencionado taller sirvió para dar a conocer la colección de audiolibros de la RBIC (Red de Bibliotecas del Instituto Cervantes), aumentando significativamente las estadísticas de uso del formato, además de permitirnos obtener datos acerca de las ventajas y dificultades del uso de los audiolibros en un entorno académico.

Una de las observaciones que pudimos realizar es que para alumnos cuya lengua materna no es el español, el audiolibro puede ser de mucha utilidad para desarrollar habilidades auditivas, pero en algunos casos fue necesario contar también con el soporte impreso.

La posibilidad de escucha grupal se mostró como un recurso muy interesante, si se desarrolla en el ambiente adecuado, como el caso del salón de actos con el que contamos en nuestro centro, además del sistema de audio centralizado y de calidad.

El uso de la velocidad del audio es una affordance muy interesante a tener en cuenta para usuarios que estudian el idioma como lengua extranjera.

Para llevar a cabo el taller, la investigadora siguió y adaptó la metodología ofrecida por la Audio Publishers Association, que sugiere comenzar por una familiarización con el formato. 
(R4) El audiolibro requiere la misma o mayor atención (dadas sus particularidades) que otro tipo de formatos; por lo cual, instamos a los editores y a los canales de distribución a prestar atención a este y a futuros trabajos de investigación que arrojen pistas para la mejora del acceso a los contenidos sonoros.

Y para finalizar este trabajo, remarcamos que gran parte del auge de los audiolibros se debe al compromiso de las editoriales españolas por producir audiolibros de calidad, lo cual favorece a la fidelización de los usuarios con el nuevo formato. 
1. Aarhus University. The audiobook circuit in digital publishing: Voicing the silent revolution. [recurso en línea] https://pure.au.dk/portal/en/publications/the-audiobook-circuit-in-digitalpublishing(0dac3ee1-3f89-48b4-b873-bbaffc146b73).html [Consultado el 7 de mayo de 2020].

2. Acedo, Shannon y Leverkus, Cathy. Update on eboks: challenges \& changes. Knowledge Quest, 2014, 43 (1), pp. 44-52.

3. AFB. American Foundation for the Blind. Chapter 10: the talking book. [recurso en línea] Disponible en: https://www.afb.org/online-library/unseen-minority-0/chapter-10. Consultado el $\underline{1 / 5 / 2010}$ [Consultado el 15 de mayo de 2020].

4. Allen, Edward. What We Talk about When We Talk about Talking Books. En: Sound and Literature [Cambridge Critical Concepts Series], ed. Anna Snaith (Cambridge: Cambridge University Press, 2020), pp. 211-33.

5. Alonso Suárez, Cristina. Necesaria revisión del concepto de libro en la era del mercado digital. En: Navas Navarro, Susana, dir. Nuevos desafíos para el derecho de autor : robótica, inteligencia artificial, tecnología. Madrid: Editorial Reus ; Fundación Aisge, 2019.

6. Alonso-Arévalo, Julio y Cordón-García, José Antonio. El libro como sistema: hacia un nuevo concepto de libro. En: Cuadernos de Documentación Multimedia. 2015, (26). https://www.audiopub.org/uploads/pdf/APAC2017PR final.pdf [Consultado el 5 de abril de 2020]

7. Alonso-Arévalo, Julio y Cordón-García, José Antonio. ¿Para qué servirá la biblioteca pública en el futuro? Mi biblioteca. La revista del mundo bibliotecario, 2015 (49), pp. 16-28.

8. Andersen, Tore Rye. "Black Box" in Flux: Locating the Literary Work between Media. Northern Lights: Film and Media Studies Yearbook, 13 (2015), pp. 121-36.

9. ASANDIS. Asociación Andaluza para la Dislexia. Guía general sobre la dislexia. Málaga: ASANDIS, 2010.

10. Asensio, Mikel y Asenjo, Elena. Lazos de luz azul: del controvertido uso de las TICs en los museos. Actas do I Seminário de Investigação em Museologia dos Países de Língua Portuguesa e Espanhola. Porto: Universidade do Porto, 2010, pp. 87-98.

11. Asociación de Editores de Madrid. El sector editorial crece por quinto año consecutivo. Avance del mercado editorial en España. 2019. [recurso en línea] https://www.editoresmadrid.org/el-sector-editorial-crece-por-quinto-ano-consecutivo-avance-del-analisis-del-mercado-editorial-en-espana/ [Consultado el 7 de abril de 2020]. 
12. Ayuso-Rodríguez, Elena. Génesis y realización del primer radioteatro de Don Quijote producido por la BBC en 1947. Index.comunicación, 2019, 9(2), pp. 35-53.

13. Azemard, Ghislaine. et al. Mutations et continuités du document numérique: similarités historiques et approche déconstructivistes de la grammatologie post-numérique. Actes du dix huitième colloque international sur le document électronique, 18-19-20 novembre 2015, Université Paul-Valéry, Montpellier.

14. Baron, Naomi S. Words onscreen: the fate of reading in a digital world. New York: Oxford University Press, 2015.

15. Barreyro, Juan Pablo. La comprensión del texto escrito. En: Burin, D. I. (comp.) La competencia lectora a principios del siglo XXI: texto, multimedia e Internet. Buenos Aires: Editorial Teseo, 2020. [recurso en línea] https://www.teseopress.com/competencialectora/ [Consultado el 25 de abril de 2020].

16. Bauman, Zygmunt. Los retos de la educación en la modernidad líquida. Barcelona: Gedisa, 2008.

17. Bauman, Zygmunt. Tiempos líquidos: vivir en una época de incertidumbre. Barcelona: Tusquets, 2007.

18. Bauman, Zygmunt. Vida líquida. Paidós: Barcelona, 2009.

19. Baylan, Satu. et al. Measuring the effects of listening for leisure on outcome after stroke (MELLO): A pilot randomized controlled trial of mindful music listening. Int J Stroke. 2020;15(2), pp. 149-158.

20. Baylan, Satu. et al. Participants' experiences of music, mindful music, and audiobook listening interventions for people recovering from stroke. Ann N Y Acad Sci. 2018, mayo 8.

21. Bednar, Lucy. Audiobooks and the Reassertion of Orality. Walter J. Ong and Others Revisited, 2010, CEA Critic 73(1), pp. 75-85.

22. Berg, Walter Bruno. Apuntes para una historia de la oralidad en la literatura argentina. En: Markus Klaus Schaüffauer. Discursos de la oralidad en la literatura rioplatense del siglo XIX al XX. Tübingen: Narr, 1999.

23. Bolea de Anta, Adelaida y Ferrando García, Pablo. Oportunidades y desafíos de la radio en la era digital. AdComunica, [en línea], 2013 (5), pp. 19-22.

24. Borges, Jorge Luis. Borges profesor: curso de literatura inglesa dictado en la Universidad de Buenos Aires, editado por Martín Ariasy Martín Hadis. Buenos Aires: Emecé, 2000. 
25. Botello, Jesús. Barataria, un cruce de caminos: entre la oralidad y la escritura. Anales cervantinos, 2010, 42, pp. 131-146.

26. Bull, Michael. iPod: un mundo sonoro personalizado para sus consumidores. Comunicar, 2010,17 (34), pp. 55-63.

27. Bull, Michael. Sound moves: iPod culture and urban experience. New York: Rougledge, 2007.

28. Cannon, Christopher y Rubery, Matthew. Introduction to "Aurality and Literacy". PMLA, 2020, 135 (2), pp. 350-356.

29. Caro Castaño, Lucía. Relaciones e interacciones parasociales en redes sociales digitales. Una revisión conceptual. ICONO 14, Revista de comunicación y tecnologías emergentes, 2015, 13(2), pp. 23-47. [recurso en línea] https://www.redalyc.org/articulo.oa?id=5525/552556568003. [Consultado el 9 de mayo de 2020].

30. Carrión, Jorge. (b) Por qué el mundo se ha vuelto una gran ficción sonora. Mayo, 2020. Centro de Cultura Contemporánea de Barcelona. [recurso en línea] En: http://lab.cccb.org/es/por-que-el-mundo-se-ha-vuelto-una-gran-ficcion-sonora/[Consultado el 3 de mayo de 2020].

31. Carrión, Jorge. (c) Literatura y viralidad. En: New York Times. 4 de abril de 2020, [recurso en línea] https://www.nytimes.com/es/2020/04/12/espanol/opinion/literatura-best-sellers.html [Consultado el 6 de mayo de 2020].

32. Carrión, Jorge. Lo viral. Barcelona: Galaxia Gutenberg, 2020.

33. Cascone, Kim. The aesthetics of failure: post-digital tendencies in contemporary computer music. En: Computer Music Journal, 2000, 24, pp. 12-18.

34. Cassany, Daniel. Tras las líneas: sobre la lectura contemporánea. Barcelona: Anagrama, 2006.

35. Cavallo, Guglielmo y Chartier, Roger. Historia de la lectura en el mundo occidental. Madrid: Taurus, 2001.

36. Cavender, Jennifer y Stuchell, Lisa. Reviving the oral tradition: the evolution of audiobooks. En: The future of the book in the digital age. Oxford: Chandos Publishing, 2006, pp. 151-160.

37. Celaya, Javier. Foro del libro 2019. Escuchando el mercado: los audiolibros en Iberoamérica. Feria del libro de Bogotá. [recurso en línea] https://www.youtube.com/watch?v=np4AnkNRoY. [Consultado el 10 de enero de 2021]. 
38. Cencerrado, Luis Miguel, Yuste, Elisa y Celaya, Javier. Se busca lector del siglo XXI. Radiografía de un «lector orquesta». En: Anuario AC/E de Cultura Digital 2018. Madrid: Agencia Cultural Española, 2018, pp. 128-133.

39. Cervantes Saavedra, Miguel de. Don Quijote de la Mancha. Edición y notas, Francisco Rico. Madrid: Real Academia Española: Asociación de Academias de la Lengua Española, 2004.

40. Cervantes Saavedra, Miguel de. El licenciado vidriera [Disco compacto] ; y el coloquio de los perros / Miguel de Cervantes; narrador Carlos Lara. [S.I. : Libervox, 2010].

41. Chao, C.; Lu, F. Emergence of e-books and related managerial issues: A preliminary study. International Journal of Business, Marketing, and Decision Sciences, 2011, 4 (1), pp. 117-126.

42. Chao, Chiang-nan, Fuxman, Leonora y Elifoglu, I. Electronic Books Impact Global Environment-An Empirical Study Focus on User Perspectives. Journal of Management and Strategy, 2013, 4, pp. 52-59.

43. Chartier, Roger. Conferencia magistral presentada en el Seminario Internacional «¿Qué leer? ¿Cómo leer? Perspectivas sobre la lectura en la infancia», organizado por el Plan Nacional de Fomento de la Lectura, Lee Chile Lee, del Ministerio de Educación y la Universidad Diego Portales. 6 y 7 de diciembre de 2012. [recurso en línea] 1363098617RogerChartier.pdf (plandelectura.gob.cl) [Consultado el 20 de mayo de 2021].

44. Chevallier, Maxime. Literatura oral y ficción cervantina. Prohemio, 1974, 5, (2-3), pp.161-196.

45. Chion, Michel. La audiovisión: introducción a un análisis conjunto de la imagen y el sonido. Buenos Aires: Paidos, 1993.

46. Clark, Christina y Rumbold, Kate. Reading for Pleasure: A Research Overview. London: National Literacy Trust, 2006.

47. Codina, Lluís. Evaluación de calidad en sitios web: metodología de proyectos de análisis sectoriales y de realización de auditorías. Barcelona: Universidad Pompeu Fabra, 2007.

48. Codina, Lluís. Evaluación de recursos digitales en línea: conceptos, indicadores y métodos. Revista española de Documentación Científica, [S.I.], 23, (1), pp. 9-44.

49. Coixet, Isabel. Banco de arena: mi hermosa lavandería. XL semanal, 23 de junio de 2020.

50. Colbjornsen, Terje. The accidental Avant-Garde. Audio book technologies and publishing strategies from cassette tapes to online streaming services. Northern Lights. Film and Media Studies Yearbook, 13. Briston: Intellect Press, 2015. 
51. Cordón-García, José Antonio y Díaz Gómez, Raquel. Documentos electrónicos y textualidades digitales: nuevos lectores, nuevas lecturas, nuevos géneros. Salamanca: Ediciones Universidad de Salamanca, 2013. [recurso en línea]. http://ebookcentral.proquest.com/lib/bibliotecaupves-ebookndetail.action?doclD=3219210.

[Consultado el 7 de febrero de 2020]

52. Cordón-García, José Antonio. Combates por el libro: inconclusa dialéctica del modelo digital. El profesional de la información, 2018(b), 27 (3), pp. 467-481.

53. Cordón-García, José Antonio. La evolución de la lectura digital: modelos, dispositivos, aplicaciones y prácticas de lectura. En: Lectoescritura digital. Madrid: Ministerio de Educación y Formación Profesional, 2019, pp. 7-17.

54. Cordón-García, José Antonio. La lectura en el entorno digital: nuevas materialidades y prácticas discursivas. Revista Chilena de Literatura, 2016 (94) pp. 15-38.

55. Cordón-García, José Antonio. Leer escuchando: reflexiones en torno a los audiolibros como sector emergente. Anuario ThinkEPI, 2018, 12, pp. 170-182.

56. Cuello, Javier y Vittone, José. Diseñando apps para móviles. Madrid: Cuello y Vittone, 2013.

57. Dakik, Martina. Preferences and attitudes of audiobook users in Sweden:

Surveying Swedish audiobook groups on Facebook. Borås: University of Borås, 2019. [tesis de maestría].

58. Dali, Keren y Brochu, Leah K. The Right to Listen: A Not So Simple Matter of Audiobooks. Library Resources \& Technical Services, 2020, vol. 64, no. 3, pp. 106-119.

59. Dayli, Jay E. The selection, processing, and storage of non-print materials: a critique of the anglo-american cataloging rules as the relate to newer media. En: Library Trends, 1967, 16 (288), pp. 283-289.

60. Delgado Lopez-Cozar, Emilio. La investigación en Biblioteconomía y Documentación. Gijón, Trea, 2002.

61. Deniz, Fatma. et al. The representation of semantic information across human cerebral cortex during listening versus reading is invariant to stimulus modality. Journal of Neuroscience, 39 (39), pp. 7722-7736.

62. Diputación Provincial de Huesca. VII Congreso del Libro electrónico "Nuevos territorios, fórmulas y formatos", 2019.

63. Dohle, Markus. La transición hacia la compra por internet, incluso los libros, es inevitable. En: El Periódico, 2018. [recurso en línea]: https://www.elperiodico.com/es/mas-periodico/20180714/entrevista-markus-dohle-ceo-penguin-random-house-6940087 [Consultado 
el 2 de febrero de 2020].

64. Dosdoce. Retos e interrogantes alrededor del libro electrónico. [recurso en línea] https://www.dosdoce.com/2010/10/12/retos-e-interrogantes-alrededor-del-libro-electronico/ [Consultado el 2 de junio de 2020].

65. Dosdoce; Bookwire (2020). VI Informe Bookwire 2020 · Evolución del mercado digital (ebooks y audiolibros) en España y América Latina. [recurso en línea] https://www.dosdoce.com/wpcontent/uploads/2020/04/INFORME-BOOKWIRE-2020.pdf [Consultado el 2 de febrero de 2021].

66. Dosdoce; Bookwire. Evolución del mercado digital (ebooks y audiolibros) en España y América Latina: Informe 2019. [recurso en línea]. https://www.dosdoce.com/wp-content/uploads/2020/04/INFORME-BOOKWIRE-2020.pdf [Consultado el 20 de enero de 2020].

67. Dosdoce; Bookwire. Evolución del mercado digital (ebooks y audiolibros) en España y América Latina: Informe 2018 [recurso en línea]. http://www.dosdoce.com/wp-content/uploads/2018/03/Informe-Bookwire-sobre-la-evolucion-de-ebooks-y-audiolibros2018.pdf [Consultado el 20 de enero de 2020].

68. Edison, Thomas. The Phonograph and Its Future. The North American Review, 1878, 126(262), pp. 527-536. [recurso en línea] www.jstor.org/stable/25110210.

69. Edmondson, Ray. Audiovisual archiving: Philosophy and principles. París: Unesco, 2004.

70. Edmondson, Ray. Memoria del Mundo: Directrices para la salvaguardia del patrimonio documental. París: UNESCO, 2002. [recurso en línea] http://www.unesco.org/new/fileadmin/MULTIMEDIA/FIELD/Quito/pdf/Directrices Salvaguarda Patrimonio Documental.pdf [Consultado el 18 de mayo de 2020].

71. El futuro del libro digital, disparado. Qué leer, 2019, 26 de julio. [recurso en línea]: http://www.que-leer.com/2019/07/26/el-futuro-del-libro-digital/. [Consultado el 9 de abril de 2020].

72. Elkin, Judith. Special Needs/Special Places. En: Reading and reader development: the pleasure of reading. London: Facet, 2003.

73. English, James. Teaching the novel in the audio age. PMLA, 2020, 135 (2), pp. 419-426.

74. Enriquez, Juan Gabriel y Casas, Sandra I. Usabilidad en aplicaciones móviles. Informe Científico Técnico UNPA, 2013, 5 (2) pp. 25-47.

75. España. Ley 10/2007, de 22 de junio, de la lectura, del libro y de las bibliotecas. BOE núm. 150, de 23/06/2007, Boletín Oficial del Estado -A-2007- 12351. [recurso en línea] 
http://www.boe.es/buscar/act.php?id=BOE-A- 2007-12351. [Consultado el 10 de abril 2019].

76. España. Ministerio de Cultura y Deporte División de Estadísticas y Estudios entidad responsable. Encuesta de hábitos y prácticas culturales, 2018-2019: septiembre de 2019. Gobierno de España, Ministerio de Cultura y Deporte, 2019.

77. España. Ministerio de Cultura y Deporte. Avance de la Panorámica de la edición española de libros 2018. Secretaría General Técnica. Centro de Publicaciones, 2019.

78. España. Ministerio de Cultura y Deporte. Panorámica de la edición española de libros 2017. Secretaría General Técnica. Centro de Publicaciones: Ministerio de Cultura y Deporte, 2019.

79. España. Ministerio de Educación, Cultura y Deporte. El sector del libro en España 2017. [recurso en línea]. https://www.mecd.gob.endam/icr:bd29177e-2c26-4dbf-80d5cc40a12a676d/el-sector-del-libro-en-espa-a--junio-2017.pdf [Consultado el 7 de mayo de 2020].

80. Europapress. La ONCE abre su biblioteca virtual a los 285 millones de ciegos del mundo: "Ya leemos desde el móvil". [recurso en línea] https://www.europapress.es/epsocial/igualdad/noticia-once-abre-biblioteca-virtual-285-millones-ciegos-mundo-ya-leemos-movil20191008153832.html. [Consultado el 1 de mayo 2019].

81. Fedecali. 2010. Comercio exterior del libro 2009. Madrid: Federación Española de Cámaras del Libro.

82. Fedecali. 2016. Comercio exterior del libro 2015. Madrid: Federación Española de Cámaras del Libro.

83. Fedecali. 2017. Comercio exterior del libro 2016. Madrid: Federación Española de Cámaras del Libro.

84. Federación de Gremios de Editores de España (Madrid). Comercio exterior del libro en España 2018 [recurso en línea] https://www.federacioneditores.org/img/documentos/comercio_interior_2018.pdf [Consultado el 2 de mayo de 2020].

85. Federación de Gremios de Editores de España (Madrid). Hábitos de lectura y compra de libros en España 2019 [recurso en línea]. https://www.editoresmadrid.org/wp-content/uploads/2020/02/Barómetro-de-Hábitos-lectura-y-Compra-de-Libros-en-España-2019.FGEE.-Presentación.pdf. [Consultado el 20 de febrero de 2019]

86. Federación de Gremios Editores de España (Madrid) (2018). Hábitos de lectura y compra de libros en España en 2017. [recurso en línea].http://federacioneditores.org/img/documentos/HabitosLecturaCompraLibros2017.pdf [Consultado el 20 de febrero de 2020]. 
87. Federación de Gremios Editores de España (Madrid) 2017. Comercio interior del libro 2016. Madrid: Federación de Gremios de Editores de España (FGEE).

88. Federación de Gremios Editores de España (Madrid). 2016. Comercio interior del libro 2015. Madrid: Federación de Gremios de Editores de España (FGEE).

89. Fernández Vallés, María José. Oyentes y escuchantes. El Blog de la RTVE, 15 de junio [Blog]. [recurso en línea]. https://blog.rtve.es/noesundiacualquiera/2010/06/oyentes-y-escuchantes.html\#comments [Consultado 10 abril 2020].

90. Fletcher, Gordon y Griffiths, Marie. Digital transformation during a lockdown. Int J Inf Manage. 2020;55:102185. doi:10.1016/j.ijinfomgt.2020.102185

91. Foucault, Michel. Las palabras y las cosas. México: S. XXI Editores, 2005.

92. Frenk, Margit. Entre la voz y el silencio: la lectura en tiempos de Cervantes. México: Fondo de Cultura Económica, 2005.

93. Fundación Telefónica. Informe La sociedad de la Información en España. Madrid: Fundación Telefónica; Barcelona, Ariel, 2016.

94. Fundación Telefónica. Sociedad digital en España. Barcelona: Fundación Telefónica, 2019.

95. Fundéu. Cervantes, claves de redacción. 20/04/2016. [recurso en línea]. https://www.fundeu.es/recomendacion/cervantes/ [Consultado el 1 de mayo de 2019]

96. Gallego Pérez, Juan Ignacio. La distribución de contenidos de audio. Relaciones entre podcasting, radio y movilidad. Telos, Cuadernos de comunicación e innovación, 92, julio- septiembre, 2012, pp. 127-135.

97. Galloway, S. EI ADN secreto de Amazon, Apple, Facebook y Google. Madrid: Penguin Random House, 2017.

98. García Rodríguez, Araceli y Gómez Díaz, Raquel. ¿Leer con los oídos?: audiolibros y literatura infantil y juvenil. Anuario ThinkEPI, 2019, v. 13 [recurso en línea].

https://doi.org/10.3145/thinkepi.2019.e13c01. [Consultado el 1 de mayo 2020].

99. García Rodríguez, Araceli y Gómez Díaz, Raquel. Las demasiadas aplicaciones: parámetros e indicadores para seleccionar las topapp de lectura para niños. Anales de documentación, 18(2). [recurso en línea]. http://dx.doi.org/10.6018/analesdoc.18.2.227071. [Consultado el 1 de mayo de 2020].

100. Goldin-Meadow, Susan y Mayberry, Rachel I. How do profoundly deaf children lear to read? Learning disabilites Research and Practice, 2001, 16 (4), pp. 222-229. 
101. Goldsmith, Francisca. Audiobooks and Engagement: Eliminating barriers to developing listening skills leads to civic participation. American Libraries, 2017,48(6), pp. 31-32.

102. Gómez Díaz, Raquel y Cordón-García, José Antonio. Aplicaciones de lectura. DINLE: Diccionario Digital de nuevas formas de lectura y escritura. Universidad de Salamanca. Red Internacional de Universidades Lectoras. 2015. [recurso en línea] http://dinle.usal.es/searchword.php?valor=Aplicaciones de lectura> [Consultado el 11 de marzo de 2020].

103. Gómez Díaz, Raquel, et al. Leyendo entre pantallas. Asturias: Trea, 2016.

104. González Conde, María Julia. La ciberradio: nueva alternativa de futuro para los jóvenes. Juventud, nuevos medios y sociedad digital. Instituto de la Juventud (INJUVE). Revista de Estudios de Juventud, 2010, pp. 51-62.

105. González-Sánchez, José-Luis, et al. Evolución del concepto de usabilidad como indicador de calidad del software. El profesional de la información, 2012, 21, (5), pp. 529-536.

106. Goody, Jack y Watt, Ian. The consequences of Literacy. Comparative studies of Society and History, 1963, (5), pp. 304-345.

107. Goody, Jack. Cultura escrita en sociedades tradicionales. Barcelona: Gedisa, 1996.

108. Gubern, Roman. Metamorfosis de la escritura. Barcelona: Anagrama, 2010.

109. Gustafsson, Helena. Empowered by stories. Conference: All about audio. Bookwire, 2020.

110. Haarmann, Harald. Historia universal de la escritura. Madrid: Gredos, 2001.

111. Hanner, Hedda y O'Connor, Alice. Audiobooks speaks for themselves: a quantitative study of consumer behaviour related to Audiobooks in Sweden. Stockholm: Stockholm School of Economics, 2019.

112. Hassan, Yusef. Experiencia de usuario: Principios y métodos. Granada: Yusef Hassan, 2015.

113. Have, Iben y Stougaard Pedersen, B. S. The audiobook circuit in digital publishing: Voicing the silent revolution. New Media \& Society, 2020, 22(3), pp. 409-428.

114. Have, Iben y Stougaard Pedersen, B. S. Conceptualising the audiobook experience. SoundEffects, 2012, 2(2), 80-95.

115. Have, Iben y Stougaard Pedersen, B. S. Digital audiobooks: new media, users, and experiences. London; New York: Routledge, 2016. 
116. Have, Iben; Stougaard Pedersen, B.S. Sonic mediatization of the book: affordance of the audiobook. Journal of media and communication research, 2013 (54), pp. 123-140.

117. Havelock, Erick A. La musa aprende a escribir: reflexiones sobre la oralidad y escritura desde la Antigüedad hasta el presente. Barcelona: Paidós Ibérica, D.L. 1996.

118. Havelock, Erik A. The oral-literatte equation: a formula for the modern mind. Literacy and orality, edited by David R Olson and Nancy Torrance, Cambridge, 1991, pp. 11-27.

119. Henning, Nicole. Selecting and evaluating the best mobile apps for Library. Services Library Technology reports, 2014, 50 (8).

120. Herpers, Sanne. et al. Vrijetijdsbesteding voor patiënten met een psychotische stoornis: haalbaarheidsstudie naar gebruik van audioboeken [Leisure-time activity for patients with a psychotic disorder: audiobooks as a useful alternative to reading]. Tijdschr Psychiatr. 2016, 58(6), pp. 476-480.

121. Hilera-González, José Ramón y Campo-Montalvo, Elena. (Eds.). Guía para crear contenidos digitales accesibles: Documentos, presentaciones, vídeos, audios y páginas web Alcalá de Henares. España: Universidad de Alcalá, 2015. https://unesdoc.unesco.org/ark:/48223/pf0000219662 [Consultado el 2 de junio de 2020].

122. Hustvedt, Siri. Filba online. Conversación. Siri Hustved en primera persona. [recurso en línea] https://www.youtube.com/watch?v=wYXgUjiYiok\&t=251s\&ab channel=FilbaLiteratura [Consultado el 20 diciembre de 2020].

123. IFLA. Manifiesto de la Unesco sobre la biblioteca publica [recurso en línea] http://www.ifla.org/VII/s8/unesco/span.htm [Consultado el 10 de mayo de 2020].

124. Iglesia Sánchez, Yolanda de la y Pérez Rodríguez, Laura. El servicio de acceso a recursos electrónicos en la Red de Bibliotecas del Instituto Cervantes. BiD: textos universitaris de biblioteconomia i documentació, 2008 (21) [recurso en línea] http://bid.ub.edu/21/igles2.htm>. DOI: https://dx.doi.org/10.1344/105.000000341 [Consultado el 12 mayo de 2020].

125. Instituto Cervantes. Narrativas digitales. 27/02/2020. [recurso en línea] https://www.facebook.com/bibliotecas.instituto.cervantes/videos/174818777301742/ [Consultado el 20 de abril de 2020].

126. ISEA. Mobile learning. Análisis prospectivo de las potencialidades asociadas al mobile learning, Blog Universo Albierto, Universidad de Salamanca. Madrid: ISEA, coop. 2009. [recurso en línea] https://universoabierto.org/2016/01/05/analisis-prospectivo-de-las-potencialidades-asociadas-al-mobile-learning/ [Consultado el 29 de abril de 2020]. 
127. Jensen, Klaus Bruhn. Meta-media and meta-communication: Revisiting the concept of genre in the digital media environment. MedieKultur, 2011, 27(51), pp. 8-21.

128. Jensen, Klaus Bruhn. Sounding the media. An interdisciplinari review and resarch agenda for digital sound studies. Nordicom Review, 2006, 27, pp. 7-33.

129. Khan, Alejandro (2/11/2020). Sonolibro: calidad y variedad, por Alejandro Khan [Club Mundo Audiolibro]. [recurso en línea] https://www.clubmundoaudiolibro.com/sonolibro-alejandro-khan [Consultado el 20 de diciembre de 2020].

130. Kopenick, Lutz. Reading on the move. PMLA, 2013, 128 (1), pp. 232-237.

131. Lambrecht, Anja y Skiera, Bernd. Paying too much and being happy about it: existence, causes, and consequences of tariff-choice biases. Journal of Marketing Research, 2006, 43(2), pp. $212-223$.

132. Lampis, Mirko. La insostenible soledad del lector: la lectura como trabajo individual y colectivo. Revista Signa, 2019 (28), pp. 25-62.

133. Lawson, Celeste. The art of audiobook narration. Washington: National Library of Congress, 2005. [recurso en línea] https://www.loc.gov/item/webcast-7157/ [Consultado el 1 de mayo de 2020].

134. Lee, Linda. Audiobooks: taking the World by storm: White paper. Frankfurt: Frankfurter Buchmesse, 2020. [recurso en línea] https://www.dosdoce.com/wp-content/uploads/2020/09/Audiobooks-Taking-theWorld-by-Storm.pdf [Consultado el 1 de junio de 2020].

135. Llamas Ubieto, Miriam (2020) Postdigital ahora. [ Cuadernos del ahora; $\mathrm{n}$ 1, ] [recurso en línea] Llamas Ubieto. Postdigital ahora Cuadernos del ahora.pdf (ucm.es) [Consultado el 10 de marzo de 2021].

136. Logan, Robert K. Understanding new media: Extending Marshall McLuhan. New York: Peter Lang Publishing, 2010.

137. López Lorenzo, María Jesús. Jornadas Archivando: la nueva gestión de archivos. León, 6 y 7 de noviembre 2014. Actas de las Jornadas. [recurso en línea] https://archivofsierrapambley.files.wordpress.com/2015/02/actas archivando 2014.pdf [Consultado el 1 de junio de 2020].

138. López Lorenzo, María Jesús. Los documentos sonoros de la Biblioteca Nacional de España como fuente de investigación del patrimonio cultural. II Jornadas de Gestión de Patrimonio Bibliográfico Santiago de Compostela, 6 y 7 de junio de 2019. 
139. López Valero, Armando, Jerez Martínez, Isabel, y Encabo Fernández, Eduardo. Aproximación educativa ante los nuevos formatos narrativos. Revista Chilena de Literatura, 2017, (94). [recurso en línea]. Consultado en: https://revistaliteratura.uchile.cl/index.php/RCL/article/view/44983/47065 [Consultado el 1 de abril de 2020].

140. López, Luis Enrique y Jung, Ingrid. (comps.) Sobre las huellas de la voz. Sociolingüística de la oralidad y la escritura en su relación con la educación. Madrid: Morata, 1998. [Ebook.Scribd].

141. Luiselli, Valeria. Desierto sonoro. Madrid: Sexto Piso, 2019.

142. Magadán Díaz, Marta y Rivas García, Jesús I. Adaptación de la industria del libro en España al cambio tecnológico: pasado, presente y futuro de la digitalización. Información, Cultura y Sociedad, 2019, (40), pp. 31-52.

143. Magadán-Díaz, Marta y Rivas-García, Jesús I. El audiolibro en españa: ¿industria o modelo de negocio? Profesional de la información, 2020, v. 29, n 6.

144. Magadán-Díaz, Marta y Rivas-García, Jesús I. El impacto disruptivo del libro electrónico sobre la cadena de valor editorial española: un estudio de casos. Revista Española de Documentación Cientifica, 2020, Tomo 43 (1), pp. 1-13.

145. Manes, Facundo. Para qué o para quién es mejor, esa es la pregunta. El País. 23 de mayo de 2020.

146. Manguel, Alberto. Entrevista. [recurso en línea] https://elcultural.com/revista/esto-es-lo-UItimo/Alberto-Manguel/40063 [Consultado el 1 de junio de 2020].

147. Manguel, Alberto. Una historia de la lectura. Buenos Aires: Siglo Veintiuno Editores, 2014.

148. Manovich, Lev. El lenguaje de los nuevos medios de comunicación. La imagen en la era digital. Barcelona: Paidós, 2005.

149. Manrique Sagobal, Winston. El audiolibro alza la voz. El país semanal. 8 de diciembre de 2019.

150. Martín García, Emiliano. El servicio bibliográfico de la ONCE «Organización y prestaciones». Revista General de Información y Documentación, 2006, 16(1), pp. 65-73. [recurso en línea]. https://search.proquest.com.ezproxy.cervantes.endocview/223566009?accountid=16245 [Consultado el 1 de enero de 2020].

151. Martín García, Emiliano. El servicio bibliográfico de la ONCE: organización y prestaciones. Revista General de Información y Documentación, 2006, 16 (1), pp. 65.73. 
152. Martín Morán, José M. Don Quijote en la encrucijada: oralidad/escritura. Nueva Revista de Filología Hispánica, 1997, 45(2), pp. 337-368.

153. Martiniello, Natalina. et al. Exploring the use of smartphones and tablets among people with visual impairments: Are mainstream devices replacing the use of traditional visual aids? Assist Technol. 2019, nov 7, pp. 1-12.

154. McHugh, Sioban. Podcast: radio reinvented. El correo de la Unesco. Enero-febrero, 2020, pp. 7-9.

155. McLuhan, Marshal. La galaxia Gutenberg génesis del «homo typographicus». Barcelona: Galaxia Gutemberg, 1993.

156. Mediatore, Kaite. Reading with your ears: Readers' advisory and audio books. Reference \& User Services Quarterly, 2003, 42(4), pp. 318-323.

157. Mendoza, Rocío. iCuéntame un cuento! El audiolibro promete devolver el placer infantil de oír historias. La verdad, 7 de marzo, 2020. [recurso en línea] https://www.laverdad.es/vivir/artes/audiolibros-plataformas-titulos-ventajas-20200307135132ntrc.html?ref=https:\%2F\%2Fwww.google.com\%2F [Consultado el 9 de marzo de 2021].

158. Mildorf, Jarmila y Kinzel, Till. Audionarratology: Prolegomena to a research paradigm exploring sound and narrative. En: Audionarratology: Interfaces of Sound and Narrative, ed. Jarmila Mildorf and Till Kinzel, 1-26. Berlin, Boston: De Gruyter, 2016.

159. Momesso, María Regina y Yoshimoto, Eduardo. Das ondas do Rádio aos Pódcasts e Audiobooks. En: Maria Regina Momesso, M. R, et al. Educar com pódcasts e audiobooks. Porto Alegre: Editora Cirkula, 2016, v. 1, pp. 57-80.

160. Moner, Michel. Cervantes conteur. Écrits et paroles. Madrid: Casa de Velázquez, 1989. [recurso en línea]. https://books.google.es/ [Consultado el 3 de mayo de 2020].

161. Montero, Rosa. La ridícula idea de no volver a verte. Barcelona: Seix Barral, 2019. [Recurso electrónico. Audio-e] / Rosa Montero; [narrado por la autora].

162. Montero, Rosa. La ridícula idea de no volver a verte. Barcelona: Booket, 2014.

163. Morante, Miriam. Diseño de apps infantiles. Consideraciones para el desarrollo de aplicaciones para niños menores de 2 años [tesis doctoral]. Valencia: Universitat Politècnica de València. [recurso en línea]: https://riunet.upv.es/bitstream/handle/10251/68500/MORANTE\%20\%20Diseño\%20de\%20Apps\%20Infantiles\%3a\%20Consideraciones\%20para\%20el\%20desarroIlo\%20de\%20aplicaciones\%20para\%20niño....pdf?sequence=1\&isAllowed=y [Consultado el 12 de mayo de 2020]. 
164. Moreno Cazalla, Lourdes. Podium Pódcast, cuando el podcasting tiene acento español. Prisma Social, 2017, (18), junio-septiembre, pp. 334-368.

165. Morrison, KF. La historia como arte visual en el renacimiento del siglo XII. NJ: Princeton. Prensa universitaria, 1990.

166. Moyer, Jessic E. Audiobooks and e-books: a literatura review. Reference \& user services quarterly, 2012, 51 (4), pp. 340-54.

167. Nadal, Jordi y García, Francisco. Libros o velocidad. Reflexiones sobre el oficio editorial. Madrid: Fondo de Cultura Económica, 2005.

168. Newman, Andrew Adam. How should a book sound? And what about footnotes? New York Times, January 20, 2006, 33.

169. Nielsen, J. Beyond Accessibility: Treating Users with Disabilities as People. Nngroup.com, 2001. [recurso línea] Disponible en: https://www.nngroup. com/articles/beyond-accessibility-treating-users-with-disabilities-as-people/ [Consultado el 12 de mayo de 2020].

170. NNELS. Lectura de informes de aplicaciones. [recurso línea] https://www.accessiblepublishing.ca/read. [Consultado el 2 de febrero de 2021].

171. Nowosielski, Robert, Trick, Lana M. y Toxopeus, Ryan. Good distractions: Testing the effects of listening to an audiobook on driving performance in simple and complex road environments. Accid Anal Prev, 2018;111, pp. 202-209.

172. Observatorio de la Lectura y el Libro. 2013. Panorámica de la edición española de libros 2012. Análisis sectorial del libro. Madrid: Secretaría General Técnica.

173. Observatorio de la Lectura y el Libro. 2014. Panorámica de la edición española de libros 2013. Análisis sectorial del libro. Subdirección General de Documentación y Publicaciones. Madrid: Secretaría General Técnica.

174. Observatorio de la Lectura y el Libro. 2016. Panorámica de la edición española de libros 2015. Análisis sectorial del libro. Madrid: Secretaría General Técnica.

175. Observatorio de la Lectura y el Libro. 2015. Panorámica de la edición española de libros 2014. Análisis sectorial del libro. Madrid: Secretaría General Técnica.

176. Observatorio del libro y de la lectura. El sector de libro en España: (2017).

177. Ong, Walter. Oralidad y escritura. Tecnologías de la palabra. México: Fondo de Cultura Económica, 2016. Edición electrónica, SCRIBD. 
178. Ong, Walter. Oralidad y escritura. Tecnologías de la palabra. México: FCE, 1987.

179. Ormaechea, Ana y Fernández Delkader, Pablo. Un viaje a través del audio. Telos, 2019, pp.16-20.

180. Orrantia Herrán, Andoni. Diez claves para contar buenas historias en podcast: o cómo producir contenidos en un entorno digital cambiante. Universitat Oberta de Catalunya, 2019. [Digitalia]

181. Otto Cantón, Elena. Integración de los dispositivos móviles en el proceso de enseñanza y aprendizaje del español como lengua extranjera. Tesis doctoral dirigida por María Ángeles Álvarez Martínez (dir. tes.), Enrique Galván Álvarez (codir. tes.). Universidad de Alcalá (2017).

182. Paganelli, Céline, Chaudiron, Stéphane y Zreik, Khaldoun (dirs.). Documents et dispositifs à l'ère post-numérique: CIDE.18: actes du 18 Colloque international sur le Document Electronique. Paris: Europia, 2016.

183. Parra Valcarce, David y Onieva Mallero, Charo. El uso del pódcast para la difusión del patrimonio cultural en el entorno hispanoparlante: análisis de las plataformas iVoox y SoundCloud. Naveg@mérica. Revista electrónica editada por la Asociación Española de Americanistas [recurso en línea]. 2020, (24), pp. 1-31. [recurso en línea] http://revistas.um.es/navegamerica>. [Consultado el 23 de mayo de 2020].

184. Paz Gago, José María. Oralidad, escritura y visualidad en el Quijote. Actas del IV Congreso Internacional de la Asociación Internacional Siglo de Oro (AISO), (Alcalá de Henares, 22-27 de julio de 1996) / María Cruz García de Enterría (ed. lit.), Alicia Cordón Mesa (ed. lit.), Vol. 2, 1998, pp. 1169-1186.

185. Pedrero Esteban, Luis Miguel y Contreras Pulido, Paloma. La radio en el entorno digital: Ios nuevos canales de las ondas hertzianas. Romero-Rodríguez, L.M. y Rivera-Rogel, D. y (Coords.) La Comunicación en el escenario digital. Actualidad, retos y prospectivas. Ecuador: Pearson-UTPL, 2019, pp. 349-378). [recurso en línea] http://bit.ly/NuevosCanalesRadio [Consultado el 23 de mayo de 2020].

186. Pérez-Rioja, José Antonio. Panorámica histórica y actualidad de la lectura. Madrid: Fundación Germán Sánchez Ruipérez, 1986.

187. Peterson, Edward. The talking book. En: Bulletin of the American Library Association, 1934, 28 (5), pp. 243-244.

188. Philips, Angus. Does the book have a future? En: S. Eliot \& J. Rose (Eds.) A companion to the history of the book. Chichester: Wiley, 2020.

189. Poerio, Giulia y Totterdell, Peter. The Effect of Fiction on the Well-Being of Older Adults: A Longitudinal RCT Intervention Study Using Audiobooks. Psychosocial Intervention, 2020, 
29(1), pp. 29-38.

190. Putnam, Robert. Bowling Alone. The collapse and revival of american community. New York. Simon \& Juster, 2001.

191. Quintero Pomares, Ana. Nuevos talentos: prácticas artísticas y consumo cultural en la era digital. En: Revista de estudios de juventud, 2017, 117, pp. 145-162.

192. Ranera Sánchez, Dunia y Crespo Arcá, Luis. Paleografía sonora: los cilindros sonoros en la Biblioteca Nacional de España : descripción y estudio, criterios de conservación. Boletín DM, 2010, pp. 50-75.

193. Reich, Lior. et al. A ventral visual stream rading center independent of visual experience. Current Biology, 2011, 21, pp. 363-368.

194. Renó, Denís. et al. Nueva ecología de los medios y desarrollo ciudadano. Bogotá : Universidad del Rosario, 2015.

195. Ribera Turró, Mireia y Moese, Santi. Daisy : un libro digital abierto, multimodal y accesible. Profesional De La Informacion, 2008, pp. 403-407.

196. Richardson, Nicole. et al. Measuring narrative engagement: The heart tells the story. 2018. [recurso en línea]. https://doi.org/10.1101/351148 [Consultado el 10 de febrero de 2021]

197. Rico Rico, Ana Belén. Evaluación del uso de APPs que abordan los procesos creativos en la educación artística formal (tesis doctoral). Universidad de Valladolid: Facultad de Educación y Trabajo Social. 2017. [recurso en línea] http://uvadoc.uva.es/handle/10324/22663. [Consultado el 3 de febrero de 2021].

198. Rico, Francisco. Prólogo de Don Quijote de la Mancha. Edición del Instituto Cervantes. BarceIona: Instituto Cervantes-Crítica, 1998.

199. Rodero, Emma. El peso creciente de la voz y el sonido para comunicar en la era digital: el protagonismo de la oralidad. En: Anuario AC/E de cultura digital 2018 (ebook). Madrid: Acción Cultural Española, 2018.

200. Rodero, Emma. Estudio Neurocientífico sobre audiolibros. Qué formato transmite mejor la historia. Fundación BBVA: Barcelona, 2020. [recurso en línea] https://www.upf.edu/documents/10193/227809157/Proyecto+audiolibros+ERodero.pdf/ebe99107-f94b-ff64-7458c57c4a878262 [Consultado el 3 de noviembre de 2020].

201. Rodríguez Bravo, Blanca. El análisis documental de documentos digitales y/o multimedia. Revista códice, 2005, 2, pp. 9-20. 
202. Rodríguez Bravo, Blanca. El documento, entre la tradición y la renovación. Gijón: Trea, 2002.

203. Rodríguez de las Heras, Antonio. La vida en digital: Un mundo digital para escuchar. Retina. 21 dic, 2018.

204. Rodríguez de las Heras, Antonio. Ultrafalso (deepfake): el fin de otra certeza. Retina, El País Economía. [recurso en línea] https://retina.elpais.com/retina/2020/02/28/tendencias/1582874570_345263.html?ssm=TW_CC [Consultado el 2 de marzo 2020].

205. Rodríguez de las Heras, Antonio. Un mundo para interrogar y escuchar: la humanidad recupera la voz. En: Telos: Cuadernos de Comunicación, Tecnología y Sociedad, 2019, (111), pp. 37-41.

206. Rodríguez Reséndiz, Perla Olivia. Digital preservation of sound recordings. Investigación Bibliotecológica: Archivonomía, Bibliotecología e Información, 2016, 30 (68), pp. 173-195.

207. Rogowsky, Beth, Calhoun, Bárbara y Tallal, Paula. Does Modality Matter? The Effects of Reading, Listening, and Dual Modality on Comprehension. SAGE Open, 2016. [recurso en línea] https://doi.org/10.1177/2158244016669550 [Consultado el 6 de marzo de 2020].

208. Romero Rodríguez, Luis Miguel y Rivera Rogel, Diana. (Eds.) La comunicación en el escenario digital. Actualidad, retos y prospectivas. Lima: Pearson, 2019.

209. Rosen, Jody. Researchers play tune recorded before Edison. En: New York Times. New York. 27 de marzo de 2008.

210. Rousseau, Jean Yve y Couture, Carol. Les fondements de la discipline arcuivistique. Québec: Presses de I'Université du Québec. Québec, 1994.

211. Rubery, Matthew. Audiobooks, Literature, and Sound Studies. New York: Routledge, 2011.

212. Rubery, Matthew. Play it again, Sam Weller: new digital audiobooks and old ways of Reading. Journal of Victorian Culture, 2008, 13 (1): 72.

213. Rubery, Matthew. The untold story of the talking book. Harvard: Harvard University Press, 2016.

214. Rueda, Juliana. La voz aún nos distingue como humanos. Telos, 2019, julio, pp. 27-34.

215. Ruiz Mantilla, Jesús y Geli, Carles. Planeta destruye su colección de Obras Completas del Círculo de Lectores. El país. 30/11/2019. 
216. Ruiz Mantilla, Jesús. Órdago a las plataformas de audiolibros. En: El País. 9 de febrero de 2020. [recurso en línea] https://elpais.com/cultura/2020/02/08/actualidad/1581161390_352095.html [Consultado el 12 de mayo de 2020].

217. Sanchiz Gandía, Álvaro. Diseño de experiencia de usuario en la museografía interactiva. Metodología proyectual para aplicaciones móviles de museos y espacios expositivos. Valencia: Universidad Politécnica de Valencia, 2017. (tesis de doctorado)

218. Sanmartín Sáez, Julia. El chat: la conversación tecnológica. Madrid: Arco Libros, 2007.

219. Schulz, Winfried. Reconstruction mediatization as an analytical concept. European Jorunal of Communication, 2004, 19:87, pp. 87-101.

220. Scolari, Carlos A. El translector. Lectura y narrativas transmedia en la nueva ecología de la comunicación. En: La lectura en España. Informe 2017. Madrid: Federación de Gremios de Editores de España, 2016.

221. Seco, Manuel; Andrés, Olimpia; Ramos, Gabino Ramos. Diccionario del español actual. Madrid: Aguilar, 1999.

222. Soames, Nicolás. Interview with Nicolas Soames of Naxos AudioBooks. [recurso en línea] https://vulpeslibris.wordpress.com/2010/09/06/interview-with-nicolas-soames-of-naxosaudiobooks/[Consultado el 4 de marzo de 2020].

223. Soccavo, Lorenzo. Inventar juntos las nuevas mediaciones del libro. S/n: Fundación Germán Sánchez Ruipérez, 2013.

224. Soffer, Oren. (2012): Liquid Language? On the personalization of discourse in the digital era, New Media \& Society, 14, 7, pp. 1092-1110.

225. Soffer, Oren. 2016. Orality. The International Encyclopedia of Communication Theory and Philosophy, pp. 1-6.

226. Soffer, Oren. 2016b. The oral paradigm and Snapchat. Social Media + Society, 2016, pp. 1-4.

227. Soffer, Oren. Silent Orality: Towards a conceptualization of the digital oral features in CMC and SMS texts, Communication theory, 2010, 20, pp. 387-404.

228. Soriano, Ana María. Diseño y validación de instrumentos de medición. Diálogos 2014, 14, pp. $19-40$.

229. Tattersall Wallin, Elisa y Nolin, Jan. Time to read: exploring the timespaces of subscriptionbased audiobooks. New Media \& Society, 2020, 22 (3), pp. 470-488. 
230. Taylor, Joanne, Davis, Matthew y Rastle, Kathleen. Mapping visual symbols onto spoken language along the ventral visual stream. Proceedings of the National Academy of Sciences. [recurso en línea]. DOI: 10.1073/pnas.1818575116.

231. Techleo. El audiolibro o libro hablado: formatos, reproductores, tiendas y producción. [recurso en línea] https://www.techleo.es/el-audiolibro-o-libro-hablado/ [Consultado el 6 de marzo de 2020].

232. Thomas, G. Secondary ritualization in a posliterate culture: reconsidering and expanding Walter Ong's contribution on secondary orality. Soundings: An Interdisciplinary Journal, 2000, 83(2), pp. 385-409.

233. Trower, Shelley. Vibrations. En: Anna Snaith (Ed.), Sound and Literature (Cambridge Critical Concepts, pp. 287-314). Cambridge: Cambridge University Press, 2020.

234. UNESCO. Aprendizaje móvil. [recurso en línea] https://es.unesco.org/themes/tic-educacion/aprendizaje-movil [Consultado el 5 de marzo de 2020]

235. UNESCO. Directrices para las políticas del aprendizaje móvil. Paris: UNESCO, 2013.

236. UNESCO. Investigaciones sobre la aplicación de la Convención de 2003. [recurso en línea].

237. University of California. A map of the brain can tell what you're reading about: Through brain imaging, scientists open another door to our inner thoughts and narratives. ScienceDaily. Berkeley. (2019, August 19). [recurso en línea] A map of the brain can tell what you're reading about: Through brain imaging, scientists open another door to our inner thoughts and narratives -- ScienceDaily [Consultado el 7 de marzo de 2020].

238. Vallorani, Cecilia María. La oralidad tecnológica-digital: estudio pragmático-comunicativo sobre la oralidad en el audiolibro. Tesis de Máster en Estudios Literarios. Universidad de Alicante. 2011. [recurso en línea]. https://rua.ua.endspace/bitstream/10045/19656/6/cecilia vallorani.pdf [Consultado el 8 de marzo de 2020].

239. Varao-Sousa, Trish, Smilek, Daniel y Kingstone, Alan. In the lab and in the wild: How distraction and mind wandering affect attention and memory. Cognitive Research, 2018, 3(42).

240. Vargas Llosa, Mario. Una Novela para el siglo XXI. In: CERVANTES, Miguel de. Don Quijote de la Mancha. Edición del IV Centenario. Madrid: RAE, 2004.

241. Vazquez Medel, Manuel Angel. La oralidad en el tercer entorno. Oralidad, comunicación audiovisual y comunicación digital. Pag. 123-134. En: Oralidades: saberes y experiencias de investigación en red. Universidad Distrital Francisco José de Caldas: Bogotá (Colombia). 2014. 
242. Vázquez, José Antonio. Retos e interrogantes alrededor del libro electrónico. Dosdoce. 2010. [recurso en línea] Dosdoce.com Retos e interrogantes alrededor del libro electrónico - Dosdoce.com [Consultado el 9 de marzo de 2020].

243. Vázquez, Karelia. La extraña moda de escucharlo todo al doble de velocidad. El País, 19 de julio de 2015.

244. Vilas, Manuel. El audiolibro se encuentra en la encrucijada entre lo tradicional y lo tecnológico. [recurso en línea] https://www.dphuesca.es/noticias4/-/asset publisher/84XLaGGBaZPJ/content/manuel-vilas-\%2560el-audiolibro-se-encuentra-en-la-encrucijada-entre-lo-tradicional-y-lo-tecnologico\%25C2\%25B4 [Consultado el 15 de marzo 2020].

245. Vilches, Fernando. La lengua española estándar en la red: tensión entre oralidad y escritura. Madrid: Dykinson, 2014.

246. Viñao Frago, Antonio. Oralidad y escritura en El Quijote: ¿̇oposición o interacción? En: Revista de Educación. 2004, (1), pp. 27-47.

247. Whitten, Robin. Grow of the audio publishing industry. Publishing Research Quarterly, 2002, 18(3), pp. 3-10.

248. Young, Renee. The alert collector: Listen up: best practices for audiobooks in libraries. Reference \& User Services Quarterly, 2019, 58(4), pp. 210-214.

249. Zickuhr, Kathryn y Raine, Lee. E-reading Rises as Device Ownership Jumps. Washington, DC: Pew Research Center, 2014.

250. Zickuhr, Kathryn. et al. Younger Americans' Reading and Library Habits. Washington, DC: Pew Research Center, 2012.

251. Zumthor, Paul. Introducción a la poesía oral. Madrid: Taurus, 1991.

252. Zumthor, Paul. Permanencia de la voz. En: El Correo: una ventana abierta al mundo, 1985 (8), pp. 4-8. 
11 ANEXO I 


\subsection{BÚSQUEDA BIBLIOGRÁFICA DEL QUIJOTE, POR PLATAFORMA.}

\section{AUDIBLE. Información y fichas de los audiolibros del Quijote que contiene}

Tanto en la versión web como en la app existen varias opciones interesantes de búsqueda. La plataforma permite elegir por categoría:

- Audiolibros infantiles

- Ciencia e ingeniería

- Educación y formación

- Historia

- Literatura y ficción

- Política y ciencias sociales

También permite filtrar la búsqueda a los 90 días previos, para aquellos que busquen novedades.

Otra opción interesante es la de búsqueda por extensión de los audios, según las siguientes opciones:

- Menos de 1 hora

- 1-3 horas

- De 10 a 20 horas

- Y más de 20 horas

Asimismo, es posible la búsqueda por acento, lo cual nos traería resultados de castellano o latino neutro.

Incluye la posibilidad de búsqueda por audio para que pueda ser sincronizado a un libro textual. Esta opción se llama: whispersync for voice. Y finalmente, ofrece la posibilidad de optar si queremos una versión resumida o íntegra.

La búsqueda bibliográfica de audiolibros se realizó introduciendo la palabra Quijote, en el casillero de búsqueda "título» (pocas plataformas permiten esta opción), en español, y en autor: Cervantes. Se recuperaron 14 resultados, de los cuales 11 se ajustan a nuestro objeto de búsqueda:

\begin{tabular}{|l|l|}
\hline \multicolumn{2}{|c|}{ Resultado de la búsqueda del «Quijote» en Audible } \\
\multicolumn{2}{|l|}{ Ficha . $^{\circ}$ 1 } \\
\hline Título & Don Quijote de la Mancha \\
\hline Duración & 37 h 52 min \\
\hline Narrador & Eladio Ramos, Jesús Ramos \\
\hline Acento de la narración & S/D \\
\hline Dramatización & S/D \\
\hline
\end{tabular}




\begin{tabular}{|c|c|}
\hline Efectos de sonido & $S / D$ \\
\hline Contenido & $S / D$ \\
\hline Lanzamiento & 06-05-2017 \\
\hline Editorial & Audiomol \\
\hline Enlace & $\begin{array}{l}\text { https://www.audible.com/pd/Don-Quijote-de-la-Mancha-Audio- } \\
\text { book/B072N6HR9R?qid=1608842671\&sr=1-1\&ref=a_search_c3_IProduct_1_1\&pf_rd_p=83218cca- } \\
\text { c308-412f-bfcf-90198b687a2f\&pf_rd_r=N415WJ00H8ECZEQ8B993 }\end{array}$ \\
\hline Tamaño del archivo & $S / D$ \\
\hline ISBN & S/D \\
\hline Demo & 1.48 minutos \\
\hline Precio & Incluido con la suscripción de $\$ 14,99$ o compra individual por $\$ 39,95$ \\
\hline Imagen & 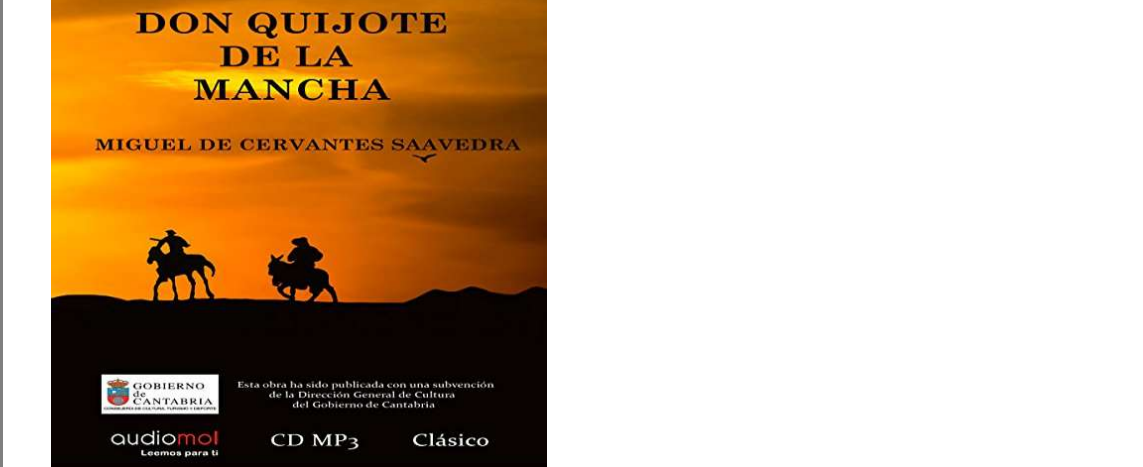 \\
\hline
\end{tabular}

\begin{tabular}{|c|c|}
\hline \multicolumn{2}{|r|}{$\begin{array}{l}\text { Resultado de la búsqueda del «Quijote» en Audible } \\
\qquad{\text { Ficha } n .^{\circ} 2}^{2}\end{array}$} \\
\hline Título & Don quijote de la mancha para jóvenes [Don Quixote of Mancha for Young People] \\
\hline Duración & $3 \mathrm{hrs}$ and $51 \mathrm{mins}$ \\
\hline Narrador & Oscar Chamorro \\
\hline Acento de la narración & S/D \\
\hline Dramatización & $S / D$ \\
\hline Efectos de sonido & $S / D$ \\
\hline Contenido & For young people \\
\hline Lanzamiento & 2020 \\
\hline Editorial & Audiomol \\
\hline Enlace & $\begin{array}{l}\text { https://www.audible.com/pd/Don-quijote-de-la-mancha-para-jovenes-Don-Quixote-of-Mancha-for- } \\
\text { Young-People-Audiobook/8418220422?qid=1608842671\&sr=1-2\&ref=a_search_c3_IPro- } \\
\text { duct_1_2\&pf_rd_p=83218cca-c308-412f-bfcf-90198b687a2f\&pf_rd_r=N415WJ00H8ECZEQ8B993 }\end{array}$ \\
\hline
\end{tabular}




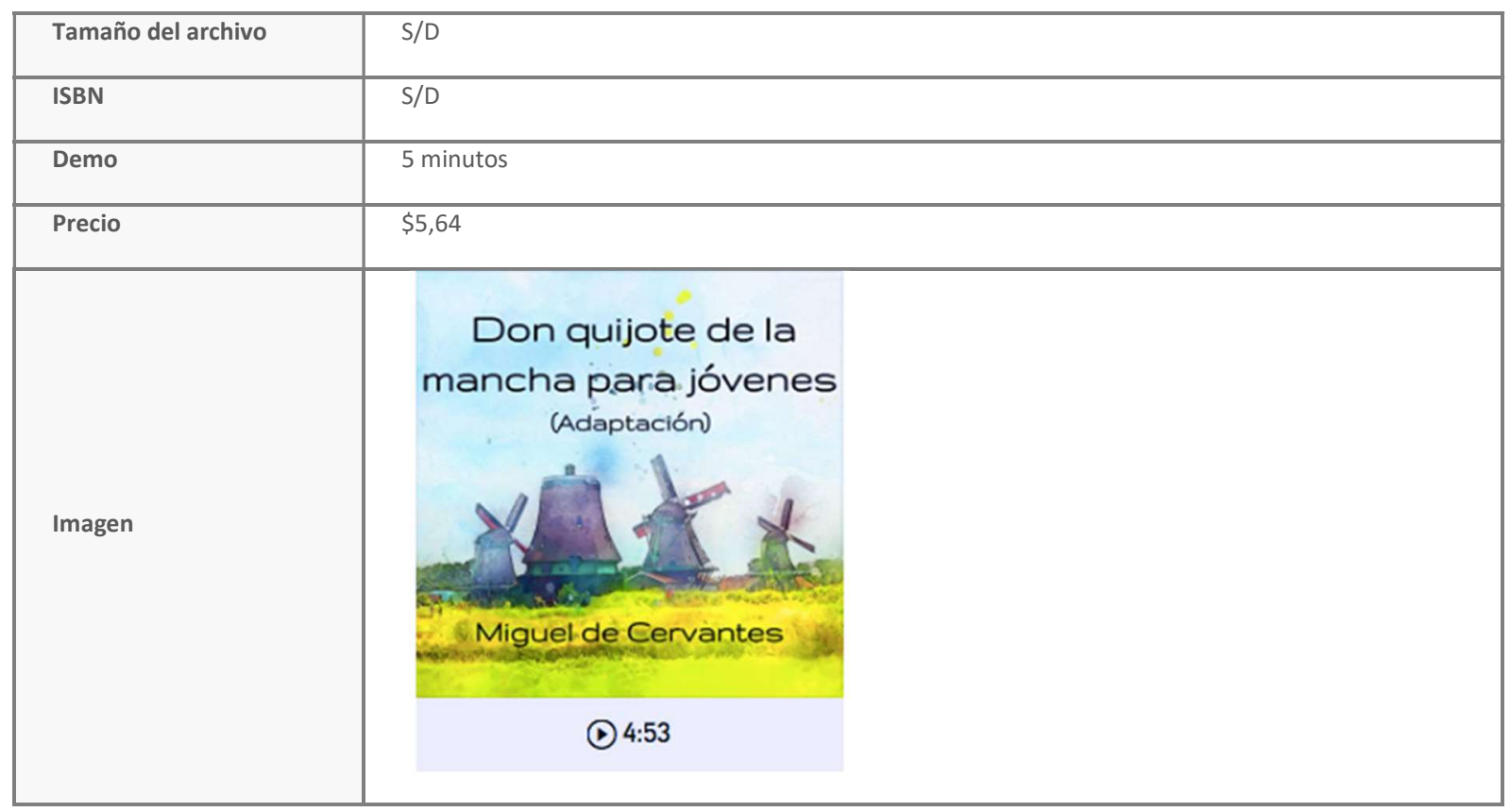

\begin{tabular}{|c|c|}
\hline \multicolumn{2}{|r|}{ 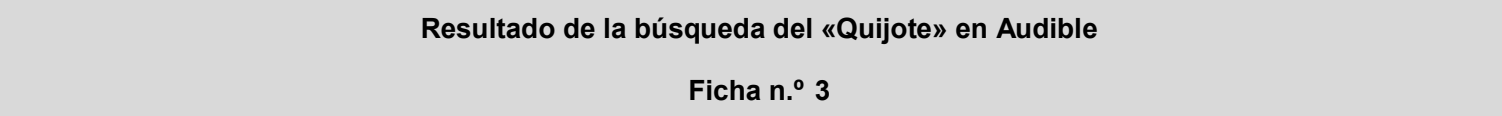 } \\
\hline Título & El Ingenioso Hidalgo Don Quijote de la Mancha [The Ingenious Don Quijote of la Mancha] \\
\hline Duración & $15 \mathrm{hrs}$ and $57 \mathrm{mins}$ \\
\hline Narrador & Various \\
\hline Acento de la narración & S/D \\
\hline Dramatización & S/D \\
\hline Efectos de sonido & S/D \\
\hline Contenido & S/D \\
\hline Lanzamiento & S/D \\
\hline Editorial & Disonex \\
\hline Enlace & $\begin{array}{l}\text { https://www.audible.com/pd/El-Ingenioso-Hidalgo-Don-Quijote-de-la-Mancha-The-Ingenious-Don- } \\
\text { Quijote-of-la-Mancha-Audiobook/B002V1A4BQ?qid=1608842671\&sr=1-3\&ref=a_search_c3_IPro- } \\
\text { duct_1_3\&pf_rd_p=83218cca-c308-412f-bfcf-90198b687a2f\&pfrd_r=N415WJ0OH8ECZEQ8B993 }\end{array}$ \\
\hline Tamaño del archivo & S/D \\
\hline ISBN & S/D \\
\hline Demo & 5 minutos \\
\hline Precio & Incluido con la suscripción de $\$ 14,99$ o compra individual por $\$ 41,99$ \\
\hline
\end{tabular}




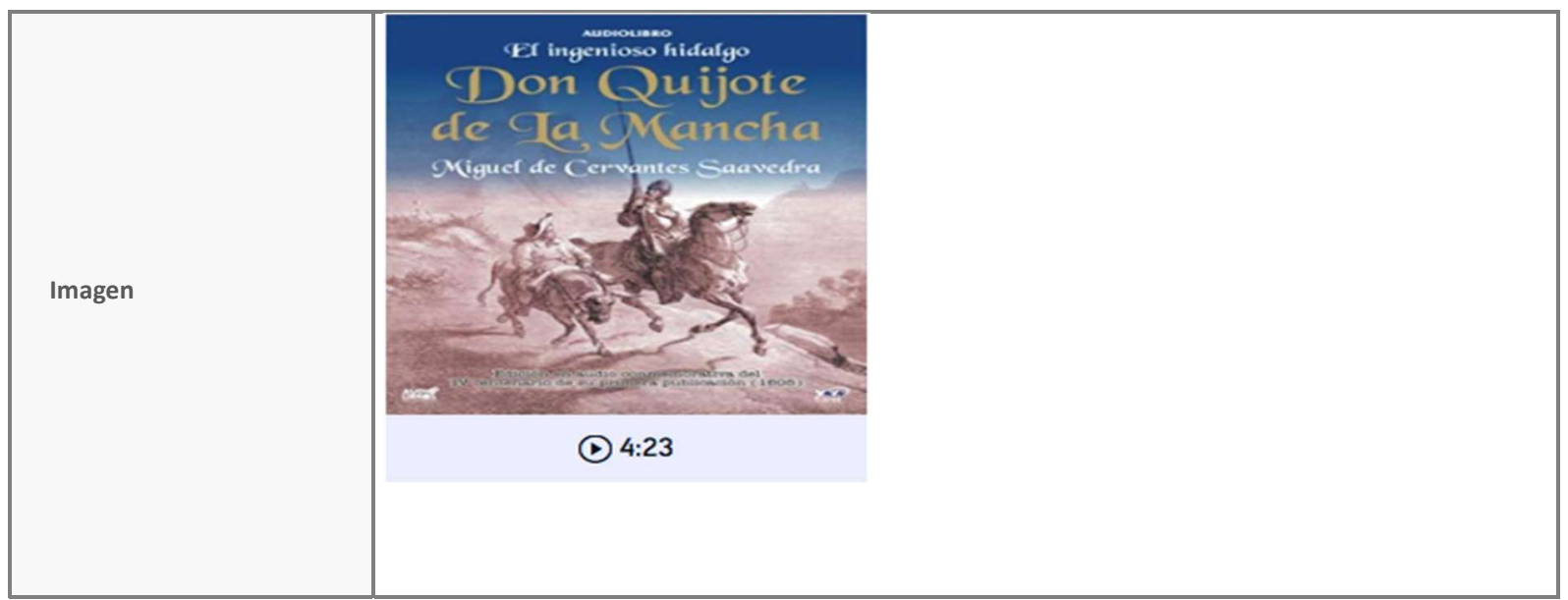

\begin{tabular}{|c|c|}
\hline \multirow{2}{*}{\multicolumn{2}{|c|}{$\begin{array}{l}\text { Resultado de la búsqueda del «Quijote» en Audible } \\
\qquad \text { Ficha }{ }^{\circ} .^{4}\end{array}$}} \\
\hline & \\
\hline Título & Don Quijote de la Mancha \\
\hline Duración & 34 horas y $7 \mathrm{~min}$ \\
\hline Narrador & Aurora de la Iglesia del Prado \\
\hline Acento de la narración & S/D \\
\hline Dramatización & S/D \\
\hline Efectos de sonido & S/D \\
\hline Contenido & S/D \\
\hline Lanzamiento & S/D \\
\hline Editorial & Trout Lake Media \\
\hline Enlace & $\begin{array}{l}\text { https://www.audible.com/pd/Don-Quijote-de-la-Mancha-Audiobook/B00CY- } \\
\text { KEHNA?qid=1608842671\&sr=1-4\&ref=a_search_c3_IProduct_1_4\&pf_rd_p=83218cca-c308-412f-bfcf- } \\
\text { 90198b687a2f\&pf_rd_r=N415WJ00H8ECZEQ8B993\# }\end{array}$ \\
\hline Tamaño del archivo & S/D \\
\hline ISBN & S/D \\
\hline Demo & 2,05 minutos \\
\hline Precio & Incluido con la suscripción de $\$ 14,99$ o compra individual por $\$ 3,49$ \\
\hline
\end{tabular}




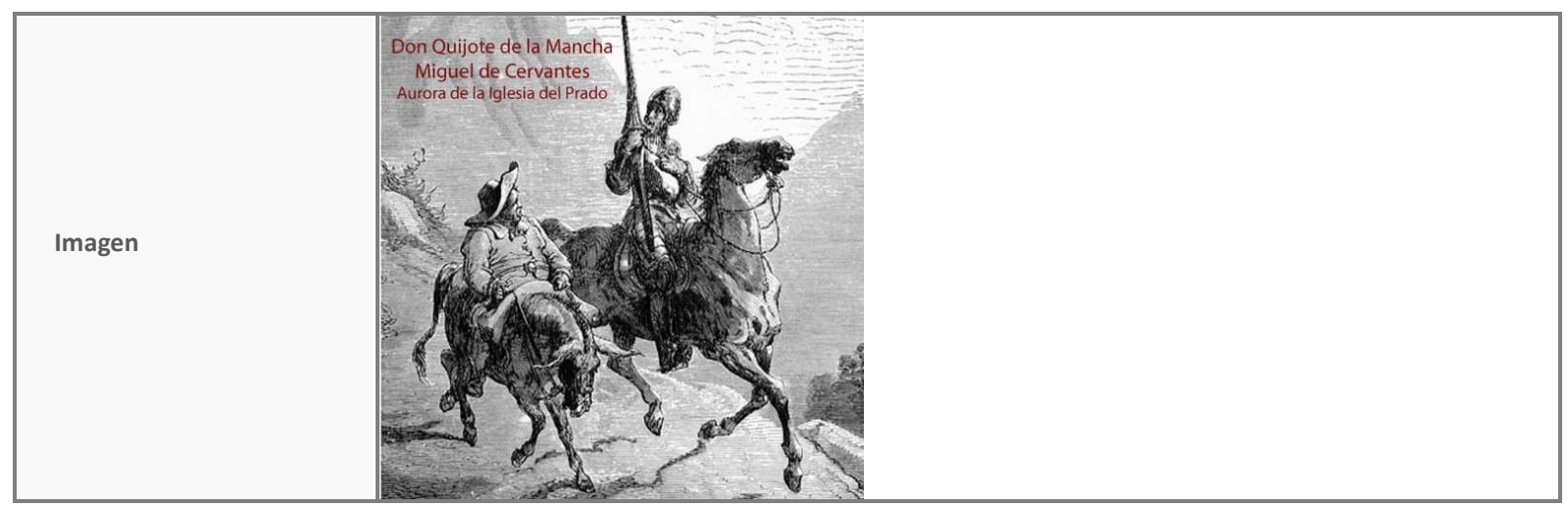

\begin{tabular}{|c|c|}
\hline \multicolumn{2}{|r|}{$\begin{array}{l}\text { Resultado de la búsqueda del «Quijote» en Audible } \\
\text { Ficha } .^{\circ} 5\end{array}$} \\
\hline Título & Don Quijote de la Mancha [Don Quixote] \\
\hline Duración & 5 horas y $24 \mathrm{~min}$ \\
\hline Narrador & Full cast \\
\hline Acento de la narración & $S / D$ \\
\hline Dramatización & S/D \\
\hline Efectos de sonido & S/D \\
\hline Contenido & $S / D$ \\
\hline Lanzamiento & $23-03-2006$ \\
\hline Editorial & FonoLibro Inc. \\
\hline Enlace & $\begin{array}{l}\text { https://www.audible.com/pd/Don-Quijote-de-la-Mancha-Don-Quixote-Audio- } \\
\text { book/B002V8NB50?qid=1608842671\&sr=1-5\&ref=a_search_c3_IProduct_1_5\&pf_rd_p=83218cca-c308- } \\
\text { 412f-bfcf-90198b687a2f\&pf_rd_r=N415WJ00H8ECZEQ8B993 }\end{array}$ \\
\hline Tamaño del archivo & S/D \\
\hline ISBN & S/D \\
\hline Demo & 5 minutos \\
\hline Precio & Incluido con la suscripción de $\$ 14,99$ o compra individual por $\$ 17,47$ \\
\hline
\end{tabular}




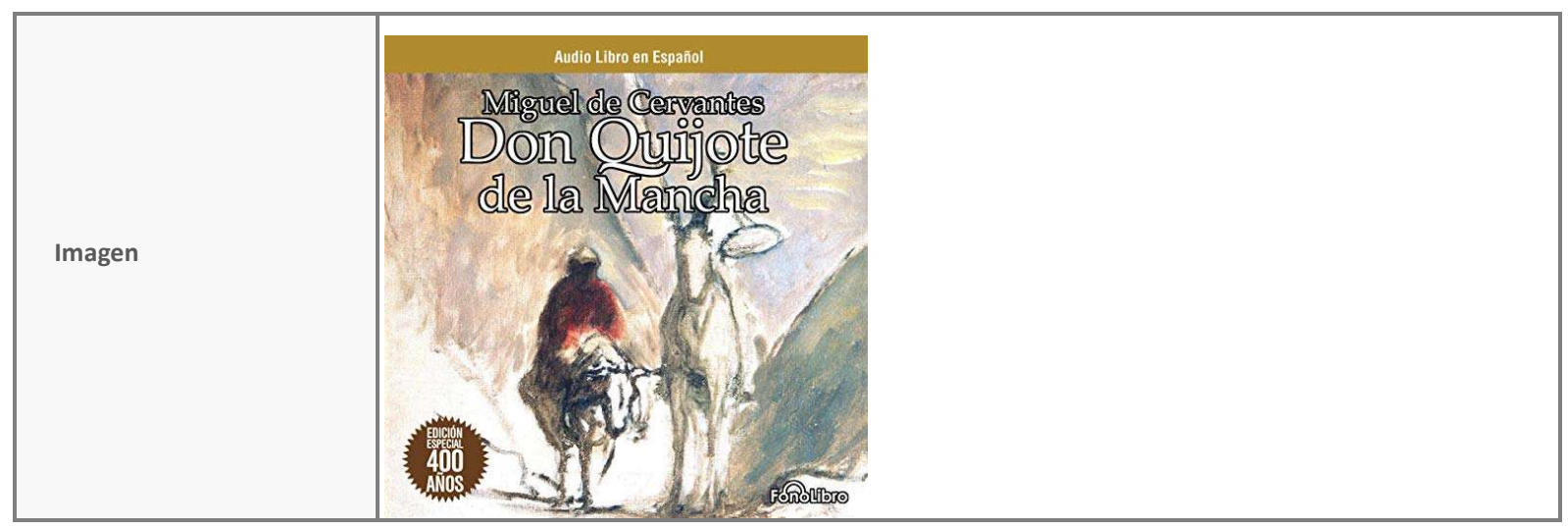

\begin{tabular}{|c|c|}
\hline \multicolumn{2}{|r|}{$\begin{array}{l}\text { Resultado de la búsqueda del «Quijote» en Audible } \\
\qquad{\text { Ficha } n .^{\circ} 6}\end{array}$} \\
\hline Título & Don Quijote de la Mancha \\
\hline Duración & 17 horas y $11 \mathrm{~min}$ \\
\hline Narrador & Carlos Ramos \\
\hline Acento de la narración & S/D \\
\hline Dramatización & S/D \\
\hline Efectos de sonido & $S / D$ \\
\hline Contenido & $S / D$ \\
\hline Lanzamiento & 2019 \\
\hline Editorial & Pegasus Classics \\
\hline Enlace & $\begin{array}{l}\text { https://www.audible.com/pd/Don-Quijote-de-la-Mancha-Audio- } \\
\text { book/2291063979?qid=1608842671\&sr=1-6\&ref=a_search_c3_IProduct_1_6\&pf_rd_p=83218cca-c308- } \\
\text { 412f-bfcf-90198b687a2f\&pf_rd_r=N415WJ00H8ECZEQ8B993 }\end{array}$ \\
\hline Tamaño del archivo & S/D \\
\hline ISBN & $S / D$ \\
\hline Demo & 5 minutos \\
\hline Precio & Incluido con suscripción mensual de $\$ 14,95$ o por $\$ 2.91$, individualmente \\
\hline
\end{tabular}




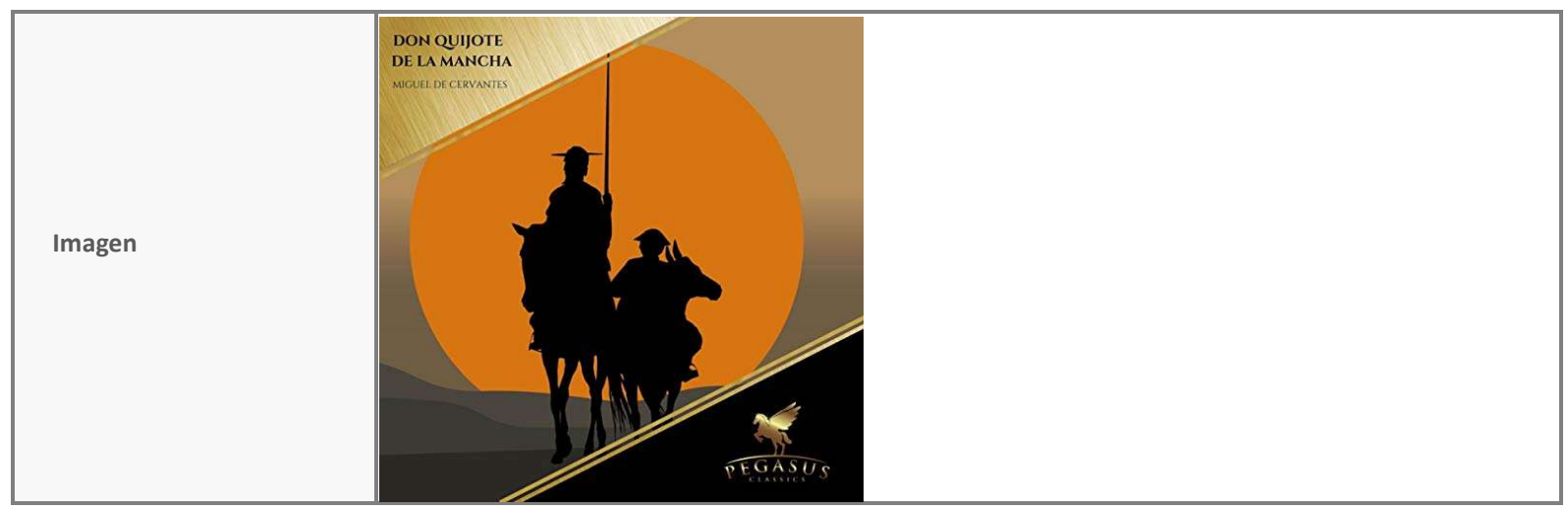

\begin{tabular}{|c|c|}
\hline \multicolumn{2}{|r|}{$\begin{array}{l}\text { Resultado de la búsqueda del «Quijote» en Audible } \\
\qquad{\text { Ficha } n .^{\circ} 7}\end{array}$} \\
\hline Título & Don Quijote de la Mancha Tomo I [Don Quixote, Part I] \\
\hline Duración & 21 horas y $27 \mathrm{~min}$ \\
\hline Narrador & Alejandro Magnone \\
\hline Acento de la narración & S/D \\
\hline Dramatización & S/D \\
\hline Efectos de sonido & S/D \\
\hline Contenido & Part I \\
\hline Lanzamiento & S/D \\
\hline Editorial & Emmanuel Michan \\
\hline Enlace & $\begin{array}{l}\text { https://www.audible.com/pd/Don-Quijote-de-la-Mancha-Tomo-I-Don-Quixote-Part-I-Audio- } \\
\text { book/B002V8LKCQ?qid=1608842671\&sr=1-7\&ref=a_search_c3_IProduct_1_7\&pf_rd_p=83218cca-c308- } \\
\text { 412f-bfcf-90198b687a2f\&pf_rd_r=N415WJ00H8ECZEQ8B993 }\end{array}$ \\
\hline Tamaño del archivo & S/D \\
\hline ISBN & S/D \\
\hline Demo & 5 minutos \\
\hline Precio & Incluido con suscripción mensual de $\$ 14,95$ o $\$ 10,50$ individualmente \\
\hline
\end{tabular}




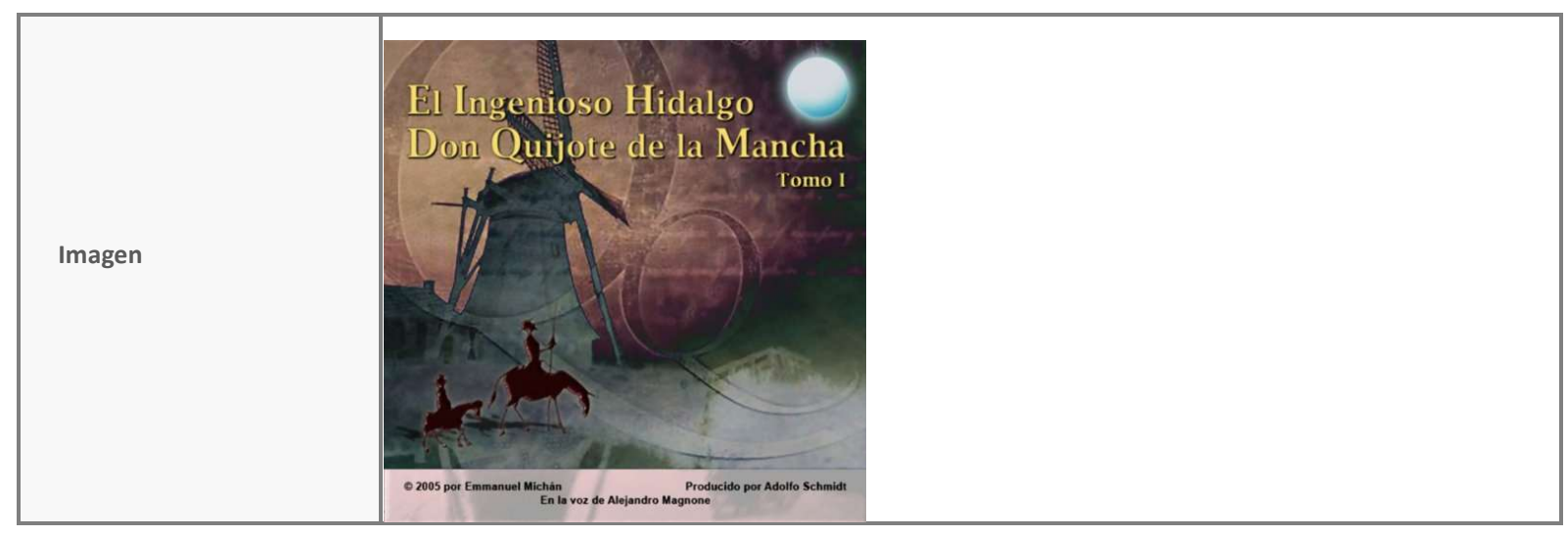

\begin{tabular}{|c|c|}
\hline \multirow{2}{*}{\multicolumn{2}{|c|}{$\begin{array}{l}\text { Resultado de la búsqueda del «Quijote» en: Audible } \\
\qquad \text { Ficha } n .^{\circ} 8\end{array}$}} \\
\hline & \\
\hline Título & Título: El Quijote Contado a los niños [Don Quixote Told to Children] \\
\hline Duración & 1hora 57 minutos \\
\hline Narrador & Eduardo Ruales \\
\hline Acento de la narración & S/D \\
\hline Dramatización & S/D \\
\hline Efectos de sonido & S/D \\
\hline Contenido & S/D \\
\hline Lanzamiento & 2020 \\
\hline Editorial & Audible Studios \\
\hline Enlace & $\begin{array}{l}\text { https://www.audible.com/pd/El-Quijote-Contado-A-Los-Ninos-Don-Quixote-Told-to-Children-Audio- } \\
\text { book/B08B46KHJV?qid=1609847065\&sr=1-5\&ref=a_search_c3_IProduct_1_5\&pf_rd_p=83218cca-c308- } \\
\text { 412f-bfcf-90198b687a2f\&pf_rd_r=RRJ3E5P1F0Q1AD0GPY7W }\end{array}$ \\
\hline Tamaño del archivo & S/D \\
\hline ISBN & S/D \\
\hline Demo & 4:07 minutos \\
\hline Precio & Incluido con suscripción mensual de $\$ 14,95$ o $\$ 7,90$, individualmente \\
\hline Imagen & \\
\hline
\end{tabular}




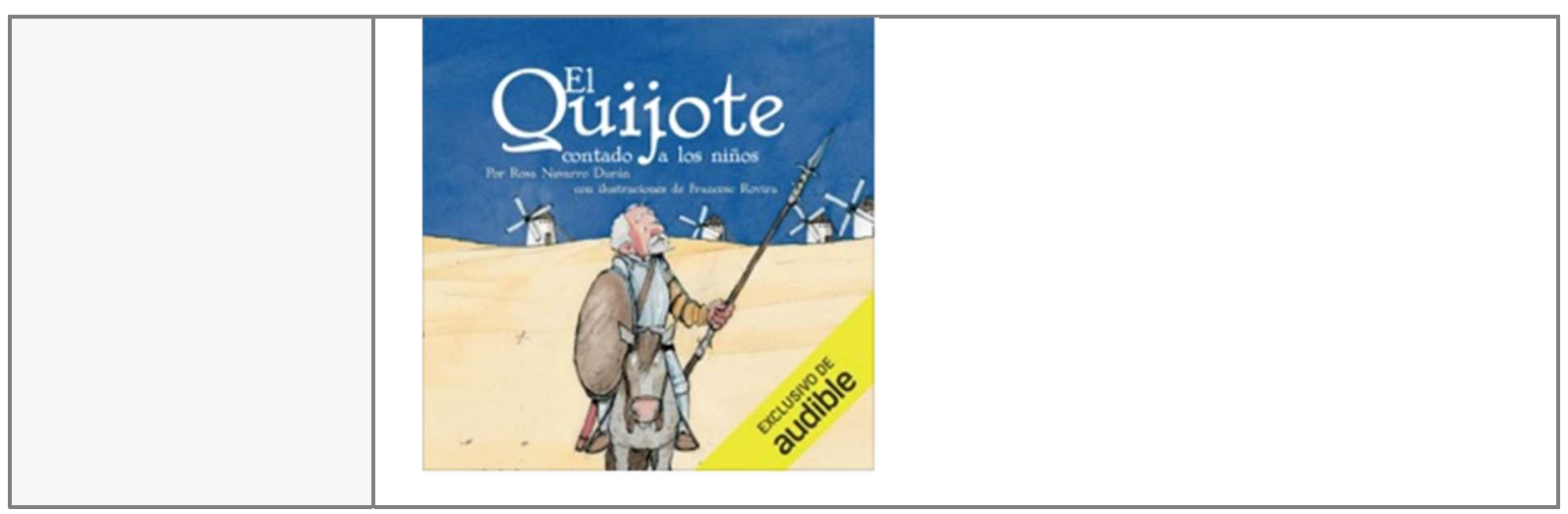

\begin{tabular}{|c|c|}
\hline \multicolumn{2}{|r|}{ 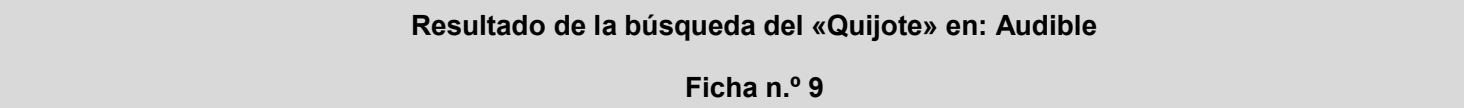 } \\
\hline Título & Don Quijote de La Mancha [Don Quijote of La Mancha] \\
\hline Duración & 3 horas y $42 \mathrm{~min}$ \\
\hline Narrador & Raúl Llorens \\
\hline Acento de la narración & S/D \\
\hline Dramatización & $S / D$ \\
\hline Efectos de sonido & S/D \\
\hline Contenido & Edición sintetizada / Escrito por: José L. Giménez Frontín \\
\hline Lanzamiento & 2018 \\
\hline Editorial & Penguin Random House Grupo Editorial \\
\hline Enlace & $\begin{array}{l}\text { https://www.audible.com/pd/Don-Quijote-de-La-Mancha-Don-Quijote-of-La-Mancha-Audio- } \\
\text { book/B07BFNNBC2?qid=1609847065\&sr=1-8\&ref=a_search_c3_IProduct_1_8\&pf_rd_p=83218cca- } \\
\text { c308-412f-bfcf-90198b687a2f\&pf_rd_r=RRJ3E5P1F0Q1AD0GPY7W }\end{array}$ \\
\hline Tamaño del archivo & $S / D$ \\
\hline ISBN & $S / D$ \\
\hline Demo & 4,35 minutos \\
\hline Precio & Incluido con suscripción mensual de $\$ 14,95$ o $\$ 10,90$, individualmente \\
\hline
\end{tabular}




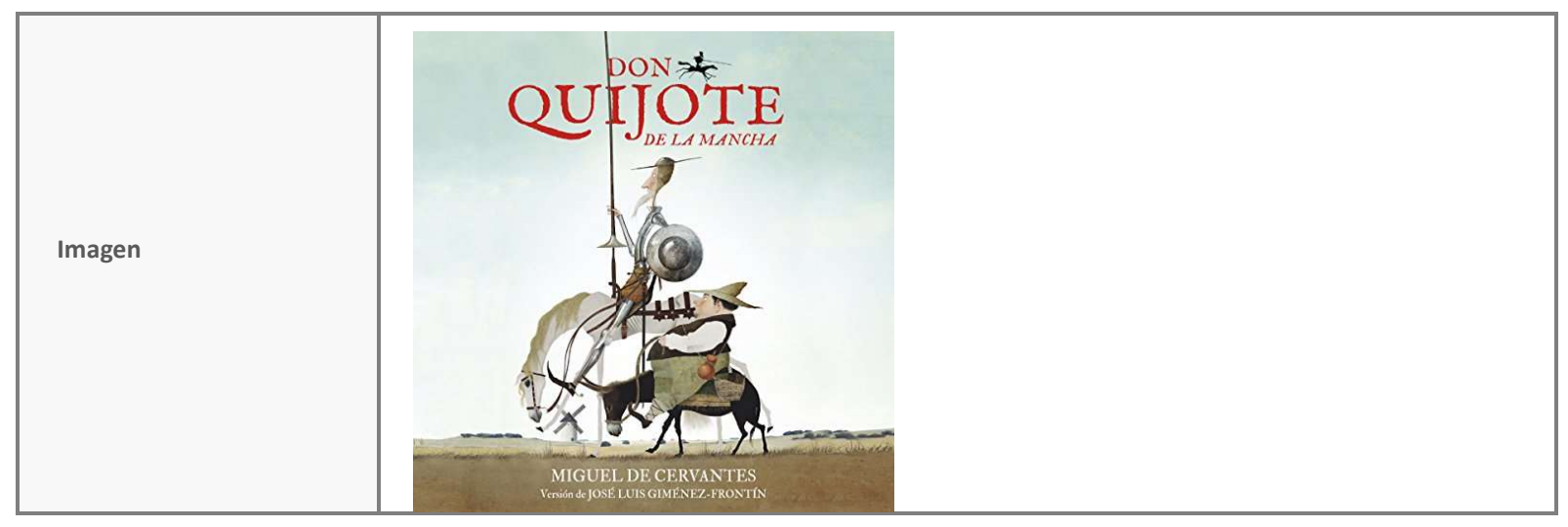

\begin{tabular}{|c|c|}
\hline \multicolumn{2}{|r|}{$\begin{array}{l}\text { Resultado de la búsqueda del «Quijote» en: Audible } \\
\qquad{\text { Ficha } \text { n. }^{\circ} 10}\end{array}$} \\
\hline Título & Don Quijote de la Mancha Tomo II [Don Quixote, Part II] \\
\hline Duración & 21 horas y $7 \mathrm{~min}$ \\
\hline Narrador & Alejandro Magnone \\
\hline Acento de la narración & S/D \\
\hline Dramatización & S/D \\
\hline Efectos de sonido & S/D \\
\hline Contenido & Tomo II \\
\hline Lanzamiento & 2005 \\
\hline Editorial & Emmanuel Michan \\
\hline Enlace & $\begin{array}{l}\text { https://www.audible.com/pd/Don-Quijote-de-la-Mancha-Tomo-II-Don-Quixote-Part-II-Audio- } \\
\text { book/B002V1CG3K?qid=1609847061\&sr=1-9\&ref=a_search_c3_IProduct_1_9\&pf_rd_p=83218cca-c308- } \\
\text { 412f-bfcf-90198b687a2f\&pf_rd_r=WVRHCHQSRTR4WSTVR98C }\end{array}$ \\
\hline Tamaño del archivo & S/D \\
\hline ISBN & S/D \\
\hline Demo & 2,58 minutos \\
\hline Precio & Incluido con suscripción mensual de $\$ 14,95$ o $\$ 10,50$, individualmente \\
\hline
\end{tabular}




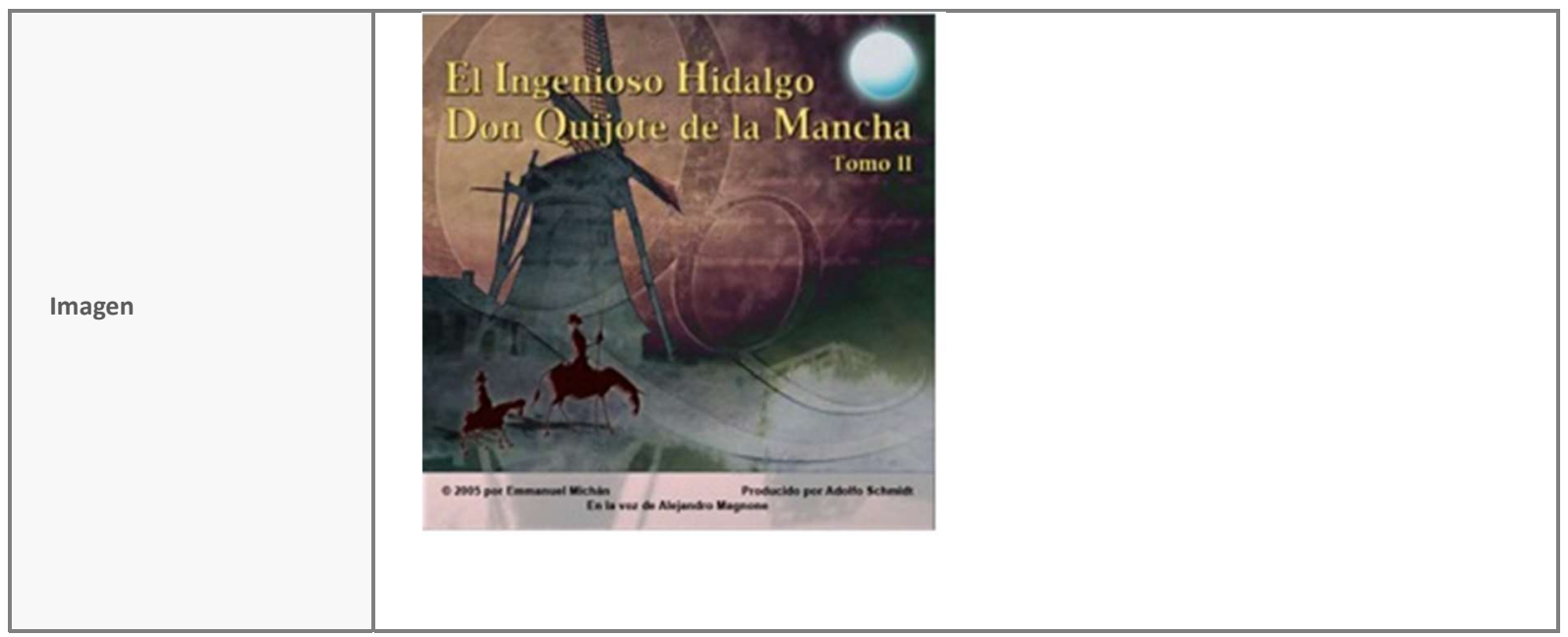

\begin{tabular}{|c|c|}
\hline \multicolumn{2}{|r|}{$\begin{array}{l}\text { Resultado de la búsqueda del «Quijote» en: Audible } \\
\qquad{\text { Ficha } \text {. }^{\circ} 11}\end{array}$} \\
\hline Título & El Quijote Contado a los niños [The Quijote Counted to Children] \\
\hline Duración & $1: 47$ \\
\hline Narrador & Diego del Arco López \\
\hline Acento de la narración & $S / D$ \\
\hline Dramatización & $S / D$ \\
\hline Efectos de sonido & $S / D$ \\
\hline Contenido & S/D / Rosa Navarro Durán (Edebé) \\
\hline Lanzamiento & 2020 \\
\hline Editorial & Audible Studios \\
\hline Enlace & $\begin{array}{l}\text { https://www.audible.com/pd/El-Quijote-Contado-A-Los-Ninos-The-Quijote-Counted-to-Children-Au- } \\
\text { diobook/B0858CX71P?qid=1609847061\&sr=1-10\&ref=a_search_c3_IProduct_1_10\&pf_rd_p=83218cca- } \\
\text { c308-412f-bfcf-90198b687a2f\&pf_rd_r=WVRHCHQSRTR4WSTVR98C }\end{array}$ \\
\hline Tamaño del archivo & $S / D$ \\
\hline ISBN & $S / D$ \\
\hline Demo & 5 minutos \\
\hline Precio & Incluido con suscripción mensual de $\$ 14,95$ o $\$ 7,90$, individualmente \\
\hline Imagen & \\
\hline
\end{tabular}




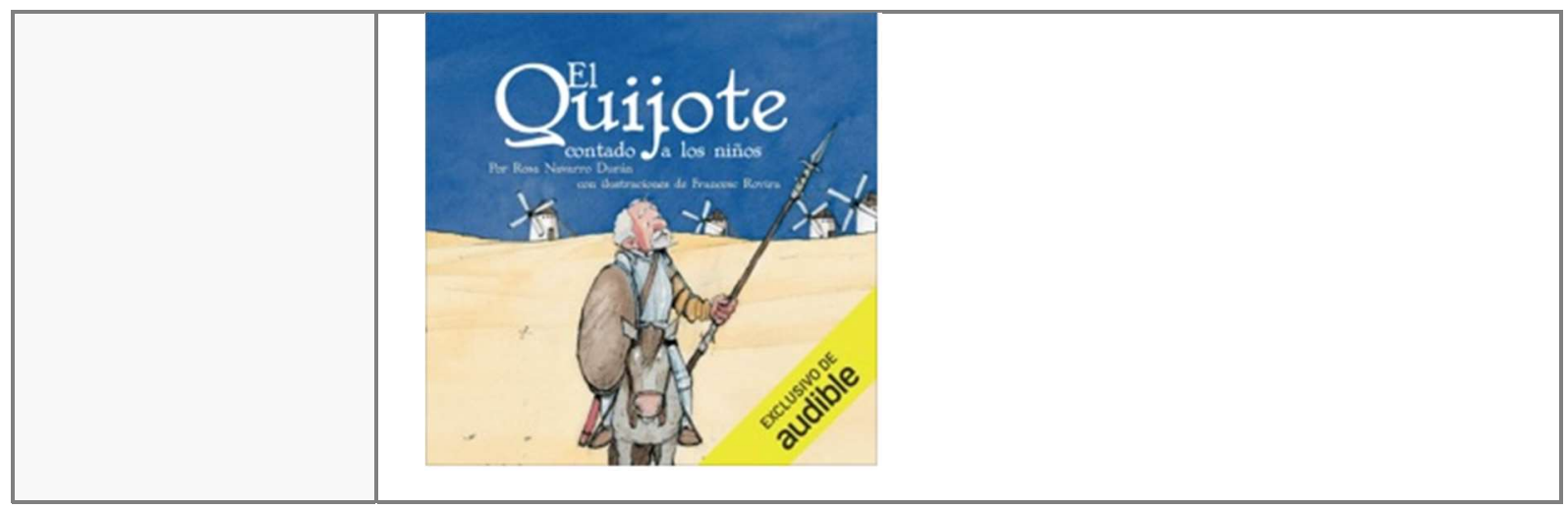

Notas:

La plataforma no ofrece información del ISBN del libro ni del tamaño del archivo, y aporta en todos los casos una pequeña demo de unos minutos del libro.

De las fichas extraemos la siguiente información:

$\checkmark$ Existen dos audiolibros, uno de 34:07 h y otro de 37:52 h, que por su extensión cualquier interesado y mínimo conocedor de la obra podría deducir que se trata de obras narradas de forma íntegra, pero no encontramos confirmación de ello en la información que aporta la misma plataforma. Tampoco se incluye información acerca de si se narran los prólogos, tasas, y otros prolegómenos.

$\checkmark$ El Quijote de 5:24 minutos no tiene descripción de ningún tipo, y solo sabemos que es narrado por varias personas. El de 3:51 h en su propio título indica, en inglés, que es un audio dirigido a los jóvenes.

$\checkmark$ Hay tres libros para niños, uno de 1:57 h, uno de $3: 42 \mathrm{~h}$ y uno de $1: 47 \mathrm{~h}$.

$\checkmark \quad$ Existe un audiolibro de 15:57 $\mathrm{h}$ que en su resumen indica que se trata de un audio conmemorativo del IV centenario de la primera publicación del Quijote.

$\checkmark$ Por último, existen otros tres audios de extensión media, uno de 17:11 h, otro de 21:27 h y el último de 23:07 h. Del primero no sabemos si se trata de la primera parte del Quijote, de la segunda parte o de una adaptación de las dos; el segundo y el tercero corresponden a la primera y segunda parte, respectivamente. 
2. AUDIO-LIBROS. Información y fichas de los audiolibros del Quijote que contiene.

Realizamos la búsqueda en la plataforma web de Audio-libros y no arrojó resultados. 


\section{AUDIOLIBROS. Información y fichas de los audiolibros del Quijote que con- tiene.}

Recuperados 34 resultados, de los cuales 8 corresponden a audiolibros del Quijote.

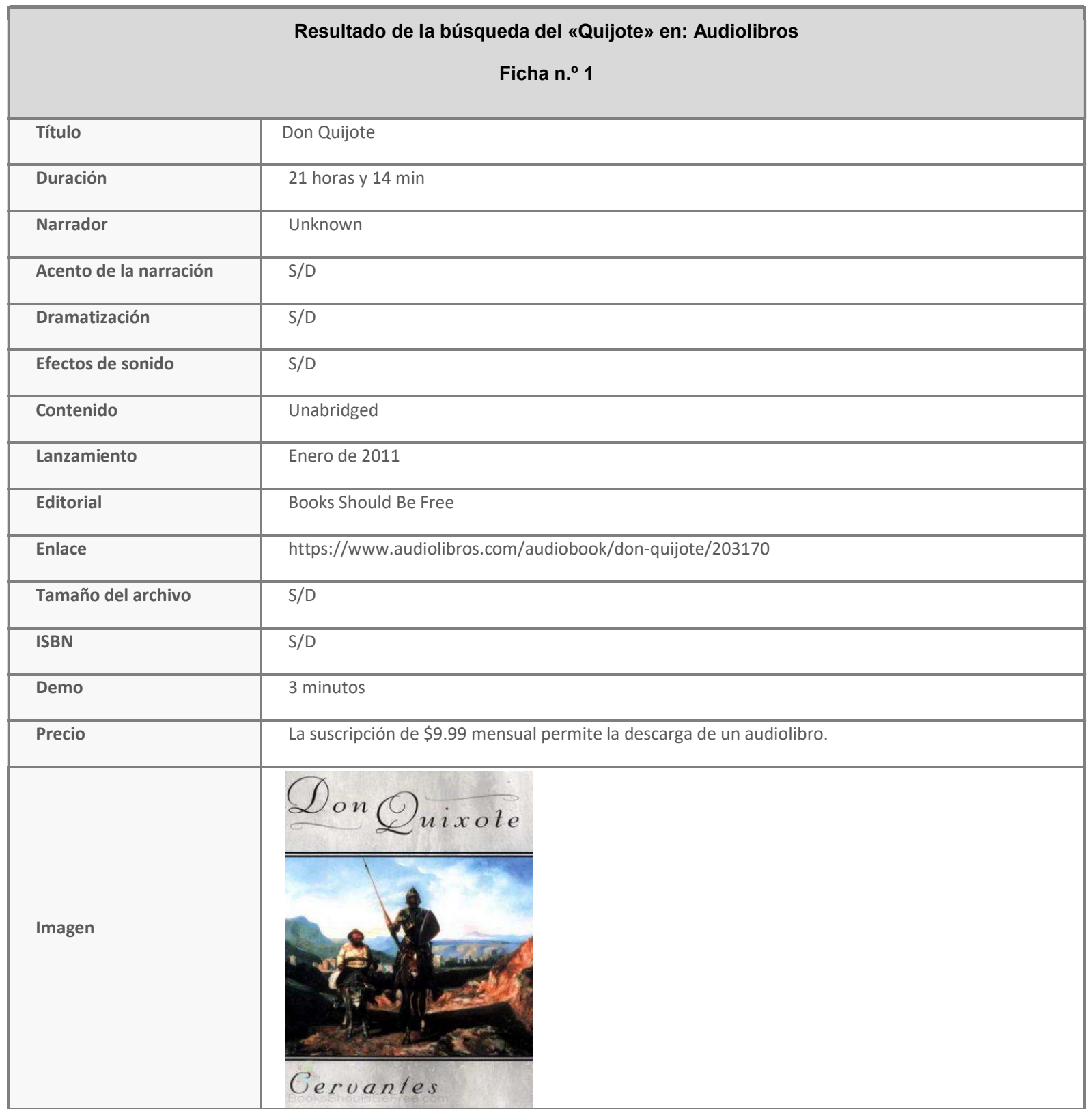

Resultado de la búsqueda del «Quijote» en: Audiolibros

Ficha $n .^{\circ} 2$ 


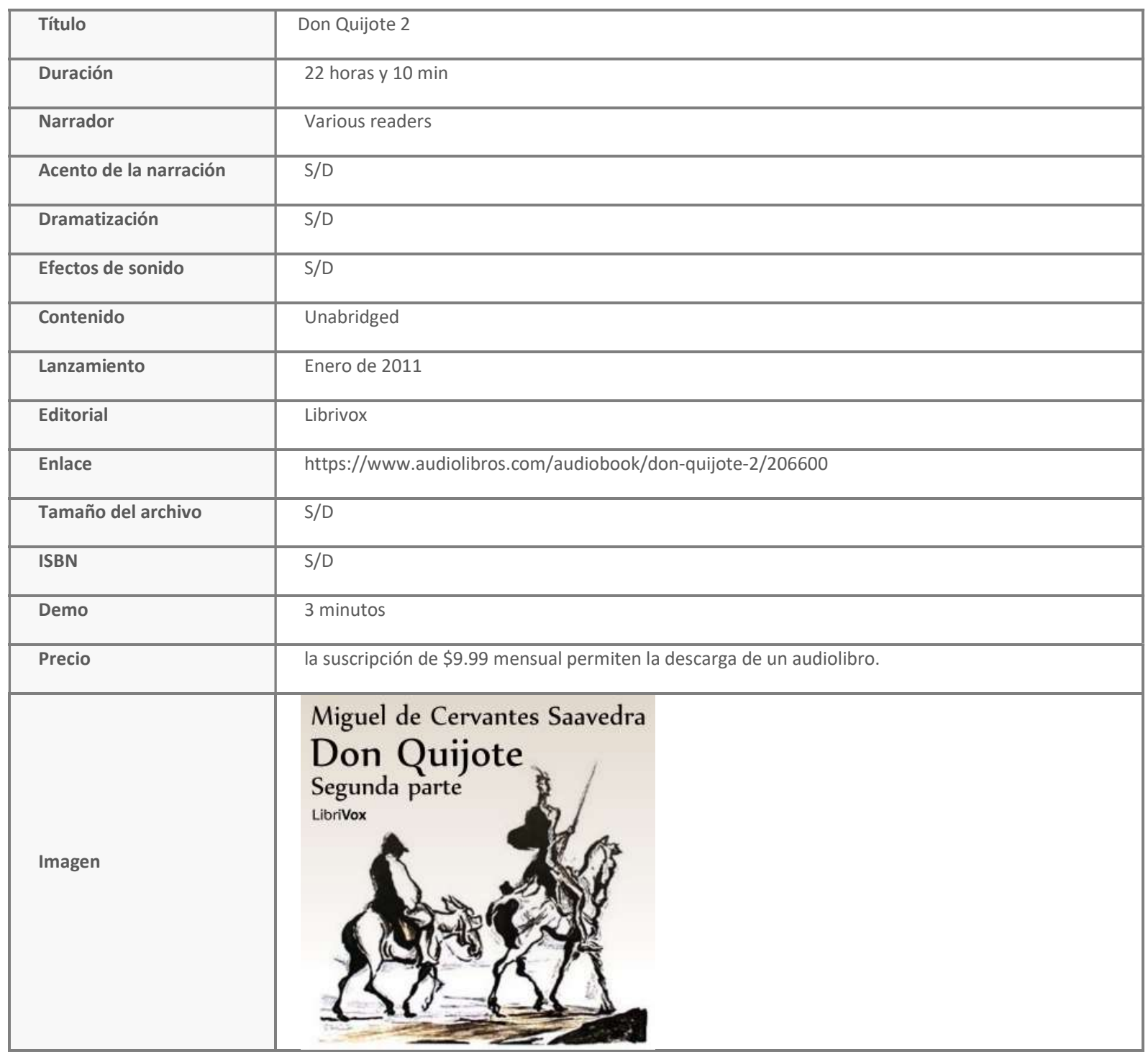

\begin{tabular}{|l|l|}
\hline \multicolumn{2}{|c|}{ Resultado de la búsqueda del «Quijote» en: Audiolibros } \\
\multicolumn{1}{|l|}{ Ficha . $^{\circ}$ 3 } \\
\hline Título & Don Quijote 1 \\
\hline Duración & 21 horas y 14 min \\
\hline Narrador & Various readers \\
\hline Acento de la narración & S/D \\
\hline Dramatización & S/D \\
\hline Efectos de sonido & S/D \\
\hline Contenido & Unabridged \\
\hline Lanzamiento & Enero de 2011 \\
\hline
\end{tabular}




\begin{tabular}{|c|c|}
\hline Editorial & LibriVox \\
\hline Enlace & https://www.audiolibros.com/audiobook/don-quijote-1/206599 \\
\hline Tamaño del archivo & S/D \\
\hline ISBN & S/D \\
\hline Demo & 3 minutos \\
\hline Precio & la suscripción de \$9.99 mensual permiten la descarga de un audiolibro. \\
\hline Imagen & $\begin{array}{c}\text { Son Quÿale, Talume } 1 \\
\\
\text { 15y }\end{array}$ \\
\hline
\end{tabular}

\begin{tabular}{|c|c|}
\hline \multicolumn{2}{|r|}{$\begin{array}{l}\text { Resultado de la búsqueda del «Quijote» en: Audiolibros } \\
\qquad \text { Ficha } n .{ }^{\circ} 4\end{array}$} \\
\hline Título & Don Quijote de la Mancha de Miguel \\
\hline Duración & 5 horas y $24 \mathrm{~min}$ \\
\hline Narrador & Elenco Fonolibro \\
\hline Acento de la narración & S/D \\
\hline Dramatización & S/D \\
\hline Efectos de sonido & S/D \\
\hline Contenido & Unabridged \\
\hline Lanzamiento & Marzo de 2014 \\
\hline Editorial & FonoLibro Inc. \\
\hline Enlace & https://www.audiolibros.com/audiobook/don-quijote-de-la-mancha-de-miguel/486266 \\
\hline Tamaño del archivo & S/D \\
\hline ISBN & S/D \\
\hline Demo & 5 minutos \\
\hline Precio & la suscripción de \$9.99 mensual permiten la descarga de un audiolibro. \\
\hline Imagen & \\
\hline
\end{tabular}




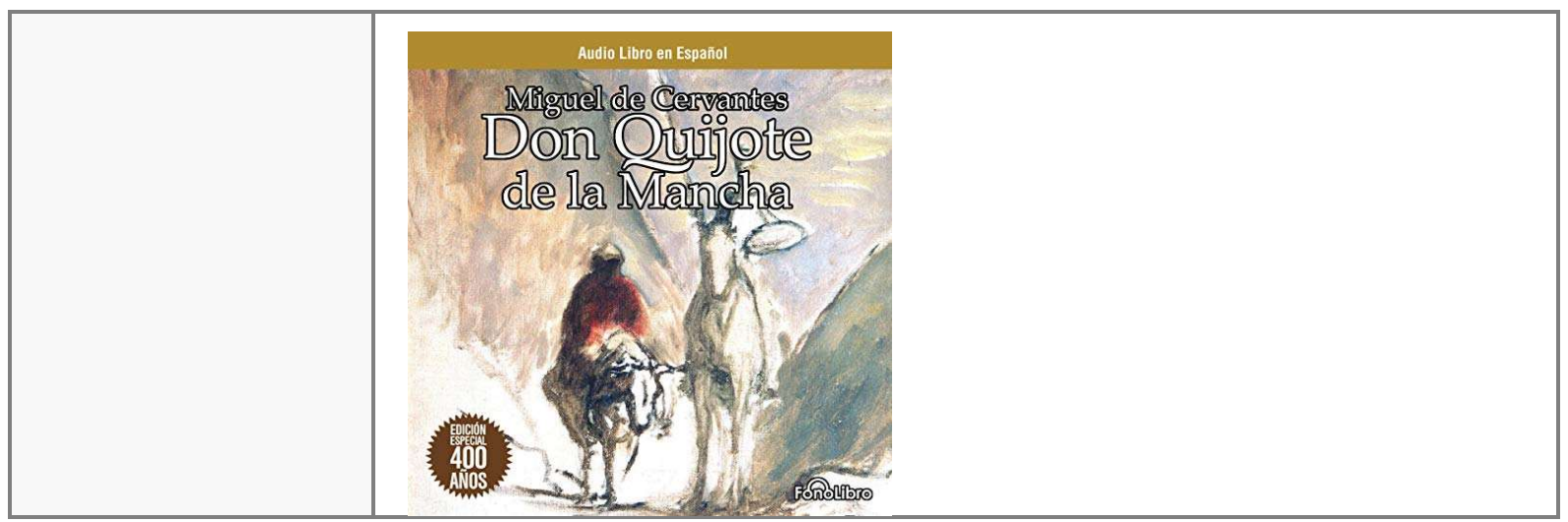

\begin{tabular}{|c|c|}
\hline \multicolumn{2}{|r|}{$\begin{array}{l}\text { Resultado de la búsqueda del «Quijote» en: Audiolibros } \\
\qquad \text { Ficha } .^{\circ} 5\end{array}$} \\
\hline Título & Don Quijote de la Mancha \\
\hline Duración & 40 horas 41 minutos \\
\hline Narrador & Juan Luis Galiardo, Carlos Iglesias, Jesús Castejón, Francisco Merino, Gloria Vega \\
\hline Acento de la narración & S/D \\
\hline Dramatización & $S / D$ \\
\hline Efectos de sonido & S/D \\
\hline Contenido & Unabridged \\
\hline Lanzamiento & Noviembre de 2020 \\
\hline Editorial & Bookwire \\
\hline Enlace & https://www.audiolibros.com/audiobook/don-quijote-de-la-mancha/490747 \\
\hline Tamaño del archivo & $S / D$ \\
\hline ISBN & $S / D$ \\
\hline Demo & 3 minutos \\
\hline Precio & la suscripción de \$9.99 mensual permiten la descarga de un audiolibro. \\
\hline Imagen & \\
\hline
\end{tabular}




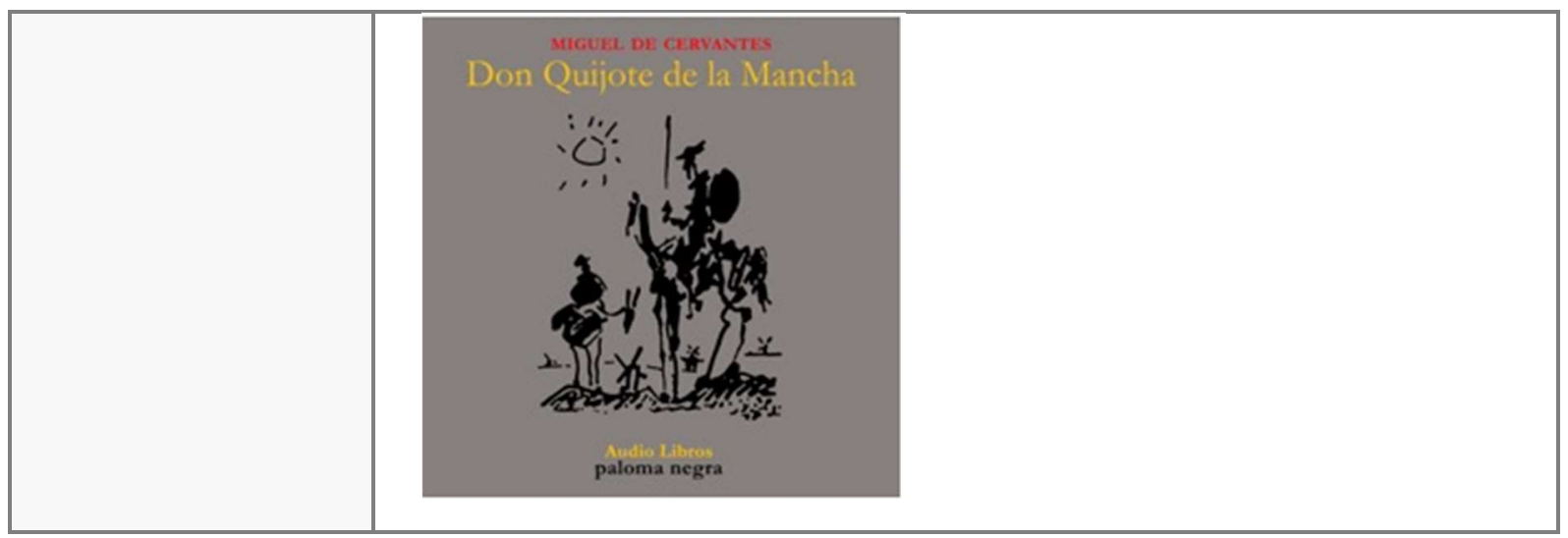

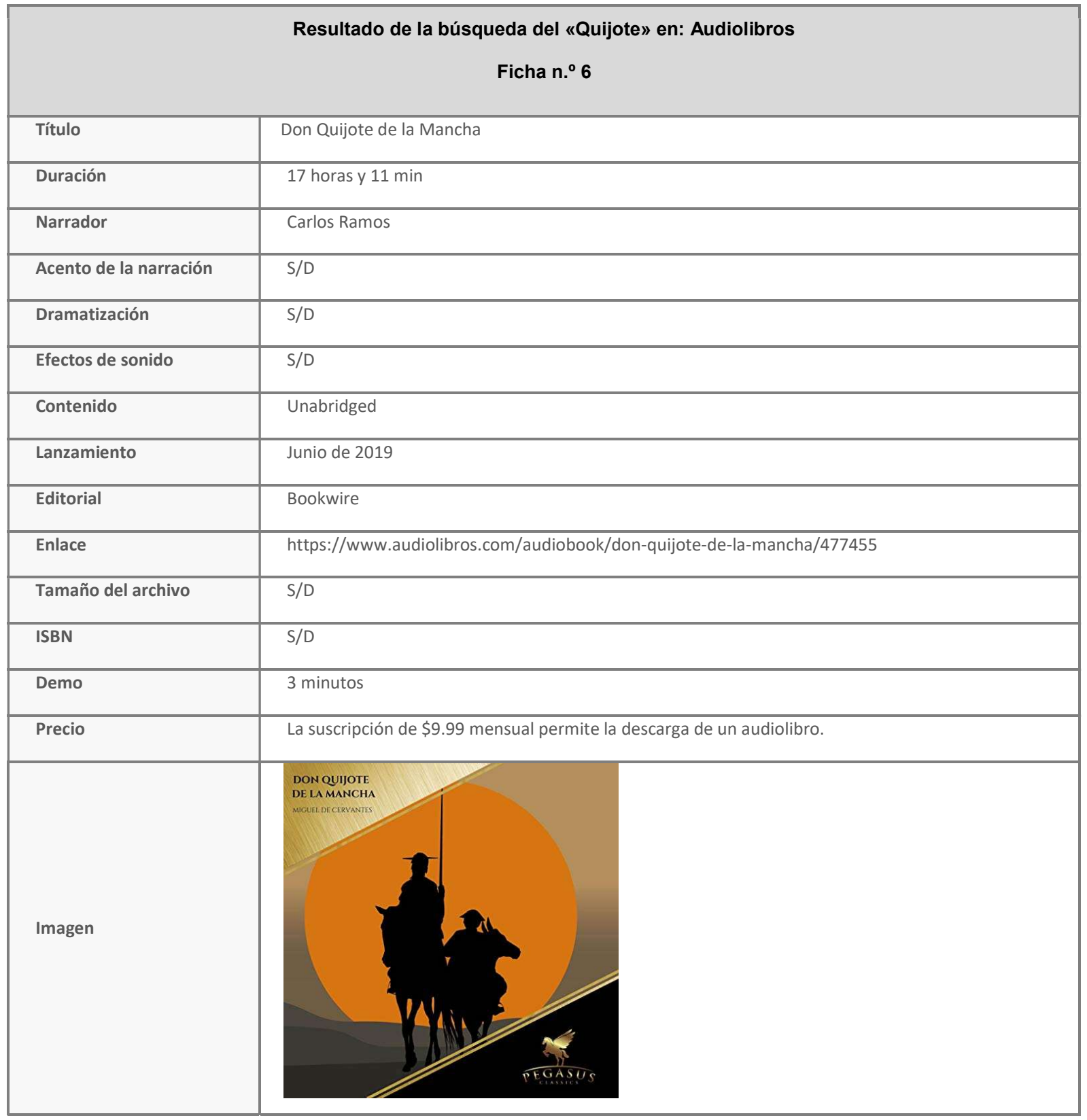




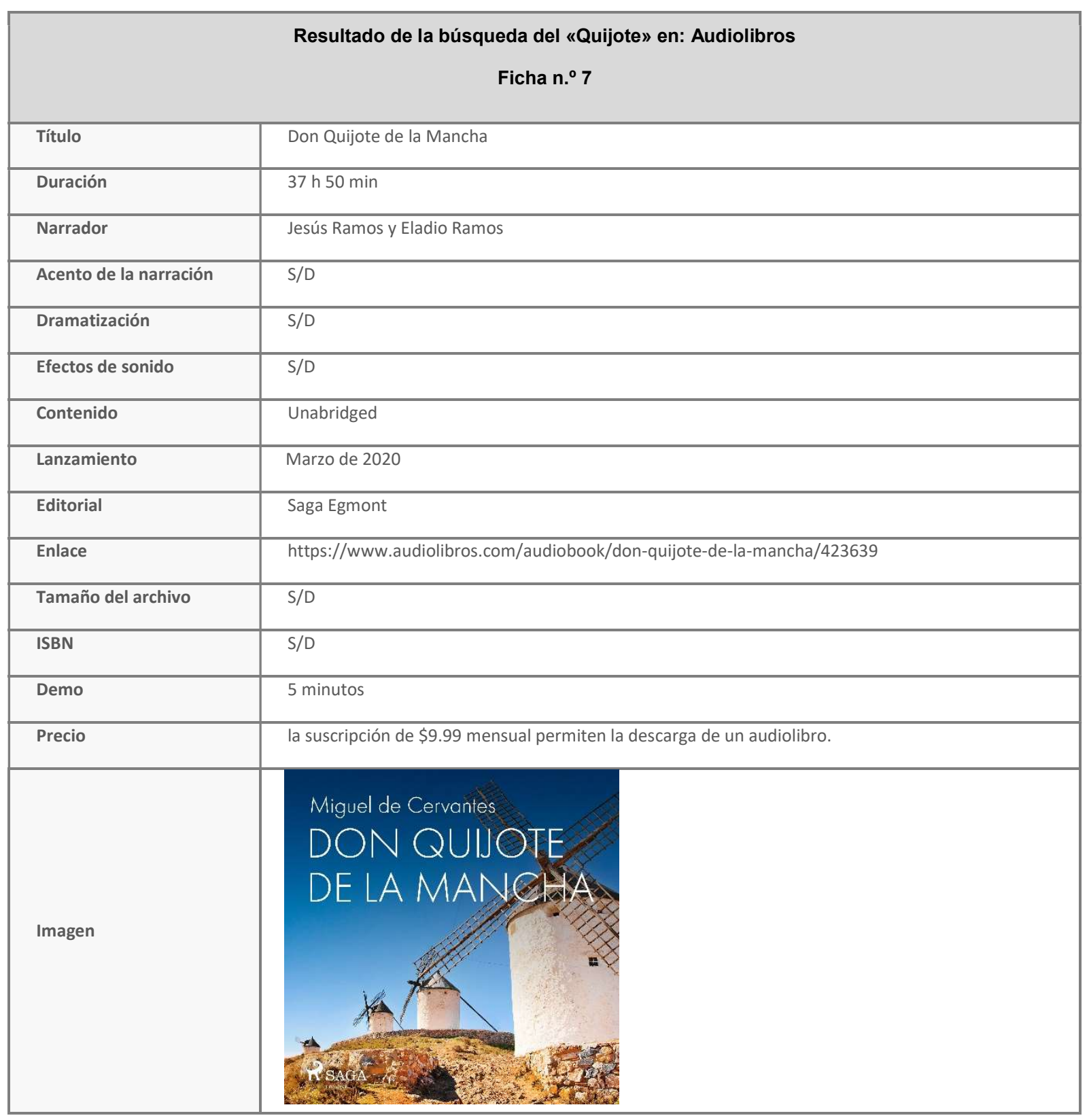

\begin{tabular}{|l|l|}
\hline \multicolumn{2}{|c|}{ Resultado de la búsqueda del «Quijote» en: Audiolibros } \\
\multicolumn{2}{|l|}{ Ficha $\mathbf{n}^{\circ}{ }^{\mathbf{8}}$} \\
\hline Título & Don Quijote de La Mancha (Colección Alfaguara Clásicos) \\
\hline Duración & 3 horas y 43 min \\
\hline Narrador & Raúl Llorens \\
\hline Acento de la narración & S/D \\
\hline
\end{tabular}




\begin{tabular}{|c|c|}
\hline Dramatización & S/D \\
\hline Efectos de sonido & S/D \\
\hline Contenido & Unabridged / Escrito por: José L. Giménez Frontín \\
\hline Lanzamiento & Marzo de 2018 \\
\hline Editorial & Penguin Random House Grupo Editorial \\
\hline Enlace & $\begin{array}{l}\text { https://www.audiolibros.com/audiobook/don-quijote-de-la-mancha-colecci-n-alfaguara-cl-si- } \\
\cos / 329825\end{array}$ \\
\hline Tamaño del archivo & S/D \\
\hline ISBN & S/D \\
\hline Demo & 5 minutos \\
\hline Precio & La suscripción de \$9.99 mensual permite la descarga de un audiolibro. \\
\hline Imagen & M $1 \times 1>1=$ \\
\hline
\end{tabular}

Notas:

La plataforma no permite realizar búsquedas por campos. Solo ofrece una casilla de búsqueda tanto en la versión web como en la aplicación. Por esta razón los resultados de la búsqueda fueron 34, de los cuales 8 se ajustaban a nuestro objetivo de búsqueda.

La plataforma no ofrece información de los precios de los audiolibros, y un dato llamativo es que en todos los audiolibros indican que es una versión unabridged, (que significa versión íntegra); sin embargo, como podemos ver en la ficha número 4, la versión tiene una extensión de 5:24 h, y con esta información podemos deducir que se trata de una versión abreviada (en inglés, abridged).

Tampoco se ofrece información acerca del tamaño de los archivos. 
4. AUDIOMOL. Información y fichas de los audiolibros del Quijote que contiene.

Se realiza la consulta web, y se obtienen 2 resultados de libros editados por Audiomol. Uno no corresponde, es El Caballero de la triste figura de Miguel de Unamuno, y el segundo es el que registramos en la siguiente ficha. ${ }^{76}$

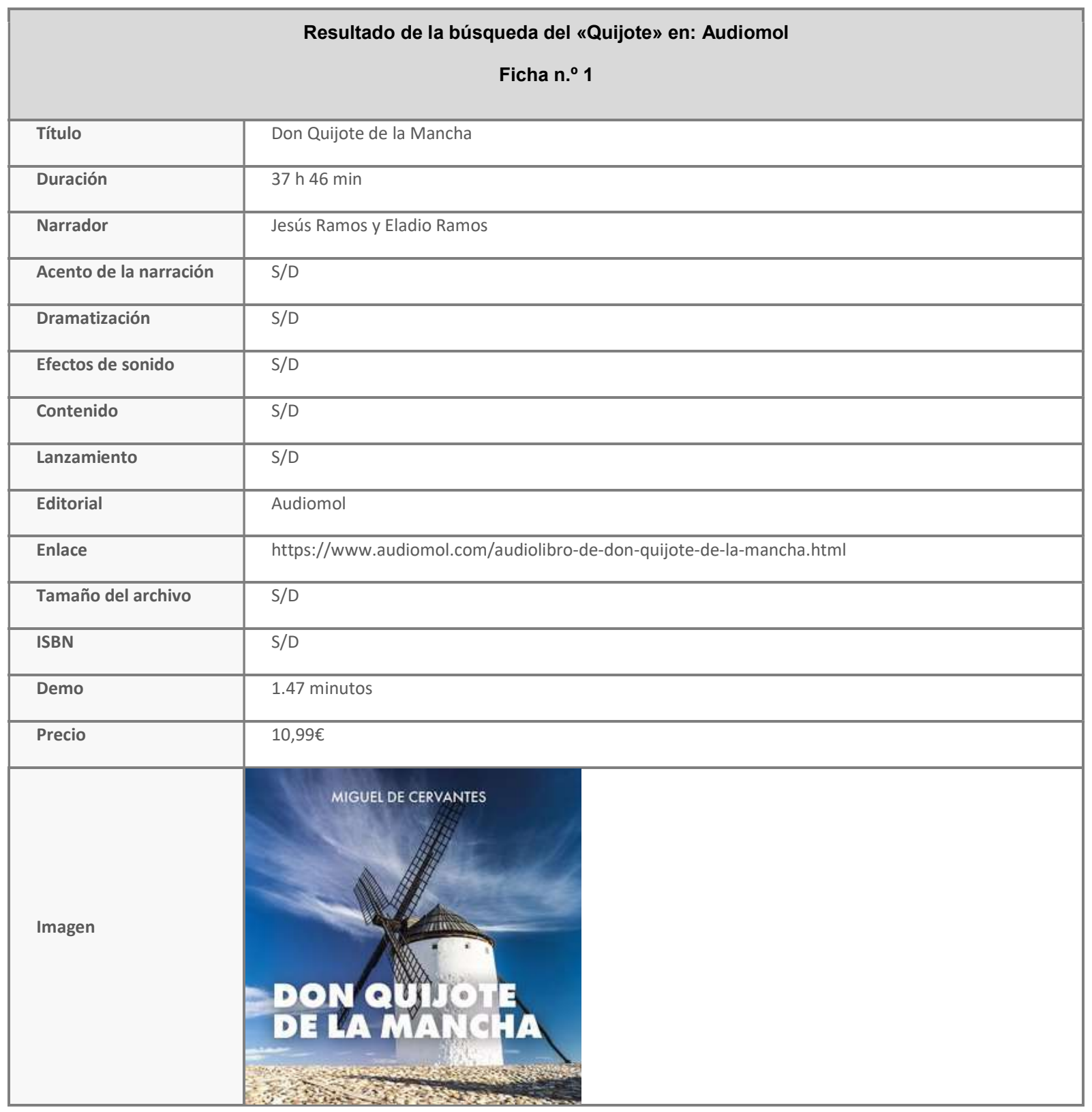

Notas:

${ }^{76}$ Datos obtenidos el 20/12/2020 
No permiten realizar búsquedas por otros campos, ni refinarlas por idioma. Teniendo en cuenta que ellos mismos han sido los editores del audiolibro no aportan más información que otras plataformas. Sin embargo, nos hemos puesto en contacto con la editorial para informarnos de cuál fue la edición leída por los narradores y hemos volcado los datos enTabla 4. Listado de audiolibros digitales del Quijote. 
5. AUDIOTEKA. Información y fichas de los audiolibros del Quijote que contiene.

La página web presenta una casilla de búsqueda en donde se puede buscar «título, autor o lector». En dicha casilla ingresamos la palabra Quijote, y nos recuperó 4 resultados pertinentes, listados a continuación en las siguientes fichas:

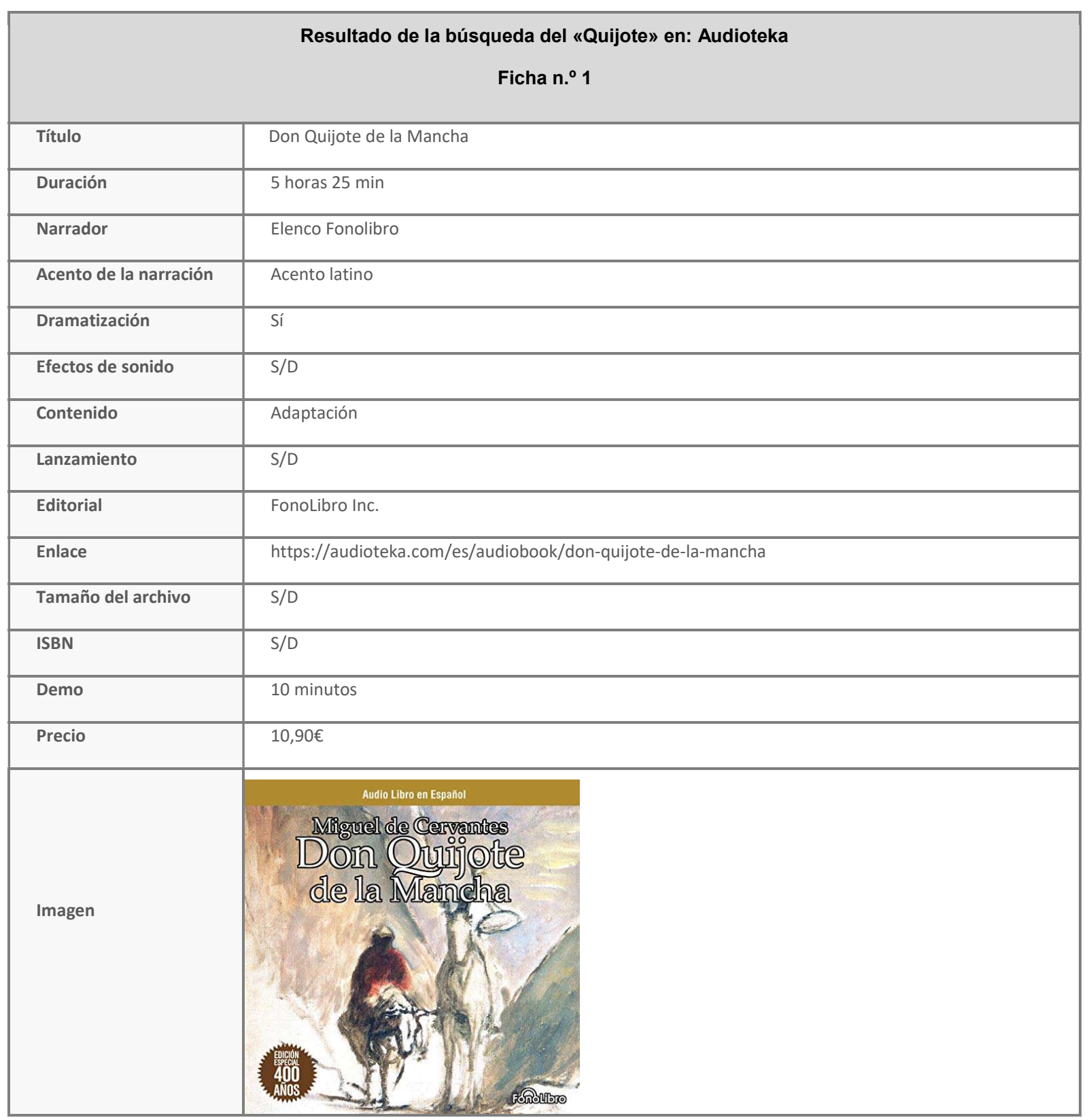




\begin{tabular}{|c|c|}
\hline & $\begin{array}{l}\text { Resultado de la búsqueda del «Quijote» en: Audioteka } \\
\qquad{\text { Ficha } n .^{\circ} 2}\end{array}$ \\
\hline Título & Don Quijote de La Mancha (Colección Alfaguara Clásicos) \\
\hline Duración & 3 horas y $42 \mathrm{~min}$ \\
\hline Narrador & Raúl Llorens \\
\hline Acento de la narración & S/D \\
\hline Dramatización & S/D \\
\hline Efectos de sonido & S/D \\
\hline Contenido & Completo \\
\hline Lanzamiento & S/D \\
\hline Editorial & Penguin Random House - Grupo Editorial \\
\hline Enlace & https://audioteka.com/es/audiobook/don-quijote-de-la-mancha-coleccion-alfaguara-clasicos \\
\hline Tamaño del archivo & S/D \\
\hline ISBN & S/D \\
\hline Demo & 24 minutos \\
\hline Precio & $9,99 €$ \\
\hline Imagen & \\
\hline & \\
\hline
\end{tabular}

\section{Resultado de la búsqueda del «Quijote» en: Audioteka}

Ficha $n .{ }^{\circ} 3$

\begin{tabular}{|l|l|}
\hline Título & Don Quijote de la Mancha \\
\hline Duración & 37 h 46 min \\
\hline Narrador & Jesús Ramos \\
\hline Acento de la narración & S/D \\
\hline Dramatización & S/D \\
\hline
\end{tabular}




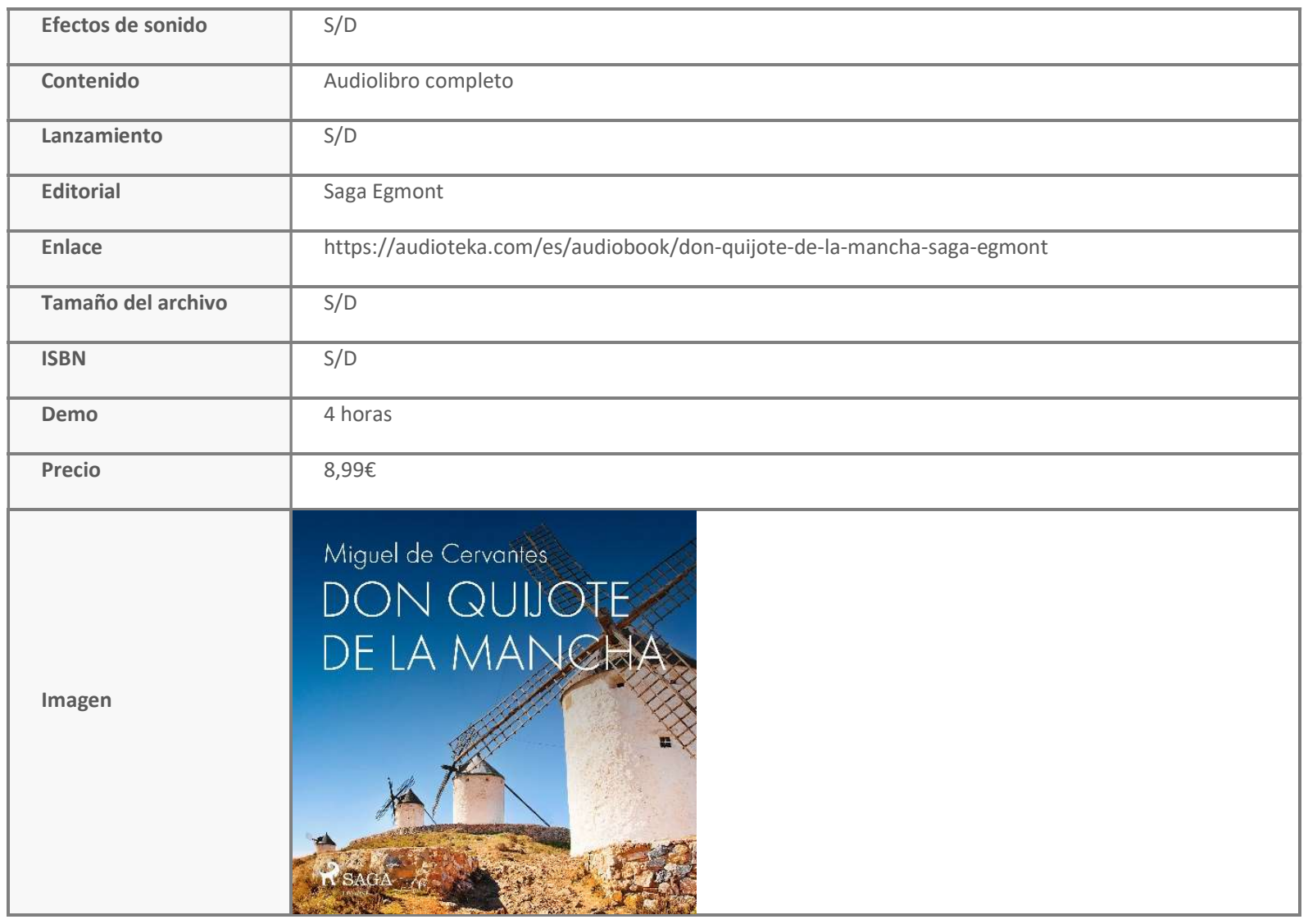

\begin{tabular}{|l|l|}
\hline \multicolumn{2}{|c|}{ Resultado de la búsqueda del «Quijote» en: Audioteka } \\
\multicolumn{1}{|l|}{ Ficha . $^{\circ} \mathbf{4}$} \\
\hline Título & El Ingenioso Hidalgo Don Quijote de la Mancha \\
\hline Duración & 15 horas y 58 min \\
\hline Narrador & Radio Teatro RNE \\
\hline Acento de la narración & Acento ibérico \\
\hline Dramatización & S/D \\
\hline Efectos de sonido & S/D \\
\hline Contenido & Audiolibro completo \\
\hline Lanzamiento & S/D \\
\hline Editorial & Yoyo Libros \\
\hline Enlace & https://audioteka.com/es/audiobook/don-quijote \\
\hline Tamaño del archivo & S/D \\
\hline ISBN & S/D \\
\hline Demo & 1 hora \\
\hline
\end{tabular}




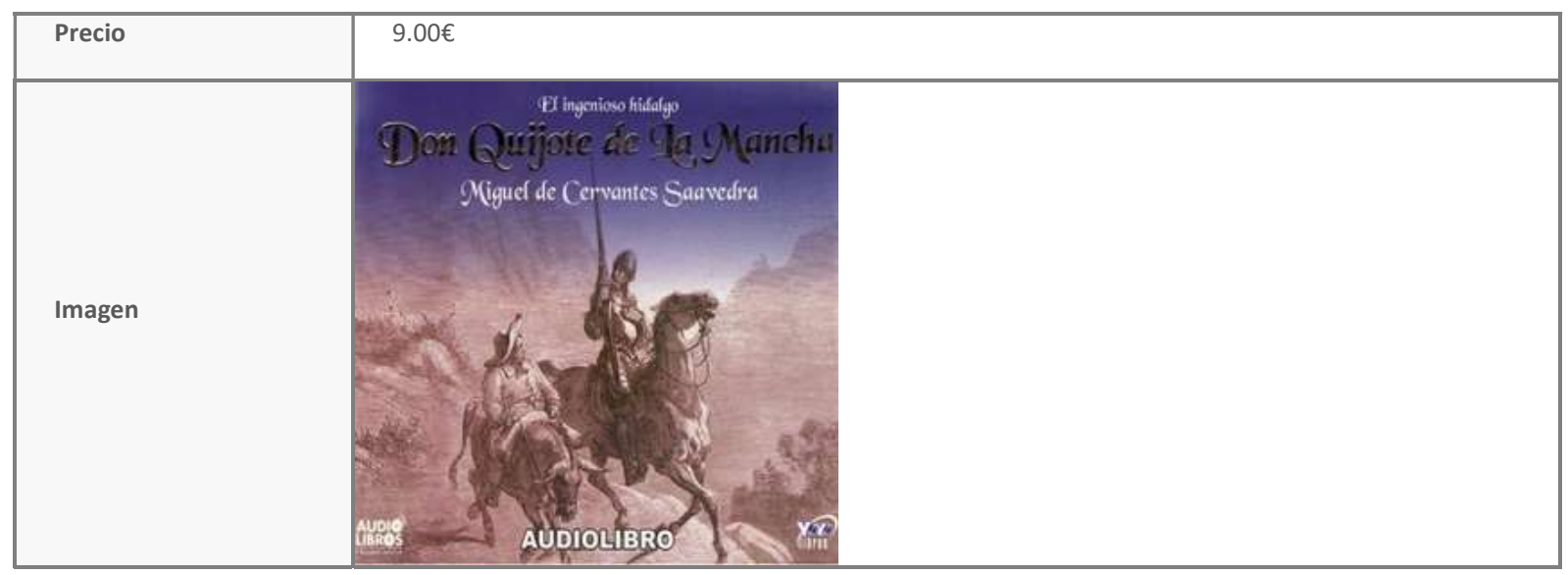

Notas:

$\checkmark$ En un caso indican que se trata de una adaptación y en los otros tres indican que es un audiolibro completo; sin embargo, estos tres casos tienen las siguientes extensiones: 3:42 h, $37: 46 \mathrm{~h}$ y $15: 58$. A simple vista uno solo de los tres se trata de un audiolibro completo. Lamentablemente tampoco se ofrece información del origen editorial, por lo cual a través de la información aportada no podemos deducir exactamente a qué edición corresponden.

$\checkmark$ En el caso de los acentos, en un caso indican acento latino, en otro acento ibérico, pero en dos casos no indican nada, por lo cual no han seguido el mismo criterio para todos los audiolibros.

$\checkmark$ Un punto favorable es la posibilidad de descargar una demostración extensa de los textos, que en un caso llega a 4 horas. 


\section{BEEK. Información y fichas de los audiolibros del Quijote que contiene.}

La plataforma ofrece 18 resultados. También ofrece la posibilidad de filtrar por los campos que podemos observar en la siguiente imagen.

2 resultados de audiolibros para "quijote":

Duración

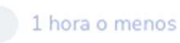

1 a 3 horas

3 a 6 horas

\section{6 a 10 horas \\ 10 a 20 horas}

20 horas o más
Idioma

\section{English}

- Spanish

German
Nuevos lanzamientos

Portuguese

Swedish

Quitar filtros

Ilustración 30. Opciones de filtrado de búsquedas en la plataforma BEEK

Tras aplicar el filtro de idioma, la aplicación nos ofrece dos audiolibros, que relevamos en las siguientes fichas:

\begin{tabular}{|l|l|}
\hline \multicolumn{2}{|l|}{ Resultado de la búsqueda del «Quijote» en: Beek } \\
\multicolumn{1}{|l|}{ Ficha . $^{\text { 1 }}$} \\
\hline Título & Don Quijote de la Mancha \\
\hline Duración & 37 horas 45 minutos \\
\hline Narrador & Jesús Ramos \\
\hline Acento de la narración & S/D \\
\hline Dramatización & S/D \\
\hline Efectos de sonido & S/D \\
\hline Contenido & S/D \\
\hline Lanzamiento & 6 -03-2020 \\
\hline Editorial & Saga Egmont \\
\hline Enlace & https://www.beek.io/libros/don-quijote-de-la-mancha-38a716ba-724e-4145-a746-f93f0c8337cf \\
\hline Tamaño del archivo & S/D \\
\hline ISBN & Incluido en la suscripción mensual de \$249 MXN \\
\hline Demo & 5 minutos \\
\hline Precio & \\
\hline
\end{tabular}




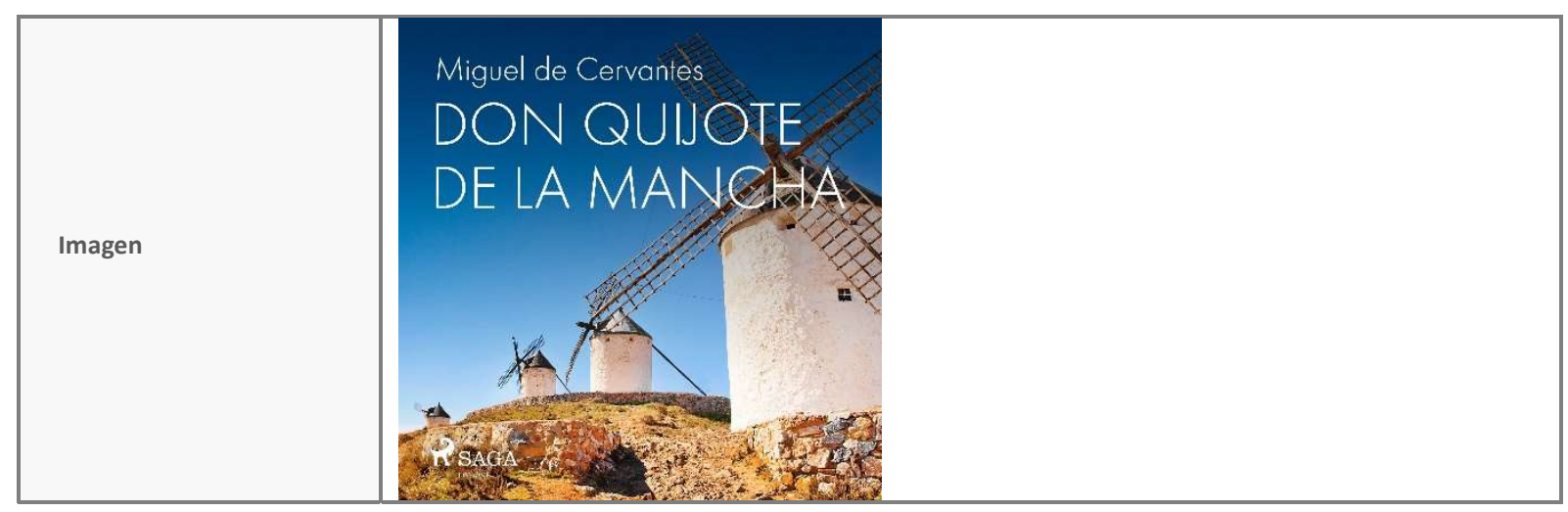

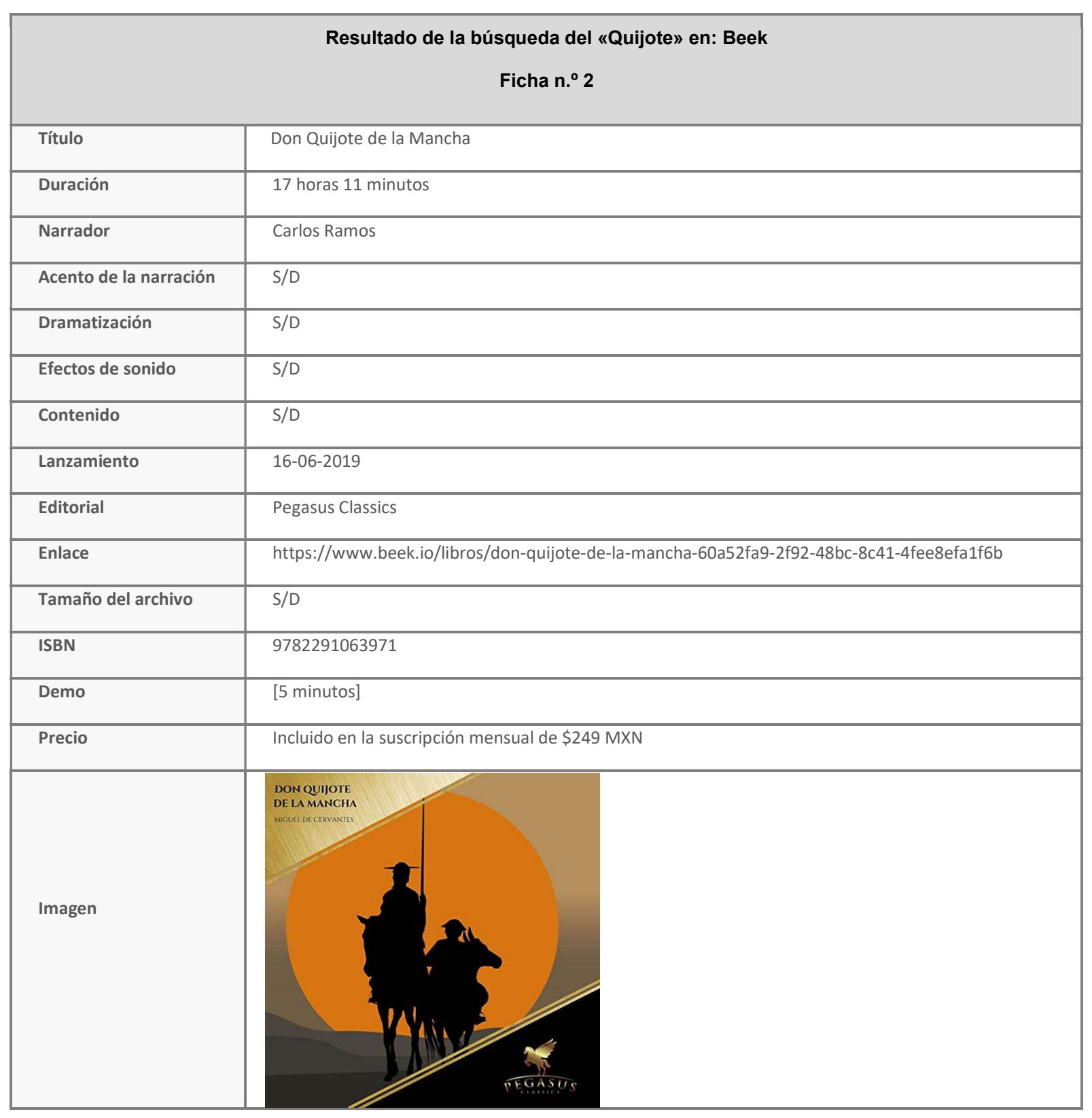


Notas:

Esta plataforma incluye dos audiolibros extensos, de los cuales no se brinda mucha información; sin embargo, es de destacar que incluyen el número ISBN de los mismos. 
7. BOOKA. Información y fichas de los audiolibros del Quijote que contiene.

No se encontraron coincidencias del título pesquisado. 
8. FONOLIBRO. Información y fichas de los audiolibros del Quijote que contiene.

La casilla de búsqueda permite buscar por autor, título y palabra clave, pero no permite realizar una búsqueda booleana, sino ingresar cualquiera de esos datos en una única casilla.

Se obtuvo como resultado un único título, editado por el propio sello editorial:

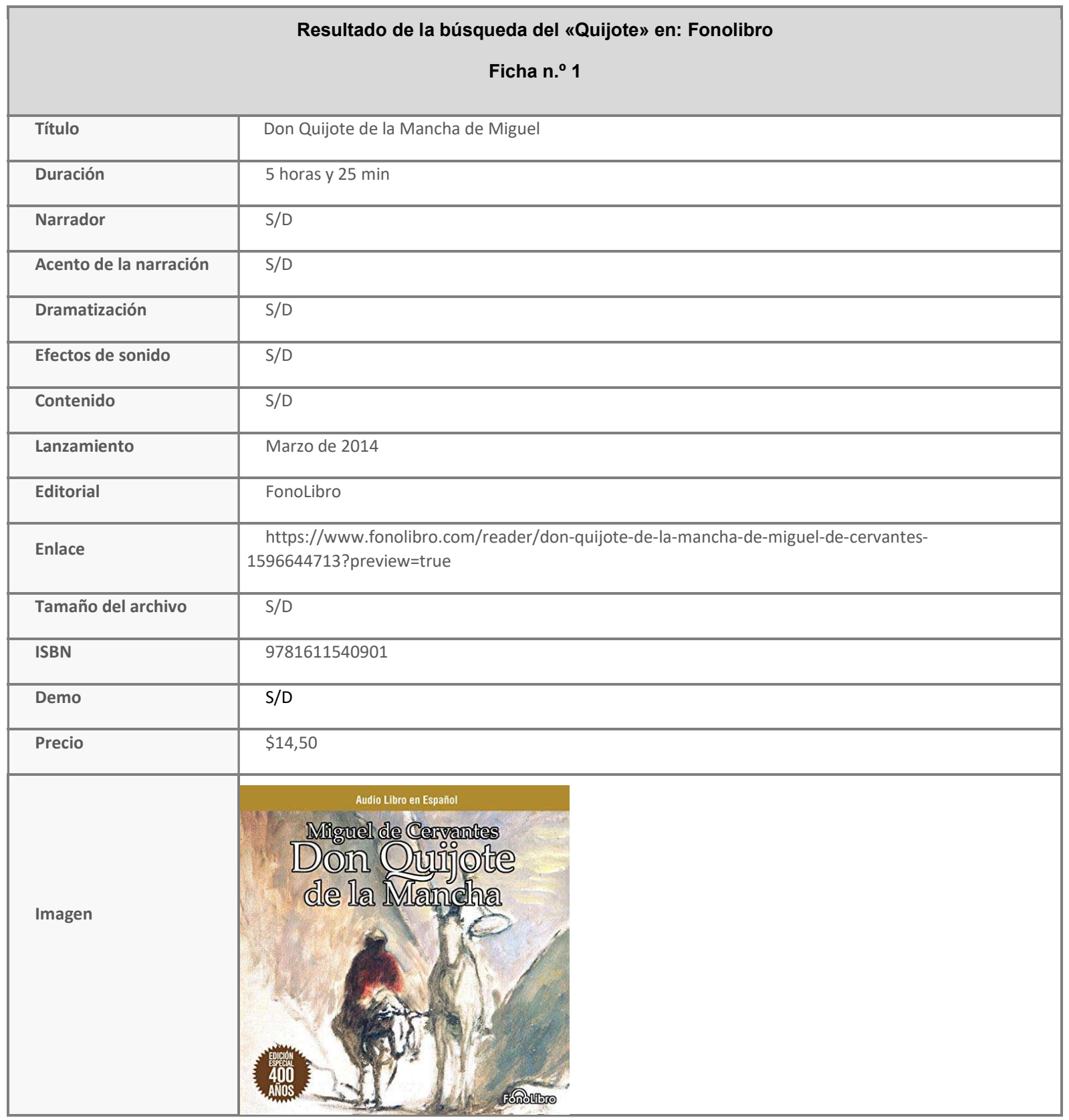

Notas: 
$\checkmark$ Teniendo en cuenta que Fonolibro además de comercializarlo es el editor del audiolibro, no ofrece más información que el resto de las plataformas. 


\section{GOOGLE PLAY LIBROS. Información y fichas de los audiolibros del Quijote que contiene.}

La casilla de búsqueda de Google Play permite introducir palabras, pero no indica qué campo estamos interrogando.

Introdujimos el término «quijote» y recuperamos 63 registros, de los cuales compilamos solo 4, como se puede observar en las siguientes fichas:

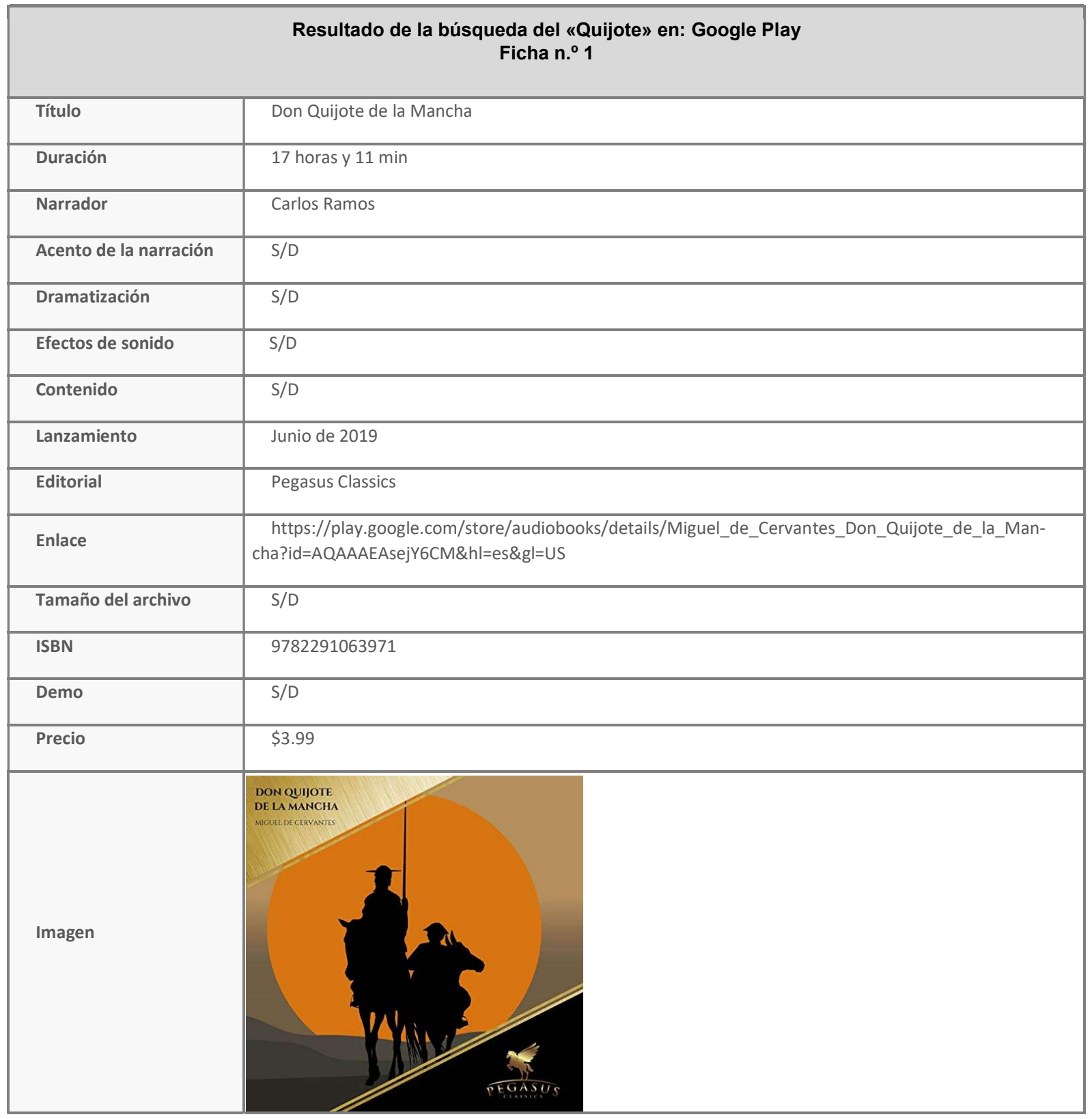




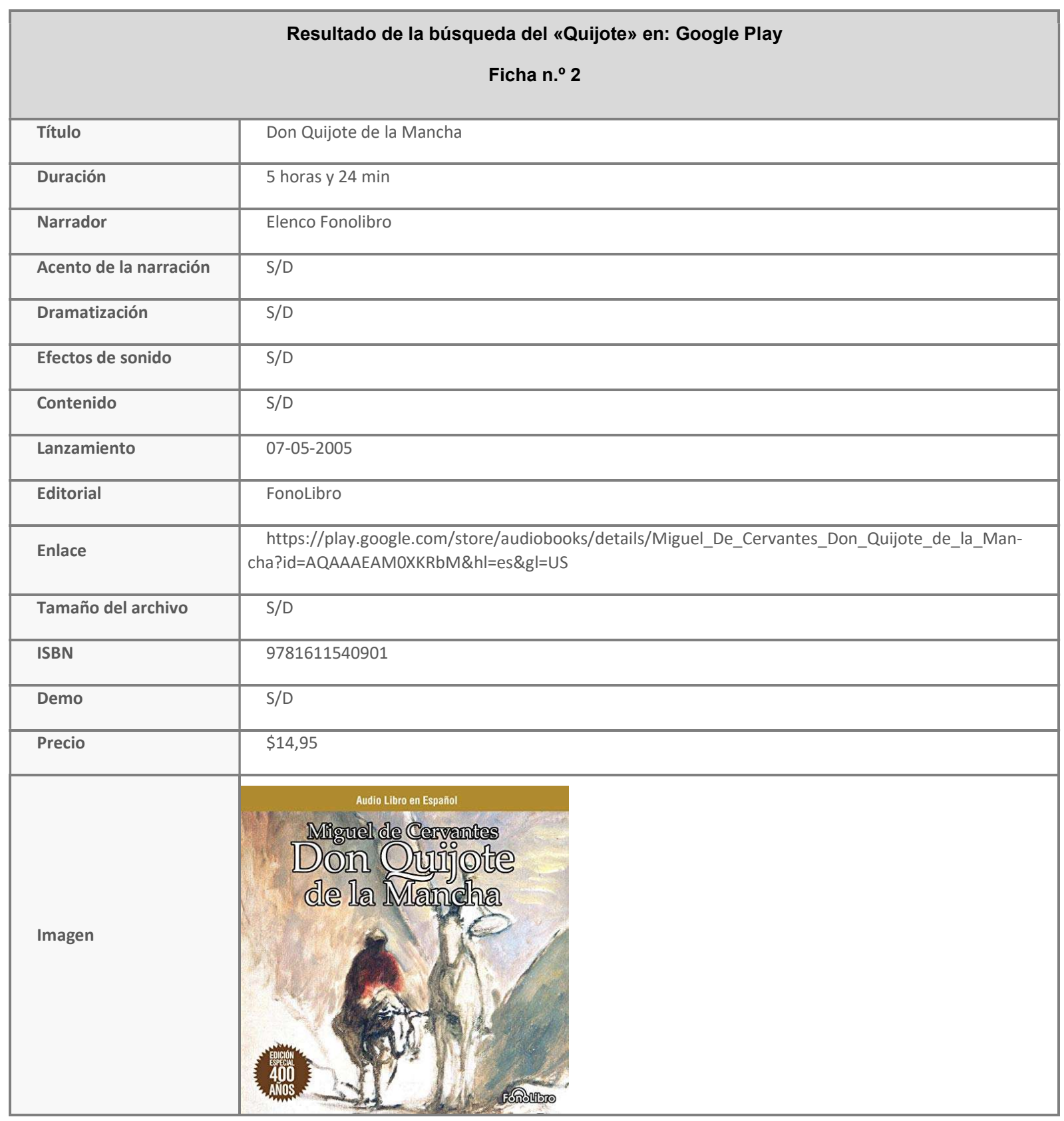

\begin{tabular}{|l|l|}
\hline \multicolumn{2}{|c|}{ Resultado de la búsqueda del «Quijote» en: Google Play } \\
\multicolumn{2}{|l|}{ Ficha . $^{\circ}$ 3 } \\
\hline Título & Don Quijote de La Mancha \\
\hline Duración & 3 horas y 42 min \\
\hline Narrador & Raúl Llorens \\
\hline Acento de la narración & S/D \\
\hline
\end{tabular}




\begin{tabular}{|c|c|}
\hline Dramatización & S/D \\
\hline Efectos de sonido & S/D \\
\hline Contenido & [Versión abreviada por José Luis Giménez-Frontín] \\
\hline Lanzamiento & $22-03-2018$ \\
\hline Editorial & Penguin Random House Grupo Editorial \\
\hline Enlace & $\begin{array}{l}\text { https://play.google.com/store/audiobooks/details/José_L_Giménez_Frot\%C3\%ADn_Don_Qui- } \\
\text { jote_de_la_Mancha_Col?id=AQAAAEAMSGwIcM\&hl=es\&gl=US }\end{array}$ \\
\hline Tamaño del archivo & $S / D$ \\
\hline ISBN & 9788420433561 \\
\hline Demo & S/D \\
\hline Precio & $\$ 10,95$ \\
\hline Imagen & 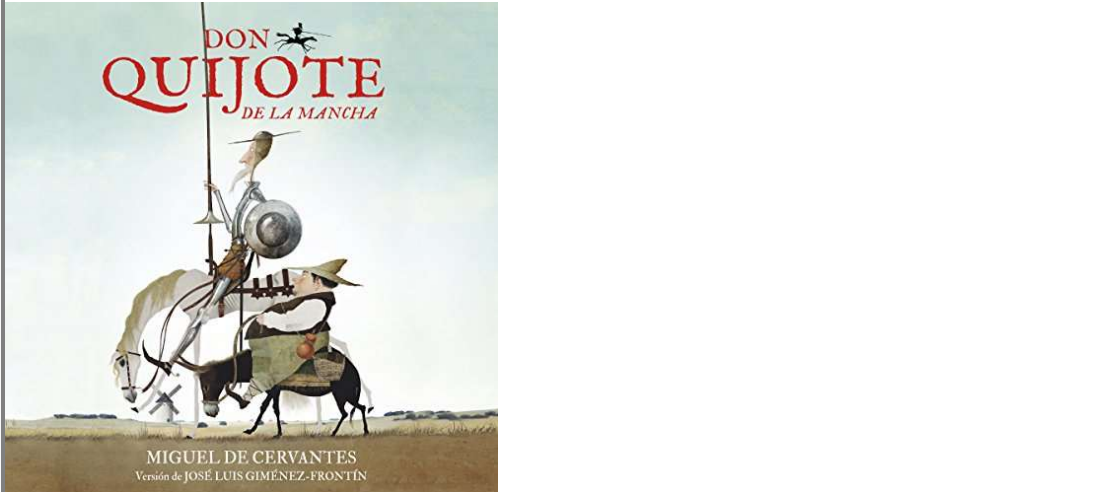 \\
\hline
\end{tabular}

\begin{tabular}{|l|l|}
\hline \multicolumn{2}{|c|}{ Resultado de la búsqueda del «Quijote» en Google Play } \\
\multicolumn{1}{|l|}{ Ficha n. $^{\circ} \mathbf{4}$} \\
\hline Título & Don Quijote de la mancha para jóvenes (adaptación) \\
\hline Duración & 3 hrs and 51 mins \\
\hline Narrador & Oscar Chamorro \\
\hline Acento de la narración & S/D \\
\hline Dramatización & S/D \\
\hline Efectos de sonido & S/D \\
\hline Contenido & Adaptación \\
\hline Lanzamiento & $10-17$-20 \\
\hline Editorial & Libervox \\
\hline Enlace & https://play.google.com/store/audiobooks/details/Miguel_de_Cervantes_Don_Quijote_de_la_man- \\
\hline
\end{tabular}




\begin{tabular}{|l|l|}
\hline Tamaño del archivo & S/D \\
\hline ISBN & S788418220425 \\
\hline Demo & S/D \\
\hline Precio & $\begin{array}{c}\$ 9,35 \\
\text { Don quijote de la } \\
\text { mancha para jóvenes } \\
\text { (Adaptación) }\end{array}$ \\
\hline & \\
\hline
\end{tabular}

Notas:

$\checkmark$ En todos los casos se incluye el número de ISBN de los audiolibros

$\checkmark$ En el caso de los primeros dos audiolibros cuya extensión es de 17:11 h y 5:24 h, no indican cuál es el contenido de los mismos; y en los dos últimos audiolibros se detalla que son adaptaciones.

$\checkmark$ En ningún caso se hace referencia a la edición que origina el audio. 
10. КОвО. Información y fichas de los audiolibros del Quijote que contiene.

Encontrados 17 audiolibros que se listan a continuación ${ }^{77}$ :

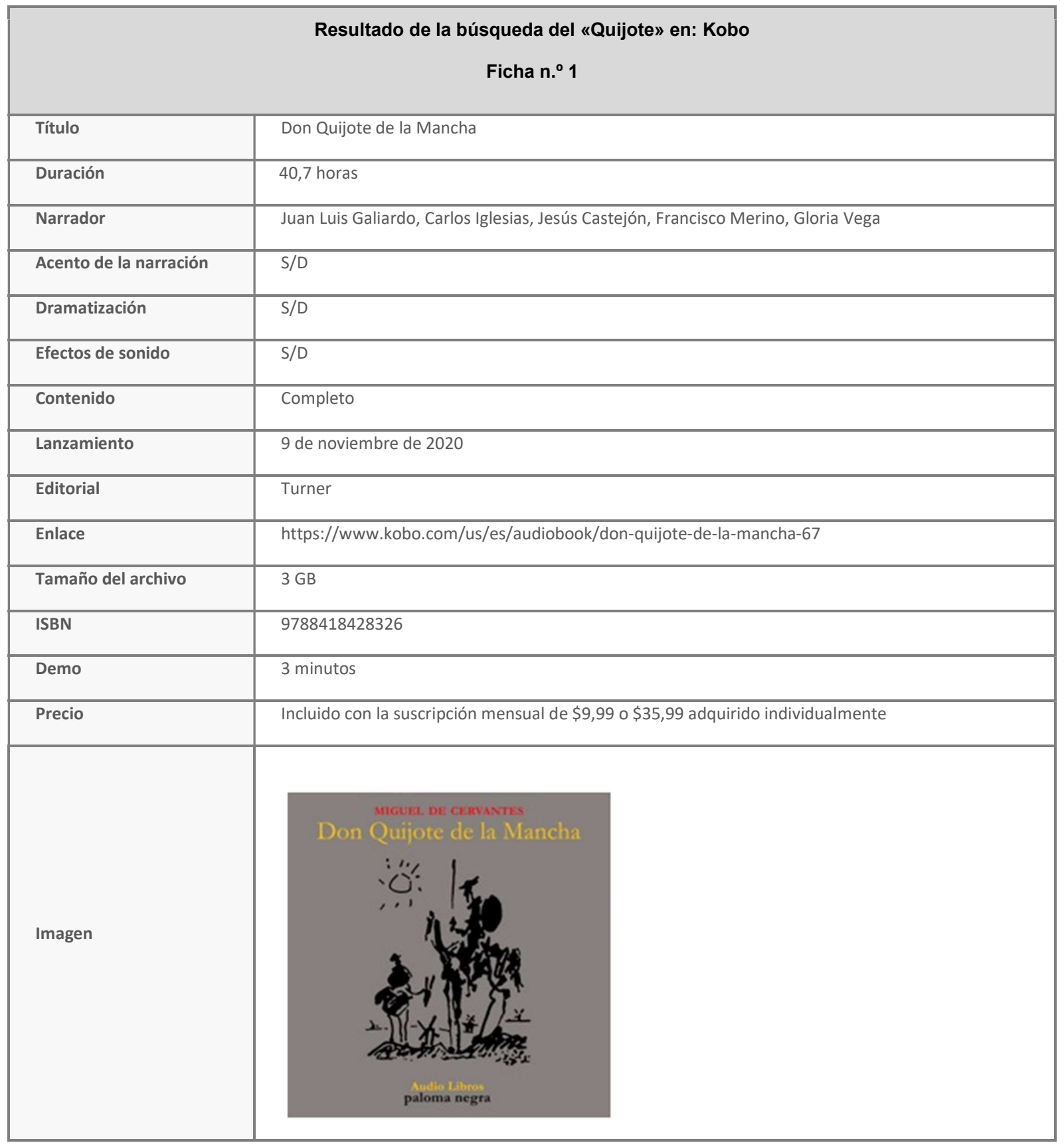

\footnotetext{
${ }^{77}$ Búsqueda realizada el 21/12/2020
} 


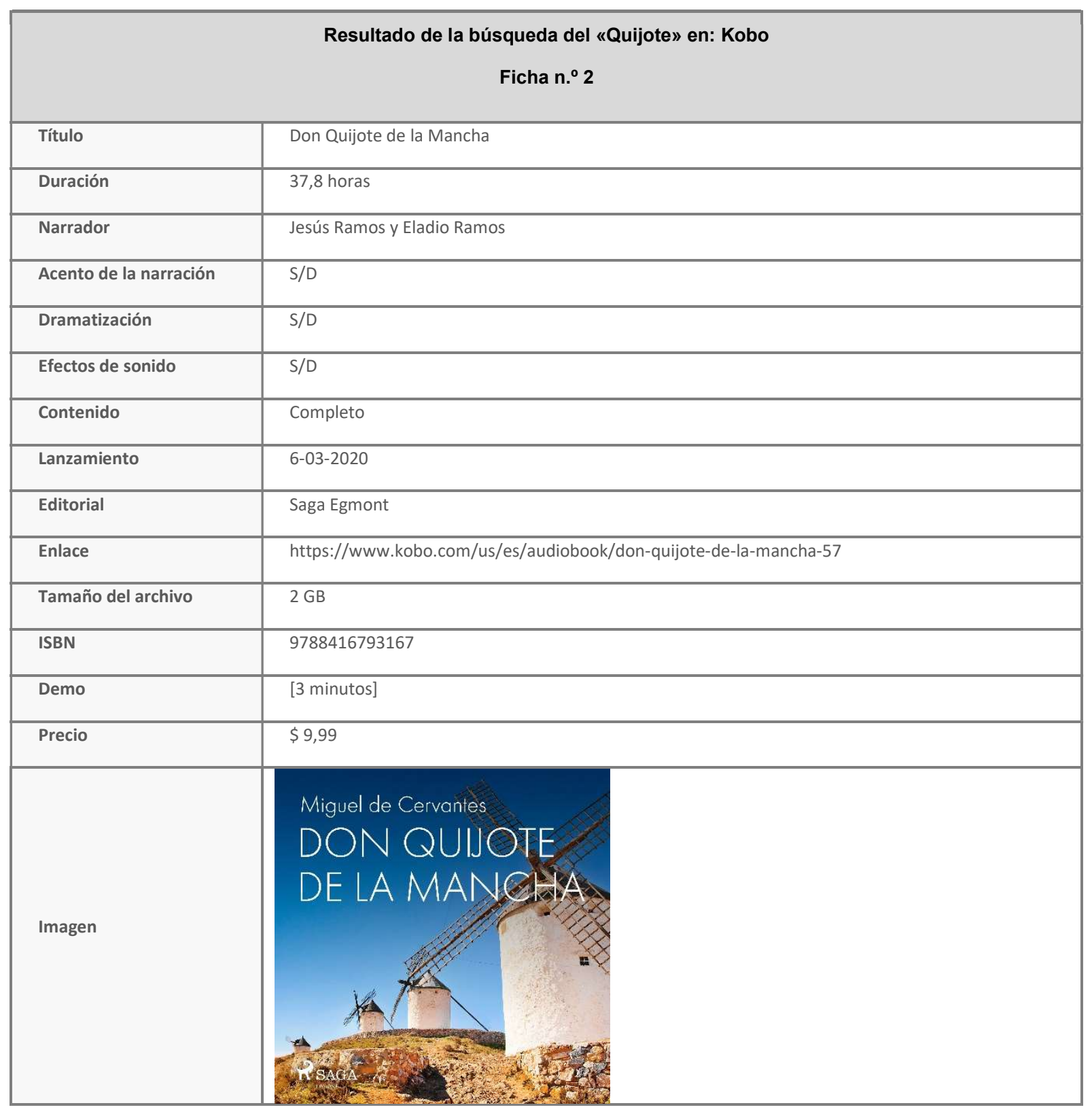

\begin{tabular}{|l|l|}
\hline \multicolumn{2}{|c|}{ Resultado de la búsqueda del «Quijote» en: Kobo } \\
\multicolumn{2}{|l|}{ Ficha . $^{\circ}$ 3 } \\
\hline Título & Don Quijote de la Mancha \\
\hline Duración & 17,2 horas \\
\hline Narrador & Carlos Ramos \\
\hline Acento de la narración & S/D \\
\hline Dramatización & S/D \\
\hline Efectos de sonido & S/D \\
\hline
\end{tabular}




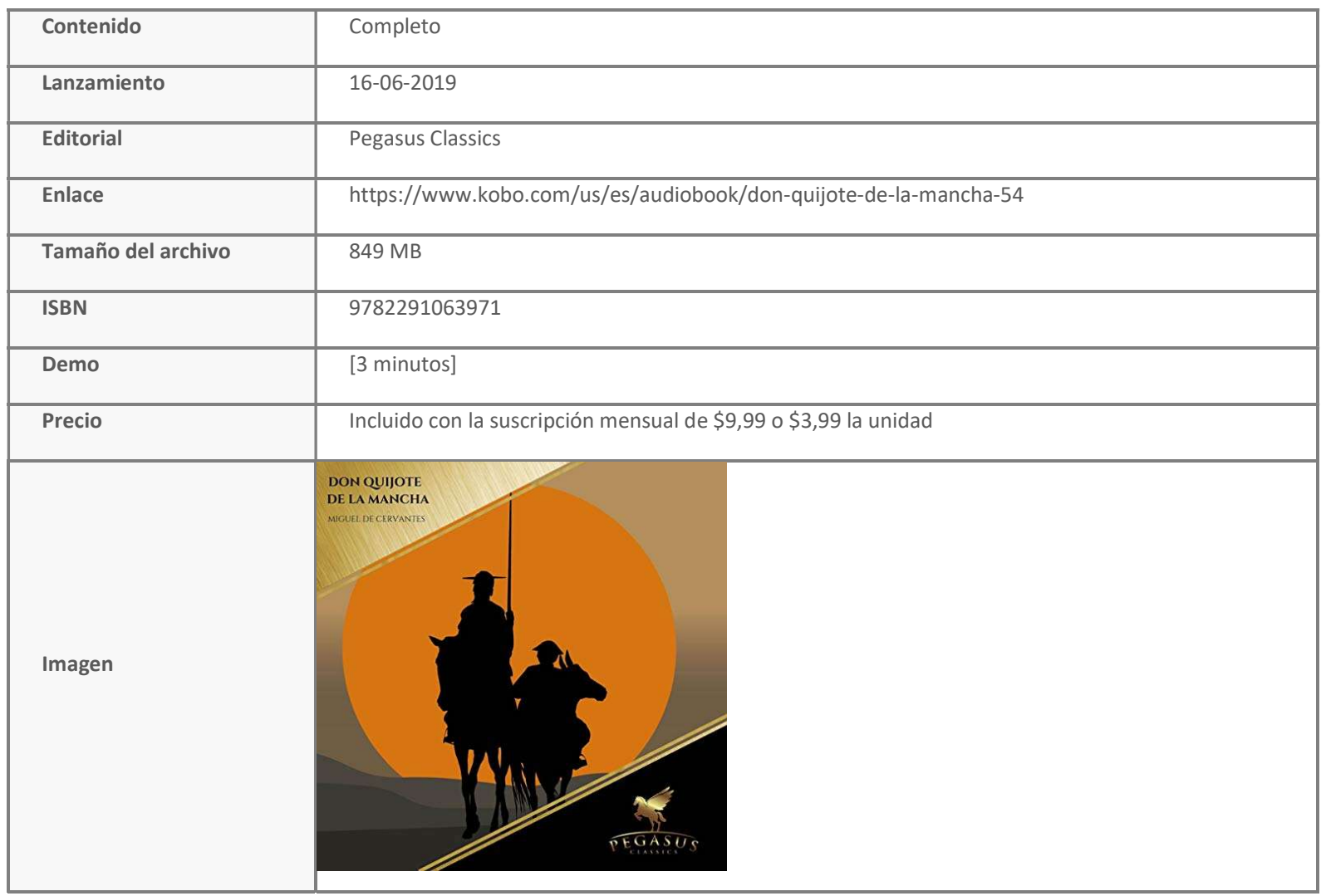

\begin{tabular}{|l|l|}
\multicolumn{2}{|l|}{ Resultado de la búsqueda del «Quijote» en: Kobo } \\
\multicolumn{1}{|l|}{ Ficha . $^{\circ} \mathbf{4}$} \\
\hline Título & Don Quijote de La Mancha (Colección Alfaguara Clásicos) \\
\hline Duración & 3,7 horas \\
\hline Narrador & Raúl Llorens \\
\hline Acento de la narración & S/D \\
\hline Dramatización & S/D \\
\hline Efectos de sonido & S/D \\
\hline Contenido & Completo \\
\hline Lanzamiento & $22-03-2018$ \\
\hline Editorial & Penguin Random House Grupo Editorial \\
\hline Enlace & https://www.kobo.com/us/es/audiobook/don-quijote-de-la-mancha-coleccion-alfaguara-clasicos-1 \\
\hline Tamaño del archivo & 102 MB \\
\hline ISBN & S788420433561 \\
\hline Demo & S/D \\
\hline Precio & \\
\hline
\end{tabular}




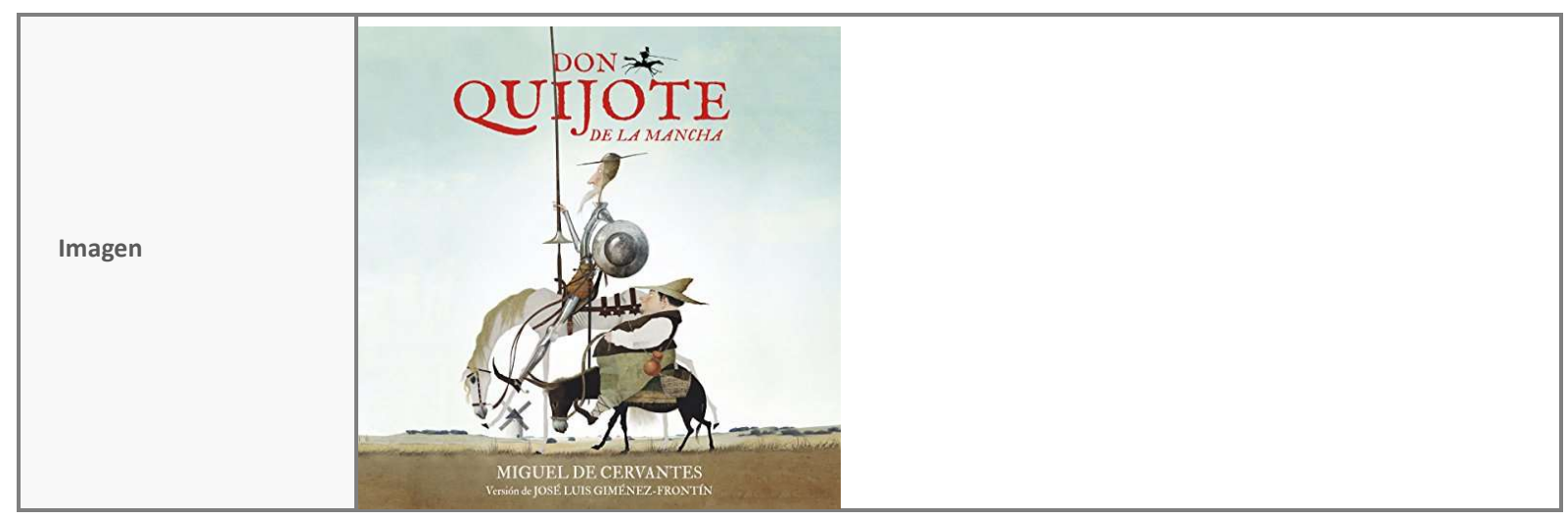

\begin{tabular}{|c|c|}
\hline \multicolumn{2}{|r|}{$\begin{array}{l}\text { Resultado de la búsqueda del «Quijote» en: Kobo } \\
\qquad{\text { Ficha } .^{\circ} 5}^{\circ}\end{array}$} \\
\hline Título & Primera Parte del Ingenioso Hidalgo Don Quijote \\
\hline Duración & 9,7 horas \\
\hline Narrador & Diego Villegas \\
\hline Acento de la narración & S/D \\
\hline Dramatización & $S / D$ \\
\hline Efectos de sonido & $S / D$ \\
\hline Contenido & Completo \\
\hline Lanzamiento & $15-12-2009$ \\
\hline Editorial & Spanish Literature Audiobooks \\
\hline Enlace & $\begin{array}{l}\text { https://www.kobo.com/us/es/audiobook/primera-parte-del-ingenioso-hidalgo-don-quijote-de-la-man- } \\
\text { cha-1 }\end{array}$ \\
\hline Tamaño del archivo & $266 \mathrm{MB}$ \\
\hline ISBN & 9783990852316 \\
\hline Demo & [5 minutos] \\
\hline Precio & Incluido con la suscripción mensual de $\$ 9,99$ o $\$ 23.94$, individualmente \\
\hline
\end{tabular}




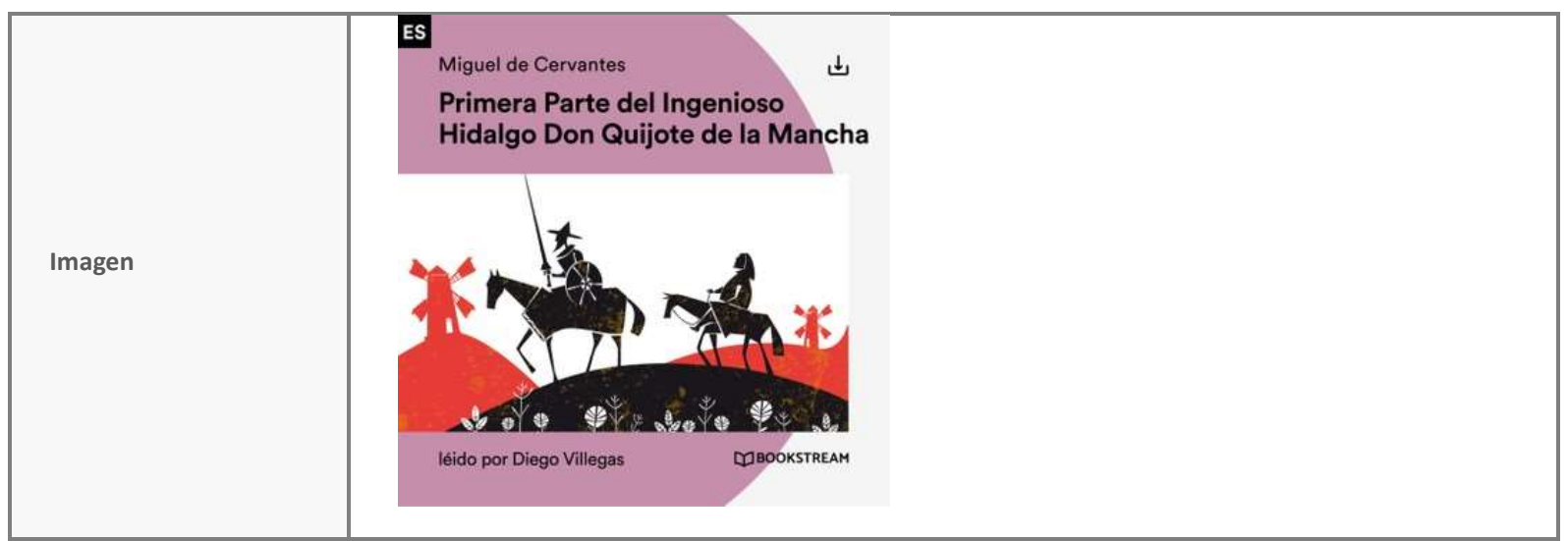

\begin{tabular}{|l|l|}
\hline \multicolumn{2}{|c|}{ Resultado de la búsqueda del «Quijote» en: Kobo } \\
\multicolumn{2}{|l|}{ Ficha . $^{\circ}$ 6 } \\
\hline Título & Primera Parte del Ingenioso Hidalgo Don Quijote (1 de 3) \\
\hline Duración & 9,1 horas \\
\hline Narrador & Diego Villegas \\
\hline Acento de la narración & S/D \\
\hline Dramatización & S/D \\
\hline Efectos de sonido & S/D \\
\hline Contenido & Completo / [Parte I, 1 de 3] \\
\hline Lanzamiento & 15 -12-2009 \\
\hline Editorial & Spanish Literature Audiobooks \\
\hline Enlace & https://www.kobo.com/us/es/audiobook/primera-parte-del-ingenioso-hidalgo-don-quijote-de-la-man- \\
\hline Tamaño del archivo & cha \\
\hline ISBN & Incluido con la suscripción mensual de \$9,99 o \$9,59, individualmente \\
\hline Demo & 9783990854822 \\
\hline Precio & {$[5$ minutos] } \\
\hline
\end{tabular}




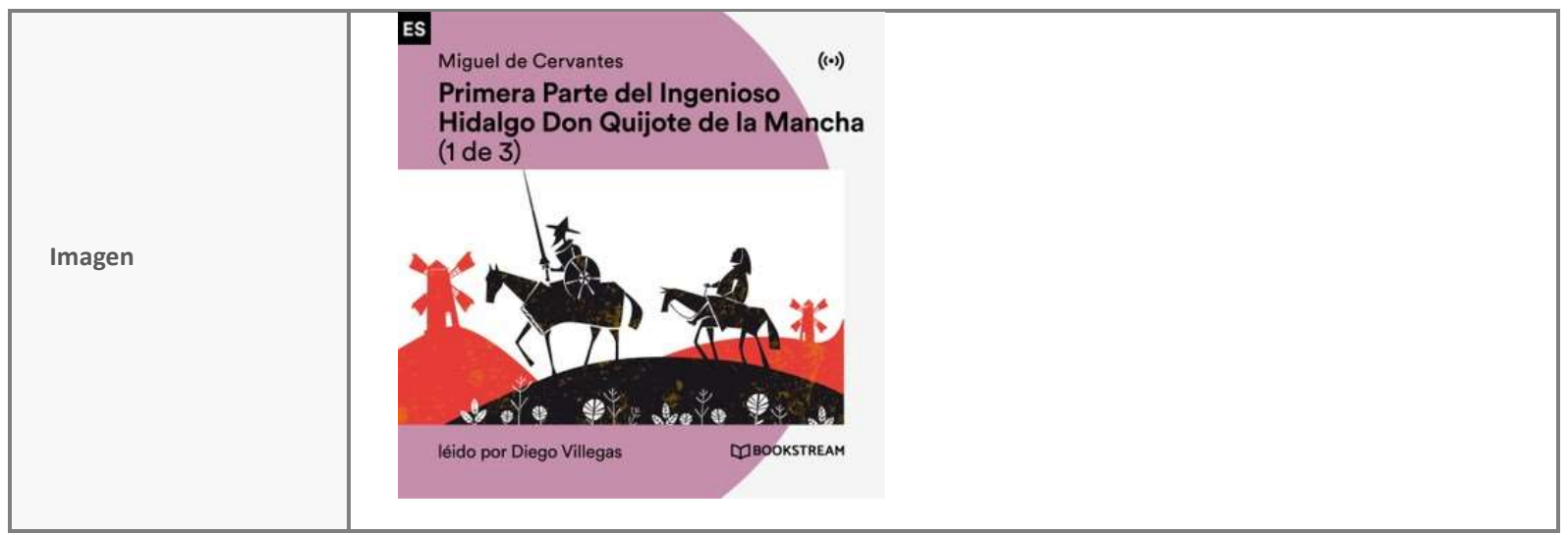

\begin{tabular}{|l|l|}
\hline \multicolumn{2}{|c|}{ Resultado de la búsqueda del «Quijote» en: Kobo } \\
\multicolumn{2}{|l|}{ Ficha . $^{\circ}$ 7 } \\
\hline Título & Primera Parte del Ingenioso Hidalgo Don Quijote (2 de 3) \\
\hline Duración & 7,8 horas \\
\hline Narrador & Diego Villegas \\
\hline Acento de la narración & S/D \\
\hline Dramatización & S/D \\
\hline Efectos de sonido & S/D \\
\hline Contenido & Completo / [Parte l, 2 de 3] \\
\hline Lanzamiento & $15-12-2009$ \\
\hline Editorial & Spanish Literature Audiobooks \\
\hline Enlace & https://www.kobo.com/us/es/audiobook/primera-parte-del-ingenioso-hidalgo-don-quijote-de-la-man- \\
\hline Tamaño del archivo & cha-2 \\
\hline ISBN & 213 MB \\
\hline Demo & 9783990854839 \\
\hline Precio & {$[5$ minutos $]$} \\
\hline
\end{tabular}




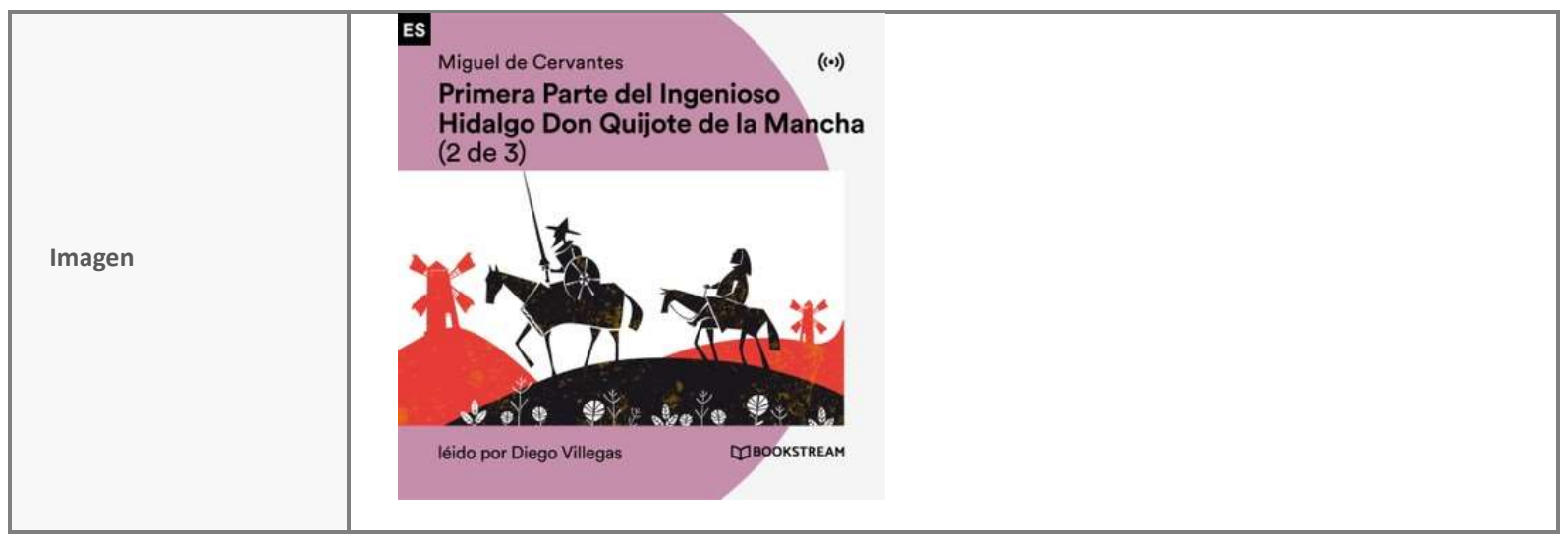

\begin{tabular}{|c|c|}
\hline \multicolumn{2}{|r|}{$\begin{array}{l}\text { Resultado de la búsqueda del «Quijote» en: Kobo } \\
\qquad \text { Ficha } n .^{\circ} 8\end{array}$} \\
\hline Título & Primera Parte del Ingenioso Hidalgo Don Quijote (3 de 3) \\
\hline Duración & 6,6 horas \\
\hline Narrador & Diego Villegas \\
\hline Acento de la narración & S/D \\
\hline Dramatización & S/D \\
\hline Efectos de sonido & S/D \\
\hline Contenido & Completo / [Parte I, 3de 3] \\
\hline Lanzamiento & $15-12-2009$ \\
\hline Editorial & Spanish Literature Audiobooks \\
\hline Enlace & $\begin{array}{l}\text { https://www.kobo.com/us/es/audiobook/primera-parte-del-ingenioso-hidalgo-don-quijote-de-la-man- } \\
\text { cha-3 }\end{array}$ \\
\hline Tamaño del archivo & $182 \mathrm{MB}$ \\
\hline ISBN & 9783990854846 \\
\hline Demo & 30 segundos \\
\hline Precio & Incluido con la suscripción mensual de $\$ 9,99$ o $\$ 9,59$, individualmente \\
\hline Imagen & $\begin{array}{l}\text { ES } \\
\text { Miguel de Cervantes } \\
\text { Primera Parte del Ingenioso } \\
\text { Hidalgo Don Quijote de la Mancha } \\
\text { (3 de 3) }\end{array}$ \\
\hline
\end{tabular}




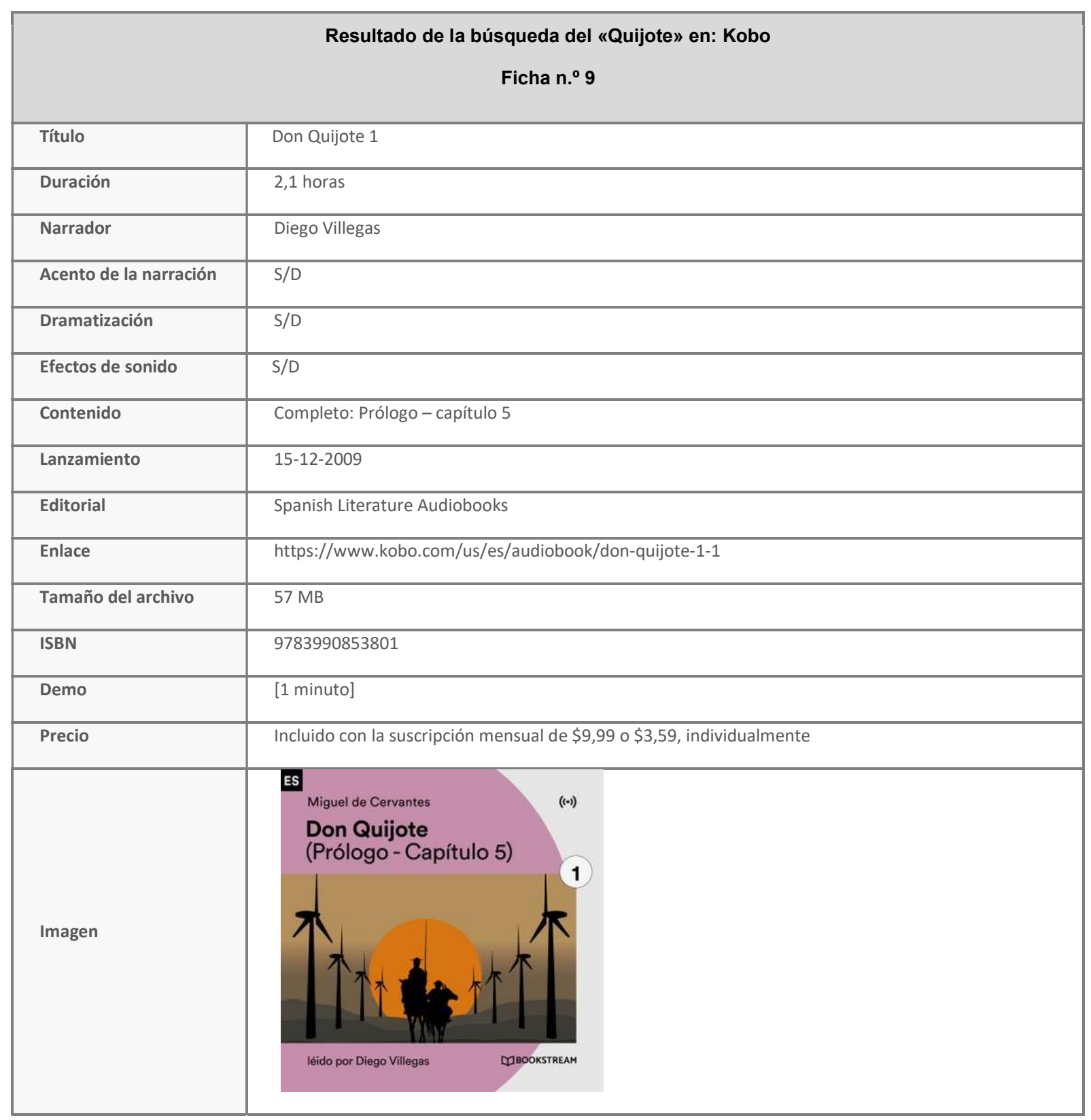

\begin{tabular}{|l|l|}
\hline \multicolumn{2}{|c|}{ Resultado de la búsqueda del «Quijote» en: Kobo } \\
Ficha $\mathbf{n} .^{\circ}$ 10 \\
\hline Título & Don Quijote 2 \\
\hline Duración & 3,2 horas \\
\hline Narrador & Diego Villegas \\
\hline Acento de la narración & S/D \\
\hline
\end{tabular}




\begin{tabular}{|c|c|}
\hline Dramatización & $\mathrm{S} / \mathrm{D}$ \\
\hline Efectos de sonido & $S / D$ \\
\hline Contenido & Completo: Capítulo 6 - capítulo 15 \\
\hline Lanzamiento & $15-12-2009$ \\
\hline Editorial & Spanish Literature Audiobooks \\
\hline Enlace & https://www.kobo.com/us/es/audiobook/don-quijote-2-1 \\
\hline Tamaño del archivo & $88 \mathrm{MB}$ \\
\hline ISBN & 9783990853818 \\
\hline Demo & [30 segundos] \\
\hline Precio & Incluido con la suscripción mensual de $\$ 9,99$ ó $\$ 3,59$, individualmente \\
\hline Imagen & $\begin{array}{l}\text { Miguel de Cervantes } \\
\text { Don Quijote } \\
\text { (Capítulo 6-Capítulo 15) }\end{array}$ \\
\hline
\end{tabular}

\begin{tabular}{|c|c|}
\hline \multicolumn{2}{|r|}{$\begin{array}{c}\text { Resultado de la búsqueda del «Quijote» en: Kobo } \\
\text { Ficha } n .^{0} 11\end{array}$} \\
\hline Título & Don Quijote 3 \\
\hline Duración & 2,2 horas \\
\hline Narrador & Diego Villegas \\
\hline Acento de la narración & $S / D$ \\
\hline Dramatización & $S / D$ \\
\hline Efectos de sonido & S/D \\
\hline Contenido & Completo: Capítulo 16 - capítulo 20 \\
\hline Lanzamiento & $15-12-2009$ \\
\hline Editorial & Spanish Literature Audiobooks \\
\hline Enlace & https://www.kobo.com/us/es/audiobook/don-quijote-3-1 \\
\hline Tamaño del archivo & $62 \mathrm{MB}$ \\
\hline ISBN & 9783990853825 \\
\hline
\end{tabular}




\begin{tabular}{|l|l|}
\hline Demo & [30 segundos] \\
\hline Precio & Incluido con la suscripción mensual de \$9,99 ó \$3,59, individualmente \\
\hline \multirow{3}{*}{ Imagen } & $\begin{array}{l}\text { ES Miguel de Cervantes } \\
\text { Don Quijote } \\
\text { (Capítulo 16-Capítulo 20) }\end{array}$ \\
\hline
\end{tabular}

\begin{tabular}{|c|c|}
\hline \multicolumn{2}{|r|}{ 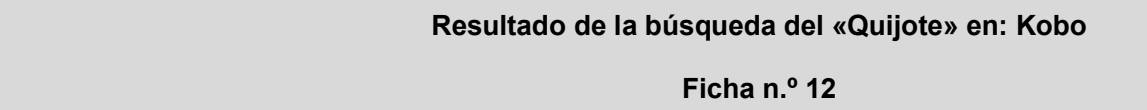 } \\
\hline Título & Don Quijote 4 \\
\hline Duración & 2,9 horas \\
\hline Narrador & Diego Villegas \\
\hline Acento de la narración & S/D \\
\hline Dramatización & S/D \\
\hline Efectos de sonido & S/D \\
\hline Contenido & Completo: Capítulo 21 - capítulo 25 \\
\hline Lanzamiento & $15-12-2009$ \\
\hline Editorial & Spanish Literature Audiobooks \\
\hline Enlace & https://www.kobo.com/us/es/audiobook/don-quijote-4-1 \\
\hline Tamaño del archivo & $79 \mathrm{MB}$ \\
\hline ISBN & 978399085832 \\
\hline Demo & [30 segundos] \\
\hline Precio & Incluido con la suscripción mensual de $\$ 9,99$ ó $\$ 3,59$ individualmente \\
\hline
\end{tabular}




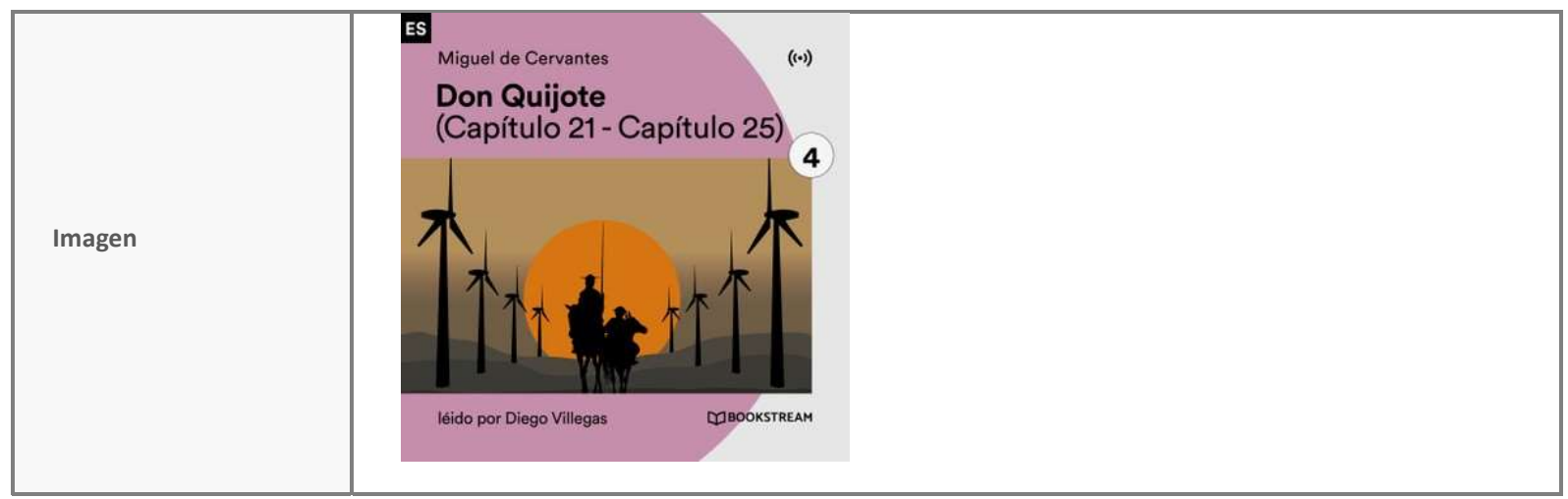

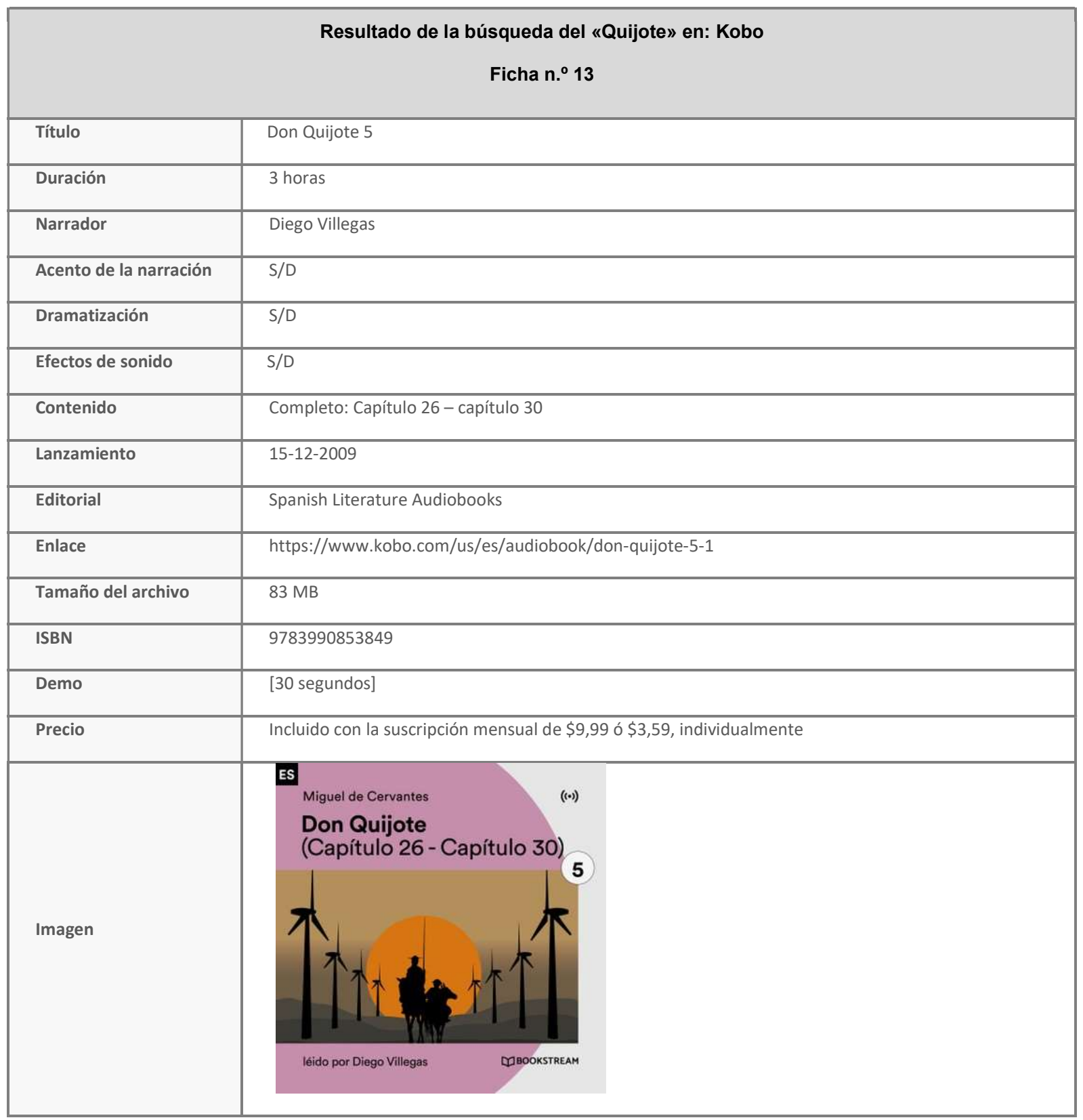




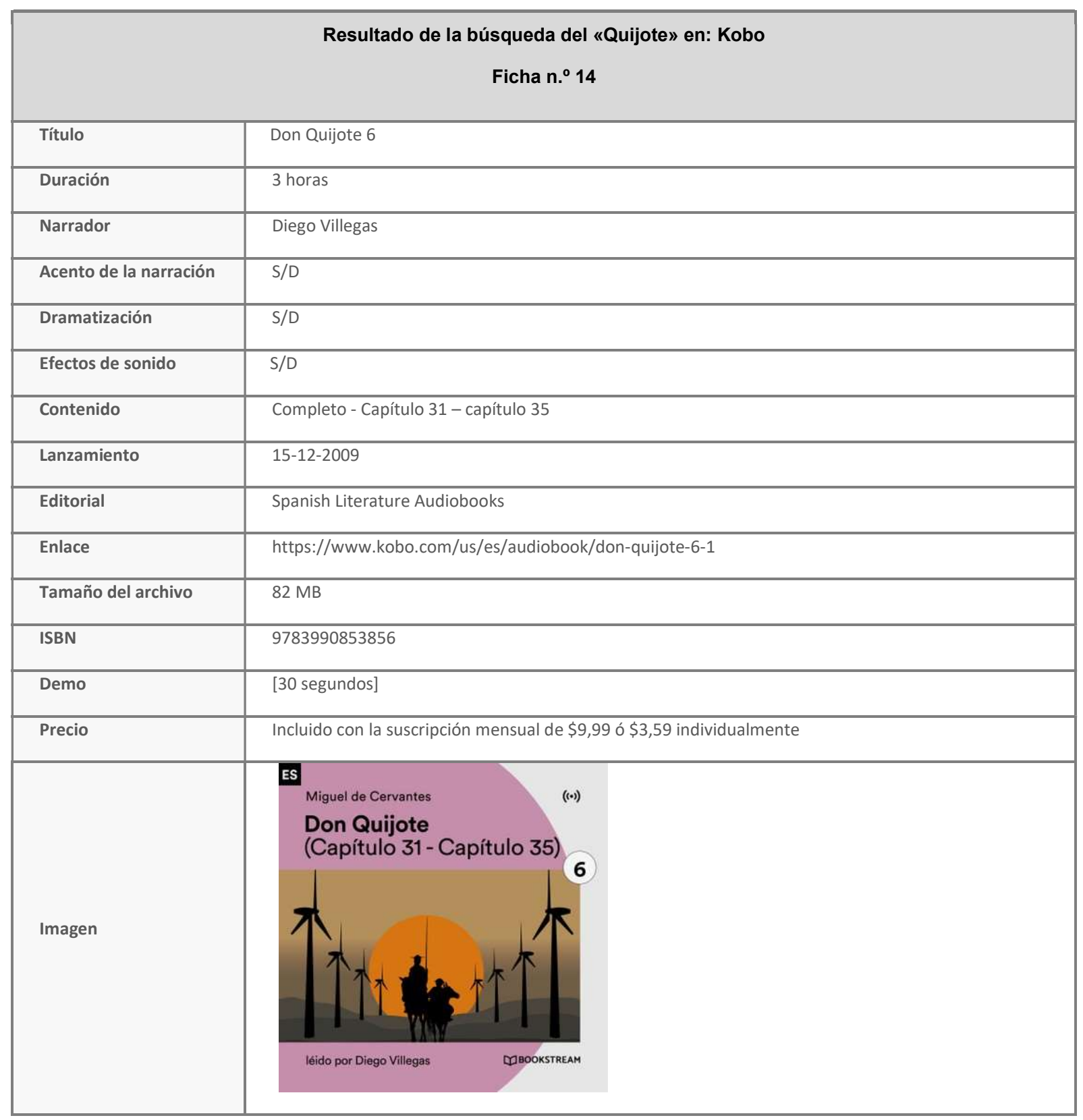

\begin{tabular}{|l|l|}
\hline \multicolumn{2}{|c|}{ Resultado de la búsqueda del «Quijote» en: Kobo } \\
\multicolumn{2}{|l|}{ Ficha $\mathbf{n} .^{\circ}$ 15 } \\
\hline Título & Don Quijote 7 \\
\hline Duración & 2,2 horas \\
\hline Narrador & Diego Villegas \\
\hline Acento de la narración & S/D \\
\hline Dramatización & S/D \\
\hline
\end{tabular}




\begin{tabular}{|c|c|}
\hline Efectos de sonido & S/D \\
\hline Contenido & Completo - Capítulo 36 - capítulo 40 \\
\hline Lanzamiento & $15-12-2009$ \\
\hline Editorial & Spanish Literature Audiobooks \\
\hline Enlace & https://www.kobo.com/us/es/audiobook/don-quijote-7-1 \\
\hline Tamaño del archivo & $59 \mathrm{MB}$ \\
\hline ISBN & 9783990853863 \\
\hline Demo & [30 segundos] \\
\hline Precio & Incluido con la suscripción mensual de $\$ 9,99$ ó $\$ 3,59$ individualmente \\
\hline Imagen & $\begin{array}{l}\text { ES Miguel de Cervantes } \\
\text { Don Quijote } \\
\text { (Capítulo } 36 \text { - Capítulo 40) }\end{array}$ \\
\hline
\end{tabular}

\begin{tabular}{|l|l|}
\multicolumn{2}{|c|}{ Resultado de la búsqueda del «Quijote» en: Kobo } \\
\multicolumn{1}{|l|}{ Ficha . $^{\circ}$ 16 } \\
\hline Título & Don Quijote 8 \\
\hline Duración & 2,4 horas \\
\hline Narrador & Diego Villegas \\
\hline Acento de la narración & S/D \\
\hline Dramatización & S/D \\
\hline Efectos de sonido & S/D \\
\hline Contenido & Completo - Capítulo 41- capítulo 45 \\
\hline Lanzamiento & $15-12-2009$ \\
\hline Editorial & Spanish Literature Audiobooks \\
\hline Enlace & https://www.kobo.com/us/es/audiobook/don-quijote-8-1 \\
\hline Tamaño del archivo & 66 MB \\
\hline ISBN & 9783990853870 \\
\hline Demo & {$[30$ segundos] } \\
\hline
\end{tabular}




\begin{tabular}{|l|l|}
\hline Precio & Incluido con la suscripción mensual de \$9,99 ó \$3,59 individualmente \\
\hline ES & $\begin{array}{l}\text { Miguel de Cervantes } \\
\text { Don Quijote } \\
\text { (Capítulo 41-Capítulo 45) }\end{array}$ \\
\hline Imagen & léido por Diego Villegas \\
\hline
\end{tabular}

\begin{tabular}{|c|c|}
\hline \multicolumn{2}{|r|}{ 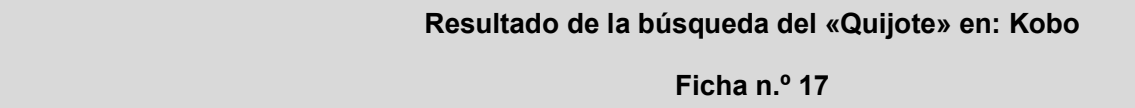 } \\
\hline Título & Don Quijote 9 \\
\hline Duración & 2,5 horas \\
\hline Narrador & Diego Villegas \\
\hline Acento de la narración & S/D \\
\hline Dramatización & S/D \\
\hline Efectos de sonido & S/D \\
\hline Contenido & Completo - Capítulo 46 - capítulo 52 \\
\hline Lanzamiento & $15-12-2009$ \\
\hline Editorial & Spanish Literature Audiobooks \\
\hline Enlace & https://www.kobo.com/us/es/audiobook/don-quijote-9-1 \\
\hline Tamaño del archivo & $70 \mathrm{MB}$ \\
\hline ISBN & 9783990853887 \\
\hline Demo & [30 segundos] \\
\hline Precio & Incluido con la suscripción mensual de $\$ 9,99$ ó $\$ 3,59$ individualmente \\
\hline
\end{tabular}




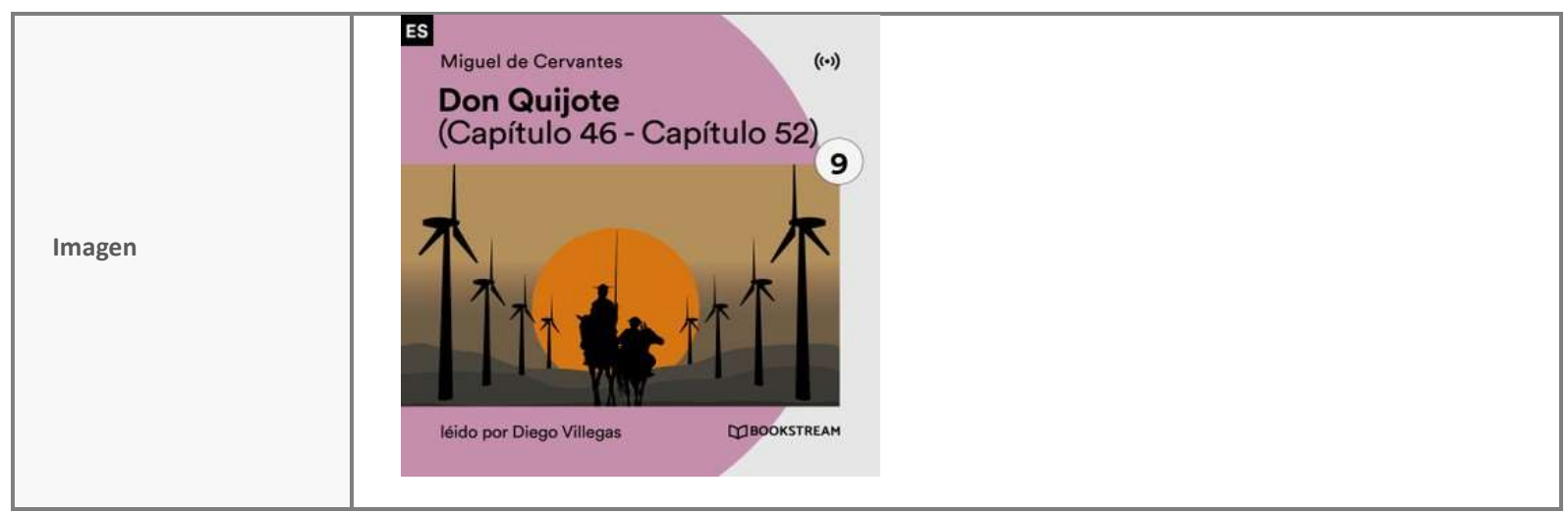

La búsqueda bibliográfica de audiolibros en la interfaz web de Kobo ofrece 17 resultados:

Dos audiolibros de más de 30 horas:

$\checkmark \quad 1$ audiolibro con el título Don Quijote de la Mancha, de 40:07 h de duración

$\checkmark 1$ audiolibro bajo el título Don Quijote de la Mancha, de 37,8 h de duración

De menos de 30 horas:

$\checkmark$ Un audiolibro de $17,2 \mathrm{~h}$ de extensión y otro de $3,7 \mathrm{~h}$.

$Y$ de una misma editorial:

$\checkmark \quad 1$ audiolibro bajo el título Primera Parte del Ingenioso Hidalgo Don Quijote

$\checkmark \quad 3$ títulos correspondientes a una colección de audiolibros, titulada Primera Parte del Ingenioso Hidalgo Don Quijote de la editorial Spanish Literature Audiobooks.

$\checkmark \quad 9$ audios que corresponden a una misma colección de audiolibros, titulada Don Quijote, de la editorial Spanish Literature Audiobooks.

En síntesis, de Spanish Literature Audiobook se ofrecen 13 títulos que corresponden a tres formas distintas de presentar un mismo audio, todos correspondientes a la primera parte del Quijote.

En los 17 audios encontrados se indica que el audiolibro está "completo», sin embargo, no se dan detalles del origen editorial de ninguno de ellos. Como dato a resaltar se incluye en todos los casos el peso del archivo y el ISBN del título. 


\section{LEAMOS. Información y fichas de los audiolibros del Quijote que contiene.}

La búsqueda nos recupera 22 resultados de los cuales 15 corresponden con audiolibros relacionados con nuestro objetivo de búsqueda.

\begin{tabular}{|c|c|}
\hline & $\begin{array}{l}\text { Resultado de la búsqueda del «Quijote» en: Leamos } \\
\qquad \text { Ficha } n .^{\circ} 1\end{array}$ \\
\hline Título & Primera Parte del Ingenioso Hidalgo Don Quijote de la Mancha \\
\hline Duración & $9: 40$ horas \\
\hline Narrador & S/D \\
\hline Acento de la narración & S/D \\
\hline Dramatización & S/D \\
\hline Efectos de sonido & S/D \\
\hline Contenido & S/D \\
\hline Lanzamiento & 2019 \\
\hline Editorial & Spanish Literature Audiobooks \\
\hline Enlace & https://www.leamos.com/ar/book/9783990852316 \\
\hline Tamaño del archivo & S/D \\
\hline ISBN & 9783990852316 \\
\hline Demo & [5 minutos] \\
\hline Precio & Incluido en la suscripción mensual de 5,95€ \\
\hline Imagen & $\begin{array}{l}\text { Miguel de Cervantes } \\
\text { Primera Parte del Ingenioso } \\
\text { Hidalgo Don Quijote de la Mancha }\end{array}$ \\
\hline
\end{tabular}




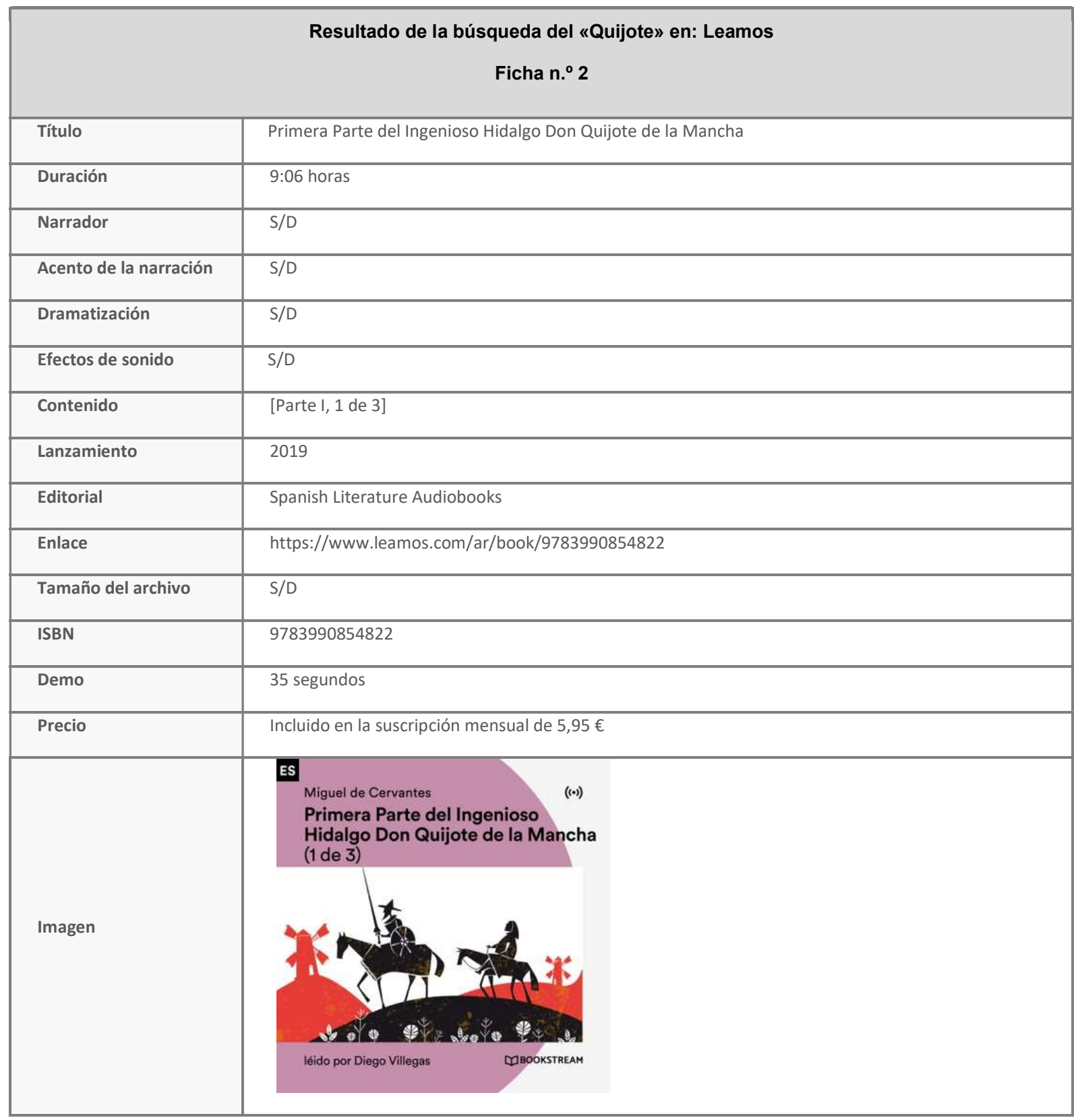

\section{Resultado de la búsqueda del «Quijote» en: Leamos}

Ficha n. $^{\circ} 3$

\begin{tabular}{|l|l|}
\hline Título & Primera Parte del Ingenioso Hidalgo Don Quijote de la Mancha \\
\hline Duración & $7: 45$ horas \\
\hline Narrador & S/D \\
\hline Acento de la narración & S/D \\
\hline Dramatización & S/D \\
\hline
\end{tabular}




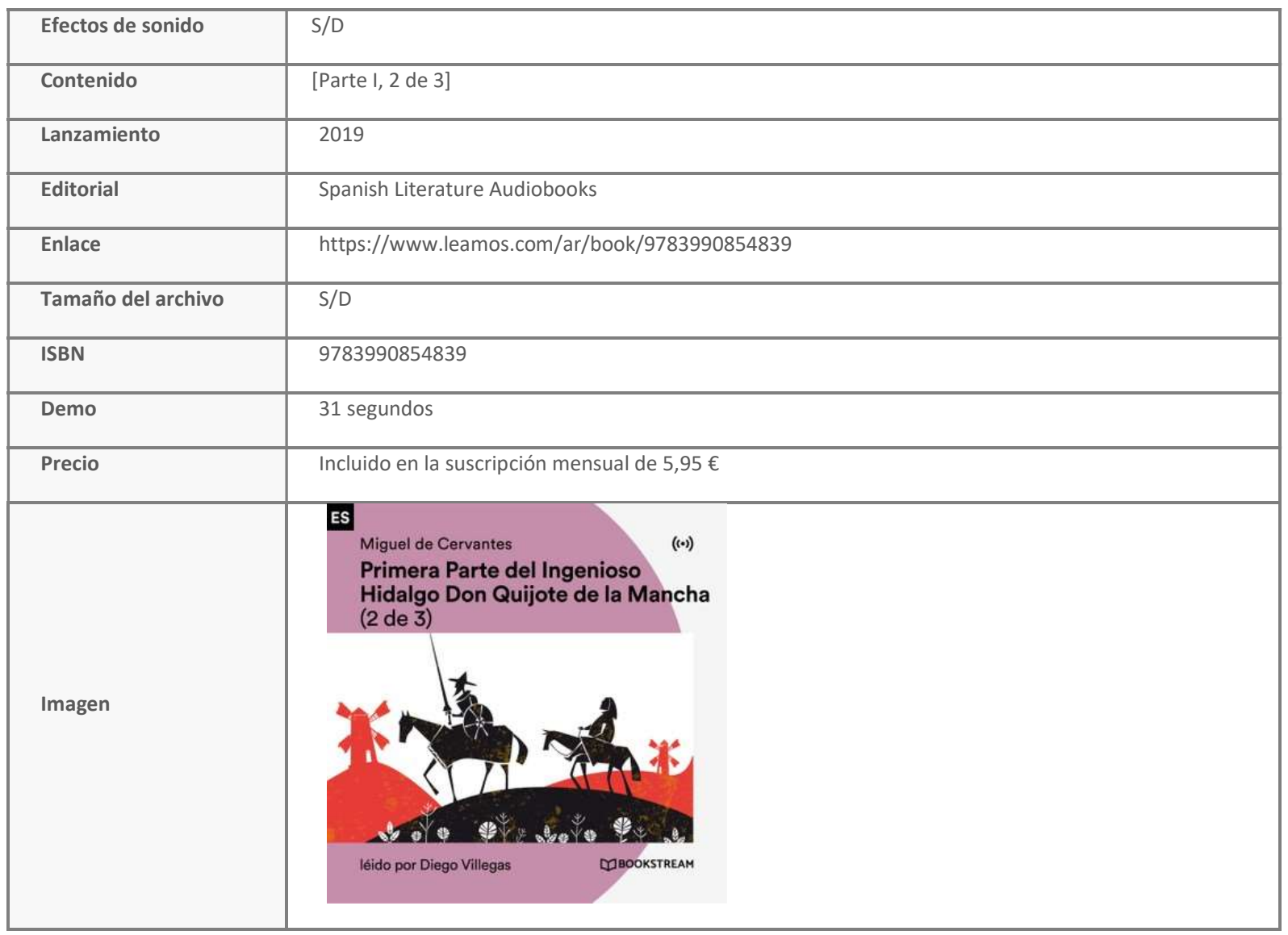

\begin{tabular}{|l|l|}
\multicolumn{2}{|c|}{ Resultado de la búsqueda del «Quijote» en: Leamos } \\
\multicolumn{2}{|l|}{ Ficha n. $^{\circ} \mathbf{4}$} \\
\hline Título & Primera Parte del Ingenioso Hidalgo Don Quijote de la Mancha \\
\hline Duración & $6: 37$ horas \\
\hline Narrador & S/D \\
\hline Acento de la narración & S/D \\
\hline Dramatización & S/D \\
\hline Efectos de sonido & S/D \\
\hline Contenido & {$[$ Parte I, 3de 3] } \\
\hline Lanzamiento & 2019 \\
\hline Editorial & Spanish Literature Audiobooks \\
\hline Enlace & https://www.leamos.com/ar/book/9783990854846 \\
\hline Tamaño del archivo & S/D \\
\hline ISBN & 9783990854846 \\
\hline Demo & S/D \\
\hline
\end{tabular}




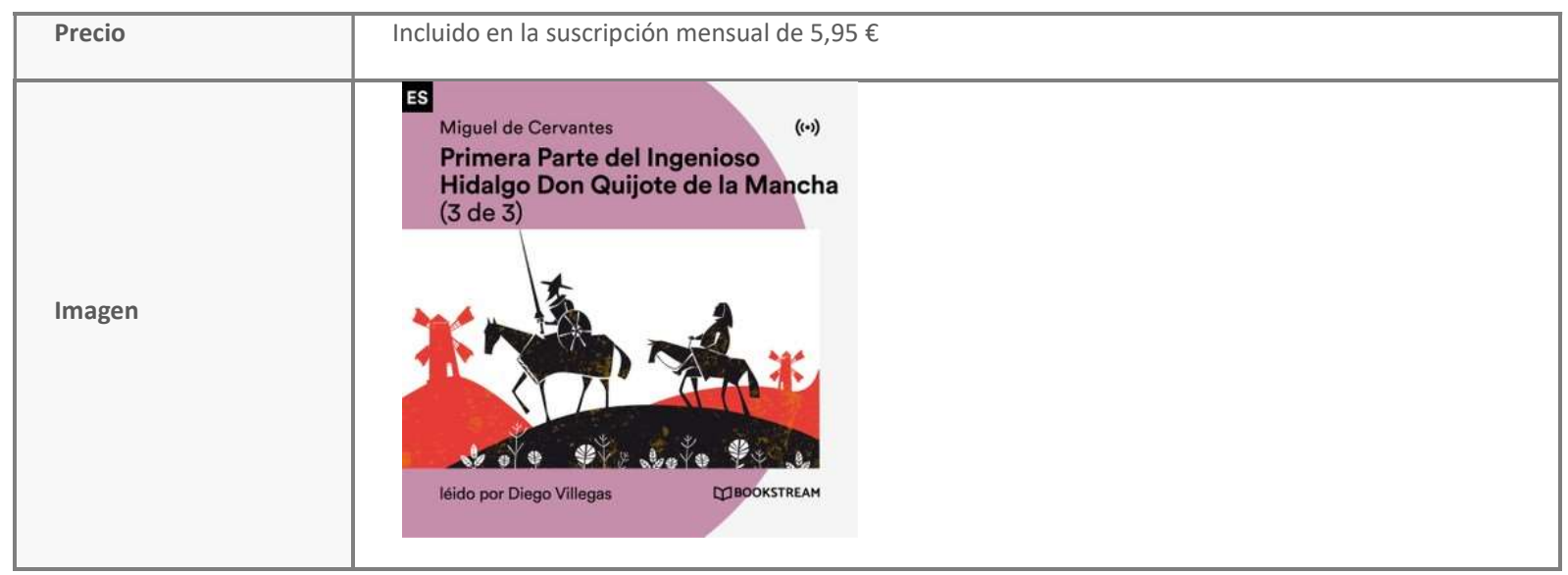

Resultado de la búsqueda del «Quijote» en: Leamos

Ficha n. $^{\circ} 5$

\begin{tabular}{|c|c|}
\hline Título & Don Quijote 1 \\
\hline Duración & 2:03 horas \\
\hline Narrador & $S / D$ \\
\hline Acento de la narración & $S / D$ \\
\hline Dramatización & $S / D$ \\
\hline Efectos de sonido & $S / D$ \\
\hline Contenido & [Prólogo - capítulo 5] \\
\hline Lanzamiento & 2019 \\
\hline Editorial & Spanish Literature Audiobooks \\
\hline Enlace & https://www.leamos.com/ar/book/9783990853801 \\
\hline Tamaño del archivo & $S / D$ \\
\hline ISBN & 9783990853801 \\
\hline Demo & $S / D$ \\
\hline Precio & Incluido en la suscripción mensual de 5,95€ \\
\hline
\end{tabular}




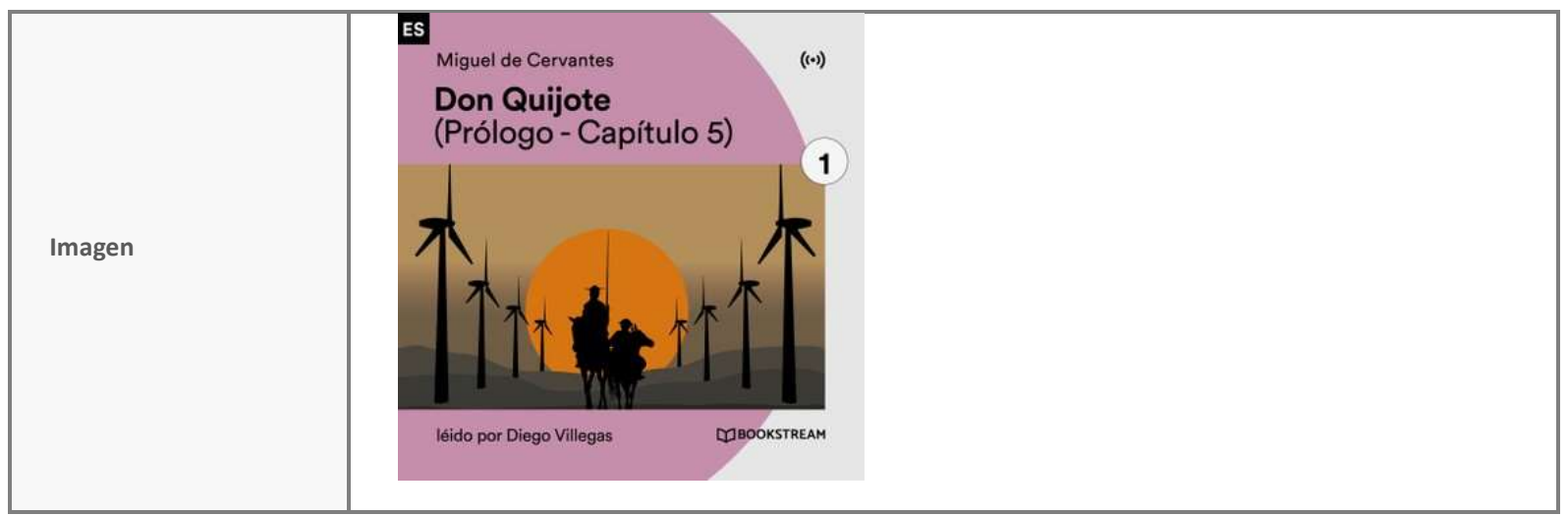

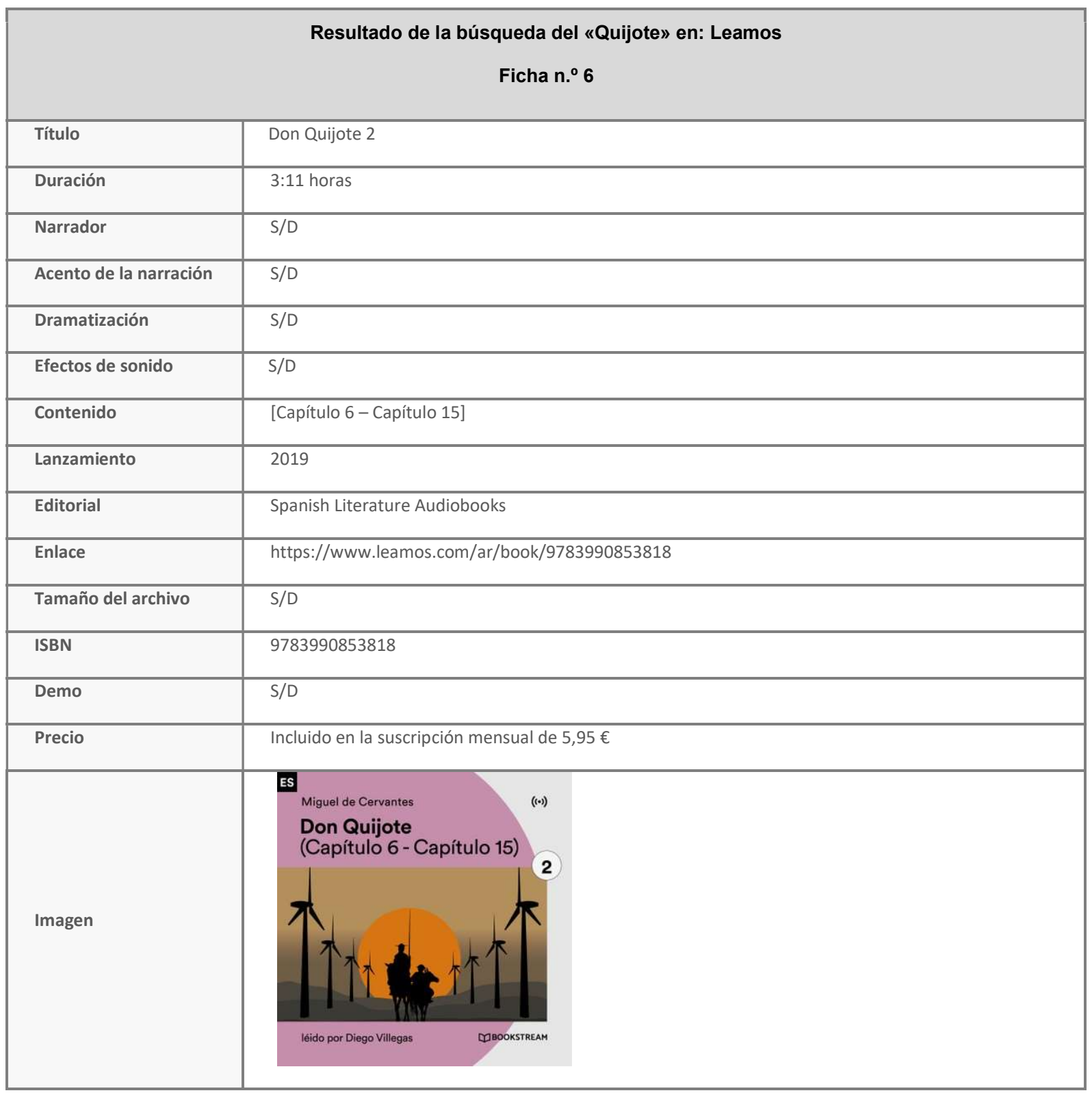




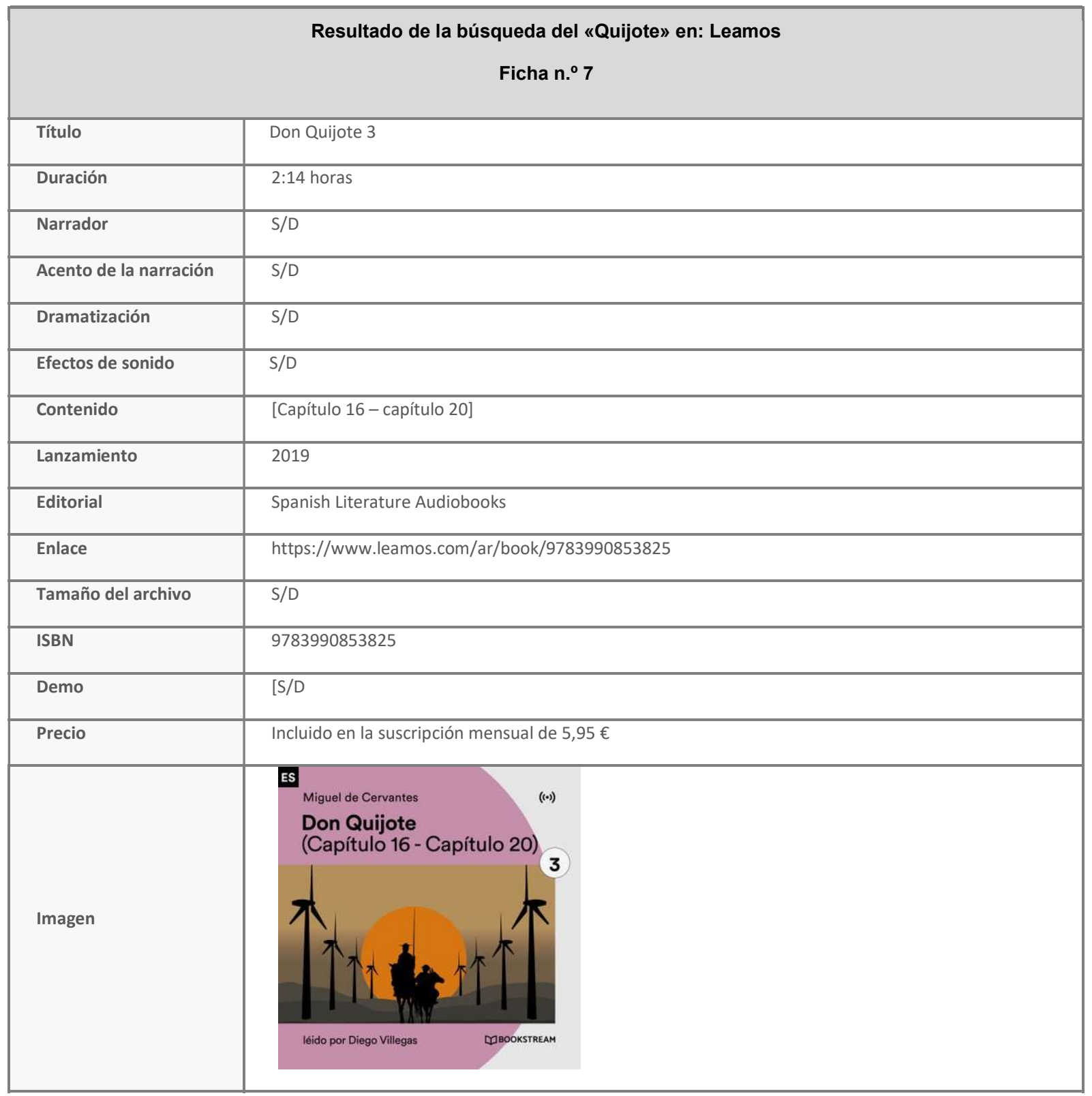

\begin{tabular}{|l|l|}
\hline \multicolumn{2}{|c|}{ Resultado de la búsqueda del «Quijote» en: Leamos } \\
\multicolumn{1}{|l|}{ Ficha . $^{\circ}{ }^{8}$} \\
\hline Título & Don Quijote 4 \\
\hline Duración & $2: 52$ horas \\
\hline Narrador & S/D \\
\hline Acento de la narración & S/D \\
\hline Dramatización & S/D \\
\hline Efectos de sonido & S/D \\
\hline
\end{tabular}




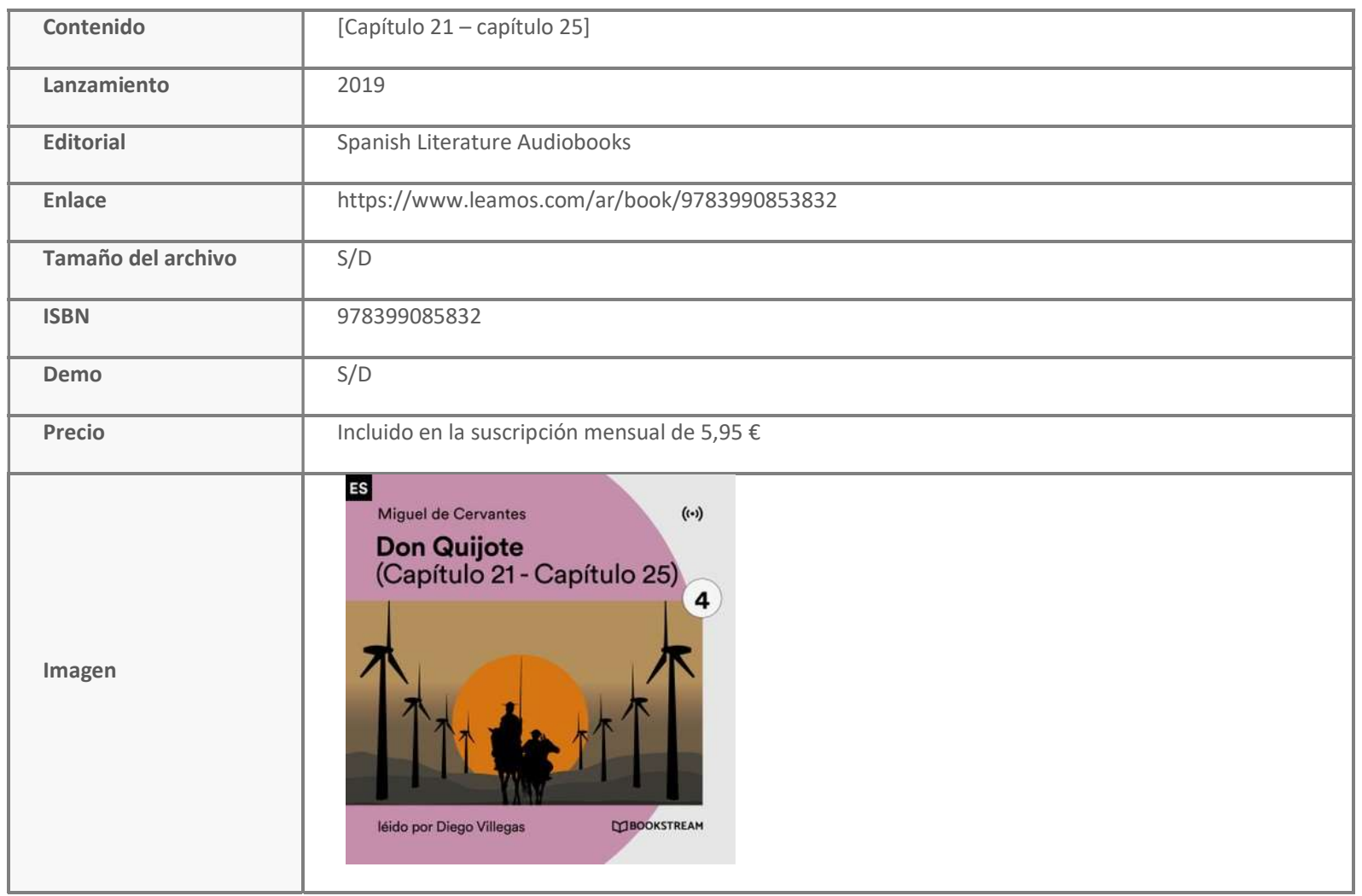

\begin{tabular}{|l|l|}
\hline \multicolumn{2}{|c|}{ Resultado de la búsqueda del «Quijote» en: Leamos } \\
\multicolumn{1}{|l|}{ Ficha . $^{\circ}$ 9 } \\
\hline Título & Don Quijote 5 \\
\hline Duración & $3: 01$ horas \\
\hline Narrador & S/D \\
\hline Acento de la narración & S/D \\
\hline Dramatización & S/D \\
\hline Efectos de sonido & S/D \\
\hline Contenido & [Capítulo 26- capítulo 30] \\
\hline Lanzamiento & 2019 \\
\hline Editorial & Spanish Literature Audiobooks \\
\hline Enlace & https://www.leamos.com/ar/book/9783990853849 \\
\hline Tamaño del archivo & S/D \\
\hline ISBN & S783990853849 \\
\hline Demo & S/D \\
\hline Precio & \\
\hline
\end{tabular}




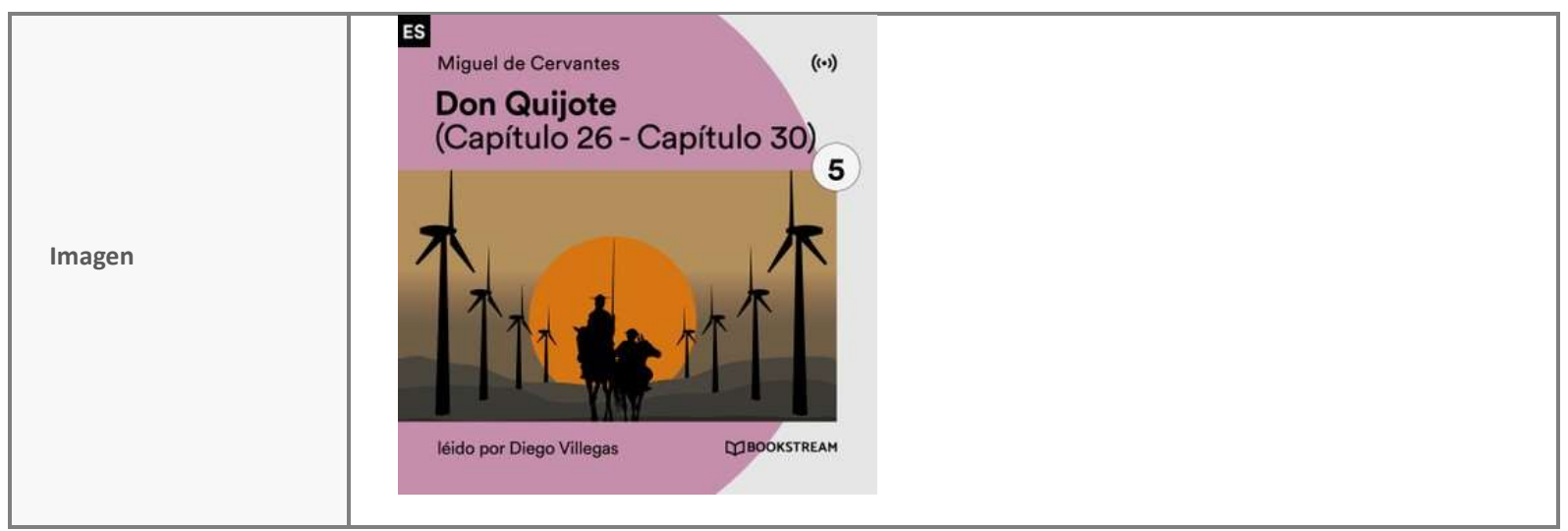

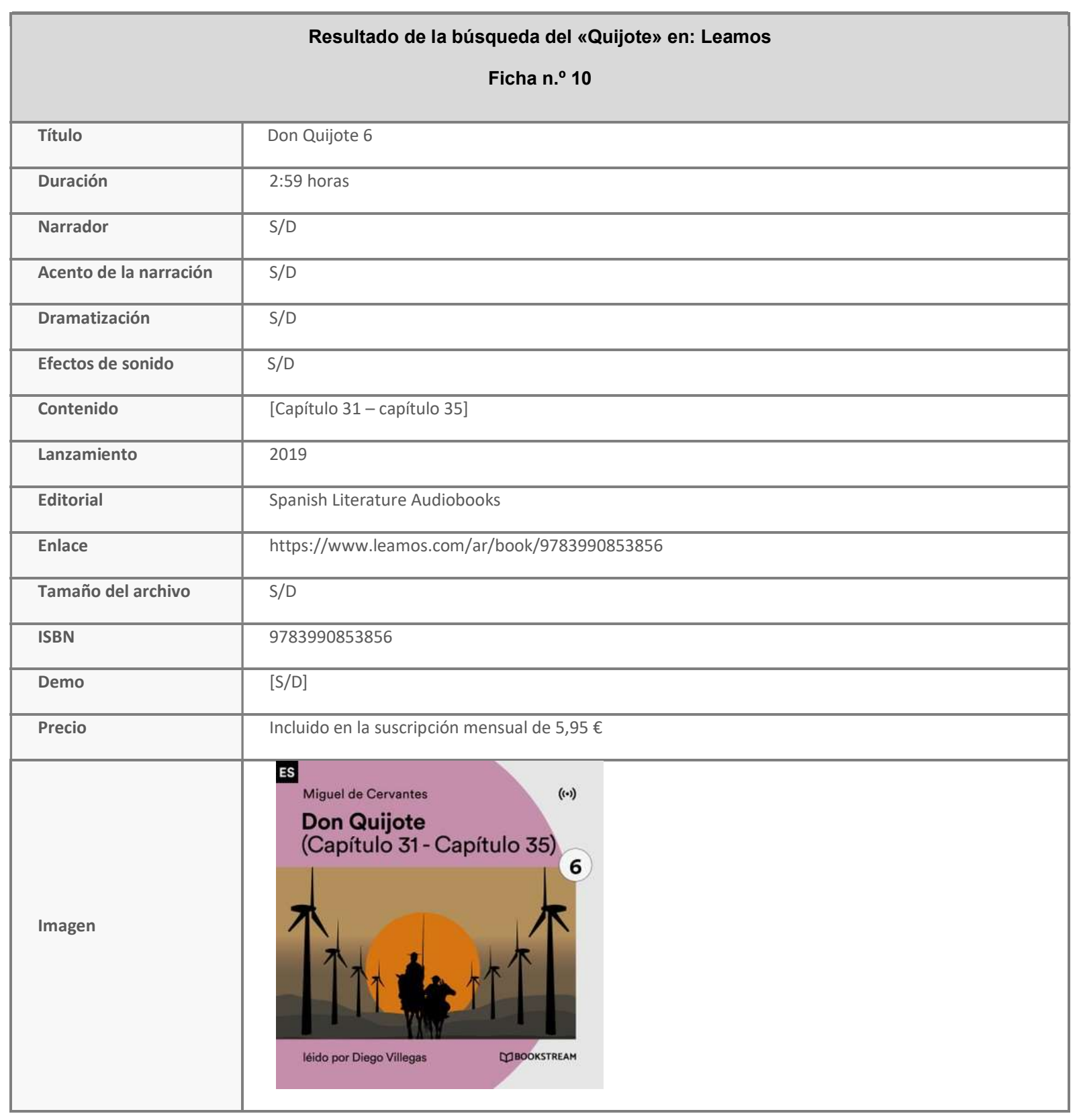




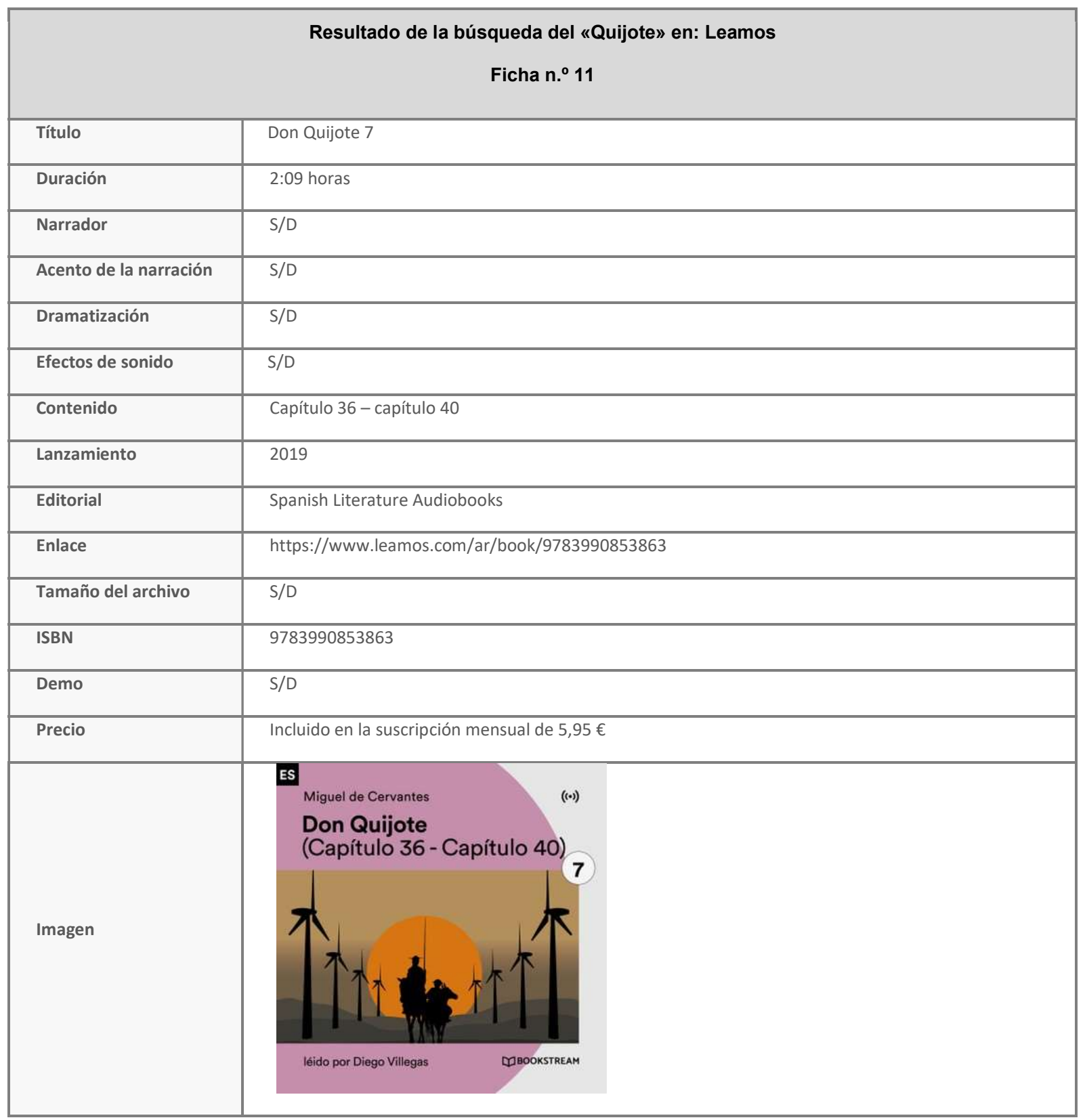

\begin{tabular}{|l|l|}
\hline \multicolumn{2}{|c|}{ Resultado de la búsqueda del «Quijote» en: Leamos } \\
Ficha . $^{\circ}$ 12 \\
\hline Título & Don Quijote 8 \\
\hline Duración & $2: 24$ horas \\
\hline Narrador & S/D \\
\hline
\end{tabular}




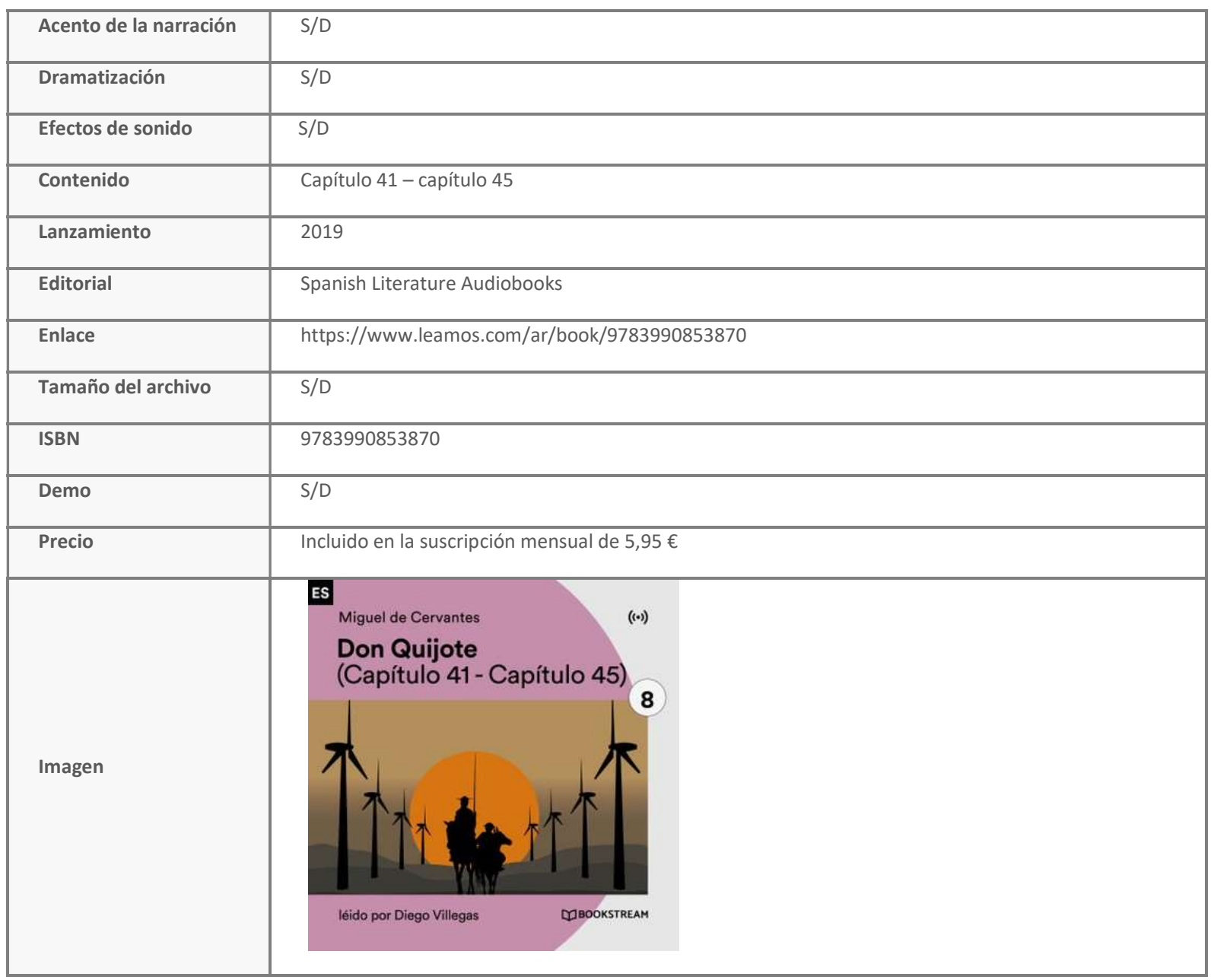

\begin{tabular}{|l|l|}
\hline \multicolumn{2}{|c|}{ Resultado de la búsqueda del «Quijote» en: Leamos } \\
\multicolumn{2}{|l|}{ Ficha . $^{\circ}$ 13 } \\
\hline Título & Don Quijote 9 \\
\hline Duración & $2: 32$ horas \\
\hline Narrador & S/D \\
\hline Acento de la narración & S/D \\
\hline Dramatización & S/D \\
\hline Efectos de sonido & S/D \\
\hline Contenido & [Capítulo 46- capítulo 52] \\
\hline Lanzamiento & 2019 \\
\hline Editorial & Spanish Literature Audiobooks \\
\hline Enlace & https://www.leamos.com/ar/book/9783990853887 \\
\hline Tamaño del archivo & S/D \\
\hline
\end{tabular}




\begin{tabular}{|l|l|}
\hline ISBN & 9783990853887 \\
\hline Demo & S/D \\
\hline Precio & Incluido en la suscripción mensual de 5,95€ \\
\hline \multirow{3}{*}{ Imagen } & $\begin{array}{l}\text { ES Miguel de Cervantes } \\
\text { Don Quijote } \\
\text { (Capítulo 46-Capítulo 52) }\end{array}$ \\
& \\
\hline
\end{tabular}

\section{Resultado de la búsqueda del «Quijote» en: Leamos}

Ficha ${ }^{\circ}{ }^{14}$

\begin{tabular}{|l|l|}
\hline Título & Don Quijote de la Mancha \\
\hline Duración & 17 horas y 11 min \\
\hline Narrador & S/D \\
\hline Acento de la narración & S/D \\
\hline Dramatización & S/D \\
\hline Efectos de sonido & S/D \\
\hline Contenido & S/D \\
\hline Lanzamiento & 2020 \\
\hline Editorial & Pegasus Classics \\
\hline Enlace & https://www.leamos.com/ar/book/9782291063971 \\
\hline Tamaño del archivo & S/D \\
\hline ISBN & 9782291063971 \\
\hline Demo & S/D \\
\hline Precio & Incluido en la suscripción mensual de 5,95 € \\
\hline Imagen & \\
\hline
\end{tabular}




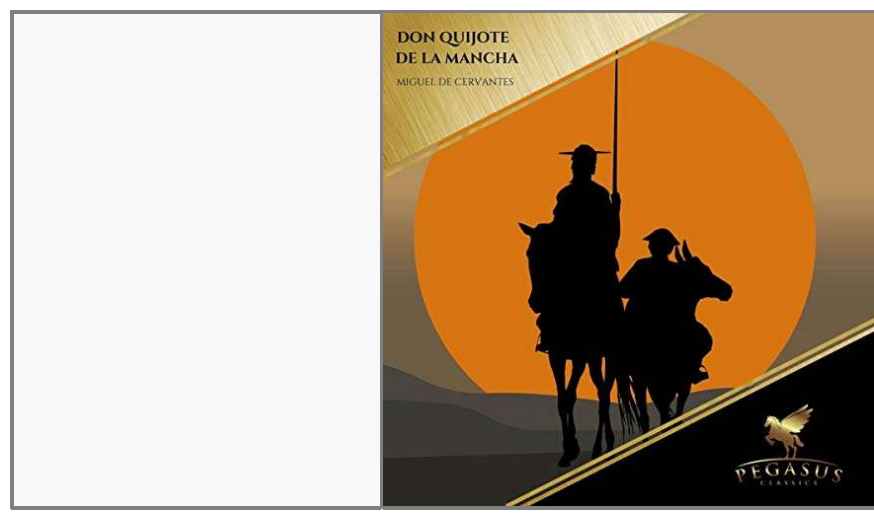

Resultado de la búsqueda del «Quijote» en: Leamos

Ficha ${ }^{0}{ }^{15}$

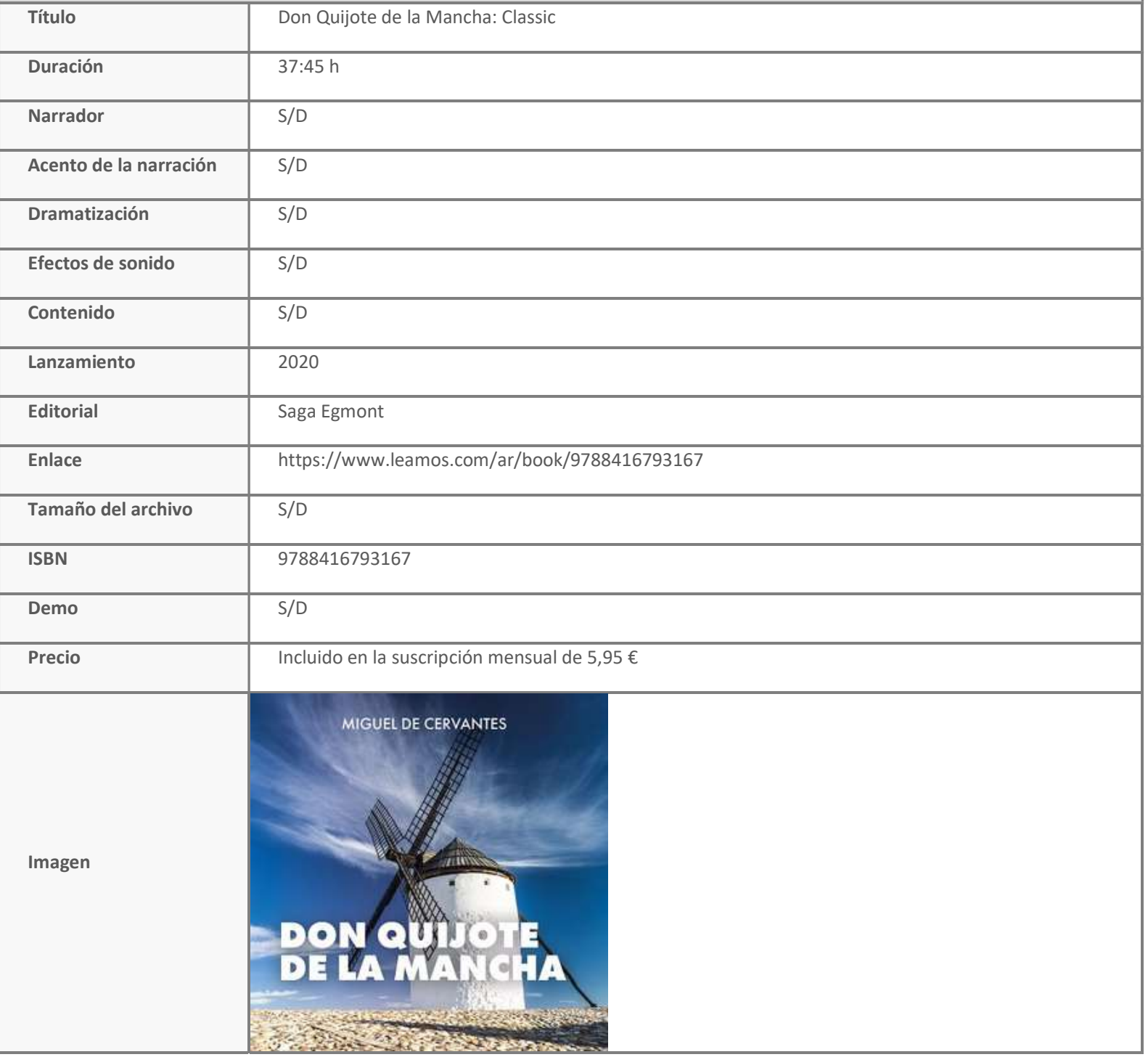


Notas:

Se ofrecen del mismo sello editorial, Spanish Literature Audiobooks, los siguientes 13 audios, organizados como se indica a continuación:

$\checkmark \quad 1$ audiolibro bajo el título Primera Parte del Ingenioso Hidalgo Don Quijote

$\checkmark \quad 3$ títulos correspondientes a una colección de audiolibros, titulada Primera Parte del Ingenioso Hidalgo Don Quijote de la editorial Spanish Literature Audiobooks.

$\checkmark 9$ audios que corresponden a una misma colección de audiolibros, titulada Don Quijote, de la editorial Spanish Literature Audiobooks.

En síntesis, de Spanish Literature Audiobook se presentan 13 títulos que corresponden a tres formas de presentar un mismo audio.

Tras ellos se incluyen dos audiolibros, uno de $37: 45 \mathrm{~h}$ y otro de 17:11 h. Los datos que incluye la plataforma son muy escasos, ya que es el único caso en el que nos encontramos una distribuidora de audiolibros que no incluye información de los narradores. 


\section{LIBRO MóVIL. Información y fichas de los audiolibros del Quijote que con- tiene.}

Se realizó la búsqueda ${ }^{78}$ en la aplicación de Libro móvil, en un teléfono iOS y la búsqueda arrojó 37 resultados de los cuales solo 1 se ajusta a nuestra búsqueda:

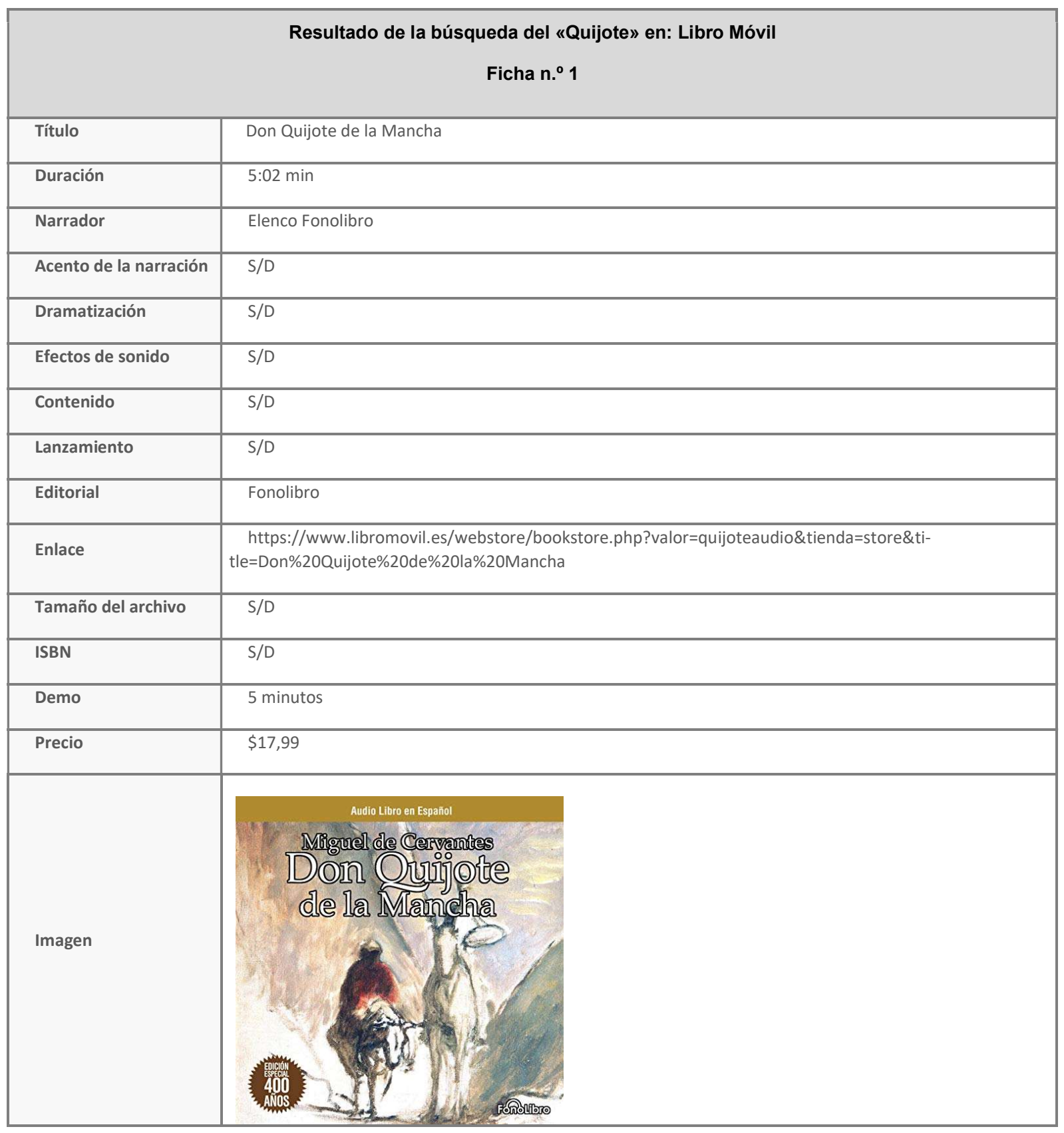

Notas:

\footnotetext{
${ }^{78}$ Datos obtenidos el 20-12-2020
} 
$\checkmark$ Como se puede evidenciar en la ficha, la información es muy básica y solamente poseen un ejemplar de nuestro interés. 
13. Literatura Sonora. Información y ficha del audiolibro del Quijote que contiene.

Esta plataforma, además de distribuir contenidos también los crea. Como veremos a continuación presentan una plataforma en línea, así como también tienen la opción de descarga de una aplicación para disfrutar los contenidos digitales.

Se accede al título del Quijote a través de la página web. Presentan un acceso directo en la parte izquierda de la página principal, como vemos en las siguientes ilustraciones. Pinchando ahí accederemos a todos los capítulos del primer y segundo tomo.

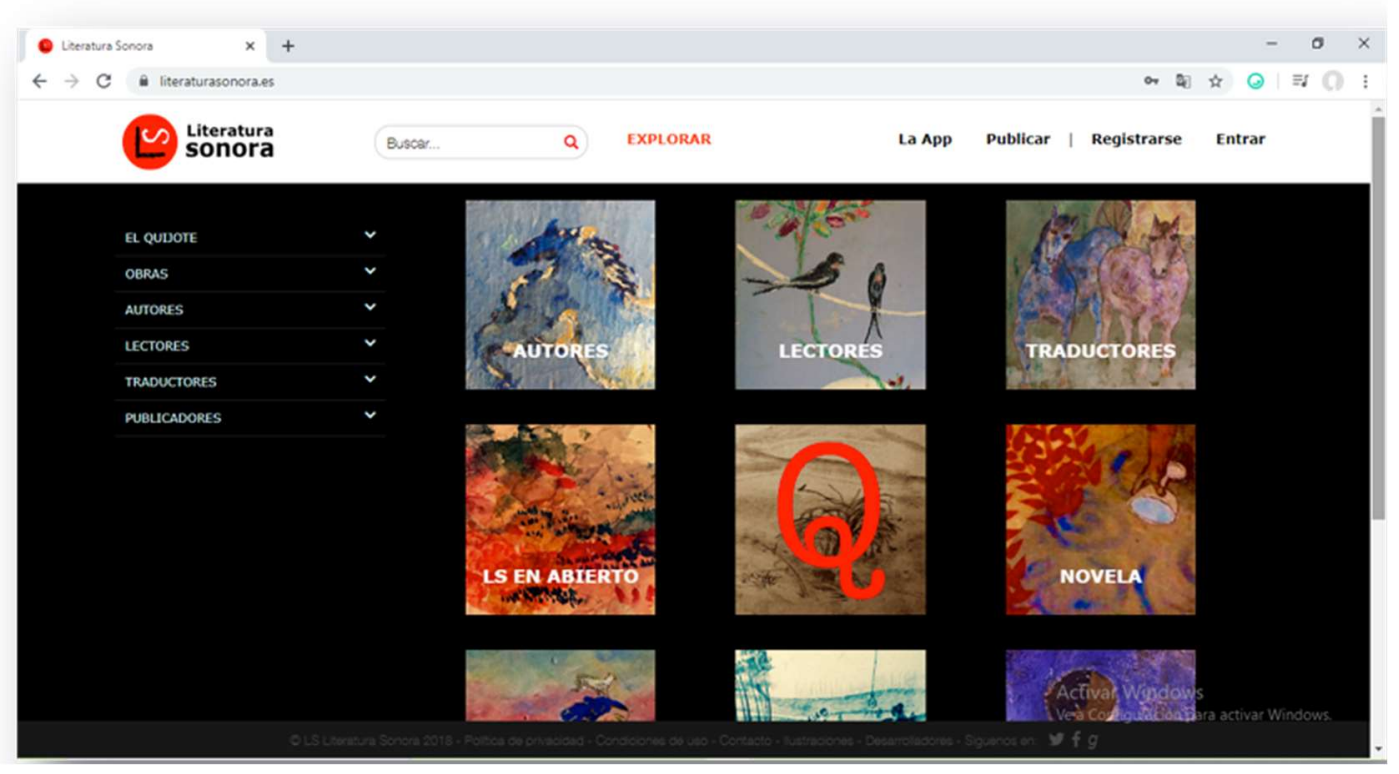

Ilustración 31. Página principal en línea de Literatura Sonora 


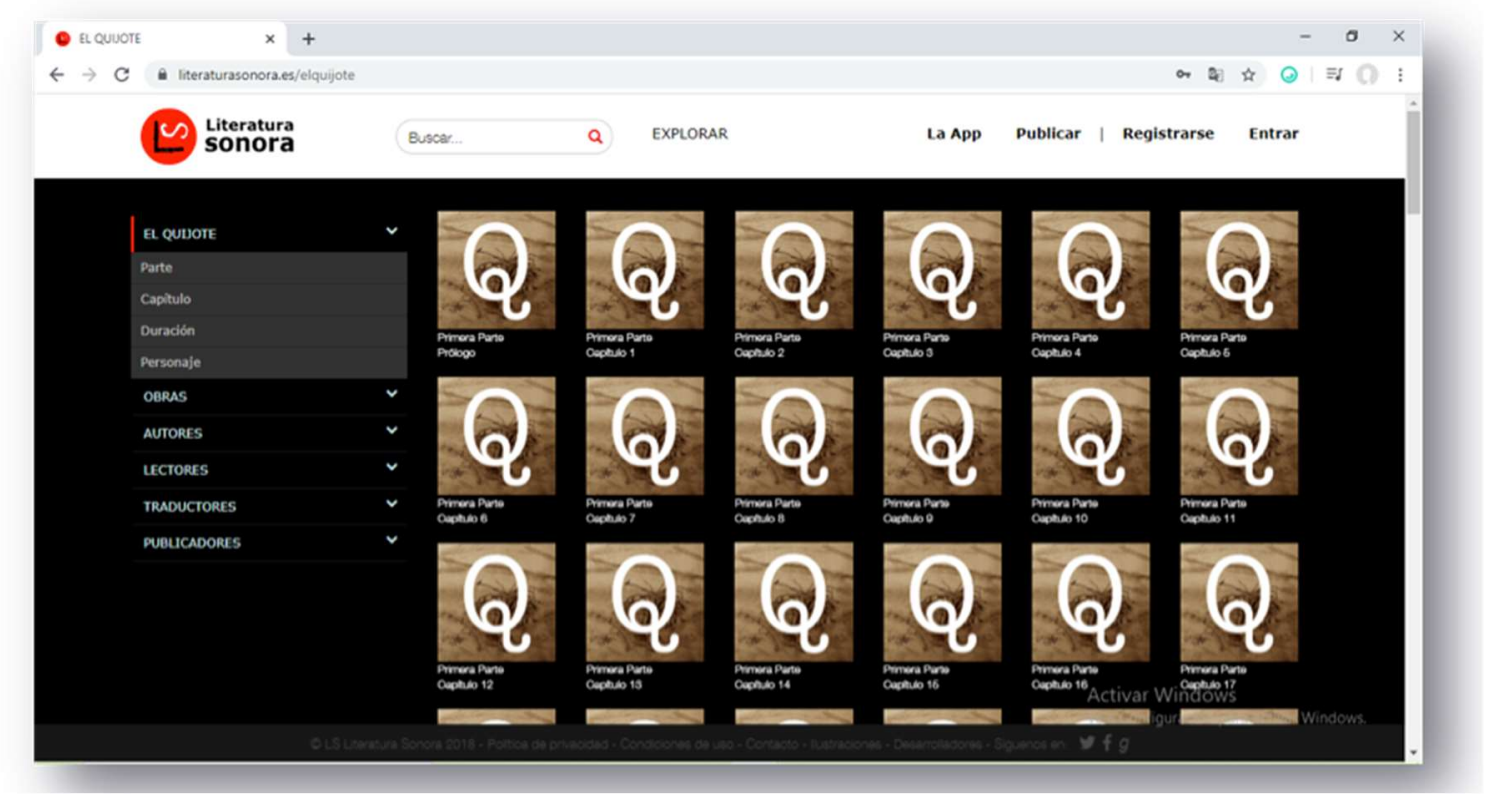

Ilustración 32. Capítulos del Quijote

Fuente: página web de Literatura Sonora

Destacamos una funcionalidad no observada en ningunas de las otras aplicaciones relevadas y es la posibilidad de búsquedas que ofrece esta plataforma:

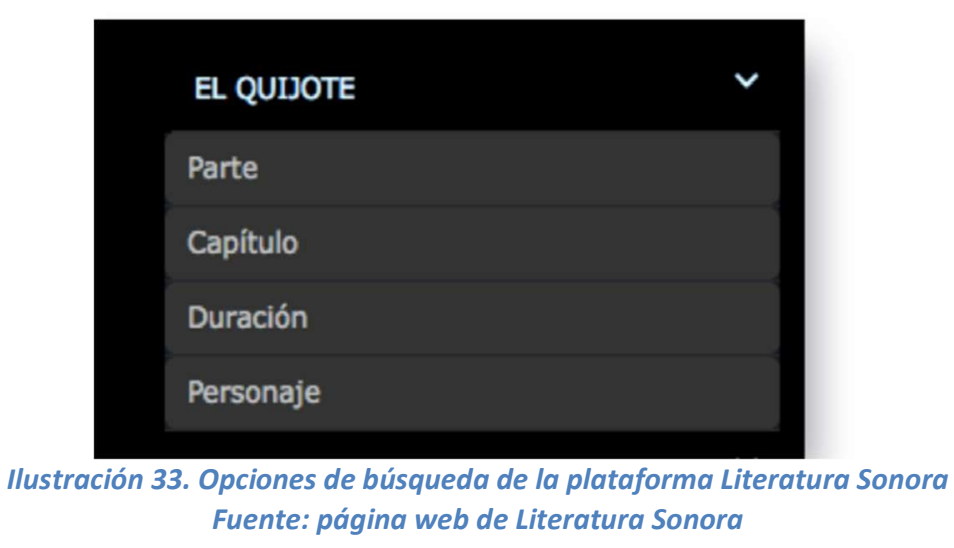

Ofrece cuatro posibilidades: búsqueda por parte, por capítulo, por duración de la grabación y por personaje.

La primera opción permite la búsqueda por el primer o segundo tomo, mientras que la segunda opción permite seleccionar un capítulo de entre los 74 de la totalidad de la obra.

Otra opción no observada en el resto de las aplicaciones de audiolectura es la de la búsqueda por un fragmento de la grabación dentro del propio libro. Si bien es una posibilidad que no todos los lectores utilizarán, puede resultar de interés para profesores que necesiten encontrar una parte del Quijote que pueda ser compatible con la disponibilidad horaria de un curso determinado. 


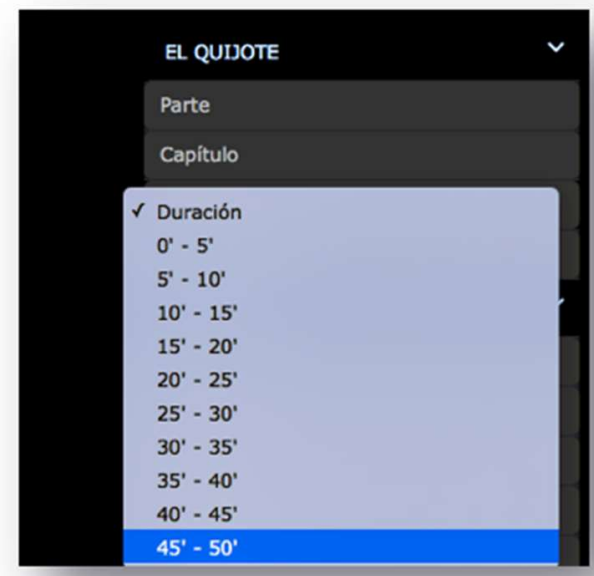

Illustración 34. Opción de búsqueda por duración del texto en Literatura sonora Fuente: página web de Literatura Sonora

La cuarta opción es inédita hasta el momento y reviste de muchísimo interés tanto para lectores en general como para estudiosos de la obra, ya que permite la búsqueda por personaje. Según esta posibilidad, si solamente se desea recuperar el monólogo de Marcela, a través del índice desplegable que vemos en la siguiente imagen podemos recuperarlo.

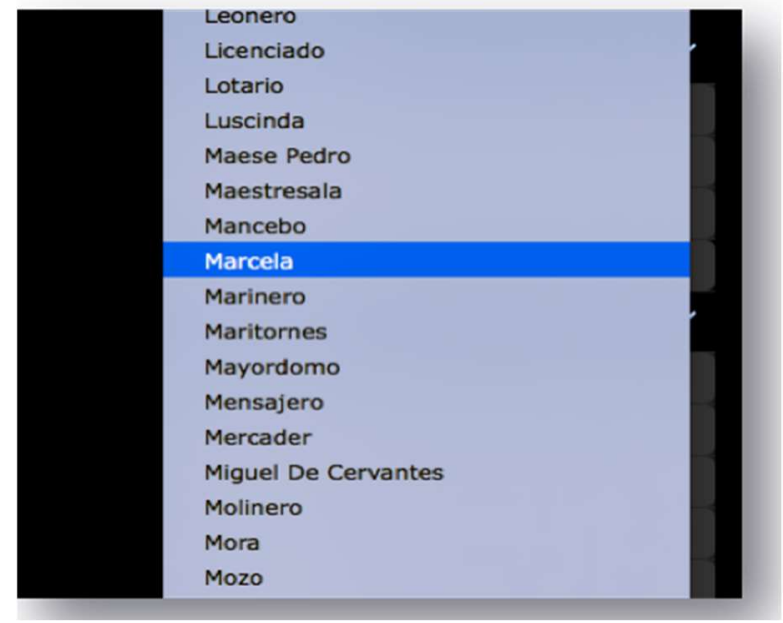

Ilustración 35. Opción de búsqueda por personaje en Literatura Sonora Fuente: página web de Literatura Sonora

El resultado de esta búsqueda nos recuperará solo el capítulo 14 ya que es el único en el que aparece este personaje. 


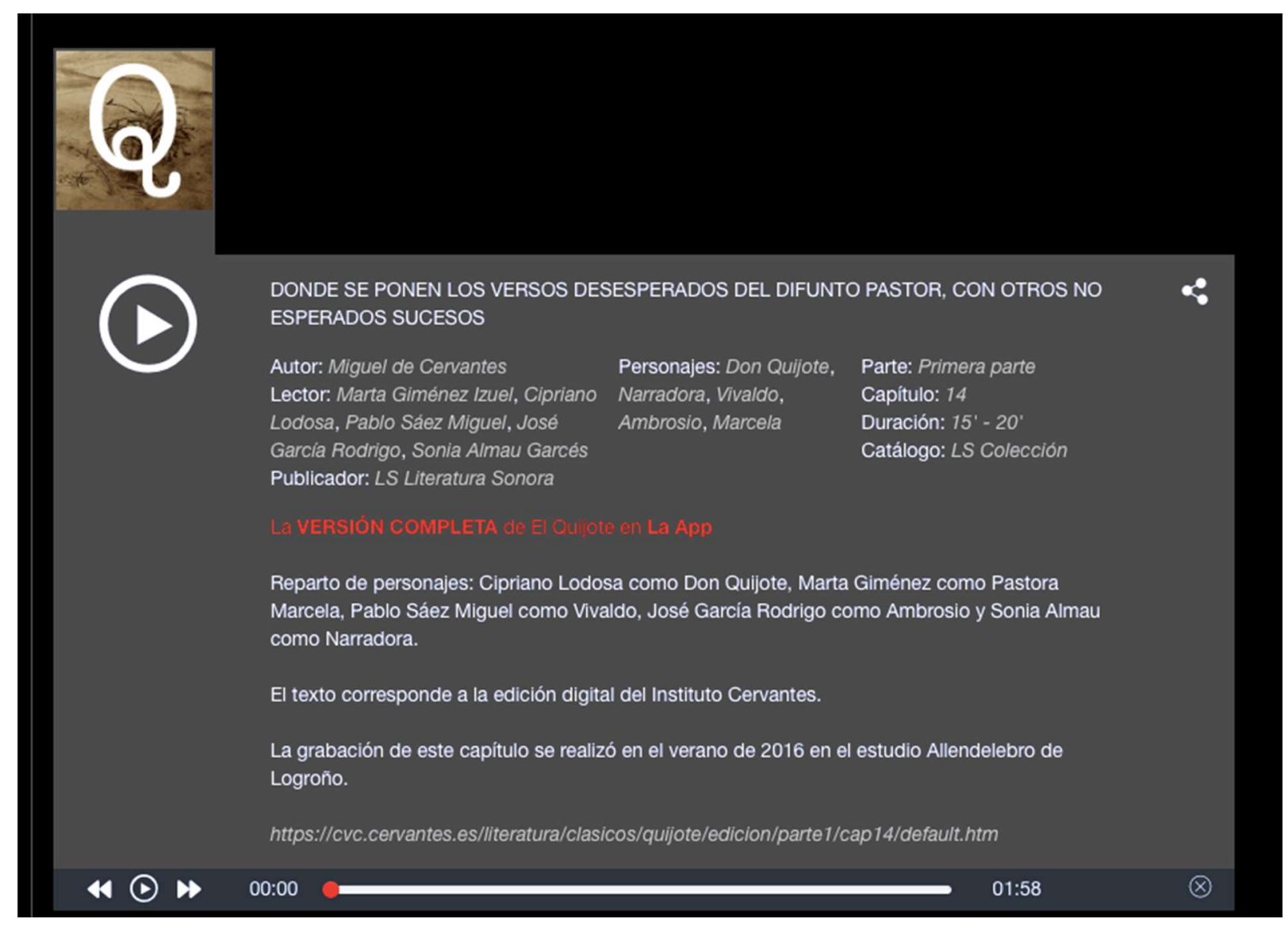

Ilustración 36. Resultado de la búsqueda por personaje en Literatura Sonora Fuente: página web de Literatura Sonora

Como en el caso del resto de los libros del Quijote, a continuación, aportamos los datos del audiolibro recuperado en la aplicación Literatura Sonora:

\begin{tabular}{|l|l|}
\hline \multicolumn{2}{|c|}{ Resultado de la búsqueda del «Quijote» en: Literatura Sonora } \\
\multicolumn{1}{|l|}{ Ficha $\mathbf{n}^{\circ} \mathbf{1}$} \\
\hline Título & El Quijote \\
\hline Duración & 37 h 50 min \\
\hline Narrador & Varios Lectores (profesionales) \\
\hline Acento de la narración & S/D \\
\hline Dramatización & S/D \\
\hline Efectos de sonido & S/D \\
\hline Contenido & Obra Completa (Prólogo, Parte I y II) \\
\hline
\end{tabular}




\begin{tabular}{|l|l|}
\hline Lanzamiento & Entre 2015 y 2016 \\
\hline Editorial & LS Literatura Sonora \\
\hline Enlace & https://literaturasonora.es/quijote/prologo \\
\hline Tamaño del archivo & S/D \\
\hline ISBN & S/D \\
\hline Demo & Para escuchar este audiolibro hay que tener descargada la App que cuesta $2 €$ al año. \\
\hline Precio & \\
\hline Imagen & \\
\hline
\end{tabular}


14. PODIMO. Información y fichas de los audiolibros del Quijote que contiene.

La búsqueda se realiza sobre programas, pódcasts y sobre todo el contenido audio que posee la plataforma y arroja 50 resultados, entre los cuales no encontramos ningún audiolibro. 
15. SCRIBD. Información y fichas de los audiolibros del Quijote que contiene.

La plataforma permite restringir la búsqueda a audiolibros, ya que además de este formato posee otro tipo de documentos. También se ofrece la posibilidad de filtrar por idiomas. En total, aplicando estos filtros, obtuvimos 21 resultados, de los cuales 14 coinciden con nuestro objeto de estudio.

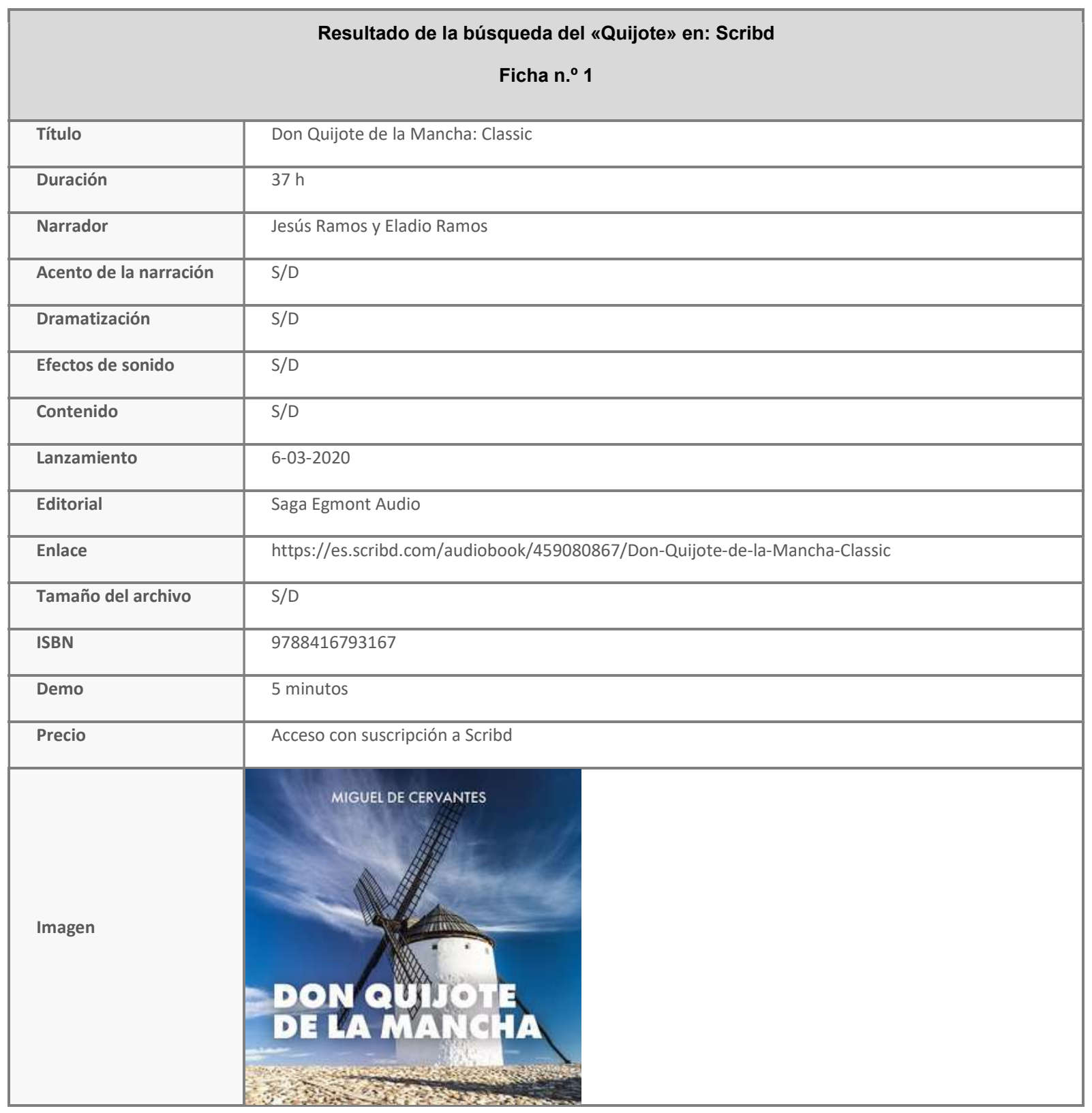

Resultado de la búsqueda del «Quijote» en: Scribd

Ficha.$^{\circ} 2$ 


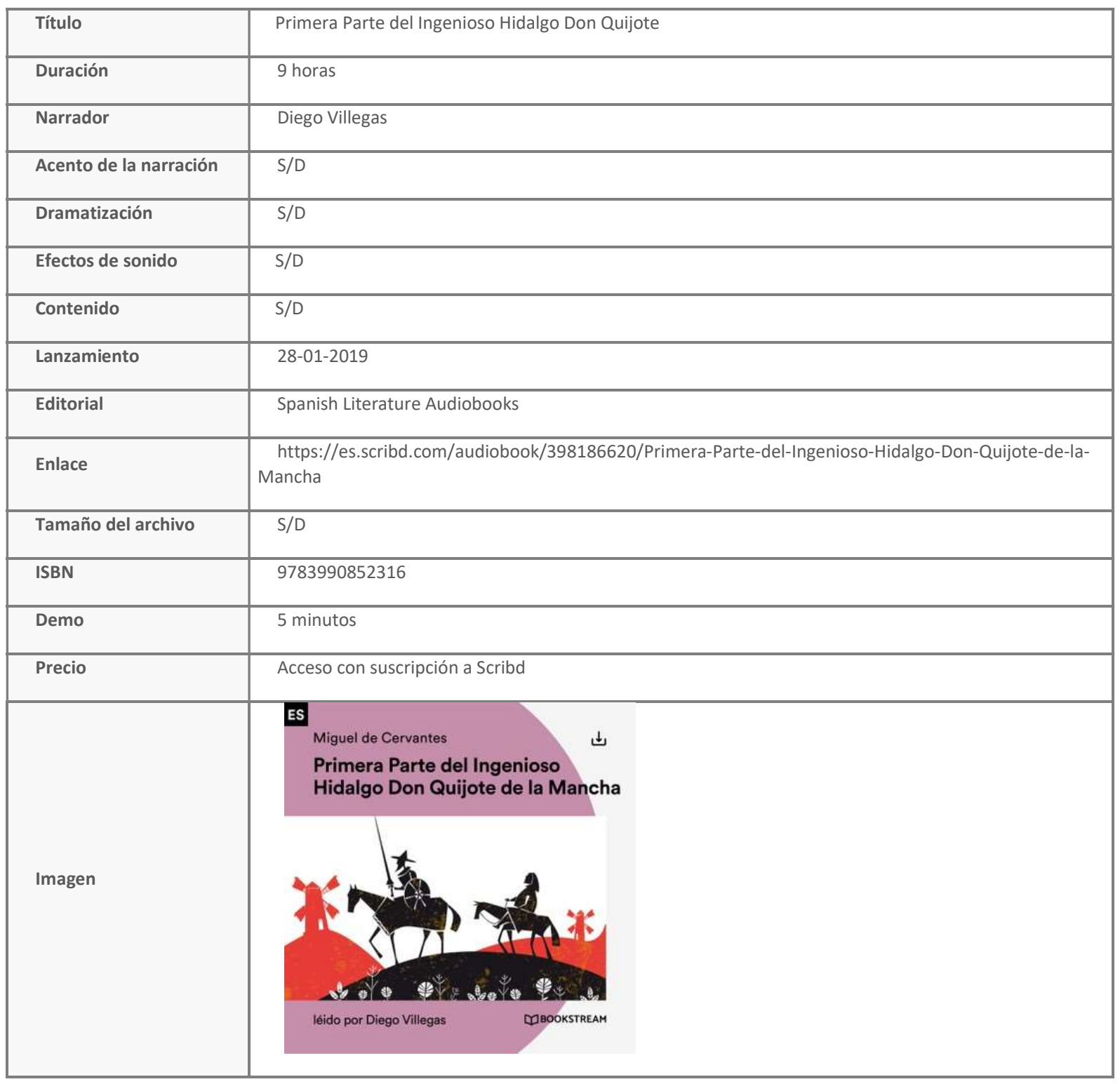

\begin{tabular}{|l|l|}
\hline \multicolumn{2}{|c|}{ Resultado de la búsqueda del «Quijote» en: Scribd } \\
\multicolumn{2}{|l|}{ Ficha . $^{\circ}$ 3 } \\
\hline Título & Primera Parte del Ingenioso Hidalgo Don Quijote: 1 de 3 \\
\hline Duración & 9 horas \\
\hline Narrador & Diego Villegas \\
\hline Acento de la narración & S/D \\
\hline Dramatización & S/D \\
\hline Efectos de sonido & S/D \\
\hline Contenido & {$[$ Parte I, 1 de 3] } \\
\hline
\end{tabular}




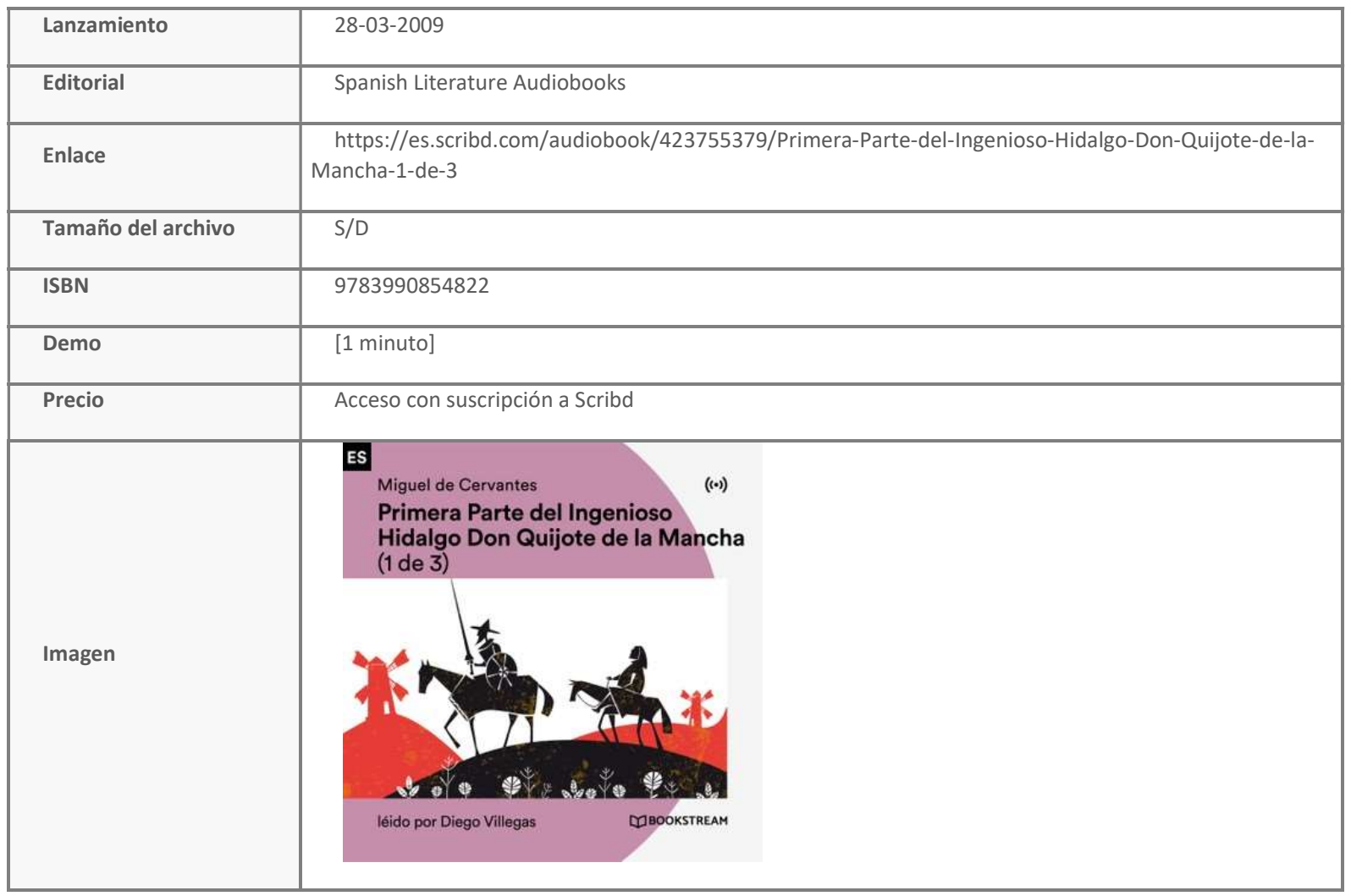

\begin{tabular}{|l|l|}
\multicolumn{2}{|c|}{ Resultado de la búsqueda del «Quijote» en: Scribd } \\
\multicolumn{1}{|l|}{ Ficha . $^{\text {* 4 }}$} \\
\hline Título & Primera Parte del Ingenioso Hidalgo Don Quijote de la Mancha (2 de 3) \\
\hline Duración & 7 horas \\
\hline Narrador & Diego Villegas \\
\hline Acento de la narración & S/D \\
\hline Dramatización & S/D \\
\hline Efectos de sonido & S/D \\
\hline Contenido & Completo / [Parte I, 2 de 3] \\
\hline Lanzamiento & $29-03-2019$ \\
\hline Editorial & Spanish Literature Audiobooks \\
\hline Enlace & https://es.scribd.com/audiobook/423755545/Primera-Parte-del-Ingenioso-Hidalgo-Don-Quijote-de-la- \\
\hline Tamaño del archivo & Mancha-2-de-3 \\
\hline ISBN & S/D \\
\hline Demo & 9783990854839 \\
\hline
\end{tabular}




\begin{tabular}{|l|c|}
\hline Precio & Acceso con suscripción a Scribd \\
\hline ES & $\begin{array}{l}\text { Miguel de Cervantes } \\
\text { Primera Parte del Ingenioso } \\
\text { Hidalgo Don Quijote de la Mancha } \\
\text { (2 de 3) }\end{array}$ \\
\hline Imagen & (..) \\
\hline
\end{tabular}

\begin{tabular}{|l|l|}
\multicolumn{2}{|c|}{ Resultado de la búsqueda del «Quijote» en: Scribd } \\
\multicolumn{2}{|l|}{ Ficha . $^{\circ}$ 5 } \\
\hline Título & Primera Parte del Ingenioso Hidalgo Don Quijote: 3 de 3 \\
\hline Duración & 6 horas \\
\hline Narrador & Diego Villegas \\
\hline Acento de la narración & S/D \\
\hline Dramatización & S/D \\
\hline Efectos de sonido & S/D \\
\hline Contenido & Completo / [Parte I, 3de 3] \\
\hline Lanzamiento & $30-03-2019$ \\
\hline Editorial & Spanish Literature Audiobooks \\
\hline Enlace & https://es.scribd.com/audiobook/423755282/Primera-Parte-del-Ingenioso-Hidalgo-Don-Quijote-de-la- \\
\hline Tamaño del archivo & Mancha-3-de-3 \\
\hline ISBN & S/D \\
\hline Demo & Acceso con suscripción a Scribd \\
\hline Precio & 30 segundos \\
\hline
\end{tabular}




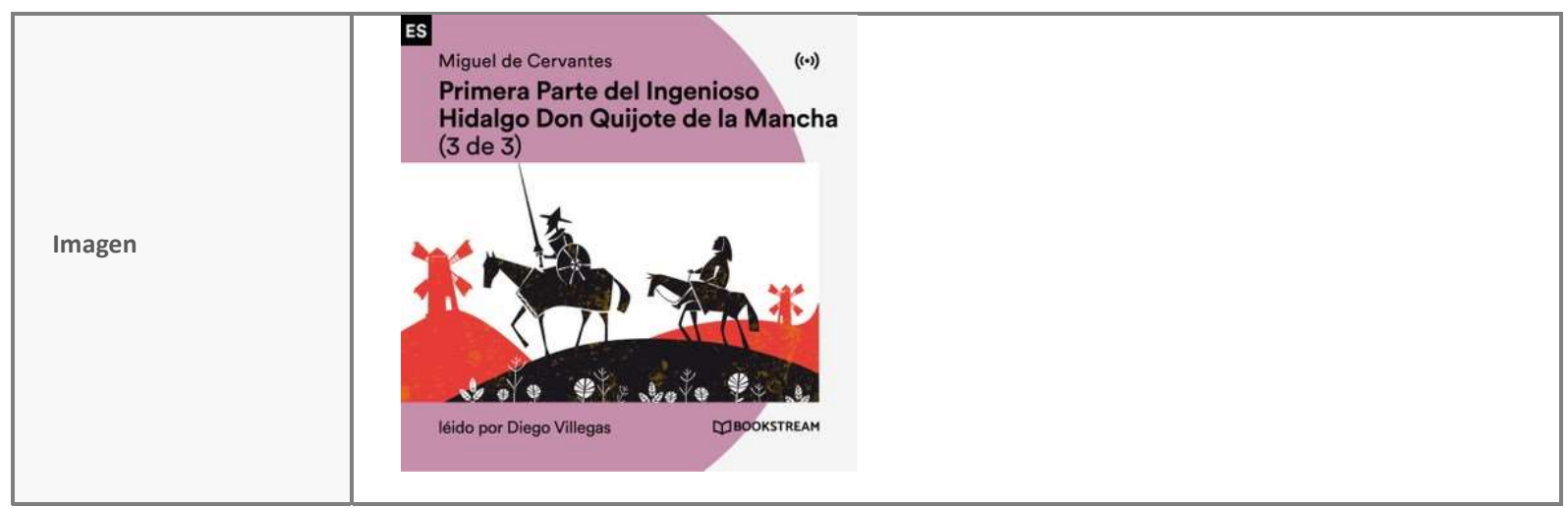

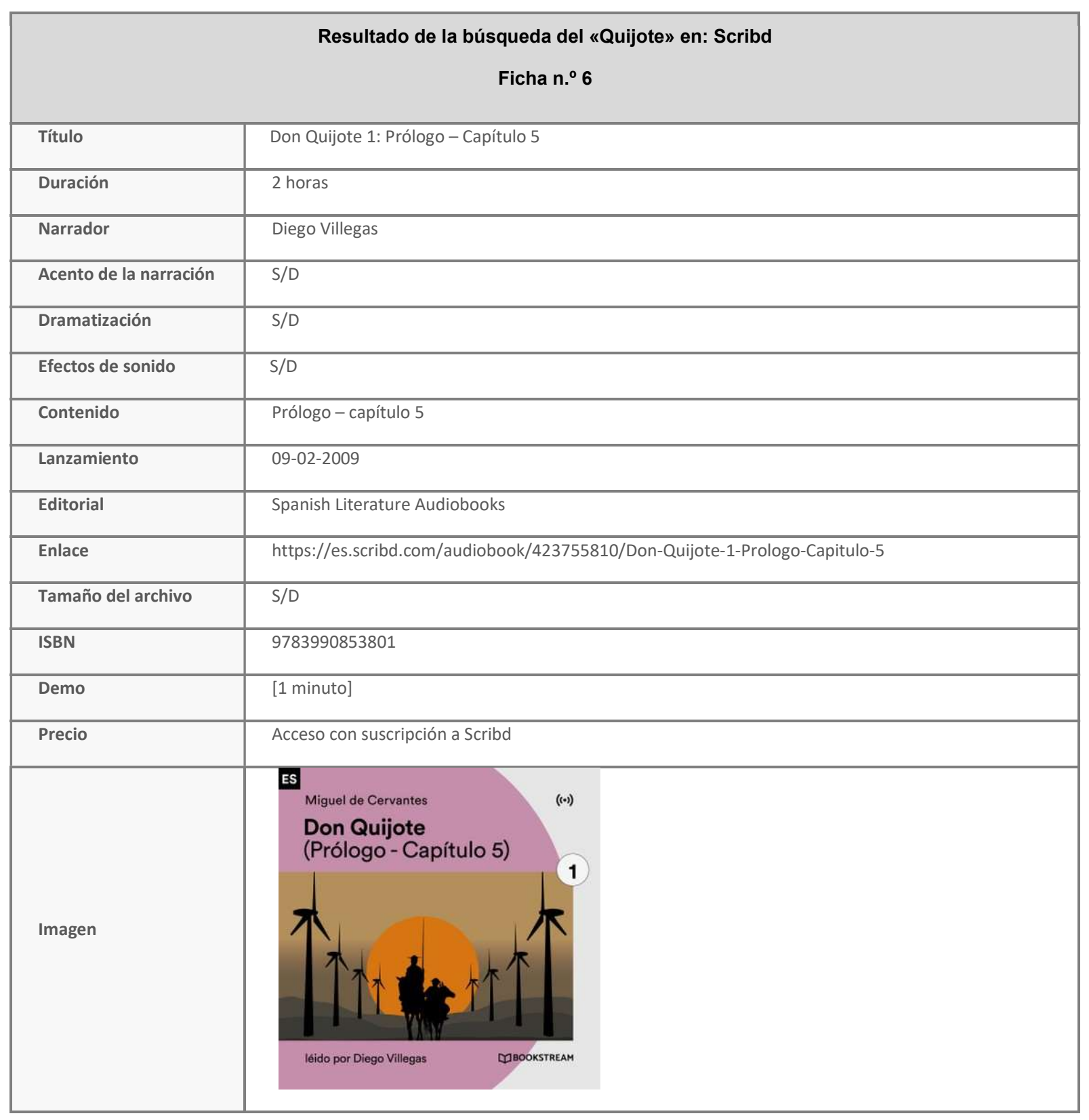




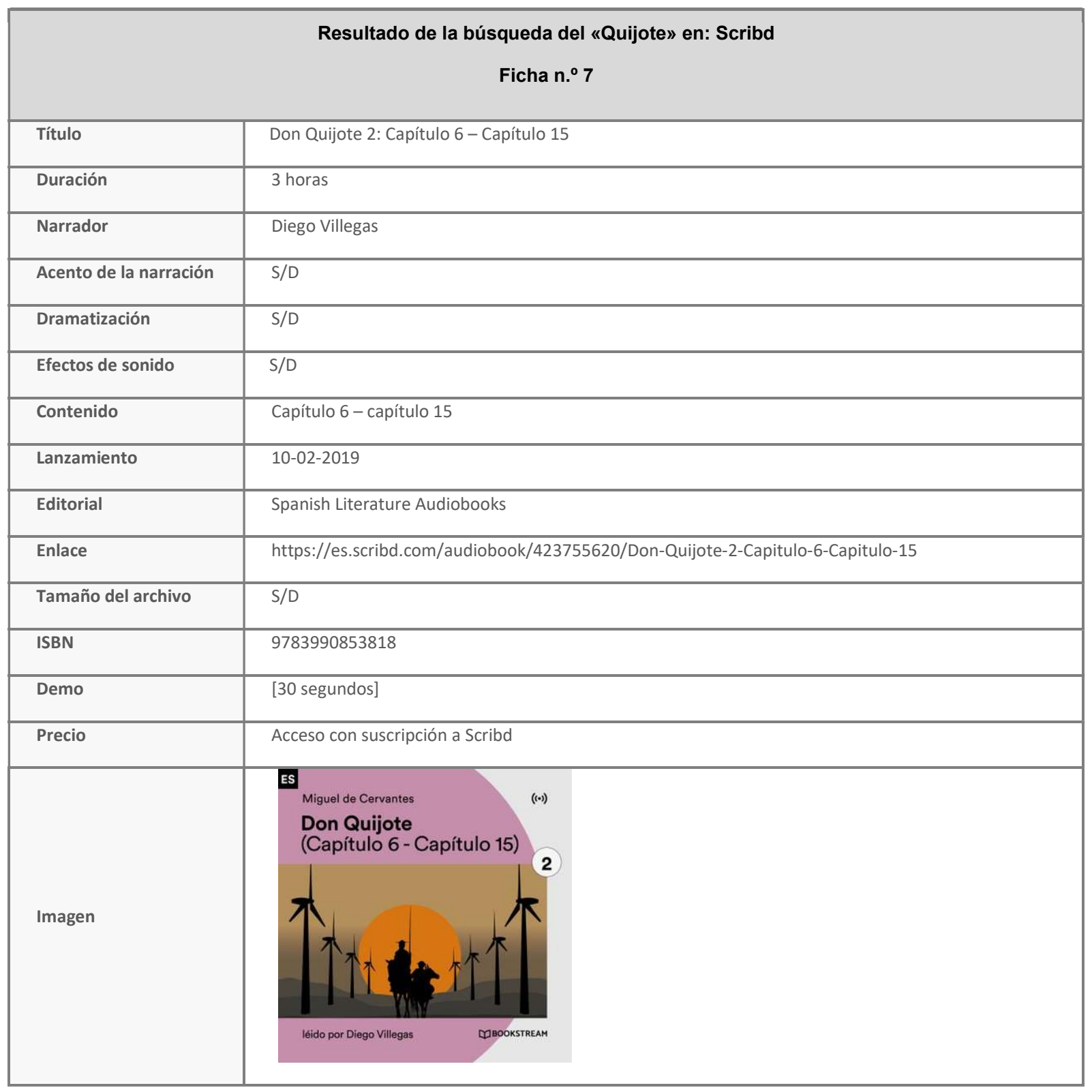

\begin{tabular}{|l|l|}
\hline \multicolumn{2}{|c|}{ Resultado de la búsqueda del «Quijote» en: Scribd } \\
\multicolumn{2}{|l|}{ Ficha . $^{\circ}$ 8 } \\
\hline Título & Don Quijote 3: Capítulo 16-Capítulo 20 \\
\hline Duración & 2 horas \\
\hline Narrador & Diego Villegas \\
\hline Acento de la narración & S/D \\
\hline Dramatización & S/D \\
\hline Efectos de sonido & S/D \\
\hline
\end{tabular}




\begin{tabular}{|c|c|}
\hline Contenido & Capítulo 16 - capítulo 20 \\
\hline Lanzamiento & $11-02-2019$ \\
\hline Editorial & Spanish Literature Audiobooks \\
\hline Enlace & https://es.scribd.com/audiobook/423755292/Don-Quijote-3-Capitulo-16-Capitulo-20 \\
\hline Tamaño del archivo & S/D \\
\hline ISBN & 9783990853825 \\
\hline Demo & [1 minuto] \\
\hline Precio & Acceso con suscripción a Scribd \\
\hline Imagen & $\begin{array}{l}\text { ES } \\
\text { Miguel de Cervantes } \\
\text { Don Quijote } \\
\text { (Capítulo 16-Capítulo 20) }\end{array}$ \\
\hline
\end{tabular}

\begin{tabular}{|c|c|}
\hline \multicolumn{2}{|r|}{$\begin{array}{l}\text { Resultado de la búsqueda del «Quijote» en: Scribd } \\
\qquad \text { Ficha } n .^{\circ} 9\end{array}$} \\
\hline Título & Don Quijote 4: Capítulo 21 - Capítulo 25 \\
\hline Duración & 2,9 horas \\
\hline Narrador & Diego Villegas \\
\hline Acento de la narración & S/D \\
\hline Dramatización & S/D \\
\hline Efectos de sonido & S/D \\
\hline Contenido & Capítulo 21 - capítulo 25 \\
\hline Lanzamiento & $12-02-2019$ \\
\hline Editorial & Spanish Literature Audiobooks \\
\hline Enlace & https://es.scribd.com/audiobook/423755623/Don-Quijote-4-Capitulo-21-Capitulo-25 \\
\hline Tamaño del archivo & S/D \\
\hline ISBN & 978399085832 \\
\hline Demo & [1 minuto] \\
\hline Precio & Acceso con suscripción a Scribd \\
\hline
\end{tabular}




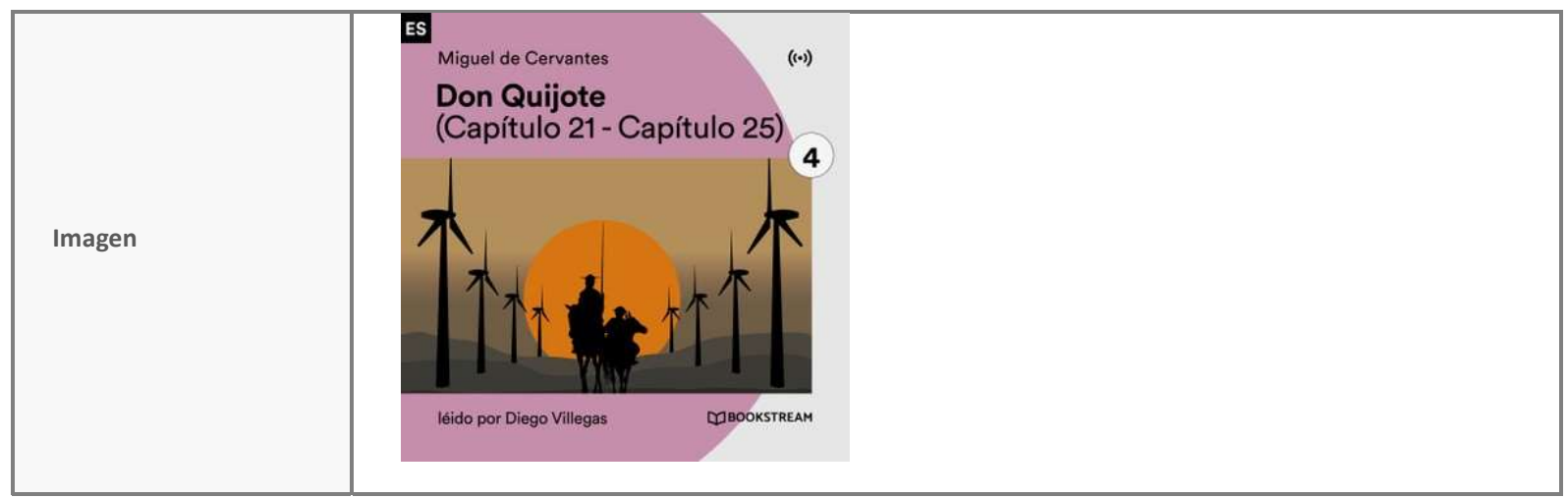

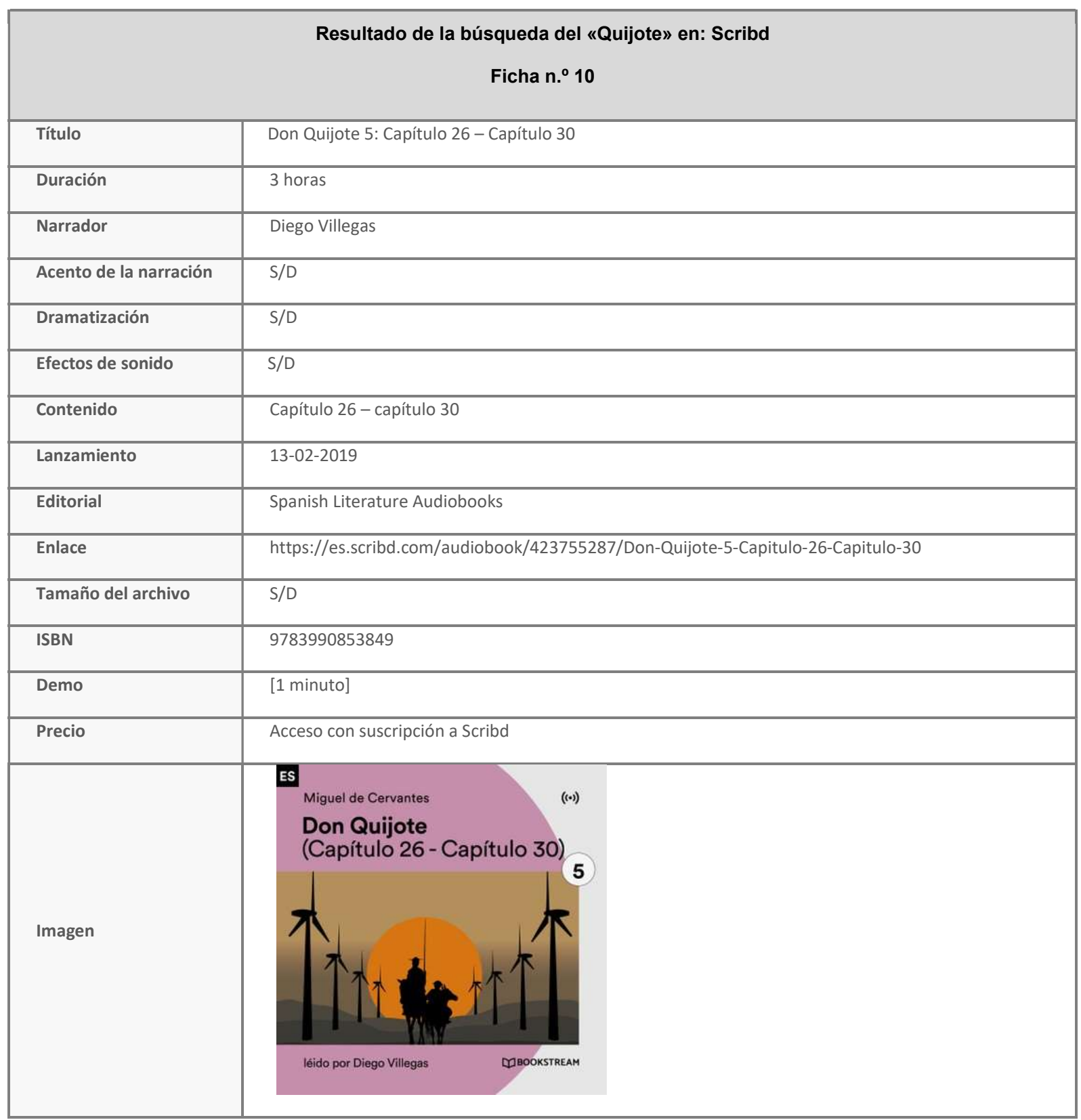




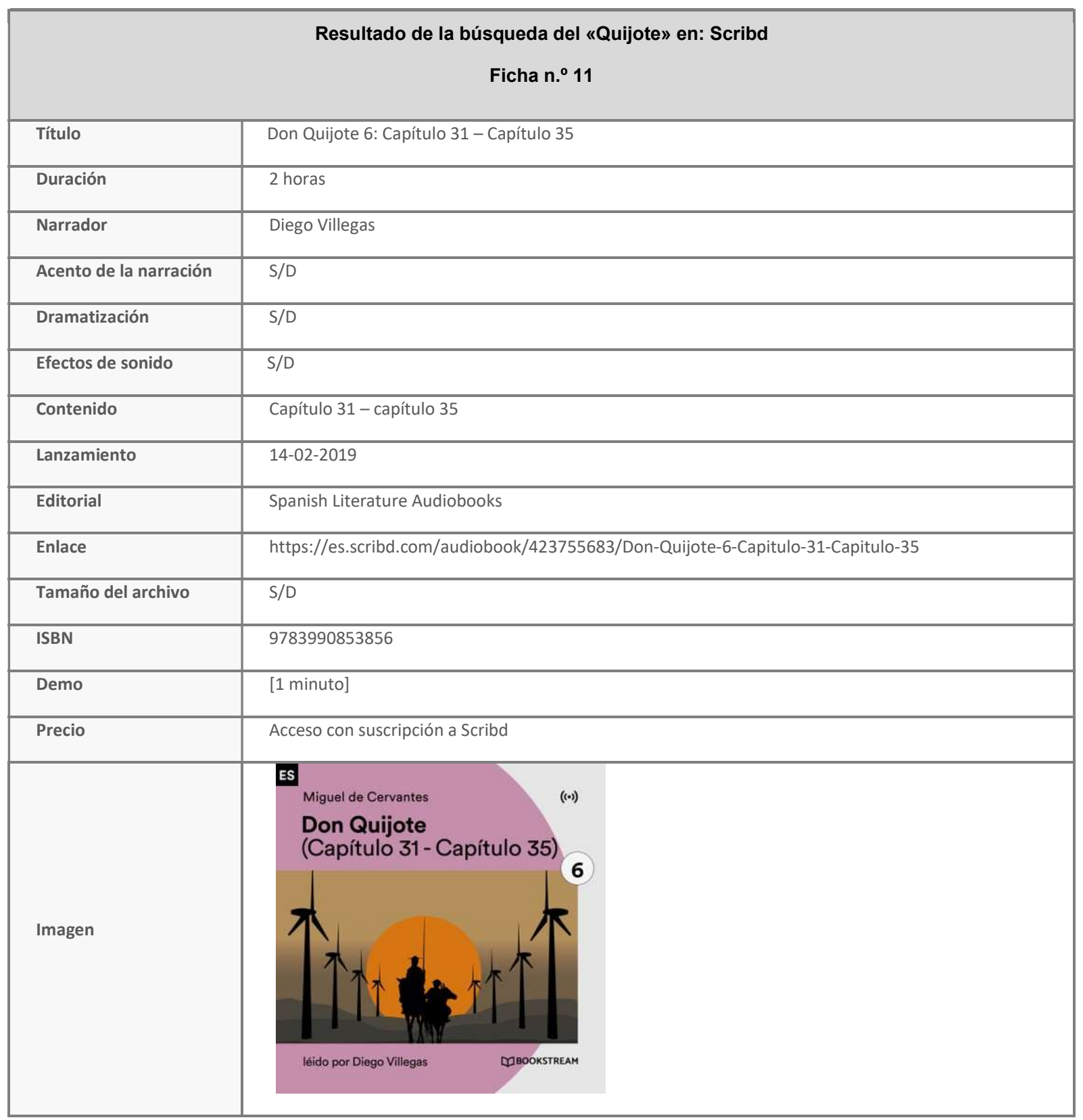

\begin{tabular}{|l|l|}
\hline \multicolumn{2}{|c|}{$\begin{array}{c}\text { Resultado de la búsqueda del «Quijote» en: Scribd } \\
\text { Ficha } \mathbf{n} .^{\circ} \text { 12 }\end{array}$} \\
\hline Título & Don Quijote 7: Capítulo 36-Capítulo 40 \\
\hline Duración & 2 horas \\
\hline Narrador & Diego Villegas \\
\hline Acento de la narración & S/D \\
\hline Dramatización & S/D \\
\hline
\end{tabular}




\begin{tabular}{|c|c|}
\hline Efectos de sonido & S/D \\
\hline Contenido & Capítulo 36 - capítulo 40 \\
\hline Lanzamiento & $15-02-2019$ \\
\hline Editorial & Spanish Literature Audiobooks \\
\hline Enlace & https://es.scribd.com/audiobook/423755814/Don-Quijote-7-Capitulo-36-Capitulo-40 \\
\hline Tamaño del archivo & S/D \\
\hline ISBN & 9783990853863 \\
\hline Demo & [1 minuto] \\
\hline Precio & Acceso con suscripción a Scribd \\
\hline Imagen & $\begin{array}{l}\text { ES } \\
\text { Miguel de Cervantes } \\
\text { (Can Quijote }\end{array}$ \\
\hline
\end{tabular}

\begin{tabular}{|l|l|}
\multicolumn{2}{|c|}{ Resultado de la búsqueda del «Quijote» en: Scribd } \\
\multicolumn{1}{|l|}{ Ficha . $^{\circ}$ 13 } \\
\hline Título & Don Quijote 8: Capítulo 41 - Capítulo 45 \\
\hline Duración & 2 horas \\
\hline Narrador & Diego Villegas \\
\hline Acento de la narración & S/D \\
\hline Dramatización & S/D \\
\hline Efectos de sonido & S/D \\
\hline Contenido & Capítulo 41 - capítulo 45 \\
\hline Lanzamiento & $16-02-2019$ \\
\hline Editorial & Spanish Literature Audiobooks \\
\hline Enlace & https://es.scribd.com/audiobook/423755653/Don-Quijote-8-Capitulo-41-Capitulo-45 \\
\hline Tamaño del archivo & S/D \\
\hline ISBN & 9783990853870 \\
\hline Demo & {$[1$ minuto] } \\
\hline
\end{tabular}




\begin{tabular}{|l|l|}
\hline Precio & Acceso con suscripción a Scribd \\
\hline ES & $\begin{array}{l}\text { Miguel de Cervantes } \\
\text { Don Quijote } \\
\text { (Capítulo 41- Capítulo 45) } \\
\text { Imagen }\end{array}$ \\
& léido por Diego Villegas \\
\hline
\end{tabular}

\begin{tabular}{|c|c|}
\hline \multicolumn{2}{|r|}{$\begin{array}{l}\text { Resultado de la búsqueda del «Quijote» en: Scribd } \\
\qquad \text { Ficha } n .^{\circ} 14\end{array}$} \\
\hline Título & Don Quijote 9: Capítulo 46 - Capítulo 52 \\
\hline Duración & 2 horas \\
\hline Narrador & Diego Villegas \\
\hline Acento de la narración & S/D \\
\hline Dramatización & S/D \\
\hline Efectos de sonido & S/D \\
\hline Contenido & Capítulo 46 - capítulo 52 \\
\hline Lanzamiento & $17-02-2019$ \\
\hline Editorial & Spanish Literature Audiobooks \\
\hline Enlace & https://es.scribd.com/audiobook/423755859/Don-Quijote-9-Capitulo-46-Capitulo-52 \\
\hline Tamaño del archivo & S/D \\
\hline ISBN & 9783990853887 \\
\hline Demo & [1 minuto] \\
\hline Precio & Acceso con suscripción a Scribd \\
\hline
\end{tabular}




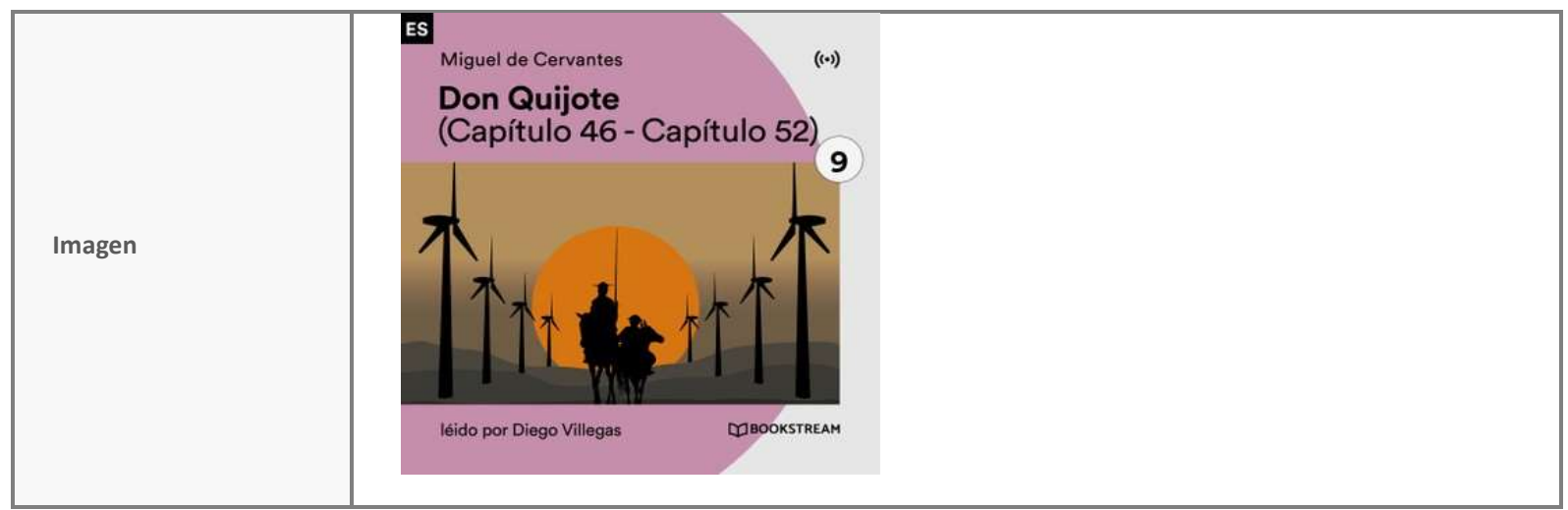

Notas:

Como en anteriores oportunidades, ofrecen de la misma editorial Spanish Literature Audiobooks, los siguiente 13 audios, organizados de la siguiente forma:

$\checkmark \quad 1$ audiolibro bajo el título Primera Parte del Ingenioso Hidalgo Don Quijote

$\checkmark \quad 3$ títulos correspondientes a una colección de audiolibros, titulada Primera Parte del Ingenioso Hidalgo Don Quijote de la editorial Spanish Literature Audiobooks.

$\checkmark \quad 9$ audios que corresponden a una misma colección de audiolibros, titulada Don Quijote, de la editorial Spanish Literature Audiobooks.

Además, ofrecen un audiolibro de $37 \mathrm{~h}$, de la editorial Saga Egmont Audio.

En todos los casos incluyen información del ISBN y una demostración de los títulos. 
16. Sonolibro. Información y fichas de los audiolibros del Quijote que contiene.

No se encontraron coincidencias con la búsqueda realizada. 


\section{Storytel. Información y fichas de los audiolibros del Quijote que contiene}

La búsqueda bibliográfica de audiolibros en la interfaz web de Storytel ofrece 5 resultados, tras utilizar las posibilidades de filtro de idioma (español) y de formato (audio). De estos 5 resultados 4 se ajustan a nuestra búsqueda:

El detalle de cada uno de estos ítems lo podemos ver en las siguientes fichas:

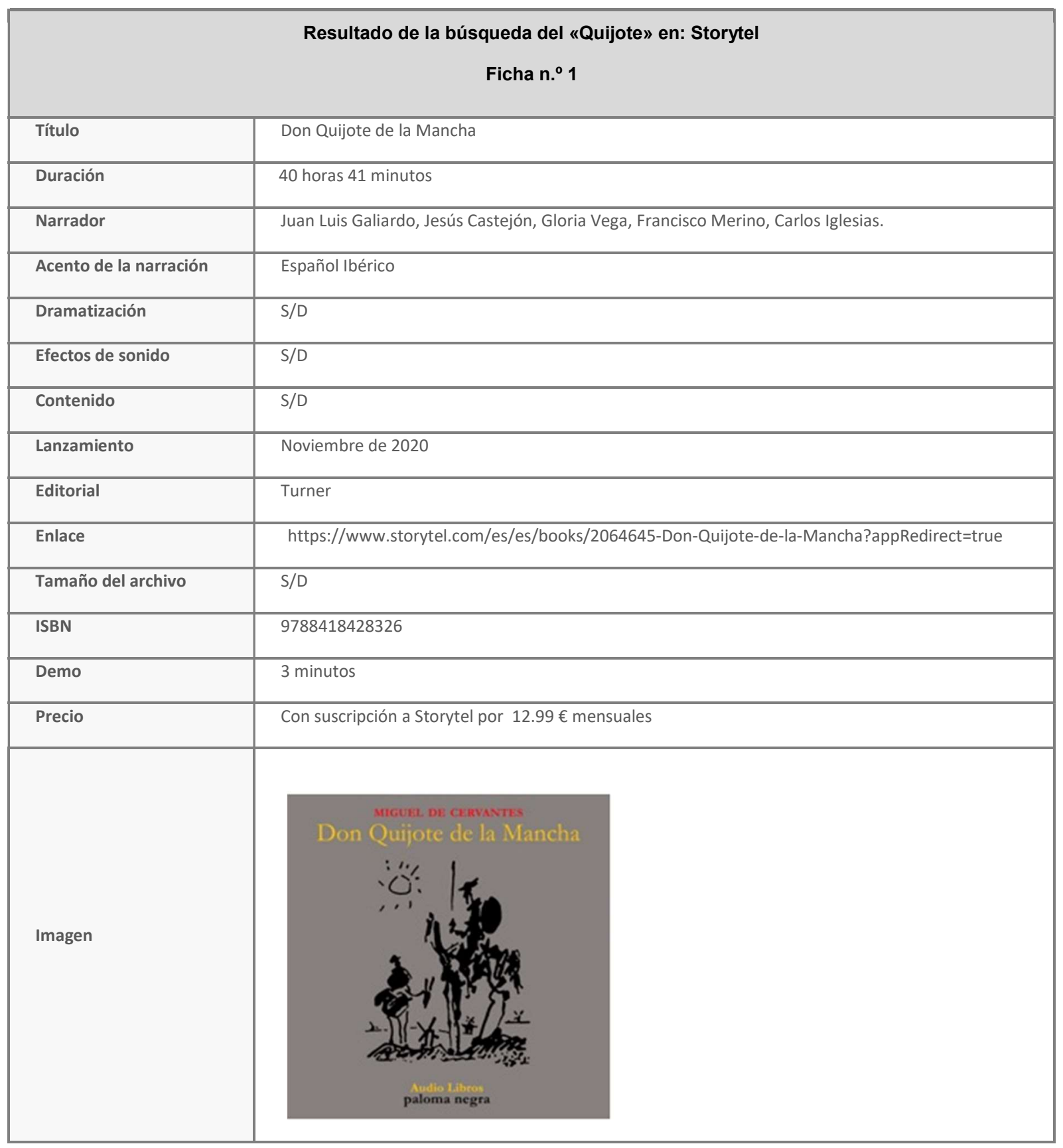




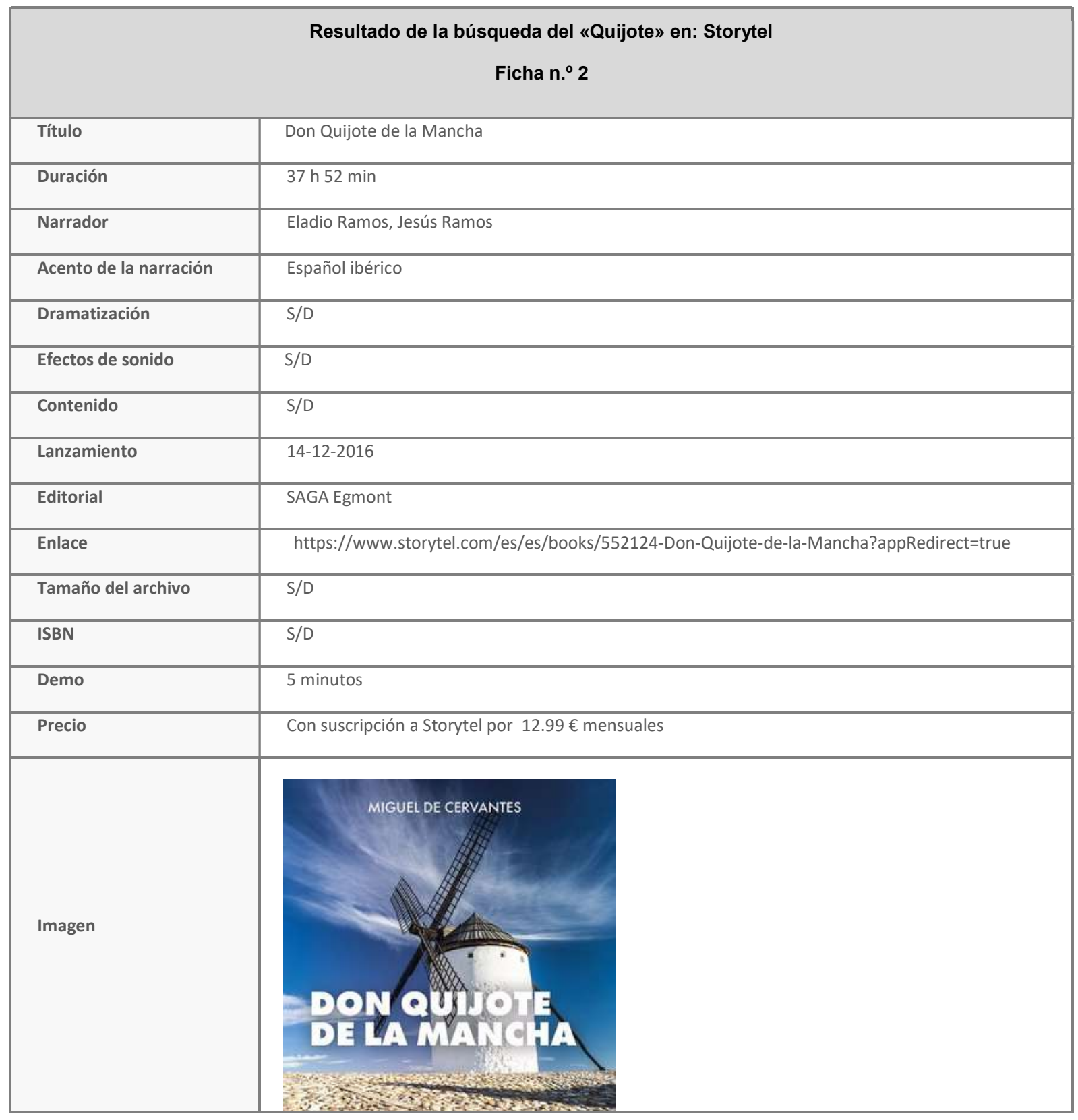

\begin{tabular}{|l|l|}
\hline \multicolumn{2}{|c|}{ Resultado de la búsqueda del «Quijote» en: Storytel } \\
\multicolumn{2}{|l|}{ Ficha $\mathbf{n}^{\circ}{ }^{\mathbf{3}}$} \\
\hline Título & Don Quijote de la Mancha \\
\hline Duración & 17 horas y 11 min \\
\hline Narrador & Carlos Ramos \\
\hline Acento de la narración & S/D \\
\hline Dramatización & S/D \\
\hline
\end{tabular}




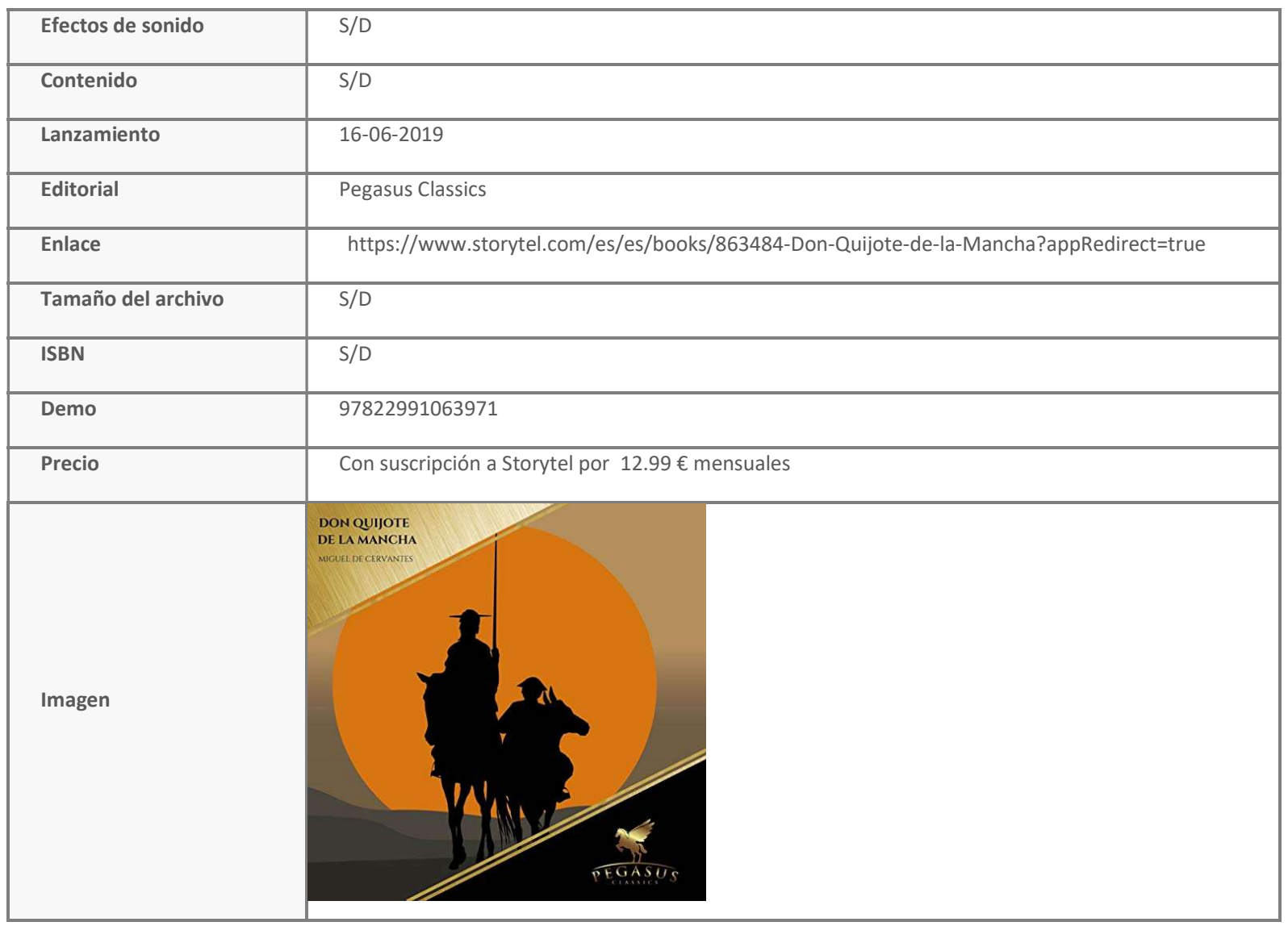

\begin{tabular}{|l|l|}
\hline \multicolumn{2}{|c|}{ Resultado de la búsqueda del «Quijote» en Storytel } \\
\multicolumn{2}{|l|}{ Ficha . $^{\text {* 4 }}$} \\
\hline Título & Don quijote de la mancha para jóvenes (adaptación) \\
\hline Duración & 3 hrs and 51 mins \\
\hline Narrador & Oscar Chamorro \\
\hline Acento de la narración & \\
\hline Dramatización & S/D \\
\hline Efectos de sonido & S/D \\
\hline Contenido & Adaptación \\
\hline Lanzamiento & $22-09-2020$ \\
\hline Editorial & Audiomol \\
\hline Enlace & https://www.storytel.com/es/es/books/1981251-Don-Quijote-de-la-Mancha-para-jovenes-Adapta- \\
\hline Tamaño del archivo & S/D \\
\hline ISBN & S/D Redirect=true \\
\hline
\end{tabular}




\begin{tabular}{|l|l|}
\hline Demo & 5 minutos \\
\hline Precio & Con suscripción a Storytel por 12.99 € mensuales \\
\hline Don quijote de la \\
mancha para jóvenes \\
(Adaptación)
\end{tabular}

Notas:

$\checkmark \quad 2$ audiolibros con el título Don Quijote de la Mancha, correspondientes a dos editoriales diferentes: Turner y Saga Edmont con diferente duración: el primer audiolibro, con una duración de 40:21 h, y el segundo, de 37:52 h.

$\checkmark \quad 1$ audiolibro de 17:11 h, de la editorial Pegasus

$\checkmark$ y el último audiolibro que es una adaptación y así lo indica en su propio título y que tiene 3:51 h de extensión.

Si bien no se indica en los dos primeros audios que corresponden a versiones íntegras ni cuál es el contenido exacto de cada audiolibro, los resultados no resultan confusos ya que 2 de ellos tienen una larga extensión y se deduce que corresponden al Quijote íntegro. El último audio indica claramente que es una adaptación. 
18. UBOOK. Información y fichas de los audiolibros del Quijote que contiene.

La búsqueda no permite filtrar por idiomas y arroja un resultado de más de 200 ítems que hemos revisado uno por uno para ver cuáles correspondían a audiolibros del Quijote.

\begin{tabular}{|c|c|}
\hline \multicolumn{2}{|r|}{$\begin{array}{l}\text { Resultado de la búsqueda del «Quijote» en: Ubook } \\
\qquad \text { Ficha } n .{ }^{01}\end{array}$} \\
\hline Título & Don Quijote de la Mancha \\
\hline Duración & $37 \mathrm{~h} 44 \mathrm{~min}$ \\
\hline Narrador & Eladio Ramos \\
\hline Acento de la narración & S/D \\
\hline Dramatización & S/D \\
\hline Efectos de sonido & S/D \\
\hline Contenido & S/D \\
\hline Lanzamiento & S/D \\
\hline Editorial & Saga Egmont \\
\hline Enlace & https://es.ubook.com/audiobook/862672/don-quijote-de-la-mancha \\
\hline Tamaño del archivo & S/D \\
\hline ISBN & S/D \\
\hline Demo & 1 minuto \\
\hline Precio & Acceso con suscripción de $\$ 9$ dólares mensuales \\
\hline Imagen & MIGUEL DE CERVANTE \\
\hline
\end{tabular}




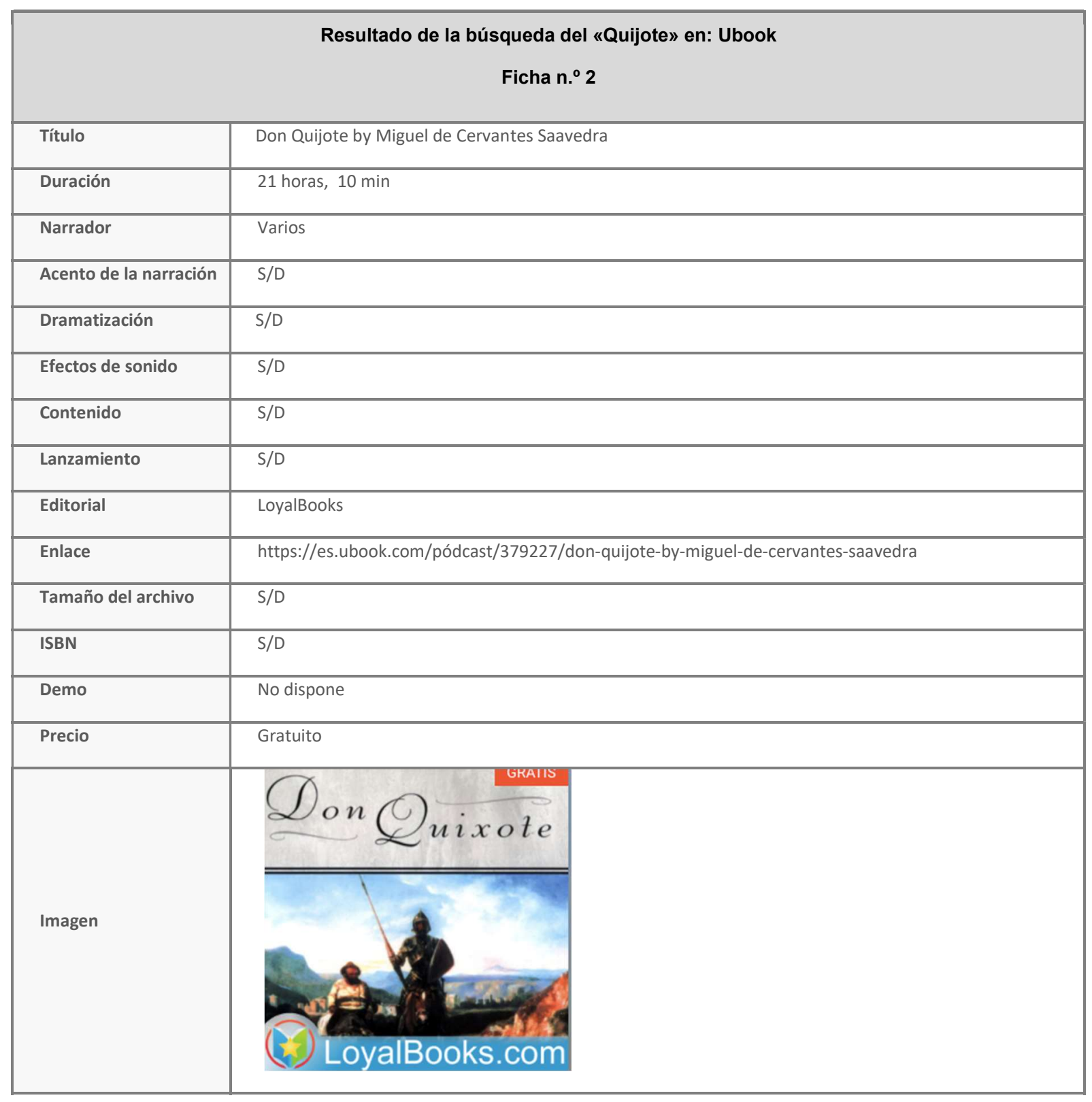

\begin{tabular}{|l|l|}
\hline \multicolumn{2}{|c|}{ Resultado de la búsqueda del «Quijote» en: Ubook } \\
\multicolumn{2}{|l|}{ Ficha . $^{\circ}$ 3 } \\
\hline Título & Primera Parte del Ingenioso Hidalgo Don Quijote \\
\hline Duración & 9 horas 40 minutos \\
\hline Narrador & Diego Villegas \\
\hline Acento de la narración & S/D \\
\hline Dramatización & S/D \\
\hline Efectos de sonido & S/D \\
\hline
\end{tabular}




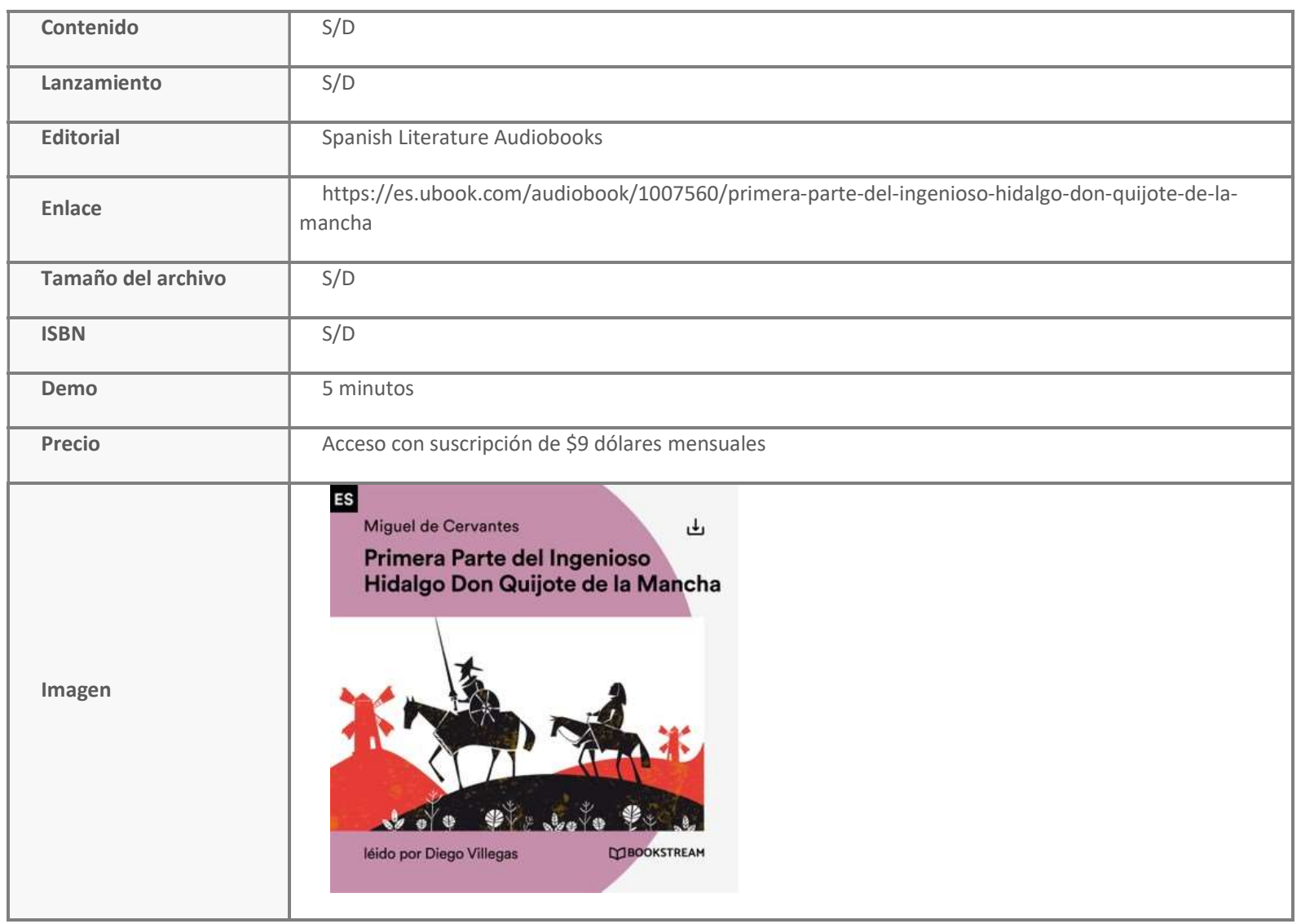

\begin{tabular}{|c|c|}
\hline \multicolumn{2}{|r|}{$\begin{array}{l}\text { Resultado de la búsqueda del «Quijote» en: Ubook } \\
\qquad \text { Ficha n. }^{\circ} 4\end{array}$} \\
\hline Título & Primera Parte del Ingenioso Hidalgo Don Quijote: 1 de 3 \\
\hline Duración & 9 horas 6 minutos \\
\hline Narrador & Diego Villegas \\
\hline Acento de la narración & S/D \\
\hline Dramatización & $S / D$ \\
\hline Efectos de sonido & $S / D$ \\
\hline Contenido & [Parte I, 1 de 3] \\
\hline Lanzamiento & $S / D$ \\
\hline Editorial & Spanish Literature Audiobooks \\
\hline Enlace & $\begin{array}{l}\text { https://es.ubook.com/audiobook/1008993/primera-parte-del-ingenioso-hidalgo-don-quijote-de-la- } \\
\text { mancha-1-de-3 }\end{array}$ \\
\hline Tamaño del archivo & $S / D$ \\
\hline ISBN & $S / D$ \\
\hline
\end{tabular}




\begin{tabular}{|l|c|}
\hline Demo & 35 segundos \\
\hline Precio & Acceso con suscripción de \$9 dólares mensuales \\
\hline Imagen & $\begin{array}{l}\text { Miguel de Cervantes } \\
\text { Primera Parte del Ingenioso } \\
\text { Hidalgo Don Quijote de la Mancha } \\
\text { (1 de 3) }\end{array}$ \\
\hline
\end{tabular}

Resultado de la búsqueda del «Quijote» en: Ubook

Ficha $n .^{\circ} 5$

\begin{tabular}{|c|c|}
\hline Título & Primera Parte del Ingenioso Hidalgo Don Quijote (2 de 3 ) \\
\hline Duración & 7 horas \\
\hline Narrador & Diego Villegas \\
\hline Acento de la narración & [Español latino] \\
\hline Dramatización & {$[\mathrm{No}]$} \\
\hline Efectos de sonido & {$[\mathrm{No}]$} \\
\hline Contenido & [Parte I, 2 de 3] \\
\hline Lanzamiento & S/D \\
\hline Editorial & Spanish Literature Audiobooks \\
\hline Enlace & $\begin{array}{l}\text { https://es.ubook.com/audiobook/1008994/primera-parte-del-ingenioso-hidalgo-don-quijote-de-la- } \\
\text { mancha-2-de-3 }\end{array}$ \\
\hline Tamaño del archivo & S/D \\
\hline ISBN & S/D \\
\hline Demo & 32 segundos \\
\hline Precio & Acceso con suscripción de \$9 dólares mensuales \\
\hline
\end{tabular}




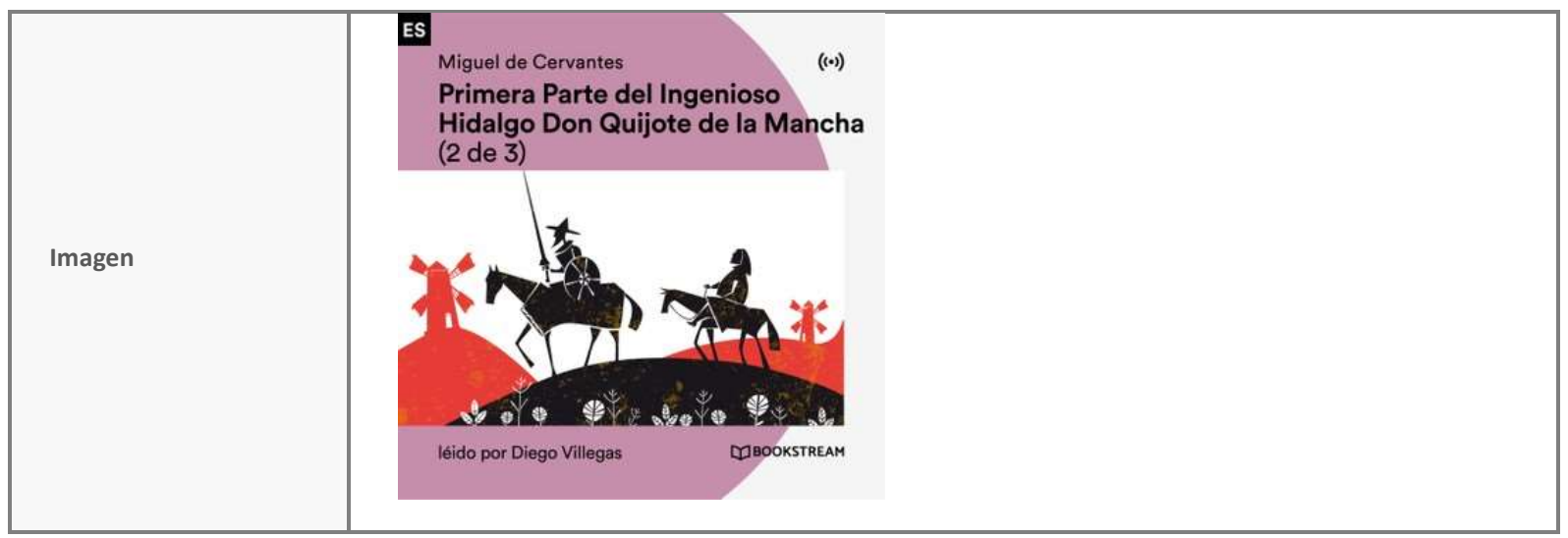

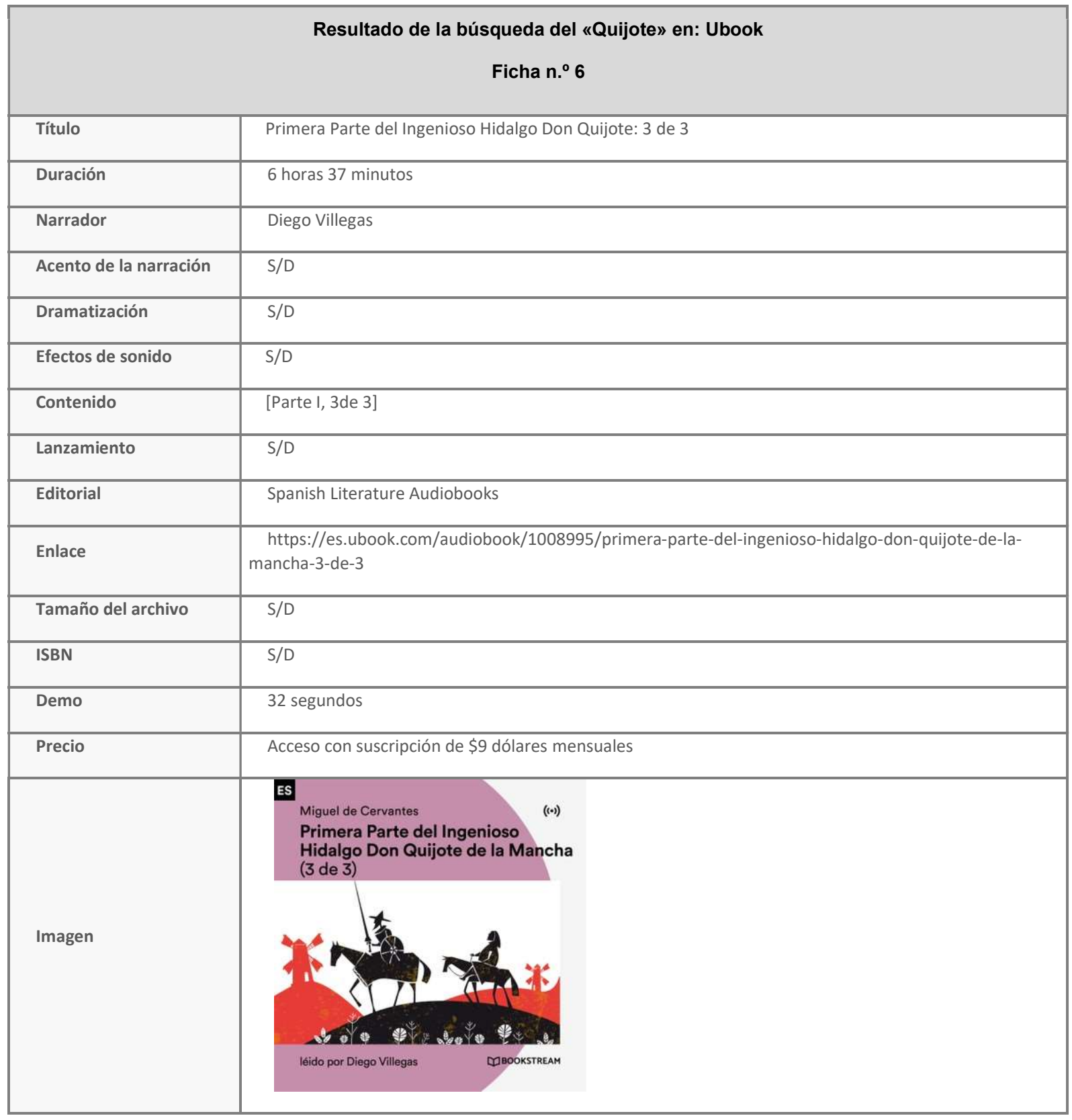




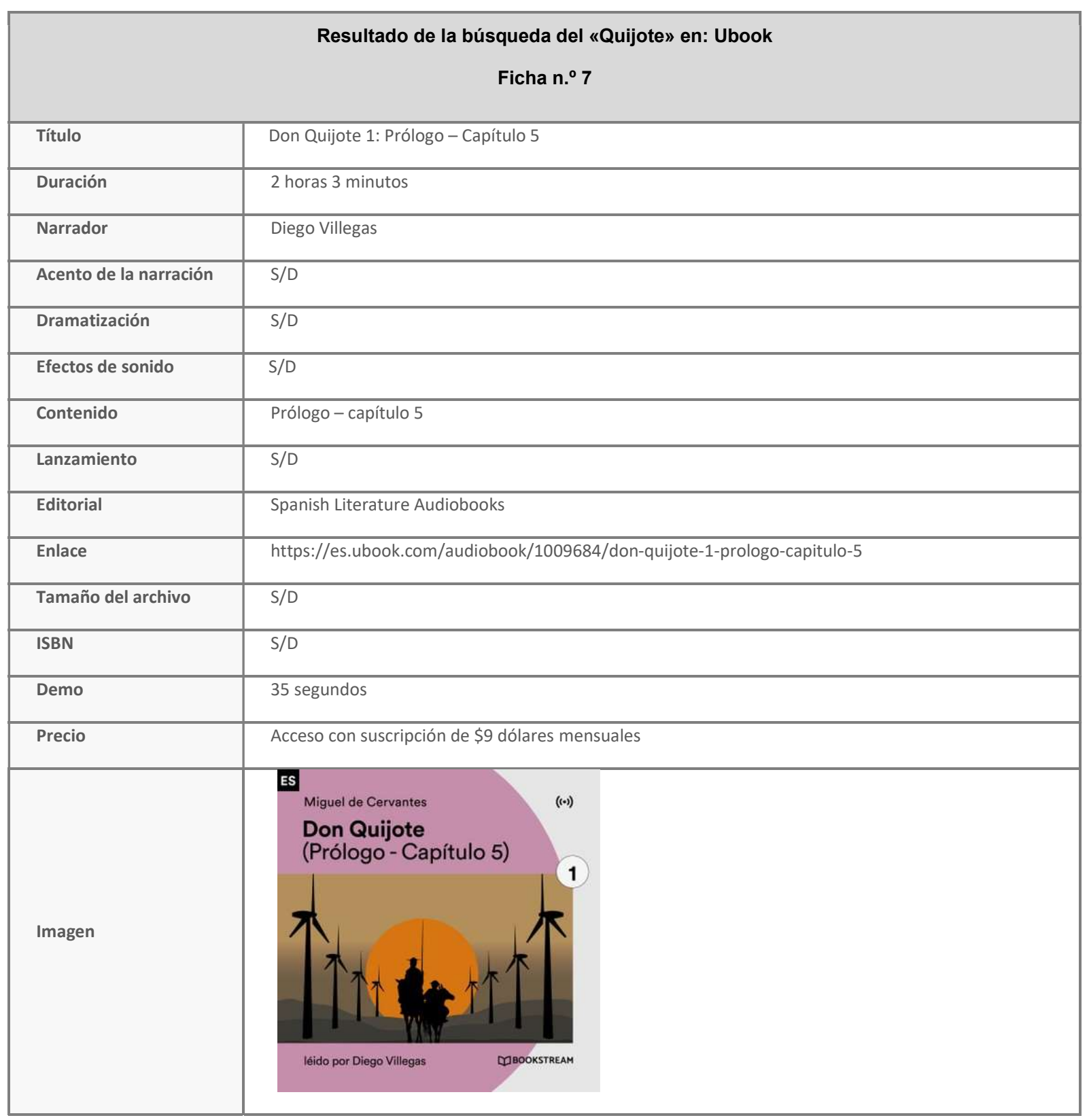

\begin{tabular}{|l|l|}
\hline \multicolumn{2}{|c|}{ Resultado de la búsqueda del «Quijote» en: Ubook } \\
Ficha n. $^{\circ} \mathbf{8}$ \\
\hline Título & Don Quijote 2 Capítulo 6-Capítulo 15 \\
\hline Duración & 3 horas 11 minutos \\
\hline Narrador & Diego Villegas \\
\hline Acento de la narración & S/D \\
\hline
\end{tabular}




\begin{tabular}{|c|c|}
\hline Dramatización & $S / D$ \\
\hline Efectos de sonido & S/D \\
\hline Contenido & Capítulo 6 - capítulo 15 \\
\hline Lanzamiento & $S / D$ \\
\hline Editorial & Spanish Literature Audiobooks \\
\hline Enlace & https://es.ubook.com/audiobook/1009690/don-quijote-2-capitulo-6-capitulo-15 \\
\hline Tamaño del archivo & $S / D$ \\
\hline ISBN & $\mathrm{S} / \mathrm{D}$ \\
\hline Demo & 32 segundos \\
\hline Precio & Acceso con suscripción de $\$ 9$ dólares mensuales \\
\hline Imagen & $\begin{array}{l}\text { Miguel de Cervantes } \\
\text { Don Quijote } \\
\text { (Capítulo 6-Capítulo 15) }\end{array}$ \\
\hline
\end{tabular}

\section{Resultado de la búsqueda del «Quijote» en: Ubook}

Ficha . $^{\circ} 9$

\begin{tabular}{|l|l|}
\hline Título & Don Quijote 3 Capítulo 16 - Capítulo 20 \\
\hline Duración & 2 horas 14 minutos \\
\hline Narrador & Diego Villegas \\
\hline Acento de la narración & S/D \\
\hline Dramatización & S/D \\
\hline Efectos de sonido & S/D \\
\hline Contenido & Capítulo 16-capítulo 20 \\
\hline Lanzamiento & S/D \\
\hline Editorial & Spanish Literature Audiobooks \\
\hline Enlace & https://es.ubook.com/audiobook/1009692/don-quijote-3-capitulo-16-capitulo-20 \\
\hline Tamaño del archivo & S/D \\
\hline ISBN & S/D \\
\hline
\end{tabular}




\begin{tabular}{|l|l|}
\hline Demo & 32 segundos \\
\hline Precio & Acceso con suscripción de \$9 dólares mensuales \\
\hline \multirow{3}{*}{ Imagen } & $\begin{array}{c}\text { ES Miguel de Cervantes } \\
\text { Don Quijote } \\
\text { (Capítulo 16-Capítulo 20) }\end{array}$ \\
\hline
\end{tabular}

\begin{tabular}{|l|l|}
\multicolumn{2}{|c|}{ Resultado de la búsqueda del «Quijote» en: Ubook } \\
\multicolumn{1}{|l|}{ Ficha . $^{\circ}$ 10 } \\
\hline Título & Don Quijote 4 Capítulo 21 - Capítulo 25 \\
\hline Duración & 2 h 52 minutos \\
\hline Narrador & Diego Villegas \\
\hline Acento de la narración & S/D \\
\hline Dramatización & S/D \\
\hline Efectos de sonido & S/D \\
\hline Contenido & Capítulo 21- capítulo 25 \\
\hline Lanzamiento & 15 -12-2009 \\
\hline Editorial & Spanish Literature Audiobooks \\
\hline Enlace & https://es.ubook.com/audiobook/1009694/don-quijote-4-capitulo-21-capitulo-25 \\
\hline Tamaño del archivo & S/D \\
\hline ISBN & S/D \\
\hline Demo & Acceso con suscripción de \$9 dólares mensuales \\
\hline Precio & \\
\hline
\end{tabular}




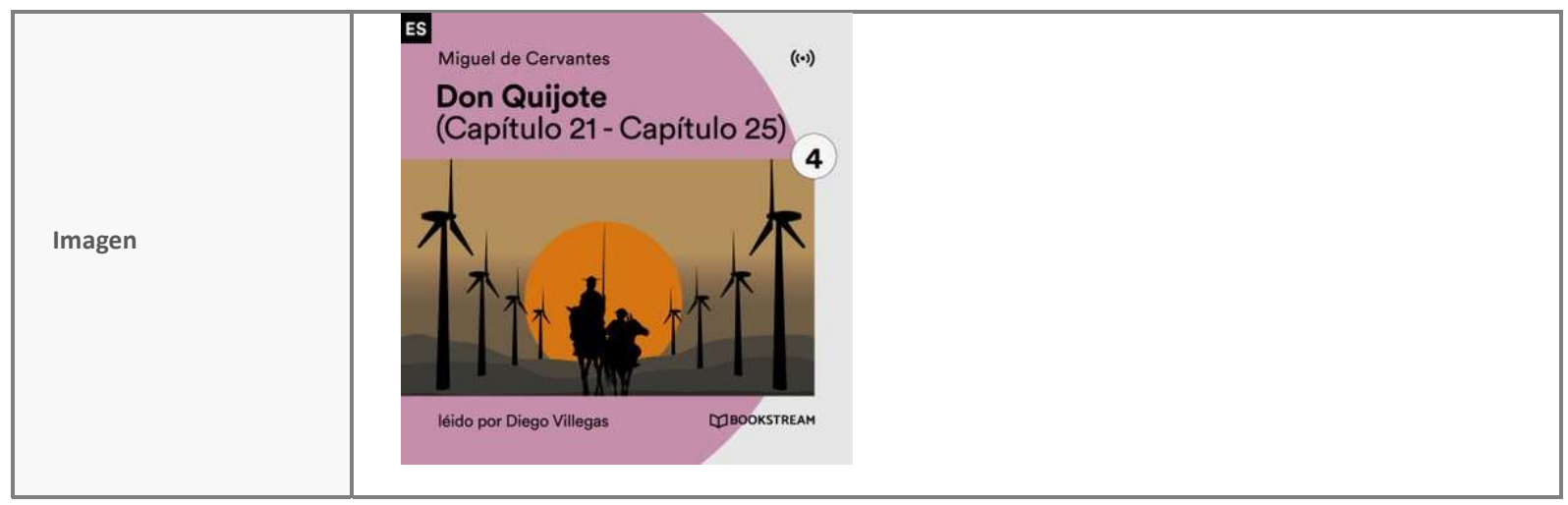

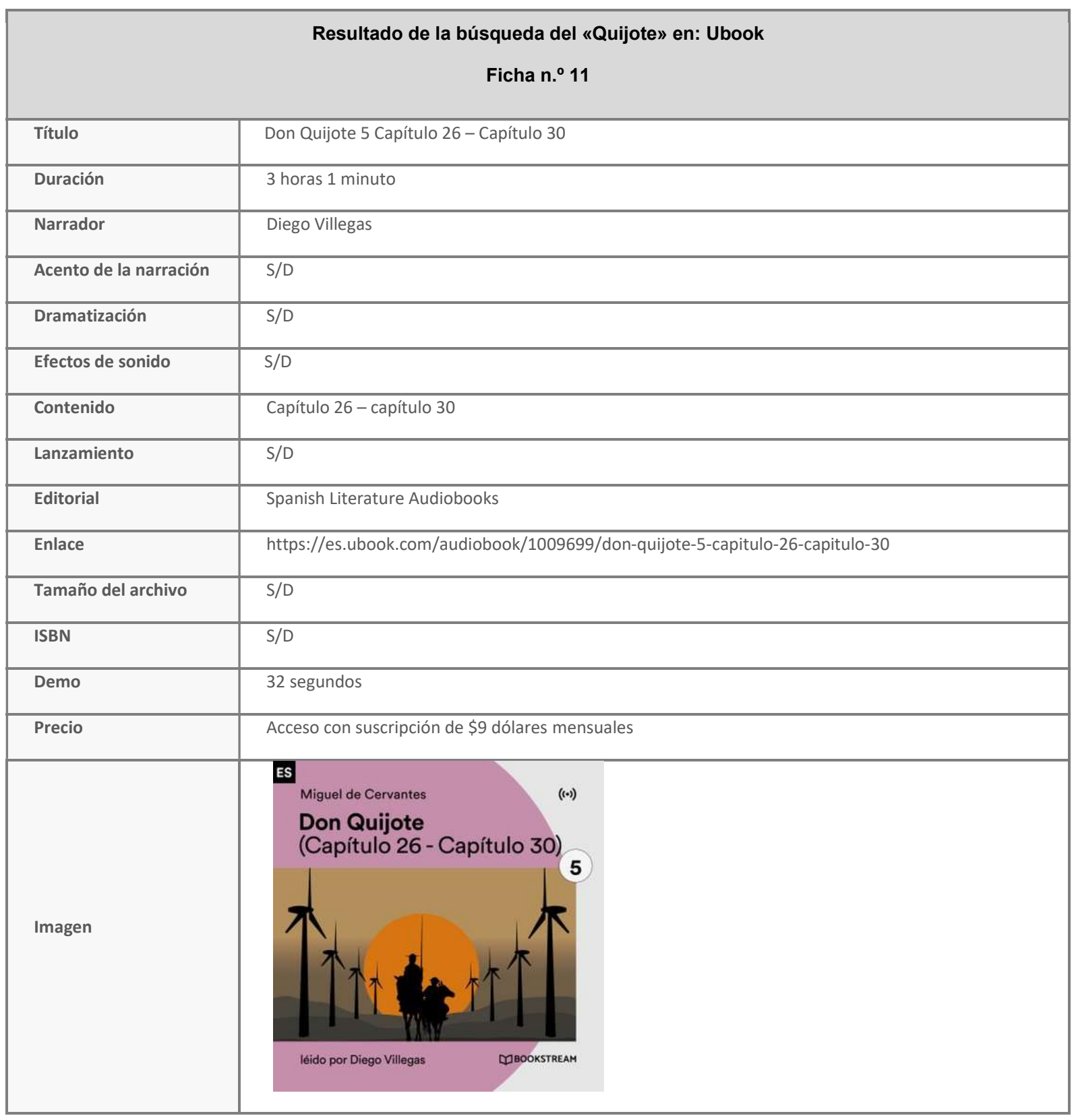




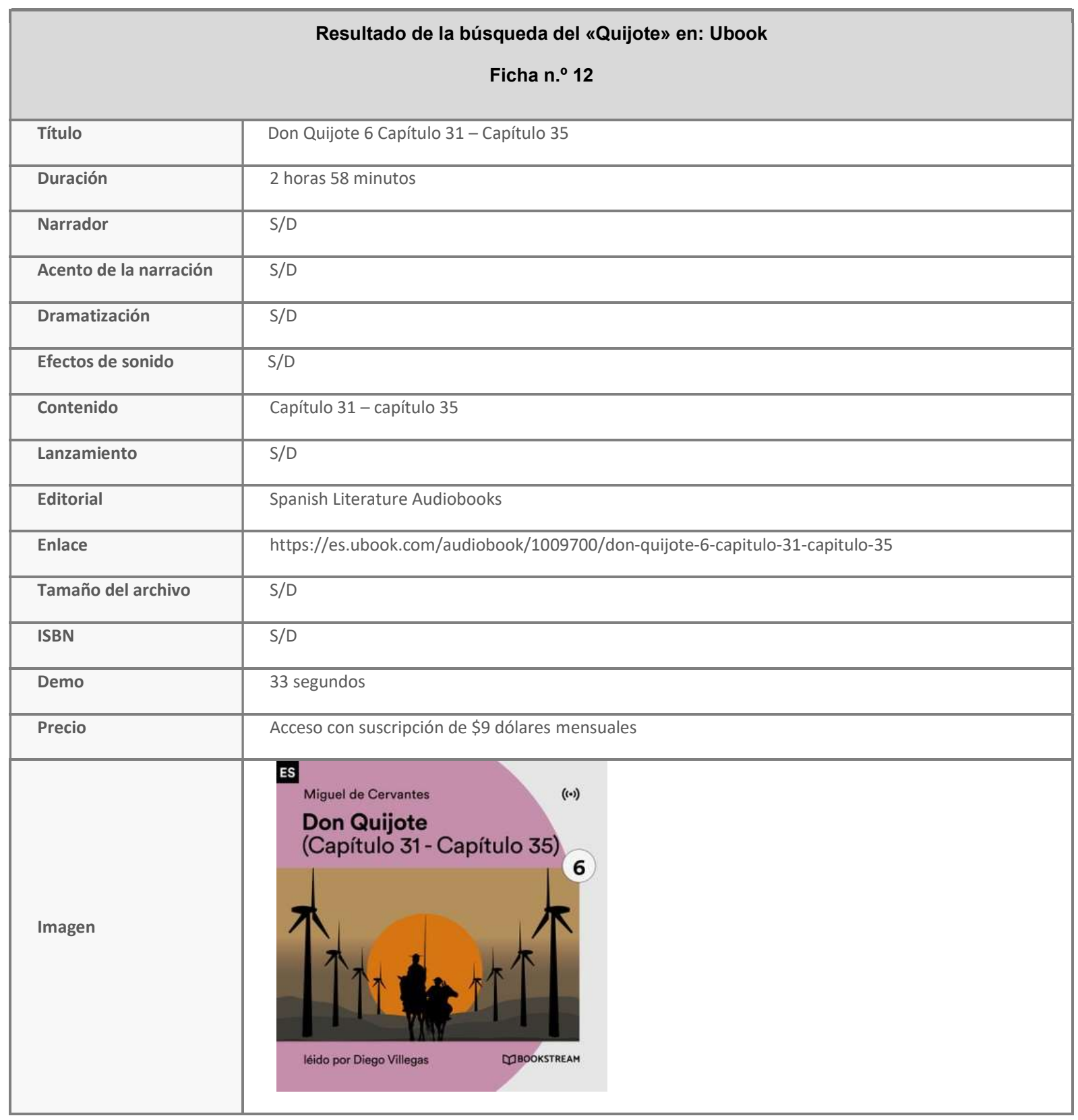

\begin{tabular}{|l|l|}
\hline \multicolumn{2}{|c|}{ Resultado de la búsqueda del «Quijote» en: Ubook } \\
\multicolumn{2}{|l|}{ Ficha . $^{\circ}$ 13 } \\
\hline Título & Don Quijote 7 \\
\hline Duración & 2 horas 9 minutos \\
\hline Narrador & Diego Villegas \\
\hline Acento de la narración & S/D \\
\hline Dramatización & S/D \\
\hline
\end{tabular}




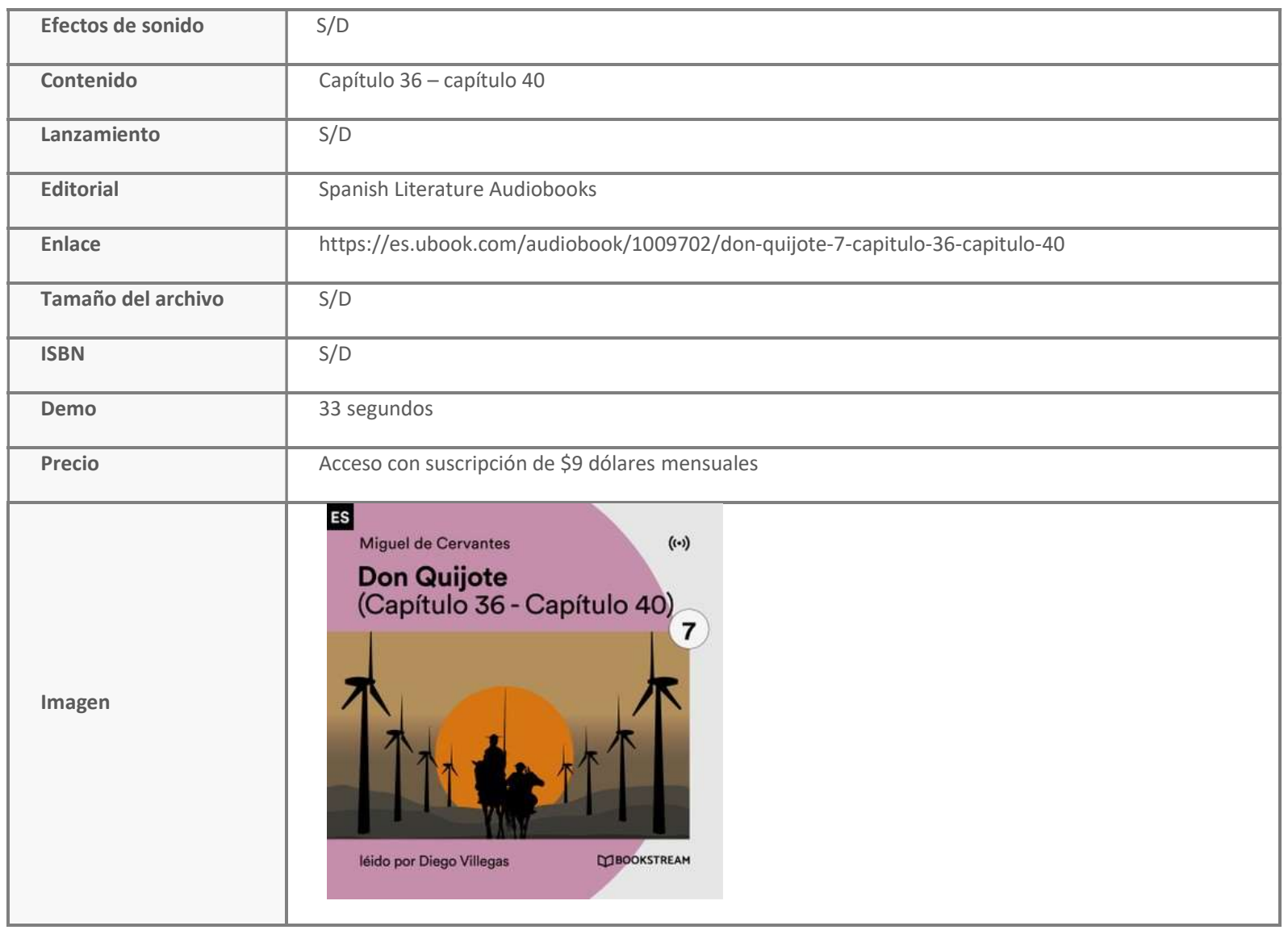

\begin{tabular}{|l|l|}
\hline \multicolumn{2}{|c|}{ Resultado de la búsqueda del «Quijote» en: Ubook } \\
\multicolumn{1}{|l|}{ Ficha . $^{\text {* 14 }}$} \\
\hline Título & Don Quijote 8 Capítulo 41 - Capítulo 45 \\
\hline Duración & 2 horas 24 minutos \\
\hline Narrador & Diego Villegas \\
\hline Acento de la narración & S/D \\
\hline Dramatización & S/D \\
\hline Efectos de sonido & S/D \\
\hline Contenido & Capítulo 41 - capítulo 45 \\
\hline Lanzamiento & S/D \\
\hline Editorial & Spanish Literature Audiobooks \\
\hline Enlace & https://es.ubook.com/audiobook/1011369/don-quijote-8-capitulo-41-capitulo-45 \\
\hline Tamaño del archivo & S/D \\
\hline ISBN & S/D \\
\hline Demo & 34 segundos \\
\hline
\end{tabular}




\begin{tabular}{|l|l|}
\hline Precio & Acceso con suscripción de \$9 dólares mensuales \\
\hline Imagen & $\begin{array}{l}\text { ES Miguel de Cervantes } \\
\text { Don Quijote } \\
\text { (Capítulo 41-Capítulo 45) }\end{array}$ \\
\hline
\end{tabular}

\begin{tabular}{|c|c|}
\hline \multicolumn{2}{|r|}{ Resultado de la búsqueda del «Quijote» en: Ubook } \\
\hline \multicolumn{2}{|r|}{ Ficha . $^{\circ} 15$} \\
\hline Título & Don Quijote 9 Capítulo 46 - Capítulo 52 \\
\hline Duración & 2 horas 32 minutos \\
\hline Narrador & Diego Villegas \\
\hline Acento de la narración & S/D \\
\hline Dramatización & S/D \\
\hline Efectos de sonido & S/D \\
\hline Contenido & Capítulo 46 - capítulo 52 \\
\hline Lanzamiento & S/D \\
\hline Editorial & Spanish Literature Audiobooks \\
\hline Enlace & https://es.ubook.com/audiobook/1020617/don-quijote-9-capitulo-46-capitulo-52 \\
\hline Tamaño del archivo & S/D \\
\hline ISBN & S/D \\
\hline Demo & 34 segundos \\
\hline Precio & Acceso con suscripción de $\$ 9$ dólares mensuales \\
\hline
\end{tabular}




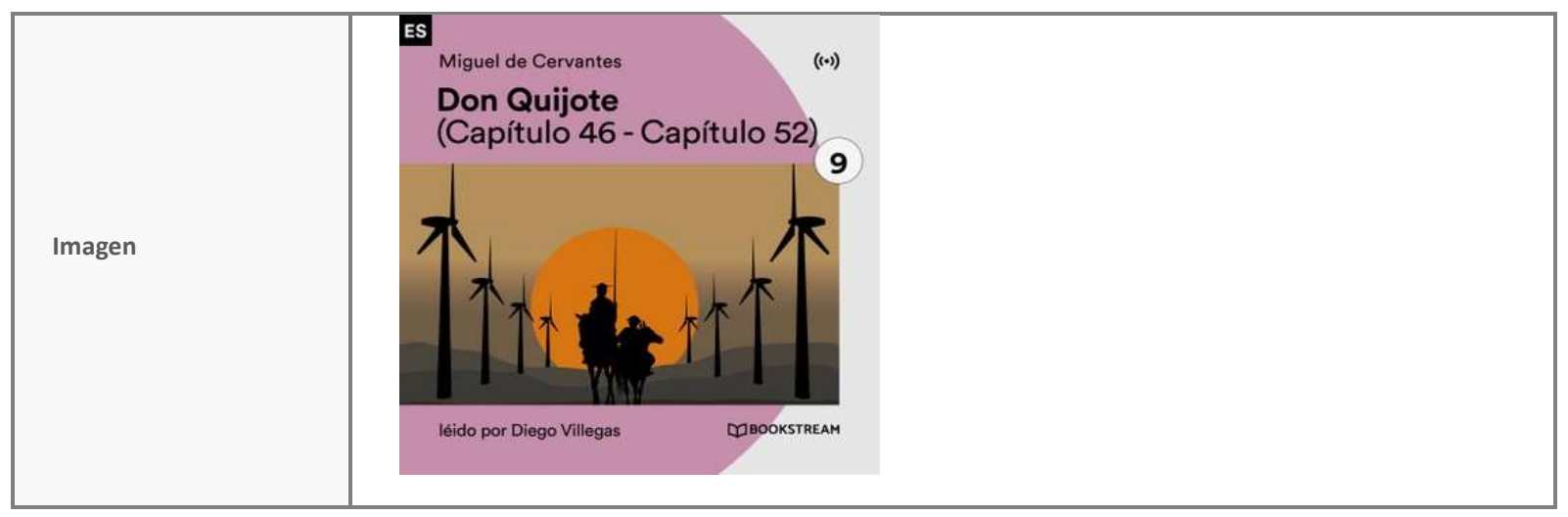

Notas:

Ofrecen un audiolibro de 37:44 h, de la editorial Saga Egmont Audio y uno de LoyalBooks de 21:10, que es un libro de una editorial que ofrece sus contenidos gratuitamente.

Tras estas dos versiones, ofrecen de 3 formas diferentes la primera parte del Quijote, divida en 1, 3 o 9 partes.

$\checkmark \quad 1$ audiolibro bajo el título Primera Parte del Ingenioso Hidalgo Don Quijote

$\checkmark \quad 3$ títulos correspondientes a una colección de audiolibros, titulada Primera Parte del Ingenioso Hidalgo Don Quijote de la editorial Spanish Literature Audiobooks.

$\checkmark 9$ audios que corresponden a una misma colección de audiolibros, titulada Don Quijote, de la editorial Spanish Literature Audiobooks.

No ofrecen información del ISBN de los títulos, ni del tipo de grabación, salvo en los casos de los libros de Spanish Literature Audiobooks. 